UNIVERSIDADE DE SÃO PAULO

FACULDADE DE FILOSOFIA, LETRAS E CIÊNCIAS HUMANAS

DEPARTAMENTO DE HISTÓRIA

PROGRAMA DE PÓS-GRADUAÇÃO EM HISTÓRIA SOCIAL

\title{
O GRUPO (DE ESQUERDA) DE OSASCO MOVIMENTO ESTUDANTIL, SINDICATO E GUERRILHA (1966-1971)
}

Sérgio Luiz Santos de Oliveira 
UNIVERSIDADE DE SÃO PAULO

FACULDADE DE FILOSOFIA, LETRAS E CIÊNCIAS HUMANAS

DEPARTAMENTO DE HISTÓRIA

PROGRAMA DE PÓS-GRADUAÇÃO EM HISTÓRIA SOCIAL

\section{O GRUPO (DE ESQUERDA) DE OSASCO \\ MOVIMENTO ESTUDANTIL, SINDICATO E GUERRILHA \\ (1966-1971)}

Sérgio Luiz Santos de Oliveira

Dissertação apresentada ao

Programa de Pós- Graduação em História Social, do Departamento de História da Faculdade de Filosofia, Letras e Ciências Humanas da Universidade de São Paulo, para obtenção do título de Mestre em História.

Orientador: Prof. Dr. Ulysses Telles Guariba Netto

São Paulo

2011 
A todos aqueles que não se submeteram a ditadura

A dona Maria Miguel, minha mãe, e a Renata Lípia Lima, mulheres da minha vida. 


\section{Agradecimentos}

Agradeço a CNPq pela bolsa de estudos que me foi de inestimável valia nestes dois últimos anos. Agradeço especialmente ao professor Marcos Silva, pelas suas dicas, orientações e indicações de leitura, fundamentais para o desenvolvimento do meu trabalho. Também sou grato as indicações do professor Lincoln Secco, presente em meu exame de qualificação, e ao professor Wilson do Nascimento Barbosa, que muito me auxiliou para um maior conhecimento sobre o terreno árido da História Econômica. Não deixando de mencionar meu orientador, Ullysses Telles Guariba Netto.

Foi de fundamental importância para o desenvolvimento dessa pesquisa os depoimentos a mim fornecidos por brasileiros que se engajaram no combate violento a ditadura civilmilitar que se impôs sobre este país durante vinte e um anos, a esses vão meus mais sinceros agradecimentos. Primeiramente, a Antonio Roberto Espinosa, que pacientemente me concedeu cinco entrevistas, sempre muito atencioso e prestativo. A José Ibrahim, também muito solícito e interessado em contribuir para a historiografia brasileira. A Roque Aparecido da Silva, Manuel Dias do Nascimento, Stanislau Zermeta e Gabriel Figueiredo, militantes políticos até os dias de hoje. A João Quartim de Moraes e sua esposa Maria Lygia Quartim de Moraes, que muito gentilmente me receberam em sua casa para uma entrevista.

Agradeço de todo coração aos amigos que acompanharam nestes anos de graduação e pós-graduação, tanto em ambiente de serviço, quanto na Faculdade, além dos bons companheiros de CRUSP. A Ronaldo Kirilauscas, pela força na formatação deste trabalho, e a Ana Paula e Sandro Venturi, por sua impressão e ajustes finais. A todos os meus alunos, do ensino fundamental, médio, pré-vestibular e superior, que muito colaboraram para meu amadurecimento enquanto pessoa, professor e pesquisador.

Agradeço muito a meus familiares, que estiveram comigo o tempo todo, mesmo antes de minha vida acadêmica, sobretudo a Maria Miguel, minha mãe, mulher que me introduziu no mundo dos livros, e a minha irmã, Daniela Santos de Oliveira, sempre disposta a dar uma mão nos momentos difíceis. Para concluir, sou eternamente grato a Renata Lipia Lima, minha companheira nestes anos de estudo e pesquisa, sempre ao meu lado. 


\section{Resumo}

A presente pesquisa tem por objetivo estudar a trajetória do Grupo de Osasco, grupo que reunia operários, estudantes e estudantes-operários. Para o desenvolvimento de nosso projeto utilizaremos fontes documentais provenientes de inquéritos policiais e material produzido pelas organizações revolucionárias (periódicos, manifestos, programas). Estes documentos são encontrados em arquivos como o Arquivo do Estado de São Paulo e o Centro de Documentação e Memória da UNESP (CEDEM). Também trabalharemos com História Oral, com base em depoimentos colhidos com personalidades que estiveram diretamente envolvidas com os eventos analisados em minha pesquisa. $\mathrm{O}$ recorte cronológico abrangerá o período que vai de 1966, início das atividades políticas do Grupo de Osasco, até 1971, quando praticamente todos os seus membros estavam exilados, presos ou mortos. Em setembro de 1971 tomba a última grande liderança remanescente de Osasco, José Campos Barreto, juntamente com Carlos Lamarca, no sertão da Bahia. Ao longo da segunda metade da década de sessenta, o Grupo de Osasco foi o principal movimento de esquerda nesta cidade. Em meados de 1968 dominava o movimento estudantil local, reunido em torno do CEO; dominava o sindicato dos metalúrgicos, e expandia sua influência a outras categorias através da criação de comissões de fábrica, mecanismo de representação que articulava os trabalhadores pela base, a margem do sindicato. Possuíam um vereador e vários representantes seus nas secretárias municipais. Pouco antes do AI-5, este grupo estava organizando associações de bairro sob sua influência, e nessas associações ministravam cursos de marxismo para populares. Coube ao Grupo de Osasco a organização da greve de julho de 1968, que se somou a onda de manifestações anti-ditadura que sacudiram o país. A repressão pós greve de julho jogou praticamente todos os militantes do Grupo de Osasco na clandestinidade, e estes acabaram por se integrar a VPR e partiram para a luta armada.

\section{Palavras Chave}

Osasco, autonomia, movimento estudantil, golpe, operariado, sindicato, greve, ditadura, guerrilha, vanguarda, 


\begin{abstract}
This research aims to study the trajectory of the Group of Osasco, group bringing together workers, students and student-workers. For development of our project will use documentary sources from of police investigations and material produced by organizations revolutionary (journals, manifestos, programs). These documents are found in archives and the Archive of State of São Paulo and the Documentation Center and Memorial of UNESP (CEDEM) Also work with oral history, based on testimonies gathered with personalities who were directly involved in the events analyzed in my research. The outline will cover the chronological period from 1966, beginning of political activities of the Group of Osasco, until 1971, when virtually all of its members were exiled, imprisoned or killed. In September 1971 falls the last great remaining leadership of Osasco, Joseph Campos Barreto, along with Carlos Lamarca, in the interior of Bahia. Throughout second half of the sixties, the Group was the main Osasco leftist movement in this city. In mid-1968 dominated the movement local student, gathered around the CEO; dominated the union metallurgical, and expanded its influence to other categories by creating workplace committees, representation mechanism which articulated the workers at the base, the margin of the union. They had a city councilman and several their representatives in the municipal secretaries. Shortly before the AI-5, this group was organizing neighborhood associations under its influence, and these ministered associations for popular courses on Marxism. It fell to Group Osasco organizing the strike in July 1968, which added to the wave anti-dictatorship protests that rocked the country. The repression of post strike July played virtually every militant group in Osasco underground, and these will eventually join the VPR and went to battle armed.
\end{abstract}

\title{
Keywords
}

Osasco, autonomy, student movement, strike, work force, union, coup, dictatorship, guerrilla, vanguard. 


\section{Lista de siglas e abreviações}

ACO - Ação Católica Operária

AERP - Assessoria Especial de Relações Públicas da Presidência da República

ALN - Aliança Nacional Libertadora

AP - Ação Popular

CCC - Comando de Caça aos Comunistas

Ceneart- Colégio e Escola Normal Antonio Raposo Tavarez

CEO - Círculo Estudantil de Osasco

CGT - Comando Geral dos Trabalhadores

Cobrasma - Companhia Brasileira de Materiais Ferroviários

Colina - Comando de Libertação Nacional

CREBS - Conselho Regional dos Estudantes da Baixa Sorocabana

CRUSP - Conjunto Residencial dos Estudantes da USP

FNT - Frente Nacional do Trabalho

Gepa - Grupo Escolar de Presidente Altino

GO - Grupo de Osasco

GR - Guerra Revolucionária

GTA - Grupo Tático Armado

IMP - Inquérito Policial Militar

JEC - Juventude Estudantil Católica

JOC - Juventude Operária Católica

JUC - Juventude Universitária Católica

MNR - Movimento Nacionalista Revolucionário

ME - Movimento Estudantil

MIA - Movimento Intersindical Anti-Arrocho

MO - Movimento Operário

Oban - Operação Bandeirantes

Olas - Organização Latino-americana de Solidariedade

ORM-Polop - Organização Revolucionária Marxista - Política Operária

OS - Oposição Sindical 
PAEG - Programa de Ação Econômica do Governo

POC - Partido Operário Comunista

SADO - Sociedade dos Amigos do Distrito de Osasco

SMO - Sindicato dos Metalúrgicos de Osasco

UBES - União Brasileira dos Estudantes Secundaristas

UEE-SP - União Estadual dos Estudantes de São Paulo

UEO - União dos Estudantes de Osasco

UME-RJ - União Metropolitana dos Estudantes do Rio de Janeiro

UMO - União da Mocidade de Osasco

UPES - União Paulista dos Estudantes Secundaristas

USAID - United States Agency for Internatinonal Development

VAR-Palmares - Vanguarda armada Revolucionária Palmares

VPR - Vanguarda Popular Revolucionária

\section{Lista de Tabelas}

Tabela I - Evolução populacional do município de Osasco. p. 27

Tabela II - Empresas instaladas em Osasco entre 1940 e 1960, por ramo de atividade. p. 30

Tabela III - Cobrasma: número de funcionários - 1946-1970. p.189

Tabela IV - Evolução do salário mínimo (1959-1970). p. 206 


\section{Sumário}

Introdução p. 6

1. Pontos de Partida p. 19

1.1. Vila p. 20

1.2 De vila a bairro operário p. 26

1.3 Cidade p. 34

1.4. Cidade Vermelha p. 43

2. Movimento Estudantil p. 65

2.1 A Formação da UEO p. 66

2.2 A formação do CEO p. 76

2.3. A setembrada e as eleições de 1966 p. 87

2.4. 1968: a rebelião estudantil (no mundo, no Brasil e em Osasco) p. 102

\section{Movimento Operário} p.161

3.1 O Sindicato dos Metalúrgicos de Osasco p. 162

3.2. Comissão de Fábrica p. 178

3.3 A Conquista do Sindicato p. 193

3.4. A Greve de Osasco de 1968 p. 205

4. Guerrilha p. 230

4.1. Por que a VPR p. 232

4.2. Por que a VAR-Palmares p. 282

4.3. Derrocada e recomeço p. 308

Considerações Finais p. 323 


\section{Introdução}


A presente dissertação tem por objetivo discutir a trajetória do Grupo de Osasco ${ }^{1}$, movimento formado por estudantes, operários, e estudantes-operários, a maioria na faixa dos vinte anos de idade, organizados no município cujo nome vem expresso na indicação do grupo. Tal movimento ganhou notoriedade após a greve insurrecional de julho de 1968, última paralisação de envergadura verificada na década de sessenta. Contudo, suas atividades não se restringiram a esse evento. Os militantes articulados no GO se fizeram presentes no meio político de sua cidade de forma abrangente entre 1966 e 1968.

Em sua breve trajetória, o grupo em análise se pautou por ideias de cunho revolucionário, de matriz marxista-leninista, mescladas a correntes de pensamento em voga no período, como o guevarismo-debraysmo. Por sua pouca experiência teórica e organizativa, o GO, através de seus representantes, não foi capaz de definir uma linha político-teórica sólida. O que unia esses ativistas era uma oposição radical a ditadura civil-militar brasileira, o desejo em interferir nos rumos políticos de sua realidade, e um interesse difuso pela teoria marxista. Outro ponto que vale salientar é o fato da maioria dos membros do grupo terem adentrado o universo da esquerda nacional distantes das teses do PCB. Sua evolução, em sentido revolucionário, apresentou contornos distintos, iniciou-se num momento posterior ao golpe de 1964. Os rancores da esquerda mais jovem diante do imobilismo dos comunistas perante o assalto ao poder esteve presente nesse agrupamento desde seus primórdios.

As atividades do GO não se restringiram a sua cidade, os mesmos estiveram presentes, através dos aparelhos políticos sob seu controle, nas movimentações estudantis do efervescente ano de 1968, em ações conjuntas junto a entidades estaduais e federais, como a UEE-SP e a UNE; nos debates em torno da oposição sindical ao regime militar, com destaque para sua atuação nos trabalhos de construção (e dissolução) do MIA (Movimento Intersindical Anti-arrocho). Posteriormente, já em situação de clandestinidade, militantes do grupo participaram das articulações em torno da formação da guerrilha urbana em São Paulo, e de suas cisões posteriores.

Compreendemos o GO como um movimento social ${ }^{2}$ em construção, um "organismo"

1 Essa designação é utilizada por Antonio Roberto Espinosa, uma das principais lideranças de esquerda do município no período em estudo. José Ibrahim, eleito presidente do Sindicato dos Metalúrgicos de Osasco em 1967, costuma se referir ao grupo como Grupo de Esquerda, assim como o fez Francisco Weffort. Roque Aparecido da Silva, outra importante liderança local, utiliza a expressão Grupo de Esquerda de Osasco. Optei por utilizar Grupo de Osasco, pois seu caráter de esquerda já vem enunciado no título de meu projeto. Doravante este grupo será indicado pela sigla GO.

2 Gianfranco Pasquino, no verbete "Movimentos Sociais", presente no Dicionário de Política organizado por este autor em parceria com Norberto Bobbio e Nicola Mateucci, a partir das proposições de A. Melucci, propõe "uma distinção entre movimentos reivindicatórios, movimentos políticos e movimentos de classe, baseada nos 
em sentido gramsciano, "um elemento complexo da sociedade no qual já tenha tido início a concretização de uma vontade coletiva reconhecida e afirmada parcialmente na ação" ${ }^{\text {. Neste }}$ excerto Gramsci se refere a formação do "partido político", o aglutinador das "vontades coletivas". O GO não teve tempo para se estruturar enquanto partido ou movimento político coeso, com diretrizes e programa definido, visto que seu período de atuação foi curto. Em sua cidade, tornou-se uma das principais forças políticas na segunda metade dos anos 1960. Após seu ingresso na Vanguarda Popular Revolucionária, os jovens ativistas de Osasco se diluíram no intrincado jogo de poder interno a essa organização, cerrando fileiras junto às tendências que possuíam maiores afinidades com suas proposições de cunho obreirista, condizentes com suas origens de estudantes-operários.

Como dito acima, o GO se tornou conhecido após a greve de julho de 1968, evento que se notabilizou mais pela repressão feroz com que foi contido, do que por seus efeitos imediatos. Essa greve fez parte da vaga de oposição ao regime que tomou conta do país no ano do AI-5, somou-se as manifestação de massa empreendidas pelo ME nas principais capitais brasileiras, e a efervescência cultural galvanizada pela onda de contestação jovem observada em nível internacional. Somou-se também ao movimento paredista de Contagem e outras paralisações de menor monta, eclodidas em pontos distintos do território nacional, e ao início das atividades da guerrilha urbana no Brasil.

Após a Greve de Osasco, o crescente processo de politização orientado pelo GO em sua região foi bloqueado. As vésperas da paralisação da Cobrasma $^{4}$, tal grupo controlava o movimento estudantil local, o Sindicato dos Metalúrgicos de Osasco e Região, boa parte das comissões de fábrica espalhadas pelas empresas da localidade; contava com três vereadores aliados, e trânsito junto ao prefeito da cidade. Organizados pelo grupo, cursos de iniciação ao marxismo eram ministrados para trabalhadores e estudantes, além de atividades culturais de

objetivos perseguidos. No primeiro caso, trata-se de impor mudanças nas normas, nas funções e nos processos de destinação dos recursos. No segundo, se pretende influir nas modalidades de acesso aos canais de participação política e de mudança nas relações de força. No terceiro, o que se visa é subverter a ordem social e transformar o modo de produção e as relações de classe. A passagem de um tipo a outro depende de numerosos fatores, dentre os quais não é de somenos importância o tipo de resposta que o Estado pode dar, bem como da capacidade dos movimentos em aumentar seus seguidores e em incrementar suas exigências". Ao longo de sua trajetória, o GO flutuou entre as três modalidades de movimentos sociais expostas acima, adotando uma postura mais radical a partir da emersão do grupo na luta armada. BOBBIO, Norberto Et alii (org). Dicionário de Política. $7^{\mathrm{a}}$ Ed. Brasília-DF: Editora da Universidade de Brasília, 1995. p. 787-791.

3 GRAMSCI, Antonio. Cadernos do Cárcere. Vol. 3. Edição e tradução Carlos Nelson Coutinho Et alii. Rio de Janeiro: Civilização Brasileira, 2000. p. 16

4 Companhia Brasileira de Materiais Ferroviários, maior empresa de Osasco no período em estudo, principal palco de atuação do GO junto ao operariado de sua cidade. Na terceira seção deste trabalho abordaremos a história e a importância desta empresa para o município de Osasco. 
viés proletário. Em fase inicial, havia um trabalho de formação de associações de bairro, voltadas especialmente ao operariado local, dentro dos parâmetros políticos do GO. Após o AI-5, tais iniciativas foram suprimidas por completo, e Osasco se tornou uma das cidades mais vigiadas pela repressão no Brasil.

Praticamente todos os trabalhos, acadêmicos ou não, ao abordarem as lutas sociais no agitado ano de 1968, fazem alguma referência a Osasco, mais especificamente, a greve de julho, ocorrida nessa cidade. Ainda sob o calor dos acontecimentos, uma série de artigos publicados pela imprensa alternativa registraram as primeiras impressões sobre o evento, longe do comprometimento com o regime verificado na mídia corporativa. Publicações produzidas pelo ME, como o periódico Contato, editado pelos alunos da Faculdade de Economia e Administração da UFRJ, saudaram a paralisação de julho por meio do artigo "Ditadura treme... Osasco". Já o tradicional Voz Operária, em sua edição de número 44, publicada em outubro de 1968, apresentou um lúcido balanço sobre o evento em análise, intitulado "Um soldado para cada três grevistas".

Em 1972, desde o exílio, a organização denominada "Tendência Leninista da ALN (Aliança Libertadora Nacional)", por meio de sua revista Unidade e Luta, número 2, publicou uma longa entrevista com José Ibrahim, presidente cassado do SMO, exilado no Chile. Tratase de um precioso relato sobre as articulações do GO junto ao operariado osasquense, passando pela formação da comissão de fábrica de Cobrasma, pelo protesto de $1^{\mathrm{o}}$ de Maio de 1968, grande ato contra as políticas de arrocho salarial da ditadura, concluindo-se com uma descrição sobre os trabalhos de construção da greve de julho, concluído com uma autocrítica com relação aos rumos do movimento ${ }^{5}$.

O primeiro texto acadêmico a discutir o tema foi o artigo de Francisco Weffort, intitulado Participação e Conflito Industrial: Contagem e Osasco - 1968, publicado pelos

\footnotetext{
5 De acordo com Celso Frederico, em agosto de 1968 o PCB posicionou-se sobre o movimento paredista de julho através do artigo "A Greve de Osasco", assinado por "os comunistas de Osasco" também pelo periódico Voz Operária. Não tivemos acesso a esse material. Também pela imprensa clandestina, o movimento de Osasco foi analisado no jornal Libertação, produzido pela Ação Popular, nos artigos "A vitória política dos trabalhadores" e "A greve de Osasco e a luta contra a ditadura", em seus números 6 e 7, publicados, respectivamente, em julho e agosto de 1968. O periódico sindical Combate, de Minas Gerais, dedicou um número especial as greves de Contagem e Osasco. O jornal Movimento Operário, distribuído em Osasco e outros centros industriais do país, redigido pelo POC (Partido Operário Comunista), dedicou sua edição de número 15 a Greve de Osasco. O artigo citado no corpo do texto se encontra disponível, em formato digital, no Centro de Documentação e Memória da UNESP - CEDEM. Para mais informações sobre outras publicações clandestinas e desde o exílio a abordar o movimento de Osasco, consultar: FREDERICO, Celso (Org). A Esquerda e o Movimento Operário, 1964-1986 (Vol.1). São Paulo: Editora Novos Rumos, 1987. p. 154
} 
Cadernos do Cebrap, em sua edição número 5, em $1972^{6}$. O artigo de Weffort suscitou críticas dos envolvidos no evento, especialmente pelo caráter espontaneísta imprimido ao movimento paredista de julho pelo sociólogo paulista. Na terceira seção desta pesquisa veremos que essa greve foi cuidadosamente planejada pelos militantes do GO, organizados no SMO e nas comissões de fábrica, sobretudo a da Cobrasma. No mesmo ano, o militante da VPR identificado pelo pseudônimo Jaques Dias, escreveu no exílio um ensaio chamado "El Movimiento de Osasco. Sus luchas, sus actores".

Em 1978, dez anos após os eventos de Contagem e Osasco, a revista Cadernos do Presente dedicou seu segundo número as duas grandes greves de 1968. Nesta edição há uma entrevista com José Ibrahim, e um artigo assinado por Antonio Roberto Espinosa, importante liderança do GO, cujo texto narra a trajetória do grupo desde os tempos do CEO (Círculo Estudantil de Osasco) até as paralisações de julho. Esse artigo apresenta, pela primeira vez, uma sistematização do Grupo de Osasco, a partir de um de seus principais articuladores.

A expressão "grupo de Osasco" foi apenas uma forma posteriormente criada para designar o conjunto de operários, operários-estudantes e estudantes que viviam em Osasco e atuavam nos movimentos locais. As relações que uniam o grupo eram informais, ou seja, ele não tinha caráter partidário. Um conjunto de concepções vagas, entretanto, dava-lhe certa unidade: defesa do socialismo, recusa das práticas conciliatórias de classe e privilegiamento da participação e ação das bases. Ainda que com visões ligeiramente diferentes, todos os membros do grupo defendiam a criação de comissões de empresa (legais ou não) e a participação em todos os instrumentos legais de organização como o Sindicato. Além disso, também havia no grupo uma evidente simpatia pela Revolução Cubana e pela luta armada. Exceto em alguns momentos de maior mobilização quando eram criadas coordenações - o grupo não possuía qualquer direção regular. As reuniões dos seus integrantes eram realizadas nos mais diversos lugares, mas sempre em função do cumprimento de tarefas ligadas à mobilização ou organização para movimentos concretos ${ }^{7}$.

A partir de um ativista envolvido diretamente no contexto, foi publicado o livreto $O$ que todo cidadão precisa saber sobre comissões de fábrica, em 1986, redigido por José Ibrahim. Nesta obra Ibrahim faz um breve histórico sobre as comissões/comitês de

6 Celso Frederico aponta que o trabalho de Weffort foi criticado na publicação contraponto ( $\mathrm{n}^{\circ} 1$, novembro de 1976), por meio do artigo "Uma Tentativa de Análise Concreta", redigido por Ronaldo Mattos L. Siqueira e Carmem Fernandes. No mesmo número foi publicada a resposta de Weffort. Idem, p. 153

7 ESPINOSA, Antonio Roberto. "Dois relâmpagos na noite do arrocho". In: CADERNOS DO PRESENTE, No

2. Greves operárias (1968-1978). Belo Horizonte: Aparte Editora, julho de 1978. p. 44 
fábrica/empresa no ocidente industrial e a formação desse tipo de organização no Brasil ao longo do Século XX. Há também uma descrição detalhada sobre a construção da comissão de fábrica de Cobrasma, em princípio controlada por grupos católicos, posteriormente sob a direção do GO. A greve de Julho é analisada nesse estudo, que praticamente não toca na experiência guerrilheira do autor e seus companheiros de movimento. Entusiasta das comissões de fábrica, Ibrahim conclui seu livro defendendo a expansão de tais aparelhos entre todas as categorias do operariado.

Outra publicação a abordar nosso tema é Abraços que sufocam e outros ensaios sobre a liberdade, por Antonio Roberto Espinosa, coletânea de artigos publicados em jornais e revistas, escritos por esse autor, especialmente para jornal Primeira Hora, em circulação na região de Osasco. Através de textos curtos, Espinosa retoma várias passagens envolvendo as atividades do GO, dos tempos do $\mathrm{ME}$ a luta armada.

A primeira tese a abordar as lutas sociais na cidade de Osasco no período que nos toca é "Campeões, pequena biografia de processo social", redigida pelo sociólogo Orlando Miranda, defendida no Departamento de Sociologia da Faculdade de Filosofia, Letras e Ciências Humanas da Universidade de São Paulo, em 1984. Miranda esteve envolvido diretamente em boa parte dos fatos que analisa em sua tese, enquanto quadro de base do GO. Em sua pesquisa, são discutidos eventos envolvendo os movimentos sociais de Osasco ao longo dos anos 1960, até o período imediatamente posterior a greve de julho. Embora o GO seja um dos elementos centrais nesse estudo, não há uma sistematização do grupo enquanto organismo político. Miranda busca caracterizar a militância jovem atuante em seu município em termos gerais, discorrendo sobre o vigoroso ME osasquense, a atuação dos estudantesoperários nos meios sindicais, e suas relações junto à comunidade política local. Em tom memorialístico, o autor busca resgatar o clima de contestação em voga no período. O trabalho acadêmico em questão foi publicado em forma de livro em 1987, com o título Obscuros

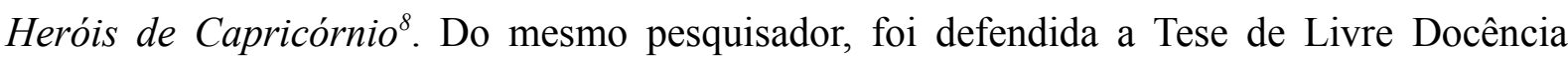
intitulada "Sindicato e Classe Operária: história do Sindicato dos Metalúrgicos de Osasco", também pelo Departamento de Sociologia da FFLCH-USP, no ano de 1987. Ambos os estudos foram de fundamental importância para nossa pesquisa.

Pela mesma instituição, Marcelo Ridenti defendeu a Tese de Doutorado "O Fantasma da Revolução Brasileira - raízes sociais das esquerdas armadas, 1964-1974”, em 1989,

8 MIRANDA, Orlando. Obscuros Heróis de Capricórnio. São Paulo: Global Editora, 1987 
trabalho publicado em $1993^{9}$. Neste estudo acerca das organizações armadas brasileiras em combate a ditadura, Ridenti comenta a participação de Osasco na ebulição política pré AI-5, e analisa a participação dos militantes dessa cidade na guerrilha urbana. $\mathrm{O}$ autor dedica um subitem ao tema de nossa pesquisa, ao qual deu o título de "Revolucionários de Osasco e Outros Ativistas"; neste há trechos de entrevistas de José Ibrahim, Antonio Roberto Espinosa e João Quartim de Moares, comandante da VPR que recrutou boa parte dos ativistas do GO.

Em 1987, uma coletânea de textos organizada por Celso Frederico dedica um capítulo a Greve de Osasco, com a já citada entrevista de José Ibrahim para a revista Unidade e Luta, e o artigo de Espinosa para os Cadernos do Presente, também supramencionado. Além destes textos, há um balanço do movimento redigido por Ibrahim e José Campos Barreto, outra grande liderança do GO, escrito pouco tempo após a greve.

Estudos diversos que enfocaram as lutas sociais no ano de 1968 e a luta armada fizeram referência a Osasco e seus atores políticos radicais, dentre estes destacamos Combate nas Trevas, de Jacob Gorender, e A Revolução Faltou ao Encontro de Daniel Aarão dos Reis Filho, ambos envolvidos diretamente no combate violento a ditadura.

Publicações de fundo biográfico também fizeram referência a Osasco e seus ativistas, dentre estas, destacamos as que utilizamos como fonte. Náufrago da Utopia, de Celso Lungaretti, aborda a formação da VPR e seus rachas posteriores; Pedro e os Lobos, escrito por João Roberto Laque, narra a trajetória do militante Pedro Lobo, quadro da VPR, próximo dos ativistas de Quitaúna. Carlos Lamarca, outro revolucionário radicado em Osasco, teve sua biografia narrada por Emiliano José e Oldack Miranda, no livro Lamarca: o capitão da guerrilha. As relações entre este oficial comunista e os membros do GO vieram a se estreitar apenas na fase clandestina do grupo. Comandante da VPR em seu período mais duro, Herbert Daniel descreve sua vivência durante a luta armada no livro Passagem para o próximo sonho: um possível romance autocrítico. Neste conferimos a formação dos Colina (Comandos de Libertação Nacional), organização que se fundiria a VPR dando origem a VAR-Palmares, sigla que teve como um de seus principais dirigentes Antonio Roberto Espinosa, quadro central do GO. Destacamos também as biografias de Maria do Carmo Brito, Uma Tempestade como sua Memória, e a de Iara Iavelberg, Iara: uma reportagem biográfica, ambas trazem dados sobre as movimentações e os debates travados entre as organizações de guerrilha urbana, com destaque para a formação da VAR-Palmares.

9 RIDENTI, Marcelo. O Fantasma da Revolução Brasileira. São Paulo: Editora da UNESP, 1993 
Pela Pontifícia Universidade Católica de São Paulo, em colaboração com o Centro e Documentação e Informação Cientificada (CEDIC) e seu acervo documental, foram publicadas uma série de teses e dissertações relacionadas aos movimentos sociais, privilegiando àqueles de matriz católica. Diversos desses trabalhos se dedicaram a pesquisar a cidade de Osasco, com uma boa quantidade de estudos sobre o período abordado em nosso trabalho. Ainda na década de oitenta, Cibele Saliba Rizek defendeu a Dissertação "Osasco: 1968. A experiência de um movimento", em 1988, sob orientação do professor Octávio Ianni. Esse estudo se concentra na formação do operariado osasquense, suas formas de organização, e se completa com uma análise sobre a greve de julho e suas consequências para o MO local.

Em 2001, Ari Marcelo Macedo Couto apresentou a Dissertação “Ao soar do apito a greve começou: Cobrasma, lutas e resistência”, pesquisa que enfoca a participação dos grupos cristãos na Greve de Osasco, com ênfase nas articulações da Frente Nacional do Trabalho (FNT). Esta agremiação católica disputava diretamente com o GO a liderança junto ao MO local. O trabalho de Ari Macedo foi publicado em 2003, com o título Greve na Cobrasma: uma história de luta e resistência.

A Tese de Doutorado “A Escola Secundária e a Cidade: Osasco, anos 1950/1960”, de Sonia Regina Martim, defendida em 2006, discute o papel do colégio Ceneart (Centro de Ensino Antonio Raposo Tavares - atualmente Escola Estadual Antonio Raposo Tavares, mais ainda identificada pela sigla Ceneart) nas lutas políticas de Osasco, do movimento autonomista até a formação do CEO, passando pela trajetória da UEO (União dos Estudantes de Osasco) e das movimentações inciais do GO. Esse estudo é fundamental para a compreensão da formação da categoria do estudante-operário. Tal colégio foi fundamental durante ciclo emancipacionista, seu ambiente altamente politizado ajudou a forjar a geração de ativistas que se destacaram na cidade até 1968. Pelo Ceneart passaram praticamente todas as lideranças do GO.

Em 2007, Paulo Sérgio de Jesus apresentou a Dissertação de Mestrado “Osasco: JOC, ACO e PO no Movimento Operário (1960-1970)", pesquisa que faz um apanhado geral sobre as entidades católicas leigas osasquenses voltadas a classe trabalhadora. Esse estudo faz referências à greve de julho e ao papel dos grupos católicos no evento, discutindo também a rearticulação do MO na cidade, sob orientação da Patoral Operária, e a retomada do SMO pelos trabalhadores a partir de 1978, após quase uma década de intervenção. 


\section{Metodologia e Fontes}

Orientamo-nos pelos referencias metodológicos provenientes da História crítica, nosso trato com os documentos se efetivará pautado por reflexões como as de Jaques Le Goff, historiador que afirma que o "documento não é qualquer coisa que fica por conta do passado, é um produto da sociedade que o fabricou segundo as relações de forças que aí detinham o poder". Le Goff se baliza pela historiografia medieval, mais distanciada no tempo, mas suas orientações acerca da análise crítica dos documentos se aplica ao contexto geral da pesquisa historiográfica. Tendo isso em mente, trabalharemos nossa documentação atentos ao embate social presente durante a produção da fontes por nós utilizadas.

O historiador francês faz menção as "relações de força" relacionadas a sociedade que "fabricou" o "documento" a ser apreciado durante a pesquisa. Em nossa dissertação, trabalharemos com fontes provindas tanto do poder de fato, representado pela ditadura civilmilitar brasileira e seus signatários, quanto com documentos fabricados pelo "contra-poder" em atuação no período, representado pelas organizações guerrilheiras. Ainda com relação a problemática em discussão, Le Goff tece o seguinte raciocínio:

O documento é uma coisa que fica, que dura, e o testemunho, o ensinamento (...) que ele trás deve ser em primeiro lugar analisado desmistificando-lhe o seu significado aparente. O documento é monumento. Resulta do esforço das sociedades históricas para impor ao futuro - voluntária ou involuntariamente - determinada imagem de si próprias. No limite, não existe documento verdade. Todo o documento é mentira. Cabe ao historiador não fazer papel de ingenuo ${ }^{10}$.

Em nossa pesquisa privilegiaremos documentos produzidos pelas forças em combate ao regime militar, nossos insumos crítico-metodológicos, a guisa do exposto acima, nos dão condições para "desmistificar" os conteúdos - intencionais ou não - presentes nas fontes documentais por nós consultadas. Estamos cientes de que o período por nós analisado é extremamente denso, violento, repleto de tragédias, rancores e traumas subsequentes. Caberá a nossa pesquisa ir além do "significado aparente" expresso nos documentos a nossa disposição.

10 LE GOFF, Jacques. "Documento Monumento". In: ENCICLOPÉDIA EINAUDI. (Vol.1) Memória-História. Portugal: Imprensa Nacional-Casa da Moeda, 1984. p. 102-103 
Em nosso trabalho utilizaremos basicamente duas categorias de fontes historiográficas: as textuais (inquéritos policiais, periódicos publicados pela imprensa corporativa; jornais, revistas e informes produzidos pelas organizações de esquerda que combatiam a ditadura; publicações de cunho memorialístico, além de dissertações, teses, e pesquisas acadêmicas referentes ao tema de nosso trabalho), e a orais (por meio de entrevistas com militantes que estiveram envolvidos diretamente nos eventos abordados em nossa pesquisa).

Com relação às fontes textuais, é necessário uma atenção especial aos inquéritos policiais, visto que as informações contidas nos mesmos foram obtidas, via de regra, sob tortura. Certo disso, faz-se necessário o cruzamento desses dados com fontes posteriores aos inquéritos, como entrevistas, biografias, artigos, etc. É pública e notória a colaboração dos veículos da imprensa corporativa com o regime militar, não deixando de também levar em conta a censura aos meios de comunicação, isto posto, informações provenientes desse tipo e fonte demandam uma filtragem ideológica, atenção as omissões e aos excessos apologéticos.

Por seu turno, tal filtragem se faz necessária também entre os materiais de origem clandestina. Uma série de estudos fizeram menção a miríade de organizações revolucionárias em atuação durante os Anos de Chumbo. Uma análise sobre as fontes redigidas por esses grupos requer um conhecimento amplo sobre a constelação de linhas teóricas e projetos revolucionários em pauta durante a fase em estudo, fator que também demanda uma maior atenção no trato de tais fontes.

Sobre o material de cunho biográfico, seguiremos as orientações de Mario Augusto Medeiros da Silva, que destaca a ambivalência dos relatos memorialísticos daqueles que estiveram envolvidos diretamente na luta armada, sujeitos ao trauma da implacável perseguição promovida pela repressão estatal. Esse autor chama as obras desse jaez de ficções políticas, considerando que

o conteúdo essencial dos textos seria o de objetivar uma denúncia; fornecer elementos para uma análise e revisões públicas de um período, de posturas e de projetos. (...) Uma ficção política não é uma mentira sobre fatos reais; mas, antes, uma narrativa com estatuto de verdade, cujo teor testemunhal consiste no amálgama das intenções de ambas as coisas. Assim, uma ficção política com teor testemunhal é uma construção social, cuja eficácia prática e simbólica é utilizada em determinados meios para determinados fins, quais sejam: narrar, através de um relato literário romance, depoimento autobiográfico - fatos e ações sofridos ou cometidos por sujeitos, apresentando- 
lhes os papéis desempenhados na constituição daqueles fatos ${ }^{11}$ (grifos do autor).

Para a análise de tal tipo de fonte também se faz necessário o cruzamento dos dados junto a outros documentos, sejam eles provenientes de outras obras de caráter biográfico; inquéritos, imprensa - seja ela corporativa ou clandestina - , entrevistas ou trabalhos acadêmicos.

No que se refere as fontes orais, trabalharemos segundo o conceito de história oral temática $^{12}$, em diálogo com os documentos de outra natureza por nós utilizados. As fontes orais vem acompanhadas de uma carga de subjetividade que deve ser mediada pelo pesquisador, visto que seu substrato é a memória dos indivíduos entrevistados. Com atenção sobre esse fator, direcionamos nossa atenção as reflexões de Alessandro Portelli, pesquisador voltado a esse gênero de fonte.

A essencialidade do indivíduo é salientada pelo fato de a História Oral dizer respeito a versões do passado, ou seja, a memória. Ainda que esta seja sempre moldada de diversas formas pelo meio social, em última análise, o ato e a arte de lembrar jamais deixam de ser profundamente pessoais. A memória pode existir em elaborações socialmente estruturadas, mas apenas os seres humanos são capazes de guardar lembranças. Se considerarmos a memória um processo, e não um depósito de dados, poderemos constatar que, a semelhança da linguagem, a memória é social, tornando-se concreta apenas quando mentalizada ou verbalizada pelas pessoas. A memória é um processo individual, que ocorre em um meio social dinâmico, valendo-se de instrumentos socialmente criados e compartilhados. Em vista disso, as recordações podem ser semelhantes, contraditórias e sobrepostas. Porém, em hipótese alguma, as lembranças de duas pessoas são - assim como as impressões digitais, ou a bem da verdade, como as vozes - exatamente iguais ${ }^{13}$.

Ciente desse fator, procuraremos cruzar os depoimentos colhidos, mediar as

11 SILVA, Mário Augusto Medeiros da. Os escritores da guerrilha urbana: literatura de testemunho, ambivalência e transição política (1977-1984). São Paulo: Editora Annablume; Fapesp, 2008. p. 26

12 José Carlos Sebe Bom Meihy contrapõe história oral temática a história oral de vida. Na segunda, o método é dedutivo, o autor se debruça sobre o histórico de vida do entrevistado; no segundo, a prática é indutiva, as perguntas visam a uma passagem específica da vida do inquirido, segundo o tema de pesquisa do entrevistador. Para mais informações sobre o tema: MEIRY, José Carlos Sebe Bom. Manual de História Oral. (4 Ed.) São Paulo: Edições Loyola, 2002.

13 PORTELLI, Alessandro. "Tentando aprender um pouquinho. Algumas reflexões sobre a ética na história oral”. In: Projeto História. Revista do Programa de Estudos Pós-graduados em História e do Departamento de História da Pontifícia Universidade Católica de São Paulo. Número 15. "Ética e História Oral”. São Paulo, 1981. p. 16. Disponível em formato digital no endereço eletrônico: http://www.pucsp.br/projetohistoria/downloads/revista/PHistoria15.pdf 
contradições encontradas nos relatos, levando-se em conta os conflitos, desencontros e rancores, tanto os superados, quanto os permanentes, considerando o tempo passado e o tempo presente, na interação entre o jovem protagonista das experiências narradas, e o adulto que pondera sobre temas muitas vezes traumáticos. Diferenças antigas e atuais podem surgir no cruzamento das informações, por isso buscaremos discorrer sobre visões e impressões que por ventura venham a se chocar, apresentando todas as informações reunidas, com o devido cuidado para não privilegiar determinadas versões em detrimento de outras.

\section{Capítulos}

Dividimos essa pesquisa em quatro capítulos, relacionados a evolução do Grupo de Osasco.

No primeiro, faremos uma breve descrição sobre a formação de Osasco enquanto distrito industrial da grande São Paulo, e sua especificidade em relação a outras regiões fabris da capital paulista. Analisaremos os primórdios do movimento operário local, a partir de imigrantes anarquistas italianos. Concluiremos a seção com uma apreciação sobre o movimento autonomista osasquense, evento a engendrar a notável movimentação política observada nessa cidade durante os anos 1960. O advento do GO está diretamente relacionado ao clima de participação e mobilização social inaugurado no ciclo emancipacionista.

No segundo capítulo analisaremos a formação do ME osasquense, a partir da UEO, criada pouco antes da emancipação da cidade, passando pelo seu fechamento após o golpe de 1964, e sua ressurreição por meio do CEO, articulado pelo GO. Discutiremos em detalhe a rebelião estudantil de 1968, e teceremos comparações entre o Maio francês e as ebulições verificadas no Brasil, com atenção sobre os trabalhos de tentativa de construção de uma frente operário-estudantil, a guisa do que ocorrera na França e na Itália. Iniciativa esta arquitetada por membros da UNE e UEE-SP, junto aos estudantes-operários de Osasco. A greve de julho de 1968 representou a grande tentativa de articulação de uma frente com essas características no Brasil.

No terceiro capítulo abordaremos a formação do MO de Osasco, a partir dos anos 1950, a criação do SMO, e a construção da comissão de fábrica de Cobrasma. Em seguida discutiremos a atuação do GO perante o operariado de sua cidade, a conquista do sindicato, os 
debates em torno do MIA, o grande protesto do $1^{\circ}$ de Maio de 1968, na Praça da Sé, e, finalmente, a greve de julho. Sua construção, seus desdobramentos, a repressão a seus organizadores, e a partida dos mesmos rumo a clandestinidade. Também faremos menção ao destaque que a cidade de Osasco ganhou entre a esquerda nacional, passando a ser vista como um polo de concentração de forças opositoras a ditadura.

No quarto capítulo, discutiremos a emersão do GO na clandestinidade, sua opção pela VPR, os debates internos a esta organização e o papel dos militantes osasquenses nos mesmos. Analisaremos a formação da VAR-Palmares, e seu racha posterior, sempre tendo como referencial o GO. Concluiremos essa seção comentado o ocaso da luta armada brasileira, apresentando o destino tomado pelos ativistas oriundos de Osasco, no momento posterior a sua desmobilização pela repressão.

Concluiremos essa pesquisa com uma breve comparação entre as experiências de Osasco e do ABCD dez anos depois. 


\section{Pontos de Partida}


A história operária de Osasco, em sua fragmentação e descontinuidade, (...) certamente expressa uma trama de práticas que permitiram a construção de uma identidade comum, que muitas vezes se perdeu para, em seguida, ser reconstruida a partir de novas instâncias, de novos patamares de organização e consciência.

Cibele Saliba Rizek ${ }^{14}$

\subsection{Vila}

No ano de 1895, Antonio Giuseppe Agu ${ }^{15}$, empresário italiano, natural de Osasco, povoado-distrito do município de San Secondo di Pinerolo, na província de Torino, região do Piemonte, norte Itália, construiu uma estação ferroviária no quilômetro dezesseis da Estrada de Ferro Sorocabana. A nova estação foi batizada com o nome de sua cidade natal, e foi concebida, inicialmente, para receber apenas trens de carga. A região onde foi construída a nova estação era repleta de sítios, e apresentava população escassa.

Os empreendimentos de Agu, nessa localidade, tiveram início por volta de 1887, quanto o mesmo comprou um sítio que pertencia a um certo João Pinto Ferreira, chamado de "Ilha de São João", situado no atual bairro Rochdale. Nesse sítio havia uma olaria, que logo foi ampliada pelo novo proprietário, dando origem a Companhia Cerâmica Industrial de Osasco, concebida em sociedade com o Barão Sensaud de Lavaud, de origem francesa. Em 1892 foi edificada a indústria de cartonagem (papelão) Cartiera, primeira do ramo na América do Sul, em parceria com o industrial Narciso Sturlini. Em sociedade com Enrico Dell Acqua, Agu fundou uma sociedade de importação e exportação, e com este mesmo sócio, também investiu na construção de uma fábrica de tecidos, no ano de 1895.

Para o financiamento desses empreendimentos, foi fundamental a participação do engenheiro italiano Giovanni Bríccola, representante do banco de Nápoles no Brasil. A estação de Osasco teve como função inicial escoar a produção das empresas de Antonio Agu e seus sócios ${ }^{16}$. "Tanto no que se refere a ligação capital-restante do Estado (Santos-Jundiaí,

14 RIZEK, Cibele Saliba. Osasco: 1968. A Experiência de um Movimento. Dissertação de Mestrado. São Paulo: PUC-SP, 1988.

15 Para informações mais detalhadas sobre Antonio Agu: OLIVEIRA, Neyde Collino de; NEGRELLI, Ana Lúcia M. Rocha. Osasco e Sua História. São Paulo: CG Editora e Distribuidora, 1992.

16 Idem, p. 19-21 
Central do Brasil e Sorocabana), quanto a ligação Capital arredores (Cantareira e São PauloSanto Amaro), as estações ferroviárias (...) se constituíram, (...) em pontos de convergência de produtos e pessoas das áreas circunvizinhas. Isto conferia ao local das estações a oportunidade de assumir uma modesta função regional"17

Em pouco mais de uma década, o povoado de população escassa, dedicado a atividades agropastoris, passou a abrigar em suas cercanias quase que uma dezena de indústrias de pequeno e médio porte. A demografia local também passou por marcantes alterações, de vila ocupada por sítios, com população dispersa, a região agora apresentava um núcleo urbano, ocupado majoritariamente por italianos. O empreendedor Agu teve por prática empregar patrícios seus em suas fábricas, e para tanto loteou terrenos para seus empregados, dando início a um processo de urbanização. “A criação do núcleo urbano em Osasco não ocorreu de maneira tão desordenada e vertiginosa como ocorrera nos núcleos operários de São Paulo e Rio de Janeiro. (...) As tensões sociais características das formações urbanas da época não foram sentidas no novo núcleo; as moradias dos operários, juntamente com o terreno, pertenciam a eles, o que não ocorria na maioria das vilas operárias da capital, onde as casas pertenciam à fábrica e o trabalhador pagava aluguel"18.

Há escassos estudos sobre a origem dos imigrantes italianos que povoaram a vila de Osasco em seus primórdios, podemos inferir que estes trabalhadores eram oriundos, em alguma proporção, da mesma região de seus empregadores, com destaque para Antonio Agu, que viera da região do Piemonte. Paquale Petrone, em estudo sobre as origens italianas da industrialização brasileira, indica que os empresários italianos tinham por hábito contratar, para suas fábricas, preferencialmente operários naturais de suas regiões de origem, quando não de sua própria cidade ${ }^{19}$.

Aos italianos, nos primeiros decênios do século XX, juntar-se-iam espanhóis, armênios, russos, judeus, sírio-libaneses, ucranianos, poloneses, alemães, dentre outros imigrantes.

Em 1909 morre Antonio Giuseppe Agu, nove anos depois, o povoado que se formara em torno da estação que recebera o nome de sua cidade natal, foi elevado a categoria de

17 LOPES, Carmen Lúcia do Evangelho. "A Organização Sindical dos Metalúrgicos de São Paulo". Tese de Doutorado. São Paulo: FFLCH-USP, 1992. p.2

18 COELHO, Maria Inês Zampolim; MORETI, Helio Marcos; MESSIAS, Maria do Carmo. Osasco, História e Identidade. Osasco-SP: Editora da Fundação Instituto Tecnológico de Osasco - FITO, 2004. p. 42

19 PETRONE, Paquale. "A influência da imigração italiana nas origens da industrialização brasileira". IN: DE BONI, Luis A. A Presença Italiana no Brasil. Porto Alegre-RS: Fondazione Giovanni Agnelli, 1987. p. 503. 
distrito, por força da lei municipal $\mathrm{N}^{\mathrm{o}} 1634^{20}$.

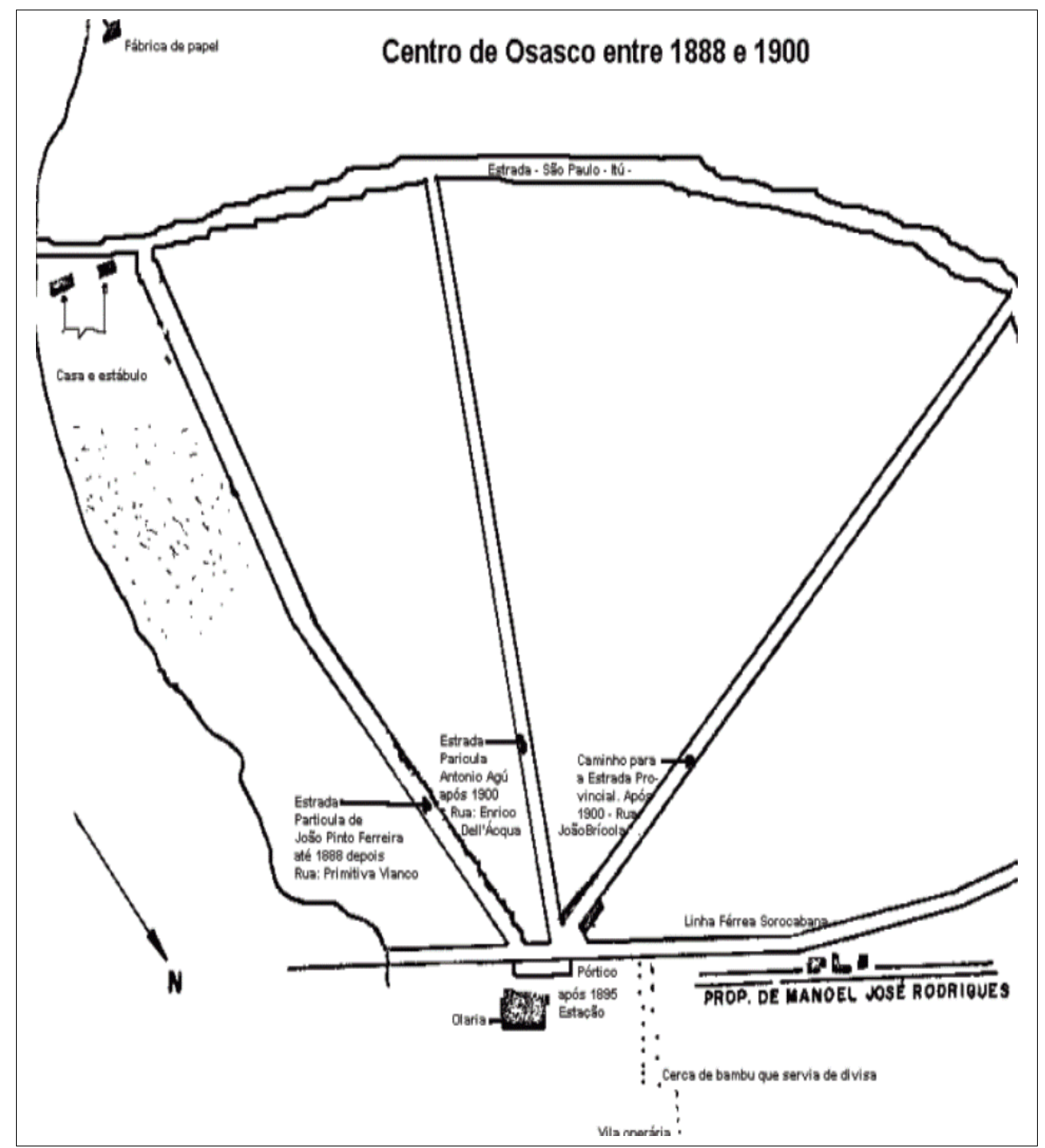

Fonte: Site da Câmara dos Vereadores de Osasco - www.camaraosasco.sp.gov.br

No mesmo ano da morte de Antonio Agu, chega a Osasco um grupo de famílias de origem italiana, cujos chefes haviam sido demitidos da Vidraria Santa Marina após uma greve. Esses imigrantes eram adeptos do movimento anarquista. Cabe aqui um parêntese, pois estes trabalhadores, até onde se tem notícia, introduziram os primeiros rudimentos de organização operária na vila de Osasco.

A Vidraria Santa Maria era de propriedade do Conselheiro Antonio Prado, que detinha o monopólio sobre este setor. Para o ofício em sua indústria, o renomado empresário paulista

20 MARTIM, Sonia. A Escola Secundária e Cidade: Osasco, anos 1950/1960. Tese de Doutorado. São Paulo: PUC-SP, 2006. p. 18 
trouxe da Europa grupos de operários especializados, pois em solo brasileiro não havia profissionais com conhecimentos técnicos na produção industrial de vidros. Boa parte desses profissionais vinha de Marselha, outro tanto da Itália.

A essa altura o movimento anarquista se batia com os comunistas e os socialistas pelo comando das agitações operárias em nível internacional. $\mathrm{O}$ anarquismo era forte sobretudo na Europa meridional, com destaque para Itália e Espanha, e em certa medida Portugal. Também possuía forte incidência em jovens nações capitalistas com diferentes níveis de atividade industrial, como os EUA, Argentina, Uruguai, México; chegando mesmo a alguns países do extremo oriente, com destaque para o Japão. O Brasil, que iniciava seu processo de industrialização de forma tímida, também foi palco de atividades anarquistas.

Segundo John W.F.Dulles, um dos organizadores iniciais do anarquismo no Brasil foi Oreste Ristori, ativista que estivera exilado na Argentina ao lado de Enrico Malatesta, um dos principais teóricos do movimento em discussão. Expulso da Argentina, Ristori passou um tempo no Uruguai, seguindo para São Paulo nos primeiros anos do século XX. Em 1904 Ristori funda, na capital paulista, o semanário anarquista La Battaglia, que era redigido em italiano. A esse semanário se juntariam O Livre Pensador, A Terra Livre, O Amigo do Povo, A Lanterna; dentre outros, todos publicados por anarquistas. Everardo Dias, companheiro de ideias e de prisão do fundador do La Battaglia, o considerava "o maior agitador aparecido no Brasil, orador fluente e ardente, sempre pronto para ação. Realizou centenas de conferências por todo o interior do Estado, agitando as massas trabalhadoras das cidades, vilas e fazendas. ${ }^{21}$. Além de Oreste Ristori e o espanhol Everardo Dias, também se notabilizou na agitação operária brasileira o italiano Gigi Damiani, o espanhol Florentino de Carvalho, o português Neno Vasco, e diversos outros militantes de origem europeia que se espalharam por todo o país a divulgar suas ideias libertárias ${ }^{22}$. A esses imigrantes logo se reuniria toda uma geração de anarquistas brasileiros, tais como Edgard Leuenroth, Benjamin Mota, José Oiticica, etc.

Das diversas correntes do movimento em discussão, a hegemônica no Brasil foi o anarcossindicalismo (ou sindicalismo revolucionário) ${ }^{23}$, tendência que tinha nos sindicatos

21 DIAS Everardo. "História das lutas sociais no Brasil”. Apud: DULLES, John W.F. Anarquistas e Comunistas no Brasil, 1900-1935. Rio de Janeiro: Nova Fronteira, 1977. p. 20. Para a construção do movimento anarquista brasileiro e suas correntes internas, CARONE, Edgard. Movimento Operário no Brasil (18771944). (2 Ed.) São Paulo: Editora Difel, 1984.

22 Idem, p. 20-21.

23 Segundo Ricardo Antunes, "os "sindicalistas revolucionários" acreditavam que somente a greve geral poderia levar à transformação radical da sociedade. Os principais teóricos dessa corrente foram o francês Georges Sorel e o italiano Arturo Labriola. Eles acreditavam que a prática da luta exclusivamente econômica, 
sua principal ferramenta de transformação social, possuindo como premissas básicas a solidariedade operária, a ação direta e a auto-gestão.

A esses ativistas se devem as primeiras greves deflagradas em solo brasileiro no início do século passado. Entre 15 e 20 de abril de 1906 foi realizado o Primeiro Congresso Operário Brasileiro, no Rio de Janeiro, dois anos depois seria organizada a Confederação Operária Brasileira (COB), entidade que buscava reunir sindicatos e federações de trabalhadores que se organizavam por todo o país ${ }^{24}$. Tanto o Primeiro Congresso Operário Brasileiro, quanto a $\mathrm{COB}$, deram-se sob hegemonia política anarquista, embora essa corrente fosse minoritária em relação às demais que atuavam junto aos trabalhadores nacionais. Nessa etapa, os grandes concorrentes dos anarquistas entre as classes laborais brasileiras eram os socialistas, que jamais obtiveram a influência alcançada por seus adversários. O ápice do movimento anarquista no Brasil se deu entre 1917 e 1919, quando grandes paredes foram organizadas no eixo Rio-São Paulo, tendo como ponto alto a greve geral que se deflagrou na capital paulista em 1917. Não obstante, após a fundação do Partido Comunista Brasileiro, em 1922, o movimento anarquista brasileiro entrou em processo de refluxo, até desaparecer quase que por completo dos meios operários nos anos 1930.

Inseridos nesse contexto estavam os funcionários do Conselheiro Antonio Prado, boa parte desses sob influência anarquista. Como era comum na Europa, e em certa medida no Brasil, os patrões tinham por prática custear a moradia de seus operários, e muitos empregadores também arcavam com a educação dos filhos de seus subordinados. O capital reunido para esses empreendimentos, via e regra, vinha de fundos subtraídos dos ordenados dos trabalhadores. Nesse sentido, havia uma vila operária nas cercanias da Santa Marina, no bairro da Lapa. Para cuidar da educação dos filhos desses operários, foi contratado Edmondo Rossoni $^{25}$, um professor anarquista que acabou por se tornar o mentor intelectual dos trabalhadores italianos da vidraria Santa Marina.

Em 1909 houve um movimento paredista na Santa Marina, que partiu da reivindicação por melhores salários para uma centena de menores que trabalhavam na empresa. Esta greve acabou sendo comandada pelos anarquistas de Rossoni. Em medida radical, Antonio Prado

através da ação direta nas fábricas e da deflagração da greve geral, constituía-se na única forma de ação efetivamente revolucionária da classe operária". Para mais informações: ANTUNES, Ricardo. O que é sindicalismo". São Paulo: Editora Brasiliense, 1985. p. 23

24 Ibidem, p. 27-28

25 Edmondo Rossoni prosseguiria com sua atividade anarquista, até ser expulso do Brasil em 1917. Após passar um tempo nos EUA, retornaria a sua terra natal, para se tornar Ministro da Agricultura de Benito Mussolini, seu amigo de longa data. Para informações sobre Rossoni e a greve dos vidreiros da Santa Marina: WERNER, Helena Pignatari. Raízes do Movimento Operário em Osasco. São Paulo: Cortez Editora. 1981. 
demitiu dezenas de funcionários, aqueles que estavam encabeçando o movimento, e os expulsou, junto com suas famílias, da vila operária contígua a sua indústria. Lideradas por Rossoni, essas famílias acabam se instalando em Osasco.

Ainda sob influência do professor anarquista, tais operários se organizaram no intuito de construir na vila uma cooperativa de vidreiros. Sobre projetos dessa natureza no Brasil, Cibele Saliba Rizek comenta:

A idéia da formação de cooperativas, inseridas dentro do clima de um movimento operário nascente, não era nova. Há registros de tentativas desse tipo, que aliás não tiveram êxito, desde 1891 (...). Como expressões de traços distintivos de classe diante de condições de vida e trabalho bastante precárias que marcaram esta fase da industrialização, surgem os ideais de "socorro mutuo" e de solidariedade, mesclados aos apelos às associações voluntárias que ecoavam a partir de correntes anarquistas. As entidades de tipo mutualista podiam se destinar às atividades produtivas ou às de consumo, assumindo contornos extremamente variados, a semelhança do quadro sindical associativo, constituído pelos trabalhadores antes do advento do sindicato único por categoria imposto pelo Estado pós-3026.

Conceitos como cooperativismo, mutualismo e auto-gestão, sempre foram caros aos anarquistas, e perpassam o discurso de todos os seus teóricos, de Proudhon a Bakunin, de Kropotkin a Enrico Malatesta. Destarte, iniciativas como a dos vidreiros do Osasco se insere em toda uma tradição de projetos de cunho libertário, que se apresentavam com uma alternativa a organização laboral e empresarial capitalista.

Além dos interesses utópicos que motivavam os anarquistas italianos liderados por Edmondo Rossoni, outros desideratos se dirigiam ao projeto da cooperativa de vidreiros. Esta iniciativa era vista com bons olhos por industriais concorrentes dos Prado, como os Matarazzo, que se prestaram a financiar a empreitada, intentando quebrar o monopólio da Santa Marina. Mas esse projeto caiu por terra quando um advogado de nome Dr. Morroni, contratado pelos vidreiros para cuidar das questões burocráticas do empreendimento, desapareceu com o dinheiro a ser empregado na futura cooperativa. Logo depois se descobriu que o Dr. Morroni agia a serviço do Conselheiro Antonio Prado, que conseguiu garantir seu monopólio. A cooperativa inconclusa seria edificada no terreno da futura Cobrasma. Apesar da frustração, esses operários permaneceram na vila, e acabaram por se integrar ao ambiente 
local.

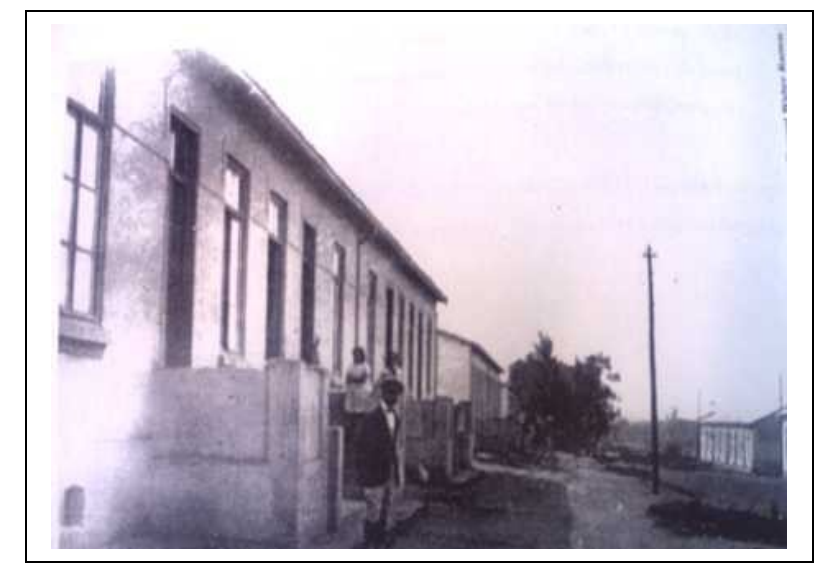

Moradia operária dos trabalhadores da empresa Cartiera, fundada por Antonio Agu em sociedade com Enrico Dell' Acqua, em finais do século XIX. Foto datada de 1928, em Rua de Osasco não identificada. Acervo pessoal de Walter Ramos, disponível no Museu Municipal de Osasco.

\subsection{De vila a bairro operário}

Até os anos 1940, Osasco apresentou um crescimento populacional bastante tímido, aumentando em pouco mais de três mil habitantes entre as décadas de trinta e quarenta. Porém, entre 1940 e 1950, a população desse subdistrito passou de 41.326 habitantes para 114.828, quase triplicando. Esta tendência prosseguiu nas décadas seguintes, e por volta de 1970, a nova cidade terá uma população beirando os quinhentos mil habitantes (ver tabela 1). Esse crescimento populacional foi impulsionado por um surto industrial que atingiu São Paulo e região. Para entendermos tal crescimento, temos que cotejar as intensas transformações político-econômicas pelas quais passou o Brasil ao longo desses anos. 
Tabela I

Evolução populacional do município de Osasco.

\begin{tabular}{|l|c|}
\hline Ano & Número de Habitantes \\
\hline 1934 & 12091 \\
\hline 1940 & 15258 \\
\hline 1950 & 41326 \\
\hline 1960 & 114828 \\
\hline 1970 & 283073 \\
\hline 1980 & 474543 \\
\hline 1991 & 568225 \\
\hline 1994 & 591370 \\
\hline 1996 & 622912 \\
\hline 2000 & 650993 \\
\hline 2005 & 705450 \\
\hline
\end{tabular}

Fonte: Sumário de Dados do Município de Osasco (2000), IBGE (2003) e IBGE (2005).

Disponível em: http://www.osasco.sp.gov.br/arquivos/31/pms_osasco.pdf

Em 1930 tem início a transição da sociedade rural a sociedade urbana no Brasil, este processo trouxe consigo o crescimento das cidades e intensos ciclos de migração interna. De acordo com dados históricos do $\mathrm{IBGE}^{27}$, em 1920, a população brasileira era de 30.635.605 pessoas. Vinte anos depois (não há contagem em 1930), a população atingia a cifra de 41.236.315. Até 1970, esta soma chegaria a 93.139.037 de habitantes, sendo que nesse censo (que abrange a década de 60), pela primeira vez, verifica-se a superação do conjunto populacional urbano sobre o rural $^{28}$.

O estado da federação que mais viu seu contingente populacional crescer, no período em discussão, foi sem dúvida São Paulo. Podemos relacionar tal crescimento a entrada de trabalhadores, pois São Paulo foi o estado que mais atraiu mão de obra, devido a sua concentração industrial. No quinquênio 1946-1950, época da grande arrancada industrial de Osasco, o número de trabalhadores a entrar neste estado foi de 445.389 , sendo que destes, $61.030(13,70 \%)$ vinha de outros países, e 384.359 (86,30\%) vinha das demais regiões do

27 IBGE: Dados Históricos dos Censos. Disponível no endereço eletrônico: www.ibge.gov.br

28 Idem. 
Brasil. Para efeitos de comparação, entre 1901-1905, período em que Osasco iniciava sua urbanização, vieram para São Paulo 205.297 trabalhadores, sendo 193.732 (94,39\%) estrangeiros, e 11.565 (5,31\%) nacionais. A partir do lustro 1936-1940, observa-se um maior fluxo de nacionais, grupo que passou a superar o número de estrangeiros a se dirigir a São Paulo. ${ }^{29} \mathrm{O}$ grosso dessa população se fixou na capital paulista e região.

Não podemos deixar de relacionar o acelerado crescimento industrial paulista ao aumento do contingente de operários fabris. O censo de 1920 já indicava que da porcentagem de brasileiros empregados na indústria, 29,1\% estavam ocupados nas fábricas paulistas, já em 1940 este número chegou a 34,9. Em 1950 chegaria a 38,6 $6^{30}$. Estes números tenderam a subir de forma mais rápida no pós-guerra. "Com efeito, a participação de São Paulo no produto

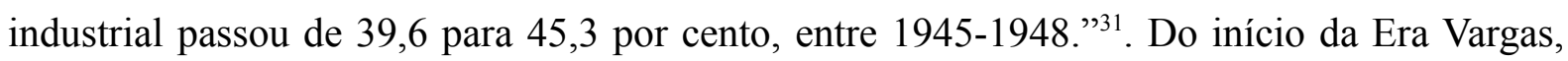
em 1930, até 1939, a produção industrial brasileira mais que dobrou sua participação no valor líquido da produção, passando de $21 \%$ em 1919, a 43,1\%, enquanto a produção agrícola passou, no mesmo período, de $79,0 \%$ a $56,9 \%^{32}$. Esta tendência prosseguiria nas décadas seguintes, e já na segunda metade dos anos 1950 a produção industrial superou a agrícola.

Como visto acima, a população de Osasco pouco crescera nas três primeiras décadas do século passado. Entretanto, ao longo de dez anos, entre 1940 e 1950, a população desse município passaria de 15.258 pessoas, a 41.326, mais que dobrando (ver gráfico 1). Este crescimento veio na esteira da grande expansão industrial que abrangeu toda a região da grande São Paulo. Wilson Cano, em seu estudo intitulado "Raízes da Concentração Industrial em São Paulo", elenca uma série de fatores que contribuíram para o crescimento industrial paulista, sendo que o ponto de partida para essa expansão se encontra no desenvolvimento da economia cafeeira, pois

(...) cabe lembrar que a economia cafeeira de São Paulo foi a que apresentou o maior dinamismo no contexto nacional. Resolvendo pioneiramente sérios problemas de infra-estrutura, como o dos transportes ferroviários, o do porto marítimo, o de comunicações e de urbanização, estava ao mesmo tempo criando um acúmulo de economias externas que beneficiaram a formação industrial, reduzindo-lhe os gastos de inversão e os custos de produção.

29 CANO, Wilson. Raizes da Concentração Industrial em São Paulo. (4a Ed.) Campinas-SP: Editora da Unicamp, 1998. p. 319.

30 FURTADO, Celso. Formação Econômica do Brasil. $6^{\text {a }}$ Ed. Rio de Janeiro: Fundo de Cultura, 1964. p. 273.

31 Idem, ibidem

32 NASCIMENTO, Benedito Heloiz. A Ordem Nacionalista Brasileira. São Paulo: Humanitas/FFLCH-USP, 2002. p. 127-129. 
Além disso, o complexo cafeeiro paulista desde cedo precipitou a gestação de algo não menos importante: a formação e o desenvolvimento de um mercado de trabalho que, dadas as condições em que é formado, e ampliado, resulta em menores pressões nos custos de produção industrial. $\mathrm{O}$ satisfatório desempenho da agricultura paulista, por outro lado, proporcionava grande parte do suprimento alimentar à sua força de trabalho, e garantia o abastecimento local de matérias-primas à indústria nascente ${ }^{33}$

Como sub-distrito de São Paulo, cortado pela Estrada de Ferro Sorocabana, importante via de transporte para o chamado "ouro verde", Osasco também foi tragado pela vaga de crescimento industrial em exposição. Vimos que a urbanização inicial do distrito se deu em torno dos empreendimentos de Antonio Agu, entre o final do século XIX e o começo do XX. Com o desenrolar dos anos, as empresas do município foram se multiplicando de forma gradual, sempre privilegiando a mão de obra imigrante.

Em princípios da década de 1900, Osasco já possuía algumas empresas de pequeno e médio porte, como a Cartiera e a Companhia de Cerâmica Industrial de Osasco, ambas de fundadas por Antonio Agu e sócios . No decênio seguinte, em 1912, surge a fábrica de cerâmica Hervy S/A (antiga Companhia de Cerâmica fundada por Agu); em 1915 os Frigoríficos Continental, em 1923 o Cotonifício Beltramo (nas dependências da antiga fábrica de tecidos de enrico Dell'Acqua); 1929 a SOMA (Companhia Sorocabana de Materiais Ferroviários), 1930 a Fósforos Granada, e em 1934 o Frigorífico Wilson ${ }^{34}$. Até o final dos anos 1930, o surgimento de novas fábricas no município se efetivou de forma lenta, diferentemente do que seria observado na década seguinte, como podemos inferir pelo quadro abaixo. 
Tabela II

Empresas instaladas em Osasco entre 1940 e 1960, por ramo de atividade

\begin{tabular}{|c|c|c|}
\hline Empresa & Ano de Instalação & Ramo de atividade \\
\hline Eternit do Brasil & 1941 & Produto de fibrocimento \\
\hline Cobrasma & 1944 & Material ferroviário \\
\hline Cimaf & 1946 & Artefatos de ferro \\
\hline Santista & 1950 & Tecidos \\
\hline Hoechst do Brasil & 1951 & Química farmacêutica \\
\hline Benzenex & 1952 & Produtos químicos \\
\hline Osram do Brasil & 1955 & Lâmpadas elétricas \\
\hline Asea Brown Boveri & 1957 & $\begin{array}{l}\text { Material elétrico pesado } \\
\left(1^{\mathrm{a}} \text { indústria do ramo na }\right. \\
\text { América Latina })\end{array}$ \\
\hline Ford do Brasil & 1957 & Fundição \\
\hline Braseixos Rockwell & 1957 & Eixos mecânicos \\
\hline White Martins & 1960 & Produtos químicos \\
\hline
\end{tabular}

Fonte: Secretaria dos Negócios da Fazenda da Prefeitura do Município de Osasco. Apud: COELHO, Maria Inês Zampolim, MORETI, Helio Marcos \& MESSIAS, Maria do Carmo. Op. Cit. p. 106

O distrito de Osasco tinha uma série vantagens que lhe propiciaram receber em suas cercanias esse montante de empresas. A primeira delas é a sua localização, a poucos quilômetros do centro de São Paulo. Além da proximidade, o distrito era cortado pela Estrada de Ferro Sorocabana, o que facilitava seu acesso da capital. Já havia uma certa estrutura fabril na localidade, o que auxiliava no recrutamento de mão de obra. Apesar dessa infra-estrutura fabril pré-existente, Osasco não possuía a concentração industrial que outras localidades apresentavam, como os bairros da Zona Leste, situação que propiciava terrenos a preço mais baixo $^{35}$.

Além do material humano já existente na cidade, de origem majoritariamente imigrante, as novas empresas acabaram por atrair grandes somas de migrantes, provindos de diversas regiões do país. O ingresso desses novos moradores alterou a composição étnica do município, que deixou de ser um povoado de imigrantes euro/asiáticos, e passou,

35 SINGER, Paul. Desenvolvimento Econômico e evolução Urbana. São Paulo: Companhia Editora Nacional, 1968. p. $62-63$ 
gradualmente, a ter a mesma configuração das demais regiões da grande São Paulo, com toda sua diversidade étnica e cultural. É necessário frisar que grande parte desse montante que se deslocou para o distrito vinha expulso "de áreas em valorização na capital”, sendo este fenômeno um "resultado dos mecanismos de expropriação que desenham, desde os anos 40, os espaços periféricos de São Paulo"36.

A nova concentração humana também trouxe transformações no que tange a distribuição espacial dos moradores. Observando-se os mapas históricos do município (ver página ...), percebe-se que desde seus primórdios Osasco foi uma cidade concêntrica, com o núcleo populacional reunido em torno da estação central. Desta estação partiam as três principais ruas do distrito, a rua central, que em princípio recebeu o nome de Enrico Dell'Acqua, e posteriormente seria chamada de Antonio Agu. Paralela a essa via, à esquerda, a rua que receberia o nome de Primitiva Vianco; a direita, a Rua João Brícola, renomeada João Batista. No limite das três ruas, a Estrada de Itu, que fazia a ligação terrestre entre a cidade de São Paulo e a região oeste, via que após a emancipação de Osasco recebeu o nome de Avenida dos Autonomistas. Neste triangulo central se encontrava o comércio do distrito; o Cartório de Paz, os colégios locais, os clubes recreativos, o Pronto Socorro distrital, etc. Aqui se concentrava a elite do bairro, formada, em boa proporção, por descendentes dos primeiros moradores.

As margens desse triângulo foram se desenvolvendo os bairros operários, o primeiro com essas características foi o de Presidente Altino, onde se fixou a colônia armênia. Entre as décadas de quarenta e cinquenta, concomitante ao salto industrial, outros bairros operários foram surgindo, como o Quilometro Dezoito, a Vila Yolanda; Jaguaribe, Bela Vista, dentre outros. Desses, talvez o mais característico seja o Quilômetro Dezoito.

Surgido na década de 1920, a partir de militares de baixa patente, que serviam em Quitaúna, o "Dezoito" - como era e ainda é chamado em Osasco - converteu-se em bairro operário após o surgimento de diversas fábricas nas cercanias da sub-região. Ainda nos anos 1930, foram implantadas a SOMA e a Fósforos Granada, a partir da década seguinte vieram a Hoeschst do Brasil, a Osram do Brasil, e a Cimaf. A Cobrasma, de 1941, ficava a pouco menos de um quilômetro de distância. Tal crescimento industrial fomentou a concentração de trabalhadores que deram ao "Dezoito" suas características de bairro operário. Desse período em diante, esse bairro seria palco de intensas agitações operárias, abrigaria diversos sindicatos, e nele seria edificada a igreja da Imaculada Conceição, inaugurada em 1954, a 
mesma que na década seguinte se converteria em paróquia voltada ao movimento operário, tema que discutiremos melhor adiante.

No ano de 1953, o $14^{\circ}$ subdistrito do Butantã era bem diferente do distrito de paz de 1918. Sua população já ultrapassara os quarenta mil habitantes, todo um parque industrial se formara em suas cercanias, e novos bairros surgiam e continuariam a surgir. Como supracitado, o povoamento inicial de Osasco teve características diferentes das demais regiões da cidade de São Paulo e região. Na vila formada a partir de Antonio Agu, formou-se um núcleo inicial de moradores que foi se estabelecendo com um certo isolamento "do centro de São Paulo, onde aconteciam as assembléias dos sindicatos; longe do pulsar frenético da cidade de vocação metropolitana, enfrentando as agruras e as necessidades próprias de uma frente avançada de urbanização, o povoado vivencia uma forma diferente de identidade" ${ }^{37}$. Osasco se desenvolve como um misto de bairro próximo a capital e cidade do interior.

Como supracitado, os descendentes dos primeiros moradores acabaram por se constituir numa espécie de elite local, fixando-se na região central do distrito, dominando o comércio, controlando o Cartório Civil, os clubes recreativos, os primeiros colégios particulares. Eram profissionais liberais, médicos, advogados, professores, dentistas, farmacêuticos; formavam o "escol" econômico e intelectual do bairro distrito. Deste substrato social partiram as lideranças em luta durante o ciclo emancipatório de Osasco, tanto os partidários da autonomia, quanto os contrários.

37 COELHO, Maria Inês Zampolim, MORETI, Helio Marcos \& MESSIAS, Maria do Carmo. Op. Cit. p. 45 


\section{PLANTA FUNCIONAL DE OSASCO - 1952}

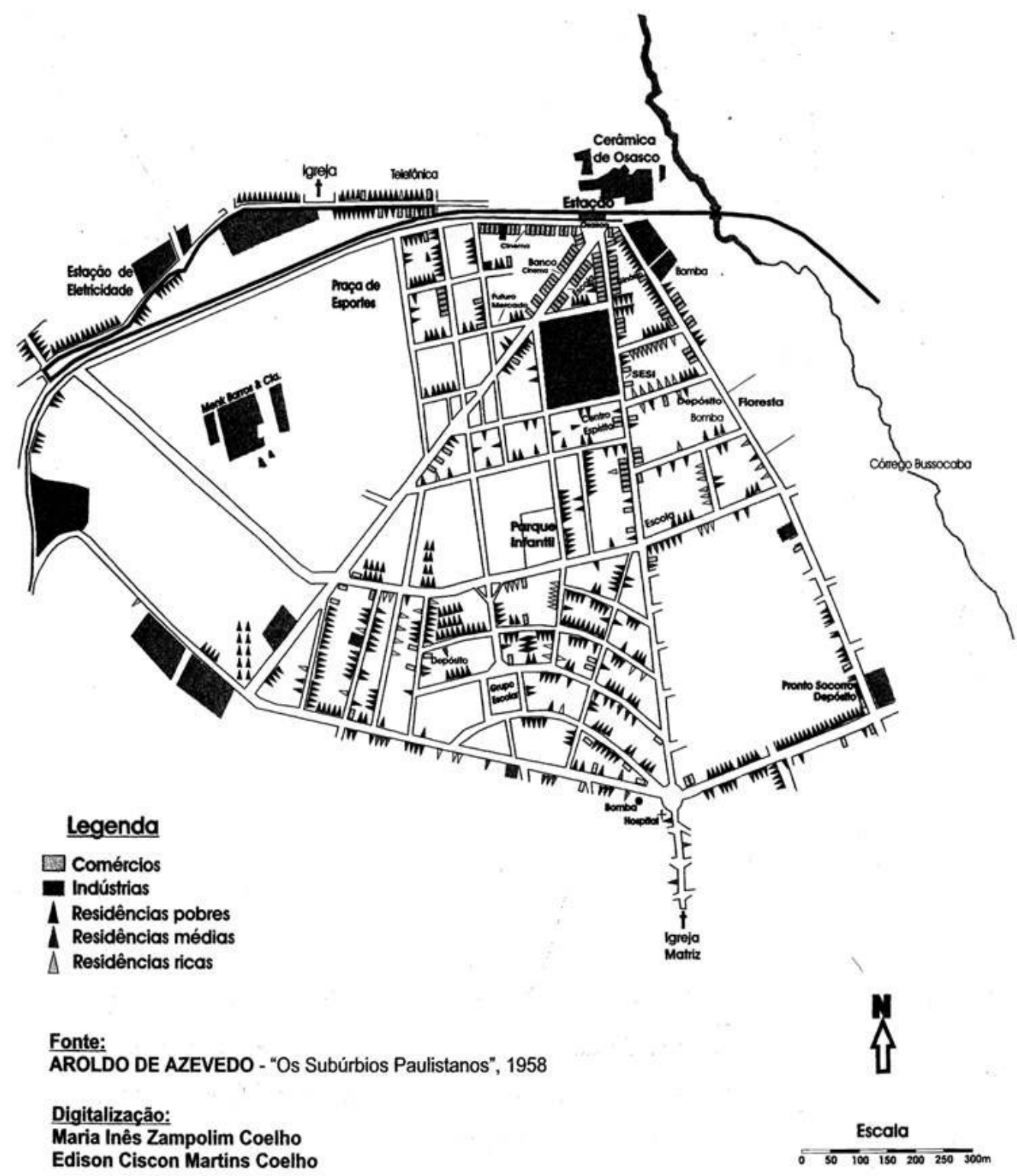

Fonte: COELHO, Maria Inês Zampolim, MORETI, Helio Marcos \& MESSIAS, Maria do Carmo. Op.

Cit. p. 96 
Na cidade de São Paulo, no ano de 1938, tem início a gestão do prefeito Prestes Maia, alcaide nomeado pelo interventor estadual Adhemar de Barros. Esta gestão durou até 1945, e representou o maior surto de renovação urbanística que a capital paulista já tivera em sua história até então. $\mathrm{Na}$ administração de Prestes Maia foram construídos o novo Viaduto do Chá, a Avenida Nove de Julho, o Estádio do Pacaembu, dentre várias outras obras. Toda uma série de novos edifícios foi erguida, o centro da cidade foi expandido, ruas estreitas foram alargadas e convertidas em avenidas ${ }^{38}$. Nesta torrente de transformações, começa chegar ao fim a era do bonde em São Paulo. Em 1946 foi criada a CMTC (Companhia Municipal de Transportes Coletivos), após a criação dessa empresa, a mesma que incorporou a estrutura e os veículos da Light, aos poucos o sistema de bondes e trólebus movidos a eletricidade foi sendo substituído por ônibus a diesel ${ }^{39}$.

Tais mudanças estão relacionadas ao desenvolvimento econômico brasileiro, que veio na esteira da industrialização capitaneada por Vargas a partir do final dos anos 1930, prolongando-se no decênio seguinte, com uma pequena retração na fase Dutra, retornando de forma mais incisiva na década de cinquenta, sobretudo em sua segunda metade. Crescimento que trouxe consigo um maior adensamento populacional, em 1940 a população da cidade de São Paulo já era de 1.337.644 habitantes. Dez anos depois, chegaria a 2.198.096, atingindo em 1970 a soma de 5.978.977 pessoas, numa taxa de crescimento de anual de 5\%, considerando apenas os moradores da capital ${ }^{40}$.

Salientei acima a modernização do sistema de transporte público rodoviário paulistano, pois aqui se encontrava uma das maiores demandas dos moradores dos bairros mais afastados da capital, dentre eles Osasco. A nova empresa de transportes públicos criada pela prefeitura não atendia as áreas mais periféricas do município, ficando restrita a região central da cidade. O percurso até o centro tinha que ser feito através de lotações e ônibus particulares, que chegavam a cobrar três vezes o valor cobrado por uma condução da $\mathrm{CMTC}^{41}$.

38 PORTO, Antonio Rodrigues. História Urbanística de São Paulo (1554-1988). São Paulo: Carthago \& Fortes Editoras Associadas Ltda, 1992. p. 140-145.

39 Idem, p. 153

40 D.J. HOOGAN. "Internal migration, acces to information an the use of urban resources in São Paulo, Brazil. A stude of population adaption in a changing". Economy Cornel University, 1972. In: MOISÈS, José Álvaro. "Classes Populares e Protesto Urbano. São Paulo". Tese de Doutorado. São Paulo: FFLCH-USP, 1978. p. 127

41 DANUSA, Mara. "A Luta pela emancipação". Artigo disponível no Site da Prefeitura de Osasco: www.camaraosasco.sp.gov.br 
Mas esse era apenas mais um dos muitos problemas que assolavam o subdistrito. Como região periférica da cidade de São Paulo, Osasco pouco desfrutou do desenvolvimento coordenado a partir da gestão Prestes Maia. No principal subúrbio da zona oeste paulistana havia sérios problemas de urbanização, como falta de água encanada; asfalto, escolas, hospitais, iluminação, segurança pública. Apesar de seu crescimento industrial nos anos 1940, e de seu expressivo aumento demográfico, fatores estes que acarretavam em uma maior arrecadação de impostos, o $14^{\circ}$ subdistrito permaneceu à margem do desenvolvimento econômico das áreas centrais da cidade.

Tal estado de coisas começou chamar a atenção dos locais, principalmente daqueles que se encontravam entre as camadas sociais médias, e tinham melhores condições de observar de maneira mais crítica o desenvolvimento desigual de sua cidade. Observemos o desabafo de Hirant Sanazar, que futuramente seria o primeiro prefeito do município autônomo de Osasco:

O espaço territorial entre o Butantã e Vila Yara era desprovido de habitações frequentes, não faltando, porém, um posto de fiscalização fazendária, que mantinha uma rígida e infalível "barreira" aos veículos de carga, a exigir a enfadonha nota fiscal sobre toda e qualquer mercadoria destinada ao comércio de Osasco.

A segurança pública se restringia a uma simplória sub-delegacia de polícia, cujo titular era escolhido dentre o partido político em destaque e nomeado pelo governador.

Os professores da escola pública pertenciam à Delegacia de Ensino da Capital, e quase todos procediam dali e não se construíam, por muito tempo, novos prédios escolares.

A conservação das ruas era uma pilhéria, prevalecendo o lamaçal provocado pelas precipitações de copiosas chuvas, que se acumulavam nas partes baixas e as águas pútridas impunham ao povo um interminável sofrimento" ${ }^{\text {42 }}$.

Apesar de carregado, o relato de Hirant Sanazar nos dá mostras da falta de compromisso da prefeitura de São Paulo para com suas regiões mais periféricas. Este descaso seria o principal fator a impulsionar a formação de associações de bairro e de alguns movimentos autonomistas, surgidos em diversos bairros da capital a partir do final da década de quarenta. Dentre esses bairros se encontrava Osasco.

A Constituição democrática de 1946 "trouxe uma série de vantagens aos municípios, entre elas: a posse tributária sobre licenças, impostos prediais e territoriais, impostos sobre a

42 SANAZAR, Hirant. Osasco, Sua História, Sua Gente. Osasco-SP: Edição do Autor, 2003. p. 74 
indústria e profissões a critério das necessidades municipais, além da criação do Fundo de Participação dos Municípios. Assim, muitas obras planejadas e não executadas tornaram-se viáveis" "43. Tais facilidades, agora expressas na Constituição brasileira, mais os fatores supracitados, deram impulso ao processo de emancipações que abrangeu todo o país no período em questão.

A grande de São Paulo, até meados dos anos 1940, possuía em seu perímetro poucos municípios circunvizinhos. Até 1970, a região testemunharia o surgimento de novas cidades, tais como São Caetano do Sul, Diadema, Carapicuíba, Barueri, Jandira, Ferraz de Vasconcelos, Osasco, dentre outras. Para a construção dos movimentos que encabeçaram os processos emancipatórios, que proliferaram na região entre finais da década de quarenta e a de setenta, foram fundamentais as Sociedades Amigos de Bairro, as SAB`s. As SAB's foram definidas por José Álvaro Moisés como "organismos elementares de articulação de alguns interesses econômicos e políticos das classes populares em face do Estado". Embora haja indícios de existência dessas sociedades desde os anos 1920, é a partir da década de quarenta que elas começam adquirir a significação que as inseriu nas lutas sociais urbanas nos decênios seguintes ${ }^{44}$.

Em Osasco, esse fenômeno teve início em finais dos anos 1940, com a criação da SADO (Sociedade Amigos do Distrito e Osasco). Esta entidade foi fundada e dirigida por membros da elite local, dentre o quais se encontravam advogados, médicos, dentistas, jornalistas, comerciantes, etc. Os membros da SADO eram, em sua maioria, descendentes dos primeiros moradores de Osasco, e seu primeiro diretor foi o dentista Reinaldo de Oliveira. As emancipações de São Caetano do Sul, do município de São Bernardo do Campo, e de Barueri, de Santana de Parnaíba, respectivamente em 1948 e 1949, serviram de impulso para os projetos autonomistas da SADO.

Em 1953 se realizou o primeiro plebiscito pela autonomia de Osasco, que resultou em derrota para os emancipacionistas. Pela lei $n^{\circ} 2.081 / 52$, consultas públicas relativas a emancipação de municípios só poderiam ser feitas a cada cinco anos, para que o mandato dos prefeitos das novas cidades coincidisse com o dos demais prefeitos eleitos ${ }^{45}$. Sendo assim, os membros da SADO tiveram que esperar até 1958 para retomar sua empreitada rumo a elevação de Osasco a categoria de município autônomo.

43 DANUSA, Mara. Op. Cit. s/p

44 MOISÉS, José Álvaro. Op. Cit. p. 171-179.

45 MARTIM, Sonia. Op. Cit. p. 69. 
Sobre o plebiscito de 1953 vale frisar dois pontos. O primeiro diz respeito ao caráter elitista que o movimento autonomista osasquense apresentou em sua primeira versão. A SADO, enquanto entidade dominada pelas classes médias locais, não foi capaz de trazer as demais camadas sociais do subdistrito para sua causa. Os adversários da autonomia, que ficaram conhecidos como adeptos do "NÃO", reuniam-se em torno de Lacydes Prado, dono do único cartório instalado no subdistrito. Lacydes Prado publicou no jornal O Estado de São Paulo, em 07 de novembro de 1953, cerca de um mês antes do plebiscito, um manifesto advertindo a população local sobre os possíveis efeitos negativos que a autonomia poderia trazer às suas vidas. $\mathrm{O}$ texto apresentava os membros da SADO com um grupo que visava se locupletar politicamente com a transformação do bairro em município. Nas palavras de Lacides Prado:

Manifesto ao Povo de Osasco: Confiando nele, nesse povo de Osasco, modesto, mas sensato, ordeiro, mas altivo, é que iniciamos hoje, de maneira despretensiosa e simples mas, com veemência, a campanha do "Não" contra a maior calamidade cívica que a demagogia de uns, a ambição de grupelhos e o descaso de muitos poderão acarretar a São Paulo, dês servindo ao Brasil. Não somos políticos e nem visamos partidos ou legendas.

Que interessa-nos, população, dos morros e das baixadas, das vilas de Piratininga, São José, Km 18, Carteira, Quitaúna, Yara, etc. que Osasco tenha o brasão de uma prefeitura que apenas beneficie o larguinho da Estação onde se fazem os conchavos e se alimentam as intrigas políticas, incapazes na sua patente desagregam de ter dado até hoje, de Osasco para Osasco, na edilidade de São Paulo, um só e modesto vereador?

É com isto que vamos deixar de ser cidadãos paulistanos para passar à categoria de interioranos sofrendo percalços morais e materiais de uma atitude que só conseguiria beneficiar políticos, cujas lunetas escuras não permitem que os veja dentro dos olhos, para que alvos dirigem as baterias das suas ambições? Serão para os impostos que majorarão talvez 10 vezes mais?...

Eles são nossos amigos mas se plantaram no alto das suas importâncias e resolveram, quase que à nossa revelia, assunto de tão transcendental importância que nos obrigou a sair do nosso mutismo e gritar bem alto para que todos ouçam: Ou tudo isso corre o risco de um erro de visão que importará no sacrifício moral e material de um povo honesto e trabalhador ou nós nada mais entendemos. Fica a critério, ao teu critério, Povo de Osasco, julgar-nos. ${ }^{46}$

46 Jornal O Estado de São Paulo, 07 de novembro de 1953. Trecho citado por: DANUSA, Mara. Op. Cit. s/p 
Este manifesto foi assinado por figuras influentes da política local, que se congregaram em torno do "NÃO". É evidente que o que estava em jogo eram interesses pessoais de grupos de poder opostos, a demagogia apontada contra os adeptos do "Sim", que estariam atuando em causa própria, não foge aos objetivos daqueles que assinaram o manifesto contra a emancipação. Com a autonomia do subdistrito, Lacydes Prado temia perder os privilégios que tinha enquanto dono do único cartório do bairro. Os demais membros da "turma do NÃO" também possuíam, em alguma medida, interesses ligados a prefeitura de São Paulo, e por isso se batiam contra a cisão. O fato é que o grupo de Lacydes Prado foi mais bem sucedido na campanha junto a população local na consulta de 1953. A restrição do embate sobre a autonomia entre as camadas médias e altas de Osasco foi favorável ao grupo do cartório, pois os mesmos tinham a seu favor a máquina da prefeitura paulistana, enquanto os autonomistas contavam apenas com a militância dos ativistas da SADO. Em que pese toda essa disparidade, todos os testemunhos indicam que houve fraude na primeira consulta pública.

O segundo ponto a se considerar, sobre o primeiro plebiscito, diz respeito às implicações políticas relacionadas a separação de Osasco da capital paulista. O $14^{\circ}$ subdistrito, a época da consulta pública, era uma importante fonte de recursos para a cidade de São Paulo, e sua perda acarretaria em prejuízo aos cofres públicos, principalmente no que concerne a receita proveniente do já ampliado parque industrial osasquense. Exatamente por isso, o prefeito paulistano de antanho, Jânio Quadros, posicionou-se contra a emancipação.

É curioso observar a trajetória em vai e vem de Quadros. Enquanto vereador, teve posição de destaque em defesa das SAB`s, denunciando o abandono das periferias, o que lhe valeu, em 1950, a posição de deputado estadual paulista mais votado. Ainda ocupando o cargo de vereador, aquele que ficou conhecido como "homem da vassourinha" soube aparelhar em torno de seu nome as inúmeras SAB`s que atuavam em sua cidade ${ }^{47}$, e certamente a SADO estava entre elas. Mas, enquanto prefeito paulistano, deu as costas a seus correligionários de Osasco em 1953, e se posicionou francamente contrário a separação de rendoso subdistrito. Já em 1958, ano do segundo plebiscito, fazendo jus a sua política de zigue-zague, apoiou os autonomistas da SADO. Essa mesma política de reviravoltas foi seguida por seus partidários. Antonio Menk, fiel seguidor de Jânio e um dos homens mais ricos de Osasco, em 1953 foi contra a emancipação, porém, em 1958, foi um de seus

47 SINGER, Paul. "Movimentos de Bairro". In: SINGER Paul; CALDEIRA BRANT, Vinícius. (Org). São Paulo: O Povo em Movimento. São Paulo: Vozes, 1980. p 86-87 
defensores mais ferrenhos, tornando-se uma das maiores lideranças do movimento, e seu principal patrocinador ${ }^{48}$.

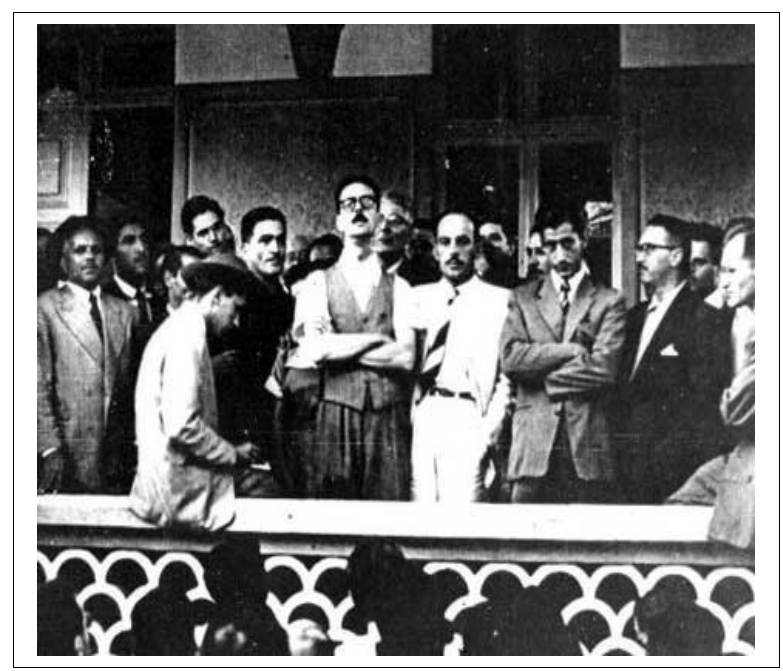

Jânio Quadros e correligionários em Osasco. A essa altura, o líder populista apoiava a emancipação do $14^{\circ}$ subdistrito, quatro anos antes, como prefeito da capital, foi contra. Fonte: Site da Câmara Municipal de Osasco: www.camaraosasco.sp.gov.br

Posição inversa tomaria a outra grande liderança populista do período a atuar no Estado de São Paulo, Adhemar de Barros, outro profissional do malabarismo político. Barros surgira na política como interventor nomeado por Vargas ao governo de São Paulo, em 1937. Em 1953 governava novamente o estado, desta vez eleito pelo povo. Enquanto governador, na conjuntura do primeiro plebiscito, viu com bons olhos a emancipação de Osasco. Já em 1958 a situação se inverteria, e ocupando o cargo de prefeito paulistano, Adhemar de Barros se colocou ostensivamente contra a autonomia.

Em 1958, o processo autonômico de Osasco tomou proporções bem maiores do que em sua primeira versão, cinco anos antes. O novo movimento emancipacionista buscou mobilizar a população nos bairros, organizando comissões entre os moradores, intentando claramente atrair as camadas mais baixas para sua causa. O novo órgão divulgador do movimento passou a ser o semanário "A Vanguarda" (o primeiro periódico pró-autonomia foi “O Emancipador”), jornal que se expressava numa linguagem mais popular, falando direto aos trabalhadores, explicando o conteúdo social que a luta assumia. A campanha agora era feita nos "vagões de

48 PITERI, Guaçu. Sonhar é Preciso: comunidade e política nos anos da ditadura. Osasco-SP: Editora da FIEO, 2008. p. 107 
trem, nos horários de maior movimento, nas fábricas, nas estações, nas ruas" ${ }^{49}$. A turma do "NÃO" voltou a se reunir em torno de Lacydes Prado e seu grupo.

Diferentemente dos demais processos emancipatórios ocorridos na grande São Paulo na época, o de Osasco foi o único a contar com massiva participação popular. A luta pela autonomia contagiou estudantes, operários, donas de casa; não se restringindo a uma contenda jurídica entre lideranças distritais e representantes de municípios sede. Em Osasco, houve participação política de fato, o movimento fugiu do controle aristocrático da SADO e foi as ruas. Nenhum outro processo autonomista da grande São Paulo atingiu dimensões dramáticas como as verificadas no $14^{\circ}$ subdistrito, onde se observou uma luta que se estendeu por quase dez anos, repleta de episódios simbólicos.

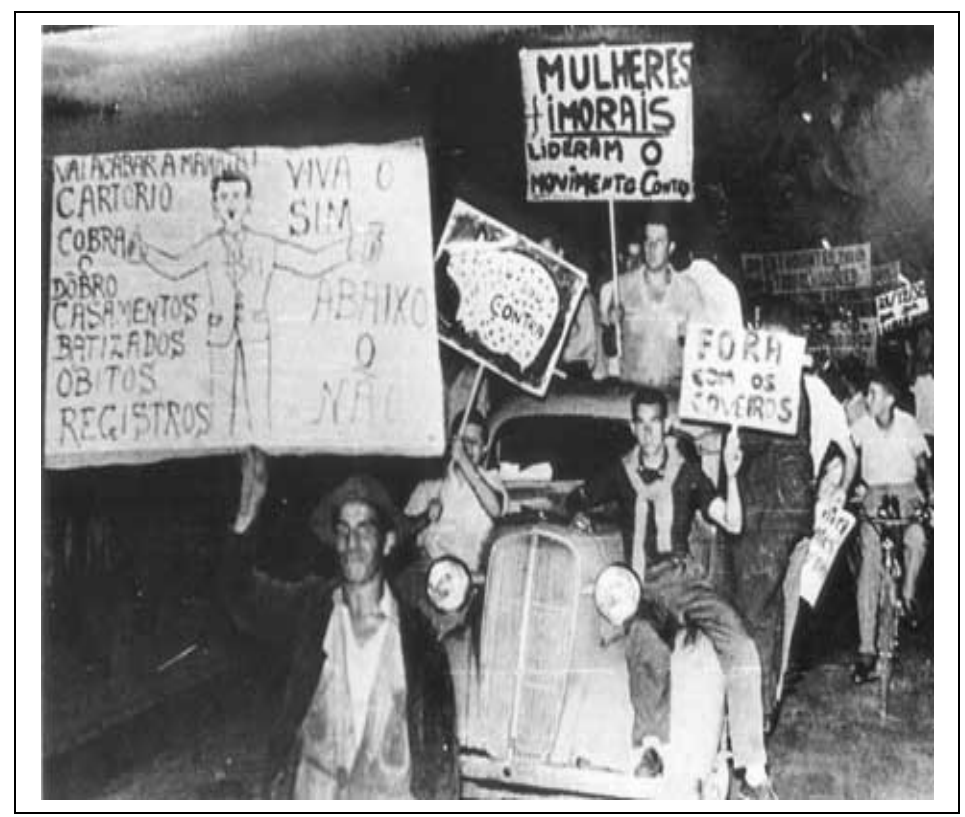

A luta entre o "SIM" e o "NÃO" pela emancipação de Osasco, a época do segundo plebiscito, efetuou-se em agressivas campanhas de rua, que não raro descambaram em agressões vindas dos dois lados. Pelo conteúdo das faixas dos autonomistas expostas acima podemos medir a agressividade da contenda. Site da Câmara Municipal de Osasco: www.camaraosasco.sp.gov.br

O grupo do "NÃO" jamais se fez de rogado, lutou com as armas que tinha a disposição para defender suas posições, e soube apelar para todas as instâncias em defesa de seus interesses. Pelas palavras de Guaçu Piteri, janista e autonomista em 1958, observamos que nenhum argumento do grupo contrário a emancipação

49 MOISÉS, José Álvaro. Op. Cit. P. 320-321 
(...) era mais decisivo do que a ameaça de extinção do popular serviço de lotação entre o bairro e o centro e São Paulo. A população ficaria privada da opção de transporte e os motoristas, de emprego. Essa ameaça mobilizou a poderosa categoria dos motoristas de lotação e de táxi que, preocupados com a própria sobrevivência, uniram-se numa frente radical, no combate a autonomia ${ }^{50}$.

A acirrada disputa pela separação municipal terminou com a vitória do "SIM", por uma diferença de 1283 votos. Seis dias depois a Assembleia Legislativa votou a lei que criou o novo município. Osasco se constituiu em município pela Lei $\mathrm{n}^{0} 5.121$, de 27 de dezembro de 1958, sancionada pelo governador Jânio Quadros e pelo secretário de Justiça Dr. Pedroso Horta $^{51}$. Mas a disputa prosseguiria, agora pela via judicial, pois o prefeito de São Paulo, Adhemar de Barros, recorreu da decisão da Assembleia Legislativa, alegando ter havido irregularidades no pleito que decidiu pela emancipação. Após pedido negado em âmbito estadual, o prefeito paulistano recorreu a instancias federais, que acolheram o recurso. A primeiras eleições municipais que estavam marcadas para 4 de outubro de 1959 foram suspensas. O fato é que os autonomistas recorreram ao mesmo expediente utilizado pela "turma do cartório" em $1953^{52}$.

A refrega jurídica se arrastaria até janeiro de 1962, dando início a terceira fase da luta autonomista. Nesse período se observa uma maior participação popular, adquirindo a luta caráter de massa. Tempo em que se verifica grande participação por parte dos secundaristas, das associações bairro, como as SAB's do Jardim Helena Maria, Vila Iara e Bussocaba, e um maior comprometimento por parte do operariado local. Pelas conclusões de Cibele Saliba Rizek:

O clima que sobrevém à fase final e à vitória dos emancipacionistas é claramente um clima de participação, o que se configura na imagem da constituição do município como conquista popular. (...)

Não me parece, assim, que se possa dimensionar o movimento autonomista simplesmente por um corte de classe, nem que esse corte possa ser observado em todas as fases do movimento. Do ponto de vista de sua composição, de sua base, sobretudo na última fase, o movimento foi heterodoxo. Suas repercussões nos anos 60, distintas e conflitantes com as iniciativas que lhe deram impulso,

50 PITERI, Guaçu. Sonhar é Preciso: comunidade e política nos anos da ditadura. Op. Cit. p.104

51 COELHO, Maria Inês Zampolim, MORETI, Helio Marcos \& MESSIAS, Maria do Carmo. Op. Cit. p. 116

52 O jornal paulistano Diário da Noite, na edição do dia 3 de junho de 1959, trazia matéria cujo título dizia: "Até mortos votaram em Osasco". A fraude no plebiscito de 1958 foi de conhecimento público, para mais informações sobre o ocorrido consultar: OLIVEIRA, Neyde Collino de, \& NEGRELLI, Ana Lúcia M. Rocha. Op. Cit. p. 96. A reportagem do Diário da Noite está disponível no Museu Municipal de Osasco. 
podem ser atribuídas à forma como estudantes e trabalhadores acabaram por tentar se apropriar de parcelas de um espaço político que não foi criado por seu próprio movimento. ${ }^{53}$

De fato, a conquista da autonomia foi tomada como uma vitória de todos os grupos que de alguma forma estiveram envolvidos na luta emancipacionista, principalmente em sua última etapa, entre 1958 e 1962. Data desta fase a criação da UEO (União dos Estudantes de Osasco), o início das atividades da FNT (Frente Nacional do Trabalho); e da ACO (Ação Católica Operária) na região. Futuramente, nos eventos em comemoração pela autonomia, predominaria a imagem da sua composição no último estágio da lua, expressa em murais, livretos, encenações; ficando para a posteridade a ideia da emancipação como uma conquista popular.

Após a longa contenda judicial, as eleições para a prefeitura do novo município foram marcadas para janeiro de 1962. Nessa época, o prefeito de São Paulo era novamente Prestes Maia, e assim como seu antecessor Adhemar de Barros, entrou com um mandado de segurança contra a cisão. Tal atitude gerou grande revolta entre os locais, o comércio "fechou as portas em sinal de luto, várias pessoas rasgaram seus títulos, em protesto". Em 11 de janeiro de 1962 "foi acesa uma Pira Simbólica na Praça João Pessoa” (atual Antonio Menk), trazida da Pira do Ipiranga. A chama só seria apagada após a liberação das eleições pela justiça. Essa manifestação reuniu milhares de pessoas. Por fim, no dia 17 de janeiro de 1962, o Supremo Tribunal Federal reconheceu a autonomia de Osasco, e em 4 de fevereiro do mesmo ano foram realizadas as primeiras eleições municipais do antigo subdistrito.

O primeiro prefeito eleito da cidade caçula da grande São Paulo foi Hirant Sanazar, do PRT. O candidato preferido pela SADO, Antonio Menk, da coligação PDC-UDN-PTN, janista, ficou em segundo lugar. Os primeiros a se baterem pela autonomia de Osasco jamais conseguiriam dominar seu município politicamente. Esses ativistas futuramente formariam a Ordem dos Emancipadores de Osasco, entidade com feições de seita, ou loja maçonica, a margem do poder local ${ }^{54}$.

53 RIZEK, Cibele Saliba. Op. Cit. P. 34-35

54 Para mais informações sobre a Ordem dos emancipadores de Osasco consultar o site: emancipadoresosasco.org.br 


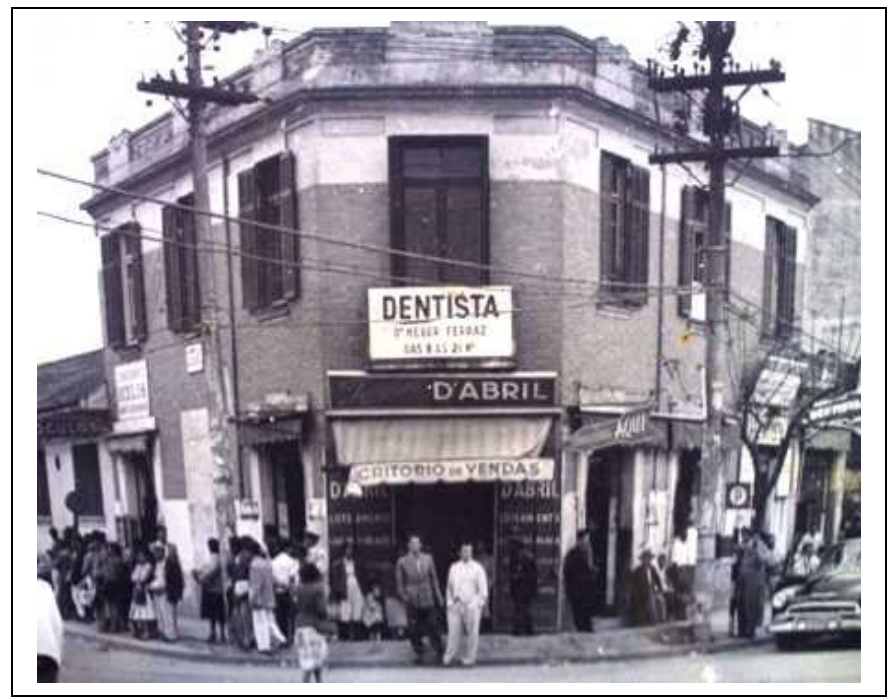

Osasco no início da década de sessenta, esquina entre as ruas Antonio Agu e João Batista, centro nervoso do município. Fonte: Museu Municipal de Osasco

\subsection{Cidade Vermelha}

No longo inquérito produzido pelo DEOPS-SP sobre a organização guerrilheira Vanguarda Popular Revolucionária (VPR), concluído no ano de 1971, há referências sobre as cinco fases da "guerra revolucionária", que segundo os órgãos de repressão estaria sendo travada no Brasil. O conceito brasileiro de "guerra revolucionária" é derivado do francês guerre révolutionnaire.

O desenvolvimento de metodologias anti-guerrilha surgiu na França, em meados da década de cinquenta, após a derrota militar de Dien Bien Phu, em 1954, quando os vietnamitas, liderados por Ho Chi Min, conquistaram sua independência frente ao império colonial francês. No mesmo ano de Dien Bien Phu, começaram as atividades da FLN (Frente de Libertação Nacional) na Argélia. Com o propósito de não repetir os mesmos erros cometidos na Indochina, os franceses desenvolveram novas técnicas militares, baseadas no conceito de guerra irregular, ou guerrilha. Os novos métodos de combate contra-insurrecional chegaram ao Brasil antes mesmo do golpe de 1964, e tiveram como principal polo de divulgação a Escola Superior de Guerra ${ }^{55}$. Por volta de 1968, concepções advindas da

55 MARTINS FILHO, João Roberto. “A Influência doutrinária francesa sobre os militares brasileiros nos anos de 1960". IN: Revista Brasileira de Ciências Sociais. Vol. 23, nº 67. 
doutrina da guerre révolutionnaire norteavam as ações de todos os aparatos repressivos da ditadura. A seção do DEOPS-SP também se fiava pelos métodos franceses, e com base nos mesmos, elaborou um cronograma acerca da "guerra revolucionária" que estaria sendo travava em solo brasileiro. A doutrina francesa foram adicionados conceitos procedentes de escritos de teóricos comunistas como Ernesto Che Guevara, Regis Debray, Ho Chi Min e Mao Tse Tung. Baseado em todo esse corpus documental, os técnicos dos serviços de informação e segurança concluíram que a luta revolucionária executada no Brasil se dividiria em cinco fases, sendo estas:

$1^{\text {a) }}$ O Alerta de Opinião: quando aparecem organizações clandestinas, há arregimentação da opinião pública, aparecem os "ativadores", surgem "slogans", como por exemplo "linha dura", isso para quebrar a unidade do Governo, etc...

$2^{\text {a) }}$ Fase de Infiltração: num trabalho silencioso e clandestino, vão (os revolucionários comunistas) conquistando postos na administração.

$\left.3^{a}\right)$ Fase Subversiva: esta fase compreende três sub-fases, a saber:

a) Desencadeamento de Greves (para testar o que chamam de organismo repressor; a receptividade e até onde o governo pode impedir a greve - exemplo, a última greve de Osasco, em nosso Estado) - grifo nosso.

b) Sub-Fase do Terrorismo: eclosão de bombas

c) Aparecimento dos Grupos Armados Guerrilheiros

$4^{\mathrm{a}}$ ) Fase Liberal: Governo Revolucionário paralelo ao governo legal constituído.

$5^{\text {a) }}$ Marcha de Libertação: Exército de libertação nacional; tomada do poder pelo Governo Revolucionário. Isso foi o que mais ou menos aconteceu em Cuba com Fidel Castro e com Tito na Iugoslávia. ${ }^{56}$

56 Arquivo do Estado de São Paulo, acervo DEOPS, pasta OS-0239. Inquérito VPR/VARPALMARES/REDE/MRM 
Os "Anos de Chumbo" serão analisados com mais detalhe adiante, por ora nosso objetivo é sublinhar a forma como Osasco era apontada pelos aparelhos de repressão da ditadura. Para os órgãos repressores, a luta armada no Brasil chegou a "sub-fase c", da " 3 " Fase Subversiva", o que motivou a formação de todo um aparato de defesa, muito superior ao de seus oponentes "subversivos". Nessa escalada, a "sub-fase a" da "3 Fase Subversiva" teve como elemento ativador a Greve de Osasco, ocorrida em julho de 1968.

O município em questão atraiu definitivamente a atenção dos militares depois da greve de julho, movimento que desencadeou uma ostensiva ocupação militar da cidade, com dezenas de presos, intervenção no sindicato dos metalúrgicos local, dissolução das entidades estudantis; das associações de bairro. Mas as atividades "subversivas" locais não se resumiram a paralisações inciadas em 16 de julho de 1968, elas foram muito além disso. Todo um movimento social de caráter revolucionário se desenvolveu no município, penetrando em suas estruturas político-sociais, e com pretensões hegemônicas. Os serviços de informação do regime autoritário sabiam disso, e por esse motivo enquadraram Osasco como "cidade vermelha".

O termo "cidade vermelha", ao que tudo indica, é de origem militar. Foi utilizado, ao logo do tempo, para identificar municípios que apresentavam altos índices de contestação popular. Esta contestação pode ser verificada através de greves, distúrbios sociais, atividades comunistas, ou "subversivas"; ação do clero católico progressista, voto de protesto, popularidade de políticos de esquerda ou não alinhados aos blocos de poder conservadores. $\mathrm{O}$ termo em questão também apresenta viés jornalístico, sendo utilizado em reportagens e editoriais, e pode ser de dimensão apologética ou pejorativa. Apesar de não constar a expressão "cidade vermelha" no inquérito do DEOPS-SP com relação a Osasco, é certo que este município era encarado desta forma pelos militares, o que se pode comprovar pelo enquadramento que recebeu o município no cronograma da "guerra revolucionária" que estaria sendo travada no Brasil. A intensa repressão que a cidade sofreu, após a greve de julho de 1968, também nos dá indícios da forma como Osasco era vista pela comunidade de informações da ditadura.

Muitas cidades brasileiras receberam tal designação ao longo do século XX, e esse termo foi explorado jornalisticamente através de outras variantes, como "Moscouzinha brasileira"; "Moscou brasileira", "Barcelona Brasileira", dentre outros nomes. Nenhuma localidade recebeu tal alcunha gratuitamente. Podemos citar algumas cidades ou regiões que 
se destacaram por sua intensa atividade de caráter esquerdizante, como Recife (e região), Santos (baixada), Niterói, Ribeirão Preto, Sorocaba; a região do $\mathrm{ABCD}$, em São Paulo. Algumas dessas cidades tiveram picos de agitação concentrados em determinadas épocas, como Ribeirão Preto, Sorocaba, Volta Redonda, etc.

Podemos mencionar o exemplo de Santos, cidade de "muitos epítetos", tais como "Barcelona brasileira", "Cidade Vermelha", "Moscouzinha", "Porto Vermelho", "Cidade de Prestes", "República Sindicalista" "57. A cidade de Santos, ao longo do século XX, sempre foi estratégica para as atividades do PCB, pois se tratava do principal porto de exportação de café brasileiro, e também a porta de entrada dos produtos importados do mundo capitalista desenvolvido. Ainda no século XIX, o médico Silvério Fontes, através de seu quinzenário $A$ Questão Social, jactava-se da formação da primeira agremiação de natureza socialistamarxista no Brasil, o Centro Socialista de Santos, e sobre o mesmo, dizia "ter iniciado, entre nós, a propaganda da doutrina reformadora que se estribava no trinômio marxista: interpretação materialista da História, determinismo econômico e luta de classes $^{58}$.

Mesmo antes das atividades do Partidão, Santos já era foco de agitação operária. Em 1920, o município abrigava uma população estrangeira que representava $35,6 \%$ do total de habitantes, e nestes, havia um expressivo contingente de espanhóis e italianos, que eram superados apenas pelos portugueses ${ }^{59}$. Como vimos acima, os introdutores do pensamento anarquista no Brasil foram trabalhadores oriundos, em sua maioria, da Espanha e da Itália. Esses anarquistas foram os primeiros a organizar politicamente os portuários e demais categorias profissionais da baixada. A série de greves de matriz anarco-sindicalista, que tomou conta do eixo Rio-São Paulo no segundo decênio do século passado, também teve Santos como cenário, o que valeu a cidade seu primeiro apelido, o de "Barcelona Brasileira". Após 1922, a liderança anarquista sobre os trabalhadores da baixada santista começou ser superada pela dos comunistas, como aliás se observou em todos os meios operários organizados no país.

No ano de 1935, os portuários de Santos já se encontravam sob esfera de influência do PCB, e esse estratégico município fazia parte dos planos revolucionários de Luís Carlos Prestes e da ANL (Aliança Nacional Libertadora). O homem a comandar o levante na baixada seria o líder tenentista Miguel Costa, também chamado de “o General Estivador”. Este militar

57 TAVARES, Rodrigo Rodrigues. A Moscouzinha brasileira: cenários e personagens do cotidiano operário de Santos (1930-1954). São Paulo: Associação Editorial Humanitas/FAPESP, 2007. p. 29

58 Periódico A Questão Social, citado por: DULLES, John W. F. Op. Cit. p. 22

59 Idem, p. 42 
era muito popular entre os portuários, e seu prestígio ajudou a engrossar as fileiras da ANL na cidade. Porém, os planos aliancistas naufragaram devido a uma ação preventiva realizada pela polícia local, após informações fornecidas por infiltrados, pouco antes de estourar o levante comunista no nordeste ${ }^{60}$.

Apesar de toda repressão que se abateu sobre a cidade, o PCB local soube se reconstituir e recuperar sua influência no arrefecer do Estado Novo. Em princípios da década de sessenta, Santos já retomara sua tradição de cidade vermelha. Nessa fase, quase todos os sindicatos da baixada estavam sob influência do PCB, e o prestígio dos comunistas se espraiava aos movimentos sociais, políticos e culturais de toda região. Foi a época da "República Sindicalista”, alcunha reforçada após a concessão do título de cidadão santista ao presidente João Goulart, em 1964. Em depoimento a Percival de Souza, o coronel Erasmo Dias afirma que no período anterior ao golpe, "Santos foi considerada como "cidade vermelha", com todos os sindicatos controlados pelo Partido Comunista do Brasil (sic). O general comandante da área, Carlos Buck, era o primeiro dos chamados onze "generais do povo"61. Erasmo Dias, comandante da $3^{\text {a }}$ Bateria de Obuses de Costa, no Forte do Andradas, Guarujá, entre 1962 e 1965, seria um dos grandes articuladores da repressão política a baixada santista durante o ciclo autoritário. Vale observar o relato sobre sua participação na ofensiva dos militares na região, apesar de longo, seu depoimento diz muito sobre a combatividade dos trabalhadores locais:

$\mathrm{Na}$ tarde de 31 de março, tivemos conhecimento do movimento em Minas, ocasião em que mantivemos nossa tropa em condições de a qualquer momento cumprir ordens. Situação difícil, eis que todas as outras unidades $-2^{\circ} \mathrm{BC}, 6^{\circ} \mathrm{GACosM}$ e a Capitania dos Portos, bem como o generalcomandante e seu chefe de Estado-maior - eram contrárias ao regime. Os demais, omissos. Nessa tarde de 31 de março o sindicalismo peleguista-comunista ocupou a Refinaria Presidente Bernardes e a Cosipa, em Cubatão, certo de que a revolução comunista se deflagrara. (...)

Recebemos ordens de "manter e garantir a refinaria de Cubatão a fim de assegurar o combustível indispensável". Não podemos dispor de nossa tropa, eis que o general-comandante não estava engajado na contra-revolução, inclusive se recolhendo ao Forte de Itaipu a fim de não ser encontrado. Fui autorizado a dispor de elementos da Polícia Marítima de Santos, órgão do governo de Adhemar de Barros, com a qual me fiz presente na refinaria, por volta de 11 horas da noite. Estava ocupada pelos

60 Ibidem, p. 119-131

61 SOUZA, Percival de. Autópsia do Medo: vida e morte do delegado Sérgio Paranhos Fleury. São Paulo: Globo, 2000. p. 416. 
"bonés vermelhos" dos pelegos-comunistas, ameaçando explodir a refinaria caso pretendêssemos ocupá-la. Eu, major, e meu oficial de operações, capitão Ribeiro, ambos portando metralhadoras, mantendo elementos da Polícia Marítima do lado externo, como se fossem nossa cobertura, adentramos a refinaria sob apupos e vaias, e mesmo xingamentos de todo tipo, além das ameaças de explosão de dois enormes carros-tanque de amônia que bloqueavam a entrada principal. Entramos os dois e nos dirigimos à Superintendência, onde estava o almirante Zavataro, pelego comunista ligado ao general Osvino, presidente da Petrobrás, da mesma linha ideológica. Alto e bom som, ante o espanto do almirante, declaramos que ocupávamos a refinaria manu militari, por ordens do generalcomandante do II Exército. Momentos difíceis, de grande tensão. Nos dias $1^{\circ}$ e 2 de abril, consolidado o movimento contra-revolucionário e a duras penas mantido certo o controle interno, a refinaria, paralisada por 21 dias, retornou ao seu funcionamento sob nova direção, com apoio de nossa tropa, que garantia a segurança. $(. .)^{62}$

De certo que Erasmo Dias carrega nas tintas e supervaloriza sua atuação no evento, mas não podemos deixar de considerar o movimento de resistência que uniu operários e militares em defesa do governo João Goulart, e mais do que disso, em defesa de suas posições corporativas enquanto grupo. Após o Golpe, houve um expurgo inicial que afastou de seus cargos milhares de brasileiros que de alguma forma estiveram engajados no modelo político deposto, e certamente essa foi a sorte de boa parte daqueles que ocuparam as refinarias de Cubatão em março de 1964.

Uma vez no poder, os militares perseguiram todas as lideranças sindicais da baixada santista e mantiveram a maior parte dos sindicatos locais sob intervenção. O prefeito santista, José Gomes, foi deposto e em seu lugar tomou posse um interventor militar. A partir de então, Santos seria considerada área de segurança nacional. Essa cidade ainda teria a oportunidade de eleger mais um prefeito por voto direto, mas a partir de 1968, todos os gestores do município passaram a ser nomeados pelo governo militar. Somente em 1983 o povo santista teria a oportunidade de escolher seu prefeito novamente.

Outro exemplo notório de cidade vermelha, por nós destacado, é o Recife. Nenhuma região brasileira teve uma história tão marcada por lutas sociais como a capital do estado de Pernambuco. Em seu livro de memórias, o pernambucano Paulo Cavalcante, militante do PCB e ex-deputado estadual por seu estado, narra as agitações sociais de sua cidade, da Coluna Prestes até a queda do governador Miguel Arraes, em 1964. Por suas memórias, observamos que ao longo do século XX, a capital pernambucana esteve envolvida de forma 62 Idem, p. 418 
intensa nos momentos mais críticos do panorama político-institucional brasileiro, arrefecendo sua combatividade somente após o ciclo militar que se iniciou em 1964. Agitações foram vistas na região na conjuntura da Revolução de 30, no ciclo de atividades a ANL, no levante comunista de 1935, quando Recife foi palco de violentos confrontos entre insurgentes e forças de segurança fiéis ao governo central. Durante o Estado Novo, a região foi duramente afetada pela repressão governamental, e nos estertores da ditadura Vargas, protestos violentos foram verificados nas ruas recifenses.

Dentre os fundadores do PCB estava o pernambucano Cristiano Cordeiro, principal liderança comunista em seu estado. Seu trabalho de base e sua solidez teórica ajudaram a transformar o PCB num partido de massas em Pernambuco. Nas eleições constitucionais de 1947, os pecebistas dominaram as cadeiras da câmara municipal de Recife. Em Jaboatão dos Guararapes (chamada de Moscouzinho), foi eleito prefeito Rodrigues Calheiros, reconhecidamente comunista. O Partidão também conseguiu forte representação em Olinda, São Lourenço, Paulista, Carpina, Moreno, Cabo e Paudalho. Representando o estado se elegeram três deputados federais pela legenda, dentre eles Gregório Bezerra, um dos líderes do levante de $1935 .{ }^{63}$ Ao longo dos anos 1950, o PCB foi conquistando posições em Pernambuco, até se tornar uma das principais forças políticas desse estado.

Nessa fase desponta a liderança de Miguel Arraes, um advogado de origem cearense, que iniciara sua vida profissional trabalhando no IAA (Instituto do Açúcar e do Álcool). Posteriormente, foi nomeado secretário de fazenda no governo de Barbosa Lima Sobrinho. Ingressou na carreira política em 1954, sob a legenda do Partido Social Trabalhista, ocupando a cadeira de deputado estadual. Em 1959 foi eleito prefeito da capital pernambucana, numa coligação que ficou conhecida como "Frente do Recife", reunindo PST, PCB (ilegal) e setores do PSD. Sua gestão na prefeitura recifense entraria para a História como uma das mais progressistas a administrar o município até então. Sobre um dos projetos mais arrojados da prefeitura de Arraes, observemos as palavras de Paulo Cavalcante, que trabalhou na gestão como secretário de administração:

O ponto mais alto da administração de Miguel Arraes foi o Movimento de Cultura Popular. O MCP era basicamente uma idéia do próprio Arraes, posteriormente ampliada por seus assessores. A

63 CAVAlCANTE, Paulo. O caso eu conto, como o caso foi. ( $3^{\text {a }}$ Ed.) Recife-PE: Editora Guararapes, 1980. p. 229-231 
princípio, o MCP consistia na criação de escolas para o povo, aproveitando salas de associações de bairros, de entidades esportivas, de templos religiosos (...).

No começo, era só um plano de alfabetização de adultos, completando o vazio deixado pela rede de ensino escolar mantida pelo Estado e por particulares.

Chamados a colaborar com a Prefeitura, intelectuais e artistas ampliaram os planos iniciais, elastecendo os horizontes do movimento. Tratou-se, em primeiro lugar, de fundar uma entidade jurídica, com estatutos, sede, diretores e corpo de colaboradores. Na própria discussão dos estatutos do MCP, as idéias cresceram, dilatando o campo das iniciativas, antes definindo-a conceptualmente. Era o ano de 1960, fértil em cometimentos dessa natureza em todo território nacional. Visava o MCP, agora, além da alfabetização, elevar o nível cultural das massas, conscientizando-as paralelamente. Ao ensinar-se a ler a um adulto, não se recorreria mais ao jogo simbólico de palavras e sílabas, abstratamente situados em seu universo social, do "ovo" e da "uva", do "menino corre da bola", da "ave" e da "ema".

Pretendia-se alcançar uma meta mais ligada a vida, o homem reencontrando na escola as suas raízes telúricas e culturais adormecidas, dentro de um mundo social alienante, aprendendo a ler realisticamente, a educação como um fulcro para elevá-lo e projetá-lo no seu meio. ${ }^{64}$

Esse revolucionário método pedagógico foi desenvolvido por educadores como Anita Pais Barreto, Norma Coelho, Josina Godói e Paulo Freire, o mais renomado do grupo. Tal metodologia de ensino seria adotada pela CNBB (Conferência Nacional dos Bispos do Brasil), e universalizada através do Movimento de Educação de Base, o MEB, a partir de $1961^{65}$. O MCP serviria também de inspiração para a criação do CPC (Centro Popular de Cultura) da UNE, criado em 1962. Mas esse foi apenas um dos projetos da gestão Arraes, também foram desenvolvidas atividades na área de saúde pública, dando proeminência a medicina preventiva, em campanhas que utilizavam literatura de cordel em sua peças; projetos de modernização urbanística, de transporte público, saneamento básico, dentre outros.

Todo esse sucesso terminou por levar Arraes ao governo estadual, em 1962. Os projetos da prefeitura foram agora ampliados para todo o estado. Talvez o grande projeto da gestão Arraes no governo de Pernambuco tenha sido o Estatuto do Trabalhador Rural. As leis trabalhistas promulgadas por Vargas, ainda nos anos 1940, jamais tiveram acolhida entre os latifundiários do nordeste, que continuaram explorando seus empregados através de práticas

64 CAVALCANTE, Paulo. Op. Cit. , 1980. p. 302

65 Idem, p. 304. 
que muitos apontavam como análogas as medievais. O Estatuto da Terra levou direitos básicos aos trabalhadores rurais pernambucanos, como direito a jornada de oito horas diárias, férias, descanso remunerado, organização sindical. Desde meados da década de cinquenta, o campo pernambucano assistia a emergência das Ligas Camponesas, lideradas por Francisco Julião, fenômeno que acirrava as tensões entre trabalhadores rurais e grandes proprietários de terras. O governo de Arraes buscou mediar os conflitos de classe no campo, controlando o radicalismo de ambas as partes, mas sempre tendo como premissa básica a justiça social.

Outra testemunha ocular das transformações por que passava Pernambuco foi o jornalista e escritor Antonio Callado, correspondente do Jornal do Brasil na região. Sobre o que viu, esse cronista disse o seguinte:

Pernambuco é, neste momento, o maior laboratório de experiências sociais e o maior produtor de idéias do Brasil. É o Estado mais democrático da Federação. Lá a gente repara, mesmo, que a democracia não tem nada de habitual no Brasil. Dois fatores principais se terão combinado para favorecer o aparecimento desse clima pernambucano de liberdade: um movimento de agitação das massas que preencheu, em poucos anos, o papel da educação que essas pessoas nunca tinham tido, e a eleição, para o Governo do Estado, de um homem do povo. Miguel Arraes é o primeiro homem do povo a dirigir uma das unidades de maior atraso mental e mais arraigadas pretensões aristocráticas do Brasil. Quando falo em atraso mental, diga-se entre parênteses, não estou esquecendo a contribuição pernambucana às letras e graças do país. Estou pensando na inadequação entre essa cultura e o que acontece no Estado, na distância entre essas graças e os horrores da realidade social." ${ }^{66}$

O "tempo de Arraes" teve fim em $1^{\circ}$ de abril de 1964, a capital pernambucana foi tomada por veículos blindados, e já nas primeiras horas do regime de exceção prisões em série foram decretadas. O próprio governador foi preso, junto com boa parte de seu secretariado. O MCP foi extinto, e o método Paulo Freire de alfabetização se tornou proscrito. O Estatuto da Terra foi anulado, e as relações de trabalho no campo pernambucano retornaram a sua antiga forma. O episódio mais emblemático da tomada de Pernambuco pelos militares talvez tenha sido o suplício ao qual foi submetido o deputado federal Gregório Bezerra, veterano de lutas do PCB. Este militante, que a altura do Golpe tinha 64 anos, foi barbaramente torturado em praça pública, e arrastado pelas ruas de Recife, tendo uma corda amarrada a seu pescoço. O objetivo de seus verdugos era enforcá-lo a guisa de exemplo, a 
vista de todos, porém as súplicas do Arcebispo Dom Lamartine impediram a execução. $\mathrm{O}$ comandante do destacamento responsável pelas torturas a Gregório Bezerra foi o tenentecoronel Darcy Villoq Vianna. ${ }^{67}$

A prática política de Arraes era de matiz populista ${ }^{68}$, porém sua relação com o povo de seu estado não pode ser definida como meramente paternalista. Não é nosso objetivo aqui realizar uma análise do fenômeno político Miguel Arraes, nem relacioná-lo ao espectro do populismo brasileiro. Nosso objetivo é mostrar como o advento de sua liderança se deu pari passu ao aumento da conscientização de seus eleitores. O processo político que tem como ponto alto o Pernambuco enquanto "maior laboratório de experiências sociais do Brasil", berço das Ligas Camponesas e do MCP, é produto direto de toda uma tradição de lutas. Não esquecendo também o papel organizador e conscientizador de alguns militantes engajados nas contendas populares locais, como Cristiano Cordeiro, Paulo Cavalcante, Pelópidas Silveira, Josué de Castro, Francisco Julião, Dom Helder Câmara, Paulo Freire. Sem desprezar o espírito de resistência e a criatividade do povo nordestino.

Os dois exemplos acima foram destacados por critérios definidos pelo autor, outras cidades brasileiras certamente se notabilizaram, em determinado estágio de sua história, por atividades contestatórias ou mesmo revolucionárias. Poderíamos arrolar a nossa relação à cidade do Rio de Janeiro, palco de inúmeras revoltas populares, praça eleitoral marcada por vitórias de candidatos de esquerda, reduto de Prestes e Brizola; capital de intensa atividade comunista, das lutas tenentistas, etc. Poderíamos utilizar o mesmo raciocínio para a cidade de São Paulo, cenário da primeira greve geral brasileira, em 1917, capital que durante um mês esteve sob poder de revolucionários tenentistas, em 1924, sendo o único município brasileiro a sofrer ataque aéreo. Cidade também de intensa atividade comunista, centro estratégico da ANL, das greves pós Estado Novo; das grandes greves de 1953, 1957 e 1963. Outro exemplo notório é a região do grande $\mathrm{ABCD}$, mas esta será apreciada adiante, em outro capítulo.

67 CAVALCANTE, Paulo. Op. Cit. , 1980. p. 374-383

68 Quanto ao populismo, norteamo-nos pelas definições de Octávio Ianni. Segundo este autor, "pode-se afirmar que a entrada das massas no quadro das estruturas de poder é legitimada por intermédio dos movimentos populistas. Inicialmente, esse populismo é exclusivamente getulista. Depois, adquire outras conotações e, também, denominações. Borguismo, queremismo, juscelinismo, janguismo e trabalhismo são algumas das modulações do populismo brasileiro. No conjunto, entretanto, trata-se de uma política de massas específica de uma etapa das transformações econômico-sociais e políticas no Brasil. Trata-se de um movimento político, antes do que um partido político. Em poucas palavras, o populismo brasileiro é a forma política assumida pela sociedade de massas no país." IANNI, Octávio. O Colapso do Populismo no Brasil. Rio de Janeiro: Editora Civilização Brasileira, 1971. p. 206-207. 
Uma discussão mais aprofundada sobre o que definiria de fato uma "cidade vermelha" fugiria ao escopo deste trabalho, para tanto teriam que ser definidos critérios empíricos de pesquisa, que abarcassem as localidades supracitadas, e só isto já valeria um outro estudo. O critério usado acima foi de caráter mais expositivo que comparativo, o objetivo foi tecer um esboço analítico acerca do termo "cidade vermelha", utilizando exemplos históricos concretos. O fato é que esse conceito ainda é pouco estudado pela historiografia e pela ciência política brasileira.

Podemos enquadrar Osasco como "cidade vermelha", assim como o fizeram os aparatos de repressão da Ditadura? Creio que sim, mas para chegar a essa constatação temos que lançar mão de dados mais consistentes.

O ápice do ativismo revolucionário osasquense se deu na greve de julho de 1968, última de um ciclo que só retornaria dez anos depois, em 1978. Mas essa greve representou o auge de um movimento que se iniciara ao menos dez anos antes. Identificamos como matrizes do pujante movimento revolucionário osasquense, que agitou a cidade na segunda metade dos anos 1960, os seguintes elementos: o ciclo emancipacionista, sobretudo em suas etapas finais, entre 1958 e 1962; o ativismo estudantil articulado em torno da UEO, a partir de 1962; a atuação do PCB junto ao operariado local, mais distanciada no tempo, remetendo a redemocratização pós Estado Novo, em 1945; a militância de base promovida pelo clero progressista em determinadas paróquias locais, como a igreja da Imaculada Conceição, no bairro do Km 18, mais as atividades dos grupos leigos, como a JOC, ACO e FNT; e por fim, as mobilizações levadas a cabo pelos militares de baixa patente nos quartéis de Quitaúna, até o golpe de 1964. O primeiro elemento já foi discutido em item anterior, o segundo será analisado na próxima seção, os seguintes serão citados abaixo.

No início deste capítulo vimos que em 1909 um grupo de famílias italianas de orientação ideológica anarquista se estabeleceu na vila fundada por Antonio Agu, e foram esses os primeiros a propor algum tipo de organização operária na localidade, através da construção de uma cooperativa. Há relatos sobre uma greve no Frigorífico Continental em 1918, porém temos poucas informações sobre esta paralisação. O que se passou entre os 
operários de Osasco nas duas décadas seguintes permanece desconhecido, tema para futuras pesquisas.

No pós Estado Novo, existem referências sobre a formação de CDP's (Comitês Democráticos Populares), organizados pelo PCB, em Osasco, elemento que indica atuação política desse partido no então $14^{\circ}$ subdistrito. Os CDP's surgiram em 1945, por orientação do próprio Luís Carlos Prestes, eram unidades de base, que se organizavam como "núcleos populares", a partir do "local de moradia", obedecendo a "divisão geográfica da cidade em bairros"69. Tais comitês foram ativos na conjuntura do "Queremismo", nas lutas constitucionais, e foram importantes nas eleições de 1946 e 1947, ajudando a eleger inúmeros políticos pela legenda dos comunistas. Os CDP's foram proscritos junto com o PCB em 1947, retornando os militantes do partido ao modelo de células clandestinas.

No ano de 1950 ocorreu mais de uma greve na Cobrasma, e no ano seguinte, um certo Mário Maia, agente da polícia, foi integrado nessa indústria, agindo disfarçado como era de praxe, com a missão de identificar elementos subversivos que atuavam na fábrica. A conclusão do relatório do agente do DEOPS foi de que havia "infiltração" comunista na empresa $^{70}$. Apesar de ilegal, o PCB continuou atuando de forma clandestina em toda grande São Paulo, sempre dando preferência a regiões com alguma concentração industrial, o que era o caso do $14^{\circ}$ subdistrito.

Ao que tudo indica, as informações fornecidas por Mário Maia não foram suficientes para conter os operários mobilizados em Osasco, pois há informações sobre greves também em 1952, e no ano seguinte, os trabalhadores da região aderiram a "greve dos 300 mil", paralisando quatros indústrias metalúrgicas locais. De acordo com Conrado Del Papa, primeiro presidente do SMO, em 1953 o subúrbio semi-industrial de Osasco já era visto como foco de agitação, segundo o mesmo, o bairro sofreu "uma repressão muito violenta" no decorrer da "greve dos 300 mil", com baixas entre operários e policiais ${ }^{71}$.

Os ativistas do PCB atuaram no município desde a redemocratização, em 1946, e ao longo de todo o decênio seguinte mantiveram algum tipo de atividade entre as classes populares locais, porém sua militância era de caráter reduzido se comparada com outras regiões de São Paulo. Sabe-se que a atuação do Partido era mais forte em outros distritos

69 MOISÉS, José Álvaro. Op. Cit. P. 236-237

70 Arquivo do Estado de São Paulo, acervo DEOPS, pasta OS (Ordem Social) - 0704, Osasco

71 MIRANDA, Orlando. "Sindicato e Classe Operária: História do Sindicato dos Metalúrgicos de Osasco". Tese de Livre Docência. São Paulo: FFLCH-USP, 1987. p. 39. 
industriais, como São Miguel Paulista ${ }^{72}$. O desinteresse do PC por Osasco começa a se transformar em interesse a altura das lutas emancipacionistas. Vimos que a região foi palco de intensas mobilizações entre 1958 e 1962, lutas que foram coroadas com a vitória autonomista. A nova situação jurídica do antigo subdistrito trouxe a possibilidade da criação de sindicatos locais, algo que acabou por atrair a militância pecebista, ciosa em sua busca por hegemonia nos meios sindicais. Outro elemento que não pode ser desprezado é o crescimento industrial e populacional da nova cidade. Todos esses fatores reforçaram a atenção do PCB para com Osasco.

Podemos observar a mudança de atitude do PC com relação ao novo município pela designação de Constantino Stoiano para atuar como dirigente do partido nessa localidade. Stoiano era um quadro altamente qualificado, veterano de lutas e com larga experiência em organização sindical e popular. As informações sobre esse militante constam em prontuário ${ }^{73}$ do arquivo do DEOPS-SP, remontam a um longo histórico de prisões, que tiveram início em 1948, e se completam com sua detenção entre 1968 e 69. Corroboram com nossa avaliação farto material fotográfico, que comprovam suas numerosas viagens pelo mundo socialista.

Stoiano iniciou suas atividades no PCB em 1946, quando se filiou ao comitê do Partido na Mooca. Em 1948 se mudou com a família para o bairro de Utinga, distrito industrial de Santo André, e nesta localidade começou militar junto aos trabalhadores locais, em novembro do mesmo ano foi preso pela primeira vez. Retomou suas atividades em 1950, quando se aproximou de Rolando Frate, liderança do PC paulista. Em 1952 viajou para a Alemanha Oriental para participar de um Festival da Juventude realizado nesse país. Da Alemanha seguiu até Moscou, a convite do PC da URSS. De volta ao Brasil, escreveu o livreto "Operário Paulista na União Soviética”, com reminiscências de sua viagem. Passou a atuar junto ao sindicato da CMTC, empresa de transporte público paulistana. Em 1960 militou num porto de extração de areia em Itaquaquecetuba, onde auxiliou na formação de um sindicato dos trabalhadores dessa categoria. Ao final desse mesmo ano viajou a China, retornando a URSS, passando também por Praga. Em 1961 foi designado para Osasco, para atuar como dirigente do PCB na cidade.

72 Ver: FONTES, Paulo. Trabalhadores e cidadãos: Nitro Química, a fábrica e as lutas operárias nos anos 50. São Paulo: Editora Annablume, 1997.

73 Stoiano aparece no prontuário como Stoianov, provavelmente para fazer alusão a uma possível origem soviética, não comprovada nos autos. Para informações sobre esse dirigente consultar: Arquivo do Estado de São Paulo, acervo DEOPS-SP, Prontuário Constantino Stoianov, OP (Ordem Política) - 95003. 
A indicação de um quadro experiente como Stoiano denota um maior interesse da direção pecebista por Osasco, o novo centro industrial agora figurava com mais destaque nos planos políticos do Partidão. Entretanto, o novo dirigente não teve tempo suficiente para fortalecer as bases de seu movimento no jovem município, visto que três anos depois estouraria o golpe de 1964, e seu trabalho seria interrompido. Stoiano foi novamente forçado a viver na clandestinidade, e acabou preso após o AI-5. Ainda assim, seu trabalho gerou frutos, ao menos a UEO se constituiu sob influência comunista, e a partir de 1963 passou a ser dirigida por Gabriel Figueiredo, membro da ala jovem do Partido ${ }^{74}$. Na direção da primeira diretoria do SMO havia dois comunistas, Lino Ferreira dos Santos, secretário geral, e Manuel Dias do Nascimento, segundo secretário ${ }^{75}$.

Ainda sobre a atuação do PCB em Osasco, sob a batuta de Stoiano, Manuel Dias do Nascimento, conhecido como Neto, membro da primeira diretoria do sindicato dos metalúrgicos local, militante do Partido desde meados dos anos 1950, comenta o seguinte:

Nessa época, em 61, eu era do PCB, nós tínhamos uma atividade, tínhamos inclusive uma célula dentro da Cobrasma, onde nós fazíamos todo um trabalho clandestino, a gente reunia as células do partido nas empresas. Se eu me recordo, tínhamos base na Cobrasma, na Braseixos, e outras pequenas empresas. O partido se compunha assim antes de existir o sindicato em Osasco, antes da emancipação. O partido comunista tinha bases, e nesse processo aí, já que você perguntou, nesse processo de 60 a 64, antes do golpe, já existia uma atuação não só de base operária, mas de estudantes dentro do próprio partido, e as discussões eram muito grandes em termos de movimento internacional, tanto da Ásia quanto da Europa, e com isso já inicia uma fusão entre o pessoal que atuava mais na prática, que eram muitos trabalhadores e trabalhadores-estudantes, que tinham a prática ligada a teoria, e havia também o estudante típico, que tinha mais a teoria e trabalhava certas discussões. Isso contribuiu muito para a retomada do sindicato e a formação da oposição no Sindicato dos Metalúrgicos de Osasco $(\ldots)^{76}$.

Como veremos adiante, a proeminência do PCB entre os ativistas osasquenses não sobreviverá ao $1^{\circ}$ de abril de 1964 . Porém, a que se considerar o histórico desse partido na cidade, que remonta aos tempos do $14^{\circ}$ subdistrito do Butantã. De certa forma, toda a esquerda que se organizou no período de exceção pós 64 - e mesmo antes - é tributária, de

74 MARTIM, Sonia. Op. Cit. P. 96

75 MIRANDA, Orlando. Op. Cit. p. 69

76 Entrevista com Manuel Dias do Nascimento, 16/02/2009. 
alguma forma, ao Partidão. Em que pese seus desacertos táticos, e seus erros teóricos, entre os anos 1930 e a primeira metade da década de sessenta o PCB foi o grande organizador dos trabalhadores brasileiros, ocupou um espaço nada desprezível entre a intelectualidade nacional, e manteve viva em nosso país a ideia de uma transição rumo a uma sociedade socialista, seja de forma violenta, seja de forma pacífica. Essa herança também se observou em Osasco.

No clero progressista, e nos movimentos cristãos de cunho popular, encontra-se outra matriz do ativismo revolucionário que empolgou toda uma geração de militantes que se destacaram nas lutas contra a ditadura na década de sessenta em Osasco. No ciclo emancipacionista se observou alguma participação de padres nas lutas em favor do "SIM", sobretudo por meio de permissões para a utilização de paróquias e espaços anexos a algumas igrejas para reuniões pró-autonomia. Mas esse apoio, ao que tudo indica, não foi muito além disso. A partir de 1960, a atuação católica junto aos movimentos sociais ganharia mais notoriedade, não só no município em estudo, mas em âmbito nacional.

Data desta época o Concílio do Vaticano II, convocado pelo Papa João XXIII, realizado entre os anos de 1962-65. De toda uma série de reformas promulgadas por esse concílio, teria destaque a incorporação por parte da igreja de uma visão mais crítica perante a sociedade. Após esse evento, a igreja procurou atuar de forma mais ativa perante as contradições do sistema capitalista. Mesmo antes do Concílio do Vaticano II, já havia esta percepção entre certas correntes do clero. Críticos as mazelas promovidas pelo mundo do capital, atuavam a mais de dez anos pensadores cristãos progressistas como Emmanuel Mournier, Pierre Teilhard de Chardin e Louis-Joseph Lebret, religiosos franceses que combatiam, em níveis diferentes, as injustiças sociais. O último, que ficou conhecido como padre Lebret, fundou no ano de 1941 a revista Economia e Humanismo, semanário que partiu de "posições democratas cristãs" para um "diálogo com os comunistas". Esse religioso esteve no Brasil pela primeira vez em 1947, ano em que lecionou um curso de dois meses na Escola Livre de Sociologia Política, em São Paulo ${ }^{77}$.

No Brasil, a primeira corrente progressista do pensamento católico esteve representada por Alceu Amoroso Lima, Candido Mendes e Dom Hélder Câmara, clérigos e intelectuais ligados ao Centro Dom Vital. Sua militância estava associada à Ação Católica, movimento cristão inspirado na Action Française. A AC de início fora conservadora, mas mudou seu

77 RIRENTI, Marcelo. “Ação Popular: Cristianismo e Marxismo”. In: RIDENTI, Marcelo; REIS, Daniel Aarão. História do Marxismo no Brasil (Vol. 5). Campinas- SP: Editora da Unicamp, 2007. p. 234-235 
caráter ao longo dos anos 1940, para no decênio seguinte, converter-se de fato em um grupo progressista $^{78}$. Ligados a esses grupos modernizadores, setores universitários católicos procuraram atualizar também a JUC, direcionando-a ao rumo progressista que tomara a AC. Inspirados na JUC, surgiram outros grupos de jovens cristãos, como JEC (Juventude Estudantil Católica, reunindo secundaristas), e a JOC (Juventude Operária Católica). Na década seguinte surgirá a AP (Ação Popular), congregando tendências mais a esquerda do catolicismo, e mesmo grupos evangélicos progressistas.

O que vale destacar de todo esse movimento de renovação da cristandade foi o seu potencial de penetração nos setores sociais mais combativos de nossa sociedade. Esse impulso atingiu os meios operários, estudantis, intelectuais, camponeses, etc. Fenômeno que Michael Löwy chamou de "Cristianismo de Libertação", algo que foi capaz de promover um amálgama entre marxismo e cristianismo. Tal fenômeno foi possível pois, segundo Löwy, existem algumas "afinidades culturais" entre o marxismo e o cristianismo. Contudo, "não se trata de um processo unilateral" e sim de "uma interação dinâmica, "dialética", que pode levar em certos casos a uma simbiose ou mesmo fusão". Segundo esse autor, algumas dessas “afinidades culturais" seriam: “1) a adesão a valores transindividuais e comunitários, em oposição ao individualismo liberal; 2) uma doutrina de tipo humanista/universalista (ecumenismo, internacionalismo); 3) a crítica ao capitalismo e ao liberalismo econômico, em nome de valores ético-sociais; 4) a simpatia ou solidariedade com o pobre e o oprimido; 5) uma utopia do futuro como "reino" de justiça e paz, liberdade e fraternidade humana"79.

Em Osasco, na virada do quinto para o sexto decênio do século passado, verificouse um relevante trabalho pastoral junto à comunidade católica progressista. Trabalho que cresceu concomitantemente ao movimento emancipacionista local. Siglas como JOC, ACO, e FNT tiveram marcante participação política no município.

A JOC era influente entre aos operários locais, atuando segundo os ideais de seu fundador, o padre belga León Joseph Cardjin, que resumiu seu método de ação pastoral em três palavras, ver, julgar e agir ${ }^{80}$. Outra sigla cristã presente em Osasco foi a ACO, operante no município a partir de 1962, dirigida por "jocistas" que se casavam e não podiam mais frequentar a JOC. A ACO privilegiava atividades junto ao operariado, tinha alguma penetração no meio sindical, e buscava atuar nas comunidades se aproximando das

78 Idem, p. 228-229.

79 LÖWY, Michael. "Cristianismo da libertação e marxismo”. In: RIDENTI, Marcelo; REIS, Daniel Aarão. História do Marxismo no Brasil (Vol.6). Campinas-SP: Editora da Unicamp, 2007. p. 413-414.

80 MURARO, Valmir Francisco. Juventude Operária Católica. São Paulo: Editora Brasiliense, 1985. 
associações de bairro. Seus preceitos não diferiam em substância dos da JOC, apresentavamse como cristãos engajados no "mundo do trabalho" importante o papel de alguns padres entre os trabalhadores locais, com destaque para a igreja da Imaculada Conceição, no bairro do Km 18.

As atividades pastorais junto aos trabalhadores mais humildes de Osasco devem muito ao vigário Rafael Busato, pároco da igreja da Imaculada Conceição, o mesmo que em 1962 organizou a "campanha do quilo", objetivando arrecadar fundos para as famílias carentes do bairro. Ações desse tipo foram ampliadas, e na paróquia foram organizados cursos de corte e costura, artesanato, carpintaria, dentre outros. A partir dessas iniciativas surgiu a escola técnica Cristo Operário, funcionando em edificação anexa a igreja. Além dos cursos que ajudou a criar, o padre Rafael procurava conscientizar e mobilizar os trabalhadores de sua paróquia em relação aos seus direitos, incentivando-os a cobrar da prefeitura melhorias em suas comunidades ${ }^{82}$.

Além do padre Rafael, também atuava junto aos locais um grupo de sacerdotes ligados a Missão Operária São Pedro e São Paulo, fundada pelo dominicano francês Tiago Loew. Deste grupo, ganha mais notoriedade o francês Pierre Joseph Wauthier. A ação dos "padres operários" teve como ponto de partida a Vila Yolanda, bairro carente da periferia da cidade. Nessa localidade os dominicanos realizaram um trabalho semelhante ao do pároco da Imaculada Conceição. Pelos mesmos foram organizados abaixo-assinados para serem entregues a prefeitura, onde os moradores cobravam dos gestores locais melhorias em seu bairro, como a construção de redes de esgotos, postos de saúde, creches, linhas de ônibus e pavimentação de ruas. Outro projeto organizado pelos religiosos foi um programa de alfabetização de adultos. Tais sacerdotes também atuavam junto ao operariado em seus espaços laborais, muitos ingressaram nas fábricas da cidade como operários, sempre em harmonia com sua missão pastoral ${ }^{83}$. A época da greve de 1968, o padre Pierre Joseph Wauthier estava empregado como metalúrgico na Cobrasma, e sua participação na parede lhe valeu alguns dias de prisão, seguida de sua posterior expulsão do Brasil, como veremos adiante.

Outro tema que será discutido com mais vagar diz respeito à FNT, grupo católico operário que se apresentava como uma alternativa ao sindicalismo de cúpula do PCB. A

81 JESUS, Paulo Sérgio de. Osasco: JOC, ACO e PO no Movimento Operário (1960-1970). Dissertação de Mestrado. São Paulo: PUC-SP, 2007. p.16

82 Idem, p. 25-26

83 Ibidem, p. 26-28 
Frente passou a atuar em Osasco no início dos anos 1960, tendo como principal método de trabalho a organização dos trabalhadores pela base. Em sua atuação se encontra uma das origens das comissões de fábrica. A FNT terá participação ativa nas diretorias do Sindicato dos Metalúrgicos de Osasco após o golpe de 1964.

Segundo Michael Löwy, os setores progressistas do clero católico brasileiro, partidários do "Cristianismo de Libertação", estiveram presentes em todas as lutas sociais brasileiras depois da década de sessenta. Fizeram forte oposição ao regime autoritário, indo contra setores do alto clero, que deram apoio, de forma direta ou velada, aos governos militares. Mesmo altas personalidades da hierarquia eclesiástica proferiram críticas ao Estado de exceção, algo que pôde ser observado em figuras como Dom Hélder Câmara, Dom Cláudio Humes, Dom Paulo Evaristo Arns, e muitos outros. Desse tipo de catolicismo brotaram organizações como as CEBs (Comunidades Eclesiais de Base), as Pastorais operárias e da terra. O novo sindicalismo surgido no ABCD, em 1978, teve ligações com a esquerda católica, e nesse impulso surgiu também o Partido dos Trabalhadores, a Central Única dos Trabalhadores (CUT), e o Movimento Nacional dos Trabalhadores Sem Terra (MST). A maior parte dos movimentos sociais que surgiram dos escombros da ditadura estão de alguma forma ligados ao "Cristianismo de Libertação". Em Osasco, também se observou tal fenômeno, com forte atuação das pastorais operárias em parceria com o recém fundado PT, a partir dos anos 1980.

Outra matriz revolucionária da esquerda osasquense, que convém salientar, está ligada ao movimento dos militares de baixa patente, que se espalhou pelo Brasil no começo da década de sessenta, também conhecido como "movimento dos sargentos". Nos quartéis de Quitaúna, bairro de Osasco, houve grande movimentação de quadros médios militares.

São de longa data os movimentos contestatórios partidos dos meios militares no Brasil, o ciclo tenentista é o exemplo mais bem acabado dessa tradição. Não obstante, uma vez no poder, a maior parte dos "tenentes" se associou as elites nacionais, integrando-se a nova coalizão de forças detentora do poder. Uma pequena parcela desse movimento optou por manter seu espírito de luta e contestação, posicionando-se ao lado das classes populares. Esse grupo era liderado por Prestes, o grande líder da Coluna que se chocou numa luta de morte contra as oligarquias nacionais entre 1924 e 1927. Os setores mais radicais do tenentismo acabaram por aderir ao PCB, seguindo sua principal liderança, Luís Carlos Prestes, aquele que se tornou o dirigente máximo desse partido ao longo da maior parte do século XX. 
Após o Levante Comunista de 1935, as esferas dirigentes da Forças Armadas nacionais introduziram o anticomunismo em sua agenda, e em nome deste tomaram o poder em 1937, chefiados por Getúlio Vargas. Após o fim do Estado Novo, e a participação do Brasil na Segunda Guerra Mundial, a alta cúpula do Exército nacional se alinhou ideologicamente aos EUA. O ponto alto desse alinhamento foi a criação da Escola Superior de Guerra, em 1949. Esta entidade, dentro do contexto de bipolaridade que dividia o mundo de antanho, professava os ideais de "mundo livre" propostos pelo National War College, dos EUA. A ESG também incorporou outras diretrizes do Pentágono, como a "contenção a URSS" e o combate ao "inimigo interno", tema que abordaremos adiante com mais vagar. O combate ao "perigo vermelho" foi o grande mote dos setores mais reacionários das Forças Armadas brasileiras, e em seu nome foi justificada toda forma de perseguição e opressão aos movimentos populares nacionais.

Mas os anticomunistas não representavam a totalidade dos quadros militares, no seio das Forças Armadas também havia elementos mais a esquerda, alguns sob influência comunista. Destes segmentos partiram lideranças que empolgaram movimentos como o "petróleo e nosso", liderados pelos generais Horta Barbosa e Newton Estillac Leal. Em meados dos anos 1950, tornou-se clara a divisão entre os militares brasileiros, de um lado estavam os oficiais ligados a ESG, alinhados politicamente a UDN e ideologicamente aos EUA, e de outro aqueles ligados ao nacionalismo varguista, próximos de partidos como o PTB. Entre estes, um setor intermediário, alheio as disputas político-partidárias, composto por militares identificados como "legalistas". Em tal grupo se encontrava o marechal Henrique Teixeira Lott, o mesmo que garantiu a posse do presidente eleito Juscelino Kubitschek, em 1955 , contra as insistentes iniciativas golpistas partidas da UDN.

O fato é que entre 1946 e 1964 os militares estiveram sempre presentes nas esferas do poder político nacional. Com o fim do Estado Novo, o Exército se fez presente no cenário político brasileiro como uma espécie de poder moderador, sempre pronto a intervir nos casos em que "ordem" político-institucional fosse ameaçada. A partir da década de sessenta, a dicotomia esquerda-direita se acirrou entre os militares brasileiros, correntes extremistas surgiram dos dois lados, cada um cerrando fileiras com grupos civis alinhados a suas proposições. É nesse contexto que surge o "movimento dos sargentos".

A hierarquia de quadros presente no Exército sempre foi um reflexo da divisão de classes da sociedade. Uma instituição comandada por grupos reduzidos de altos oficiais, 
contando com setores médios de oficialato, que por sua vez são superiores as camadas representadas por sargentos e sub-tenentes, tendo logo abaixo de si os cabos e o grosso da tropa, os soldados. Esse sistema rígido de hierarquia ajuda a reforçar a divisão social entre os militares. Nesse meio, os sargentos exercem um papel que é desempenhado pela baixa classe média entre os civis, cabe a tais graduados fazer a ponte entre a oficialidade e os soldados.

$\mathrm{O}$ "movimento dos sargentos" teve papel de destaque nos eventos que se seguiram a renúncia do presidente Jânio Quadros, garantindo a posse de seu vice, João Goulart. Em 1963 tal grupo alcançou projeção nacional, quando em setembro do mesmo ano, cerca de "500 sargentos do Exército, da Marinha e da Aeronáutica se sublevaram, ocupando, durante a madrugada, importantes centros administrativos de Brasília," este ato foi comandado pelo sargento da Aeronáutica Antonio Prestes de Paula. O motivo da sublevação foi "a recusa do Supremo Tribunal Federal em reconhecer a elegibilidade dos sargentos, em consequência do que alguns deles, que se candidataram e venceram, tiveram seus mandatos cassados." Não obstante, tal ato de força carecia de qualquer orientação teórica, suas reivindicações ficaram restritas ao protesto contra o TSE, e "quando os rebeldes se apoderaram da Rádio Nacional de Brasília, não sabiam, entretanto, que mensagem transmitiriam a nação" ${ }^{\text {}}$. Há quem atribua a organização dessa rebelião a agentes provocadores, e como depois se pôde comprovar, as cúpulas militares mantinham agentes infiltrados entre os ativistas das Forças Armadas. $\mathrm{O}$ assalto ao poder em 1964 teve como estopim uma rebelião de marinheiros liderada por um agente provocador conhecido como Cabo Anselmo, um agente infiltrado a serviço das forças de repressão.

Em Quitaúna, Osasco, o grande líder dos militares de baixa patente, até o golpe, foi Onofre Pinto, presidente da Associação dos Sargentos e Subtenentes do Segundo Exército. Como presidente da entidade, este graduado conseguiu apoio e verba do presidente João Goulart para a construção de uma vila militar em Osasco, que recebeu o nome de Jardim Alvorada. O lançamento da pedra fundamental da nova vila, no início de 1964, contou com a presença do próprio presidente da república. Onofre Pinto foi exonerado do Exército após o AI-1, passando em seguida a se movimentar junto ao MNR (Movimento Nacionalista Revolucionário), organização próxima a Leonel Brizola. As ligações do líder dos sargentos paulistas com Quitaúna não desapareceriam, e caberá ao mesmo o recrutamento do capitão

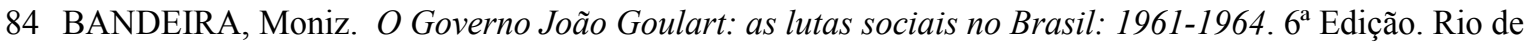
Janeiro: Civilização Brasileira, 1983. p. 122-123 
Carlos Lamarca e seu grupo para a luta revolucionária contra a ditadura. A esse líder militar também foi creditada a criação a Vanguarda Popular Revolucionária.

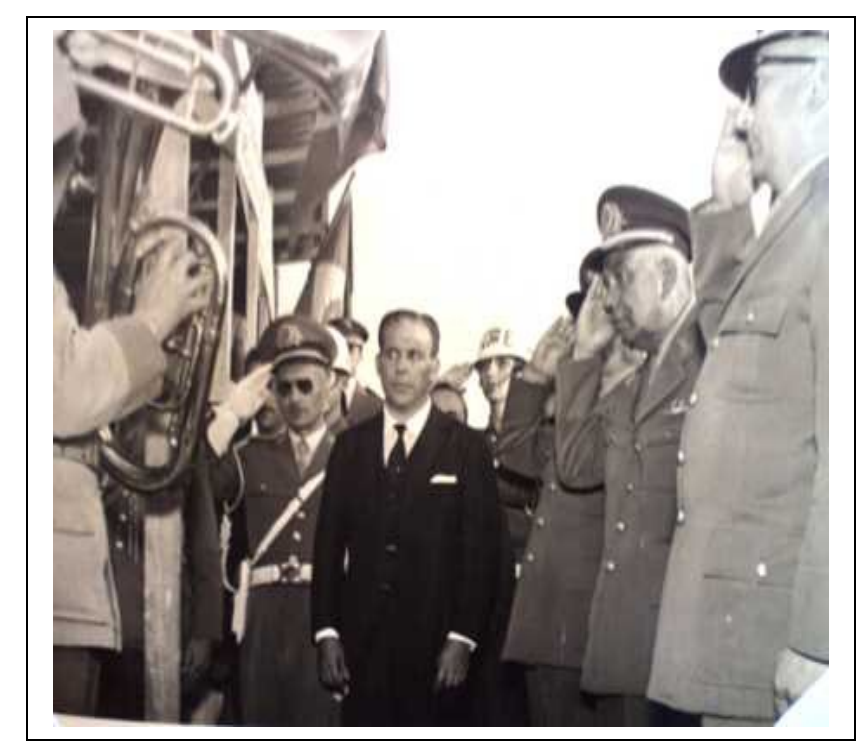

Inauguração da pedra fundamental da vila militar de sargentos e subtenentes de Osasco, chamada de Jardim Alvorada, em 1964, a poucas de semanas do Golpe de $1^{\circ}$ de abril. Fonte: Osasco: um século de fotografia. Osasco-SP: projeto, edição e fotografia, Eduardo Metrovichi; edição, Maxprint, 2007. p. 63

Os militares engajados dos quartéis de Quitáuna não mantiveram ligações orgânicas com os movimentos sociais osasquenses, não se tem notícia de participação militar efetiva no ciclo emancipacionista, tampouco nas agitações político-sociais do município até o AI-5. Não obstante, havia contatos entre os movimentos populares civis locais e grupos militares de esquerda que serviam em Quitaúna, sobretudo na conjuntura revolucionária de 1968. O principal intermediador dessas conexões era Onofre Pinto. Ao se iniciar os Anos de Chumbo, a simbiose entre revolucionários civis e militares em Osasco irá se adensar, e essa cidade fornecerá boa parte dos quadros guerrilheiros da VPR.

$* * * * *$

Pois bem, com a breve investigação observada acima, vemos que a jovem militância osasquense, atuante no pós 1964, é herdeira de toda uma geração de ativistas que 
se movimentaram na região em anos anteriores, cidadãos que se engajaram nas lutas pela emancipação, na construção do movimento operário local, no meio estudantil, junto às camadas sociais mais carentes, entre os militares. Todo este caldo de ativismo político influenciaria a geração seguinte, e ajudaria a forjar o Grupo de Osasco. Como vimos na introdução deste trabalho, o GO se converteu numa das principais forças políticas de sua cidade, especialmente no biênio 1967-68. Segundo Antonio Roberto Espinosa,

(...) em 68 já éramos tidos como a intelectualidade da cidade, o pessoal que pensava, já tínhamos uma espécie de liderança moral e intelectual. A direita buscava amizade com os militares, que era o novo poder, agora, o charme estava do nosso lado, não tenho dúvidas sobre isso, e era uma coisa crescente ${ }^{85}$ (grifo meu)

Nosso objetivo, com este estudo, é demonstrar que o Grupo de Osasco representou uma das experiências mais originais em termos de movimentos sociais organizados no Brasil. $\mathrm{O}$ GO se somou a toda uma geração de contestadores que optaram por reagir a ditadura civilmilitar imposta ao povo brasileiro a partir de 1964. Em que pese seus erros e desacertos, o que marcou de tal movimento foi sua peculiaridade, a convergência de fatores pouco verificados em outros panoramas de luta e mobilização. Conceitos que frequentaram o léxico da esquerda nacional, ao longo dos anos 1960, estiveram concentrados em Osasco. Termos como organização pela base, comissão de fábrica, comissão de bairro, pastoral operária, oposição operária, vanguarda operária, nacionalismo militar, radicalismo estudantil, frente operário-estudantil, guerrilha urbana e rural, etc. Tais temas candentes estiveram presentes no dia a dia do principal subúrbio da Zona Oeste da grande São Paulo. Nas próximas seções veremos como se construirá a liderança moral e intelectual do GO sobre a população de sua cidade, e qual foi sua contribuição para o processo revolucionário brasileiro.

85 Depoimento de Antonio Roberto Espinosa, 15/05/ 2008. 
2. Movimento Estudantil 
Esse período, década de sessenta, foi um período muito denso viu, as coisas aconteciam muito depressa, muito depressa, as pessoas amadureciam em semanas ... Enfim, todo mês acontecia muita coisa (...) Antonio Roberto Espinosa

\subsection{A Formação da UEO}

Como vimos na última seção, o movimento autonomista osasquense contagiou todos os grupos políticos organizados no então $14^{\circ}$ subdistrito do Butantã. Dentre os segmentos engajados na luta emancipacionista, os estudantes tiveram posição de destaque. Em todas as mobilizações de massa desenvolvidas na luta pela emancipação, sobretudo no período que vai de 1958 a 1962, época em que a disputa se acirra, os estudantes se fizeram presentes.

Do ciclo autonomista brotaram as lideranças políticas que disputariam o poder no novo município nos anos seguintes. Políticos de ofício se agruparam em torno de legendas partidárias, associações cristãs passaram a se articular entre os trabalhadores, com ênfase no operariado fabril; a sede do sindicato dos metalúrgicos local se desmembrou de sua matriz paulistana, e a cidade ganhou sua primeira agremiação estudantil, a UEO (União dos Estudantes de Osasco). De acordo com Antonio Salgueiro, liderança estudantil local, houve "uma febre de auto-organização na cidade"

A UEO teve vida curta, sendo fechada pelos militares após o golpe de 1964. Francisco Rossi, último presidente da entidade, diz ter entregue toda a documentação referente a agremiação aos diretores do CEO (Círculo Estudantil de Osasco), segunda organização estudantil do município, constituída em finais de 1965. Após o AI-5, o CEO também foi fechado, e toda sua documentação confiscada pelos órgãos de repressão. O destino desse material permanece desconhecido, não estando disponível nos arquivos do DEOPS-SP. Destarte, as informações referentes as agremiações estudantis de Osasco se baseiam em fontes orais, periódicos, e trabalhos acadêmicos que abordaram o tema em questão.

No auge da mobilização emancipacionista, em finais da década de cinquenta, Osasco possuía dois ginásios públicos, o Ceart (Centro Estudantil Antonio Raposo Tavarez) e o Gepa (Grupo Escolar de Presidente Altino). Além dos dois ginásios supracitados, havia também 
duas escolas de ensino secundário particular, o Colégio Nossa Senhora da Misericórdia, de clientela feminina, e o Colégio Técnico de Contabilidade Duque Caxias ${ }^{87}$. Destes, o de maior atuação política foi sem dúvida o Ceart (posteriormente Ceneart).

No estudo de Sonia Regina Martin, “A Escola Secundária e a Cidade: Osasco, anos 1950-1960", vemos como o Ceart se tornou o centro da política estudantil local. Fundado em 1953, esse colégio teve como endereço inicial o grupo escolar Marechal Bittencourt, distante do centro da cidade. O ginásio surgiu como uma alternativa aos filhos dos trabalhadores locais que tiveram acesso ao ensino primário. Antes de sua construção, jovens nessas condições tinham que se deslocar até escolas públicas localizadas nas regiões centrais da capital paulista. A essa época, o Brasil ainda era um país majoritariamente analfabeto, e o acesso ao ginásio se apresentava como uma alternativa de ascensão social. Pelas palavras do ex-aluno do Ceart Antonio Rodrigues, em entrevista a Sonia Regina Martin, a condição de estudante ginasial dava "status junto aos jovens da localidade. Quem não passava no exame de admissão do Ceart virava pária local, (...) ninguém dava prestígio - só se projetava na sociedade entrando no Ginásio (...), as meninas só queriam namorar meninos que estivessem no Ginásio" ${ }^{\text {. }}$.

Na conjuntura do segundo plebiscito, após 1958, o Ceart se tornou um dos núcleos de mobilização pró-autonomia, e para o engajamento dos secundaristas foi de fundamental importância o trabalho de conscientização feito por alguns professores desse colégio, aqueles que cerraram fileiras junto aos grupos partidários da emancipação. Podemos notar esse engajamento pelo depoimento da professora de História Maria Helena Pignatari Werner:

Por que o aluno vai votar... Uma das coisas, sérias, que eles aprenderam dentro do Ceart era o voto. Isso não era na cadeira de História, todas as cadeiras explicavam que, especialmente quando chegava perto da eleição, conscientizar que o voto era uma coisa muito séria. Não se falava em arma ainda né? Quando o voto era uma arma. Mas que era muito sério, que tinha que pensar, que tinha que conhecer o candidato e tal e coisa. Eu acredito que muito aluno votou com consciência no $\operatorname{sim}^{89}$.

Em princípios dos anos 1960, a professora Maria Helena Pignatari Werner passou uma temporada em Recife, e lá tomou contato com o MCP da gestão Miguel Arraes, e com o método de alfabetização de Paulo Freire (ver página ...). De volta a Osasco, introduziu em sua cidade os modernos métodos pedagógicos então praticados na capital de Pernambuco. Além

87 MARTIN, Sonia Regina Op. Cit. p. 95

88 Idem, p. 40

89 Ibidem, p. 76 
da professora Maria Helena, também se destacaram entre seus alunos os professores Emir Macedo, de Português, Fortunato Antiório, de Matemática, Josué da Silva Leite, de História, dentre outros ${ }^{90}$.

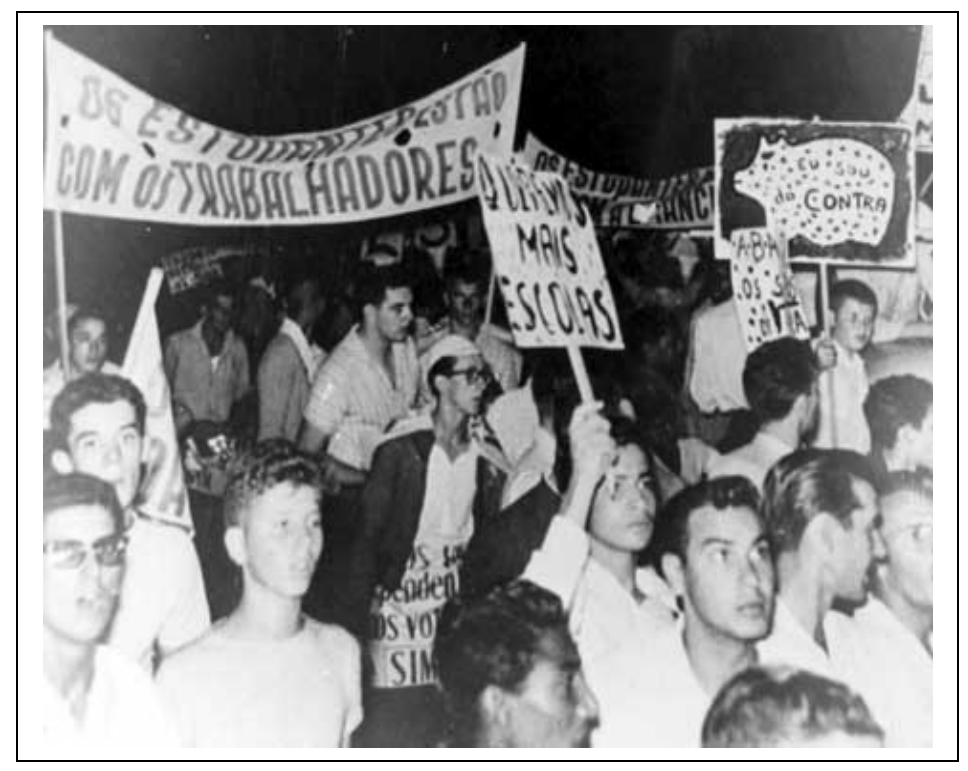

O movimento autonomista de Osasco contou com uma expressiva participação da juventude local, sobretudo de estudantes secundaristas, que se mobilizavam a partir dos grêmios de seus colégios, contando com o apoio do professorado local também engajado na luta pela emancipação. Destaque para o número de adolescentes presentes na manifestação. Fonte: $\underline{\text { www.camaraosasco.sp.gov.br }}$

O Ceart foi o principal polo de concentração daquilo que Francisco Weffort chamou de estudante-operário, em seu conhecido estudo publicado pelos Cadernos do CEBRAP em 1972, intitulado "Participação e Conflito Industrial: Contagem e Osasco, 1968". Grande parte das lideranças estudantis atuantes em Osasco, na conjuntura das lutas autonomistas, obedecia a essa característica. Após o golpe de 1964, também entre as lideranças sindicais irá se observar a figura do estudante-operário, ou operário-estudante.

Em 1963 o ainda Ceart mudou de endereço, algo que representou um substancial aumento de vagas, pois as novas instalações agora possuíam 41 turmas, sendo 25 no período noturno, no antigo prédio eram cerca de dez. Também passa a haver um curso ginasial no período diurno. Além do endereço, o colégio recebe também um novo nome, passando a se

90 Ibidem, p. $72-76$ 
chamar Ceneart (o acréscimo de letras ocorre devido a inclusão de um curso normal nas novas instalações, sendo o ginásio chamado a partir de então de Colégio e Escola Normal Antonio Raposo Tavares) ${ }^{91}$. O novo edifício ficava bem situado no centro do município, próximo a estação de Osasco, e a poucas quadras da Cobrasma, maior empresa da cidade. Boa parte dos estudantes do período noturno trabalhava de dia nas empresas locais, e estudava a noite no Ceneart, e tinham, via de regra, contato tanto com a política estudantil, quando com a operária. Uma parte considerável das lideranças políticas osasquenses, no período em análise, estudou no Ceneart, por lá passaram João Gilberto Port, Antonio Roberto Espinosa, José Campos Barreto, Francisco Rossi, etc.

O surgimento da UEO está fortemente ligado ao Ceart-Ceneart e seus estudantes engajados na luta emancipacionista. $\mathrm{O}$ ambiente de politização, observado no primeiro ginásio público do município, na conjuntura da demanda autonomista, espraiou-se para os demais colégios da cidade. Em princípios da década de sessenta, todos os colégios locais apresentavam grêmios atuantes, muito disputados entre os secundaristas, em eleições cada vez mais politizadas (a exceção do colégio das madres). Da articulação entre os grêmios locais se formou a UEO. De acordo com Antonio Salgueiro, a UEO "surgiu no ambiente comunista", e teve como primeiro núcleo articulador um grupo de estudantes universitários ligados ao PCB, com destaque para Sérgio Zanardi ${ }^{92}$. O estudante de Direito Sérgio Zanardi foi muito importante para a articulação inicial do ME osasquense, seu trabalho de base foi fundamental para o recrutamento de um dos primeiros líderes secundaristas locais de atividade reconhecida, Gabriel Figueiredo.

(...) foi após o meu ingresso na Companhia Industrial e Mercantil de Artefatos de Ferro (CIMAF - multinacional belga), em 1958, aos 14 anos de idade, que comecei a me interessar por política e sindicalismo. Nesta época conheci o também metalúrgico e estudante de Direito Sérgio Zanardi, que trabalhava no setor administrativo de uma outra metalúrgica próxima da CIMAF. Mais velho e experiente do que eu, Zanardi influenciou na minha formação ideológica me fornecendo textos, sobretudo de Marx e Engels, como "O manifesto do Partido Comunista”, “A Ideologia Alemã", "A Dialética da Natureza", entre outros. Sérgio também me abriu as portas para o sindicalismo de maneira que aos 15 anos eu já era sindicalizado de carteirinha. Tal como Sérgio Zanardi, muitos outros comunistas conheci participando das atividades sindicais. Destacaria entre eles Lino Ferreira dos

91 Ibidem, p. 49

92 Entrevista Antonio Salgueiro, 16/04/2010 
Santos, Constantino Stoiani (Stoiano) e Conrado del Papa. Este último oscilava entre o Partido Socialista Brasileiro (PSB) e o Partido Comunista Brasileira (PCB) ${ }^{93}$.

A UEO trazia o localismo em sua essência - além de trazê-lo no nome - sem se desligar por completo das “colorações ideológicas típicas do período ${ }^{94}$ ". É filha do ciclo autonomista, e como os demais movimentos surgidos nessa vaga, tinha como principal foco de atuação a política local. Embora estivesse formalmente subordinada a UPES (União Paulista dos Estudantes Secundaristas), e buscasse dialogar com outras agremiações do ME nacional, a UEO sempre privilegiou as demandas políticas de sua cidade e região.

Há que se salientar que após seu desmembramento da capital, o novo município foi vítima de represálias por parte da prefeitura paulistana, chefiada por Prestes Maia. Consumada a separação, o prefeito de São Paulo providenciou a "retirada de objetos de grande valor para a continuidade da prestação dos serviços público para o povo de Osasco”, tais como a "geladeira do pronto-socorro" local, "os caminhões para a coleta de lixo e o piano para o conservatório musical. (...), não repassou o cadastro imobiliário e o mobiliário, únicas fontes de receita para o jovem município ${ }^{95 \%}$. O primeiro prefeito eleito da localidade, Hirant Sanazar, ao tomar posse, sequer tinha uma prefeitura para instalar seu gabinete. Em sua gestão, foi necessário se desenvolver a toque de caixa um aparato burocrático e fiscal, garantir a manutenção de serviços básicos a população, como saúde, educação e segurança, e trazer as melhorias cobradas pela exigente sociedade civil osasquense, desperta durante a luta emancipacionista. A recente vitória autonomista, somada a necessidade de construção da nova cidade, atraia as atenções dos movimentos sociais de Osasco para as demandas locais.

O primeiro presidente da UEO foi João Gilberto Port, eleito em 1962, estudanteoperário e um dos principais agitadores da ala estudantil autonomista. Port também foi eleito vereador nas eleições legislativas municipais de 1963, com apoio do estudantado. O ano inicial de existência da UEO foi um período de estruturação para a entidade, que foi ganhando importância por sua marcante atuação no ciclo emancipacionista. "A primeira diretoria tratou, então, de instalar e legalizar a entidade, projetando passá-la ao controle dos ginasianos locais"96. O prestigio da agremiação acabou por chamar a atenção da juventude que de alguma forma estava envolvida na política de sua cidade. Em 1963, nas eleições para a

93 Entrevista de Gabriel Figueiredo ao autor, 31/05/2010.

94 RIZEK, Cibele Saliba, Op. Cit. P. 68

95 DANUSA, Mara. Op. Cit. s/p

96 MIRANDA, Orlando. Op. Cit.. p 47 
segunda gestão da entidade, a disputa se deu em níveis bem mais intensos do que no ano anterior. "A conexão autonomista desde logo emprestava ao movimento estudantil um prestígio político institucional, a UEO cedo se tornou um aparelho político cobiçado"97

Em princípios de 1963, formaram-se duas chapas em disputa pelo controle da UEO, a “Ação 63”, liderada por Gabriel Figueiredo, secretário na primeira gestão da agremiação, e a chapa "Bandeirantes", encabeçada por Francisco Rossi de Almeida, representado a juventude católica conservadora. As eleições foram marcadas para abril. A polaridade direita versus esquerda, cada vez mais se intensa em nível nacional, no agitado ano de 1963, esteve presente nos discursos dos dois grupos em disputa pela UEO.

De um lado estava a corrente de Francisco Rossi, diretor da UMO (União da Mocidade de Osasco), grupo católico que contava com a simpatia dos setores conservadores locais, composta por jovens cristãos, oriundos de "famílias tradicionais" do município. Francisco Rossi se apresentava como "cristão e anti-comunista", mas se dizia de esquerda, contrário as teses do PCB. Antonio Salgueiro, que concorreu ao cargo de segundo vice-presidente pela chapa "Ação 63", representando o colégio Duque de Caxias, profere o seguinte relato sobre prócere da chapa "Bandeirantes", seu adversário político:

Apesar de adversários, eu o Chico Rossi nos tratávamos com respeito, então o Chico monta a UMO, eles faziam muitos bailinhos, organizavam a molecada, era um pessoal muito educado, de família tradicional, só que não eram caras assim muito atirados a ponto de terem aprendido a participar na movimentação política de uma cidade, o cabalar voto. Nós éramos muito mais desembaraçados do que eles, por que a gente viveu isso desde os quinze, dezesseis anos. Mas o Chico montou sua chapa com esse pessoal, pra enfrentar aqueles puta daqueles dragão, gente que já tinha subido em carro de polícia, com experiência em campanha política, acostumados a tudo isso, coisa que o pessoal do Chico não tinha. O Chico tinha uma certa habilidade, mas o pessoal dele claudicava muito, eles tinham um certo receio da gente, mas o Francisco, como ele era boa pinta, do tipo "bom genro", ele tinha uma influência enorme no Colégio da Madres, um colégio de meninas, tanto é que ele ganhou a eleição nesse colégio(.. $)^{98}$

A outra chapa, além da experiência adquirida durante a campanha emancipacionista, contava com o apoio da primeira diretoria da UEO. Era composta, em sua maioria, por filhos de trabalhadores das fábricas locais, sendo que muitos de seus quadros, a começar pelo 
candidato a presidente, Gabriel Figueiredo, enquadravam-se na categoria de estudanteoperário. A composição política dessa chapa era heterogênea, seu candidato principal era membro da juventude do $\mathrm{PCB}$, mas os demais não tinham vínculos com movimentos políticos mais avançados. Em linhas gerais, os membros da "Ação 63" eram militantes organizados a partir do grêmio do Ceneart, egressos da ala juvenil autonomista.

Em que pese à fraca mobilização levada a cabo pelos partidários de Francisco Rossi, a eleição foi extremamente disputada, devido à notória habilidade política do líder da chapa "Bandeirantes". Observemos o relato de Gabriel Figueiredo sobre o desenvolvimento da campanha entre os secundaristas de Osasco:

As eleições para a UEO-63 foram aquecidas pela tomada de consciência dos secundaristas de que necessitavam de uma entidade representativa dos seus interesses, com projetos de realizações, bandeiras de luta e respeitada na correlação das forças políticas que emergiam no jovem e pujante município. Duas chapas foram formadas para disputar a liderança do movimento estudantil da cidade e as quatro escolas secundaristas existentes abriram as suas portas para as chapas expressarem seus programas e solicitarem apoio. Havia muitos professores progressistas em Osasco, o que facilitou a entrada da política estudantil nos estabelecimentos. Tínhamos o direito, as chapas é claro, de fazer uma visita em cada sala de aula para expor nossos programas. Lamentavelmente o Colégio e Escola Normal Nossa Senhora da Misericórdia, dirigida por freiras e destinada a estudantes do sexo feminino, impediu o ingresso da chapa que eu liderava - Ação 63 - nas suas dependências, autorização que foi dada a chapa adversária - Bandeirantes - liderada por Francisco Rossi de Almeida. O motivo desta proibição, anti democrática, nunca nos foi explicado oficialmente e nem amistosamente pela Madre Superiora, o que ensejou uma série de especulações,, sendo que a mais difundida era a de que nossa chapa era de comunistas e que estes não deveriam usufruir do direito de pregarem suas idéias no sacrossanto espaço do Senhor.

O centro do debate entre as duas chapas era a busca de melhores condições para os estudantes se desenvolverem. Bolsas de estudo, atividades culturais, científicas e sociais, bibliotecas, Casa do Estudante, eram alguns pontos de debates.

O diferencial da chapa Ação-63 para a chapa Bandeirantes é que a Ação incluiu política no seu discurso. Isto porque, em termos locais, estávamos numa época conturbada de irregularidades políticoadministrativas no nascente município, e em termos mais gerais, um panorama nacional complexo com o presidente João Goulart e a sua política de reformas ${ }^{99}$.

99 Entrevista de Gabriel Figueiredo ao autor, 31/05/2010 
A contenda terminou com a vitória da chapa "Ação 63", Rossi venceu com larga vantagem no colégio Nossa Senhora da Misericórdia, mas perdeu nos demais ginásios da cidade. Ainda assim, a vitória se deu por apertada margem de votos. A nova diretoria foi composta por: presidente, Gabriel Figueiredo (Ceneart); primeiro vice-presidente, Hélio Bahovsky (Ceneart); Segundo-vice, Antonio Salgueiro (Duque de Caxias); secretário geral, Arnaldo Vieira (GEPA); primeiro-tesoureiro, Enio Spitaletti (Duque de Caxias); segundo secretário, Antonio Moura (GEPA); primeiro tesoureiro, Moisés Pereira Neto (Duque de Caxias); segundo tesoureiro, Jair Sanches (Ceneart) ${ }^{100}$. A nova diretoria conquistou uma sede, cedida por Fortunato Antiório, tio de Gabriel Figueiredo, dentista e professor de matemática no Ceneart. A sede funcionava em sala anexa ao consultório odontológico de Antiório, um andar acima do Bar Central, localizado na Rua Antonio Agu, principal via de Osasco. A primeira diretoria realizava suas atividades no Ceneart.

Também contribuiu para o prestígio dos estudantes vinculados a chapa “Ação 63” a mobilização realizada contra manobras políticas promovidas pela primeira bancada de vereadores da cidade. João Gilbert Port, ao tomar conhecimento de um projeto apresentado por seus colegas de vereança, que propunha aumentar os vencimentos da edilidade local numa quantia que superava em duas vezes os valores recebidos por seus homólogos de São Paulo, acionou o estudantado. A partir do grêmio Ceneart, secundaristas contrários a manobra dos edis organizaram um grande protesto que se dirigiu a recém inaugurada Câmara Municipal de Osasco. O protesto terminou em quebra-quebra, invasão das dependências da câmara e fuga dos vereadores, temerosos ante a indignação dos manifestantes. Como consequência das mobilizações, os salários dos representantes legislativos foi estipulado em "valores razoáveis para a época" ${ }^{\prime 101}$.

A UEO surgiu como um aparelho de mobilização altamente politizado, herdeiro de lutas bem sucedidas, e até mesmo Francisco Rossi estava ciente disso, o que o forçava a se apresentar como uma liderança de "esquerda", contrário apenas, segundo suas palavras, ao aparelhamento da agremiação por grupos políticos profissionais, entenda-se o PCB. Gabriel Figueiredo estava inserido nas lutas históricas dos estudantes engajados de sua cidade, e seu discurso coadunava com a recente tradição da UEO. A composição de sua chapa era uma garantia de que o "espírito de luta" da agremiação permaneceria o mesmo.

Já consolidada localmente, a UEO ambicionava expandir sua influência em âmbito

100 PITERI, Guaçu. Op. Cit. p.317

101 MARTIN, Sonia Regina. Op. Cit. p. 94-95 
regional, o que se realizaria através da constituição do CREBS (Conselho Regional Estudantil da Baixa Sorocabana). Pelas palavras de Antonio Salgueiro, essa associação regional foi proposta por Moisés Pereira Neto, tesoureiro da chapa “Ação 63”. O projeto da nova sigla foi apresentado num Congresso da UBES (União Brasileira dos Estudantes Secundaristas), realizado em Itu, no ano em questão. Internamente, o tesoureiro da UEO justificava a associação nos seguintes termos, segundo Salgueiro:

(...) e o Moisés, quando chegamos lá (congresso em Itu), falou assim, "olha, eu queria que vocês prestigiassem o meu projeto, porque Osasco tá uma cidade, que do ponto de vista do movimento operário, nós só perdemos para o $\mathrm{ABC}$, temos um sindicato forte pra burro, e nós precisamos expandir para a região", o movimento estudantil precisava expandir no mesmo nível do movimento operário ${ }^{102}$.

Ainda sobre o CREBS, comenta Gabriel Figueiredo:

A ideia do Conselho Regional de Estudantes da Baixa Sorocabana (CREBS) partiu da UEO que entendia a importância de ampliar na região o movimento estudantil. Seu presidente, eleito em Assembleia realizada na cidade de Itu-SP, foi o tesoureiro da UEO, Moisés Pereira Neto, estudante do Caxias" ${ }^{103}$.

Antonio Salgueiro não era comunista, apresenta-se como um "defensor da democracia", e diz que essa sempre foi sua postura, sobretudo durante sua militância no ME. Vimos acima que a composição da chapa dirigente da segunda gestão da UEO era heterogênea, composta por diretores formados nas lutas emancipacionistas. Contudo, é inegável a influência pecebista na diretoria, representada por Gabriel Figueiredo, presidente da entidade. Há controvérsias sobre a coloração política de Moisés Pereira Neto, tesoureiro da UEO. Antonio Salgueiro o aponta como quadro do PCB; Gabriel Figueiredo se identifica como único membro do Partidão na diretoria eleita através da chapa "Ação 63". Pelos depoimentos acima, vemos que a proposta do CREBS tem alguma consonância com a política sindical pecebista, pois o Sindicato dos Metalúrgicos de Osasco responde não apenas por seu município sede, mas por toda região oeste da grande São Paulo. Nesta etapa, o presidente do SMO era Conrado Del Papa, primeiro dirigente da entidade, ligado ao PSB, mas articulado a grande política pecebista. Até que ponto Moisés Pereira Neto estava envolvido na política comunista, 
ou socialista, é algo que nossa documentação não pôde responder. Mas esse projeto estava apenas em construção, os eventos de finais de 1963 e começo do ano seguinte impediram a sua consolidação.

Tal clima de polarização ideológica esteve presente na campanha pela terceira diretoria da UEO, realizada em março de 1964. Gabriel Figueiredo indicou para candidato a presidente da nova diretoria Helio Bahovsky, vice-presidente da chapa "Ação 63", representando o Ceneart. A outra chapa foi novamente liderada por Francisco Rossi, dessa vez mais experiente. Porém, um fato viria contrabalançar o equilíbrio de forças no pleito a ser realizado em abril: a prisão de Gabriel Figueiredo, logo após o Golpe de Estado. Num clima de grande tensão, Rossi foi finalmente eleito presidente da UEO. O novo presidente da agremiação atribuiu sua vitória ao fato de seus adversários não terem feito a campanha "como deviam" 104 . O clima de perseguição imposto a Osasco após o dia $1^{\circ}$ de abril do ano em discussão dispersou os militantes comprometidos com a candidatura de Helio Bahovsky. Vejamos mais este relato de Gabriel Figueiredo, para um melhor entendimento de como se efetuaram as eleições para a nova diretoria da União dos Estudantes de Osasco:

Rossi foi candidato novamente nas eleições de 1964 e venceu. Na ocasião eu estava preso, incomunicável, no $4^{\circ}$ Regimento de Infantaria, localizado em Quitaúna, bairro de Osasco. Só fui saber da vitória eleitoral do Rossi dias depois da sua realização, por razões obvias. Quando, após cerca de aproximadamente 40 dias, fui removido da solitária, à noite (ou de madrugada), para interrogatório no $4^{\mathrm{o}} \mathrm{RI}$. Lembro-me que o primeiro a me dar a notícia sobre a vitória da chapa Bandeirantes, foi, em tom jocoso, sarcástico e provocador, o major Oyama Olinto de Almeida, que presidia o Inquérito Policial Militar de Osasco (IPM-Osasco). Tentou abalar meu estado moral com a notícia, me desmoralizar, me ofender e ameaçar-me. Não me chamava pelo nome mas por "comunistinha de merda" e "vermelho filho da puta". O interrogatório levou horas, nem sei quantas pois eu estava desorientado no tempo. Só me lembro que ví o dia clarear. Devo aproveitar este momento para reiterar que Rossi, independentemente das nossas posições contrárias, não me delatou para a ditadura, conforme foi acusado, injustamente, durante muitos anos. Já fiz esta declaração pública mais de uma vez. Não há nenhum documento, e procurei em várias fontes, para comprovar esta leviana acusação. Fui preso pelos golpistas porque sabiam que eu era uma jovem liderança comunista, cuja evolução das atividades precisava ser cortada pela raiz. Não sei até hoje como sobrevivi. (...)

Atribuo a vitória de Rossi à desmobilização da Ação-63, que impactada pela minha prisão, não pôde manter sua atividade plena. Lembro-me, apesar de ausente, incomunicável no cárcere, por 
informações posteriores, que Antonio Salgueiro, meu segundo vice-presidente, foi quem presidiu as eleições, visto que o primeiro vice, Hélio Bahovsky, nem compareceu ao evento porque sentia-se ameaçado, e acho que com razão, pelo seu próprio sobrenome. Foi nesta atmosfera que Rossi venceu a eleição e ainda assim sua gestão foi inexpressiva, até porque a ditadura dissolveu as entidades que representavam o movimento estudantil. (... $)^{105}$.

O temor de novas prisões afugentou a militância estudantil de esquerda de Osasco. Foi necessário algum tempo para o ME local se recompor do baque inicial proporcionado pela intensa repressão levada a cabo pelos militares contra os movimentos sociais do município, especialmente marcado pela volúpia punitiva dos golpistas. O fato de a cidade contar com vários quartéis apenas reforçava os ímpetos repressivos dos novos donos do poder.

\subsection{A formação do CEO}

A repressão pós golpe atingiu todos os movimentos sociais do país que de alguma forma estavam alinhados ao governo deposto. Para agilizar os expurgos, uma das primeiras medidas adotadas pelo novo regime foi a instauração dos IPM's (Inquéritos Policiais Militares), ferramenta da justiça militar que agora era expandida para toda a população. A principal característica dos IPM's é a sua agilidade, e o novo governo empossado em 15 de abril de 1964 tinha pressa em desmobilizar seus adversários, sobretudo os grupos articulados em torno da Frente de Mobilização Popular. Antes mesmo da posse de Castelo Branco, foi decretado o AI-1, em 9 de abril, mecanismo que garantia a eleição indireta do novo presidente, permitia a cassação dos direitos políticos por dez anos de todos os cidadãos considerados nocivos a nova ordem estabelecida, e abria caminho para a institucionalização dos Inquéritos Policias Militares.

$\mathrm{Na}$ onda de perseguições, o ME foi especialmente atingido. Faculdades, centros acadêmicos e agremiações estudantis foram atacadas no país inteiro, "tiros de metralhadora atingiram as escolas mais politizadas, como a Faculdade Nacional de Filosofia", no Rio de Janeiro. O prédio da Faculdade de Filosofia da USP, localizado na Rua Maria Antonia, foi invadido pela tropa de choque paulista, em ação que não economizou em danos e destruição ao patrimônio público. O mesmo se verificou na Universidade de Brasília. A sede histórica da

105 Entrevista de Gabriel Figueiredo ao autor, 31/05/2010 
UNE, localizada na Praia do Flamengo, Rio de Janeiro, foi invadida e incendiada, tendo seus documentos apreendidos pelos serviços de inteligência da Marinha ${ }^{106}$. Destino semelhante tiveram todas as escolas e faculdades que primavam pelo espírito crítico nos demais estados da federação.

Esse processo se completou com a decretação da Lei $\mathrm{n}^{\circ} 4464$, de 11 de novembro de 1964, que ficaria conhecida como Lei Suplicy, em homenagem ao seu criador, o Ministro da Educação de Castelo Branco, Flávio Suplicy de Lacerda.

A Lei Suplicy de Lacerda visou, especialmente, a extinção do movimento estudantil brasileiro. Para acabar com a participação política dos estudantes, a Lei procurou destruir a autonomia e a representatividade do movimento, deformando as entidades estudantis, em todos os escalões, ao transformá-las em apêndices do Ministério da Educação, dele dependentes em verbas e orientação.

Pelo documento, a UNE era substituída pelo Diretório Nacional de Estudantes e as Uniões Estaduais pelos Diretórios Estaduais (DEEs). Impedia-se, além disso, através de restrições as mais variadas, o livre curso do diálogo entre os Diretórios acadêmicos e os alunos. Na regulamentação das entidades estudantis, feita inteiramente a revelia dos estudantes e sem qualquer consulta a eles, a Lei Suplicy de Lacerda tornava possível a convocação do Diretório Nacional dos Estudantes pelo Ministério da Educação, ferindo, assim, o mais elementar princípio de funcionamento de uma entidade de representação - o direito a autonomia. ${ }^{107}$

Ao nível dos centros universitários, deveriam ser implementados os DCEs (Diretórios Centrais dos Estudantes), e para a representação nos cursos deveriam ser organizados os DAs (Diretórios Acadêmicos), ambos subordinados a política geral dos militares para as organizações estudantis. Com relação às associações secundaristas, não há um enquadramento definido, o artigo 18 da Lei $\mathrm{N}^{\circ} 4.464$ se refere as tais agremiações nos seguintes termos:

Art. 18. Poderão ser constituídas fundações ou entidades civis de personalidade jurídica para o fim específico de manutenção de obras de caráter assistencial, esportivo ou cultural de interesse dos estudantes.

Parágrafo único: nos estabelecimentos de ensino de grau médio, somente poderão constituirse grêmios com finalidades cívicas, culturais, sociais e desportivas, cuja atividade se restringirá aos

106 MARTINS FILHO, João Roberto. Movimento Estudantil e Ditadura Militar - 1964 -1968. Campinas- SP: Editora Papirus, 1987. p. 82-83

107 POERNER, José Arthur. O Poder Jovem, história da participação política dos estudantes brasileiros. Rio de Janeiro: Civilização Brasileira. 1968. p. 242. 
limites estabelecidos no regimento escolar, devendo ser sempre assistida por um professor.

A Lei Suplicy não tinha como objetivo extirpar do país toda e qualquer forma de organização estudantil, visava sim enquadrar as associações do ME nos moldes do sindicalismo corporativista, inaugurado por Vargas durante o Estado Novo. Instituir uma espécie de peleguismo estudantil, vinculando agremiações ao Ministério da Educação, tornando-as dependentes de verbas provindas de arrecadação governamental, a guisa do que ocorria no sindicalismo oficial. A nova Lei visava "sanear" o ME brasileiro, livrá-lo de toda e qualquer influência esquerdizante. Dentro desta perspectiva, foram fechadas e postas na ilegalidade a UNE, as UEEs, a UBES; uniões metropolitanas, e organizações secundaristas, dentre estas, a UEO.

Mas antes de discutirmos o ocaso da União Estudantil de Osasco, é necessário um breve retrospecto sobre as atividades estudantis brasileiras nos agitados anos iniciais da década de sessenta. Com relação a esse período, concentrarei minha análise nas atividades da UNE, porque esta organização era o principal e mais visível aparelho de atuação do ME nacional, embora não fosse desprezível a atuação das Uniões estaduais universitárias e das entidades secundaristas.

A UNE reconhece o ano de 1937 como sendo o de sua fundação, de agremiação formada para fins assistenciais e recreativos, a entidade rapidamente se politizou e passou a se posicionar perante os debates políticos nacionais. Participou ativamente de manifestações anti-Eixo, durante a Segunda Guerra Mundial. Esteve engajada nas campanhas em favor da nacionalização da exploração do petróleo brasileiro, conhecidas como "o petróleo é nosso", especialmente em finais dos anos 1940, campanhas que foram fundamentais para a posterior criação da Petrobrás. Apesar de sua recente trajetória de lutas sociais e vitórias políticas, entre 1950 e 56, a UNE foi comandada por estudantes conservadores, chamados de "ministerialistas" por seus adversários à esquerda, assumindo tendências liberais e antipopulares. No $19^{\circ}$ Congresso da UNE ocorreu a "recuperação democrática", pelas palavras dos próprios estudantes. A retomada da entidade pelos grupos opositores aos "ministerialistas" foi encabeçada pela União Metropolitana dos Estudantes (UME) da capital federal de antanho, Rio de Janeiro.

O diretor da agremiação carioca, José Batista de Oliveira Jr, esteve a frente de um movimento grevista local, contrário a um aumento abusivo nas passagens dos bondes. "Este 
movimento atingiu amplos setores estudantis e populares, criando-se daí a União Operária Estudantil contra a carestia e provocando nova invasão policial a UNE, sendo espancados estudantes e deputados ali presentes. Apesar da invasão de sua sede a UNE obteve vitória nessa luta. O preço das passagens de bonde sofreu um aumento de 50\% menos do pretendido pela empresa"108. A vitória da UME-RJ teve ressonância nacional, o que possibilitou a vitória de José Batista, dando início a uma nova fase para UNE. É marcante nos eventos supracitados a tentativa de formação de uma frente operário-estudantil, projeto que será retomado nas jornadas de luta pré golpe, e recuperado no agitado ano de 1968.

$\mathrm{O}$ ascenso das lutas populares, crescente entre as classes laborais, contagiou a UNE a partir da gestão Aldo Arantes, entre 1961 e 1962. Aldo Arantes estava integrado a vaga progressista cristã identificada por Michel Löwy como "cristianismo e libertação". Egresso dos setores esquerdistas da JUC, sua presidência marcou uma virada programática na UNE. Até seu $23^{\circ}$ Congresso - pós hiato liberal-conservador - esta entidade se encontrava atrelada ao projeto nacional-desenvolvimentista defendido pelos intelectuais do PCB, referendados pelas teses do ISEB, em consonância com o novo programa político do Partidão, em vigor a partir de março de 1958. Em linhas gerais, a nova diretriz política adotada pelos comunistas defendia uma aliança tática entre trabalhadores (ou classes populares), "burguesia nacional" e setores progressistas das classes médias. Pela "carta de março", os inimigos a serem combatidos pelas forças progressistas nacionais seriam: o imperialismo e seus agentes em solo nacional; e a secular concentração fundiária existente no campo brasileiro, ocupado por latifúndios geridos por regras análogas as dos regimes feudais. Nesse panorama, o ME agiria como força auxiliar da "frente única" democrático-burguesa.

Apesar de engajada nas propostas nacionalistas da esquerda nacional, a UNE, após a gestão Aldo Arantes, alçou voo solo, deixando de atuar como um setor juvenil do PCB. Nos momentos mais críticos do quadriênio pré-ditadura, a UNE esteve mais próxima das proposições de líderes radicais como Francisco Julião, a propor reformas "na lei ou na marra", do que das opções moderadas de Luís Carlos Prestes e seus signatários. Datam desse período os projetos mais arrojados do ME nacional, como a UNE-Volante, série de palestras e espetáculos teatrais que percorreu todo o país, expondo propostas para uma Reforma Universitária e Educacional. Neste impulso também foi criado o CPC, trincheira de atuação cultural promovida pela UNE, berço de uma série de artistas engajados que se fariam

108 “MEMOREX: elementos para uma história da UNE”. São Paulo: Edições Guaraná. Único exemplar, s/d 
presentes no cenário cultural brasileiro nos anos seguintes ${ }^{109}$.

Além da luta contra os "subversivos", outra bandeira a empolgar os golpistas foi o combate a corrupção, para muitos generalizada durante a "república sindicalista" de João Goulart, herdeira direta do "mar de lama" dos tempos getulistas. O principal grupo a encampar tal discurso foi a UDN, ecoando a pregação de seu maior ativista, Carlos Lacerda. Em se tratando de Osasco, com base no primeiro inimigo a ser extirpado, a subversão, foi decretada uma intervenção no SMO, e a prisão de seu presidente, Conrado Del Papa. As lideranças do PCB osasquense, dentre elas Constantino Stoiano, tiveram que partir para a clandestinidade $^{110}$. Militares que serviam em Quitaúna, e estavam vinculados as associações de quadros subalternos das forças armadas, foram exonerados do exército. Onofre Pinto, presidente da Associação dos Sargentos e Subtenentes do Estado de São Paulo, foi cassado, e a entidade a qual presidia fechada. A UEO também não resistiu por muito tempo. De acordo com Hirant Sanazar, houve cerca de "45 prisões no município", envolvendo militantes do setor "metalúrgico, estudantil e bancário" "111. Com essas medidas, os militares visavam por fim a agitação política do município, ainda sob os efeitos da vitória autonomista.

Com relação ao segundo inimigo a ser perseguido, a corrupção, foi decretada uma intervenção na prefeitura de Osasco, e o administrador da cidade, Hirant Sanazar, foi destituído do cargo e teve seus direitos políticos cassados. A mesma sorte do prefeito teve boa parte dos vereadores do município. O vice de Hirant Sanazar, Pedro Nicolleti, membro da UDN, foi nomeado interventor pelos militares, a partir de maio de 1964. Até 1966, o posto de prefeito de Osasco seria disputado entre o titular cassado e seu vice, numa batalha de mandados de segurança. Em meio a essa disputa jurídica, Hirant Sanazar chegou a governar a

109 Para um melhor conhecimento dessa fase da UNE, e sobre a formação e atividades do CPC, consultar: MEMOREX: elementos para uma História da UNE”, Op. Cit.; BARCELOS, Jalusa. CPC da UNE: Uma História de Paixão e Consciência. Rio de Janeiro: Editora Nova Fronteira, 1994; e Depoimento de Altino Dantas para: História da UNE (Vol. 1). Depoimentos de ex-dirigentes. São Paulo: Editorial Livramento, 1980.

110 Além de Stoiano, foram identificados pelos órgãos de repressão como militantes comunistas, atuantes em Osasco: Francisco Campos da Costa, vulgo Costinha (dirigente); Modesto Gabriel de Oliveira; Domingos Fernandes da Silva, vulgo Baiano ( jornaleiro); Luiz Sérgio Zanardi (estudante de direito na USP); Lino Ferreira dos Santos (diretor do SMO); Manuel Dias do Nascimento, identificado apenas como Neto (mecânico industrial, setor jovem do PCB, posteriormente membro do GO); Ubirajara Pereira dos Monteiro, vulgo Bira ( $1^{\circ}$ secretário, seção Osasco). Esta lista é evidentemente parcial, pois a militância pecebista osasquense era bem mais extensa. Pasta OS - 0704, Delegacias do Interior, acervo DEOPS-SP.

111 DANUSA, Mara. Op. Cit. s/p 
cidade durante vinte quatros horas, até ser impedido por nova ação judicial ${ }^{112}$. O mandato da primeira gestão se encerrou em 1966, e Pedro Nicoletti foi novamente nomeado interventor local, no ano seguinte foram realizadas eleições diretas.
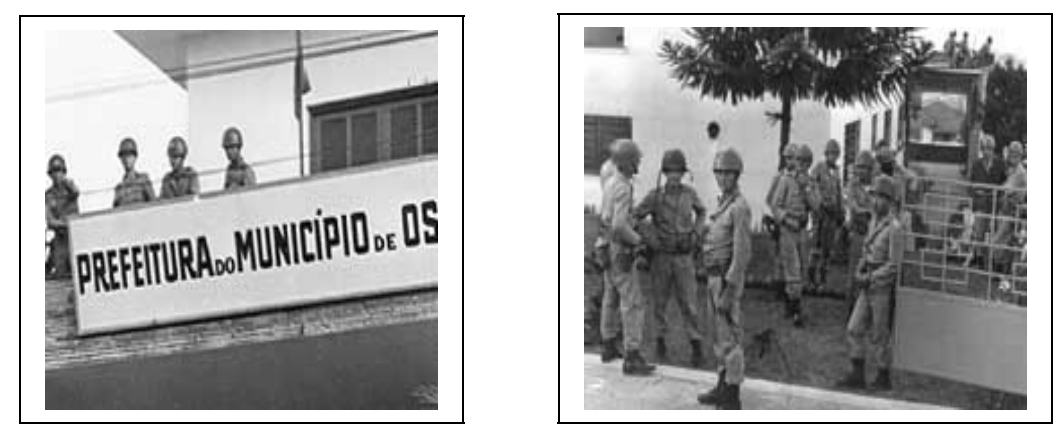

A Prefeitura e a Câmara dos Vereadores de Osasco sofreram intervenção militar após o Golpe de 64, prefeito e vereadores tiveram seus direitos políticos cassados. A cidade só voltaria a ter eleições diretas em 1967. Na foto vemos os soldados do $4^{\circ}$ RI de Quitaúna que ocuparam a prefeitura da cidade. Fonte: Site da Câmara Municipal de Osasco: www.camaraosasco.sp.gov.br

Como vimos acima, em $1^{\text {o }}$ de abril de 1964, a UEO era presidida por Francisco Rossi, que liderava um grupo que possuía certas afinidades ideológicas com os novos mandatários da Nação. Não obstante, nem o caráter conservador da nova diretoria da UEO foi suficiente para livrar a agremiação das medidas autoritárias do novo poder. Os membros da diretoria em vigor ainda tentaram uma tímida resistência, em protesto contra o fechamento de sua entidade representativa, pouco após o golpe. Segundo Francisco Rossi, foi organizada uma manifestação em Osasco contra o governo e sua postura de cerceamento as organizações estudantis, rapidamente reprimida por cerca de "200 soldados". Após o ato, Rossi diz ter sido vítima de intimidações por parte das forças da repressão, o que o fez abandonar por completo a política estudantil ${ }^{113}$. Mas os temores de Francisco Rossi logo se dissipariam, e o mesmo retornaria a vida política, sendo eleito prefeito de Osasco em 1973, pela ARENA. Retornaria mais uma vez ao cargo, em 1989.

Assim se encerraram as atividades da União dos Estudantes de Osasco, agremiação criada em 1962, no calor do movimento autonomista. Não houve tentativas de se continuar com a UEO na clandestinidade, como se deu com a UNE e as UEEs. A prisão de lideranças 
estudantis como Gabriel Figueiredo, e a falta de representatividade e disposição de luta da última diretoria da entidade apressaram seu final melancólico. Seria necessário uma nova geração para reorganizar o ME local, agora sob outra sigla.

\section{$* * * * *$}

Sobre o conceito de geração, Marialice M. Foracchi desenvolve o seguinte raciocínio:

Este fenômeno traduz-se, (...) pela estratificação da experiência que representa um estilo comum de estruturar a vida, e modo a organizar um substrato essencial, no qual são rebatidas as experiências vividas pelos membros de uma geração. Para que entre eles se firmem laços sólidos não basta apenas o traço comum da contemporaneidade. Há uma "estratificação diferencial de vida", no jovem e no adulto, que se explica pelas diferenças de locação social.

Isto significa que os membros de uma geração compartilham de um acervo comum de experiências, situações de vida e oportunidades de trabalho. Usufruem, juntos e contemporaneamente, os benefícios e a opressão, as vantagens e a vilania, a tensão e a alegria do destino prefigurado pelo seu modo de inserção na estrutura social $(. . .)^{114}$.

A geração pré-64, engajada nas lutas sociais e populares do período, compartilhou um "acervo comum de experiências" no que tange seu comprometimento com as Reformas que visavam suprimir estruturas seculares de poder em seu país. Aqui estava o elemento comum aos diversos "substratos" sociais inseridos na disputa pela hegemonia em seu meio político, o leitmotiv a amparar e dar coesão a suas demandas específicas, que por sua vez se articulavam a demandas globais. Ou seja, tratava-se de mudar o Brasil. Essa geração compartilhou os "benefícios" e as "vantagens" de se integrar há um projeto de transformação de sua sociedade, e ao mesmo tempo foi vitimada pela "opressão" e pela "vilania" quando seu projeto foi bloqueado a fórceps. Ainda segundo Foracchi, o que diferencia uma geração da outra é sua "expectativa" quanto ao futuro. O bloco nacional-popular, anterior ao ciclo autoritário, norteava-se, em larga medida, pelas teses do binômio PCB-ISEB. Suas ideias força partiam do nacionalismo varguista e do nacional-desenvolvimentismo a emanar dos intelectuais de esquerda isebianos, e alguns pensadores independentes, como Celso Furtado.

A esquerda marxista, a exceção de algumas cisões recentes, alinhava-se as diretrizes do 
PCB. Este bloco tinha como perspectiva de futuro, em tese, a construção de país soberano, com instituições voltadas a atender a população como um todo; um país comprometido com a justiça social, em condições de oferecer emprego e renda para o povo. Uma nação que não se subordinasse ao capital multinacional, exercesse uma liderança positiva na América Latina, e fosse um contraponto as políticas intervencionistas dos EUA. Não se falava em supressão do sistema capitalista, a questão era desenvolver as forças produtivas nacionais, em parceria com setores burgueses comprometidos com o crescimento do país. Tal processo seria gradual, o avanço a uma sociedade socialista estava postergado, mas ainda era uma meta, ainda que distante. Dentro dessa ótica, os movimentos sociais teriam um papel crucial, mas suas demandas não poderiam ultrapassar os limites estabelecidos pelo compromisso de classes. Tratava-se de reformar o Brasil.

Esse projeto caiu por terra em $1^{\circ}$ de abril de 1964, e todos os grupos alinhados a essa perspectiva pagaram caro. A derrota sem luta e o silêncio pós-derrocada dos mandarins do PCB reforçaram a frustração daqueles que compartilhavam da mesma "expectativa" quanto ao futuro de sua sociedade, e essa expectativa passava bem longe do projeto de país proposto pelas elites civis e militares que se apossaram do Estado. Além do que elencamos acima, também serviu para o descrédito do PCB a ausência de uma autocrítica perante seu fracasso.

A maioria da direção do PCB não soube lidar com a derrota, nem foi capaz de fazer uma autocrítica profunda da própria atuação antes de 1964. Isso provocou a maior luta interna de sua história, ao final da qual o secretário geral, Luís Carlos Prestes, e a maioria da direção lograram manter a velha linha do Partido, mas a custa da perda de prestígio e de influência política, além de sofrer uma infinidade de cisões por todos os lados $(\ldots)^{115}$

A frustração foi maior entre a juventude, e a nova geração de esquerda que se formou a partir dos escombros dos primeiros Atos Institucionais do regime militar passou a formular

115 Jacob Gorender, em seu estudo histórico-biográfico comenta que após o Golpe, na segunda quinzena de maio de 1964, um grupo de dirigentes do PCB, clandestinos no Rio de Janeiro, redigiu um documento intitulado "Esquema para Discussão". Este documento trazia uma autocrítica inicial sobre os rumos pecebistas pré-Golpe, e antecipava uma reação aos militares, em termos que poderiam derivar a uma resistência violenta. A distribuição de tal conteúdo só foi possível devido ao clima de perseguição que se abateu sobre a militância do PCB logo após o assalto ao poder pelos militares, estando o Comitê Central do partido na mais severa clandestinidade. Após a readaptação a vida clandestina, o CC recuperou suas posições de comando, e o documento autocrítico foi censurado por Prestes e o núcleo do Partidão. Ainda segundo Gorender, o documento em questão foi redigido por Carlos Marighella, Mario Alves, Jover Telles, Giocondo Dias e Orlando Bonfim Jr. Os três primeiros aderiram a luta armada. Para trecho citado acima: RIDENTI, Marcelo. O Fantasma da Revolução Brasileira. São Paulo: Editora da UNESP, 1993. p. 28; para informações de Gorender: GORENDER, Jacob. Combate nas Trevas. $4^{a}$ Ed. São Paulo: Editora Ática, 1990. p. 86-87 
suas próprias linhas de atuação política. Os novos quadros que se engajaram na luta contra a ditadura não aceitaram mais os limites estipulados pelos militantes tradicionais da velha esquerda pecebista. De igual forma, não aceitaram o enquadramento proposto pelos militares ao ME, que se manifestava em sua forma ideal através da Lei Suplicy de Lacerda. Tal posição também se manifestou no que concerne aos padrões de comportamento impostos pelos mais velhos, trata-se de uma geração que optou por viver e se portar a sua maneira, ao menos em sua fase jovem.

Em Osasco não foi diferente, um ativismo político de novo tipo se estabeleceu no município. A recente vitória autonomista livrou a militância local do sentimento de "impotência ou aniquilamento" visto em outros centros ${ }^{116}$. O setor estudantil osasquense rapidamente se recuperou do trauma das perseguições de 1964, e buscou se rearticular em outras bases, mantendo o espírito de luta que pautou suas atividades desde o início de sua atuação organizada. A construção de uma nova agremiação estudantil se efetuou como uma continuidade natural da entidade fechada pelos militares, realizou-se norteada por uma trajetória recente de lutas e conquistas. Mas a nova organização apresentou contornos bem mais radicais. Os ativistas do novo ME osasquense se articularam balizados por concepções de ação e militância diferentes das dos jovens organizados em torno da UEO, de matriz pecebista. O raciocínio de Antonio Roberto Espinosa nos dá mostras dessa substancial diferença:

Em 1964, aos dezesseis anos, eu me dizia socialista, mas democrático, socialismo com democracia, e em 65, 64 mesmo, fazendo o primeiro clássico, depois do golpe, eu resolvi ler o Marx pra combatê-lo, então eu fui ler o Manifesto Comunista, aqueles manuaizinhos, Trabalho Assalariado e Capital; Salário Preço e Lucro, com o objetivo de combater o pessoal do PC que era da minha classe. Mas aí eu fui ganho pelo Marx, eu falei “ Pô! esse negócio é lógico, esse negócio funciona”. (...) e eu falei "então é isso, é o Marx mesmo, são esses supostos marxistas que não entendem o marxismo". Então de quem foi ler o Marx pra combater, eu acabei me transformando num marxista combatendo os marxistas antigos, a quem eu achava burocráticos, espiritualmente pobres, então eu nunca passei pelo Partidão, eu já nasci dentro do marxismo contrário ao Partido. Mas até aí o movimento estudantil e mesmo o movimento operário era dominado pelo Partidão, e eu tinha essa visão, primeiro porque eu me dizia socialista democrático, depois porque eu me dizia marxista e eles deturpadores do marxismo ${ }^{117}$.

116 MIRANDA, Orlando. Obscuros Heróis de Capricórnio. Apud: RIDENTI Marcelo. Op. Cit. 179 117 Entrevista de Antonio Roberto Espinosa ao autor, 15/05/2008. 
Pelas palavras de Antonio Roberto Espinosa percebemos o desgaste da velha esquerda sobre a juventude. Os limites teóricos do PCB não encontravam mais espaço nos anseios daqueles que viram o projeto de seus professores de militância naufragar. O pensamento de Espinosa, em larga medida, assemelhava-se ao dos demais jovens que formaram a nova esquerda de Osasco, ativistas que, em sua maioria, adentraram ao marxismo distantes das teses do Partidão. Caberá a esses militantes a formação do Grupo de Osasco.

Assim como nos tempos da UEO, o Ceneart foi o espaço de formação da nova agremiação estudantil local, o CEO. Este aparelho político foi criado em finais de 1965, com um "modelo alternativo de organização, sem estatuto e registro, funcionando praticamente na clandestinidade"118. A nova agremiação era apresentada como uma "ingênua associação recreativa e cultural. Na prática, entretanto, a entidade atuava como instrumento de ação política com presença marcante no processo de resistência democrática. Apesar de ilegal, o CEO não chamava a atenção já que era tido como organização destinada à realização de "bailinhos" e de eventos sociais " 119 . Em seu núcleo de fundadores está Antonio Roberto Espinosa, José Campos Barreto, Roque Aparecido da Silva, Pedro Proskursin, dentre outros. A maioria dos articuladores da nova associação estudava no Ceneart.

A figura do estudante-operário, engajado nas lutas sociais de Osasco, salientada por Weffort, tem como modelo a geração que despontaria a partir do CEO, daqui brotaram os líderes políticos que ganharam destaque nacional em 1968. Essa nova militância promoveu uma simbiose entre movimento estudantil e operário que não se observou nos tempos da UEO. Na primeira fase, pré 1964, a articulação entre os segmentos supracitados se praticava entre setores, com certa predominância dos meios sindicais, embora os secundaristas gozassem de uma independência organizativa. Após o golpe, os setores estudantil e operário passaram a se influenciar mutuamente, interpenetrando-se, convergindo no que respeita a atuação de seus militantes. O exemplo típico desse mutualismo se encontrava nas atividades de ativistas como Roque Aparecido da Silva, eleito vice-presidente do CEO, em 1966, e secretário da comissão de fábrica da Cobrasma, no mesmo ano.

Já vimos que a partir de 1963 o Ceneart expandiu sua oferta de vagas, para atender a crescente demanda por matrículas. Pouco antes foi criado o GEPA, em Presidente Altino. A população de Osasco, em meados da década de sessenta, girava em torno de duzentos mil habitantes, quase $80 \%$ destes estavam empregados no setor industrial, sendo que a maioria 
trabalhava fora da cidade. Dos operários locais, cerca de quinze mil estavam ocupados nas fábricas da cidade. Havia uma forte concentração de operários no centro do município e em bairros limítrofes, como Presidente Altino e Km 18 ${ }^{120}$. Tanto Ceneart quanto Gepa se encontravam a poucas quadras do centro industrial da cidade, o primeiro, como mencionado, situava-se a poucos quarteirões da Cobrasma, maior empresa da localidade. Esta proximidade facilitava a articulação entre a política sindical e a estudantil.

Sobre o convívio social, o ambiente de encontro e recreação da velha e da nova guarda política da cidade se concentrava em bares específicos. Segundo Espinosa, o "bar deles ficava na rua Primitiva Vianco, chamava Cristal, era o bar do pessoal pré 64; o nosso ficava na Antonio Agu, nós chamávamos de Bar do Careca, careca nem era o dono, era o garçom" ${ }^{121}$.

O crescimento industrial local engendrou a concentração de trabalhadores supracitada, e esse adensamento demográfico, por sua vez, fez proliferar o número de jovens no município. O ciclo de crescimento econômico verificado nos anos 1950 proporcionou maior poder aquisitivo as classes laborais, especialmente as ocupadas no setor industrial, que além de se beneficiarem com a expansão da produção, formavam o segmento mais organizado politicamente. Em regiões industriais como Osasco e ABCD era natural o surgimento da categoria do estudante-operário, filho de trabalhadores ocupados nas fábricas de suas cidades. O intercâmbio fábrica-escola fazia parte da trajetória profissional dos jovens dessas localidades, e esse intercâmbio, muitas vezes, também se verificou no que respeita a organização política.

Mas como explicar o fenômeno do estudante-operário osasquense, definir sua excepcionalidade, seu radicalismo não verificado em outros centros industriais? A primeira inclinação é atribuir o perfil contestatório desses jovens a recente vitória autonomista, reforçando o caráter localista do fenômeno em análise. Mas essa explicação não soluciona o problema por completo. Após a emancipação, os grupos que se engajaram na luta pela efetivação do plebiscito de 1958, em sua maioria, adotaram posturas conservadoras, muitos aderindo a direita. Poderíamos inferir que o espírito de luta do início da década foi mantido na agremiação dos secundaristas de Osasco. Vimos que a ala estudantil era a vanguarda do movimento autonomista, seu setor mais radical, mas também se faz necessário matizar essa afirmação. Gilberto Port, primeiro presidente da UEO, elegeu-se vereador pela UDN em

120 WEFFORT, Francisco C. Movimiento Obrero y Política em Brasil: Las Huelgas da 1968 em Contagem e Osasco. s/d. p. 56

121 Entrevista de Antonio Roberto Espinosa ao autor, 15/05/2008. 
1963. Gabriel Figueiredo, outra grande liderança do ME local, manteve-se fiel as diretrizes do PCB, e não compartilhava das opções da esquerda radical do país e de sua cidade, aos quais chama de "patriotas equivocados".

Outra explicação poderia ser buscada no vazio de lideranças pós 1964 visto na esquerda local, no desprestigio do PCB depois do golpe; no choque de gerações entre militantes novos e veteranos; no desejo de reinventar as lutas populares. Mas isso por si só não esgota a questão, pois os fatores elencados acima também foram observados em outros centros brasileiros, num ambiente internacional de questionamento aos velhos paradigmas da esquerda. O radicalismo presente em Osasco não foi diferente do testemunhado em outros polos de contestação ao regime militar, não obstante, uma série de fatores conjunturais possibilitaram a inédita força política dos estudantes-operários do GO, característica não encontrada em outros lugares.

Inclinamo-nos a considerar em conjunto os elementos supracitados, elencados de forma parcial, pois não é nosso objetivo dar uma definição conclusiva do estudante-operário osasquense. Nosso objetivo é fornecer pistas sobre os fatores que foram fundamentais para a formação do caráter e da radicalidade da juventude do Osasco, reforçado a partir da segunda metade da década de sessenta, pari passu ao que se passava no restante do Brasil e do mundo.

\subsection{A setembrada e as eleições de 1966}

Como visto, o CEO foi construído no Ceneart, mais precisamente a partir do grêmio do curso clássico desse colégio. O cerceamento das associações estudantis pelos militares também coibia o funcionamento de organizações representativas em escolas de $2^{\circ}$ grau. Mas a reabertura dos trabalhos da agremiação dos secundaristas do curso clássico de Ceneart furou o bloqueio imposto pela repressão, e reativou o ME de Osasco. Em pouco tempo, foi possível a criação de uma nova entidade municipal. Segundo Antonio Roberto Espinosa, houve um mandato tampão na presidência da associação estudantil recém criada, "enquanto não se definia estatuto", e nesse ínterim quem fez às vezes de presidente foi Nilton Landa, remanescente da UEO. Uma vez definido o estatuto, foi eleita a primeira diretoria do CEO, presidida por José Campos Barreto, tendo Roque Aparecido da Silva na vice-presidência. Pelos relatos e informações que reunimos, o GO foi hegemônico ao longo da breve existência do CEO. Não se observou, nas trocas de comando deste aparelho político, eventos como os 
vistos nas campanhas de 1963 e 1964 na disputa pela UEO. A direita local não foi capaz de formar lideranças estudantis com o mesmo potencial de Francisco Rossi, o que permitiu a esquerda jovem da cidade controlar o ME local sem sobressaltos até o AI-5.

Vimos que na formação do CEO se encontra a origem do Grupo de Osasco, de seu núcleo original de organizadores brotou a vanguarda política de esquerda do município. $\mathrm{O}$ núcleo duro do GO era representado por Antonio Roberto Espinosa, Roque Aparecido da Silva e José Campos Barreto, mais atuantes no meio estudantil. Relacionado ao ME, mas atuante no meio sindical, destacava-se José Ibrahim, membro mais notório do grupo, cuja atuação será melhor discutida na próxima seção. Espinosa faz menção há quinze membros permanentes a participar do centro decisório do movimento. Podemos também arrolar a esse núcleo os nomes de Manuel Dias do Nascimento, Laurindo Martins Junqueira Filho, Pedro Proskursin, João Domingues da Silva, Natael Custódio Barbosa, atuantes em âmbito sindical e estudantil. "No início era uns quinze ou vinte, (...). Ele (GO) nunca chegou a ter uma formalidade, uma estrutura e tal, mas tinha uma espécie de direção, que era uns oito ou nove, tinha um pessoal que era mais constante, que formava uma espécie de comitê, que era uns 25 a 30 (...) ${ }^{\text {"122 }}$. A composição operário-estudantil do grupo lhe permitia uma elástica gama de alianças, o que garantia uma maior flutuação entre os movimentos sociais de Osasco. As reuniões do GO eram realizadas nos grêmios estudantis, posteriormente na sede do CEO, constituída a partir de 1967, como veremos a seguir; no SMO, nos espaços laborais e nas casas de seus membros. Não havia homogeneidade teórica entre os militantes do grupo, o que os unia era o combate a ditadura, o interesse pelo marxismo, uma certa perspectiva revolucionária, que foi se depurando com o passar do tempo, e o interesse pelos problemas de sua cidade. Esses jovens ativistas de esquerda buscavam atuar em todas as frentes, respeitando a via institucional. Veremos que os horizontes do GO foram se alargando ao longo de sua trajetória, ultrapassando os limites de sua comunidade e mesmo os limites da via institucional, para além da legalidade estabelecida pelo regime.

O passo inicial na busca por uma intervenção política em sua comunidade se deu através do CEO, organismo que surgiu estreito, organizado por militantes egressos da UEO, entidade que possuía uma considerável base de simpatizantes na conjuntura de seu fechamento. A oportunidade para a recuperação - ou conquista - de uma nova base de massas por parte da nova sigla secundarista de Osasco se efetivou com a organização da setembrada, 
jornada de lutas nacionais convocada pela UNE. Para um melhor entendimento da conjuntura em que foi programada a série de protestos de setembro de 1966, traçaremos um breve histórico dos rumos do ME nos anos iniciais do período autoritário.

A Lei no 4.464 não foi capaz de desmobilizar e enquadrar o ME brasileiro, entidades postas na ilegalidade, como a UNE, UEEs, uniões municipais e movimentos secundaristas, seguiram atuando na semi-clandestinidade. A proposta dos militares de criação de associações estudantis subordinadas ao Ministério da Educação não teve boa recepção entre o estudantado nacional, e poucos centros se submeteram a tais medidas. Apesar de seu caráter cerceador, a Lei Suplicy não bloqueou de imediato o funcionamento das agremiações, não impediu sua existência enquanto "entidades civis", o que explica a existência de associações como o CEO, que funcionava sem definição jurídica clara, contando com a conivência, ou tolerância, dos aparelhos político-repressores de sua região. Martins Filho, situando sua análise na UNE, atribui a ausência de medidas mais contundentes no sentido de bloquear de vez o ME nacional, na fase inicial do novo regime, "à visão de que a força da entidade era "artificial" e devida a fatores externos, não representando as aspirações dos "verdadeiros estudantes"',123.

A busca pela supressão definitiva das organizações estudantis brasileiras foi posta em prática no início de 1967, com o Decreto Lei-228, conhecido como "Decreto Aragão", em homenagem ao novo Ministro da Educação, substituto de Flávio Suplicy de Lacerda, Raymundo Moniz de Aragão. O novo decreto tinha como objetivo "evitar possíveis rearticulações do movimento estudantil e contornar as dificuldades imediatas de constituição dos DEEs e do DNE, o Decreto Aragão extinguiu essas entidades, assim como todos os órgãos estudantis de âmbito estadual, "ainda que organizados como entidades de direito privado", numa clara alusão as UEEs. (...) No lugar do DNE, que se pretendeu substituísse a UNE, seria instituída uma Conferencia Nacional do Estudante Universitário, que não chegou a se reunir" ${ }^{\prime 24}$.

Os decretos do governo militar se revelaram inoperantes, as associações estudantis mais combativas, em todos os níveis, continuaram suas atividades. Somente no período mais duro da repressão houve de fato um recesso nas atividades do ME nacional. A visão de que o estudantado brasileiro funcionava a reboque da política do PCB se mostrou equivocada. Como visto, antes mesmo de 1964 a hegemonia sobre o movimento era dividida com outros

123 MARTINS FILHO, João Roberto. Op. Cit. p. 88

124 CUNHA, Luiz Antônio Constant Rodrigues da. A Universidade Reformada: o golpe de 1964 e a modernização do ensino superior. São Paulo: Editora da UNESP, 2007. p. 60. 
grupos, alguns refratários aos ditames do Partidão.

Em 1965 boa parte dos segmentos sociais que deram um voto de confiança a "revolução" perpetrada no ano anterior começou rever seus conceitos. O novo governo não vinha obtendo bons frutos no setor que mais tocava a vida dos brasileiros, a economia. Ainda que a inflação tivesse baixado, em relação ao ano anterior, de $87,8 \%$ para $55,4 \%$, a política recessiva posta em prática por Roberto Campos e Octávio Gouvêa de Bulhões jogou o país numa séria recessão. Nesse mesmo ano, o setor industrial apresentou uma taxa de crescimento negativa $(-4,7 \%)$, os salários dos trabalhadores permaneceu congelado, e uma onda de falências penalizou pequenas e médias empresas. Uma sondagem de opinião pública, realizada na Guanabara, deu conta de que $63 \%$ dos inquiridos desaprovavam as políticas econômicas do governo ${ }^{125}$. Tal insatisfação seria expressa nas eleições de outubro do ano em questão, que deram vitória a Negrão de Lima na Guanabara, candidato que era alvo da antipatia dos militares linha dura. O mesmo se verificou em Minas Gerais, com a vitória de Israel Pinheiro.

A resposta de Castelo Branco, pressionado pela linha dura, foi a decretação do AI-2. Maria Helena Moreira Alves divide as medidas adotadas através do novo Ato em três categorias: "aquelas destinadas a controlar o Congresso Nacional, com o consequente fortalecimento do poder Executivo; as que visavam especialmente o judiciário. E as que deveriam controlar a representação política" ${ }^{126}$. Com o novo Ato, o governo aumentou seu poder discricionário, obteve controle quase absoluto sobre o Congresso Nacional, diminuiu os poderes do judiciário, e limitou o direito dos brasileiros no que concerne a escolha de seus representantes legislativos, restritos a duas legendas. Igualmente, tolhiu o direito do povo escolher seu presidente da república, a partir do AI-2 eleito de forma indireta. O fato é que a política recessiva e concentradora de renda da ditadura cada vez mais desagradava largas parcelas da sociedade nacional, algo que punha em estado de alerta os guardiões do regime, temerosos frente ao crescimento da insatisfação popular.

Foi nesse panorama que se realizou o $27^{\circ}$ Congresso da UNE, organização que retomou suas atividades como "associação civil”, sem fins políticos. Quatrocentos delegados, reunidos na Escola Politécnica de São Paulo, elegeram uma nova diretoria. A antiga tivera que se exilar, e a entidade se encontrava sem comando, sem sede, e sem uma definição clara acerca

125 MOREIRA ALVES, Maria Helena. Estado e Oposição no Brasil (1964-1984). Bauru-SP: Edusc, 2005. p. 98. 126 Idem, p. 111 
de sua legalidade. O novo presidente escolhido pelo Congresso foi Altino Dantas, que se apresentava como parte de "uma geração nova de estudantes que surgiram das bases para substituir as antigas lideranças ceifadas pela repressão" ${ }^{127}$. Nesse impulso, agremiações estaduais e municipais também passaram a se rearticular em todo Brasil.

A aparente calmaria verificada nos dois anos posteriores ao golpe terminou já em inícios de 1966, em março foi realizada uma greve na Escola Paulista de Medicina em repúdio a "transferência arbitrária de estudantes excedentes". Alguns dias depois, uma passeata de calouros, realizada em Belo Horizonte, foi reprimida com violência pela polícia mineira. Em solidariedade aos estudantes agredidos em Minas Gerais, uma série de passeatas foram organizadas nas principais capitais do país ${ }^{128}$.

Em julho do mesmo ano foi realizado o $28^{\circ}$ Congresso da UNE, do qual saiu eleito presidente José Luís Guedes. Esse encontro ocorreu em Belo Horizonte, e foi realizado sob forte pressão policial. A onda de agitação estudantil era um indício de que o modelo políticoeconômico adotado pelos militares e seus técnicos cada vez mais desagradava a sociedade, e Castelo Branco, pressionado pela linha dura das Forças Armadas, adotou medidas drásticas contra o ME. O semanário Visão, em 29 de abril de 1966, publicou uma matéria onde foi exposta a opinião dos setores mais autoritários do regime sobre os recentes protestos estudantis. Segundo a linha dura, o "governo chegou à conclusão de que a agitação estudantil que se observa neste momento tem inspiração comunista e alcance subversivo e vai agir em consequência". Com relação ao Congresso de Belo Horizonte, o jornal O Estado de São Paulo deu ressonância as declarações do Secretário de Segurança de Minas Gerais, que afirmou que "o certame seria o ponto de partida para um movimento nacional destinado a promover a dissolução violenta da estrutura social" ${ }^{129}$. Com base nessa certeza, o secretário mineiro determinou a ocupação da capital de seu estado por batalhões da polícia militar e de "todas as tropas situadas" na cidade e arredores, que por sua vez foram postas em "pontos estratégicos de Belo Horizonte, assim como em todas as vias de acesso" ao município ${ }^{130}$. Mesmo com toda pressão e vigilância, os trabalhos do encontro foram realizados nos porões do Convento dos Padres Franciscanos, com a participação de cerca de trezentos delegados

Apesar de toda campanha midiática contra o $\mathrm{ME}$, certos setores da opinião pública demonstravam certa simpatia por algumas das reivindicações dos estudantes, e alguns jornais,

127 DANTAS, Altino. In: História da UNE (Vol. 1). Op. Cit. p 33-34

128 MARTINS FILHO, João Roberto. Op. Cit. p.104

129 Idem, p. 100

130 POERNER, José Arthur. Op. Cit. p. 283 
como o carioca Correio da Manhã, mostravam-se favoráveis aos mesmos. Em meio às agitações que percorriam todo o país, em inícios de setembro, foram abertos os trabalhos do Congresso da União Estadual dos Estudantes de São Paulo, nas dependências da Faculdade de Engenharia Industrial (FEI), em São Bernardo do Campo. Policiais infiltrados se anteciparam ao evento e prenderam 178 estudantes. A ação foi criticada pelo novo governador paulista, Roberto de Abreu Sodré, que ocupava o cargo desde 3 de setembro, eleito de forma indireta pela Assembleia Legislativa. A maioria dos detidos foi posta em liberdade em poucas horas, porém 36 permaneceram presos, sendo os mesmos enquadrados pela Lei de Segurança Nacional. Para a libertação dos universitários que prosseguiram detidos, foi impetrado um mandado de segurança pelo professor Dalmo de Abreu Dallari. Após três dias de detenção, “de madrugada a fim de evitar demonstrações", os estudantes presos foram libertados ${ }^{131}$. Em repúdio a dissolução do Congresso da UEE-SP, a prisão dos delegados ali presentes, e contra as recentes manifestações de violência perpetradas pelas forças da repressão, ocorridas em diversos centros do país, foi convocada uma greve geral pela UNE, e foi marcado para o dia 22 de setembro um "dia nacional de luta contra a ditadura". Tal jornada de lutas ficou conhecida como setembrada.

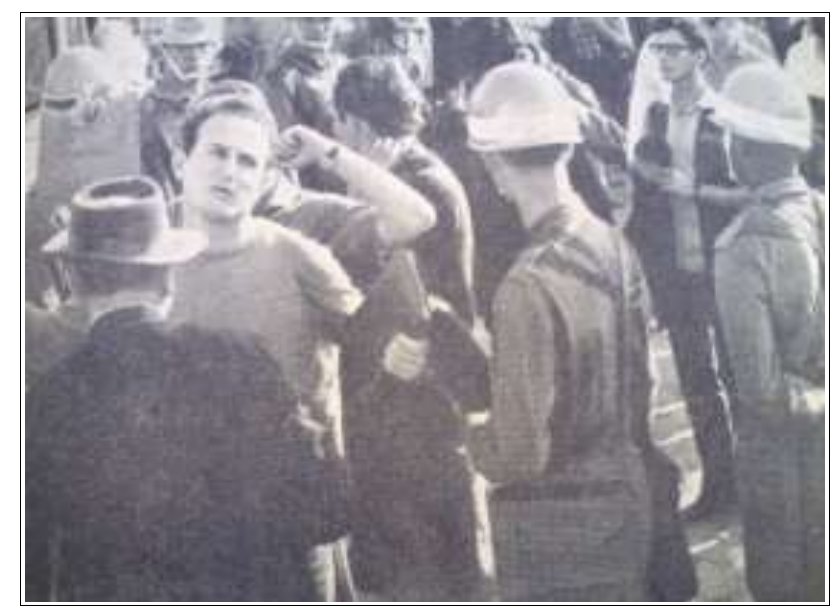

Estudantes presos no Congresso da UEE-SP, realizado na FEI (Faculdade de Engenharia Industrial), em São Bernardo do Campo, em setembro de 1966. Ao menos 36 estudantes foram enquadrados na Lei de Segurança Nacional. Fonte: Arquivo do DEOPS-SP, Pasta OP-1449, Movimento Estudantil, 1966.

131 PATARRA, Judith. Iara: reportagem biográfica. (2a Ed). Rio de Janeiro: Rosa dos Tempos, 1992. p. $135-$ 136 
Os principais polos universitários do país aderiram a greve, e grandes passeatas foram organizadas em São Paulo, Rio de Janeiro, Belo Horizonte, Curitiba, Recife, Niterói, Salvador, Goiânia, Florianópolis, Brasília; cidades do interior de São Paulo, etc. Os eventos mais dramáticos se desenrolaram no Rio de Janeiro, com violenta repressão a passeatas realizadas no dia 15, cerca de cem prisões, além de um grande número de feridos. O episódio mais grave ocorreu no dia 23, e ficou conhecido como o "massacre da Praia Vermelha". Na madrugada desta data, cerca de dois mil estudantes se encontravam sitiados por centenas de policiais na Faculdade Nacional de Medicina. Por volta das três da madrugada, teve início uma violenta invasão das dependências do centro de ensino, seguida de espancamentos aos manifestantes ali presentes. Houve dezenas de detenções e feridos com gravidade, além da depredação das instalações da Faculdade ${ }^{132}$.

Preocupado com as agitações provenientes do ME, o cardeal Dom Agnelo Rossi, em declaração dada a um programa de televisão dominical, reproduzida pelo jornal $O$ Estado de São Paulo, preconizava que:

O estudante vê muita coisa errada e pensa que pode resolver tudo com suas manifestações, sem saber que a melhor forma de resolver os problemas do mundo é estudar mais. (...) os estudantes brasileiros poderiam aproveitar o exemplo de colegiais de Minessota, Estados Unidos, que coletaram entre os moradores de uma pequena cidade mais de 19 mil dólares, e enviaram o dinheiro ao Brasil, para a construção de casas destinadas aos favelados. Para conseguir o dinheiro, os jovens lavaram automóveis e retiraram a neve da porta das casas ${ }^{133}$.

A declaração de Dom Agnelo Rossi revela o abismo de sentido que havia entre as proposições do ME brasileiro e as classes conservadoras. Via de regra, as mobilizações da juventude, ao longo de toda a década de sessenta, foram encaradas de duas maneiras pelos mais velhos: como reboquismo de organizações comandadas por adultos, como o PCB, por exemplo; ou como manifestação de imaturidade ideológica, revoltas típicas de adolescentes. As camadas conservadoras do país tinham dificuldade em aceitar que os jovens agiam como protagonistas políticos, e não como coadjuvantes, não dependendo dos mais velhos para definir suas demandas e batalhar por suas conquistas.

132 Para um relato minucioso do "massacre da Praia Vermelha", ver: POERNER, José Arthur. Op. Cit. p. 290291

133 Trecho de reportagem publicada pelo OESP, presente na Pasta OP-1449, Movimento Estudantil, acervo DEOPS-SP; localizada no Arquivo do Estado de São Paulo. 
Mas, ao menos temporariamente, os temores de Dom Agnelo Rossi foram mitigados, pois após a setembrada houve um refluxo nas lutas estudantis brasileiras. O ME só retornaria as ruas em 1968. Autores como José Arthur Poerner atribuem esse descenso nas mobilizações ao fato de que as "lideranças universitárias não souberam (...) promover um recuo organizado, para a acumulação de forças" reorganização das entidades estudantis, (...) o isolamento social do protesto universitário e a atitude "dura" do Estado (... $)^{135}$. O mesmo autor faz menção a troca de poderes que se efetivou no comando da Nação, a partir de março de 1967 chefiada pelo general Costa e Silva. O novo presidente vinha com a proposta de por em marcha uma "liberalização" do sistema político brasileiro, proposta que animou os segmentos mais moderados da oposição ao regime, esperançosos numa possível volta a democracia. Mas o diapasão moderado de Costa e Silva cedo cairia por terra, setores mais radicais das forças armadas inviabilizaram qualquer aceno no sentido de uma abertura. A política educacional do novo governo também não apresentou indícios de mudança, e as diretrizes iniciadas com Castelo Branco não apenas permaneceram as mesmas, como foram reforçadas. Já no segundo semestre de 1967 se observariam conflitos de rua envolvendo estudantes e policiais.

\section{$* * * * *$}

Em Osasco, a setembrada se manifestou no "dia nacional de luta contra a ditadura", através de uma passeata que percorreu as ruas do município. A organização da manifestação se deu a partir do grêmio livre do Curso Clássico do Ceneart, observemos o relato de Antonio Roberto Espinosa:

Houve as passeatas em São Paulo, a chamada setembrada, e nós fizemos em Osasco também, e fizemos graças a uma entidade chamada Associação dos Estudantes do Curso Clássico do Ceneart, foi a primeira (associação) reorganizada depois de 64. Eu fui presidente, o vice presidente era o Geraldo, o Barreto (Zequinha) fez parte da diretoria, foi meu colega no Exército também. (...) Essa associação surge como uma entidade livre, nós fomos no cartório e tal, mas não tinha nenhuma lei que regulasse isso, e ela (a associação) acabou dirigindo as passeatas de setembro de 66 em Osasco, dirige o Ceneart, e estudantes de outros seis colégios da cidade. Só havia seis na época, e eles também 
acabaram se mobilizando a partir da Associação do Curso Clássico do Ceneart, e tanto é que passadas essas passeatas, foi organizado um grêmio livre do Ceneart, aí já foi eleita uma chapa de todos os cursos (deste colégio), inclusive do ginásio, do científico, do normal. (...) nessa setembrada foram organizados grêmios em todos os colégios, a partir da Associação do Curso Clássico do Ceneart, e do CEO $(\ldots)^{136}$.

Pelo depoimento, vemos que a organização da setembrada em Osasco foi crucial para a solidificação da influência dos estudantes organizados no Curso Clássico do Ceneart. $\mathrm{O}$ protesto também marcou o fortalecimento do CEO enquanto entidade representativa, $\mathrm{e}$ reforçou as posições do GO. A articulação de grêmios estudantis nos seis colégios da cidade significou um importante processo de consolidação de bases, pois as agremiações que foram sendo constituídas, pelo que podemos depreender pelo relato acima, sob influência direta dos estudantes-operários do Ceneart, que por sua vez eram majoritários no CEO.

Em outubro de 1966 o GO já era uma realidade. Embora não fosse reconhecido como um grupo político, movimento ou organização, era a vanguarda da esquerda de sua cidade. Seu principal aparelho político era o CEO, e a influência do grupo entre os estudantes de seu município era crescente. Tal autoridade acabou por chamar a atenção de ativistas de jaez mais moderato, embora também contrários ao regime militar. Esses grupos de matriz liberaldemocrática estavam mobilizados no MDB local, e tinham origem no movimento autonomista.

O governo federal marcou eleições (restritas ao campo legislativo e executivo municipal) para 15 de novembro de 1966. Nesta etapa, Osasco era governada pelo interventor Mário Nicoletti, que substituíra a atribulada gestão Hirant Sanazar. A partir do MDB, apresentaram-se para o pleito três candidatos, destes, conseguiu maior destaque um jovem político ligado a liderança de Franco Montoro, remanescente das lutas emancipacionistas. Seu nome era Guaçu Piteri, candidato que representava a ala mais progressista de sua legenda. $\mathrm{O}$ nome forte da ARENA municipal, que também apresentou três postulantes, era Hugo Crepaldi, concorrente a prefeitura local que fora secretário de negócios jurídicos durante a interventoria de Mário Nicoletti.

Guaçu Piteri fora um dos fundadores do Centro Acadêmico da Faculdade de Agronomia Luiz de Queiroz, em Piracicaba, e acompanhava de perto o ME de sua cidade desde os tempos da UEO. Ciente da influência do CEO, observada nas mobilizações de 
setembro, Guaçu buscou apoio dos estudantes. A costura política entre o candidato do MDB e os secundaristas de Osasco não se efetivou sem sobressaltos, pois havia uma certa desconfiança entre os jovens da cidade com relação a política partidária, limitada pelo sistema dicotômico imposto pelo AI-2. A fortalecer a oposição a aliança, a campanha pelo voto nulo ${ }^{137}$ lançada pela UNE em âmbito nacional. Antonio Salgueiro, membro da chapa "Ação 63", que dirigiu a UEO entre 1963-64, foi um dos interlocutores entre o CEO e o candidato do MDB, e em sua casa ocorreu o acerto definitivo que garantiu a aliança. Guaçu Piteri, em seu livro de memórias, conta em detalhes a dificuldade em se obter o apoio dos secundaristas.

Os primeiros protestos vieram de diferentes pontos da sala; faltavam algumas lideranças; por que não haviam convidado os outros candidatos a prefeito? Com a presença de todos a decisão seria mais democrática. Preliminarmente foi esclarecido que todos os integrantes do grupo haviam sido avisados. Os que não podiam aparecer, haviam se manifestado solidários com a decisão da maioria. Quanto a segunda objeção, Moisés, que liderava seus colegas do GEPA, foi direto: ninguém estava ali para perder tempo com candidatos representantes da ditadura e das elites burguesas ${ }^{138}$.

Pelas palavras do secundarista identificado apenas como Moisés, têm-se uma amostra do ânimo dos estudantes brasileiros para com o sistema eleitoral bi-partidário imposto pelos militares. O ME nacional, em todos os seus níveis, adotou a bandeira do voto nulo nas eleições de 1966. A reforçar tal animosidade, a recente repressão a setembrada, ainda viva na memória do estudantado. Romper o acordo nacional poderia ser encarado como uma capitulação, ou mesmo conivência com o sistema repressor e anti-democrático da ditadura civil-militar. A se somar as dificuldades elencadas, estava o fato de Guaçu Piteri ser egresso do janismo, algo que o identificava a modelos políticos vistos como ultrapassados pelos mais jovens. O candidato do MBD se encontrava em posição difícil as vésperas da eleição, precisava conquistar o apoio da juventude local, mas ao mesmo tempo tinha a necessidade de garantir votos junto aos setores conservadores, que poderiam garantir a sua vitória.

Como superar essa resistência sem constranger a legião de bons companheiros janistas que me apoiavam? Essa questão assegurou-me certa vez Roberto Espinosa - foi contornada por Gabriel Figueiredo que, respeitado entre os colegas pela coerência ideológica, acabou por cunhar a frase 137 Segundo Maria Helena Moreira Alves, a campanha de voto nulo foi organizada pela Ação Popular, "começou nas eleições de 1966 e adquiriu crescente importância nas de 1968 e 1970". Para mais informações sobre essa conjuntura: MOREIRA ALVES, Maria Helena. Op. Cit. p. 123-128

138 PITERI, Guaçu. Op. Cit. p. 324 
mágica que causou impacto no meio estudantil: "Guaçu é janista de esquerda" 139.

Vimos no primeiro capítulo que Jânio Quadros foi figura presente no processo de emancipação de Osasco, boa parte do núcleo duro do movimento autonomista era adepta do janismo, e seguidores do ex-presidente se tornaram personalidades importantes do meio político local. Mas apenas a credencial de janista de esquerda não habilitava a candidatura de Guaçu Piteri entre os setores políticos mais avançados de sua cidade, foi necessário algo mais para se conseguir o apoio dos secundaristas do que uma simples manobra retórica. Neste sentido, de acordo com Roque Aparecido da Silva, o GO apresentou algumas exigências, falando em nome do CEO.

(...) a gente decidiu apresentar alguns pontos, primeiro, como na época a gente tinha muita dificuldade para divulgar as nossas ideias, a gente só tinha mimeografo a álcool, para reproduzir material a gente tinha muita dificuldade. Então uma das coisas que a gente negociou com o Guaçu foi que a gente faria um manifesto ao povo de Osasco e o MDB imprimiria 150 mil cópias e a gente distribuiria em todos os bairros, e esse manifesto começava com uma denúncia da ditadura, das torturas, da falta de democracia, e concluía chamando ao voto para prefeito no Guaçu, e para vereador dois candidatos que a gente indicava e ponto. Não fala nada em MDB, porque a gente oficialmente não apoiava o MDB, apesar de estar utilizando o MDB né, porque a gente indicou dois nomes para concorrer a vereador pelo MDB, que eram nossos representantes. Ao mesmo tempo, em cada comício que o MDB realizasse, o grupo teria um representante que teria direito a palavra, tinha que falar um representante nosso, esse representante iria falar na mesma linha de colocação que estava no manifesto, fazendo a denúncia a repressão, a ditadura, as torturas e tal, e para ajudar a avançar a luta pela democracia a gente apoiava aqui em Osasco o Guaçu e os dois candidatos a vereador. E uma outra questão era que se o Guaçu fosse eleito nós indicaríamos um representante do movimento estudantil e um representante da oposição sindical, do movimento operário. O Guaçu nomearia essas pessoas como assessores do gabinete dele, pra podermos ter uma fiscalização da administração por dentro, desde o gabinete mesmo do prefeito ${ }^{140}$.

Guaçu aceitou as exigências, os dois nomes indicados pelos estudantes para concorrer a câmara dos vereadores foram Pedro Proskursim, membro do GO e diretor do CEO, e Lucídio Vieira dos Santos, vindo do meio sindical bancário. Também foi adotada uma posição de "simpatia" para com a candidatura de Saburo Matsubara, dono de um curso pré vestibular 
na cidade.

Mas ainda havia a questão do voto nulo, a querela foi resolvida a partir de uma solução híbrida, em âmbito estadual e federal, ou seja, para deputados e senadores, seguir-seia a campanha da UNE; para prefeito, vice-prefeito e vereador, decidiu-se votar. Vimos que os movimentos sociais osasquenses eram fortemente marcados pelo localismo, o GO se estruturou permeado por essa concepção, o que nos confirma Roque Aparecido da Silva, atestando que "quando se constitui então o GO, ele ainda refletia muito essa identidade local, enfim, era Osasco e o resto do mundo né. Então essa característica foi muito marcante (...)”. Sobre críticas partidas do ME para com o arranjo com Guaçu Piteri, "setores criticaram, outros setores concordaram, mas a gente não tava nem aí, certo, a gente tava desenvolvendo o nosso trabalho, a nossa política aqui em Osasco, então acho que isso revela bem as características que consolidaram o Grupo de Esquerda $(. . .)^{141}$. Além de sua propensão ao localismo, o GO agia em consonância com sua proposta de atuar em todas as frentes. Sobre o desenrolar da campanha, Antonio Roberto Espinosa narra o seguinte evento:

Bom, no primeiro comício, que foi no Jardim D'Abril (bairro de Osasco), esta frente ampla do GO que apoiava o Guaçu e o MDB no plano local, me indicou para falar, em cada comício falaria um, e eu fui indicado para falar no primeiro, depois outros companheiros falaram nos seguintes, mas a tônica dos discursos foi a mesma, a diferença é que no primeiro comício no Jardim D’Abril estava o Covas, que era candidato a depurado federal, Mario Covas. E eu no palanque fiz um discurso pelo voto nulo no plano federal, que era para não votar para senador, falei, "olha, desculpe o candidato Covas (risos), que está aqui, mas é pra não votar nem nele, nem nele, é voto nulo no campo federal, e no campo local, é Guaçu para prefeito, e para vereador é Pedro Proskursin, mas, se por algum motivo não poderem votar no Pedro Proskursin, também pode votar no Lucídio, e em último caso, nesse Saburo $^{142}$.

Ao término das apurações do pleito realizado em 15 de novembro de 1966 foi anunciada a vitória de Guaçu Piteri, os três candidatos a vereador apoiados pelo ME foram eleitos. O compromisso estabelecido pelo novo prefeito foi cumprido, e suas bases jovens foram orientadas a indicar dois representantes seus para atuarem como assessores junto à gestão municipal. Representando o estudantado, foi indicado Roque Aparecido da Silva, pelo setor operário sindical, foi escolhido José Ferreira Batista. Guaçu também cedeu o imóvel 
onde foi constituída a cede do CEO, e emprestou um equipamento de som, o mesmo que era acoplado a um alto-falante, e frequentemente posto junto a entrada da entidade, "do lado de fora, e o dia inteiro, em meados de 67, tocando a Internacional, discursos, debaixo da ditadura" $" 143$.

\section{$* * * * *$}

Outra prática inaugurada pelo $\mathrm{GO}$, relacionada tanto ao meio estudantil quanto ao operário, foi a aplicação de cursos ministrados por militantes do grupo. Esses cursos passaram a ser oferecidos a partir de 1967, e eram pautados por literatura marxista. Lia-se e se discutia obras como Trabalho Assalariado e Capital; de Karl Marx, Que Fazer?, de Lenin, Princípios Fundamentais de Filosofia, de Pulitzer; Revolução na Revolução, de Regis Debray. Abordava-se também "um pouco de teoria das classes baseado no Estado e a Revolução do Lenin, lia-se Sálario, Preço e Lucro, pra entender os mecanismos da mais-valia, da exploração" ${ }^{144}$. Stanislau Zermeta, que frequentou tais cursos, tece o seguinte comentário, acerca do que era discutido nas aulas: "Ah... Era mais o Guevara né, o Guevara e o Debray, o Debray (Revolução na Revolução) era o livro da moda, mas também se lia Salário, Preço e Lucro, Trabalho Assalariado e Capital, se lia o Manifesto, então se lia a ideia de construção de uma crítica ao regime capitalista" ${ }^{\text {145 }}$. Ainda sobre esse ponto, Roque Aparecido da Silva desenvolve o seguinte raciocínio:

(...) eu acho que é importante dizer que não foram cursos que a gente deu no $\mathrm{CEO}$, foram cursos que a gente deu em Osasco, não foram organizados pelo CEO, foram organizados pelo Grupo de Esquerda. Então não é uma coisa dos estudantes para os operários, de jeito nenhum, era uma coisa do Grupo de Esquerda que era composto por operários e estudantes. Bom, aí a gente tinha vários cursos, e o principal era a gente estudar, enfim, qual eram as características da exploração do sistema capitalista, a partir daí, como que isso se manifestava concretamente para os operários, as relações de trabalho, o salário como é que era e como é que não era, etc. Depois, as características especificas daquele momento de ditadura, e aí a necessidade, enfim, a alternativa a isso era o socialismo, então as

143 Idem. Guaçu Piteri também faz menção a atitude desafiadora do CEO em suas memórias: "O sistema de som onde se tocavam músicas tidas como subversivas era emprestado pela municipalidade. Não raro, estudantes tomavam o microfone para repetir denúncias contra a ditadura dos patrões a serviço do imperialismo". PITERI, Guaçu. Op. Cit. 423

144 Ibidem.

145 Entrevista de Stanislau Zermeta ao autor, 04/11/2008 
experiências socialistas, etc; e no final, o caminho para se derrubar a ditadura, destruir o capitalismo e construir o socialismo, que passava pelas mais diferentes formas de luta, inclusive a luta armada, certo $^{146}$.

Pelos relatos acima, fica claro que a proposta dos cursos era divulgar as concepções políticas do GO, norteadas por literatura marxista tradicional, mas também balizadas por conteúdo mais atual, como textos de Ernesto Che Guevara e Regis Debray. Em que pese o interesse dos jovens ativistas osasquenses em consumir e divulgar conteúdo marxistarevolucionário, seu conhecimento teórico era ainda incipiente, o que os levava a recorrer a divulgadores com maior bagagem teórica. Segundo Espinosa, a primeira geração de universitários, da ala jovem da esquerda osasquense pós-64, começou frequentar a faculdade a partir de 1967. Destarte, militantes de movimentos da esquerda universitária começaram a ser convidados para ministrar cursos e orientar grupos de estudo em Osasco. Além do conteúdo das aulas, eram apresentadas as opções político-revolucionárias dos palestrantes. Polop, AP, e dissidência do PCB, enviaram quadros para realizar trabalho político na cidade vizinha a capital paulista, algo que muitas vezes gerou certo desconforto, porque nem sempre as diretrizes das organizações supracitadas eram bem digeridas pelos alunos:

(...) nós tivemos um problema sério, por que depois de algumas reuniões com esses professores de fora (...), era comum a gente receber reclamações dos participantes dos cursos, e aí a gente identificava muito claramente, era onde estavam as divergências grandes que a gente tinha com esse pessoal, enfim. Aí vinha o pessoal de um grupo reclamar que o cara só falava em "imperialismo, imperialismo, imperialismo"; e aqui, de concreto como é que gente vai se comportar, aqui, nossa atuação aqui, nada. O outro, "pô, o cara só fala em socialismo, socialismo, socialismo, mais nada", enfim. Era socialismo POLOP e imperialismo AP, certo, e só tinham aquela visão genérica, mas que não conseguiam vincular aquela teoria a realidade e a prática concreta, entende, então isso deu problema. E depois, já em 67, 68 particularmente, a gente passou a selecionar mais, a gente não aceitava mais qualquer um que se oferecia, por que a gente também já estava mais definido enquanto VPR, tínhamos então as nossas afinidades mais definidas, e passamos a selecionar diferentemente as pessoas que viriam, preferíamos as pessoas mais vinculadas a (futura) VPR ${ }^{147}$.

146 Entrevista de Roque Aparecido da Silva ao autor, 05/11/2008

147 Entrevista Roque Aparecido da Silva ao autor, 05/1/2008. Entre 1967 e 68, quando eram ministrados os cursos de marxismo em Osasco, ainda não havia se constituído a VPR, que começa se formar em meados de 1968, e passa a se anunciar como VPR só em dezembro desse mesmo ano. O grupo ao qual Roque faz menção era a dissidência da Polop, que posteriormente se converteria em VPR, articulada a outros grupos, dentre eles o GO. Este tema será abordado na quarta seção deste trabalho. Dentre os "professores fora" 
Antonio Roberto Espinosa comenta que "pelo menos setenta, ou oitenta lideranças de fábrica" passaram por seus cursos de "iniciação ao marxismo"; e cerca de "200" estudantes assistiram suas aulas ${ }^{148}$. Levando-se em conta o fato de que Espinosa não era o único a mediar os cursos, o número dos que frequentaram as aulas propostas pelo GO foi considerável, e serve como explicação para a influência do grupo entre à parcela mais engajada da população de sua cidade. A partir de 1968, tais cursos começaram ser aplicados também nos bairros. Mas junto aos moradores do município, não comprometidos com a política estudantil ou sindical, a tarefa de levar e popularizar concepções esquerdistas era mais complexa, e ao mesmo tempo mais ambiciosa.

(...) nos bairros, veja, nos éramos metalúrgicos, mas nos bairros tinha bancário, tinha químico, construção civil, não é, e nós tínhamos uma visão de não ficar só nos metalúrgicos, nós tínhamos que organizar de uma maneira mais ampla, e tomar os sindicatos, o sindicato dos químicos sempre foi uma batalha pra gente conquistar, o dos bancários também. Nos bairros a gente tinha uma outra visão, era necessário ter uma estrutura nos bairros, por que o aparato sindical é muito visível, a repressão tem instrumento de intervir, fechar sindicatos, cassar toda a diretoria, prender, você não pode ficar reduzido, basear todo o seu trabalho em cima de uma estrutura que é facilmente neutralizada, então nós tínhamos que ter uma estrutura nos bairros.

Sobre conteúdo marxista, José Ibrahim comenta que eram aplicados

Onde tinha condições, tinha setores em que era difícil a gente fazer isso por que eram lugares mais atrasados, mas quando o pessoal já tinha avançado a gente levava esses cursos pra comunidade. (...), mas a gente tinha que tomar cuidado, tinha lugar que a gente falava que era curso de fundo político, e tinha lugar em que a gente falava que era curso de marxismo, a gente tinha que ter essa sensibilidade de saber onde você abre mais e onde você não abre tanto, por que boa parte do trabalho nosso era clandestino ou semi-clandestino ${ }^{149}$.

A influência da jovem esquerda local, ascendente desde 1966, começou incomodar políticos tradicionais da cidade, chegando a desagradar até mesmo o prefeito Guaçu Piteri, eleito com o apoio do GO. Espinosa relata que o crescimento do prestígio, somado ao

citados Roque Aparecido, José Ibrahim destaca Clemer Schrader, um alemão que trabalhava como professor de Biologia na USP, ligado a AP, e Pio Chaves, estudante de medicina, próximo a AP.

148 Entrevista de Antonio Roberto Espinosa ao autor, 15/05/2008.

149 Entrevista de José Ibrahim ao autor, 27/01/2009 
aumento da combatividade do grupo, num contexto de acirramento das lutas anti-ditadura em âmbito nacional, era visto pelo prefeito como algo perigoso para sua posição de administrador local. “(...) "essa molecada vai começar a radicalizar e vai me levar de roldão, vou acabar sendo cassado"; então ele próprio (Guaçu Piteri) começa marcar uma dissidência em relação a gente. Mas aí também a gente começa a fazer um trabalho de bairro, começa fundar associações de bairro, e aí nós vamos disputar com as direitas de cada bairro e com o prefeito, que queria ter a hegemonia sobre a cidade" ${ }^{\prime 150}$.

As vésperas da decretação do AI-5, o GO controlava o ME de sua cidade, o sindicato dos metalúrgicos da região (cuja conquista será abordada na próxima seção), e contava com vereadores aliados. $\mathrm{O}$ crescimento do grupo ameaçava suplantar até mesmo a preponderância de líderes políticos tradicionais, como Guaçu Piteri. Em meados de 1968, o GO já expandia sua influência pela região oeste de São Paulo, com bases sendo formadas em cidades vizinhas, como Carapicuíba e Barueri.

\subsection{8: a rebelião estudantil (no mundo, no Brasil e em Osasco)}

\section{8 no mundo}

A década de sessenta marca o período em que a juventude se constituiu enquanto "camada social separada"151. Até então, a delimitação entre a infância e a fase adulta era pouco nítida, sendo que a etapa da adolescência não se considerava dentro dos parâmetros de hoje. A transição se dava da criança para o adulto. Não havia o jovem como categoria social, a juventude era um estágio inicial da maturidade. Também não havia um mercado voltado a essa camada. A partir dos anos 1960 os padrões começaram a mudar, podemos associar essas transformações ao período de prosperidade iniciado após o término da Segunda Guerra Mundial.

Os chamados "anos dourados" foram possíveis graças a um ciclo de crescimento econômico, que abrangeu o período que vai do início dos anos 1950 até meados da década seguinte. Esse crescimento foi observado sobretudo nos países desenvolvidos, com destaque

150 Entrevista de Antonio Roberto Espinosa ao autor, 15/05/2008.

151 HOBSBAWM Eric. Era dos Extremos. O breve século XX (1914-1991). São Paulo: Editora Companhia das Letras, 2009. p. 318. 
para os EUA, Europa Ocidental e Japão. Mas foi verficado também em países periféricos do sistema capitalista, como Brasil, Argentina, México, Índia, etc; ainda que reduzidas parcelas dessas nações tenham de fato desfrutado dos anos de prosperidade. Mesmo as repúblicas do bloco socialista desfrutaram desse ciclo de estabilidade econômica engendrado pelas potências capitalistas. Tal período de desenvolvimento trouxe estabilidade e paz social a regiões recém saídas do maior conflito bélico da história da humanidade.

Em se tratando de nações desenvolvidas, essa prosperidade foi possível graças à adoção de modelos políticos e econômicos voltados ao bem estar social, conceito que pode ser resumido num "consenso suprapartidário em torno aos valores de crescimento e pleno emprego", pautados por políticas de matriz keynesiana. O advento do walfare state foi definido também como produto do "ambiente econômico global criado pelos acordos de Breton Woods e que abria espaço para a conciliação entre o desenvolvimento dos walfare e a estabilidade econômica internacional" ${ }^{152}$. Esse modelo de administração estatal permitiu uma relativa conciliação entre capital e trabalho, atenuando conflitos de classe.

Esse período trouxe consigo grande crescimento populacional, o conhecido baby boom. A população mundial, em 1950, era de 2,5 bilhões de habitantes, destes, cerca de 461 milhões tinham entre 15 e 24 anos (período em que se convencionou situar a juventude), representado $18 \%$ do total. Dez anos depois, as cifras eram de 3 bilhões de habitantes, com 504 milhões entre 15 e 24 anos, sendo 16,7\% do conjunto. Em 1970, o montante chegou a 3,6 bilhões de habitantes, com 665 milhões na faixa entre os 15 e 24 anos, representando 18,1\% do total ${ }^{153}$. Pelas cifras acima vemos que a população de jovens (entre 15 e 24 anos) do planeta cresceu proporcionalmente ao número total de habitantes, variando entre 16 e $18 \%$. Não houve uma disparidade entre os membros dessa faixa etária em relação às demais. Contudo, foi notável o protagonismo cultural e político da juventude nos anos 1960. Assim sendo, o que explica a ascensão do elemento jovem na fase em análise, seu protagonismo político? O que explica sua influência decisiva no campo cultural e comportamental?

A segunda pergunta foge ao escopo de nosso trabalho, podemos, a guisa de hipótese, em se tratando da imagem do jovem enquanto formador de cultura, considerar o advento da indústria cultural, presente desde os anos 1930, mas impulsionada a partir dos 50, via Hollywood. De certo que a imagem da juventude, veiculada pelos filmes estadunidenses,

152 FIORI, José Luís. “Estado de Bem-Estar Social: padrões e crises”. Artigo disponível em: http://www.iea.usp.br/iea/artigos/fioribemestarsocial.pdf

153 As cifras supracitadas se encontram disponíveis no site das Nações Unidas, no endereço eletrônico: www.un.org 
condizia mais com estratégicas mercadológicas do que com uma reprodução do universo da faixa etária em discussão razoavelmente fiel a realidade. Ainda assim, as produções hollywoodianas influenciaram toda uma geração, moldando estilos e padrões comportamentais, ao menos nos recantos do globo contemplados pelos produtos da indústria cultural estadunidense. Podemos arrolar a discussão o crescimento sem par da indústria fonográfica na década de cinquenta, e sua internacionalização no decênio seguinte, tendo como epicentro o eixo anglo-saxônico, mas também alimentada por artistas de outras praças, como França e América Latina. Também a indústria da moda, a completar as decisivas transformações nos padrões estéticos; a revolução sexual, a alterar de maneira irreversível modos e costumes. Este turbilhão de mudanças era o mote da nascente cultura pop. Mas paralelo ao pop, desenvolveu-se outro tipo de cultura, cujo centro não se encontrava no mercado, e sim na política. Aqui começamos a responder a primeira questão proposta acima.

As raízes do advento do jovem enquanto ator político podem ser encontradas no aumento dos estudantes universitários em todo planeta. Eric Hobsbawm comenta que antes da Segunda Guerra Mundial, “Alemanha, França e Grã-Bretanha, três dos maiores países, mais desenvolvidos e instruídos, com uma população total de 150 milhões, não tinham juntos mais que aproximadamente 150 mil universitários, um décimo de $1 \%$ de suas populações”. Não obstante, no fim dos anos 1980, estudantes eram “contados aos milhões" na Europa, URSS, EUA, América Latina, Índia, Filipinas ${ }^{154}$. Em que pese políticas educacionais pouco ambiciosas, ao longo da década de sessenta a América Latina apresentou um crescimento anual de $8 \%$ em seu estudantado, com destaque para a camada universitária ${ }^{155}$. Com essas cifras, Hobsbawm pôde concluir que "só na década de 1960 se tornou inegável que os estudantes tinham constituído, social e politicamente, uma força muito mais importante do que jamais tinham sido, pois em 1968 as explosões de radicalismo estudantil em todo o mundo falaram mais alto que as estatísticas. Mas também estas se tornaram impossíveis de ignorar" ${ }^{\prime 156}$.

Concluímos, pois, que o protagonismo dos jovens no período em discussão esteve em larga medida ligado ao ambiente universitário, pois aqui se encontrava o espaço ideal para o debate político, para a militância, para a busca de novos quadros por parte de movimentos e organizações revolucionárias; para a assimilação de conhecimentos; descoberta de novas

154 HOBSBAWM, Eric. Op. Cit. p. 290 
sensações. Não temos elementos para comentar a contento o papel dos secundaristas nas jornadas de 1968 mundo afora, portanto, concentramos nossa discussão no ensino superior.

As demandas estudantis tiveram conteúdos diversos nos países em que se observou militância mais ativa por parte de seus respectivos ME's, porém, certas lutas convergiram. O que havia de comum nos ambientes universitários, naqueles que apresentavam militância ativa, era a peleja contra estruturas arcaicas de ensino e pesquisa; contra cátedras ultrapassadas e descoladas da realidade, pouca renovação nos quadros docentes; luta por maior diálogo entre professores, alunos e corpos dirigentes universitários; maior participação dos alunos na política de seus centros de ensino. Não em caráter geral, mas com forte incidência, viu-se também exigências de expansão de vagas, melhoria nos espaços acadêmicos, aumento de moradias; alimentação, bolsas de estudo. Algumas jornadas de luta se deram em países democráticos, outras em ditaduras veladas, ou abertas; em regimes socialistas, ou democracias populares; mesmo em países remanescentes do fascismo, como a Espanha franquista, houve levantes estudantis.

A reforçar o clima de animosidade entre os ME's e seus respectivos governos estava o fim (ou o início do fim) do estado de opulência vivido nos anos 1950. A partir da segunda metade da década de sessenta, o "Estado de bem estar social" começou apresentar sinais de crise. Segundo Fiori,

(...) os novos conservadores viram no welfare state peça no seu diagnóstico da crise dos estados democráticos que já vinham formulando desde a segunda metade dos anos sessenta. $\mathrm{Na}$ mesma época em que a nova esquerda, em nome de um projeto de aprofundamento da "democracia participativa" também viu no Estado de Bem Estar Social uma peça central do imenso e anônimo aparelho de Estado responsável por um gigantesco trabalho de "cooptação" e desativação da classe trabalhadora ${ }^{157}$.

A crise nos modelos políticos de "bem-estar social" contrapunha movimentos sociais e classes dominantes. Em finais dos anos 1960, o ambiente de relativa coexistência pacífica entre capital e trabalho, visto em anos anteriores, começa dar sinais de esgotamento. O paradigma até então vigente, pautado pelos walfare, chegara a seus limites, e tanto representantes mais avançados das classes populares, quanto das burguesias nacionais, estavam atentos a essa realidade. Elites liberais preconizavam uma crise que só poderia ser 
superada com cortes de gastos nas áreas sociais, e no desmonte dos serviços de proteção ao trabalhador. Teóricos da nova esquerda viam como esgotada a proposta de conciliação entre trabalhadores e patronato, expressa através associações sindicais comprometidas com os grupos dominantes. Aqui se encontrava o grande ponto de inflexão entre as classes conservadoras e progressistas verificado no centro do mundo capitalista. Mas essa inflexão não se manifestou apenas no terreno das lutas laborais, duas concepções de mundo foram contrapostas, e essa dicotomia se fez presente no terreno político, cultural, filosófico, existencial, etc. Não se efetivou apenas no âmbito da velha contenda entre esquerda e direita, esteve também presente em disputas dentro da própria esquerda. Embora os walfare tenham se desenvolvido de maneira mais pujante nos países centrais do sistema capitalista, os efeitos de sua crise foram sentidos nas periferias do sistema, cujas economias sempre se encontram fortemente vinculadas as potências centrais.

A crise do Estado atingia suas instituições, e a Universidade se encontrava em situação delicada, cada vez mais vilipendiada por governos nacionais, assediada pelo mercado, e pressionada por comunidades docentes e discentes a exigir reformas. Sobre a tensão verificada nos meios acadêmicos, Foracchi identifica no estudante seu elo mais fraco, e ao mesmo tempo seu ponto de ebulição:

O crescimento numérico da população estudantil excede, com intensidade variável, as necessidades sociais de quadros superiores. Essa massa crescente de estudantes converte-se num dos "pontos fracos" do sistema e é encarada pelo movimento estudantil como uma de suas "contradições". Os mesmos mecanismos sociais seletivos que conduzem o estudante à universidade, permitem-lhe perceber que não há lugar na sociedade para uma elite tão numerosa e que os critérios seletivos são inerentes a estrutura do sistema. Sua condição é vivida como uma crise que, longe de ser pessoal, é eminentemente social ${ }^{158}$.

O estudante, dentro da ótica do período, via-se as portas de uma sociedade competitiva, voltada ao consumo, e excludente; uma sociedade seletiva, onde as chances de sucesso profissional eram cada vez mais reduzidas. Mas o ME não foi o único protagonista nesse contexto de levantes, "havia outra figura social presente nesse ciclo de rebeliões mundiais: o operário-massa, a parcela hegemônica do proletariado da era taylorista-fordista. As lutas de classes ocorridas em 1968 solapavam o domínio do capital pela base e traziam à 
tona a possibilidade de uma hegemonia (ou contra-hegemonia) oriunda do mundo do trabalho" "159. Mobilizações operárias também foram vistas nos pontos de ebulição política do globo, embora sua intensidade tenha sido menor que a do estudantado.

Os estudantes, em suas respectivas sociedades, desempenharam o papel de vanguarda revolucionária, em alguns pontos atuando de maneira isolada, em outros buscando coalizões políticas com o operariado. Algumas bem sucedidas, outras não. No "terceiro mundo", tentarse-á a convergência entre estudantado e outras camadas sociais precarizadas, como os camponeses, a exemplo do que ocorreu na China e em Cuba, e do ocorria no Vietnã. Mas em 1968 também estava em pauta a transmutação dos valores impostos pelos mais velhos, buscava-se revolucionar o pensamento; as velhas concepções de mundo, refundar a sociedade.

O ano de 1968 recusou cabalmente pertencer ao século XX: criticou a sociedade do espetáculo, a ética do consumo, o urbanismo da alienação em nome da lógica do mercado, da indústria, da ciência e da técnica despoetizadora. Criticou o cientismo - a adesão a "ciência em si", atitude que não interroga seus fins, se justos ou desejáveis. Recusou o trabalho alienado, que "arruína o corpo e martiriza o espírito"; recusou a alienação material e moral. Recusou a política tradicional, a moral tecnocrática, a lógica da hierarquia e da submissão muda; recusou a transcendência do poder e a eficácia das leis ${ }^{160}$.

Esse estado de coisas começou ser gestado no início da década, e teve no ano de 1968 seu ápice. Há diversos estudos, relatos de memória, textos jornalísticos, dentre outras referências, sobre esse ano emblemático. Não há consenso sobre o legado de 68 , para alguns representou uma revolução cultural, que mudou para sempre os costumes da sociedade ocidental; para outros foi um evento rapidamente assimilado pelo mercado, cuja herança ajudou a reformular a nova sociedade de consumo. O fato é que logo após a onda de contestação jovem, governos conservadores foram se apossando sucessivamente dos países cujos levantes estudantis e populares foram mais intensos, reforçando o desmonte do walfare state, desmonte que se prolongaria pela década de setenta, postergando-se pelas seguintes. Ainda assim, diversos movimentos da sociedade civil atual tem 1968 como seu ponto de referência, a partir desse ano ganhariam destaque internacional o movimento negro dos EUA; grupos feministas, o movimento homossexual; a arrancada inicial de grupos ecologistas, 
ecossocialistas. Em larga medida, a esquerda do século 21 é tributária das lutas de 68. Mas não é nosso objetivo aqui definir o significado e a herança desse ano, nossa discussão é mais de caráter expositivo, a fim de salientar o espírito de contestação do período, que se espalhou por quase todo o globo, chegando, inclusive, a cidade de Osasco, nosso objeto de análise.

\section{$* * * * *$}

Os levantes estudantis de 1968 tiveram lugar na Europa ocidental, na Polônia, na Iugoslávia, na Tchecoslováquia. Nos EUA, no Canadá, na América Latina, em alguns pontos da África, Coréia do Sul, China, Japão. Faremos uma breve exposição dos principais pontos do globo onde se observaram levantes estudantis, e nos concentraremos em três regiões, que a nosso ver tiveram maior influência em nível internacional, sendo estas a Alemanha, a Itália, e a França. Mas antes de descrever os principais palcos de lutas, citaremos dois eventos que foram cruciais para os acontecimentos do ano em análise.

O primeiro fato de monta, a influenciar jovens militantes de esquerda mundo afora, foi a morte de Che Guevara, em 8 de outubro de 1967, no interior da Bolívia. A informação sobre sua morte rapidamente foi divulgada pelas agências internacionais de notícia, e para comprovar o fato, foi exibida sua fotografia, retirada após o fuzilamento. O martírio do revolucionário argentino causou comoção mundial. O mito Che se tornou referência obrigatória nos meios estudantis engajados, seu exemplo de vida (e de morte) representava a noção de que "valia a pena se sacrificar por suas ideias". A morte seria apenas um obstáculo no caminho da revolução. A imagem de Che Guevara atingiu contornos quase sagrados entre os ativistas mais radicais, e esteve presente em todas as manifestações estudantis de 1968, de Osasco ao México, de Londres a Tóquio.

Outro evento simbólico foi a Ofensiva do Tet (ano novo lunar), levada a cabo em $1^{\mathrm{o}} \mathrm{de}$ fevereiro do ano em discussão. "Todas as cidades do Vietnã do Sul e as maiores bases norteamericanas" foram atacadas pela FNL (Frente Nacional de Libertação). Em Saigon, “os comandos guerrilheiros penetraram nos jardins" da embaixada dos EUA, causando pânico entre as forças de ocupação. Após os ataques, a FNL "mostrava que não havia um único local seguro no Vietnã do Sul e que podia atacar todo o país simultaneamente, com uma precisão cronométrica"161. A Ofensiva do Tet pôs em xeque a superioridade do exército estadunidense, 
e ao mesmo tempo revelou a todos a audácia dos guerrilheiros vietnamitas. Apesar de contido, o levante conseguiu repercussão internacional e se transformou numa vitória política para a FNL. O exército mais poderoso da Terra se viu fustigado por uma guerrilha composta por camponeses, de poucos recursos bélicos. A demonstração de força dos partidários de Ho Chi Min obrigou os Estados Unidos, pela primeira vez, a reconhecer a existência da FNL enquanto movimento político, e a abrir negociações. O exemplo dos vietnamitas mostrou que um grupo bem organizado e ideologicamente coeso era capaz de derrotar uma máquina de guerra. Bandeiras do vietcong também foram vistas em passeatas estudantis mundo afora.

Dois meses antes da Ofensiva do Tet, em dezembro de 1967, a Faculdade de Ciências Econômicas e Políticas de Madri foi fechada por seu reitor, sob a acusação de "rebelião generalizada". Em janeiro, a "rebelião" apontada pelo reitor madrilenho se espalhou para todo o país. Dentre as reivindicações dos manifestantes estava a exigência de expansão de vagas para os filhos dos trabalhadores no ensino superior, pois "apenas 3\% dos universitários vinham da classe operária e camponesa". Também se exigia maior assistência estudantil, porque a evasão de alunos girava em torno de "40 ou 50\%"; igualmente os espanhóis se batiam contra "estruturas hierárquicas e feudais" dentro das faculdades. Os conflitos nos país ibérico foram constantes até maio, nesse período, parte significativa dos 175 mil estudantes espanhóis estiveram em "estado e rebelião permanente"162 até meados de 1968.

Em 30 de janeiro, cinquenta estudantes foram presos em Varsóvia, ao se manifestarem contra a proibição de uma peça de teatro, que de acordo com a censura oficial, fazia alusões “anti-russas". Os acontecimentos de Varsóvia abriram uma jornada de protestos estudantis que se estenderiam por toda a Polônia, e durariam até meados de maio. O principal alvo dos protestos era o presidente Wladyslaw Gomulka, acusado de ser excessivamente serviu ao governo soviético. Milhares de estudantes poloneses foram presos nesse ciclo de protestos ${ }^{163}$.

Em março, no Japão, militantes da facção Sampa Rengo, dos Zengakuren (Federação Nacional das Associações Estudantis) ocuparam o aeroporto de Nurita, e resistiram a desocupação do espaço pelas forças da ordem. Até o fim do ano ocorreriam violentos protestos estudantis em todo o país, com a ocupação de diversas faculdades. Em maio o governo ordenou a desocupação da Universidade de Tóquio, onde se verificaram violentos confrontos entre policiais e estudantes. O principal alvo dos protestos dos Zengakuren era o Tratado de Segurança entre Estados Unidos e Japão, que permitia a nação norte-americana 
mobilizar sua base em Okinawa em apoio às tropas de ocupação do Vietnã. O levante estudantil japonês ofuscou as comemorações do centenário da Restauração Meiji ${ }^{164}$.

Em 4 de março, foi assassinado o grande líder do movimento negro nos EUA, Martin Luther King. Sua morte abriu uma temporada de violência que duraria até o dia 11 do mesmo mês, os tumultos atingiram "125 cidades em 28 estados", e o saldo final foi de "46 mortos, 2.600 feridos e mais de 20 mil presos" ${ }^{\prime 165}$. A insurreição de março estreitou os laços de solidariedade entre o movimento negro e a SDS (Estudantes por uma Sociedade Democrática), organização criada em 1962. A causa dos negros se somou a luta contra a Guerra do Vietnã. Protestos e ocupações se multiplicaram pelo país até dezembro, a violência institucional radicalizou os ânimos, e tanto facções do movimento negro, quanto do ME, partiram para a luta armada. Os primeiros, representados pelos Black Panters, os segundos, pelos Whether Underground, cisão da SDS, organização armada a partir de 1969. A radicalização nos EUA se estendeu para além de 1968.

Embora o ano de 1968 seja o mais lembrado, as maiores mobilizações estudantis aconteceram entre 1969 e 1971. Uma pesquisa feita em 1969 em mais de 232 universidades mostrou que pelo menos 215 mil alunos participaram de protestos contra a guerra, que 3.652 foram presos e mil foram suspensos ou expulsos da universidade por envolvimento em atividades políticas. Somente no ano escolar de 1969-1970, o FBI listou mais de 1.785 manifestações estudantis, inclusive 313 ocupações 166 .

Em 10 de agosto, tropas do Pacto de Varsóvia, "num total de 650 mil homens", invadiram a Tchecoslováquia para por fim ao projeto de "socialismo de rosto humano" proposto pelos dirigentes Alexander Dubcek e Ludvik Svoboda, que foram presos após a ocupação soviética. As medidas do governo Tcheco buscavam liberalizar o panorama político de seu país, ampliar as liberdades democráticas e relaxar as restrições a liberdade de imprensa. Tais mudanças não visavam suprimir o modelo de Estado socialista, e sim abrandar a rigidez do sistema, afastando-se do padrão soviético. Para o Kremlin, essas reformas representavam uma "capitulação" frente ao bloco capitalista. Operários e estudantes tentaram uma tímida resistência contra a invasão, inócua frente ao poderio bélico dos invasores. A

164 Idem, p. 358-363

165 REIS FILHO, Daniel Aarão. 1968, a paixão de uma utopia. Rio de Janeiro: Editora Espaço e Tempo, 1988. p. 203

166 Entrevista do historiador Sean Purdy a revista Cult, disponível em:

http://revistacult.uol.com.br/home/2010/03/1968-a-rebeliao-estudantil-nos-estados-unidos 
"Primavera de Praga" marcou a cisão definitiva entre o marxismo soviético e a nova geração de esquerda, e essa cisão foi verificada em âmbito internacional.

Em setembro, o presidente mexicano, Gustavo Díaz Ordaz Bolaños, deu ordens para que sua polícia de choque, os granaderos, invadissem e ocupassem a Universidade Nacional Autônoma do México (UNAM), que se encontrava sob controle discente. Dois meses antes, uma grande manifestação em homenagem a Revolução Cubana havia sido dissolvida a bala, tendo como resultado dez mortes. O clima entre o ME e as forças de repressão era cada vez mais tenso no México, e a ocupação militar da UNAM tornou a situação ainda mais dramática. Os estudantes, levando em conta o fato de que a capital do país abrigaria os XIX Jogos Olímpicos, a partir de 12 de outubro, decidiram utilizar o evento para chamar a atenção da comunidade internacional para as violências praticadas pelo governo Díaz Ordaz. Em 2 de outubro, milhares de estudantes tomaram as ruas da Cidade do México em protesto contra a ocupação militar da UNAM. Após o por do sol, os manifestantes se reuniram na Plaza de las Tres Culturas, em Tlatelolco, a fim de realizar uma concentração pacífica. Sob ordens oficiais, forças do exército e granaderos cercaram a praça onde se realizava o ato, e abriram fogo. $\mathrm{O}$ saldo final foi de mais de quinhentos mortos, centenas de feridos e cerca de mil e quinhentas pessoas presas. Segundo relatos, os mortos foram enterrados em valas comuns no dia seguinte. Os responsáveis pelo "Massacre de Tlatelolco" jamais foram punidos, e os Jogos Olímpicos puderam se realizar a contento ${ }^{167}$.

Protestos estudantis, ao longo de 1968, também foram vistos em Seul, Pequin, Dakar, Joanesburgo, Maputo, Montevidéu, Buenos Aires, Lima, Quebec, Bruxelas, Zurique, Londres, Belgrado, Cartun, Adis-Abeba, Cairo ${ }^{168}$.

Na Alemanha Ocidental, as agitações se iniciaram ainda em 1967, após o assassinato do estudante de Letras Benno Ohnesborg, morto a tiros por um policial. Ohnesborg participava de uma manifestação organizada contra a visita do Xá do Irã ao país, realizada defronte a Ópera de Berlim Ocidental. Neste endereço ocorria uma solenidade em homenagem ao dirigente persa. A morte do universitário causou revolta nos meios estudantis de todo o país, e marcou o início de um ciclo crescente de radicalismo.

O ambiente estudantil alemão foi o que apresentou maior densidade teórica dentre seus

167 Referências sobre o evento também disponíveis em: CAUTE, David. Op. Cit. p. 349-350. O número de mortos apresentado por Caute segue as fontes oficiais, que apresentaram o saldo de vinte mortos e 75 feridos. Ainda sobre o assunto, há o documentário "Tlatelolco, las claves del masacre", produzido em 2003, dirigido por Carlos Mendoza.

168 Para listagem de países em que se verificou agitação estudantil: CAUTE, David. Op. Cit. p. 412-420; e REIS FILHO, Daniel Aarão. Op, Cit. p. 201-214. 
homólogos vizinhos, aqui se desenvolveu um movimento que ficou conhecido como "universidade crítica". Os signatários dessa proposição defendiam um ensino superior com "base na experimentação de formas de apropriação teórica, pela inquirição crítica de investigações científicas que contribuam para resolver a irracionalidade das relações sociais de dominação. Dando-se por tarefa a auto-organização dos portadores do processo teórico, compreendendo, outrossim, o esforço de converter a ciência em força teórica emancipadora, a serviço da emancipação da existência humana"169.

O ME alemão enxergava a universidade como um meio para intervir nos rumos de sua sociedade de uma maneira revolucionária, e agir como um contra-poder em face ao status quo capitalista. Sua crítica se voltava a sociedade de massas, a ética do consumo, a alienação, e a exploração aos países subdesenvolvidos. Dentro dessa linha de pensamento, a Universidade seria um polo de formação de militantes e de contra-ideologias de combate ao capital. Os grandes divulgadores das concepções da "universidade crítica" foram os ativistas da SDS (União Socialista dos Estudantes Alemães), tendo como sua principal liderança Rudi Dutschke, jovem criado na República Democrática Alemã. Dutschke era partidário das concepções político-filosóficas de Herbert Marcuse, e foi muito influente nos meios estudantis europeus. Tariq Ali, ativista paquistanês radicado na Inglaterra, comenta que o líder da SDS falava em

(...) ampliar a base do movimento estudantil com a "longa marcha através das instituições", expressão muito usada e discutida pela SDS. (...) a longa marcha não significava "tomar por dentro", mas sim ganhar experiência em todas as frentes: na educação, na informática, nos meios de comunicação de massa, na organização da produção, preservando, ao mesmo tempo, a consciência política. A meta da "longa marcha" era construir contra-instituições: zonas livres no interior da sociedade burguesa que equivaleriam às áreas libertadas pelos partidários de Marx na China, durante a longa guerra civil, e administradas pelos comunistas chineses. A universidade era decisiva nesse processo, já que era ali que seria possível treinar e preparar quadros alternativos para substituir os quadros da classe governante ${ }^{170}$.

Na França, tais concepções ganharam eco na liderança de Daniel Cohn-Bendit, jovem de ascendência alemã, adepto de concepções revolucionárias semelhantes a dos SDS alemães.

169 FORACCHI, Marialice. Op. Cit. p. 84

170 ALI, Tariq. O poder das barricadas: uma autobiografia dos anos 60. São Paulo: Editora Boitempo, 2008. p.263-264. 
Mas se o discurso Rudi Dutschke possuía prestígio entre os universitários europeus, nos setores conservadores de sua sociedade, despertava a ira. O porta voz dos segmentos ultraconservadores da sociedade alemã ocidental era Axel Springer, dono de uma cadeia de diários e revistas. Era de sua propriedade a revista Bild Zeitung (com tiragem de cinco milhões de exemplares), nesse semanário eram feitas críticas violentas a SDS, e o alvo preferencial dos ataques era o principal expoente da entidade. Os jornais do grupo Springer traziam manchetes do tipo: "Dutschke, inimigo público número 1 - acabemos com sua gangue"171.

Tamanha foi a campanha negativa, que em 14 de abril de 1968, um jovem trabalhador de extrema-direita disparou diversos tiros contra o líder da SDS, que escapou com sequelas do atentado. A tentativa de assassinato da mais destacada personalidade do meio estudantil germânico provocou uma onda de protestos que tomou conta de todo o país. No dia seguinte a emboscada, em Berlim, "milhares de estudantes tomaram as ruas com bandeiras vermelhas e cartazes de Rosa Luxemburgo e Karl Liebknecht, os mártires espartaquistas de 1919, e entraram em confronto com a polícia ao tentar invadir a prefeitura". Tumultos também foram verificados em "Dusseldorf, Colônia, Munique (onde se contaram duas mortes), Heidelberg, Mannheim, Fribourg, Essen, Badem-Badem e Frankfurt" ${ }^{\prime 12}$.

Durante o ciclo de manifestações estudantis na Alemanha Ocidental, houve tentativas de aproximação entre o ME e movimento operário local, mas o envolvimento entre os dois grupos sociais não foi além de sentimentos de solidariedade ante a violência policial. Os sindicatos nacionais, filiados ao SPD (Partido Social Democrata), optaram por seguir as diretrizes do seu partido, e não apoiaram, enquanto instituição, a rebelião dos estudantes alemães. A que se mencionar que o pensamento da SDS não coadunava com as proposições da social democracia germânica, que desde o fim da Segunda Guerra Mundial atuava em coalizão com as demais forças políticas de seu país, evitando conflitos trabalhistas de grande monta, e mantendo os sindicatos sob controle. O pensamento da nova esquerda alemã ocidental também não era visto com bons olhos pelo comunismo oficial do lado oriental da fronteira.

As manifestações se prolongaram por todo o ano, tiveram continuidade em 1969, e desse ciclo de contestação brotou a organização guerrilheira que se intitulava Facção do Exército Vermelho (em alemão RAF), mas que ficou conhecida internacionalmente como grupo Baader-Meinhof, devido aos nomes de duas de suas principais lideranças. Até seu 
desmantelamento, no final da década de 1970, seriam vistas ações armadas perpetradas pela RAF em toda Alemanha Ocidental, com um rastro de atentados, prisões, torturas e assassinados, envolvendo forças de segurança e guerrilheiros da RAF.

Os conflitos na Itália também remontam a 1967, desde o início desse ano, protestos e ocupações de universidades ocorreram em todo o país. Entre 1967 e 1968, "19 das 33 universidades públicas italianas foram tomadas por agitações estudantis; 13 foram ocupadas"173. Além de militantes provindos do ensino superior, nesse país também se verificou maciça participação de secundaristas, o ponto central a amalgamar todas as categorias do estudantado italiano foi a reforma educacional proposta pelo Ministro democrata-cristão Aldo Moro. Ainda em fevereiro de 1968, "assembleias permanentes" foram instituídas em centros de ensino ocupados por seu corpo discente, com o objetivo de realizar debates e discussões acerca das questões candentes em voga na conjuntura em questão.

Quadros da esquerda sindical, lideranças dos bairros proletários, professores, intelectuais e operários desiludidos com o reformismo dos partidos da esquerda parlamentar (PCI, PSIUP, PSU) começaram a participar nestas primeiras "assembleias permanentes", nas escolas e faculdades ocupadas. Por outro lado, a repressão policial e as represálias dos diretores contra os estudantes que militavam nos coletivos aceleraram o nascimento de um movimento de ruptura, promovido pelos estudantes, e da consciência de ser parte integrante do conflito social italiano ${ }^{174}$.

Vimos acima que na Alemanha não foi possível a construção de uma coalizão entre o ME e o movimento operário, em poucos centros europeus foi possível tal costura política. $\mathrm{Na}$ Itália, essa aliança política pôde ser levada a cabo, pois aqui se observou o estreitamento de laços, entre os dois grupos sociais supracitados, mais bem sucedido e duradouro dos cenários de luta do Velho Continente. Tal coalizão pôde ser verificada em movimentos como os efetuados na Universidade de Trente, em Turim, onde se realizou uma grande ocupação estudantil, entre novembro e dezembro de 1967, em solidariedade a uma greve dos trabalhadores da Fiat. No contexto político italiano também se destacou a figura do estudanteoperário, outra semelhança com o ambiente brasileiro e osasquense foi a atuação de comissões de fábrica, que se apresentavam como uma alternativa ao sindicalismo oficial,

173 Idem, p. 74

174 LOLLO, Achille. "Itália-1968: movimento estudantil e conflito social". In: Revista História: Debates e Tendências / Universidade de Passo Fundo, Instituto de Filosofia e Ciências Humanas, Programa de PósGraduação em História. - Vol. 1, n. 1, (junho, 1999). Passo Fundo-RS : UPF, 1999. p. 115 
preso aos esquemas políticos do PCI (Partido Comunista Italiano) ${ }^{175}$. Assim como nos demais polos de agitação revolucionária jovem, a esquerda tradicional condenou os levantes estudantis-operários ${ }^{176}$.

Estudantes e trabalhadores organizados em "comitês de base" passaram a debater lado a lado nas "assembleias permanentes" os rumos de seu país, solidificando uma união que para as classes produtoras era de forte caráter subversivo. De forma a coibir o movimento em seu nascedouro, o governo mobilizou contingentes policiais para dissolver a ocupação da Faculdade de Magistério, localizada em Roma. A retomada dessa faculdade se efetivou com grande violência por parte das forças repressoras, gerando revolta em todo país, ensejando uma série de novas ocupações por toda Itália.

Em meados de 1968 a rebelião estudantil se espraiou para os principais centros universitários do país, trazendo mais uma vez a ameaça de um levante de esquerda no Itália. Desde finais da Segunda Guerra Mundial essa região foi palco de tensões, tendo em vista a força adquirida por diversos movimentos de matriz socialista-comunista, em uma sociedade recém-saída de uma longa ditadura de extrema-direita. Tal panorama não inquietou apenas a burguesia local, gerou tensão também entre os demais membros da OTAN. Não era do interesse das potências econômicas da Europa ocidental um vizinho que adotasse um regime de governo alternativo. Notem que a Itália possuía uma larga tradição de lutas populares, sua classe operária era das mais organizadas e combativas do mundo, e o ME local caminhava a passos largos em sentido revolucionário. Se por um lado era notável o grau de organização e influencia da esquerda italiana em sua sociedade, por outro lado esta República possuía em seu território uma direita poderosa, chefiada por remanescentes do sistema fascista mussoliniano, com estreitos laços com a comunidade de informações nacional e estrangeira (CIA). Por meio da ação de grupos estudantis neofascistas, violentos enfrentamentos foram

175 Não há estudos em português que abordem a categoria do estudante-operário na Itália, encontramos referências em David Caute, Op. Cit. p 74-75. Sobre as comissões de fábrica italianas, consultar ANTUNES,

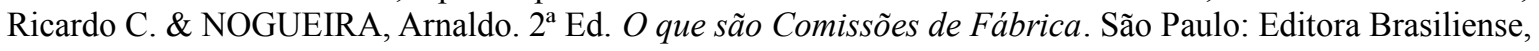
1982. p. 80-83.

176 Em meio a rebelião estudantil em seu país, Pier Paolo Pasoline dedicou um poema aos policiais atingidos por coquetéis molotovs, atirados por estudantes, na série de batalhas campais ocorridas na Itália entre estudantado e repressão no ano de 1968. Vejamos um trecho de seu poema: "pobre policial, filho do proletariado do Sul, que veste o uniforme de policial para defender o Estado democrático, enquanto é agredido por estudantes pequeno-burgueses que rejeitavam a escola". A seguir, em 15 de junho, na revista $L$ 'Espresso, Pasolini publicou outro polêmico poema, que iniciava com a frase: "Odeio vocês, caros estudantes por serem filhos de papai que atacam os pobres policiais, filhos do povo." Pasolini, que alguns anos mais tarde pediria desculpas por essas declarações, representava o pensamento típico dos intelectuais ligados ao PCI, bem como o posicionamento político da maioria dos dirigentes desse partido para com o ME. LOLLO, Achille. Op. Cit. p. 123 
travados nos centros de ensino maios combativos, dando a vazão ao clima de caos estimulado pela imprensa corporativa, associada aos interesses do grande capital, e por isso mesmo, ciosa em sua campanha de difamação do ME.

Assim como verificado em todos os palcos de luta da Europa ocidental - muito graças a postura dos comunistas tradicionais - a juventude italiana não se identificava com o velho PCI e congêneres, seu modelo de sociedade passava longe do padrão soviético, tão rechaçado quanto a sociedade de consumo capitalista. Tal ambiente de agitação política não ficou restrito ao ano de 1968, prolongando-se ao seguinte, com greves, ocupações de universidades e fábricas, e violentos confrontos com a polícia. Aqui, foi possível a construção de uma frente operário-estudantil, apesar das inciativas para isolar ambos os segmentos, promovidas por sindicatos comprometidos com a política moderada do PCI.

O ponto alto dessa jornada de lutas foi o "outono quente", em 1969, quando um milhão e meio de trabalhadores aderiram a uma greve geral coordenada a margem do sindicalismo oficial, colocando a luta política em novos patamares. O "outono quente" determinou uma ação conjunta entre os sindicatos oficiais, o PCI, a extrema-direita, a democracia-cristã e o governo italiano, vigiado de perto pela OTAN. A ofensiva se deu via repressão ao estudantado, retomada de escolas e fábricas, prisões em série, e toda uma gama de concessões calculadas oferecidas aos operários, causando divisionismo entre grupos mais avançados e moderados. A partir da década de setenta, segmentos radicais do ME e do movimento operário local formaram as Brigadas Vermelhas, organização revolucionária que travou uma luta sangrenta contra o estado italiano até os anos 1980.

\section{$* * * * *$}

De todos os levantes estudantis ocorridos em 1968, o francês foi sem dúvida o de maiores dimensões, o mais espetacular, e o que mais abalos provocou nas estruturas de poder de sua sociedade. Sobre seu questionamento radical aos costumes, sua crítica a alienação e a reificação do homem, ou seja, sua trincheira filosófico-cultural, muito já foi publicado ${ }^{177}$. Igualmente, sobre sua composição estudantil, há farta documentação e muito continua a se pesquisar e publicar até os dias de hoje. O que nos interessa, neste trabalho, é salientar a união 
- ou tentativa de união - entre operários e estudantes, algo que também foi buscado no contexto de lutas travadas no Brasil, no mesmo agitado ano de 1968. Faremos uma breve cronologia dos eventos de maio, para em seguida nos concentrarmos na greve geral levada a cabo pelos trabalhadores franceses, movimento que reuniu dez milhões de pessoas, sendo a maior paralisação já vista na história do movimento operário mundial.

As tensões entre estudantes e repressão tiveram início na Universidade de Nanterre, subúrbio de Paris, quando em 22 de março, seis membros do comitê de protestos contra a Guerra do Vietnã foram presos, após apelo do reitor Pierre Grappin as forças policiais. Em protesto, a reitoria da universidade foi ocupada, nessa movimentação teve início as atividades do Movimento 22 de Março, grupo que tinha como principal liderança um estudante judeu, nascido na França mas filho de pais alemães, chamado Daniel Cohn-Bendit. O nome do novo movimento era uma referência a organização 26 de Julho, formada por Fidel Castro, em homenagem ao assalto ao Quartel de Moncada, na mesma data, em 1954. O dia da prisão dos seis universitários de Nanterre foi tomado como um marco na luta dos estudantes dessa faculdade, assim como o fora a rebelião em Santiago de Cuba, mais de uma década antes.

Em meados de abril, o reitor Grappin ordenou o fechamento da Universalidade devido à agitação política estudantil, e tomou medidas disciplinares contra as lideranças locais, dentre elas Cohn-Bendit. Em 3 de maio, uma sexta-feira, as agitações que estiveram restritas a Nanterre, ganharam Paris. Universitários da capital se uniram aos do subúrbio, num protesto contra perseguições ao estudantado. O reitor da Sorbonne, Paul Roche, conselheiro de seu homônimo Grappin, convocou a tropa de choque, conhecida como CRS (Companhia Republicana de Segurança) sob pretexto de evitar um confronto entre os manifestantes e um grupo de extrema direita francês, conhecido por Occiente. A Sorbonne foi invadida pela polícia, estudantes foram espancados e presos. Este evento abriu o mês revolucionário na França.

Em 6 de maio, segunda-feira, teve início uma jornada de lutas que duraria até o final da semana, executada por estudantes, professores e populares do Quartier Latin, que desde o início se posicionaram ao lado dos manifestantes. A encabeçar os protestos, despontaram três organizações, o já mencionado 22 de Março, capitaneado por Daniel Cohn-Bendit, a UNEF (União Nacional dos Estudantes Franceses), presidida por Jacques Sauvageot, e a SNE-Sup (Sindicato Nacional do Professores do Ensino Superior), representada por Alain Geismar. Além dos três grupos supracitados, havia também a JCR (Juventude Comunista 
Revolucionária), movimento trotskista liderado por Daniel Bensaïd e Alain Krivine, a UEC (União dos Estudantes Comunistas), ligada ao Partido Comunista Francês, o PCF; a UJC-ML (União da Juventude Comunista Marxista Leninista), sigla de orientação maoísta; dentre outros grupos menores.

A primeira semana de lutas se convencionou considerar a fase inicial do movimento, quando as mobilizações ficaram restritas a uma maioria estudantil. Nessa fase, os protestos se espraiaram para outros centros universitários do país, e ganharam a adesão dos secundaristas, através dos CAL's (Comitês de Ação dos Liceus). Intelectuais e artistas de renome aderiram ou manifestaram solidariedade a revolta, como Jean Paul Sartre, Alain Touraine, Jean Genet, Paul Ricoeur, Nicos Poulantzas, Jean Luc Godard, Pablo Picasso, Ernest Mandel; alguns participaram pessoalmente da edificação das barricadas ${ }^{178}$. Do dia 10 para o dia 11 , ocorreu a célebre noite das barricadas, no Quartier Latin, especialmente na rua Gay Lussac, com forte reação dos CRS. Em solidariedade aos estudantes presos e espancados, foi convocada uma greve geral pelos trabalhadores para o dia 13, segunda-feira.

Até o final de maio as agitações se espalhariam para todo o país, combates entre manifestantes e forças policiais seriam observados nos principais centros universitários, inúmeras faculdades seriam ocupadas, num movimento que chamaria a atenção do mundo todo. As reivindicações imediatas não diferiam muito dos demais cenários de luta verificados nos países desenvolvidos, exigia-se melhorias nas condições de ensino e pesquisa, aumento de vagas, supressão de métodos pedagógicos ultrapassados e renovação nos quadros docentes. Também se lutava contra aquilo que ficou conhecido como reforma Fouchet, em homenagem Christian Fouchet, Ministro da Educação entre 1962 e 1967, substituído por Alain Peyrefitte, que deu prosseguimento ao projeto de seu antecessor. Dentre os pontos polêmicos da reforma, estava a divisão do ensino superior em ciclos de dois e quatro anos, sendo dificultada ao máximo a progressão nos cursos, estando os diplomas facultados aos que completassem todo o período prescrito. Essa medida visava solucionar o inchaço das universidades, eliminando no meio dos cursos boa parte dos alunos, desobrigando o governo a expandir as vagas ${ }^{179}$.

Não obstante, mais do que foi testemunhado em outros cenários de mobilização da juventude, na França, as demandas subjetivas ganharam maior destaque e chegaram mesmo a alçar voo solo. Era questionada a ordem capitalista burguesa, os costumes da tradicional sociedade francesa, os padrões de comportamento, a sexualidade, a sociedade de consumo. A 
perspectiva da "universidade crítica", desenvolvida na Alemanha de Rudi Dutschke, também se fez presente nos debates franceses, mas entre estes, as possibilidades iam além da conquista de contra-instituições, a revolução estava na ordem do dia, e possuía pretensões que ultrapassavam o terreno da cultura.

Nas jornadas de maio, foram ocupados a Sorbonne e o teatro Odéon, monumentos que foram "abertos ao povo e se transformaram em centros de debates ininterruptos sobre a nova sociedade". O tradicional festival de cinema de Cannes foi interrompido sob a acusação de "festival burguês"; o Quartier Latin, ocupado pelos manifestantes, foi rebatizado com o nome de "bairro do Vietnã Heroico". A Bolsa de Valores foi incendiada. A prefeitura de Paris, fortemente vigiada, não pôde ser tomada pelos manifestantes, como acontecera em 1871. Os funcionários da ORFT (Escritório (Office) de Radiodifusão e Televisão Francesa) se rebelaram contra seus superiores e se comprometeram a noticiar os fatos de forma "honesta, completa e objetiva""180.

Os muros de Paris foram tomados por frases que se perpetuaram no imaginário de movimentos sociais mundo afora. Frases como: "É proibido proibir", "A imaginação no poder", "Não mude de emprego, mude o emprego da sua vida", dentre outras, tornaram-se populares em todo o planeta. Frases rapidamente apropriadas pelo mercado publicitário, reproduzidas fora de seu contexto original e absorvidas pela arte pop. O ápice da rebelião cultural jovem de 1968 foi assistida no maio francês. Mas como mencionamos acima, tal movimento não esteve restrito as demandas estudantis.

Desde 1958, a França era governada pelo carismático presidente Charles de Gaulle, e seu primeiro ministro, desde 1962, era Georges Pompidou. O crescimento econômico da década de cinquenta estava em fase de desaceleração, o desemprego aumentara em 2,3\%, há cinco anos os salários se encontravam congelados, para uma classe operária que crescera em torno de $30 \%$ nos anos anteriores a $1968^{181}$. A insatisfação entre trabalhadores era latente, e os acontecimentos de maio trouxeram a tona seu descontentamento.

A partir de 13 de maio teve início a greve geral na França, a paralisação fora convocada em apoio a luta dos estudantes e em protesto contra a truculência policial. Um milhão de pessoas marcharam sobre Paris dois dias após a "noite das barricadas". Mas o movimento não se restringiu a um ato contra a violência dos CRS, e já no dia seguinte, uma

180 MARTINS, Luciano. A Geração do AI-5 e Maio de 68: Duas manifestações intransitivas. Rio de Janeiro: Editora Argumento, 2004. p. 121-122

181 ALI, Tariq. Op. Cit. p. 288-289 
onda de greves se espalhou por todo o país. À noite, o Primeiro Ministro Georges Pompidou anunciou um recuo, ordenou a reabertura da Sorbonne e a soltura dos estudantes presos, mas sua manobra não obteve êxito. Em 14 de maio, dois mil operários da Sud-Aviation, empresa próxima a Nantes, não apenas aderiram ao movimento paredista, como ocuparam a fábrica e sequestraram seus diretores. $\mathrm{O}$ mesmo foi verificado entre os quatro mil funcionários da Renault de Rouen, no dia seguinte. No dia 15 será a vez da filial de Renault em Paris, que possuía 23 mil empregados ${ }^{182}$.

As greves atingiram as indústrias mecânicas e químicas, as empresas de exploração de carvão; os empregados da EDF-GDF, do setor do gás, aderiram ao movimento, mas decidiram continuar com o fornecimento do produto a população. Os trabalhadores do setor postal cruzaram os braços, assim como os ferroviários, os portuários, os condutores de ferry-boats; que foram acompanhados por pequenos produtores rurais e camponeses ${ }^{183}$. Igualmente marcante foi a adesão daqueles que foram identificados por Alain Touraine como profissionais, trabalhadores de classe média, boa parte diplomados, sendo os mesmos professores, médicos, arquitetos, bancários, funcionários públicos, "gente do rádio e da televisão". Segundo Touraine, nesse setor se encontrava "o principal protagonista do movimento de maio", os elementos mais "ativos e independentes" ${ }^{184}$. Para se entender o raciocínio de Touraine, é necessário verificar o papel das centrais sindicais francesas perante os eventos de maio.

A principal federação sindical da França era a CGT (Confederação Geral do Trabalho), ligada ao PCF, entidade que possuía, a altura dos acontecimentos em análise, aproximadamente um milhão e quinhentos mil sócios. Em segundo lugar vinha a CFDC (Confederação Francesa Democrática do Trabalho), de origem cristã, contando com setecentos e cinquenta mil associados ${ }^{185}$. A greve geral que se desenvolveu após o dia 13 se desenrolou a margem dos sindicatos oficiais, os pegou de surpresa. A grande paralisação teve como foco detonador o ativismo estudantil. Os operários se mobilizaram a partir das barricadas, não a partir de suas federações laborais, domesticadas pelo sistema. No entanto, o sindicalismo oficial rapidamente se antecipou aos eventos e tomou a frente das negociações. Mas a simbiose entre estudantes e operários definia o caráter do movimento, levando até

182 As greves com ocupação de fábrica se popularizaram a partir do "biênio vermelho", ciclo de agitações e greves operárias ocorridos entre 1918 e 1920 na Itália. Na próxima seção discutiremos tal conjuntura.

183 CAUTE, David. Op. Cit. p. 215-219

184 TOURAINE, Alain. "Le mouvement de mai ou le communisme utopique". Apud: HOBSBAWM, Eric. Op. Cit. p. 243

185 CAUTE, David. Op. Cit. p. 216 
mesmo a comedida CGT a encampar certas exigências mais avançadas de seus associados.

Dois dias após a grande paralisação, um grupo de discussões, organizado na Sorbonne, orientava a todos os trabalhadores grevistas a ocupar imediatamente suas fábricas e organizar conselhos operários. O termo em voga era a autogestão, ideia propalada, sobretudo, pelo movimento 22 de Março, que a preconizada tanto para os meios estudantis quanto para os laborais. As ideias partidas dos ativistas acantonados na Sorbonne contagiavam os trabalhadores mais jovens, cansados do burocratismo da CGT e congêneres, porém, tais propostas eram avançadas demais para seduzir as camadas operárias em seu conjunto. Partindo da vanguarda do movimento, as palavras de ordem não se restringiam a reivindicações corporativas laborais, buscava-se também a supressão do modo de produção capitalista. Assim como o modelo estatal burguês ocidental, o modelo de Estado de economia planificada do bloco socialista era igualmente rechaçado pelos enrages franceses. $\mathrm{O}$ que estava em pauta era a criação de um novo tipo de sociedade, com um novo tipo de organização social. A supressão do próprio Estado era a meta a ser alcançada para muitos. Observemos como tal concepção era expressa pelo movimento 22 de Março:

(...) há perspectivas revolucionárias concretas mais claras que no início do Movimento. Para nós, o estabelecimento de uma sociedade sem classes passa pela autogestão. Quando os operários forem retomar o trabalho, eles farão a seguinte pergunta: Como e porque se vai recomeçar? Poder-seia fazer funcionar a empresa sem os patrões? É preciso que a autogestão se instaure para destruir o capitalismo.

\section{(...)}

A autogestão, gestão direta, pouco importam as palavras. Mas é preciso evitar que o capitalismo seja sucedido por um socialismo rígido. A tomada das responsabilidades pelos trabalhadores dispensa o centralismo, a organização, os partidos. O poder do Estado não se imporá sempre ${ }^{186}$.

O grosso dos operários que cruzaram os braços a partir de 13 de maio o fez por questões corporativas, o discurso revolucionário de Daniel Cohn-Bendit e seus companheiros soava abstrato ao trabalhador comum. Ainda assim, os dirigentes da CGT se encarregaram de formar um cordon sanitaire entre seus filiados e os estudantes. Nas passeatas de protestos iniciadas na segunda semana de maio, estudantes e operários marcharam separados, o esforço

186 Trecho retirado do livro A Revolta Estudantil, que apresenta entrevistas das principais lideranças do movimento de maio na França. Cohn-Bendit D./ Sauvageot J./ Geismar A./ Duteuil J.-P. A Revolta Estudantil. Rio de Janeiro: Editora Laudes S.A. 1968. p. 49. 
da CGT em apartar o movimento ia no sentido de evitar um possível contágio entre seus signatários pelas ideias radicais dos estudantes avançados.

A atitude da CGT era coerente com as diretrizes do PCF, a muito inserido ao status quo de sua sociedade, fiel as diretrizes do PC soviético, num contexto de detente entre as duas potências nucleares do mundo bipolar. Não seria interessante para o jogo político internacional o surgimento de um Estado revolucionário de novo tipo no coração da Europa ocidental, um dos centros do bloco capitalista. As propostas dos rebelados de maio não coadunavam com o programa moderado dos tradicionais comunistas franceses, que desde a final da Segunda Guerra Mundial optaram por atuar em seu cenário político respeitando as regras do jogo. Em contra partida, as forças do levante, seus setores mais avançados e combativos, não traziam em suas propostas alternativas ao poder estabelecido, suas bandeiras eram carregadas de demandas subjetivas, que não discutiam a fundo o estabelecimento de uma sociedade em transição a um estágio superior de organização política e econômica, com ou sem a supressão do Estado. As propostas a emanar das barricadas não podiam seduzir os trabalhadores em seu conjunto. Sobre essa problemática, Eric Hobsbawm, mais uma vez citando Alain Touraine, comenta o seguinte:

O inimigo já não é uma pessoa ou uma categoria social, o monarca ou a burguesia. É a totalidade dos modos de ação do poder socioeconômico despersonalizado, 'racionalizado', burocratizado...” O inimigo, por definição, não tem rosto e nem sequer é uma coisa ou uma instituição, mas um programa de relações humanas, um processo de despersonalização, não é a exploração que envolve exploradores, mas a alienação. (...) O movimento popular foi, pois, subpolítico ou antipolítico. A longo prazo, isto não diminui sua importância ou influência histórica. A curto prazo, porém, foi fatal. $(\ldots)^{187}$

Procurando por um ponto final ao movimento de maio, no dia 26, a CGT buscou uma solução negociada com o poder francês, nas conversações que ficaram conhecidas como Acordos de Grenelle, costuradas entre as centrais sindicais e o próprio Primeiro Ministro, Georges Pompidou. Dentre as medidas acordadas no encontro, estava um aumento do salário mínimo de 35\%, um aumento global nos vencimentos dos trabalhadores de $10 \%$, e o estabelecimento de quarenta horas semanais de trabalho (os franceses trabalhavam em média 44 horas por semana). Sobre a participação dos operários na gestão de suas empresas, foram 
feitas vagas propostas ${ }^{188}$. O acordo foi fragorosamente rejeitado pelos operários, e no dia 27 a crise chegou a sua dimensão máxima, pela primeira vez a Quinta República se viu efetivamente ameaçada. Nesse panorama, o socialista François Mitterand propôs a formação de uma Frente Popular, tendo como Primeiro Ministro Pierre Mendès France, que propunha um governo de coalizão entre as forças progressistas do país.

No mesmo dia, De Gaulle deixou Paris e se dirigiu a Alemanha para firmar um acordo com o exército. Para tanto, negociou com oficiais da extrema-direita francesa. Veteranos da OAS (Organização do Exército Secreto), movimento formado após a independência da Argélia, receberam o perdão oficial. Dentre os indultados estavam os generais Massú e Salan, notórios torturadores. Uma vez garantido o apoio do exército, De Gaulle retornou a França e proferiu um incisivo discurso a nação condenando o movimento de maio, lançando o brado la reforme, oui, la chienlit (bagunça) non! No mesmo discurso convocou o povo a marchar sobre o Champs-Élysées contra a "subversão e a ameaça do comunismo totalitário".

Atendendo ao chamado, milhares de pessoas se dirigiram as ruas de Paris, aos gritos de "Argélia francesa", "franceses ao trabalho", "desinfetem a Sorbonne","Cohn-Bendit a Dachau (campo de concentração nazista)" "189. De Gaulle também dissolveu a Assembleia Nacional e convocou eleições para o mês seguinte, nas quais sai vitorioso, com ampla maioria no parlamento. As forças da repressão foram voltadas contra o movimento paredista, fábricas foram violentamente desocupadas pela repressão, houve prisões em massa, e até o dia 5 de julho as greves foram suprimidas em todo o país. Todas as faculdades ocupadas foram retomadas pela polícia. O saldo final foi de cinco mortes, sendo um policial, dois operários e dois estudantes.

Mas De Gaulle não pôde refutar por completo as exigências populares, um aumento de $35 \%$ foi concedido aos trabalhadores, e foi estabelecido o regime de quarenta horas semanais, para satisfação da CGT. No entanto, não mais se falou em comissões de empresa. Os benefícios foram destinados principalmente aos operários, a categoria dos profissionais pouco foi contemplada, e entre estes as represálias foram mais ostensivas. A medida governamental foi uma estratégia clara para dividir o movimento, isolando suas facções mais radicais.

Uma reforma universitária foi negociada com comunistas e socialistas, a revelia dos

188 CAUTE, David. Op, Cit. p. 226

189 Idem, p. 228 
grupos estudantis mais avançados. Onze organizações foram postas na ilegalidade, dentre elas a JCF e o 22 de Março. Também foi proscrito o grupo Occidente, de extrema-direita. A derrota do levante de maio abriu espaço para o florescimento de uma nova direita, a mesma que dominaria o espaço político e cultural francês nos anos subsequentes, em detrimento de uma esquerda que jamais conseguiu recuperar o prestígio que obtivera em 1968.

\section{$* * * * *$}

Três questões sobre o maio francês devem ser destacadas e relacionadas ao contexto de nosso trabalho: o predomínio do elemento jovem, a união operário- estudantil, e as greves com ocupação de fábrica e detenção de diretores. Estes três elementos estiveram presentes na greve de Osasco de 16 de julho de 1968. Até que ponto os eventos da França influenciaram os estudantes-operários do GO? Até que ponto influenciaram o ME brasileiro?

Acerca da segunda questão, as barricadas de Paris tiveram ressonância em todo o mundo, serviram como exemplo e referência para a juventude em âmbito internacional. No calor dos acontecimentos, imagens e relatos sobre os levantes foram divulgados diariamente, em coberturas jornalísticas que levavam informações detalhadas sobre os combates de rua entre a CRS e os estudantes. No Brasil, já no dia 7 de maio, o jornal Ultima Hora trouxe estampado em sua capa "Barricadas na Sorbonne: estudante luta na rua" ${ }^{190}$. Demais diários da imprensa escrita corporativa dedicaram atenção ao assunto, que foi amplamente noticiado pelos jornais brasileiros, apesar da censura a imprensa. Nos periódicos estudantis o assunto também se fez presente, o Jornal da UEE-SP ${ }^{191}$ abordou o tema em dois exemplares seguidos, nos meses e junho e julho de 1968. O principal ponto do movimento de maio a chamar a atenção dos estudantes brasileiros foi a coalizão entre MO e estudantes. Era evidente o fato de que a abrangência do levante francês só foi possível graças à adesão dos trabalhadores. Essa percepção explica o grande interesse por parte do ME para com as greves de Contagem e Osasco.

Como veremos adiante, o estudantado engajado brasileiro, assim como seus homólogos europeus, definia-se como "força auxiliar" na construção da revolução em seu país, e nesse sentido, sempre buscaram uma união com os trabalhadores. No Brasil, mais 190 Jornal Última Hora, 02 de maio de 1968, disponível no site: http://www.arquivoestado.sp.gov.br/uhdigital/pesquisa.php

191 Exemplares disponíveis no Arquivo do Estado de São Paulo, na pasta OP (Ordem Política) - 1450, Movimento Estudantil, acervo DEOPS-SP. 
especificamente em São Paulo, tentou-se construir algo semelhante ao que ocorrera na França, a partir da Greve de Osasco. Porém, o grande levante estudantil-operário, tão aguardado pela jovem esquerda radical, foi bloqueado em seu nascedouro. A greve ficou restrita ao município paulistano. É ponto pacífico entre os estudiosos que a onda de protestos estudantis, verificados nos principais centros nacionais, não pôde ir mais adiante em seu combate a ditadura devido ao seu isolamento, seu distanciamento perante os demais setores da sociedade, sobretudo os trabalhadores.

Sobre a segunda questão proposta acima, Antonio Roberto Espinosa relata que os militantes do GO acompanharam com muita atenção os eventos franceses. O levante de maio, sem dúvida, influenciou na construção da greve de julho, o objetivo era construir algo semelhante no Brasil. O modelo de greve com ocupação de fábrica e detenção de diretores foi seguido a risca. Em tom de brincadeira, dizia-se que Osasco seria convertida na "Paris brasileira". Entretanto, o potencial de expansão do movimento osasquense, como é bem sabido, foi nulo. A paralisação de julho, movimento com pretensões insurrecionais, teria tido condições de se alastrar por todos os centros industriais paulistas e brasileiros? As oposições sindicais espalhadas pelo restante do estado e do país teriam condições de sobrepujar as lideranças "pelegas" e dirigir o movimento? Estas questões não podem ser respondidas, não obstante, os objetivos, tanto do GO, quanto do ME paulista iam nesse sentido. Nas próximas páginas discutiremos esse projeto mais a fundo.

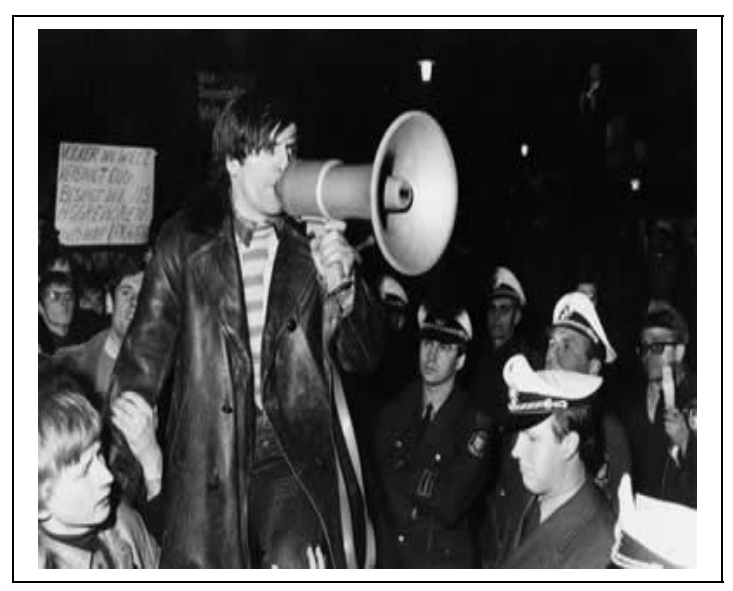

Rudi Dutschke, o grande líder do ME alemão do final da década de sessenta. Suas propostas radicais atraíram o ódio das classes conservadoras de seu país, e uma violenta campanha contra suas ideias foi patrocinada pela mídia. Como resultado, Dutschke sofreu um atentado a tiros por um jovem 
fanático de extrema-direita, tendo sobrevivido. Morreria dez anos depois devido a sequelas do atentado. Fonte: http://www.aworldtowin.net/blog/german-student-revolt.html
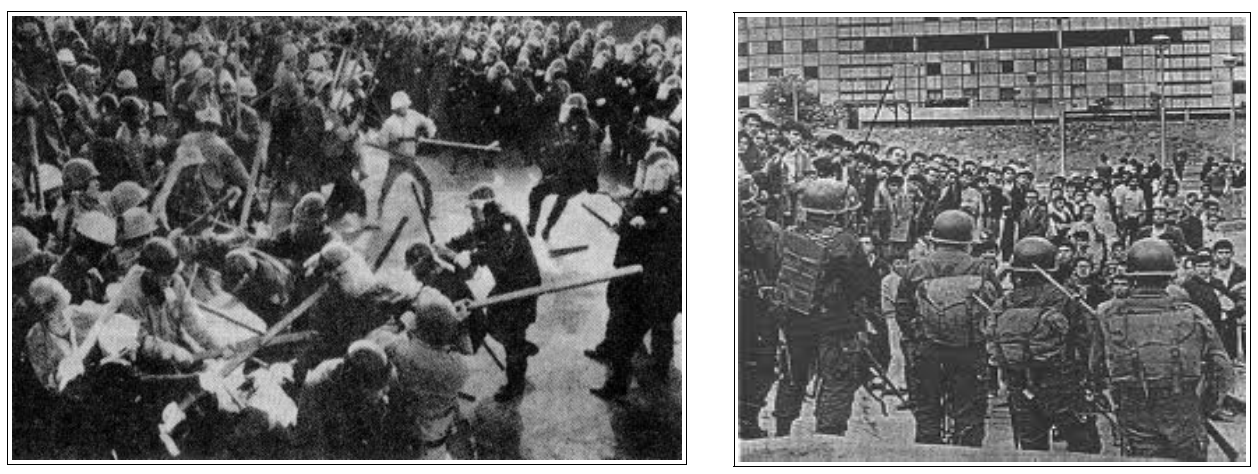

A esquerda, estudantes de correntes radicais dos Zengakuren (Federação Nacional das Associações Estudantis) em confronto contra forças policiais de Tóquio. As agitações estudantis tomaram conta de todo o Japão em 1968, e ofuscaram as comemorações do centenário da Restauração Meiji. No México (à direita), soldados cercam estudantes que se reuniam da Plaza de Las Três Culturas em protesto contra violências praticada pelo governo Días Ordaz. Na noite de 03 de outubro de 1968, cerca de quinhentas pessoas foram assassinadas pelas forças de repressão mexicanas. Pouco mais de uma semana depois, foram realizados XIX Jogos Olímpicos na cidade do México.

Fonte das imagens: http://denki-kawaraban.blogspot.com/2009 07 16 archive.html ; http://www.gwu.edu/ nsarchiv/NSAEBB/NSAEBB10/cover.htm
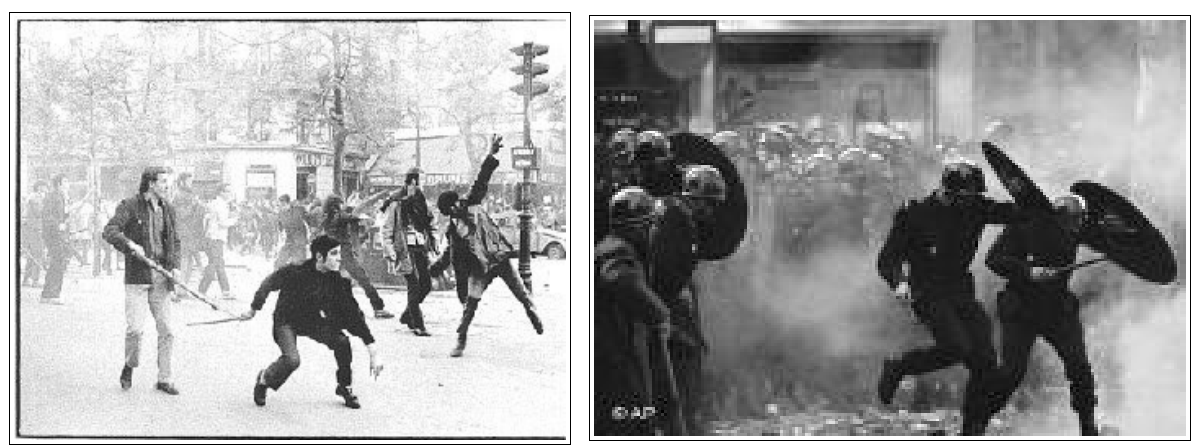

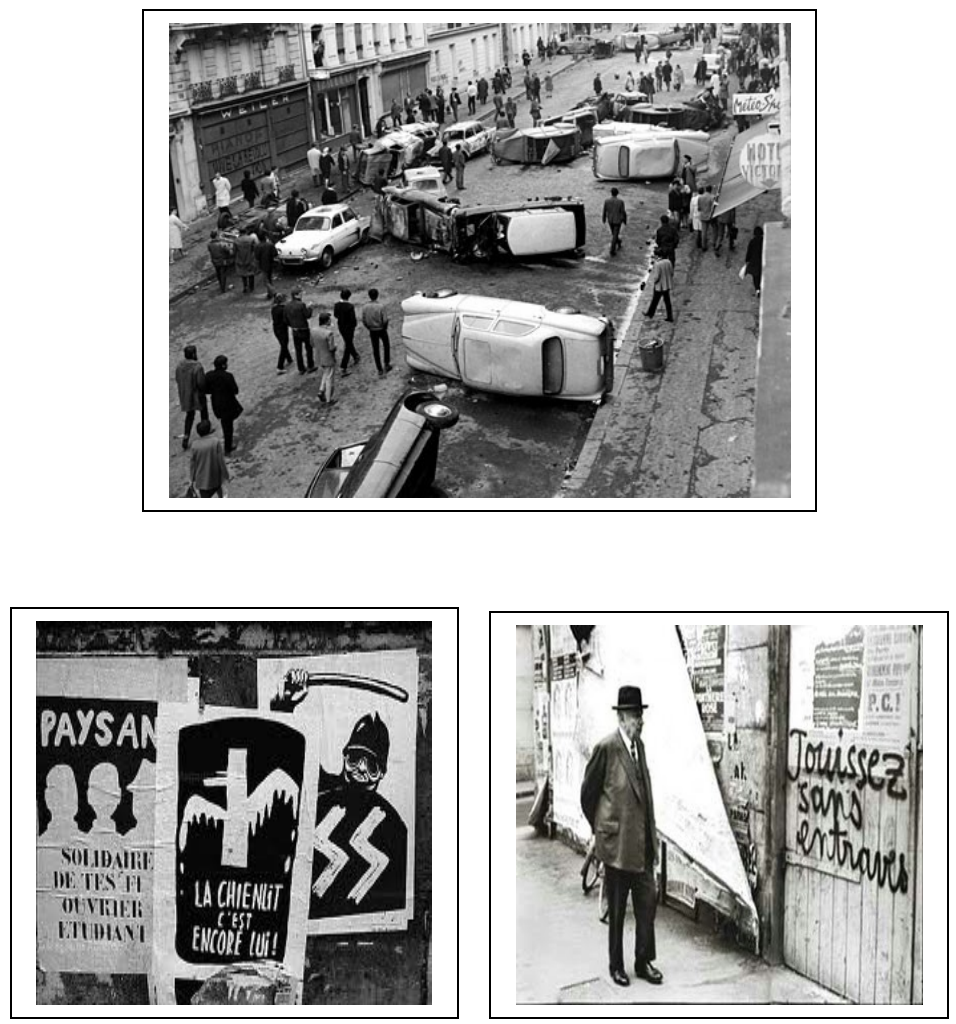

Violentos combates de rua foram travados entre estudantes, trabalhadores e membros da CRS (Companhia Republicana de Segurança), logo acima vemos dois exemplos da magnitude dos combates. Ao centro, a Rua Gay Lussac, principal palco da célebre noite das barricadas, entre 10 e 11 de maio de 1968. Logo abaixo, exemplos da criatividade dos manifestantes franceses, a esquerda, vemos chamados de união operário-estudantil, ataques ao general Charles De Gaule, e a CRS. À direita, pichadores pregavam o "gozo sem limites", vários foram os slogans lançados pelos manifestantes de maio, frases que foram repetidas pela juventude mundo afora ${ }^{192}$.

\section{8 no Brasil}

Vimos que o general Costa e Silva, em seus primeiros meses de mandato como presidente do Brasil, esboçou uma certa distensão política, e se mostrou aberto ao diálogo com os movimentos sociais. Esse período de relaxamento teve fim em 1968, ano em que as

\footnotetext{
192 Fonte para as imagens:

http://www.cenasdocotidiano.com/2008/05; $\quad$ http://noticias.sapo.pt/info/artigo/817910.html ; http://www.dailymail.co.uk/femail/article-566980/My-French-
} 
contradições políticas e econômicas do regime vieram a tona. Nos próximos capítulos discutiremos a crise econômica dessa conjuntura, e sua breve superação nos anos subsequentes. Por ora, vamos nos ater as contradições presentes na política educacional da ditadura, e a resistência do estudantado frente às mesmas.

Apesar da abertura política esboçada por Costa e Silva, as relações entre ME e Estado pouco se alteraram, o programa de enquadramento das agremiações prosseguiu, o governo insistiu em sua proposta de consolidação dos DCE's e DA's, e UNE, UEE's, UBES e demais entidades seguiram em situação de ilegalidade. O Ministro da Educação era Tarso Dutra, o mesmo que deu prosseguimento as diretrizes iniciadas com a Lei Suplicy. Desde o golpe, o governo adotava uma política de "concentração de recursos nas áreas diretamente produtivas", o que redundava em contenção de investimentos nos setores sociais. Tal postura de corte de verbas penalizava sensivelmente o MEC, que por sua vez, dava prioridade a redução de gastos no ensino superior. Segundo Florestan Fernandes, entre 1964 e 1968, “as universidades federais receberam cortes que reduziram seus orçamentos em $37 \%$... Chegou-se a tal extremo que os reitores tiveram que romper a barreira do silêncio e cumplicidade, denunciando a gravidade do processo de deterioração financeira adotado pelo Executivo" ${ }^{193}$. Essa postura apenas agudizava toda a série de problemas que assolavam o ensino superior brasileiro, como a falta de estrutura física para os cursos, ausência de expansão, déficit de vagas, e o antigo problema dos excedentes ${ }^{194}$.

Para solucionar tal estado de coisas, o regime recorreu aos conhecidos acordos MECUSAID (United States Agency for Internatinonal Development), um compromisso que previa a "assessoria de técnicos estrangeiros para auxiliar o governo militar na formulação de uma nova política educacional" ${ }^{195}$. Todos os níveis de ensino deveriam ser contemplados pelo projeto, mas desde o início, o nível que suscitou mais polêmicas foi sem dúvida o superior, pois aqui se encontrava o segmento mais penalizado pelas diretrizes da reforma, o setor em que o Estado mais fazia concessões a iniciativa privada. Esses acordos começaram ser firmados logo depois do golpe, e foram fortalecidos pelo Relatório Atcon, redigido pelo técnico estadunidense Rudolph Atcon, cujo estudo visava fornecer "um diagnóstico das falhas

193 FERNANDES, Florestan. “Universidade brasileira: reforma ou revolução?” Apud: MARTINS FILHO, João Roberto. Op. Cit. p. 123

194 Estudantes que obtinham a nota mínima no vestibular, para ingresso na Universidade, mas que não podiam se matricular devido a ausência de vagas, tornando-se "excedentes", a espera pelo surgimento de novas vagas.

195 Idem, p. 130 
e pontos de estrangulamento do sistema universitário brasileiro" ${ }^{196}$. Vejamos como os próprios estudantes enxergavam os acordos MEC-USAID:

Tendo como referência o sistema educacional norte-americano, o (acordo) MEC-USAIDATCON procuraria transplantar para o Brasil o que hoje os estudantes dos EUA estão combatendo: a influência nefasta da indústria sobre o ensino, colocando este não a serviço da sociedade, mas apenas a uma parte desta. Realmente, a educação daquele país é um apêndice da máquina industrial americana a tal ponto que grande parte da economia de guerra dos EUA se estriba na educação.

(...)

Sabemos que o vínculo de subordinação que liga a Universidade norte-americana as grandes indústrias se deve, principalmente, a estrutura privada do ensino mais qualificado daquele país. A transposição disto para o nosso país representa mesmo a transferência dos centros de decisões para o exterior, no que diz respeito à educação brasileira, pois o controle econômico de nossa Universidade pelos grupos monopolistas internacionais se faria - como já o fazem nos EUA - através de verbas e doações. Assim, a Universidade brasileira seria ainda menos livre e não passaria de um mero celeiro de quadros técnicos a nutrir o sistema de produção neo-colonialista, porquanto a desnacionalização de nossa economia já impede o controle interno.

\section{(...)}

Um trabalho do professor Rudolf Atcon, intitulado "Anteprojeto de concentração da política norte-americana na América Latina, na organização universitária e sua integração econômica" declara que "a Universidade Latino-Americana deve consolidar sua autonomia e adquirir um grau maior de independência real. O melhor sistema legal para alcançar êste grau de liberdade é transformar a Universidade numa fundação privada". Em seguida julga melhor "a colocação do ensino superior em bases rentáveis, cobrando matrículas crescentes durante um período de dez anos".

\section{$(\ldots)$}

Outra faceta do MEC-USAID-ATCON é a abolição da influência dos estudantes nos destinos da vida universitária, pois "a reforma administrativa inclui a eliminação da interferência estudantil na administração tanto colegial como gremial”, conforme propõe o professor Atcon. (...) $)^{197}$

O informe da UEE-SP carrega nas tintas ao definir os acordos MEC-USAID apenas como ferramentas de dominação neocolonialista, embora esse caráter não possa ser negado.

196 Ibidem, p. 131

197 Trecho extraído do suplemento UEE-Debate, distribuído pela UEE-SP, as informações sobre os acordos MEC-USAID são retiradas do próprio documento concernente ao acordo, sobre o qual os estudantes tiveram acesso. Esse suplemento está disponível em formato digital no CEDEM (Centro de Documentação e Memória da UNESP), localizado na cidade de São Paulo, informações referentes ao acervo podem ser encontradas no endereço eletrônico: www.cedem.unesp.br 
Houve uma certa superestimação dos convênios firmados com a agência estadunidense, e pouca atenção era dada ao fato de que mudanças como as preconizadas nos acordos vinham sendo buscadas "desde fins da década de 40 por administradores educacionais, professores e estudantes, principalmente aqueles, como um imperativo de modernização, e até mesmo da democratização do ensino superior no país. Quando os assessores norte-americanos aqui desembarcaram, encontraram um terreno arado e adubado para semear suas idéias"198. A filosofia tecnicizante das economias industriais desenvolvidas já seduzira largas parcelas de nossos pedagogos. A concentração das críticas em "agentes externos" camuflou aqueles que trabalhavam em solo nacional por um alinhamento absoluto com o modelo educacional estadunidense.

A corroborar a estratégia de colaboração técnica dos especialistas norte americanos, estava o panorama de acirramento das lutas sociais em âmbito internacional, panorama que não livrava de conflitos internos nem mesmo os próprios EUA. Em se tratando de América Latina, era de vital importância para as diretrizes geopolíticas do Pentágono reforçar o alinhamento entre Washington e seus aliados, e esse alinhamento compreendia não apenas a área econômico-política, espraiava-se por outros campos. Dentro dessa perspectiva, era importante para os técnicos vinculados a USAID convergir o sistema educacional brasileiro as suas propostas, e essa convergência deveria se dar num duplo sentido. Primeiro, na educação compreendida como um aparelho ideológico, na medida em que o Estado brasileiro estaria disposto a cerrar fileiras com os ideais anticomunistas dos EUA, comungar com suas concepções de mundo e manifestações culturais. Segundo, na educação compreendida como um filão de investimento, tanto no que respeita seu viés mercadológico, quanto na perspectiva de formação de quadros técnicos para a indústria. Os projetos de modernização conservadora da ditadura previam o desenvolvimento industrial do país, embora a posição preconizada pelos Estados Unidos, em relação ao Brasil, fosse de um membro secundário entre as nações do mundo capitalista industrial. A colocação brasileira seria de um país semi-industralizado, associado ao grande capital internacional, com um parque fabril constituído a partir de empresas multinacionais. Tal modelo de crescimento demandava certa quantidade de profissionais qualificados.

Através desse projeto, delineava-se um modelo de ensino voltado a formação de

198 CUNHA, Luis Fernando. "A Universidade Reformada” Apud: REIS, Ana Maria. Formas de Acesso a Educação Superior: Méritos e Privilégios. p. 10. Artigo disponível em formato PDF no site: www.histedbr.fae.unicamp.br 
quadros para a indústria, pautado pelo mercado. $\mathrm{O}$ ensino superior deveria progressivamente migrar para a iniciativa privada, entregue a universidades particulares, ou gerenciado por fundações. A educação perderia a finalidade de produção social do conhecimento, para se tornar tão somente um processo de formação profissional. Para o segundo grau, o convênio previa a designação de um grupo de professores brasileiros para "trabalharem com os consultores norte-americanos na prestação de serviços de assessoramento aos Estados". Os educadores deveriam "cooperar com os consultores norte-americanos na formulação e execução de um plano detalhado com vistas à prestação de serviços consultivos ao ensino secundário nos Estados, da forma mais eficiente possível". Algo semelhante deveria ser aplicado ao ensino primário e cursos técnicos, os acordos também faziam referência ao ensino especial e a produção de livros didáticos ${ }^{199}$.

Contra essa reforma autoritário-conservadora, opuseram-se estudantes, professores, intelectuais, reitores. O repúdio aos acordos, tendo o ME como vanguarda, mas englobando também os demais setores vinculados a educação, não pôde ser ignorado pela Ditadura. Para discutir a Reforma Universitária, técnicos do governo militar apresentaram o Relatório do Grupo de Trabalho sobre a Reforma Universitária (GRTU), no final do primeiro semestre de 1968. No final desse mesmo ano, o Congresso Nacional aprovou a Reforma Universitária, pela Lei $\mathrm{n}^{\circ} 5.540$, assinada pelo Ministro Tarso Dutra. Para formulação da nova Lei, o regime também se pautou pelas conclusões do relatório do general Meira Matos, oficial que montou e coordenou uma comissão encarregada de estudar e propor soluções tendo em vista o bloqueio das atividades do movimento estudantil engajado.

Em 1971 seria apresentada uma nova LDB (Lei de Diretrizes a Bases da Educação), norteada pelas concepções do regime. As sugestões dos relatórios MEC-USAID-ATCON foram adotadas no que respeita suas concepções gerenciais e tecnicizantes. Contudo, a prerrogativa nacional foi mantida, e o controle ideológico almejado pelos técnicos estadunidenses foi em boa parte contido. As Universidades públicas e gratuitas foram mantidas, mas a expansão de vagas foi delegada ao ensino privado. Com relação ao problema dos excedentes, a medida implementada foi a adoção do mesmo modelo de vestibular que era aplicado nos EUA, com provas eliminatórias, divididas em fases. Embora o ME tenha sido derrotado enquanto movimento, sua combatividade impediu o governo militar de implementar

199 MOREIRA ALVES, Márcio. Beabá dos MEC-Usaid. Rio de Janeiro: Edições Gervasa, 1968. p. 60. Também disponível formato digital, no site: $\underline{\text { www.marciomoreiraalves.com }}$. Este livro panfleto traz todos os acordos firmados entre 1964 e 1968. 
uma série de medidas que iam no sentido de uma completa privatização do ensino superior, e uma adequação quase absoluta ao modelo educativo estadunidense. $\mathrm{O}$ ensino superior público e gratuito, embora elitizado, foi mantido.

Mas em princípios de 1968 o ME ainda podia acreditar e lutar por suas demandas. Vimos acima que a essa altura a economia nacional ainda estava em fase recessiva, e boa parte da sociedade civil (inclusive parcelas da classe média que haviam apoiado o golpe) começavam a se opor a ditadura. Os trabalhadores se encontravam cerceados em seus direitos de contestação, representados por sindicatos atrelados ao sistema. A oposição políticopartidária engessada sob uma legenda oficial, sem liberdade de movimento; o PCB, duramente perseguido. Nesse contexto, os estudantes tomaram a dianteira na oposição ao regime.

O levante estudantil brasileiro teve início em 28 de março, quando o secundarista Edson Luis de Lima Souto foi morto a tiros pela polícia militar no restaurante universitário calabouço, no Rio de Janeiro. Sessenta mil pessoas acompanham o velório de Edson Luis, adolescente natural do Pará, que tinha dezoito anos à altura de sua morte. Em protesto contra o assassinato do jovem, passeatas foram realizadas em Belo Horizonte, São Paulo, Brasília, Recife, Porto Alegre; em Goiânia dois estudantes foram baleados pela polícia. Na missa de sétimo dia do jovem, houve violenta repressão por parte da cavalaria da PM carioca, deixando dezenas de feridos. Em 8 de abril, estudantes e operários de Osasco saíram as ruas em protesto contra os eventos ocorridos no Rio de Janeiro ${ }^{200}$.

Em 21 de julho ocorreu a maior batalha campal da rebelião estudantil brasileira de 1968, evento que ficou conhecido como "sexta-feira sangrenta". Durante mais de sete horas, estudantes e populares enfrentaram as forças da repressão no centro da antiga capital federal. O saldo final foi de mais dez camburões incendiados, cerca de mil presos, centenas de feridos, dentre estes, 35 policiais. Oficialmente foram anunciados quatro vítimas fatais, sendo um PM. Extra-oficialmente, falou-se em 28 pessoas mortas. ${ }^{201}$ Em resposta a violência da repressão, no dia 26 foi realizada a "passeata dos cem mil", maior ato anti-ditadura visto na década de sessenta, sem intervenção da polícia.

Em 29 de agosto houve a grande invasão da Universidade de Brasília (desde 1964 a UNB era assediada pela repressão, tendo passado por outras invasões). "Tropas de polícia militar do Distrito Federal, polícia civil, polícia do exército e agentes do Dops a paisana 
entraram na Universidade às $10 \mathrm{~h}$ da manhã em 50 viaturas e choques policiais, após bloquear todas as vias de acesso." Logo no início da operação, cerca de 20 policiais se dirigiram a sede da FEUB (Federação dos Estudantes Universitários de Brasília) e prenderam o presidente da entidade, Honestino Guimarães (desaparecido político a partir de 1973), que foi "arrastado a socos e pontapés". Cerca de cinquenta estudantes foram presos, diversos laboratórios destruídos. Professores e alunos foram barbaramente espancados, um estudante de engenharia foi baleado na cabeça, mas sobreviveu. O deputado Santilli Filho, do MDB paulista, foi espancado junto a seu filho, estudante da $\mathrm{UNB}^{202}$. Em 3 de setembro, em protesto contra a invasão de Universidade de Brasília, Márcio Moreira Alves, deputado pelo MDB carioca, proferiu um violento discurso no plenário da Câmara Federal contra o regime militar. Esse discurso será o estopim para os eventos que deram origem ao AI-5, em 13 de dezembro.

Em 2 de outubro, a Faculdade de Filosofia da USP, na Rua Maria Antonia, encontravase sob uma ocupação que tivera início em junho. Sobre os motivos da ocupação, Bernardino Figueiredo, vice presidente da UEE-SP, esclarece que:

Os motivos da tomada foram dois: manter a faculdade aberta nas férias, transformando-a em centro de reunião, discussão política, mobilização e organização dos universitários e secundaristas para garantir a continuidade do movimento. Em segundo lugar, assumir o controle político da faculdade, visando a formação de comissões paritárias para dirigir a reestruturação dos cursos. Foi uma resposta a repressão ostensiva que o governo fez ao movimento estudantil na Guanabara e á repressão velada que Sodré vem desenvolvendo em São Paulo. Até agora, temos 42 colegas presos, a maioria deles detidos em suas próprias casas ou na saída da escola. A população nem fica sabendo. Por isso, nossa principal reivindicação no momento é a libertação desses colegas ${ }^{203}$.

Bem em frente a Faculdade de Filosofia USP, situava-se a tradicional Universidade Mackenzie. Nesse período, entre os estudantes da instituição protestante estava organizado um grupo de extrema-direita que se intitulava Comando de Caça aos Comunistas (CCC), organização surgida na Faculdade de Direito da USP, no início dos anos 1960. Apesar de representativo, o CCC não compreendia a maioria dos universitários do Mackenzie, era um grupo de cerca de cinquenta pessoas, todos homens, boa parte praticante de artes marciais. $\mathrm{O}$

202 GURGEL, Antônio de Pádua. A rebelião dos estudantes, (Brasília, 1968). Brasília-DF: Editora da UNB, 2002. 250-259.

203 “O Que Fazer", periódico da UEE-SP, julho de 1968, Apud: VALLE, Maria Ribeiro do. 1968: o diálogo é a violência. Movimento estudantil e ditadura militar no Brasil. Campinas-SP: Editora da Unicamp. p. 159 
clima de animosidade entre os CCC e estudantes da Filosofia USP remontava a antes de golpe de 1964, e na conjuntura dos protestos de 1968, a animosidade entre os dois grupos era crescente. A galvanizar o ambiente de tensão estava o fato do agrupamento de extrema-direita ser assessorado por membros da comunidade repressiva, muitos pertences ao Dops. Dentre estes, estava o delegado Raul Nogueira, vulgo Raul Careca ${ }^{204}$, um dos fundadores da organização paramilitar.

No dia 2 de outubro, um grupo de universitários da USP e secundaristas recolhia fundos, na Rua Maria Antonia, para a organização do XXX Congresso da UNE. Ovos e pedras partiram em direção aos jovens que executavam o "pedágio" pré-congresso, tal agressão, segundo testemunhos, partiu dos muros do Mackenzie. Assim teve início a batalha campal da Maria Antonia. De um lado, estavam universitários e secundaristas, acantonados na Filosofia USP, do outro, estudantes do Mackenzie mobilizados pelo CCC e apoiados por policiais do Dops. A luta de rua durou dois dias, e não se resumiu a pedras e coquetéis molotov, tiros também foram disparados, sobretudo por parte dos grupos anticomunistas. No dia 3 de outubro, o secundarista José Guimarães, de 20 anos, estudante do Grupo Escolar Marina Cintra, foi assassinado com um tiro na cabeça. Até hoje não há confirmação de onde partiu o disparo.

Dentre os estudantes aquartelados na Filosofia estava Gabriel Figueiredo, primeiro presidente da UEO, a essa época cursando medicina. Gabriel atesta que pouco antes da invasão policial se retirou do edifício da USP sitiado para "participar da organização e da facilitação de socorros médicos aos estudantes feridos, na Santa Casa, vizinha da Maria Antonia", onde estudava ${ }^{205}$. Ao cair da tarde do dia 3 de outubro, a Faculdade de Filosofia da Rua Maria Antonia foi invadida e depredada por policiais acompanhados por militantes do CCC. Após a destruição da Faculdade, os cursos foram transferidos para a Cidade Universitária, localizada no bairro do Butantã. Em protesto contra a invasão, uma violenta passeata foi organizada pela UEE-SP, tendo a frente José Dirceu, empunhando a camisa ensanguentada do secundarista José Guimarães.

Em 12 de outubro teve início o XXX Congresso da UNE, realizado em Ibiúna, interior de São Paulo. Os trabalhos do encontro foram abertos em meio a uma atmosfera de tensão que cada vez mais tomava conta do país. Os candidatos a presidência da entidade, a serem

204 Raul Nogueira chefiava uma divisão do Dops voltada a vigilância e repressão no meio estudantil, também tomou parte na operação que executou Carlos Marighella. O mesmo confirma essas informações em entrevista a Percival de Souza . SOUZA, Percival. Op. Cit. p. 379-388.

205 Entrevista de Gabriel Figueiredo ao autor, 31/05/2010 
escolhidos no evento, foram três: José Dirceu, apoiado por Vladimir Palmeira e ligado ao grupo chamado Dissidência (em relação ao PCB); Jean-Marc van der Weid, apoiado por Luis Travassos, da AP; e Marcos Medeiros, do Partido Comunista Brasileiro Revolucionário, o PCBR, outra cisão do PCB. Algumas lideranças do ME paulista alertaram os organizadores do Congresso de Ibiúna sobre os riscos de se realizar o encontro nessa localidade, com a presença de oitocentos delegados. Recomendou-se a realização do encontro no CRUSP (Conjunto Residencial dos Estudantes da USP, que já servira como sede para congressos da UEE-SP), com um número de participantes reduzido. Mas os organizadores do Congresso garantiram que havia um dispositivo de segurança eficiente para garantir a concentração de universitários na cidade do interior paulista. Nilton Santos, que nessa fase era vice-presidente da UNE, faz um balanço crítico acerca da organização do evento.

O Congresso foi deixado nas mãos da UEE de São Paulo. Estado sede do Congresso, como era de praxe no ME. Mas a diretoria não assegurou as condições de controle das decisões políticas que seriam impulsionadas na condução e na montagem do Congresso. A condução dada pela comissão organizadora foi marcada pelas concepções políticas que vão se desdobrar depois no militarismo, onde as questões políticas eram vistas muito dentro da ótica de aparelho, de segurança armada, quando efetivamente o ME não tinha capacidade de defesa armada do seu Congresso.

Foi um erro pensar que se poderia manter clandestino um Congresso com 800 delegados eleitos na massa. E é ingênuo pensar que uma segurança com algumas "pistolas 22" poderiam defender o Congresso. Não se podia confiar a segurança em métodos muito mais "militares" do que políticos. Seja porque o ME não tinha potencial de fogo, seja porque não se apoiava no movimento de massa, que era de onde vinha a força da $\mathrm{UNE}^{206}$.

O dispositivo de segurança alardeado pelos organizadores do evento se demonstrou inócuo, no primeiro dia dos trabalhos, o sítio onde se realizava o encontro foi cercado por forças da polícia e do exército. Após a dissolução do Congresso, cerca de 720 estudantes foram presos. Vladimir Palmeira, José Dirceu e Luis Travassos foram encaminhados ao Dops, os demais levados para o presídio Tiradentes, cuja população carcerária "sobe de 500 para 1216 em uma hora" ${ }^{207}$. Os detidos deram início a uma greve de fome logo após a chegada ao presídio. A grande maioria foi libertada, porém 71 estudantes permaneceram em prisão

206 Depoimento de Nilton Santos, presente em História da UNE, Op. Cit. p. 73; também presente em VALLE, Maria Ribeiro. Op. Cit. p. 204 207 Idem. p. 207. 
preventiva, e todos os liberados foram enquadrados na Lei de Segurança Nacional. Protestos contra a dissolução do Congresso foram realizados nas principais capitais do país. O delegado Paulo Bonchristiano, membro da equipe de Sérgio Paranhos Fleury, do Dops, demonstrou grande satisfação ao conceder uma entrevista ao Jornal da Tarde, logo após a dissolução do encontro: "Foi uma boa jogada. Nenhuma polícia até hoje conseguiu prender os estudantes, todos. Desta vez a caguetagem trabalhou firme. O José Dirceu se gabou que na última passeata passou a 20 metros de mim. Prometi que o pegava na próxima vez em que nos encontrássemos. E hoje nós pegamos"208.

Pelo depoimento de Nilton Santos acima percebemos que suas críticas não se dirigem apenas a organização do Congresso de Ibiúna, seu questionamento também perpassa a esfera programática. A principal crítica do ex-líder estudantil diz respeito ao militarismo da corrente a organizar o encontro dissolvido pela repressão. Para entender a natureza do posicionamento de vice-presidente da UNE, quadro da Ação Popular, é necessário contextualizar o debate que era travado entre as duas principais tendências do ME brasileiro.

Vimos que desde 1960 a UNE era dominada pela AP, não obstante, correntes paralelas foram se fortalecendo dentro da entidade, sobretudo após sua reorganização a partir de 1965. Dentre as correntes alternativas a AP estava a Polop, em atividade desde o início da década; e a ala estudantil do PCB, em processo de crise interna desde 1964. Desse processo de ruptura surgiriam as Dissidências (DI's), retirando do Partidão grande parte de seus quadros organizados dentro do ME. No Congresso de Vinhedo-SP, realizado em 1967, o processo de diferenciação de posições se intensificou na UNE. Embora a AP tenha mais uma vez ganho a presidência da agremiação, com Jorge Luis Guedes, Polop e DI's saíram fortalecidas do encontro. Em contrapartida, o PCB teve seu processo de declínio intensificado com a perda de militantes frente às inúmeras cisões, tornando-se uma força pouco expressiva na UNE.

Em 1968, no auge das mobilizações, duas tendências distintas disputavam espaço político entre o estudantado nacional. A primeira, capitaneada pela AP, tinha como base de estratégia política de lutas de massa, expressa em grandes manifestações de rua, com o objetivo de criar fatos políticos. O que se buscava era chamar a atenção de toda sociedade para a truculência da ditadura, que "tiraria sua máscara" frente à resistência dos estudantes. Uma vez exposta a "verdadeira face" da elite civil-militar que controlava o país, as classes populares se mobilizariam para combater o regime ao lado do ME. Nesse programa, as 
questões específicas do estudantado eram secundárias, o objetivo imediato era derrubar o governo militar.

A onda de manifestações verificadas em nível internacional se apresentava como um indício da viabilidade desta proposta. Deve ser levado em conta também o fato de que a Ação Popular, desde finais de 1967, encontrar-se em processo de adesão ao maoísmo. Tal viragem se completaria após o AI-5, dando ensejo a adoção da luta armada, quando essa organização de matriz cristã cerraria fileiras junto ao PC do B. O principal expoente do movimento em análise, em 1968, era Luis Travassos, ex-presidente da UEE-SP. Vejamos uma pequena amostra do pensamento presente nesta tendência, pelo trecho abaixo notamos tanto a linha programática da corrente, quanto uma crítica a seus adversários:

$\mathrm{Na}$ etapa atual, embora sustentada por uma pequena minoria, a força do imperialismo é maior que a força do povo. É necessário, na luta, mudar esta correlação de forças.

Embora no plano global o inimigo seja mais forte, em cada luta particular é possível realizar ações em que as forças do povo são superiores e impor derrotas ao inimigo. Para isso é necessário que os mais amplos setores se mobilizem e cada ação seja realizada com a participação de maior número possível. (...)

Com a participação da maioria do povo e não apenas com a luta de uns poucos bem preparados tecnicamente é que iremos acumular forças para desgastar as forças do inimigo. Este processo é longo e não é possível a vitoria total a curto prazo, é uma luta de longa duração em que pouco a pouco se organiza, ganha experiência e acumula forças enquanto o inimigo se desgasta e a cada dia mais se isola. Mesmo quando este inimigo usa a força armada o povo na luta pode vencer. (...)

Ousar lutar e saber lutar significa hoje para o movimento estudantil ousar se mobilizar contra a ditadura e o imperialismo nas universidades e nas ruas e saber lutar mobilizando maior parte possível dos estudantes e unir-se com os demais setores, participando ativamente da luta popular ${ }^{209}$.

A "segunda posição", questionadora do grupo que desde 1960 dominava a UNE, defendia o programa de lutas especificas. Formavam essa tendência as dissidências da Polop (surgida em finais de 1967) e do PCB. Segundo seus articuladores, os movimentos de massa se encontravam em desgaste após as grandes manifestações observadas no primeiro semestre de 1968, e, portanto, o movimento deveria retornar ao meio universitário, e realizar um trabalho de conscientização dos estudantes com relação a luta contra o regime. Nesse esquema, o ME deveria concentrar seus esforços na formação de quadros dentro da 
Universidade, preparando militantes para um inevitável combate violento ao governo militar, tendo como meta a construção de uma sociedade socialista, ou em transição para tal modelo.

Ao lutar contra apolítica educacional do regime, os estudantes partiriam de suas próprias condições no meio em que viviam, das condições que expressam a dominação de classe da burguesia de uma forma concreta e, desse modo, cada luta reivindicativa serviria para caracterizar o governo como ditatorial, como uma ditadura de classe, chegando, por esse caminho, a compreensão da impossibilidade de resolver os problemas universitários dentro do sistema capitalista ${ }^{210}$.

Acerca do papel dos estudantes no processo revolucionário, a posição dessa corrente era mais modesta que a de seus adversários. Para os defensores das lutas reivindicatórias, o ME deveria adotar a posição de auxiliar na construção da revolução brasileira. Destarte, caberia aos estudantes uma aproximação junto aos operários e aos camponeses, verdadeiros atores do levante a ser organizado contra a autocracia burguesa. Os expoentes dessa facção eram Wladimir Palmeira, ex-presidente da UME-RJ, principal personagem das grandes manifestações estudantis ocorridas na cidade do Rio de Janeiro, no primeiro semestre de 1968, e José Dirceu, presidente da UEE-SP a altura do Congresso de Ibiúna.

Mas entre os defensores das lutas especificas também havia uma divisão, como mencionado, nessa corrente estavam organizados membros das dissidências do PCB e da Polop. Para o primeiro grupo, o caminho da revolução brasileira teria que passar por uma etapa nacional popular, por isso se identificavam com a bandeira da libertação nacional. Tais militantes tinham na Revolução Cubana sua principal referência para a tomada do poder no Brasil, e nos textos de Che Guevara e Regis Debray sua orientação teórica central. O modelo ideal para eclosão de um movimento insurrecional no país, dentro dessa concepção, seria o foco guerrilheiro. O segundo grupo preconizava a passagem imediata ao socialismo, após a tomada do poder pela via revolucionária, abrindo mão de uma etapa de transição dentro do capitalismo. As concepções teóricas dessa tendência eram de matriz leninista, sem abrir mão do diálogo com estratégias contemporâneas, como o guevarismo-debraysmo. A primeira corrente supramencionada daria origem a ALN, a segunda, a VPR ${ }^{211}$.

210 Depoimento de Vladimir Palmeira presente em CASO, Antonio. “A esquerda armada no Brasil, 1967-1971”. Apud: MARTINS FILHO, João Roberto. Op. Cit. p. 175

211 A passagem da via estudantil para a luta guerrilheira será discutida a fundo na seção 4, para uma análise mais completa das duas posições em disputa dentro do ME brasileiro em 1968. Idem, p. 171-201 
Em São Paulo, as atividades do ME se encerraram por completo em 17 de novembro de 1968, com a invasão do CRUSP, quatro dias após a decretação do AI-5. O CRUSP foi fruto de uma invasão a um conjunto de prédios que foi construído para abrigar os atletas que participaram dos Jogos Panamericanos de 1963, realizados em São Paulo. Após o evento, os edifícios ficaram ociosos, e no mesmo ano dos Jogos, o espaço foi ocupado por estudantes da USP que não tinham condições de arcar com os custos de moradia na capital paulista. Grande parte dos ocupantes provinha do interior do estado. Até seu fechamento, o conjunto residencial se tornou uma espécie de território livre para o ME paulista, palco de congressos, assembleias e reuniões. No acirramento das lutas contra a ditadura, o residencial também se converteu em refúgio para militantes visados pela repressão. Foram diversas as invasões policiais perpetradas contra o CRUSP, e a derradeira se efetuou em 17 de dezembro. Na madrugada da invasão, os edifícios que abrigavam cerca de 1400 estudantes, encontravam-se ocupados por apenas 800 , pois boa parte voltara para casa devido às férias e as festas de final de ano. Após a tomada dos prédios, centenas de universitários foram detidos (muitos conseguiram fugir) pela polícia e conduzidos a presídios da capital ${ }^{212}$. Por dez anos o conjunto permaneceu evacuado, sendo novamente ocupado em 1978.

O militar encarregado de produzir o IPM da invasão do CRUSP, coronel Sebastião Alvim, alegou que desde a "destruição" da Faculdade de Filosofia da Rua Maria Antonia, a moradia dos estudantes da USP havia se convertido no "principal foco de subversão estudantil da cidade". Num extenso relatório, o IPM define o CRUSP como uma espécie de "abrigo" para guerrilheiros, e enfatiza a apreensão de provas que atestavam o potencial subversivo do conjunto residencial.

212 Segundos informações de Pedro Lobo, presentes em sua biografia redigida por João Roberto Laque, toda uma operação de guerra foi montada para a invasão do CRUSP, considerado pelos militares como um"covil de subversivos e o maior centro de contestação do regime do país". Carlos Lamarca, capitão lotado no $4^{\circ}$ Regimento de Infantaria, em Quitaúna, Osasco, a essa altura já estava integrado a corrente que daria origem a VPR, e ao saber dos preparativos da invasão, enviou o sargento Darcy Rodrigues, seu colega de regimento, membro de sua célula comunista, ao CRUSP. O militar avisou a tempo os quadros de sua organização que residiam no conjunto, e os mesmos alertaram os membros de outros agrupamentos armados também ali residentes. Quando os militares invadiram o residencial, armas, explosivos e munições já haviam sido retirados do local, levados por estudantes já comprometidos com a guerrilha urbana. Estas informações estão presentes em: LAQUE, João Roberto. Pedro e os Lobos. Os anos de Chumbo na trajetória de um guerrilheiro urbano. São Paulo: Ava Editorial, 2010. p. 233-235 


\section{CAPÍTULO VIII}

\section{GUERRILHA URBANA}

Foi apreendida no CRUSP grande quantidade de coquetéis "molotov", revólveres, espingardas, matéria prima para explosivos, granadas de pedaços de cano, para introdução de dinamites e meios auxillares para fabricação de bombas.

Os coquetéis "molotov" se encontravam distribuídos pelos Blocos residenciais, nos saguões de seus andares.

No apartamento n. ${ }^{\circ}$ 511-B foram apreendidas as espingardas, ocultas em uma parede falsa do apartamento (...), as granadas de pedaços de cano, com tampas atarracháveis nas extremidades, facões de mato, punhais, matéria prima para explosivos e meios auxiliares para fabricação de bombas. $(. . .)^{213}$

Mas o CRUSP não foi apontado apenas como polo de subversão, o IPM também o define como foco de dissolução dos costumes:

\section{CAPÍTULO IX DISSOLUÇÃO DOS COSTUMES}

A invasão e ocupação do Bloco G pelos estudantes, sob a direção da ASSOCIAÇÃO UNIVERSITÁRIA RAFAEL KAUAN, que distribuiu apartamentos daquele bloco indiscriminadamente a rapazes e moças, permitiu criar um ambiente de baixo amoralismo.

As moças ocupavam os apartamentos do $5 .^{\circ}$ andar daquele Bloco, o que permitia facilmente a entrada de rapazes nos apartamentos das moças e vice-versa. Pelo regimento interno do CRUSP, as moças residentes no mesmo, se encontravam nos blocos A e $\mathrm{D}$, onde não era permitida a entrada de rapazes.

(...)

A falta de pudor e a promiscuidade causavam indignação aos empregados responsáveis pela limpeza dos andares e apartamentos. Moças e rapazes eram encontrados dormindo completamente nús, o que chegou a motivar protestos das empregadas. (...).

Testemunhas davam conta de que

213 O IPM sobre a invasão do CRUSP se encontra disponível em formato digital na internet, no endereço eletrônico: http://movebr.wikidot.com/crusp:ipm-68 
o ambiente de promiscuidade entre rapazes e moças, no Bloco G, principalmente, concorria muito para a degradação moral e dissolução dos costumes da família brasileira; que no acesso ao Pavilhão G havia um cartaz com os dizeres: VIRGINDADE CAUSA CÂNCER e que ainda essa dissolução de costumes se estendia a numerosos outros casos isolados, envolvendo moças e rapazes no CRUSP; (...) é de parecer que o CRUSP não deve ser reaberto nos moldes como vinha funcionando.

Numerosas obras de literatura pornográfica e sexualismo, panfletos e revistas, encontrados em apartamentos de moças, propagando os princípios negativistas do rompimento com os fundamentos de nossa formação cultural e social, herdados de nossos antepassados, constituíam um dos instrumentos de propaganda dos princípios de formação da sociedade marxista-leninista.

Dos autos dêste IPM, constam várias citações sôbre focos de prostituição no CRUSP. Havia casos de prostituição de moças residentes no mesmo e os casos de moças, de vida suspeita, vindas de fora, inclusive menores, que pernoitavam nos apartamentos de rapazes, principalmente aos sábados ${ }^{214}$.

O estilo de vida dos moradores do CRUSP não diferia dos padrões de comportamento dos estudantes brasileiros que compartilhavam do espírito contestatório de 1968. Os modos libertários apregoados pelos ditos "jovens subversivos" cruspianos fugia ao controle social dos militares, e era uma afronta a moral e aos bons costumes apregoados pelos segmentos mais conservadores da sociedade brasileira. No ano seguinte, os cidadãos que se norteavam por posições de insubmissão, sejam elas políticas ou morais, refugiaram-se nos guetos da luta armada ou da contracultura. Não obstante, o regime foi mais condescendente com os segundos.

Esse breve balanço das atividades e do panorama político que envolveu a militância estudantil brasileira, no festejado ano de 1968, teve como objetivo definir o clima de lutas e de contestação que tomou conta do país, tendo no ME seu principal ator. Creio ser importante contextualizar esse ambiente, pois o mesmo contagiou boa parte dos jovens politizados nos centros mais importantes do Brasil, sobretudo os antenados ao que se passava em seu país e no mundo. E assim o foi também em Osasco. 

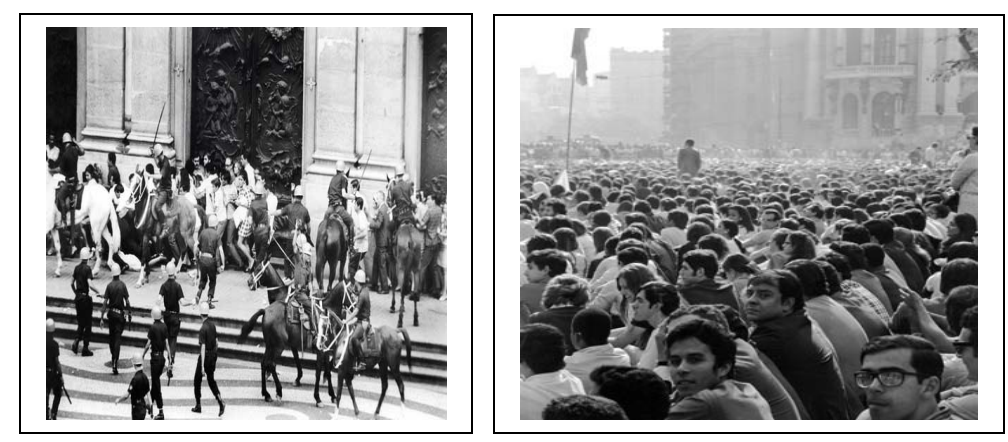

À esquerda, repressão aos presentes a missa de sétimo do estudante Edson Luis, na Igreja da Candelária, no Rio de Janeiro. A intensa repressão aos estudantes mobilizou boa parte da sociedade carioca no primeiro semestre de 1968. À direita, vemos imagem da "passeata dos cem mil", auge dos protestos contra a ditadura na capital fluminense. Fonte: http://www.almacarioca.net/violencia-emdois-tempos/ ; http://www.pstu.org.br/esp68_multimidia.asp\#
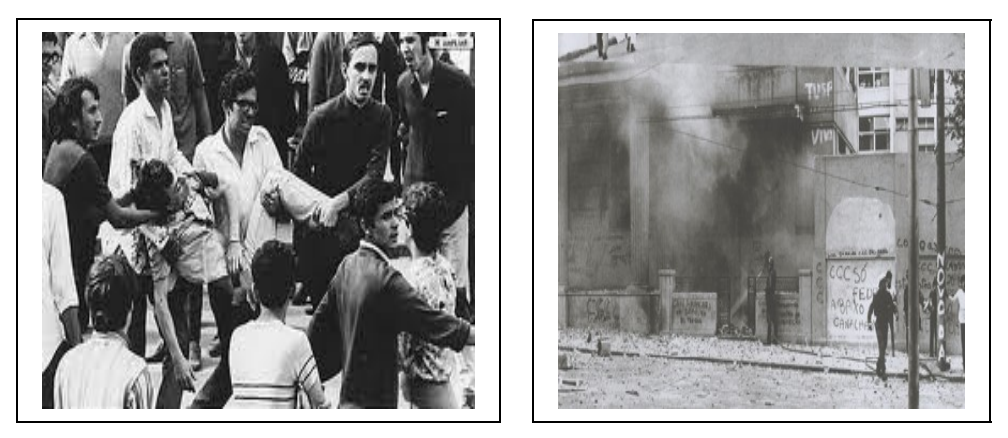

Acima, duas cenas da "Batalha da Maria Antonia", na primeira vemos o secundarista José Guimarães, alvejado durante os confrontos contra estudantes do Mackenzie, mobilizados pelo CCC (Comando de Caça aos Comunistas). O tiro é atribuído a policiais que atuavam em conjunto com estudantes de extrema-direita. A foto seguinte mostra as dependências da Faculdade de Filosofia da USP após a invasão policial. Após a invasão, os cursos da Maria Antonia foram transferidos para o Campus Butantã. Fonte: $\quad \underline{\text { http://www.tcexp.com.br/blog/2010/08/06 }}$

http://mariantonia.locaweb.com.br/institucional.htm 

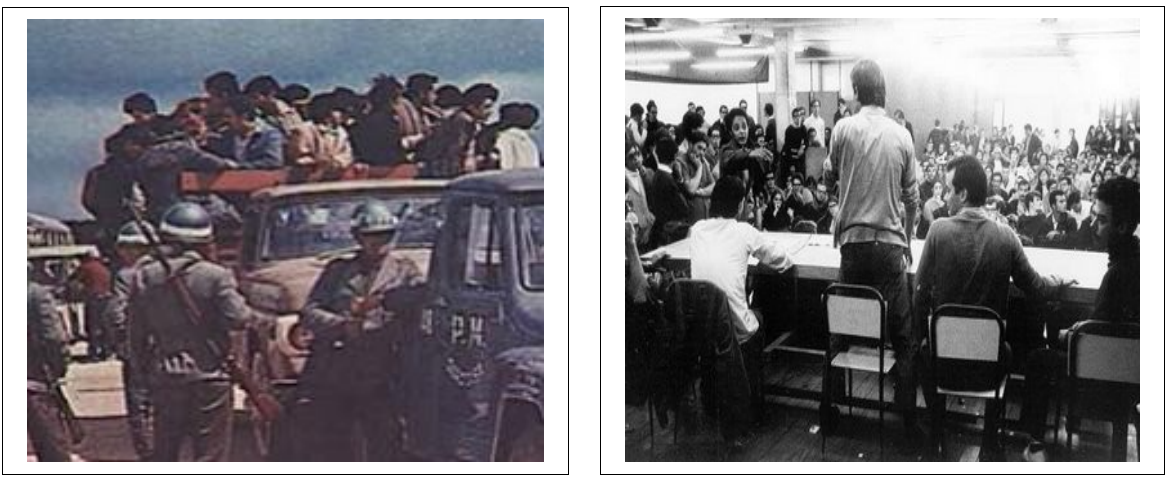

A dissolução do Congresso de Ibiúna encerra as atividades do ME em 1968, à esquerda vemos uma fotografia dos detidos no encontro que foi exibida por jornais e revistas de circulação nacional. À direita, vemos uma assembleia no CRUSP, último foco de oposição estudantil, o mesmo que seria invadido poucos dias após a decretação do AI-5. Dez anos depois, o CRUSP seria novamente ocupado pelos estudantes da USP. Fonte: http://www.sarinho.adv.br/lermais materias.php? $\underline{\text { cd_materias }=8915} ; \quad \underline{\text { http://ramonjrfonseca.blogspot.com/2009/04/helenira-no-crusp.html }}$

\section{8 em Osasco}

A série de manifestações, verificadas em todo Brasil, em repúdio ao assassinato do estudante Edson Luis, também ocorreram em Osasco, numa passeata organizada pelo CEO, em princípios de abril. Cerca de cinco mil pessoas percorreram as ruas do município, sem incidentes. Desde a conjuntura autonomista não se via uma movimentação de tais proporções na cidade. Nessa fase, a hegemonia política do GO dentro dos movimentos sociais do município já chamava a atenção dos aparelhos repressivos locais, algo que cada vez mais se tornava um problema para o prefeito Guaçu Piteri. O comandante militar da região, nesse período, era o coronel Lepiane, encarado como linha dura. Os serviços de informação fizeram chegar ao seu conhecimento as atividades subversivas de um grupo de jovens militantes de esquerda que atuava em sua jurisdição. Segundo Roque Aparecido da Silva, o coronel Lepiane

(...) controlava tudo, e quando a gente teve a primeira manifestação estudantil e obviamente eu estava lá, o coronel Lepiane, no dia seguinte, ligou pro Guaçu, o prefeito, e disse: "olha, você tem um subversivo aí no seu gabinete, exonere imediatamente, certo". Então o Guaçu me chamou e falou: "o meu, aconteceu isso, isso, isso, eu to preferindo não te exonerar, mas desaparece aí por uns tempos 
pros caras se esquecerem de você”. Aí, enfim, como desaparecer, no meio da ebulição desaparecer pô! (risos). Dez dias depois, outra passeata, dez mil pessoas, bandeira do vietcong na frente, e o Roque desaparecido embaixo da bandeira, aí então no dia seguinte o coronel Lepiane ligou e falou: "olha, ou você exonera o Roque, ou vai haver uma intervenção aí na prefeitura". Bom, claro, aí o Guaçu não perguntou nada comigo, apenas me chamou e mostrou o decreto assinado me exonerando. Claro, o movimento estudantil protestou, não aceitava, e falaram na linguagem daquela época que o Guaçu tava "baixando as calças pros milicos", e houve um rompimento do movimento estudantil com a prefeitura, eu inclusive voltei a trabalhar numa fábrica, na Mecânica Santos, em Presidente Altino, esse foi processo de radicalização aqui na cidade de Osasco. (... $)^{215}$

De fato, o rompimento entre o $\mathrm{GO}$ e a prefeitura marcou o início da radicalização do movimento. Mas essa guinada a esquerda foi se dando concomitantemente a radicalização dos demais grupos que se dispunham a combater a ditadura. Vimos que desde suas origens, o GO se definia enquanto um movimento revolucionário, sua atuação institucional era coerente com a estratégia de acumular forças e conquistar espaços em seu meio. Porém, seu viés radical sempre se fez presente, sendo uma ruptura com os canais políticos consentidos pela repressão algo inevitável.

Nesse estágio, os principais líderes do GO já se encontravam matriculados no ensino superior, Antonio Roberto Espinosa cursava Filosofia, José Campos Barreto e Roque Aparecido da Silva estudavam Ciências Sociais, os três na USP. José Ibrahim dava prioridade a sua atuação no meio operário, e não ingressou no ensino superior. $\mathrm{O}$ acesso a faculdade era uma oportunidade para estreitar os laços entre os ativistas de Osasco e as principais entidades do ME paulista e nacional. Vimos que militantes de esquerda, atuantes no circuito universitário, frequentavam o município desde 1967.

Sobre a segunda manifestação de abril, citada no excerto acima, notícias veiculadas pela imprensa informavam que "o discurso do presidente da UEE (José Dirceu) teria sido discutido previamente com José Ibrahim e tinha como tema o combate à compressão salarial". Embora majoritariamente estudantil, quadros operários (e estudantes-operários) estiveram presentes na passeata, que trouxe a Osasco centenas de ativistas de outras regiões da Grande São Paulo. Segundo Weffort, a "mescla entre uns e outros já ia adiantada, especialmente nos temas de discurso que eram praticamente os mesmos, e isso deveria ter repercussões sobre

215 Entrevista de Roque Aparecido da Silva ao autor, 05/11/2008. O jornal Correio da Manhã noticiou o evento da seguinte maneira: "na passeata de Osasco os estudantes abriram a marcha com uma bandeira da Frente de Libertação Nacional (Viet-Cong)". Correio da Manhã, 14/04/1968. Apud: WEFFORT, Francisco C. Op. Cit. p. 77 
suas perspectivas de ação" ${ }^{216}$. Vale registrar que a aliança operário-estudantil, costurada entre o GO, UNE e UEE-SP, precede os eventos de maio na França.

Vimos que tal tipo de união já havia sido tentada em 1956, delineada pela UME-RJ, e retomada na conjuntura pré-64, quando da formação da FMP, período em que se buscava uma coalizão entre todos os movimentos populares. Em 1968, tal proposta estava apenas em construção, e esbarrava num MO desorganizado pelo regime, contando com o apoio apenas do SMO, e membros dispersos das oposições sindicais paulistas. Mas esse era o panorama de São Paulo, nos demais centros do país, a situação era ainda mais dificultosa no que respeita a construção de uma frente anti ditadura.

A parceria operário-estudantil, resultado das negociações entre GO e ME, foi retomada nos eventos do $1^{\circ}$ de Maio da Praça da Sé. Para se entender as agitações da capital paulista, é necessário analisar a dissolução do MIA (Movimento Intersindical Anti-Arrocho), formado em finais de 1967. A proposta do MIA era criar uma união operária de modo a combater, por vias consentidas pelo regime, a política recessiva e de baixos salários governo militar. No entanto, desde sua formação, o movimento se encontrou cindido entre sindicatos de atuação política conciliatória, refratários a uma posição de combatividade frente a ditadura, e as oposições sindicais, capitaneadas por Osasco, de viés mais agressivo. As relações entre os signatários do MIA foi tensa até a sua completa dissolução, após o $1^{\circ}$ de Maio de 1968.

O presidente do Sindicato dos Metalúrgicos de São Paulo, Joaquim dos Santos Andrade, conhecido como Joaquinzão, coerente com suas posições, saiu a frente das oposições sindicais na preparação dos eventos em comemoração ao Dia do Trabalhador. Acenando com uma proposta de diálogo junto ao poder estabelecido, Joaquinzão convidou para o ato do $1^{\circ}$ de Maio o governador Abreu Sodré. A presença do mandatário paulista no palanque interessava aos grupos mais moderados, pois sua participação no evento marcaria a posição de conciliação proposta pelos sindicalistas paulistanos, e também sua diferença programática em relação às oposições sindicais. Abreu Sodré compactuava com a perspectiva de abertura dos momentos iniciais do governo Costa e Silva - a essa altura já superada buscando dialogar com os movimentos sociais.

Mas as oposições sindicais estavam cientes da inviabilidade do diálogo com o regime militar, que seguia com seu modelo econômico recessivo e concentrador de renda. A recente repressão aos estudantes cariocas demonstrava que a liberalização propagandeada pelos 
mandatários da Nação não se efetivaria. Por isso foi repudiada a presença do governador paulista nas comemorações do Dia do Trabalhador, e uma manifestação foi organizada contra a solenidade. Sobre a organização do ato, observemos o relato de Roque Aparecido da Silva, diretamente envolvido na articulação do protesto. Embora extenso, seu depoimento trás informações cruciais sobre o $1^{\circ}$ de Maio paulista mais agitado desde o golpe de 1964:

Bom, no $1^{\circ}$ de Maio, em sua organização, teve algumas dificuldades, porque no final de 1967 se formou o MIA, e a gente tentou aglutinar as oposições sindicais nele, mas nos primeiros encontros as dificuldades foram grandes, em função do racha que havia entre os pelegos e a gente das oposições sindicais. De forma que na terceira manifestação convocada pelo MIA, em seguida o pessoal fez uma avaliação e decidiu suspender as outras manifestações que estavam programadas e concentrar os esforços na organização do Primeiro de Maio, que tinha que ser um Primeiro de Maio grande, etc. E isso assumido por todos os dirigentes do MIA, inclusive os pelegos todos. Aí teve toda uma discussão de onde seria, e se decidiu que deveria ser na Praça da Sé. O Joaquinzão e outros dirigentes sindicais foram ao palácio do governador Sodré, para pedir autorização para realizar a manifestação na Praça da Sé, e claro, convidaram o governador para participar e tudo mais, e o governador, claro, "como primeiro trabalhador do Estado, lá estarei”. Então autorizou e já aceitou o convite para estar presente, aí houve um debate muito grande entre as oposições sindicais e o sindicato de Osasco, como é que a gente ia fazer? Então, tinha um pessoal da AP, que inclusive tinha um trabalho bom em São Bernardo, no $\mathrm{ABC}$, que propunha que a gente fizesse duas manifestações, esvaziando a Praça da Sé, convocando uma manifestação no $\mathrm{ABC}$ e outra em Osasco, e com isso esvaziar e deixar os pelegos com o governador lá na Praça da Sé. Agora, nós do Grupo de Esquerda não concordamos com isso, nós achamos que deveria levar todo mundo para a Praça da Sé, e realizar uma manifestação autêntica de trabalhadores, tomando o palanque, ou então acabando com a manifestação na praça, e sair para outro lugar, para fazer a nossa, enfim, não deixar a Sé na mão dos pelegos. (...) a nossa posição venceu, então decidimos ir para a Praça da Sé. Aí foi a questão toda de como organizar essa manifestação, de como garantir que fosse uma manifestação autêntica da oposição contra a conciliação. Então a gente começou a fazer esse trabalho de organização com bastante antecedência, por exemplo, fizemos o levantamento e tinha onze ruas que davam acesso a praça, verificamos quais seriam no caso da chegada da repressão, quais seriam as ruas pelas quais chegaria a polícia, a cavalaria, etc. Aí começamos a organizar os grupos que iriam ficar em cada entrada, nas entradas onde poderia chegar a repressão nós colocamos grupos grandes, com bolinha de gude para derrubar os cavalos caso chegasse a cavalaria, ao mesmo tempo tinha uns com cabos de aço, e lá perto da Praça da Sé tinha uma obra da construção civil, onde o Dorival Ferreira, que era o líder da oposição na construção civil, trabalhava. Então a gente passou a noite de trinta de abril pro dia primeiro de maio cortando barras de ferro (...), 
enrolando em jornal, e tínhamos no dia primeiro, as sete e meia da manhã, pelo menos uns duzentos companheiros organizados e armados, seja com barra de ferro, seja com bolinha de gude, enfim, as nossas armas, pra enfrentar a repressão. Chegamos mais cedo para colocar o nosso pessoal em torno do palanque, então estávamos com o aparato todo montado. A gente fez articulações com as organizações de esquerda, com as oposições sindicais, com o movimento estudantil, a UEE, o DCE, o grêmio da Filosofia, enfim, todas as organizações estudantis para garantir uma coisa bem organizada, bem feita. Bom, então távamos lá, muita gente, aqui de Osasco nós levamos oito ou dez ônibus, gente chegando de todo lado. Quando chegaram os dirigentes sindicais pelegos junto com o Sodré foi uma vaia generalizada, um agito total. Tinha um companheiro de "uns dois metros e meio por uns dois", que estava logo na frente e agarrou a grade, que era de madeira, agarrou e derrubou, todo mundo foi pra cima, aí foi ovo e pedra pra cima dos pelegos. O Sodré mesmo recebeu uma pedra na testa, aí eles todos se refugiaram lá na catedral, e nós fizemos a manifestação ali na Praça da Sé, alguns companheiros falaram no palanque, e dali saímos em passeata para a Praça da República ${ }^{217}$.

Pelo minucioso relato de Roque Aparecido depreendemos que a ação contra a solenidade foi cuidadosamente planejada, e não um simples ato de "desordeiros" e "provocadores" como foi apregoado pela imprensa. Outro fato que deve ser salientado é a participação das entidades estudantis no protesto, dando continuidade a proposta de frente junto aos operários. No dia seguinte, Abreu Sodré, em nota oficial, condenou seus agressores:

(...) Repressão à desordem e á agitação inconsequente é indispensável ao exercício legítimo das liberdades democráticas e o meu compromisso com estas é antigo e inabalável. Não me desviarei dele um milímetro, em nenhum instante, quaisquer que sejam as provocações dessa minoria irresponsável cuja ação objetiva precisamente por em perigo aquelas mesmas liberdades. Assegurei aos líderes trabalhadores que me procuraram o direito de comemorar em praça pública o Dia do Trabalho, associei-me pessoalmente a essas comemorações. Dirigindo a palavra aos operários. Lamento apenas que um restrito grupo de agitadores, cuja covardia os levou a utilizar até mesmo a ingenuidade de menores - mas todos preparados e ocultamente armados de bastões, barras de ferro e pedras - tenham impedido o desenrolar normal de uma solenidade a qual o Governador compareceu acompanhado apenas de seus auxiliares mais próximos. $(\ldots)^{218}$

217 Entrevista de Roque Aparecido da Silva ao autor, 05/11/2008

218 Jornal Última Hora, 02/05/1968, disponível no sítio: http://www.arquivoestado.sp.gov.br/uhdigital/pesquisa.php 
A busca de conciliação proposta pelo Sindicato dos Metalúrgicos de São Paulo foi ofuscada pelas oposições, no entanto, Joaquinzão e seu grupo seguiram sendo majoritários entre os trabalhadores organizados. Os manifestantes que dissolveram a solenidade do Dia do Trabalhador formavam um "restrito grupo", se comparado a todo o espectro sindical paulista. Fugiria ao escopo deste trabalho analisar todas as correntes em atuação no meio sindical de São Paulo na conjuntura em discussão. O que cabe ressaltar é que as oposições, embora restritas, possuíam um maior poder de mobilização se comparadas as associações atreladas ao regime. Na próxima seção veremos que o cupulismo e a desmobilização do sindicalismo oficialista o afastava de suas bases. As agitações da Praça da Sé, segundo estimativas oficiais e extra-oficiais, não mobilizaram mais que dez mil pessoas, entre trabalhadores e estudantes.

Joaquinzão e seu grupo atuavam de acordo com as diretrizes do PCB, partido que controlava a grande política sindical do estado. A tática de conciliação e não enfrentamento ao regime coadunava com as propostas moderadas dos comunistas. Dentro dessa perspectiva, duras críticas foram feitas pelos pecebistas ao protesto do $1^{\circ}$ de Maio.

É certo que, em São Paulo, grupos provocadores e divisionistas, aproveitando-se do comparecimento do Sr. Abreu Sodré, conseguiram interromper a realização do comício. A ação "ultraesquerdista" e aparentemente radical desses grupos levou-os a se identificarem, na realidade, com os interêsses dos inimigos dos trabalhadores e com a própria ditadura, a quem em última análise serviram. Eles dissolveram um comício ao qual o ministro Passarinho não teve condições de comparecer. A circunstância de o governador do Estado participar ou não do ato tinha uma importância secundária diante do fato de que o comício possuía um nítido sentido de combate a ditadura e sua política, atingindo, consequentemente, também o senhor Sodré. (... $)^{219}$

O cerne da crítica pecebista ao protesto está no fato de que desde 1964 não se permitiam concentrações organizadas pelos trabalhadores em comemoração ao $1^{\circ}$ de Maio. A

219 Jornal Voz Operária, número XL, junho de 1968. Disponível em formato digital no CEDEM (Centro de Documentação e Memória da UNESP), localizado na cidade de São Paulo, informações referentes ao acervo podem ser encontradas no endereço eletrônico: www.cedem.unesp.br. O periódico sindical O Metalúrgico também repudiou os eventos da Praça da Sé, por meio de um manifesto assinado por 27 Sindicatos e Federações, onde os mesmos manifestavam "sua mais profunda revolta pelos lamentáveis acontecimentos verificados na Praça da Sé, quando milhares de trabalhadores convocados pelas entidades lá estavam a espera de orientação que lhes tem faltado nestes últimos anos" ressaltaram "a atitude corajosa de sua excelência o senhor governado do Estado, Dr. Roberto Costa de Abreu Sodré, expondo-se conosco a fúria irracional desses indivíduos", e deixaram "a opinião pública paulista e brasileira, o julgamento definitivo de fatos e pessoas". O Metalúrgico, No 227, agosto de 1967 a julho de 1968. Apud: LOPES, Carmen Lúcia Evangelho. "A Organização Sindical dos Metalúrgicos de São Paulo". Tese de Doutorado, FFLCH-USP, 1992. p. 155 . 
conquista do direito de realizar um comício na Praça da Sé, no Dia do Trabalhador, foi considerada uma vitória. A dissolução do ato bloqueava a tática do Partidão de ir constituindo canais de diálogo e conquistando espaço entre as elites civis e militares, na perspectiva de que a ditadura poderia, nessa conjuntura, ser superada pela via institucional.

Outro ponto da nota de Abreu Sodré que vale ressaltar é sua menção a presença de "menores" no ataque ao palanque. Pelo relato de Roque Aparecido vimos que estiveram presentes no evento militantes da UNE, UEE-SP, e secundaristas, os últimos representados pelo CEO e por quadros da Frente Estudantil Secundarista, ligada a José Dirceu. Segundo Celso Lungaretti, liderança da Frente na Zona Leste de São Paulo, “a base secundarista foi informada do que se planejava e compareceu e peso, com um bom estoque de pedras." ${ }^{220}$ José Barbosa Monteiro, líder sindical metalúrgico de São Bernardo, trás o ponto de vista das demais oposições sindicais envolvidas no protesto.

(...) este é um ponto que é bom esclarecer: quando se fala de $1^{\circ}$ de maio muita gente acha que tudo saiu de Osasco. Na verdade, foi um movimento muito mais amplo: gente de São Paulo, do ABC, Guarulhos, Osasco e Campinas. E toda uma participação do povo. De Santo André saíram 2 ônibus, da minha vila 6 ônibus com moradores, mulheres e crianças. Foi uma preparação política em profundidade onde colocávamos todos os riscos que corríamos. Fizemos uma coleta para comprar leite para todo o mundo e amoníaco contra o gás lacrimogéneo. Todo o mundo organizado em grupos de 5 com um responsável. Tínhamos aprendido com a experiência do MIA: agora, quando a polícia viesse buscar um os outros quatro caíam de pau para libertá-lo ${ }^{221}$.

Um último ponto deve ser comentado, a ausência de repressão aos manifestantes da Praça da Sé. Após o ataque ao governador e a expulsão de seus apoiadores, o palanque foi invadido, e representantes das oposições sindicais tomaram a palavra. Por Osasco falaram Manuel Dias do Nascimento (Neto) e José Campos Barreto (Zequinha), o mesmo que fez um contundente discurso contra o regime, incitando os trabalhadores a combater os militares pela via armada. Foi a "primeira vez que em uma manifestação operária, na praça pública, se colocou diretamente para os trabalhadores que o enfrentamento contra a ditadura, tal como se colocava a conjuntura, tinha que ter um desdobramento armado e os operários deveriam se 220 LUNGARETTI, Celso. Náufrago da Utopia. São Paulo: Geração Editorial, 2005. p. 43

221 Revista Cadernos do Presente - Greves Operárias (1968-1978), № 2; 2 de julho de 1978. São Paulo: Editora Aparte, 1978. p. 25. Em 2009, o Centro de Estudos Victor Meyer (CVM), a partir de seu projeto "Memória das Lutas Operárias", digitalizou o segundo exemplar da revista Cadernos do Presente, acima citado. Nossa apreciação obedecerá a formatação presente na edição digital da revista. $\mathrm{O}$ exemplar se encontra disponível em: www.centrovictormeyer.org. 
organizar e enfrentar a ditadura de armas nas mão" ${ }^{\text {222 }}$. Após as falas, o palanque foi incendiado, e uma passeata seguiu em direção a Praça da República. No caminho, uma filial do Citibank foi apedrejada, aos gritos de "abaixo o imperialismo".

Completado o percurso, novos discursos contra o governo militar foram proferidos, e mais uma vez Barreto incitou os trabalhadores a combater o regime de forma violenta. Poucas prisões foram feitas, a polícia acompanhou tudo a distância. Na opinião de Antonio Roberto Espinosa, "Abreu Sodré era um político mais moderado da ARENA, mesmo tendo sido expulso do palanque, ele teve sangue frio pra não... o Abreu Sodré era mais castelista, não era do grupo que viria a puxar o Ato 5 em dezembro, e ele evitou de qualquer maneira provocação, não quis dar esse pretexto, enfim, eu acho que isso se deveu em grande parte a sabedoria dele. Da nossa parte, nós provocamos, nós provocamos...(...)"223 .

$\mathrm{O}$ fato é que a jornada terminou sem maiores incidentes, de acordo com o jornal Última Hora, cerca de vinte pessoas foram presas, entre estudantes e operários, além de dois jornalistas ${ }^{224}$. Entretanto, segundo depoimentos, o protesto poderia ter tido um desfecho trágico, pois membros da futura VPR, que a essa altura já mantinha fortes conexões com os ativistas do GO, decidiram intervir no protesto em favor das oposições sindicais e do ME. O plano dos guerrilheiros era defender a manifestação à bala, caso houvesse repressão policial. Com esse intento foram montados "ninhos de metralhadoras nas entradas (da Praça da Sé), por onde a polícia poderia vir. Se houvesse repressão, provavelmente ela encontraria uma barragem de fogo de metralhadoras da (futura) VPR, o que teria uma influência na História seguinte, com certeza, só não imagino para onde levaria" ${ }^{, 225}$. De fato, as repercussões de um ataque armado a tropas da PM poderiam ter atingido dimensões muito mais trágicas do que as que se observaram ao longo de 1968 e anos posteriores.

O Primeiro de Maio da Praça da Sé serviu para solidificar o compromisso que já havia entre o GO e as entidades estudantis paulistas, e ajudou a alimentar o projeto de união operário-estudantil. Depois dos eventos de maio na França, a percepção de que tal união poderia ser bem sucedida na derrubada dos militares se acentuou no Brasil. Desde março os

222 Depoimento de Roque Aparecido da Silva ao semanário Visão Oeste, edição 247, 11 a 17 de julho de 2008.

223 Entrevista de Antonio Roberto Espinosa ao autor, 09/06/2008.

224 Jornal Última Hora, 02/05/1968, disponível no site:

http://www.arquivoestado.sp.gov.br/uhdigital/pesquisa.php

225 Esta história é relatada por Antonio Roberto Espinosa e Roque Aparecido da Silva em entrevistas ao autor. Pedro Lobo, em seu livro de memórias, afirma que quadros da ALN também estiveram presentes no esquema de defesa armada da manifestação, a frente dos homens de Marighella estava Marco Antonio Brás de Carvalho, o Markito, guerrilheiro que seria assassinado em janeiro de 1969 pela repressão. LAQUE, João Roberto. Op. Cit. p. 166-167 
estudantado nacional se encontrava mobilizado e ativo, desafiando o regime em atos cada vez mais ousados, mas faltava o MO se levantar. Em se tratando de São Paulo, o protesto do Dia do Trabalhador foi visto como uma espécie de ensaio, contudo era necessário uma movimentação mais incisiva por parte dos trabalhadores para se criar uma poderosa frente de combate ao governo ditatorial. Essa oportunidade foi vislumbrada com a greve de 16 de julho, no município de Osasco.

O primeiro dia 16 a chamar a atenção da sociedade brasileira, no ano de 1968 , foi o de abril. Nessa data, uma inesperada greve na cidade de Contagem, distrito industrial mineiro, furou o bloqueio governamental que desde 1964 calara os trabalhadores. Cerca de 16 mil operários cruzaram os braços contra o "arrocho" salarial da ditadura, e exigiram um aumento de $25 \%$ em seus vencimentos. A greve apresentou algumas características distintas, foi organizada totalmente a margem do sindicalismo oficial, e se efetivou com ocupações de fábrica, algo inusual no Brasil. Em Minas também se verificou a presença de "comitês de empresa" e a figura do estudante-operário. ${ }^{226}$. O movimento de Contagem apresentou algo novo nos meios operários brasileiros, fato que chamou a atenção das oposições sindicais organizadas em outros centros do país. O GO acompanhou com muita atenção os desdobramentos do movimento paredista mineiro. Ao término das paralisações, foi conquistado um aumento de $10 \%$, considerados por muitos uma vitória, algo inédito desde o golpe militar.

A greve de Minas não sofreu uma repressão ostensiva por parte dos aparatos militares de sua região, só ao final do movimento tropas invadiram as empresas ocupadas, sem maiores confrontos. Os eventos de Contagem foram tomados como referência para os opositores ao regime, mostraram que era possível furar o bloqueio do sistema autoritário, e que também era possível construir uma greve a margem do sindicalismo oficial. Para o governo militar, serviu como alerta. O retorno das mobilizações de massa, capazes de atrair amplos setores populares,

226 Circulava nos distritos industriais mineiros o periódico-panfleto Comitê de Empresa, conclamando os trabalhadores a se organizarem no âmbito de suas fábricas, e defendendo a união operário-estudantilcamponesa contra a Ditadura. Para informações sobre o panfleto Comitê de Empresa, consultar arquivos digitais do CEDEM. Mais informações sobre os "comitês" mineiros: FREDERICO, Celso. Op. Cit. p. 16768. Sobre a participação estudantil na Greve de Contagem, Weffort faz menção ao renascimento do ME nos "três colégios" do município; WEFFORT, Francisco C. Op. Cit. p 33. 
contidas após o assalto ao poder, poderiam ser perigosas para um regime que cada vez mais suscitava descontentamentos entre os grupos organizados da sociedade.

O outro dia 16, agora em julho, a chamar a atenção do país, teve como cenário Osasco. A partir da empresa Cobrasma foi organizado um movimento paredista, que rapidamente se espalhou para outras empresas da cidade. Não obstante, ao contrário do que se observou em Contagem, no subúrbio paulistano a repressão não abriu margem para negociações, e ocupou o município militarmente horas depois da deflagração da greve. Ainda assim, a paralisação durou cerca de uma semana, outras fábricas da cidade aderiram a parede, e o SMO encampou o movimento, algo que não se viu na cidade mineira. Assim como em Contagem, a greve de julho se deu com ocupação de fábrica (ao menos duas fábricas), mas em Osasco também foi adotada a tática de sequestro de diretores, mantidos reclusos nas empresas que passaram ao controle dos operários. Essa tática era mais uma influência do maio francês. O elemento novo dessa paralisação foi a presença do estudante-operário enquanto elemento central em sua construção e condução. Coube ao GO a organização e o comando do movimento.

A principal exigência dos operários osasquenses era um aumento de $35 \%$, mas essa greve possuiu caráter insurrecional, o objetivo era espalhá-la para toda a cidade de São Paulo, e se possível fosse, para todo o país. Contudo, a repressão intercedeu de maneira rápida e eficaz, e manteve o movimento restrito a Osasco. Poucos dias depois a cidade já se encontrava sob controle, a repressão patronal pode ser executada sem resistência, e dezenas de lideranças operárias foram demitidas de suas empresas. O SMO sofreu intervenção federal, e seus diretores foram destituídos. As comissões de fábrica, que desde meados da década haviam sido reconhecidas pelos patrões, foram anuladas. O CEO foi fechado e seus diretores perseguidos. Quanto aos articuladores do GO, os mesmos foram obrigados a entrar para a clandestinidade, vistos pelos órgãos repressivos como perigosos subversivos sujeitos a Lei de Segurança Nacional. Dos militantes do grupo, somente Zequinha Barreto permaneceu preso, passando mais de três meses na cadeia.

No que respeita a coalizão com os estudantes, tema que nos interessa por ora, foi buscada uma parceria como a levada a cabo no $1^{\circ}$ de Maio. Mas desta vez as pretensões eram maiores, buscava-se o fortalecimento da união operário-estudantil, e dar início a um movimento que deveria se completar com a derrubada da ditadura. Nessa fase ainda estava em pauta a supressão do regime pela via pacífica, ou não armada, através de grandes movimentos 
de contestação popular, com o objetivo de conquistar a anuência de toda a sociedade, e isolar os militares no poder. A greve de julho seria a oportunidade ideal para se iniciar essa escalada.

O movimento se encontrava em tal nível de organização, que dias antes foi acertada a composição de um panfleto, a ser distribuído pelos estudantes, chamando a participação e a solidariedade a paralisação. Sobre essa articulação, observemos e relato de Antonio Roberto Espinosa, que atesta que o documento convocando à adesão a greve de Osasco

(...) foi rodado pela UEE de São Paulo, e na época era mimeografo a álcool, demorado, cinquenta por hora. Pra você poder ter o manifesto pronto no dia 16, tinha que ser escrito três dias antes, pros estudantes ficarem rodando três dias, na Maria Antonia ocupada. Um manifesto que contava o que não tinha acontecido, só com base no plano, que acabou dando certo, pelo menos até aí. O que não deu certo foi a repressão que não participou de nosso ensaio, que não esperou e veio no mesmo dia 227 .

Sobre o mesmo tema, mas com maior riqueza de detalhes, Roque Aparecido da Silva comenta que:

É necessário dizer que a greve ficou muito bem organizada, por exemplo, com quinze, dez dias antes, quando já tava decidido inclusive o dia que ia começar a greve, eu fui conversar com o Zé Dirceu, então presidente da UEE, pra ver o tipo de apoio que o movimento estudantil poderia dar a greve. Aí concluímos que o Zé Dirceu convocaria, já que a greve ia começar dia 16 de julho, ele convocaria para a mesma data, a noite, uma assembleia universitária. Tendo se iniciado a greve de manhã (...), a questão da greve passaria a ser o tema da assembleia, e decidimos que ele proporia organizar grupos para no dia 17, de manhã, de madrugada, fazer panfletagem nas fábricas de São Paulo, Guarulhos e ABC, chamando os operários dessas localidades todas a aderirem a greve em solidariedade a Osasco. Bom, aí... Tá, perfeito, ótimo... Mas como é que ia ser impresso esse material, que não poderia ninguém ficar sabendo com antecedência, já pensou? Um panfleto chamando à solidariedade a greve ia chamar a atenção para o acontecimento antes dele tá acontecendo, aí o Zé falou, "olha, pra rodar com segurança eu tenho um mimeógrafo a tinta, eu posso ter uma pessoa de total confiança que vai rodar, agora, com um mimeógrafo a tinta pra rodar o número de panfletos necessários eu preciso do texto com três dias de antecedência". Então eu disse "pô, mas como, pra um panfleto ser distribuído no segundo dia de greve, chamando à solidariedade ao movimento, tem que falar o que aconteceu no dia anterior, e como é que eu vou falar isso com três dias de antecedência?

227 Entrevista de Antonio Roberto Espinosa ao autor, 09/06/2008 
Bom, deixa pra lá, eu vou pra Osasco e a gente vê isso lá”. E aí justamente eu sentei com o Espinosa, e a gente tinha tanta segurança na nossa organização, que quatro dias antes redigimos: "ontem, quinze pras nove da manhã, um toque extra da sirene da Cobrasma deflagrou a paralisação da fábrica, meia hora depois os trabalhadores reunidos dentro da fábrica decidiram greve e ocupação da fábrica por prazo indeterminado. As onze e trinta, horário do almoço, os operários da Barreto Keller paralisaram o trabalho, foram em passeata até o sindicato, e em assembleia decidiram greve por prazo indeterminado. Às catorze horas, horário de troca de turnos da Lonaflex, os operários decidiram ocupar a fábrica e fazer greve por tempo indeterminado, é greve em Osasco em solidariedade, pa-papá". A gente entregou isso com quatro dias de antecedência, e até o final da tarde aconteceu exatamente o que tava no panfleto, só que a gente não previa que a repressão ia chegar no primeiro dia e fazer tudo que fez. Mas esse era o nível de organização e de confiança que a gente tinha na nossa organização, e assim se deu"228.

O cronograma foi cumprido a risca pelos trabalhadores de Osasco, quanto ao ME, suas atribuições também foram postas em prática de acordo com o acertado junto ao GO. No jornal da UEE, publicado no mês de agosto, há um balanço crítico sobre a participação dos estudantes na greve, vejamos parte de seu conteúdo:

No dia em que eclodiu a greve, com a tomada das fabricas Lonaflex e Cobrasma, pelos operários, e com a ocupação do Sindicato dos Metalúrgicos de Osasco pelos grevistas da Barreto Keller e da Granada (que permaneceram em assembléia permanente), a UEE realizou uma Assembléia na qual houve um comparecimento maciço. Em plenas férias, mais de 1000 estudantes discutiram como prestar uma solidariedade ativa aos grevistas. Das decisões tiradas em Assembléia, surgiu, através de proposta da UEE-UNE, o Comitê Popular de solidariedade aos Grevistas de Osasco. A finalidade deste comitê era de contactar os vários setores da população que estão se organizando, procurando, através dêles e do M.E., criar as condições para a manutenção da greve. As condições necessárias eram:

1 - Finanças para ajudar os grevistas;

2 - Propaganda entre a população em geral para divulgar os objetivos e as reivindicações do movimento;

3 - Propaganda e agitação nas portas de fábricas e nos centros operários levando os panfletos do Comitê dos grevistas de Osasco e as notícias verdadeiras sobre o desenrolar da greve (notícias essas que a imprensa burguesa sabotava);

228 Entrevista de Roque Aparecido da Silva ao autor, 05/11/2008 
4 - Um esquema eficiente de assessoria jurídica aos prêsos; $;^{229}$

A rapidez e a contundência da repressão a greve pegou também o ME de surpresa. A panfletagem por conta de UEE, UNE e UPES foi posta em prática, mas a solidariedade ao movimento não teve tempo de se expandir a contento. O Comitê formado em solidariedade aos grevistas chegou a reunir artistas, professores, membros do clero progressista; partidários das oposições sindicais de outros centros da grande São Paulo, que manifestaram apoio a paralisação. Sobre as tarefas do Comitê, o periódico da UEE atesta que:

A função do Comitê de Solidariedade era, de um lado, criar uma infra-estrutura material que permitisse a sustentação da greve; de outro, tentar, através da organização, da agitação e propaganda, sob a orientação das oposições sindicais e do Comitê dos Grevistas, fazer com que a greve se alastrasse a outros setores da produção. Nesta última tarefa, foi inteiramente mobilizada a comissão de panfletagem e comícios-relâmpagos da ocupação Filo-USP que, intensificando seu trabalho, conseguiu mobilizar de 40 a 80 pessoas para fazer agitação de 4 a 5 vezes por dia ${ }^{230}$.

Embora o movimento tenha sido exemplarmente contido, foi considerado uma vitória no que concerne a construção de uma união operário-estudantil, e visto como o primeiro passo para a constituição de novas articulações. O artigo do Jornal da UEE que discutiu o evento foi intitulado: "As lições de uma greve de operários". Suas conclusões foram otimistas, e vislumbraram novas paralisações como as de Osasco, tidas como uma espécie de experiência piloto, a primeira de um ciclo que estaria apenas começando.

(...) Esta greve foi derrotada. As reivindicações dos grevistas: 35\% de aumento de salário, reajustes de 3 em 3 Mêses, contrato coletivo de trabalho de 2 em 2 anos, não punição para os grevistas, nenhuma delas foi conseguida. Operários foram presos e torturados. (José Campos) Barreto se encontra até hoje preso, houve dispensas em massa.

Porem o avanço político que a greve representou tem que ser considerado como uma vitória. A grande lição é a necessidade de criação de uma estrutura clandestina, desligada dos sindicatos e a necessidade de formação dos comitês de empresa por fábrica. A classe operária fará outra greve ainda esse ano. $(\ldots)^{231}$

229 Jornal da UEE, agosto de 1968. Disponível no Arquivo do Estado de São Paulo, pasta OP -1450, UEE-SP, acervo DEOPS-SP.

230 Idem.

231 Ibidem. 
Pelo trecho acima verificamos que o processo de construção da Greve de Osasco foi considerado correto pelo ME, a mobilização extra-sindical, uma das características da paralisação de julho, foi ressaltada pelo periódico da UEE. A principal recomendação foi no sentido de se organizar "estruturas clandestinas", a margem do sindicalismo oficial, engessado pela burocracia e pelo controle da política trabalhista do regime militar. Destarte, o melhor caminho seria a formação de "comitês de empresa", ou comissões de fábrica, como as organizadas em Osasco desde inícios dos anos 1960. Sobre a eclosão de novas greves em 1968, tentativas foram levadas a cabo em outras regiões de São Paulo e do país, mas a vigilância dos aparatos de repressão deixou claro que não seriam permitidos outros movimentos paredistas de envergadura no Brasil.

A greve de julho também chamou a atenção do ME do restante do país, entidades de outros estados acompanharam de perto o desenrolar dos fatos, atentas a possível consolidação da aguardada união operário-estudantil. Vladimir Palmeira, presidente da UME-RJ, ligado a corrente de José Dirceu, a mesma que pleiteava a presidência da UNE, recebeu da UEE-SP os panfletos redigidos pelos organizadores da Greve de Osasco, com a incumbência de divulgar o movimento em seu estado. Sobre sua participação na divulgação, Vladimir Palmeira comenta que:

Quando houve a greve de Osasco, fizemos quatro ações de vanguarda no Rio (...). Ocupamos o Ministério do Trabalho, ocupamos o Sindicato dos Metalúrgicos do Rio de Janeiro, ocupamos a Estação da Leopoldina e houve alguma repressão (...). Fomos lá, ocupamos e demos apoio, fizemos comícios-relâmpago, fomos para a Zona Oeste do Rio. Lembro que fizemos um comício em Bangu, o que para nós era um fenômeno, a Zona Sul era mais separada do subúrbio que era hoje. Fizemos comício em porta de fábrica. (...) Nós dizíamos: não estamos aqui inventando nada, queremos que os operários de Osasco falem diretamente para vocês. Aí líamos e distribuíamos o panfleto aos operários e, claro, fazíamos alguns comentários, que ninguém é de ferro, $(. . .)^{232}$

Se a união operário-estudantil, em São Paulo, encontrava-se em construção em meados de 1968, no Rio de Janeiro era um sonho distante, assim como nos demais centros políticos brasileiros. Não obstante, tal perspectiva se tornou o mote da política estudantil, sobretudo entre os partidários do grupo que fazia oposição as teses da AP na UNE. Vimos acima que o 
ME do período se encontrava cindido entre duas posições, embora ambas as tendências preconizassem uma união entre estudantes e forças populares, as posições de José Dirceu e Vladimir Palmeira, membros das dissidências do PCB, definiam como prioritária uma aproximação junto aos operários, de modo a atacar o regime e a burguesia nacional em seu ponto mais sensível, a produção.

A greve de julho também foi vista como exemplar pelos estudantes cariocas, sua construção e seus desdobramentos foram amplamente discutidos pelo ME fluminense. $\mathrm{O}$ suplemento Contato, alinhado as posições da UME, publicado pelo grêmio dos estudantes da Faculdade de Economia e Administração, da UFRJ (Universidade Federal do Rio de Janeiro), em sua edição de agosto, apresentou o artigo "Ditadura treme...Osasco". Os acontecimentos do subúrbio industrial da Zona Oeste da Grande São Paulo foram apresentados como "um exemplo a ser seguido", e seus mecanismos de auto-organização são ressaltados pela matéria, que em tom elogioso informa que os trabalhadores osasquenses procuraram "criar uma organização própria, em seus locais de trabalho, formando Comitês de Empresa, independentes do aparelho burocrático da ditadura dos seus patrões."233

No inquérito sobre os eventos de julho em Osasco, existe um panfleto assinado por uma “Comissão Popular dos Cem Mil”, redigido pelo ME carioca, chamando a solidariedade a greve, e se prontificando a contribuir "não apenas no nível formal, mas também no nível prático" 234 . Em outras capitais brasileiras também foi manifestada solidariedade e apoio a Osasco. Contudo, uma semana depois de sua deflagração, a greve insurrecional já se encontrava restrita a balanços críticos e perspectivas para novas ações vindouras.

\section{$* * * * *$}

Em 1968 grande parte da esquerda brasileira acreditava que era possível derrubar a ditadura por meio de pressão popular, mas para tanto, era necessário a construção de uma frente que pudesse efetivamente colocar o regime contra a parede. Até meados desse ano, essa era a bandeira dos setores políticos mais avançados em oposição ao regime. A proposta de

233 Contato, $\mathrm{N}^{\mathrm{o}}$ 12, edição de agosto de 1968; jornal publicado pelo Grêmio da Faculdade de Economia e Administração da UFRJ. Disponível em formato digital no CEDEM. Entre os estudantes cariocas ganhou destaque a figura de José Ibrahim, tido com um líder exemplar, chamou a atenção também por sua pouca idade. Tal prestígio o colocou na lista de presos a serem trocados pelo embaixador Charles Elbrick, em setembro de 1969, assunto que será abordado no quarto capítulo deste trabalho.

234 Panfleto disponível no Arquivo do Estado de São Paulo, pasta OS - 0704, Osasco: 1951-1982, acervo DEOPS-SP. 
frente ampla partida de velhos caciques da política nacional não empolgou a esquerda, tratava-se de combater os militares por meio de ações de massa, nas ruas, de maneira a chamar a atenção da sociedade para a natureza autoritária e anti-democrática de um governo que chegara ao poder por meio das armas.

Coube ao ME chamar para si a responsabilidade de tal tarefa, mas mesmo os estudantes mais engajados nas lutas de rua tinham consciência do papel auxiliar que seu movimento poderia exercer na escalada revolucionária rumo a conquista do poder. Até julho, todas as fichas foram postas no sentido de uma coalizão com o MO. Vimos que o Maio francês mostrou que tal união era viável, uma greve geral operária e estudantil paralisou dez milhões de trabalhadores, e quase botou abaixo a V República do General Charles De Gaule. A culpa da derrota da insurreição foi atribuída a CGT, braço sindical do PCF, alinhado as tradicionais regras do poder. O levante francês tinha no ME sua vanguarda, embora também tenha empolgado outras categorias sociais, como os profissionais de nível médio.

No Brasil, o panorama era mais complexo, o país vivia sob regime ditatorial, e os meios de oposição legal ao governo eram quase nulos. Para os estudantes brasileiros, as agitações verificadas na Europa serviam como modelos de luta, sendo o exemplo da França o mais festejado. A questão que se propunha era como construir algo igual no Brasil, aproveitando a larga experiência de lutas sociais que a esquerda nacional tinha, e a fartura de modelos contemporâneos de contestação praticados em todo planeta. Como somar forças com os trabalhadores, se o meio sindical se encontrava engessado pela política sindical cerceadora dos militares?

A alternativa se encontrava junto às oposições sindicais, e o local onde estas foram mais bem sucedidas foi Osasco. A greve de julho representou o sonho de um movimento insurrecional que se espalharia para todo o país, reunindo estudantes e operários, espraiandose em direção a todas as categorias profissionais, culminando com a paralisação total da produção no país. O passo seguinte seria a mudança de regime. Muitos falavam em socialismo.

Embora tivesse a percepção de que a luta dos estudantes não podia mobilizar a sociedade como um todo, e que os focos de oposição sindical eram bastante reduzidos, o governo militar optou por sufocar toda e qualquer fagulha de rebelião ${ }^{235}$. Com relação ao foco

235 Jarbas Passarinho, Ministro do Trabalho do governo Costa e Silva, comenta em seu libro de memórias, acerca da Greve de Osasco, tecendo comparações com o Maio francês: "De fato, o grande objetivo dos agitadores era associar os trabalhadores aos estudantes e repetir o que se passara na França. Ao enfrentar a greve política de Osasco, declarei a imprensa que "o Tietê não é o Sena", repercutindo uma frase do 
operário, a Greve da Osasco foi a última de um breve ciclo que se iniciara em Contagem, no mês de abriu. A partir de julho, não se permitiu mais mobilizações operárias a margem do sindicalismo oficial, refém das regras do sistema. Houve algumas tentativas, como veremos na próxima seção, rapidamente contidas pela repressão. Ao término de 1968, todos os canais legais de oposição ao regime se encontravam bloqueados.

Com relação ao GO, seu modelo de organização, que fugia ao tradicional sistema cupulista, tanto no meio sindical, quanto no estudantil, chamou a atenção dos grupos de esquerda de São Paulo. Sua capacidade de articulação, tanto dentro do ME, quanto do MO, representava algo de novo em termos de movimentos sociais no Brasil. Após conquistar a hegemonia política sobre os principais aparelhos políticos de sua cidade, os militantes do GO concluíram que poderiam dar sua contribuição para o processo revolucionário brasileiro. $\mathrm{O}$ tentaram por meio da união operário-estudantil, e foram mal sucedidos. O passo seguinte, dentro desse mesmo desiderato, foi a tentativa pela via das armas. Mas antes de investigarmos tal trajetória, é necessário entender como o GO se tornou hegemônico entre os operários de seu município.

presidente, que, enquanto no cargo, jamais admitira ver o Rio transformado em Paris. Longe de uma paranóia nossa, sabíamos que ali estava a chave de sustentação do próprio Governo, quiçá do regime. PASSARINHO, Jarbas. Um híbrido fértil. Rio de Janeiro: Editora Expressão e Cultura, 1997. p. 287-288 


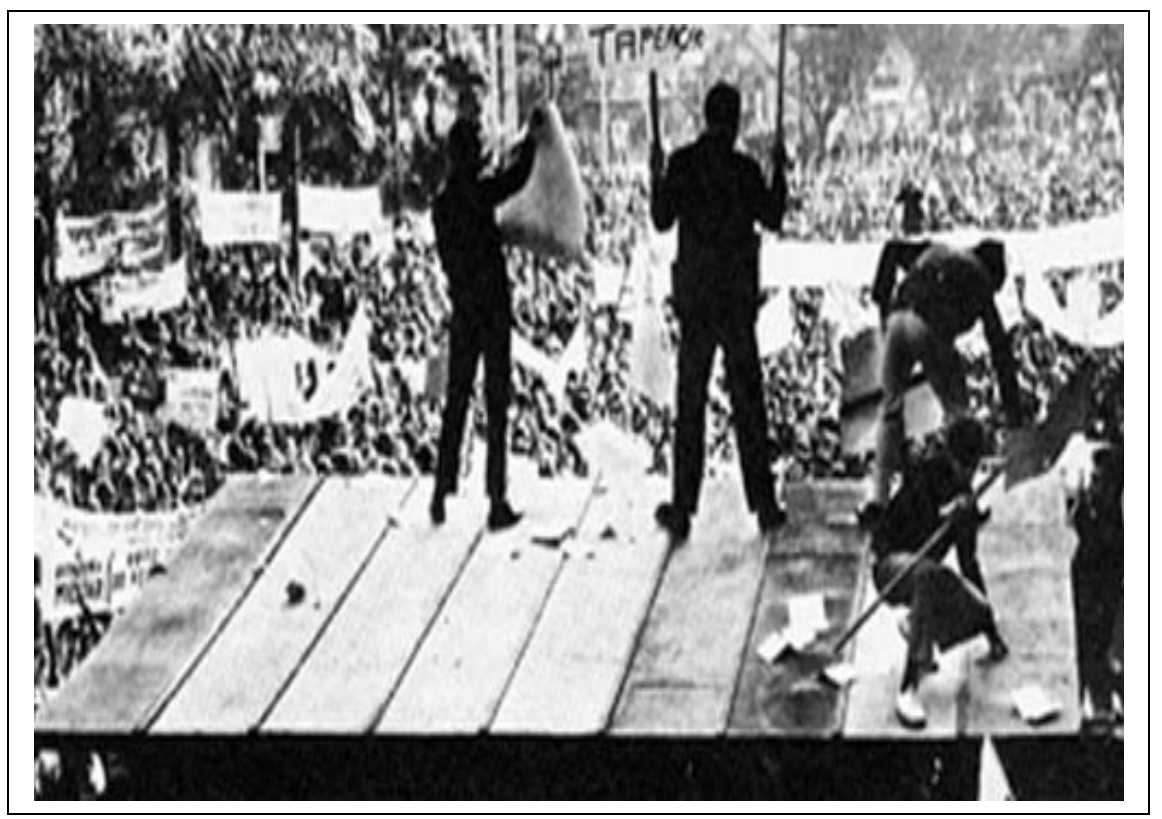

160

Ocupação do palanque na Praça da Sé, $1^{\circ}$ de Maio de 1968. Representando Osasco discursaram Manuel Dias do Nascimento (Neto), e José Campos Barreto (Zequinha). O palanque foi tomado após a expulsão do governador paulista Abreu Sodré, que foi alvejado por uma pedra. Após os discursos, o palanque foi incendiado. Fonte: http://www.zequinhabarreto.org.br/ 


\section{Movimento Operário}


"Toda greve importante contém o germe da luta de classe levada às últimas consequências: põe em discussão o poder do capitalista na sociedade e no Estado”.

\author{
Ernest Mandel ${ }^{236}$
}

\title{
3.1 0 Sindicato dos Metalúrgicos de Osasco
}

No presente capítulo discutiremos a trajetória do GO sob a ótica do movimento operário, algumas questões já apresentadas na última seção serão retomadas, sempre tendo como referencial o operariado. O primeiro item abordado será a formação do Sindicato dos Metalúrgicos de Osasco e Região. No seguinte analisaremos o surgimento e a evolução das comissões de fábrica em Osasco, com destaque para o aparelho de base da Cobrasma. Também traçaremos um breve histórico sobre o advento das comissões/comitês no panorama político ocidental, na primeira metade do Século XX. No terceiro item deste capítulo discutiremos o processo que desencadeou a vitória da Chapa Verde, de oposição, nas eleições sindicais de 1967, em disputa pela diretoria do SMO. Essa chapa foi formada a partir de uma coalizão entre o GO e a FNT, veremos como foi possível tal articulação, seus desdobramentos e debates internos. No último item, será apreciada a construção da Greve de Osasco de 1968, seus principais atores políticos, o papel do GO no desenrolar dos fatos, as consequências do movimento, e o posterior destino do MO local.

Antes de discutirmos a formação do SMO, traçaremos um breve panorama da conjuntura sindical e político-econômica dos anos 1950 e início dos 60. Com relação ao SMO, abordaremos o período que vai dos primórdios da entidade em questão, a partir de uma sub-sede, subordinada a matriz paulistana, até sua separação da mesma, logo após a emancipação do município, para se estruturar enquanto sindicato autônomo.

Diversos estudos ${ }^{237}$ já foram publicados sobre a estrutura e a legislação sindical

236 MANDEL, Ernest. Controle Operário, Conselhos Operários e Autogestão. São Paulo: Centro Pastoral Vergueiro, 1987.

237 Para um melhor entendimento da evolução das leis trabalhistas e da legislação sindical no Brasil, consultar: SOUZA MARTINS, Heloísa Helena. O Estado e a Burocratização no Brasil. São Paulo: Editora Hucitec. 1979; BOITO Jr. Armando. Sindicalismo de Estado no Brasil. Campinas-SP: Editora da Unicamp \& Editora Hucitec, 1991; ANTUNES, Ricardo. O que é sindicalismo. São Paulo: Abril Cultural \& Brasilense, 1985; CARONE, Edgard. Movimento operário no Brasil (1945-1964). 2a Ed. São Paulo: Editora Difel, 1981, 2v; CASTRO, Sandra. "Apogeu e Crise do Populismo - (1945-1964)". In: Movimento Operário Brasileiro. Belo Horizonte-MG: Editora Vega, 1980. 
brasileira ao longo do século XX, o recorte que nos toca agora diz respeito ao período que ficou conhecido como "República populista", fase que se estendeu de 1945 até 1964. Esse ciclo foi regido pela Carta Magna de 1946, norteada por princípios democráticos, embora tais princípios tenham se mostrado frágeis durante todo o período. No que respeita as relações entre Estado e classes trabalhadoras, foi mantida a legislação sistematizada pela Consolidação das Leis do Trabalho, a conhecida CLT. A CLT data de 1943, e foi promulgada por Getúlio Vargas, ainda durante o Estado Novo, consolidando uma série de decretos trabalhistas que se encontravam dispersos, aplicados somente a algumas categorias profissionais. Mas origem da política de Vargas para os sindicatos precede a esse período, seu nascimento remonta ao ano de 1931, quando foi promulgado o Decreto 19.770, estipulando a nova "Lei de Sindicalização".

O ambiente de pluralidade e liberdade de associação, presente durante a Primeira República, foi extinto pelo novo Decreto. A nova lei definia os sindicatos como "órgãos de colaboração e cooperação com o Estado". As organizações laborais foram vistas, a partir de então, como órgãos de conciliação entre o capital e o trabalho, voltados a questões burocráticas e assistenciais. $\mathrm{O}$ controle financeiro das entidades passou a ser rigorosamente fiscalizado pelo Ministério do Trabalho, e se tornou expressamente proibida a utilização de verbas para fundo de greve ${ }^{238}$. A inspiração para a nova legislação foi a Carta Del Lavoro, criada na Itália de Mussolini, como é bem sabido. Em linhas gerais, essa filosofia norteou a política sindical do período Vargas em diante, com algumas alterações pontuais.

Outros pontos da legislação que vale a pena serem destacados dizem respeito à obrigatoriedade do sindicato único por categoria, e o imposto sindical, principal ferramenta de controle por parte do Ministério do Trabalho. Com relação ao segundo ponto, a "sobrevivência do sindicato não depende da sua representatividade e número de associados, pois, tenha ele dez sócios ou mil, o dinheiro vem de qualquer jeito - e descontado em folha de pagamento de todos os trabalhadores, sejam eles sindicalizados ou não" ${ }^{239}$. Também era vedada a formação de centrais sindicais, mantendo-se uma estrutura vertical e corporativa. Para entendermos melhor o funcionamento desse tipo de estrutura, na fase que nos toca, observemos o raciocínio de José Ibrahim:

238 ANTUNES, Ricardo. Op Cit. p. 59

239 IBRAHIM. José. O que todo cidadão deve saber sobre comissões de fábrica. São Paulo: Editora Global, 1986. p. 40 
A diretoria de um sindicato é composta por, no máximo, 24 diretores. Pela legislação só eles podem representar a categoria profissional. Na prática, o que acontece é que numa base territorial onde existam, por exemplo, 500 fábricas, tem-se apenas 24 pessoas em condições legais de representatividade. Deve-se levar em conta também que o aparelho sindical é uma maquina pesada, com inúmeros departamentos assistenciais, e que, portanto, ocupa boa parte do tempo dos dirigentes na burocracia. São "sindicatos de diretoria", onde um punhado de homens concentra o monopólio de representatividade da categoria. A legislação oferece todas as condições para a manutenção da triste figura do pelego ${ }^{240}$.

Tal modelo de associação privilegiava articulações de cúpula, e não primava pela mobilização da classe trabalhadora. A figura do "pelego", citada por Ibrahim, é o representante ideal desse tipo de estrutura, mais voltada a conciliação entre o capital e o trabalho do que a organização laboral.

Não obstante a essa legislação limitadora, o MO foi capaz de levar a cabo grandes mobilizações no primeiro biênio pós 1945 . Até 1947 foram vistas intensas movimentações por parte da classe trabalhadora, organizada, nessa conjuntura, pelo PCB. Uma vaga de greves se alastrou pelo país, e teve o início um processo de desenvolvimento de organismos intersindicais com caráter horizontal, como o MUT (Movimento Unificado dos Trabalhadores), em 1945. No ano seguinte se organizou uma Confederação Geral dos Trabalhadores $^{241}$. Ambas as iniciativas foram coibidas durante o governo Dutra, o mesmo proibiu a realização de greves em território nacional.

O refluxo aberto durante o severo período Dutra só foi superado no segundo governo Vargas, a partir da década de cinquenta. Apesar do Decreto 9.070, que proibia a realização de greves no Brasil, nos anos de 1950 (ainda na gestão Dutra), 1951 e 1952 foram observadas paralisações no país. Mas essas greves foram largamente superadas pelo movimento paredista de 1953, paralisação que ficou conhecida como a "greve dos 300 mil". Este movimento eclode num período em que a economia nacional começava apresentar sinais de crise, após um breve ciclo de crescimento impulsionado pelo acúmulo de reservas cambiais no imediato pós II Guerra Mundial. Essa crise trouxe consigo aumento da inflação, desequilíbrio na balança de pagamentos e retração da produção industrial, que desde 1947 vinha apresentando

240 Idem, ibidem.

241 Para mais informações sobre o MUT e a CGT de 1946, consultar: CASTRO, Sandra. "Apogeu e Crise do Populismo - (1945-1964)". Op Cit; e MARANHÃO, Ricardo. Sindicatos e Democratização (Brasil, 1945/1950). São Paulo: Editora Brasiliense, 1979. 
índices positivos.

A “greve dos 300 mil” teve início em março de 1953, e se estendeu até o mês seguinte. A primeira categoria a cruzar os braços foram os têxteis, sendo seguidos pelos metalúrgicos, gráficos, marceneiros e vidreiros. Exigia-se $60 \%$ de aumento, a um patronato que estava disposto a conceder apenas $20 \%$. Com o passar dos dias, as exigências se estenderam a imediata liberdade para os trabalhadores presos - uma vez que os grevistas foram duramente reprimidos -, pagamentos dos dias parados, e garantias contra represálias por parte dos patrões. Ao término da parede, foi concedido um aumento de $32 \%$ aos trabalhadores, sendo que os gráficos conseguiram $60 \%$. Apesar da repressão e do aumento abaixo do exigido pela maioria das categorias profissionais, a greve foi considerada vitoriosa.

Mas esse movimento se tornou célebre não apenas por suas proporções e por seu relativo êxito, data dessa fase o surgimento das organizações paralelas, estruturas que atuavam a margem da legislação oficial, as mesmas que teriam presença marcante nas lutas operárias brasileiras até o ano de 1964. Outro ponto deste acontecimento que merece destaque é a atuação da base operária, mobilizada por meio das "comissões de salário", que se converteram, no desenrolar da parede, em "comissões de greve".

A partir de 1952 os militantes do PCB retomaram suas atividades sindicais, congeladas desde a proscrição do partido em 1947. A tênue liberalização do governo democrático de Vargas, mais a popularidade do movimento "O petróleo é nosso", cujos comunistas foram grandes incentivadores, foram as senhas para o Partidão abandonar sua política de isolamento (expressa no radical Manifesto de agosto de 1950) e retornar as suas atividades no seio das entidades representativas da classe trabalhadora ${ }^{242}$. A medida encontrada pelos pecebistas para driblar a estrutura sindical atrelada ao Estado foi o incentivo a formação de organizações de base entre os operários, articuladas, em princípio, por meio das comissões de salário. Tais organismos foram convertidos em mecanismos de pressão junto a diretorias sindicais "pelegas", e se credita aos mesmos a preparação da "greve dos 300 mil", como supramencionado.

Após o início da paralisação, coube as comissões de greve o papel de núcleo ativo do movimento. Assembleias diárias foram realizadas com o objetivo de coordenar os rumos da

242 "Diante da razia do Governo Dutra, que varreu o movimento sindical em 1947, a direção do PCB instruiu os militantes a abandonarem os sindicatos oficiais e a organizarem centros operários fora da estrutura submetida ao enquadramento do Ministério do Trabalho. A experiência dos centros operários - algumas dezenas em São Paulo - foi estéril. Em princípios de 1952, uma resolução da Comissão Executiva, aprovada em julho pelo Comitê Central, determinou a dissolução dos centros operários e a volta dos comunistas aos sindicatos oficiais". GORENDER, Jacob. Op. Cit. p. 23 
parede. Dessas assembleias surgiu o Comando Geral de Greve, no terceiro dia do movimento, e a partir do CGG foi constituída a Comissão Intersindical de Greve. Através da CIG, foi celebrado o "Pacto de Unidade Intersindical" (PUI), o mesmo que, juntamente aos sindicatos do Rio de Janeiro, formaria alguns anos mais tarde o Pacto de Unidade e Ação (PUA), um dos pilares da estrutura dual do movimento sindical brasileiro. Nesse processo se encontra as origens do Comando Geral dos Trabalhadores (CGT), criado durante o governo João Goulart"243. Tais siglas se apresentaram como a materialização das estruturas paralelas, ou duais, foram seus órgãos de representação e veículos de atuação política. Essas estruturas se desenvolveram a margem do sindicalismo oficial, possuíam caráter suprasindical e cupulista, e não se chocavam efetivamente com o aparato legal, embora apresentassem viés mais combativo. Por trás da construção desses organismos estava o PCB.

O incentivo as mobilizações pela base foi deixado de lado pelos comunistas após a retomada da influência de seu partido nos meios políticos nacionais, em meados dos anos 1950, retornando a legenda a sua velha estrutura hierárquica. Mesmo ilegal, o PCB foi uma das maiores forças em atuação no cenário político brasileiro até abril de 1964.

O que vale salientar dessa fase é o modelo de desenvolvimento proposto, conhecido por nacional-desenvolvimentismo. O que se propunha era um padrão de industrialização em bases nacionais, pautado por medidas de planejamento estatal em escala macroeconômica, amparado por projetos consubstanciados em iniciativas como o Plano Láfer (Plano Nacional de Reaparelhamento Econômico), de 1951, ou o Grupo Misto BNDE-CEPAL, iniciativa "que visava completar os trabalhos da Comissão Mista Brasil-EUA, que encerrara suas atividades em 1953, por pressão do governo estadunidense, descontente com os rumos nacionalistas tomados pelo governo brasileiro"244. Data dessa época a criação do BNDE (Banco Nacional de Desenvolvimento Econômico), a criação da Petrobras; o início das atividades da Companhia Siderúrgica Nacional (CSN), a tentativa de construção de uma Companhia Nacional de Álcalis, e a apresentação do projeto de constituição da Eletrobrás, concluído cerca de dez anos depois.

243 MOISÉS, José Álvaro. Greve de Massa e Greve Politica (estudo da Greve dos 300 Mil em São Paulo). São Paulo: Editora Polis, 1978. p. 148

244 Em 1953 o democrata Harry Truman foi substituído pelo republicano Dwgith D. Einsehower. A plataforma do novo presidente dos EUA preconizava investimentos para a América Latina através da participação direta de capitais privados, privilegiando ações via mercado e não mais empréstimos e investimentos em nível estatal. MANTEGA, Guido. A economia política brasileira. $8^{\mathrm{a}}$ Ed. Rio de Janeiro: Editora Vozes, 1995. p. $130-131$ 
Na primeira metade dos anos cinquenta, que corresponde quase inteiramente à presidência Vargas, o padrão de acumulação intentado para a economia brasileira fundava-se numa previa expansão do setor produtor de bens de produção, que poderia - atente-se para o condicional - fundar as bases para uma expansão industrial mais equilibrada entre os três departamentos básicos: o produtor de bens de produção, o produtor de bens de consumo não duráveis, e o produtor de bens de consumo duráveis" ${ }^{\prime 245}$

O modelo descrito por Francisco de Oliveira não sobreviveu a seu principal promotor, após 24 de agosto de 1954, grupos contrários ao padrão de acumulação em vigor se apossaram do poder, e a balança pendeu para os setores vinculados ao capital externo. Eugenio Gudin, diretor da SUMOC (Superintendência da Moeda do Crédito) nomeado pelo então presidente Café Filho, instituiu no ano de 1955 a conhecida Instrução 113, mecanismo legal que permitia a entrada de máquinas e equipamentos no país sem cobertura cambial (sem depósito de dólares para a aquisição no Banco do Brasil). O objetivo da Instrução era facilitar a entrada de maquinário e de equipamentos no país, em investimentos efetuados diretamente entre as empresas importadoras (majoritariamente multinacionais) e as economias centrais fornecedoras. A meta era acelerar o processo de industrialização brasileiro.

Há uma mudança qualitativa em relação ao antigo modelo varguista, o nacionaldesenvolvimentismo foi substituído por um padrão de desenvolvimento associado ao grande capital internacional. No lustro JK, as diretrizes da Instrução 113 da SUMOC não só foram mantidas, como ampliadas. Data dessa época o grande salto industrial brasileiro, sob a bandeira dos "50 anos em 5". A grande vitrine da nova gestão foi o Plano de Metas, cronograma de investimentos elaborado a partir dos dados reunidos pelo Grupo Misto BNDECEPAL.

Pelo raciocínio de Francisco de Oliveira, exposto acima, vimos que o modelo de industrialização posto em prática na segunda metade da década de cinquenta privilegiava o Departamento III da economia nacional, ou seja, aquele voltado a produção de bens de consumo duráveis. O carro chefe desse padrão de industrialização foi a indústria automobilística, mas outros setores também se beneficiaram da vaga de crescimento, como o segmento dos eletrodomésticos. Sabemos que esses setores da produção estão direcionados as classes altas. O Departamento II, voltado a produção de bens de consumo não duráveis, ou bens salário, foi delegado a segundo plano.

245 A definição de Departamentos Industriais é retirada de Marx. OLIVEIRA, Francisco. "Padrões de acumulação, oligopólios e Estado no Brasil (1950-1976)". In: A Economia da Dependência Imperfeita. $2^{\text {a }}$ Ed. Rio de Janeiro: Edições Graal, 1977. p. 77 
O modelo fabril implementado durante o ciclo em análise era concentrador de mão de obra, e sua produção se dirigia a uma pequena parcela da população, compreendida entre as classes médias e altas. As empresas postas em operação empregavam poucos trabalhadores, pagavam baixos salários, e não eram capazes de ampliar seu mercado consumidor. ${ }^{246}$ "Daí a tendência para capacidade ociosa e a vigência de preços elevados (para compensar a capacidade ociosa), reforçando a concentração de renda (...)"247. O efeito perverso desse modelo de crescimento foi a inflação, que penalizava especialmente as classes mais baixas.

Após o IV Congresso do PCB, realizado em novembro de 1954, foi adotado pelos comunistas o programa nacional-democrático, preconizando uma "união de forças" entre "todos os patriotas e democratas brasileiros" contra o "inimigo comum". O inimigo a ser combatido estava personificado nos "latifúndios feudais" e nos "agentes do imperialismo" incrustados em território nacional. O novo programa defendia uma aproximação com o PTB e convidava os trabalhadores getulistas "para uma ação comum". A nova diretriz abria a possibilidade para uma aliança tática com a "burguesia nacional" e demais setores progressistas comprometidos com o desenvolvimento do país. E esse desenvolvimento estava diretamente relacionado - na visão dos comunistas - ao processo de industrialização em voga no período.

Em nome do crescimento nacional, os pecebistas se dispuseram a incorporar o modelo democrático burguês, tendo em vista o desenvolvimento das forças produtivas no país. Essa visão era etapista, tratava-se de fortalecer o país economicamente, aperfeiçoar a democracia e elevar de forma gradativa o nível de vida dos trabalhadores. A perspectiva socialista estava presente, mas a longo prazo, e a via revolucionária insurrecional, neste novo paradigma, era coisa do passado. Tal visão foi adotada pelas cúpulas sindicais (comunistas e trabalhistas), que se comprometeram a manter seus representados sob controle.

A coalizão desenvolvimentista atingiu seus contornos mais estáveis durante o governo

246 Durante "os anos 1955-61: o produto real da indústria de material de transporte (incluindo a automobilística) cresceu 549,9\%, o da indústria de material elétrico e de comunicações (incluindo eletrodomésticos e eletrônicos domésticos) cresceu 367,7\%; enquanto isso a indústria de alimentos teve um crescimento de apenas $46,4 \%$ e o ramo têxtil apenas $28,9 \%$ ", ambas indústrias de bens salário. ANTUNES, Ricardo. $A$ Rebeldia do Trabalho (O Confronto Operário no ABC Paulista: As greves de 1978/80). $2^{\mathrm{a}}$ Ed. Campinas-SP: Editora da Unicamp, 1992. p. 105-106.

247 Idem, p. 84-85 
JK. Na vice-presidência se encontrava o grande interlocutor entre os aparelhos sindicais e o executivo. Na parceria PSD-PTB, coube ao segundo o controle da "máquina do Estado na área trabalhista e previdenciária, como as DRT's (Diretorias Regionais do Trabalho), e postos chave na Justiça do Trabalho"248. Os petebistas também detinham a guarda dos fundos arrecadados mediante imposto sindical, um poderoso instrumento de cooptação junto às lideranças sindicais. Esse era o quadro da política trabalhista do governo JK-Jango: um panorama de crescimento econômico, sob a bandeira do desenvolvimentismo, amparado por uma frágil conciliação de classes, cujos menos beneficiados eram sem dúvida os trabalhadores. A referendar esse estado de coisas, o modelo político populista. Contudo, tal modelo começou apresentar sinais de esgotamento já em meados do governo Kubistchek.

De acordo com Francisco Weffort, a concessão de direitos aos trabalhadores pelo populismo lhes conferia cidadania, e esta os levou a cobrar do Estado a efetivação de seus direitos, acirrando os conflitos de classes. A "manipulação das massas entrou em crise (...) exatamente quando a economia urbano-industrial começava a esgotar sua capacidade de absorção de novos migrantes e quando se restringiram as margens do redistributivismo econômico. É nessa fase que a temática das reformas de estrutura começa a se fazer popular"249. O compromisso de classes tacitamente estabelecido pelo populismo impunha limites aos avanços sociais, e a capacidade do Estado em atender as demandas populares estava limitada por esse mesmo compromisso.

O crescimento das mobilizações populares, nessa conjuntura, foi uma reação as políticas excludentes praticadas ao longo de toda a década de cinquenta, e intensificadas a partir de 1954. Ao término da gestão JK, a inflação se encontrava na casa dos $80 \%$, corroendo cada vez mais o poder de compra dos trabalhadores. A política conciliatória articulada entre as cúpulas sindicais e o Ministério do Trabalho, nessa etapa, passou a sofrer forte oposição por parte das bases. Desde 1956 foi observado o alastramento de greves no país, mas a partir de 1957 a resistência da classe trabalhadora atingiu novos patamares. Nesse ano eclodiu em São Paulo um movimento grevista de largas proporções, paralisando cerca de 500 mil trabalhadores dos setores têxtil, metalúrgico, gráfico, dentre outros. Exigia-se um aumento de $45 \%$, ao término da parede se obteve $25 \%$. A organização da greve coube ao PUI, estrutura paralela que adquiriu maior relevância a partir de então. Nos anos seguintes, novas greves

248 BENEVIDES, Maria Victória. O PTB e o Trabalhismo. Partido e sindicato em São Paulo (1945-1954). São Paulo: Editora Brasiliense, 1989. p. 104

249 WEFFORT, Francisco. Op. Cit. p. 75 
foram desencadeadas em todo território nacional, acirrando os ânimos e agudizando a luta de classes no país.

Data também dessa época o advento das correntes sindicais renovadoras, grupos contrários a política sindical atrelada ao populismo, encabeçada pela coalizão PTB-PCB. O novo movimento reunia católicos de esquerda, comunistas dissidentes, lideranças sindicais independentes, socialistas, anti-comunistas. Tais militantes tinham como principal bandeira de luta o combate ao imposto sindical e a organização dos trabalhadores pela base, a margem da estrutura oficial. Nos meios católicos, ganharia destaque a FNT, atuante a partir de 1962, com marcante presença em Osasco; e o Movimento Católico de Orientação Sindical, atuante no Rio de Janeiro e no Rio Grande do Sul ${ }^{250}$.

Embora o panorama fosse de acirramento das lutas populares, o PCB, em sua celebre “declaração de março", apresentada no ano de 1958, adotou a política de "frente única que luta por um governo nacionalista e democrático". Com a nova postura, buscava-se uma coalizão junto a burguesia "interessada no desenvolvimento independente e progressista da economia nacional; setores de latifundiários que possuem contradições com o imperialismo norte-americano (...); grupos da burguesia não ligados à monopólios dos Estados Unidos e que são prejudicados por estes"251. O novo paradigma ia mais longe com seus propósitos aliancistas, superando as diretrizes do IV Congresso de 1954, visto acima. Numa conjuntura em que o sistema populista caminhava rumo ao colapso, o PCB intensificou sua estratégia de conciliação de classes.

O novo padrão de crescimento, proposto pela tecnocracia recém instalada no país, herdou do ciclo Vargas apenas o conceito de desenvolvimento, o caráter nacional foi posto der lado. Em 1956 a economia industrial superou a agrícola no Brasil, abrindo um caminho sem volta. Frente a uma aristocracia rural enfraquecida pela queda do valor de seus produtos exportáveis no mercado internacional (com destaque para a queda do valor do café, constante durante toda a década), o empresário foi finalmente aceito como membro da classe dirigente. Sua nova posição, agora central, dispensava-lhe do embate contra os setores vinculados ao capital agrícola, visto que a industrialização do país já era uma realidade. Destarte, não havia mais a necessidade em se utilizar a bandeira do nacionalismo para arregimentar o apoio das camadas sociais urbanas - entenda-se os trabalhadores e os sindicatos - para fazer frente as oligarquias do campo. A burguesia industrial não precisava mais instrumentalizar o 
nacionalismo, pois já não possuia oponentes a altura. Assim sendo, o nacionalismo deixou de ser uma ideologia industrial, aos olhos das classes produtoras, tornando-se uma "ideologia de esquerda" $" 252$.

Não obstante ao exposto acima, o PCB seguiu com sua política de frente policlassista, orientando seus quadros sindicais a atenuar os conflitos trabalhistas dentro de seus órgãos de atuação. Mas a insatisfação das bases era forte demais para ser administrada a contento pelas cúpulas da organização laboral. O meio de canalizar a revolta popular, sem romper com o compromisso populista, foi o fortalecimento das estruturas paralelas. Em 1960, uma greve vitoriosa, que reivindicava a paridade nos aumentos entre civis e militares, deu origem ao PUA (Pacto de Unidade e Ação). Os organizadores dessa parede foram os ferroviários, marítimos, e portuários, sendo esta paralisação geral no Rio de Janeiro e em Santos, e parcial no restante do país. Após esse movimento vitorioso, correntes mais combativas foram ganhando destaque entre os trabalhadores. O PUA foi a organização a impulsionar a efetivação do IV Encontro Sindical Nacional, realizado em São Paulo, nos dias 17, 18, e 19 de agosto de 1962. Nesse encontro foi criado o CGT (Comando Geral dos Trabalhadores), reunindo 574 entidades sindicais e 2.566 delegados credenciados em todos os estados, representando os mais variados setores.

O CGT congregava as três maiores confederações sindicais do país, a CNTI (Confederação Nacional dos Trabalhadores da Indústria), a CNTTMFA (Confederação Nacional dos Trabalhadores em Transportes Marítimos, Fluviais e Aéreos); e a CONTEC (Confederação Nacional dos Trabalhadores nas Empresas de Crédito). Dentre as reivindicações retiradas do encontro, estavam: direito de greve, 6 horas de trabalho diárias, reconhecimento dos sindicatos rurais, reforma agrária radical, limitação da remessa de lucro ao exterior, etc ${ }^{253}$. Coube ao CGT a organização do MO nacional em seu período mais combativo, só no ano de 1963, eclodiram 120 greves no país, sobretudo na Guanabara e em São Paulo ${ }^{254}$. Os limites estabelecidos pelo pacto populista estavam sendo ultrapassados, a mobilização dos trabalhadores do campo e dos setores subalternos das forças armadas representaram os principais pontos de ruptura dentro do compromisso de classes em vigor

252 Para se entender melhor esta viragem no que respeita o caráter e a mentalidade das elites nacionais: BRESSER PEREIRA, Luis Carlos. Desenvolvimento e crise no Brasil: 1930-1983. $3^{\mathrm{a}}$ Ed. São Paulo: Editora Brasiliense, 1985. p. 96-120; CARDOSO, Fernando Henrique. Empresário Industrial e Desenvolvimento Econômico no Brasil. São Paulo: Editora Difel, 1972; IANNI, Otávio. O Colapso do Populismo no Brasil. $4^{\mathrm{a}}$ Ed.. Rio de Janeiro: Civilização Brasileira, 1978; e SAES, Décio. Op. Cit.

253 COSTA, Sérgio Amad. CGT: e as lutas sindicais brasileiras (1960-64). São Paulo: Editora do Grêmio

Politécnico, 1981. p. 34-66

254 Idem, p. 140 
desde a década anterior. O antagonismo capital-trabalho, contido desde os tempos de Vargas, fugira ao controle das lideranças mais moderadas.

Contudo, os núcleos centrais da organização laboral seguiram com seu viés cupulista, em movimentações que dependiam em demasia das lideranças sindicais. Embora as bases tenham pressionado seus representantes em direção ao enfrentamento, a estratégia de frente dos comunistas continuou em voga. Seguia-se acreditando na dicotomia nação x anti-nação, e a natureza da luta seguia desgarrada de seu conteúdo de classe. O Partidão manteve intactas suas diretrizes expressas na carta de 1958. Os sindicatos controlados pelo bloco PTB-PCB acreditavam contar com o apoio de uma certa burguesia nacional, alinhada a seu projeto, e disposta a garantir a governabilidade do presidente João Goulart. Esse projeto de nação, pela ótica pecebista-trabalhista, estava salvaguardado pelos grupos militares da esquerda nacionalista pró Jango. Caso a direita golpista se levantasse, os trabalhadores estariam de prontidão, prontos a seguir a orientação de suas lideranças e se mobilizar em defesa de seu governo. Os “Grupos de 11" de Leonel Brizola representariam a objetivação desse esquema.

E as bases? Não havia a orientação para se organizar os trabalhadores para a defesa de seus interesses desde a base, esta iniciativa era apanágio dos sindicatos renovadores, com pouca expressão no período. Após o assalto ao poder, em $1^{\circ}$ de abril de 1964, bastou aos golpistas encarcerar as lideranças sindicais, deixando a classe trabalhadora organizada acéfala. A rápida resignação do presidente deposto apenas reforçou a desmobilização daqueles que se encontravam dispostos a reagir ao golpe. A estratégia pecebista caiu por terra, a burguesia nacional em peso referendou o novo poder, trazendo a luz a inconsistência das teses do Partidão. O operariado, sem liderança, sem reação, foi desarticulado por completo. Segundo Octávio Ianni, a esquerda do período "não se deu conta de que "massa" e "classe" não são a mesma coisa, não percebeu que se tratam de categorias histórica e estruturalmente diversas" $" 255$.

Ao organizar a classe trabalhadora no sentido de "massa", o complexo PTB-PCB desviou a mesma de seus interesses específicos e vinculou suas demandas a um projeto policlassista fadado ao fracasso. Não dando subsídios aos trabalhadores para que estes tivessem condições de se auto-organizar, pela base, os comunistas centralizaram a coordenação das lutas sociais no país em torno de lideranças facilmente neutralizáveis. Uma vez desprovidos de seus guias, os operários não tiveram condições de articular uma 
resistência imediata ao golpe, e tiveram sérias dificuldades para se reorganizar após o estabelecimento da ditadura.

Em abril de 1964 o modelo de organização sindical atrelado ao sistema populista foi suprimido no Brasil. Junto ao populismo, naufragou também seu padrão de organização laboral. Em que pese seus desacertos teóricos e estratégicos, tal modelo foi destruído pela força das armas, através de um Golpe de Estado classista, promovido por uma elite civilmilitar de natureza autoritária, não mais disposta ao diálogo. Os sindicatos pós ciclo militar retornaram a um esquema de controle e intervenção estatal só vistos nos tempos do Estado Novo, voltaram a velha forma de associações recreativas e assistenciais. Para driblar o peso da repressão, os trabalhadores tiveram que desenvolver novas formas atuação.

$* * * * *$

Na primeira seção vimos que Osasco já abrigava rudimentos de organização operária nas primeiras décadas do Século XX, foi palco das mobilizações pecebistas entre 1945 e 1947, e em princípios da década de cinquenta movimentos grevistas foram observados nas fábricas da região. Vimos também que operários da localidade aderiram a "greve dos 300 mil", em 1953, e que violentos confrontos envolvendo trabalhadores e forças policiais ocorreram no então subúrbio paulistano, em virtude dessa paralisação. A "greve dos 300 mil" inseriu Osasco nas lutas operárias dos anos 1950, no bairro havia algum trabalho por parte do PCB, mas o interesse pela região era reduzido se comparado a outros distritos industriais de São Paulo. O interesse pelo subúrbio aumentará concomitantemente a expansão de suas indústrias e seu crescimento populacional, como visto no primeiro capítulo deste trabalho.

A partir do ciclo JK e a vaga de desenvolvimento impulsionada pelo Plano de Metas, o parque industrial osaquense foi contemplado por um novo surto de expansão. Nessa fase, os setores fabris beneficiados foram os de "material de transporte e eletromecânico" "256. Datam dessa época a construção da Asea Brown Boveri (1957), Braseixos Rockwell (1959), FordMotor do Brasil (1959) e White Martins (1960) (ver página...). No mesmo período, empresas já estabelecidas, como a Cobrasma, ampliaram seu contingente de empregados.

Vinculado ao meio metalúrgico (principal ramo da região), havia uma sub-sede do

256 RIZEK, Cibele Saliba. Op. Cit. p.41 
sindicato paulistano da categoria, localizado na Rua Primitiva Vianco, sendo a mesma descrita como "muito fraca, pouco frequentada, funcionando com estrutura provisória" 257 . O delegado designado pela matriz paulistana para dirigir a política sindical metalúrgica em âmbito distrital foi Conrado Del Papa, que seguia a risca as diretrizes de sua diretoria, que dava pouca atenção as demandas locais. Segundo Orlando Miranda, tal postura seria uma das explicações para a pouca participação dos operários no processo emancipatório osasquense $\mathrm{e}^{258}$.

As coisas começaram mudar para o sindicalismo osasquense em 1957, vimos acima que nesse ano eclodiu em São Paulo um movimento paredista que levou cerca de 500 mil trabalhadores a cruzar os braços. Essa paralisação se estendeu a Osasco, tendo a Cobrasma como palco de luta. O governo Janio Quadros, declarando a greve ilegal, mobilizou um grande contingente de policiais para reprimi-la. No caso específico da Cobrasma, além do aumento salarial (25\%), exigia-se melhoria nas péssimas condições de serviço na empresa que possuía um alto índice de acidentes - e adicional de insalubridade. O movimento foi violentamente reprimido pela "cavalaria da Força Pública do Estado, que aliás acampou dentro da fábrica". Onze anos depois a Cobrasma seria novamente ocupada por forças policiais, num contexto de ditadura aberta.

Apesar do aumento concedido a toda categoria, em Osasco houve inúmeras demissões e perseguição a lideranças grevistas. A reação da direção da empresa demonstrou a fragilidade do MO local, e levou os grupos organizados, atuantes tanto na Cobrasma, quanto nas demais fábricas do subdistrito, a procurar formas de atuação política mais eficientes, de modo a proteger os trabalhadores, ao nível das lideranças e das bases ${ }^{259}$. A partir dessa conjuntura começa se articular, de fato, o operariado osasquense. Nesse impulso, duas correntes se estabeleceram e pleitearam para si o papel de comandar o processo de organização da classe trabalhadora local.

A primeira esteve representada por uma articulação entre PCB e PSB, ambos alinhados ao sindicalismo oficial. A frente dos comunistas atuantes no meio sindical de Osasco estava Lino Ferreira dos Santos, norteado pelas teses políticas do Partidão, professando a linha de atuação cupulista corrente em sua legenda, vinculado ao esquema populista, disposto a organizar os metalúrgicos locais de forma não muito diferente da que era praticada em São

257 Depoimento de Lino Ferreira dos Santos a Orlando Miranda, membro da primeira diretoria do Sindicato dos Metalúrgicos de Osasco e Região. MIRANDA, Orlando. "Sindicato e Classe Operária: História do Sindicato dos Metalúrgicos de Osasco". Tese de Livre Docência. São Paulo: FFLCH-USP, 1987. p. 41

258 MIRANDA, Orlando. Op. Cit. p. 53

259 MIRANDA, Orlando. Op. Cit. p. 43-45. 
Paulo. Representando o PSB, Conrado Del Papa, o responsável pela sub-sede distrital metalúrgica desde inícios da década. Papa era ligado a liderança de Remo Forli, presidente do Sindicato dos Metalúrgicos de São Paulo entre 1953 e 1958, também socialista ${ }^{260}$.

A outra vertente em disputa pelo MO de Osasco pertencia ao espectro daquilo que foi chamado por alguns pesquisadores de correntes sindicais renovadoras, como supracitado. No município em questão, os renovadores buscavam desenvolver ações paralelas ao sistema sindical em vigor, a seu ver cupulista, centralista, e descolado das bases. Embora professasse modos de organização para além dos sindicatos, tal tendência abria margem para atuação dentro desses aparelhos, como forma de combater os comunistas e divulgar suas concepções. E tais concepções iam em direção a um modelo de organização laboral centrado nas bases, consubstanciado através da formação de comissões de fábrica, compostas por operários eleitos por seção. O principal veículo de propagação das propostas das correntes católicas operárias em Osasco foi a FNT, agremiação formada a partir de militantes egressos de organizações como a JOC e a ACO. Tais siglas, antes mesmo de sua constituição enquanto organismos para-sindicais, já realizavam palestras junto aos trabalhadores, reunidos nos bairros da região, sempre privilegiando atuações centradas no trabalho de base.

A FNT surgiu em 1962, concebida pelo advogado trabalhista Mario Carvalho de Jesus, ex-militante da JUC atuante no meio sindical. O fundador da Frente passou uma temporada na França, trabalhando junto a ativistas ligados ao padre Lebret. De volta ao Brasil, dedicou-se a militância católica operária. Foi o grande organizador da greve dos funcionários da empresa Cia de Cimento Portland Perus, localizada na periferia de São Paulo. Na conjuntura dessa paralisação foi desenvolvido o embrião da futura FNT. A linha teórica dos frentistas se baseava nos preceitos da doutrina social cristã, tendo como documentos básicos as encíclicas

260 A parceria entre PCB e PSB, em Osasco, atingiu contornos não vistos em outras praças políticas do país. A peculiaridade do panorama político local permitia uma aproximação que se mostrava problemática em outros centros. Ao final da década de cinquenta, quando a corrente de Carlos Lacerda se tornou hegemônica na UDN, rompeu-se a aliança entre socialistas e udenistas (desde a redemocratização essas legendas atuavam em conjunto no Legislativo federal, em oposição ao bloco populista). A partir dos anos 1960, o PSB reforçou suas origens socialistas e se aproximou dos movimentos sociais brasileiros, com destaque para a Ligas Camponesas. Francisco Julião, grande líder das Ligas, foi eleito deputado federal por essa legenda, representando o estado de Pernambuco, em 1962. Membros do partido foram duramente reprimidos após o golpe de 1964, quando do retorno a democracia, nos anos 1980, o PSB retornou as suas atividades partidárias. Dentre as personalidades que militaram por essa legenda, além de Francisco Julião, cabe destacar Antonio Cândido, Sérgio Buarque de Holanda, Paul Singer, Barbosa Lima Sobrinho, Paulo Emílio Sales Gomes, dentre outros.

Para informações fornecidas por Fúlvio Abramo: MOISÉS, José Álvaro. "Classes populares e protesto urbano". Op. Cit. p. 268; para mais informações sobre a trajetória do PSB entre 1946 e 1965: VIEIRA, Margarida Luiza de Matos. "O Partido Socialista Brasileiro e o marxismo (1947-1965)". In: HISTÓRIA DO MARXISMO NO BRASIL. Partidos e organizações dos anos 1920 aos 1960. (vol. 5). RIDENTI, M. \& REIS FILHO, D. A. (org). (2 ${ }^{\text {a }}$ Edição) Campinas-SP: Editora da UNICAMP, 2007. 
Rerum Novarum e Mater et Magistra, textos centrais para se compreender o pensamento social católico. Outro escrito fundamental para as concepções frentistas eram os Princípios para a Ação, do padre Lebret, prócere do cristianismo de libertação em voga no período ${ }^{261}$.

As duas correntes mencionadas dividiram a tarefa de organizar os trabalhadores em Osasco na virada dos anos 1950 para os 60. Embora concorrentes, souberam atuar em conjunto. Segundo Orlando Miranda, o impulso inicial para a formação do SMO se deu mais por obra do "voluntarismo" das bases locais, que acompanhavam de perto o movimento autonomista, do que pelos grupos políticos partidários. PCB e PSB apenas encamparam as demandas dos operários que iniciaram as movimentações no sentido de uma cisão frente à matriz paulistana. Segundo o mesmo autor, o grupo mais orgânico em atividade no município, no período em análise, era a FNT. Em todo caso, um sindicato representando a categoria dos metalúrgicos em âmbito regional era um aparelho deveras oportuno numa região de importância econômica crescente ${ }^{262}$.

Em junho de 1962, poucos meses após a emancipação, foi inaugurada a nova subsede do Sindicato dos Metalúrgicos de São Paulo, na Rua Erasmo Braga, próximo a estação central do município. O edifício foi batizado com o nome de "O Metalúrgico". Acompanhando o processo de municipalização do aparato político-burocrático da nova cidade, o MO local passou a trabalhar pela criação de entidades representativas locais. A primeira conquista, dentro dessa proposta, relativa ao meio metalúrgico, foi a elevação da subsede local a categoria de Associação, em 1963. Nesse mesmo ano, graças a apelos a Almino Afonso, Ministro do Trabalho do governo João Goulart, foi concedida a Carta Sindical ao município. Com a obtenção da Carta, no mês de julho, foi fundado o Sindicato dos Trabalhadores nas Indústrias Metalúrgicas, Mecânicas e de Material Elétrico de Osasco e Região, representando toda a Zona Oeste de São Paulo. Em setembro foi eleita a primeira diretoria, tendo como presidente Conrado Del Papa (PSB); no posto de vice Roberto de Oliveira (FNT); secretário geral Lino Ferreira dos Santos, e segundo secretário Manuel Dias do Nascimento, ambos quadros do PCB. Como se pode notar, a distribuição política da diretoria buscou contemplar todos os grupos envolvidos na criação do sindicato. Outro ponto que deve ser salientado é o fato da diretoria ser quase toda composta por empregados da Cobrasma.

261 Para um melhor conhecimento sobre a FNT: COUTO, Ari Marcelo Macedo. Greve na Cobrasma: uma luta de resistência. São Paulo: Editora Anna Blume, 2003; MIRANDA, Orlando. Op. Cit.; JESUS, Paulo Sérgio de, Op. Cit.

262 MIRANDA, Orlando. Op. Cit. p. 56-59. 


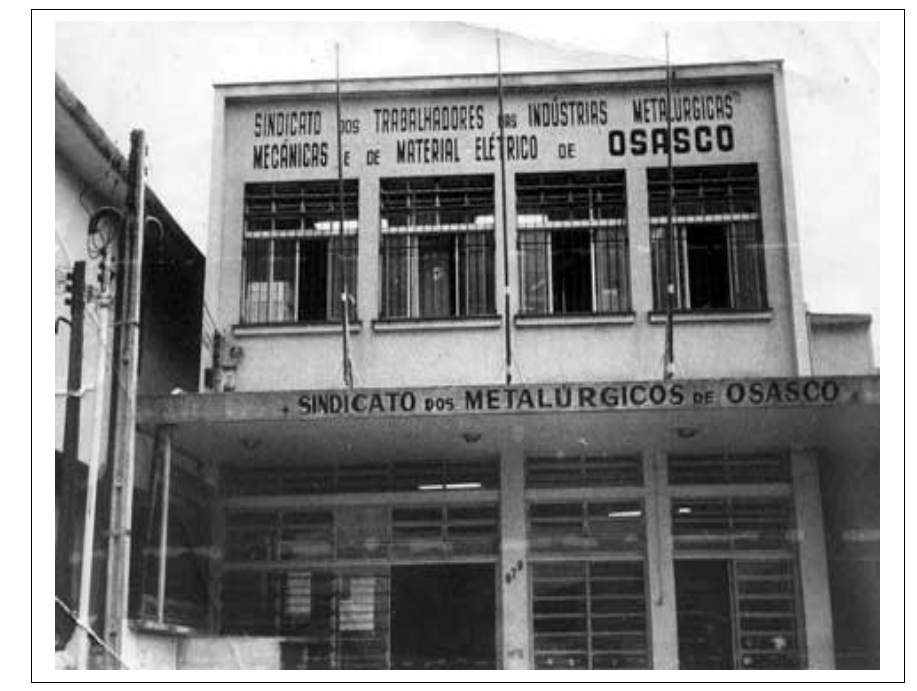

Fachada do SMO, criado em 1963, no impulso da emancipação da cidade de Osasco. Fonte: www.camaraosasco.sp.gov.br

Em sua fase inicial de existência, o SMO esteve a margem das grandes articulações políticas correntes no período. O nível de sindicalização era baixo na região, e o histórico de lutas operárias locais estava reduzido a movimentos pontuais, como a greve da Cobrasma de 1957.

Atenta a esse fator, a gestão Conrado Del Papa procurou "consolidar a estrutura administrativa e de serviços", fortalecer a posição financeira do novo sindicato, e ampliar seu número de sócios. A busca por uma articulação com as centrais já estabelecidas e atuantes no jogo político nacional foi relegada a segundo plano, tratava-se de solidificar o novo aparelho em âmbito regional, afirmar sua legitimidade, para só então alçar voos mais altos. A tarefa de aproximação junto as grandes movimentações, vinculadas ao projeto trabalhista-populista em vigor, começaram a ser desenvolvidas tardiamente, e "o esforço de conexão com a estrutura política oficial e extra-oficial (CGT) não se conclui; e por ocasião do Golpe de Estado, Osasco ainda se encontrava politicamente isolada"263. Este isolamento não impediu os operários locais de aderir a "greve dos 700 mil”, organizada pela CGT, em novembro de 1963.

Após o golpe civil-militar de $1^{\circ}$ abril de 1964, o presidente do SMO foi preso e toda sua diretoria deposta, ficando a entidade sob intervenção até julho do ano seguinte. Com a primeira diretoria toda destituída, a Secretaria do Trabalho do governo Adhemar de Barros nomeou como interventor Luis Camargo, sindicalista ligado as lideranças de Joaquim dos Santos Andrade, o Joaquinzão, e Remo Forli, membro do PSB. Sobre Luis Camargo pesava a 263 MIRANDA, Orlando. Op. Cit. p. 78-79 
pecha de pelego. O assalto ao poder desarticulou o MO de Osasco em seu período inicial de organização autônoma, desmobilizou as lideranças locais, pôs em descrédito a política pecebista, que vinha colhendo bons frutos no município, e vitimou mesmo a cristã FNT, que teve sua sede invadida pela polícia.

Como ocorreu no restante dos centros industriais do país, tratou-se de silenciar as lideranças populares e bloquear os sindicatos para desconcertar a classe trabalhadora, amarrada a um esquema de atuação dependente de orientações de cúpula. A mobilização via sindicato foi anulada pela ditadura. Em se tratando de Osasco, coube aos militantes da cidade encontrar formas alternativas de movimentação política. Dentro das comissões de fábrica se efetivou a continuidade das lutas trabalhistas no novo município. A grande ironia é que tais mecanismos paralelos de organização acabaram por dar sobrevida ao sindicalismo local, poucos anos após a instauração dos governos militares.

\subsection{Comissão de Fábrica}

Embora a ideia de organizações de base, promovidas por extratos das classes populares, remeta a formação dos sovietes de Petrogrado, em 1905, há referências sobre a articulação de “comitês operários” já em 1850, citados por Karl Marx. Segundo esse autor, tais organismos tinham origem nas mobilizações revolucionárias de 1848, conhecidas como Primavera dos $\operatorname{Povos}^{264}$. Na Comuna de Paris também se registrou a criação de comitês, mas foi a partir do Século XX que esses aparelhos se popularizaram nas regiões industriais capitalistas. De acordo com Ricardo Antunes, "não existe uma teoria acabada das comissões ou conselhos de fábricas, sendo que o seu entendimento só é possível através do estudo das várias experiências histórico-concretas do movimento operário (...)"265. Tendo isso em vista, apresentaremos um breve histórico de experiências similares verificadas no Ocidente, privilegiando certos cenários, como a Itália, região que a nosso ver possui um distanciamento menor com relação ao panorama latino-americano, e por sua vez, brasileiro.

Na vaga revolucionária europeia pós 1917, desenvolveu-se na Hungria a República dos Conselhos Operários, em 1919, movimento insurrecional que durante quatro meses deteve o controle sobre esse país. Esse processo teve como centro articulador conselhos formados a

264 MANDEL, Ernest. Op. Cit. p. 31

265 ANTUNES, Ricardo \& NOGUEIRA, Arnaldo. O que são Comissões de Fábrica. São Paulo: Editora Brasiliense, 1981. p. 8 
partir de operários e soldados. Vale ressaltar que a essa altura os bolcheviques já haviam consolidado seu poder na Rússia, mobilizados por meio dos sovietes (comitês). Na mesma época, a Alemanha passava por um ciclo de levantes populares que só cessariam em 1923; na Áustria, operários e intelectuais se articulavam para tomar o poder, reunidos na "Viena Vermelha". Tal ciclo de tensão revolucionária não ultrapassaria a segunda metade dos anos 1920, e ao término das agitações populares, a União Soviética prosseguiria como único país socialista do planeta até então, regida por um sistema que se distanciava dos ideais preconizados por Lenin. Se em solo russo, a "instituição" capaz de reunir e mobilizar o proletariado em direção a supressão do modo de produção capitalista foi o soviete, no restante da Europa tal estrutura esteve consubstanciada nos conselhos operários.

A que se salientar que tais estruturas ganharam força numa fase em que os sindicatos cada vez mais assumiam posições reformistas e se distanciavam de suas bases, fenômeno este observado na maioria dos países com atividade industrial relevante. É nesse panorama que a questão dos conselhos ganha destaque, fomentando um intenso debate que envolveu figuras de proa como Lenin, Antonio Gramsci, Amadeo Bordiga, Georg Lukács, Karl Korsh, Anton Pannenkoek, Herman Gorter, dentre outros. Sobre o clima que tomou conta da Europa nesse período, observemos a seguinte passagem.

A Revolução Russa espalhou como fogo no palheiro a ideia dos conselhos, fossem no interior das fábricas ou com funções especificamente políticas. Se um observador bem informado fizesse uma viagem, em junho de 1919, da Rússia em direção à Europa Central, e uns meses depois chegasse ao sul do continente, certamente acreditaria na hipótese de uma revolução mundial. E, de acordo com suas inclinações políticas, ficaria satisfeito, como Lênin, à espera do levante na Alemanha, ou muito preocupado, como vários políticos e empresários ocidentais ${ }^{266}$.

Um dos mais originais estudiosos das comissões/conselhos foi o marxista italiano Antonio Gramsci, testemunha de uma conjuntura de lutas que teve seu ponto máximo no "biênio vermelho", etapa de grandes mobilizações por parte das classes populares da península itálica. Entre 1918 e 1920, os trabalhadores italianos mobilizados se converteram numa ameaça real aos interesses da burguesia, espalhando greves insurrecionais nas regiões industriais de seu território. Como dito acima, foi um período turbulento para as grandes

266 SECCO, Lincoln. "Cooperativas e Conselhos Operários". Artigo publicado pelo site da PUC, disponível em formato digital:

_http://www.pucsp.br/neils/downloads/v9_artigo_lincoln_secco.pdf 
economias capitalistas europeias, e o teórico sardo, radicado em Turim, procurou organizar a luta em sua pátria através de organismos que a seu ver seriam análogos aos sovietes russos. Mas não se tratava de uma transposição mecânica do aparelho político festejado pelos bolcheviques, e sim de um direcionamento dos organismos de base laborais, existentes em seu contexto político, tendo em vista a realidade concreta de sua Nação. Gramsci enxergou nas "comissões internas de empresa" o veículo ideal para articular a classe operária de seu país em sentido revolucionário.

Essas comissões existiam desde 1906, mas cedo se converteram em órgãos de colaboração entre capital e trabalho, exercendo atividades de cunho burocrático, subordinadas aos sindicatos. Tratava-se de alterar o caráter desses organismos, convertê-los em meios de luta e mobilização, pois de acordo com o editor do periódico L'Ordine Nuovo, aqui se encontrava o "germe" do futuro Estado socialista italiano. Uma vez convertidos em veículos de luta, compostos por operários conscientes moral e intelectualmente, certos de sua posição central na esfera da produção capitalista, e dispostos a galgar cada vez mais posições de poder, até obtê-lo de fato, as comissões de empresa se elevariam a categoria de conselhos de fábrica. A partir dessa concepção, “os Conselhos não são mais concebidos como instrumentos de defesa dos interesses imediatos dos trabalhadores diante dos interesses do capitalista industrial, mas sim como o meio de elevar o operário de sua condição de assalariado à nova condição de produtor. E aqui reside a diferença básica entre o sindicato e o conselho."267 Gramsci via os sindicatos como ferramentas de negociação dos trabalhadores junto aos patrões, mas nesse tipo de relação os operários agiam como "assalariados" e não como "produtores". Essa distinção fica clara no excerto abaixo:

As relações entre Sindicato e Conselho não podem ser estabelecidas por outra ligação que não seja esta: a maioria ou uma parte respeitável dos eleitores do Conselho são organizados no Sindicato. Qualquer tentativa de ligar as duas instituições por relação de dependência hierárquica não pode conduzir a qualquer outra coisa que não seja o aniquilamento de ambos.

Se a concepção que faz do Conselho um mero instrumento de luta sindical se materializa em uma disciplina burocrática e sem uma faculdade de controle direto do Sindicato sobre o Conselho, este se torna estéril como expansão revolucionária, como forma de desenvolvimento real da revolução proletária, que tende espontaneamente a criar novas maneiras de produção e de trabalho, novas maneiras de disciplina, que tende a criar a sociedade comunista. Pelo fato de que o Conselho nasce em 
dependência da posição que a classe operária foi adquirindo no campo da produção industrial, e porque o Conselho é uma necessidade histórica da classe operária - a tentativa de subordiná-lo hierarquicamente ao Sindicato determinaria antes ou depois um choque entre as duas instituições. A força do Conselho consiste no fato de que ele adere à consciência da massa operária, é a própria consciência da massa operaria que quer se emancipar autonomamente, que quer afirmar a sua liberdade de iniciativa na criação da história: toda a massa participa da vida do Conselho, e sente que significa alguma coisa para essa sua atividade ${ }^{268}$.

Segundo Carlos Nelson Coutinho, Gramsci incidiu em erro "corporativista” ao "conceber a fábrica como "território nacional" da classe operária". O grupo reunido em torno do periódico L'Ordine Nuovo superestimou o papel do operariado dentro de uma realidade complexa como a italiana, e subestimou o papel do partido político como "agregador e mediador" da classe operária. Ainda segundo Coutinho, o Gramsci conselhista não se apercebeu de que "a dominação e a direção politica da classe operária (...) não se esgotam no controle imediato da produção material, mas implicam também uma ação hegemônica sobre o conjunto dos mecanismos (políticos, sociais e culturais) que asseguram a reprodução da vida social e global e, inclusive, a reprodução das próprias relações de produção."269

A experiência revolucionária italiana atingiu seu ponto de ebulição em setembro de 1920, mês em que uma grande greve paralisou a cidade de Turim. Como reação a intensa mobilização operária, o patronato local decidiu impor um lockout as empresas da cidade. Adiantando-se a medida patronal, os operários, organizados pelos conselhos, ocuparam as principais fábricas da cidade e deram continuidade a produção. Tal medida era um meio de mostrar aos proprietários que os trabalhadores eram capazes de controlar todas as etapas da produção sem o intermédio de diretores e patrões. Somente na Fiat, o operariado tocou a produção durante um mês, sem a interferência do patronato. Não obstante, o movimento insurrecional acabou restrito a Turim, abandonado pela CGL (Confederação Geral do Trabalho (Lavoro)) e pelo PSI, instituições que se recusaram a coordenar a expansão do levante turinense para o restante da península. Isolado, o movimento foi rapidamente sufocado pela repressão, e uma forte represália foi instaurada contra suas lideranças, além de que os conselhos de fábrica e as comissões internas foram abolidas, pela força da repressão capitalista." 270

268 GRAMSCI, Antonio. "Sindicatos e Conselhos". Idem. p. 103-104

269 COUTINHO, Carlos Nelson. Ibidem. p. 11

270 ANTUNES, Ricardo \& NOGUEIRA, Arnaldo. Op. Cit. p. 79 
Mas a ofensiva do grande capital não se restringiu a perseguição aos grevistas de 1920, dois anos depois Mussolini chegou a poder com amplo respaldo das classes produtoras, dando início a um dos períodos mais sombrios da história desse país. O MO local foi desmobilizado, sindicatos e partidos de esquerda duramente perseguidos, e o maior expoente do marxismo italiano, Antonio Gramsci, encarcerado a partir de 1926, época em que atuava como deputado no Parlamento italiano. A temática dos conselhos operários na Itália só retornaria em 1968, em outra conjuntura insurrecional.

$* * * * *$

De acordo com Valdemar S. Pedreira Filho, na primeira fase do MO brasileiro, compreendida nos anos da República Velha, já se encontravam no país organismos elementares de organização laboral, de forma incipiente, articulados por militantes ligados a vaga anarco-sindicalista ${ }^{271}$. Tais organismos foram levados de roldão após o ciclo de enquadramento sindical varguista, pós 1930. Com a derrocada do Estado Novo, entre 194547, tais mecanismos foram novamente postos em prática entre os trabalhadores, dessa vez organizados pelo PCB, sobretudo em São Paulo. "De 33 greves ocorridas em São Paulo (1946), 13 delas foram decididas fora do sindicato e em 15 destes movimentos constatou-se a presença de comissões de fábrica como elemento organizador. Em 1947, das 22 greves, 12 delas também apresentaram aquela forma de organização de base"272. Durante o lustro autoritário do governo Dutra, o trabalho de base que vinha se desenvolvendo a contendo, no biênio inicial pós retomada da democracia, foi coibido.

Vimos acima que a partir de 1952 os pecebistas retornaram a suas tarefas de organização junto aos trabalhadores, e num primeiro momento a forma adotada foi a de articulações pela base, via comissões de salário, organismos que se notabilizaram na preparação da "greve dos 300 mil”, em 1953. Entretanto, após reconquistar seu espaço e sua influência nas esferas de poder nacional, os comunistas se enquadraram no pacto populista, em associação com os trabalhistas, e passaram a se articular politicamente dentro do sindicalismo oficial. Atendendo a pressão das bases, os pecebistas aderiram as organizações paralelas, mais combativas, embora também cupulistas. Em tempos de sindicalismo populista,

271 PEDREIRA FILHO, Valdemar S. Comissões de Fábrica: um claro enigma. São Paulo: Entrelinhas/Cooperativa Cultural da UFRN, 1997. p. 21-43

272 MARANHÃO, Ricardo. "Sindicatos e Democratização". Apud: ANTUNES, Ricardo \& NOGUEIRA, Arnaldo. Op. Cit. 86-87 
coube aos renovadores a retomada das organizações de base. Em Osasco, tal modelo de organização se tornou uma das principais formas de mobilização operária após o golpe.

No ano de 1965 foi reconhecida oficialmente a comissão de fábrica da Cobrasma, aceita pela administração, com estatuto e eleições. Numa conjuntura ditatorial, tal fato representou uma vitória para os trabalhadores da empresa e da cidade, pois rapidamente o êxito desse projeto foi propagado por toda a região. Duas forças políticas se encontram na raiz da comissão de fábrica da Cobrasma: a FNT, maior responsável pelo sucesso do empreendimento, e militantes egressos do comitê da fábrica da Braseixos, empresa localizada no outro lado da rua, pertencente ao mesmo grupo. Esse comitê era formado por ativistas em processo de afastamento do PCB.

Com relação à primeira força, vimos que em princípios da década de sessenta ativistas da (futura) FNT iniciam suas atividades em Osasco. O principal responsável pela organização primeva dos frentistas na cidade foi João Batista Cândido, militante católico egresso da JOC, ligado a liderança de Mario Carvalho de Jesus. Cândido fora um dos construtores da comissão de fábrica da Cia de Cimento Portland Perus, palco de uma greve de grandes proporções em 1959. Passara também por Cajamar, e a partir de 1960 se transferiu para Osasco, dando continuidade a seu projeto. No ano seguinte, recrutou para seu grupo o militante católico Albertino de Souza Oliva, chefe da Seção de Pessoal da Cobrasma, homem com fama de severo junto aos operários da empresa. Em 1962, João Batista Candido, em companhia de Albertino de Souza Oliva e um grupo de jovens militantes, oriundos do meio operário católico, constituiram em Osasco a FNT. No mesmo ano, articulou-se a "comissão dos dez", embrião da futura comissão que seria reconhecida três anos depois. Embora ainda incipiente, o novo organismo conseguiu algumas melhorias para os funcionários da empresa, obteve um certo diálogo com a direção, através da interlocução de Albertino de Souza Oliva, mas as negociações, nessa fase, permaneceram “em nível precário e semi-clandestino ${ }^{273}$.

Sobre as origens do segundo grupo, também pioneiro na articulação de organismos de base na cidade, observemos o raciocínio de José Ibrahim:

Antes mesmo do golpe, um grupo de militantes operários, dissidentes do PCB (...), tomou a iniciativa de organizar um comitê de fábrica na Braseixos (indústria metalúrgica) com o objetivo de romper com a excessiva centralização da cúpula, trazendo a luta sindical para o interior da fábrica.

273 Para informações sobre a constituição da FNT e da "comissão dos dez", consultar os dois estudos de Orlando Miranda sobre o tema: "Sindicato e Classe Operária: História do Sindicato dos Metalúrgicos de Osasco"; e Obscuros Heróis de Capricórnio; ambos já citados nesse trabalho. 
Mantinha discussões organizadas com os trabalhadores da fábrica e articulava-se com militantes de outras fábricas na tentativa de expandir a ideia de organizar comitês. No plano interno da Braseixos, fazia propaganda através de panfletos e "mosquitinhos" e, no externo, chegou a editar um pequeno jornal. Essa experiência foi abortada pouco antes do Golpe, pois foi condenada pela direção sindical e pela cúpula dirigente do PCB local que a taxou de divisionista e a acusou de fazer o jogo patronal, a medida que os patrões poderiam reconhecer o comitê como interlocutor e não mais o sindicato; foi também liquidada pelos patrões, e seus membros foram todos postos na rua, pois esses ativistas faziam um trabalho na fabrica bastante aberto e os patrões já estavam empenhados em "limpar" suas fábricas dos "agitadores comunistas" 274 .

A comissão frentista dos dez, criada em 1962, começou ganhar destaque após o período militar. O vazio deixado pelas lideranças de esquerda perseguidas pelo novo poder, somado a intervenção no SMO, abriu espaço para novos grupos atuarem no meio operário local. Ainda em 1964, um acidente fatal envolvendo um trabalhador da Cobrasma gerou revolta entre os empregados de uma empresa que até então era conhecida por suas péssimas condições de segurança e salubridade. Como forma de protesto, os metalúrgicos fizeram uma paralisação de dez minutos em memória do operário falecido. Essa manifestação foi organizada pela "comissão dos dez". Após o feito, a diretoria da empresa aceitou negociar com os funcionários, e a comissão foi reconhecida pela administração como órgão de interlocução junto aos empregados. Esse fato representou um salto qualitativo na construção da comissão idealizada pelos frentistas . Uma vez reconhecido o novo aparelho de mobilização, seu controle não pôde mais se restringir as diretrizes de seus fundadores frentistas, outros grupos se deram conta do potencial político do mesmo, e passaram a disputar espaço dentro do organismo. Dentre esses grupos estava um punhado de jovens reunidos em torno da liderança de José Ibrahim, herdeiro político do comitê da Braseixos.

274 Há poucas referências sobre os ativistas do comitê da fábrica da Braseixos, segundo José Ibrahim, em entrevista ao autor, tal grupo reunia trotskistas e pecebistas pró-China. Sobre as referências teóricas do grupo, Ibrahim comenta que os mesmos idealizaram o aparelho de base na Braseixos influenciados pelo escrito $O$ Partido Baseado no Sindicato, de Leon Trotski. Ainda segundo o depoente, a respeito desses militantes: "Eu posso citar três expoentes dessa época que eram pessoas preparadas e que influenciaram bastante a gente, porque eles eram um pouco mais maduros, ou um pouco mais velhos que a gente, tinha o Sérgio Camati, que era funcionário da Braseixos, e os dois irmãos Ananias, o Mario e o Luis Ananias, esses três caras que eram comitê municipal, eram dirigentes portanto, do $\mathrm{PC}$ em Osasco, eles faziam essa crítica, diziam que tinha que organizar na base, que o partido era muito cupulista, e então eles passaram a fazer dentro da Braseixos". No IPM sobre a atividade comunista em Osasco, redigido após 1964, os nomes dos militantes supracitados não estão presentes. Sobre seus contatos com esses ativistas, Ibrahim comenta: "Olha, nessa época Osasco já tinha uma efervescência no movimento operário, Osasco sempre teve uma tradição, eu era operário da Cobrasma, portanto frequentava o sindicato, e ao mesmo tempo eu a noite estudava”. IBRAHIM, José. Op. Cit. p. 51-52; e entrevista de José Ibrahim ao autor, 27/01/2009. 
Outro elemento que deve ser levado em conta é o fato da Cobrasma, nessa conjuntura, estar passando por um processo de reformulação no que respeita as "relações de trabalho" dentro da empresa ${ }^{275}$. A nova mentalidade era fruto do "Terceiro Grande Plano de Expansão" da fábrica, iniciado em princípios da década. Nesse processo, o pessoal do setor administrativo começou ser substituído por funcionários de maior qualificação técnica, agora norteados por dois conceitos básicos: "modernização e aumento da produtividade". Toda essa "modernização" não se restringia ao "reequipamento e ao aperfeiçoamento de métodos de produção", implicava "também em mudança substancial nas relações internas, no advento de uma "racional" burocracia"276.

Os antigos chefes de seção passaram a ser substituídos por engenheiros, alterando a composição de forças dentro da empresa, e o setor administrativo foi separado da produção, instalado em um edifício vizinho. Relações de verniz liberal foram postas em prática, tendo por meta estabelecer um diálogo entre operariado e direção. A nova postura da diretoria perante comissão de fábrica, muito além de seu viés modernizante, era uma forma de tratar

275 A Cobrasma foi criada em 1944, sob o impulso nacionalista varguista, num contexto de relações amistosas entre Brasil e EUA. Desde o início da década de quarenta, interessava ao governo estadunidense assessorar seu grande parceiro em solo sulamericano, dentro do esforço de guerra contra o Eixo. Nesse sentido, foram iniciados os trabalhos da Missão Cooke, em 1942 (os trabalhos dessa primeira empreitada tiveram prosseguimento através da Missão Abbink, em 1948, e da Comissão Mista Brasil-Estados Unidos (195153) ). Os relatórios da Missão Cooke recomendavam investimentos nos setores de base da produção industrial (com destaque para o campo siderúrgico), no setor de produção de energia, e nos meios de transporte. O projeto de criação da Cobrasma está ligado a esse contexto. A empresa foi idealizada pelo banqueiro Gastão Vidigal, na época em que se iniciaram os trabalhos para a construção da metalúrgica, Vidigal se encontrava a frente da Cexim (Carteira de Exportação e Importação do Banco do Brasil). Suas boas relações no governo foram fundamentais para a criação e consolidação da empresa em análise, que sempre teve nas encomendas estatais sua principal fonte de divisas. Gastão Vidigal era diretor da Cia Mogiana de Estradas de Ferro, empresa esta que se consolidou como uma das principais acionistas da Cobrasma. Juntamente a Mogiana, com $25 \%$ das ações da nova firma, estava a Cia Paulista de Estradas de Ferro (24\%), e a Siderurgia Belgo Mineira (12\%). O restante das ações foi dividido entre uma série de grupos econômicos. A influência de Vidigal na Cexim permitiu o constante fluxo de maquinário importado para a fábrica, que se especializou na montagem de vagões ferroviários, mas com o tempo foi diversificando sua produção, desenvolvendo também peças fundidas, carros de transporte (ônibus), eixos automotivos, dentre outros materiais. Devido a sua dependência de encomendas governamentais, a Cobrasma sempre esteve sujeita as crises econômico-institucionais que frequentemente assolavam o país. A empresa apresentou um faturamento estável durante a década de cinquenta, com retração entre 1954-55. Na década seguinte, somente após 1968 houve aumento no faturamento. Os anos 1970 foram os que a empresa obteve maior crescimento econômico, num ciclo que se estendeu até 1981, após essa data, seu rendimento se estabilizou em níveis médios. Contudo, após o advento do neoliberalismo, e o início do desmonte do setor ferroviário nacional, a fábrica edificada a partir do banqueiro Gastão Vidigal encerrou suas atividades. Em 1994, com a empresa atolada em dívidas trabalhistas, a direção da Cobrasma pediu concordata. A Braseixos, pertencente ao mesmo grupo, em associação com a estadunidense Rockwell Spring and Axle Co, foi vendida a sua parceira internacional, sobrevivendo a crise. A filial da fábrica edificada em Sumaré, no final da década de setenta, também fechou suas portas. As informações supracitadas estão presentes em: MOTTA, Antônio Carlos Casulari Roxo. "Cobrasma: trajetória de uma empresa brasileira". Tese de Doutorado. São Paulo: FFLCHUSP, 2006. Esta tese também se encontra disponível em formato digital, no endereço eletrônico: http://www.teses.usp.br/teses/disponiveis/8/8137/tde-10072007-115106/pt-br.php

276 MIRANDA, Orlando. Op. Cit. p. 64-65 
diretamente com seus empregados sem a necessidade do intermédio sindical. A FNT era o organismo ideal para as pretensões da direção da empresa, pois se tratava de um grupo de matriz cristã, com discurso anti-comunista e anti-sindical. Como a "comissão dos dez" fora organizada por esse movimento, as desconfianças da chefia se atenuaram, o que permitiu seu reconhecimento ao nível da administração. Roque Aparecido da Silva, estudante-operário, funcionário da Cobrasma, e testemunha dos eventos citados acima, descreve a criação da comissão nos seguintes termos:

(...) a comissão de fábrica começou, concretamente, em 1962, quando foi criando o "grupo dos 10", começou basicamente por iniciativa da FNT. A Frente era uma organização que tinha uma ligação muito forte com a igreja, com seus setores progressistas, e tinha uma visão mais humanista, uma visão socialista, tinha por princípio procurar conscientizar os trabalhadores da sua realidade e fortalecer a organização dos trabalhadores na luta pelos seus direitos. E aí, num primeiro momento, é importante ter claro que a FNT tinha também um certo posicionamento anti-comunista, enquanto organização cristã, e fazia oposição a atuação dos comunistas no meio operário. Então, em 62, quando a Frente é criada, quando o "grupo dos 10 " é criado na Cobrasma, de certa forma, o patrão também facilita sua existência, por que a Frente não conciliava com o sindicato, era oposição, e na verdade já era quase o próprio sindicato, criando uma organização parasindical, e um movimento que se contrapunha ao sindicato e buscava resolver os problemas numa relação direta com os patrões. Claro que houve uma evolução, em 1966 a consciência da maioria dos companheiros da FNT já tinha evoluído bastante, mas efetivamente o grupo nasce aí, em 62, quando o "grupo dos 10 " passa a ter reuniões periódicas com a direção da empresa, portanto é reconhecida pela direção e tudo mais. E de fato a comissão vai se consolidando, e nós, eu, o Ibrahim, e outros companheiros, que não éramos ligados a igreja, e já tínhamos uma visão mais de esquerda mesmo, também fomos participando, por que era o que tinha de organizado lá dentro da Cobrasma. Enfim, foram várias lutas, várias reivindicações que foram se consolidando, até que em... 1965 se forma realmente a omissão de fábrica, até então "grupo dos 10 " (....). 277

Em seu período inicial de atividades, o aparelho de base frentista obteve junto a direção da Cobrasma o pagamento de adicional de insalubridade sobre os vencimentos dos operários da empresa, e a edificação de um restaurante para os funcionários. Numa fase em que o sindicato se encontrava desmobilizado, a comissão se converteu na grande representante dos trabalhadores perante os patrões, e por suas conquistas, adquiriu respeito e 277 O depoente se refere a "comissão dos dez" como "grupos de dez". Entrevista de Roque Aparecido da Silva ao autor, $05 / 11 / 2008$ 
reconhecimento entre os funcionários da fábrica. Já consolidado, o organismo em análise se tornou oficial em 1965, com diretoria eleita via voto. O primeiro presidente escolhido por seus homólogos foi João Batista Cândido, veterano de mobilizações da FNT, Orlando Miranda foi eleito vice; como $1^{\circ}$ secretário, foi escolhido Liceu Domingues da Silva (irmão de Roque Aparecido da Silva), e como $2^{\circ}$ secretário, José Ibrahim. Albertino de Souza Oliva foi indicado como assessor jurídico permanente ${ }^{278}$.

Para o pleito interno, a "fábrica foi dividida em 19 setores", cada um com direito a eleger dois representantes para a comissão. Os 38 operários eleitos por seção escolheram a diretoria supracitada. Os contemplados tinham direito a estabilidade por um ano, e podiam "ser sindicalizados ou não". O novo aparelho "se reunia pelo menos uma vez por mês com a direção da empresa para discutir a pauta de problemas previamente preparada. As reivindicações de cada setor, se não solucionadas ao nível da chefia de departamento, eram levadas a reunião mensal com os patrões" ${ }^{279}$. O poder dentro da comissão de fábrica da Cobrasma estava diluído entre militantes da FNT, ativistas cristãos de outras organizações, lideranças independentes, e os herdeiros do comitê de empresa da Braseixos, agora articulados no GO.

Paralelamente as movimentações operárias, desenvolviam-se as atividades estudantis no município, vimos na última seção que da intersecção entre essas duas frentes foi forjado o GO, por meio da figura do estudante-operário. Com viés mais operário que estudantil, José Ibrahim descreve essa evolução:

Isso aí foi todo um processo que houve lá... Que funcionou sempre assim, era o sindicato e era o movimento secundarista. Tinha companheiros, tipo o Espinosa, o Roque, que atuavam mais no movimento secundarista, mas eles também eram operários, o Espinosa trabalhava na Cobrasma, o Roque também. Mas a prioridade deles em termos de atividade política era mais no movimento estudantil. E esse grupo foi se formando assim, eu tinha uma participação no movimento secundarista devido a minha relação com esses companheiros, com o Gabriel, o Dudu, todos empregados da Cobrasma, da Brow Boveri, da Braseixos. Quando precisava eles iam no sindicato, quando era necessário iam a uma assembleia, para uma votação ou coisa assim, mas a prioridade deles era no movimento estudantil. $\mathrm{O}$ grupo foi se formando naturalmente, nós tínhamos nosso ponto de encontro, depois que saíamos do colégio à noite pra tomar um chope, tinha a própria sede da UEO. Eu chamo de Grupo de Esquerda de Osasco não porque existia uma direita forte em Osasco, a direita lá era o Rossi

278 MIRANDA, Orlando. Op. Cit. p. 163-164

279 IBRAHIM, José. Op. Cit. p. 55 
e outros grupos mais conservadores. Chamei de Grupo de Esquerda muito mais para polarizar com a FNT, porque a Frente em Osasco era forte, eles tinham representação em várias fábricas, estavam na Braseixos, na Cobrasma. Eles tinham uma visão de comissão de fábrica que se dedicava a negociação direta, a negociação por empresa, afim de polarizar com o sindicato, porque na visão deles, o sindicato era controlado por comunistas. Então tinha um ranço anticomunista por trás, e eles buscavam compensar desse jeito. Era diferente da visão que nós tínhamos de comissão de fábrica, que era para organizar, para mobilizar e fortalecer o sindicato. Mas o sindicato que a gente queria não era o da pelegada, nem o do Partidão, era outro tipo de sindicato, que nós viemos a fazer depois que nós ganhamos a eleição ${ }^{280}$.

O GO assumiu posição importante na comissão da Cobrasma, com espaço na diretoria e influência crescente junto aos colegas de trabalho. O principal articulador do grupo no meio operário foi sem dúvida José Ibrahim, jovem que contava com dezoito anos em 1965, estudante-operário que se destacou entre seus companheiros de serviço por suas qualidades de liderança e sua capacidade de articulação. Mas ao lado de Ibrahim estavam outras lideranças de envergadura, como Roque Aparecido da Silva, Pedro Proskursin, Antonio Roberto Espinosa, José Campos Barreto, Manuel Dias do Nascimento, dentre outros. Coube a esses jovens direcionar a comissão de fábrica de sua empresa a esquerda.

De acordo com Ibrahim, em princípios de 1966 (a primeira diretoria da comissão oficial fora eleita em setembro do ano anterior) já ficara claro aos empregados da Cobrasma que a disposição da chefia em atender suas reivindicações era mínima, e o diálogo junto a comissão de fábrica nada mais era do que um subterfúgio para mitigar a militância operária e anular o sindicato. Embora essa percepção fosse crescente entre os trabalhadores da empresa, os frentistas seguiram com suas proposições moderadas, desagradando as bases. $\mathrm{O}$ ponto alto do descontentamento dos funcionários da fábrica contra seus patrões se deu após a demissão por justa causa de 46 operários que se dirigiram ao Departamento Pessoal para reclamar equiparação salarial com os demais setores da produção. A justificativa da diretoria foi "abandono de serviço", mas para todos ficou claro que se tratava de uma armadilha. O paradigma "modernização e aumento da produtividade" também preconizava outro conceito básico, "corte de gastos". O objetivo era produzir cada vez mais, empregando cada vez menos pessoal, agudizando a extração da mais-valia absoluta. Vejamos a tradução dessa política em números.

280 Entrevista de José Ibrahim ao autor, 27/01/2009. 
Tabela III

\section{Cobrasma: número de funcionários - 1946-1970 281}

\begin{tabular}{|l|c|}
\hline Ano & Quantidade \\
\hline 1946 & 492 \\
\hline 1949 & 1.039 \\
\hline 1960 & 2.538 \\
\hline 1964 & 6.833 \\
\hline 1965 & 4.279 \\
\hline 1970 & 2.764 \\
\hline
\end{tabular}

Fonte: Cobrasma, 1994. Apud: MOTTA, Antônio Carlos Casulari Roxo. Op. Cit. p. 67 (dados parciais).

Para debater as demissões sumárias foi convocada uma assembleia geral no SMO, concentração que contou com comparecimento maciço por parte dos funcionários da Cobrasma. Sindicato e executiva da comissão defenderam o encaminhamento da questão para a Justiça do Trabalho, o que revoltou os presentes, e acabou com a expulsão dos dirigentes sindicais. A proposta tirada da assembleia foi: ou o retorno imediato dos demitidos por justa causa, ou greve. Dois dias depois a direção da empresa acenou com uma "solução intermediária", a "reincorporarão de uma parte do pessoal, e a outra parte seria dispensada pagando-se todos os direitos, sendo que os critérios para decidir quem ficava seria da própria Comissão junto aos trabalhadores (...)"282. A proposta foi aceita, e após esse acontecimento, aquele grupo de jovens militantes combativos, reunidos em torno de José Ibrahim, o mesmo que tomou a frente no enfrentamento a intransigência dos patrões, ganhou destaque dentro da fábrica. Em contrapartida, a atitude contemporizadora dos ativistas da FNT começou afastálos das bases. Esse desgaste engendrou o crescimento da influência do GO, e lançou as bases para a conquista da diretoria da comissão de fábrica no pleito a ser realizado em setembro de

281 Verificando-se o faturamento da empresa no mesmo período, em milhões de dólares, vemos que em 1963 a Cobrasma obteve um rendimento de 22,28 milhões, o maior do primeiro lustro da década. No ano seguinte, época de grave crise institucional, o faturamento foi de 15,72 milhões. Em 1965 e 66, tempo de recessão econômica, e empresa não forneceu os números de seu rendimento, que obviamente foi baixo em relação aos anos anteriores. A recuperação começou a partir de 1968, com faturamento de 19,75 milhões; no ano de 1970, o rendimento foi de 25,48 milhões. Notem que o empreendimento atingiu o seu faturamento máximo na década de setenta empregando cerca $40 \%$ dos operários que empregava em 1964, ano do golpe. Esses números indicam um aumento substancial na extração da mais valia absoluta. Em 1964 a empresa produziu, levando-se em conta apenas os números do setor de fundição, 11.440 peças. Já em 1970, o número foi de 14.016, com um montante de empregados bastante reduzido. MOTTA, Antônio Carlos Casulari Roxo. Op. Cit. p. 63-68.

282 IBRAHIM, José. Op. Cit. p. 57-58 
1966.

Numa conjuntura de fechamento político, a constituição de veículos alternativos de representação se apresentava como uma saída viável, uma maneira de driblar as imposições do sistema autoritário. O velho PCB estava atento ao que se passava nos meios sindicais brasileiros, e viu nas comissões de empresa iniciativas oportunas de resistência a ditadura por parte da classe operária.

As comissões sindicais de empresa - qualquer que seja o nome que adotem - poderão funcionar legal ou ilegalmente, tudo dependendo das condições concretas da própria empresa e também das condições gerais políticas. Em muitos casos será necessário ligar as duas formas, a legal e a ilegal. O importante é que elas estejam em condições de encabeçar a luta dos trabalhadores pelas suas reivindicações mais sentidas, ligando-as ao mesmo tempo as aspirações gerais mais sentidas pelas massas. A solidariedade aos presos políticos, a luta pela sua libertação e a assistência as suas famílias são tarefas que devem preocupar as comissões de empresa ${ }^{283}$.

A comissão da Cobrasma, após seu reconhecimento, tornou-se uma referência em termos de mobilização laboral, suas conquistas rapidamente chegaram ao conhecimento dos trabalhadores de outras empresas da cidade. A disseminar os feitos do novo aparelho as demais fábricas do município estiveram os ativistas da FNT, atuantes em toda região, e os membros do GO, que também se dispuseram a tornar público o seu modelo de comissão. Assim como na Cobrasma, ambos os movimentos trabalharam pela popularização de seu modo de ação política, dentro de suas respectivas concepções. Com relação ao GO, seu crescimento esteve diretamente ligado a aplicação dos cursos de iniciação ao marxismo comentados na última seção. Destarte, já em finais de 1966, signatários do grupo já atuavam

283 Vale mencionar que o PCB faz menção a "comissões sindicais de empresa", deixando clara sua perspectiva de subordinação dos aparelhos de base aos sindicatos. Trecho de artigo publicado pelo periódico Voz Operária, $\mathrm{n}^{\circ}$ 14, fevereiro de 1966, presente em: FREDERICO, Celso. A Esquerda e o Movimento Operário - 1964-1984. (Vol. 1) São Paulo: Editora Novos Rumos, 1987. p. 26-30. O periódico Política Operária, pertencente a organização ORM-Polop, no seu primeiro exemplar, em editorial de capa intitulado "Por uma Frente Única dos Trabalhadores da Cidade e do Campo", conclama a formação de "comitês de empresa" por parte do operariado, e também faz menção a criação de "comitês populares" nos bairros. A Polop, ao longo de toda sua trajetória, sempre defendeu a formação de organismos de base entre a classe trabalhadora. Para consulta: jornal Política Operária, $\mathrm{n}^{\mathrm{o}}$ 1, janeiro de 1962; disponível em formato digital no CEDEM da UNESP. Na região de Osasco, militantes da Polop, entre 1968 e 1970, distribuíram um periódico/panfleto chamado Movimento Operário, informativo que também orientava os trabalhadores a se organizarem desde a base por meio de comissões. A tendência responsável por esse periódico/panfleto recrutou alguns militantes do GO para suas fileiras, tendencia esta que se engajou no POC (Partido Operário Comunista), grupo radical obreirista. No próximo capítulo discutiremos com mais vagar as diretrizes e os rumos dessa sigla. $\mathrm{O}$ informativo Movimento Operário também se encontra disponível em formato digital no CEDEM da UNESP. 
em outras empresas de Osasco, organizando seus pares de acordo com os preceitos do movimento.

Um exemplo dessa prática foram as atividades de Manuel Dias do Nascimento (Neto), quadro egresso do PCB com larga experiência em organização operária. Com esse desiderato, Neto engajou-se na fábrica Lonaflex, com o objetivo de "criar um trabalho", seguindo a proposta do GO que preconizava "criar comissões onde (elas) não existiam e consolidar aquelas que já existiam". Nosso depoente dá mais detalhes sobre seu trabalho de recrutamento:

Até chegar na formação da comissão, primeiro nós passávamos por uma discussão com os companheiros, criávamos os sindicalizados, dávamos condições para eles se deslocarem para os sindicato nos fins de semana, condições que a gente criava através de conscientização; então ele (o operário) pegava a bicicleta dele, ou a ia a pé, ou de ônibus, e se deslocava ate lá. Em seguida, de acordo com a evolução desses companheiros, nós passávamos a nos reunir na casa de cada um, de três em três, aqueles que tavam evoluindo mais, a gente passava para uma discussão diferente. Aqueles que já davam os primeiros passos, a gente discutia sobre questões de sobrevivência, e pros que já tavam exigindo mais, a gente já colocava uma discussão política sobre movimento sindical internacional, sobre o movimento revolucionário, sobre o processo revolucionário brasileiro, e assim sucessivamente, mas nunca tirando o companheiro das lutas internas da empresa (...) ${ }^{284}$

Em que pese sua postura insurrecional, o GO jamais se desgarrou das questões imediatas da classe trabalhadora, sua proposta de comissão sempre teve como premissa básica a busca por melhores condições de trabalho e subsistência ao nível da fábrica, mesclando reivindicações corporativas com outras de caráter mais geral, como derrubada do regime militar, por exemplo. Ativistas como Neto se engajaram em outras firmas da cidade, e comissões semi-legais - e mesmo ilegais - foram sendo constituídas, reunindo as militâncias ali lotadas, congregando opositores de matizes diversos, como frentistas, independentes, trotskistas, dentre outros. Para essa função também foram articuladas as "vanguardas operárias", assunto que será discutido no próximo item.

Comissões de empresa também foram observadas em outras regiões da grande São Paulo, como Guarulhos. Em novembro de 1966 passou a circular na cidade o periódico Comitê de Empresa, chamando os trabalhadores da localidade para a luta contra a ditadura, e

284 Entrevista de Manuel Dias do Nascimento ao autor, 16/02/2009 
a formação de organismos de base a revelia do sindicato. O periódico-panfleto - por questões obvias apócrifo - definia que o "esforço maior de organização da classe operária pelas bases faz-se hoje através da constituição dos comitês de empresa" ${ }^{285}$. Em Minas Gerais, na região de Contagem, também se verificou a formação de aparelhos de base, popularizados a partir da greve de abril de 1968. Esse tipo de organização laboral se tornará popular em todo Brasil após a Greve de Osasco, festejado em periódicos estudantis e operários, incorporado pelas oposições sindicais, e por isso mesmo visto com maus olhos pelas classes patronais e pelos órgãos de repressão.

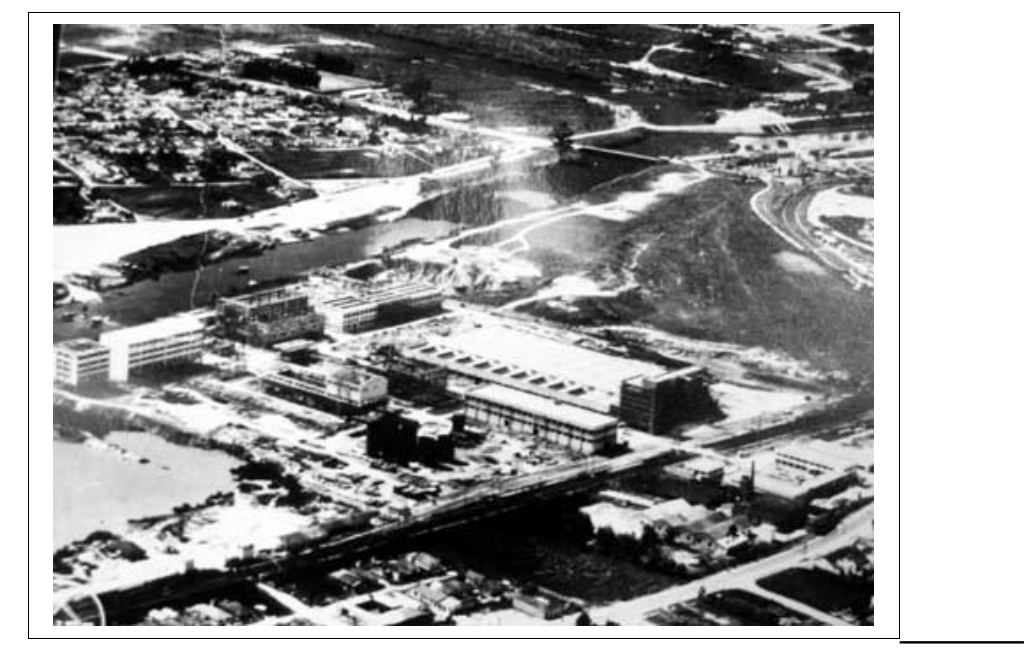

Cobrasma, década de cinquenta

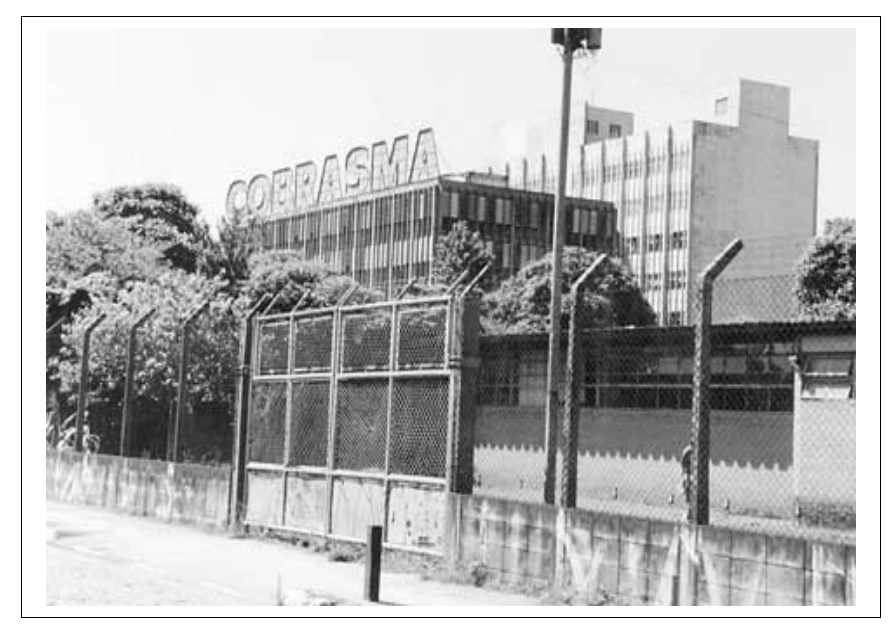

285 Os exemplares disponíveis desse panfleto vão de novembro de 1966 a fevereiro de 1968 . O exemplar citado acima é: Comitê Empresa: boletim dos trabalhadores, $\mathrm{n}^{\circ} 1$, novembro de 1966. Com o mesmo título, outro panfleto foi distribuído nas regiões industriais de Minas Gerais. Ao tudo indica, os dois informativos foram iniciativa de militantes da Polop. Ambos se encontram disponíveis em formato digital no CEDEM da UNESP. 
Cobrasma, após seu fechamento nos anos 1990. Duas fases distintas da empresa fundada por Gastão Vidigal, na primeira imagem, a fábrica pouco após sua fundação. Na segunda fotografia, vemos o prédio da administração da empresa, edificado em meados da década de sessenta, fruto do "terceiro grande plano de expansão" do empreendimento, norteado pelos conceitos de "modernização e aumento da produtividade". A construção do novo edifício separou produção e administração dentro da fábrica. Fonte: www.camaraosasco.sp.gov.br

\subsection{A Conquista do Sindicato}

Vimos que o SMO não escapou a onda de repressão que tomou conta do país após o golpe civil-militar de 1964, toda sua diretoria foi deposta, e seu presidente, Conrado Del Papa, preso. Sorte semelhante tiveram outros 452 sindicatos do país, 45 federações e três confederações. Somente em São Paulo, 70\% das entidades que tinham mais de 5 mil membros foram atingidas, $38 \%$ das que contavam entre mil e 5 mil afiliados, e " $19 \%$ dos sindicatos que contavam com menos de mil membros ${ }^{286}$.

O novo bloco histórico que se apossou do Estado brasileiro em 1964 assumiu a incumbência de superar a grave crise econômica que vitimava o país desde inícios da década. Décio Saes define essa transição autoritária como uma "contra-reforma destinada a criar as condições institucionais indispensáveis à aceleração da acumulação do capital própria a uma etapa monopolista de desenvolvimento capitalista" ${ }^{287}$. Com esse objetivo, foi criado o Ministério do Planejamento e Coordenação Econômica, sob a direção inicial de Roberto Campos, ex-embaixador em Washington, técnico com estreitos vínculos junto ao grande capital internacional, entenda-se o estadunidense. Para o Ministério da Economia foi indicado Octávio Gouvêa de Bulhões, economista que passara pela Escola de Chicago, egresso dos núcleos decisórios do complexo IPES-IBAD. Para a superação da crise foi desenvolvido o PAEG (Programa de Ação Econômica do Governo), sob as ordens do General do Humberto de Alencar Castelo Branco. O Programa pôs em prática "uma política de recessão calculada, cujo sentido é o de preparar as bases institucionais para um processo de concentração de capital que vinha se dando caoticamente. Não se muda o padrão de acumulação, sustentado na

286 MOREIRA ALVES, Maria Helena. Op. Cit. p. 84-85

287 SAES, Décio. Op. Cit. p. 147 
expansão do Departamento III (...)"288.

O plano estipulou como suas principais metas o combate a inflação, a redução do déficit público, e a retomada do crescimento econômico, sempre em bases monetaristas. A "politica de recessão calculada" penalizou especialmente a classe trabalhadora, pois uma das medidas adotadas pelo PAEG foi um severo controle salarial, logo apelidado de "arrocho". Foi posto em prática um drástico corte nos gastos públicos, algo que também penalizou especialmente os setores populares; restringiu-se consideravelmente o crédito, gerando falências em série, houve aumento sobre as tarifas públicas, e elevação da taxa de juros. A rigor, a política da dupla Campos-Bulhões foi altamente recessiva, jogou os trabalhadores no sub-consumo, facilitou o processo de concentração de renda, privilegiando os grupos ligados ao capital externo, condenando os setores industriais pequenos e médios a bancarrota, ou a absorção por empresas com maior capacidade de resistência a crise, com destaque para as multinacionais.

O ponto central do PAEG foi sem dúvida seu programa de controle salarial. Tais ajustes não seriam possíveis dentro do panorama pré-1964, em meio a um sistema que cada vez mais ampliava o protagonismo da classe trabalhadora. Os expurgos iniciais desorganizaram os movimentos sociais, e abriram terreno para as medidas recessivas dos governos militares. Mas não bastava apenas impor a política do arrocho, era necessário regulamentar a ofensiva patronal, dentro de um regime que buscou, durante toda a sua existência, dar respaldo legal a suas medidas de exceção, mesmo em seus períodos mais duros.

$\mathrm{O}$ ativista do $\mathrm{PCB}$ conhecido por Mauro Brito, na edição número 12 do periódico comunista Voz Operária, faz menção a um evento em que o Ministro do Trabalho do governo Castelo Branco, Arnaldo Sussekind, viu-se em "palpos de aranha para explicar as perseguições aos trabalhadores e as violações dos direitos sindicais" em seu país ${ }^{289}$. O viés legalista da ditadura sempre foi uma forma de apresentar o Brasil no cenário externo como um Estado a operar dentro das normas do direito internacional. O evento em que o ministro brasileiro se viu em "palpos de aranha" foi uma reunião da OIT (Organização Internacional do Trabalho), realizada em Genebra. De volta a sua pátria, Sussekind incumbiu aos juristas do regime a elaboração de um novo quadro de leis, de modo a legitimar a atuação do governo na

\footnotetext{
288 OLIVEIRA, Francisco de. Op. Cit. p. 92. O Departamento I seguiu sendo abastecido por empresas multinacionais, após a recuperação do ciclo recessivo, no "período que vai de 1968/71, a indústria de material se transporte (na qual predomina a automobilística) cresceu $19,1 \%$ ao ano, a de material elétrico (na qual se inclui a de aparelhos eletrodomésticos e a de eletrono-domésticos) cresceu 13,9\% ao ano, ao passo que a indústria têxtil cresceu apenas 7,7\% ao ano, e a de produtos alimentares 7,5\% ano e a de vestuário e calçados $6,8 \%$ ao ano". ANTUNES, Ricardo. Op. Cit. p. 107-108

289 Artigo assinado por Mauro Brito para o periódico Voz Operária. FREDERICO, Celso. Op. Cit. p. 22.
} 
área.

Uma das primeiras medidas, nesse sentido, foi a elaboração da Portaria 40, que autorizava a realização de eleições sindicais, em entidades que se encontravam, em sua maioria, sob intervenção. Não obstante, mecanismos de modo a barrar antigas lideranças combativas foram desenvolvidos, impedindo que as mesmas se lançassem as candidaturas. Ainda assim uma série de diretorias independentes foi eleita nos primeiros pleitos sindicais pós golpe, levando o Ministro a "emendar sua própria portaria", atribuindo a decisão final sobre a aprovação das chapas vencedoras a polícia política. Outra medida posta em prática foi o adiamento sucessivo de eleições nos sindicatos de maior tradição de luta ${ }^{290}$. Seguindo no desiderato de cercear a liberdade sindical, foi promulgada a Lei $n^{\circ} 4.330$, conhecida como Lei de Greve. O novo dispositivo legal foi uma emenda

a Constituição de 1946 (que garantia o direito de greve), ela definia as condições em que as greves seriam consideradas legais. Funcionários públicos federais, estaduais e municipais ou de empresas estatais recebiam expressa proibição de entrar em greve. Proibidas eram ainda as greves de trabalhadores em serviços "essenciais", as de solidariedade e as consideradas "de natureza politica, social ou religiosa". A definição do que constitui uma greve política cabe ao governo. Fora dessas áreas, as greves por "melhores condições de trabalho ou salários" eram permitidas, mas submetidas a condições que na prática tornavam-nas virtualmente impossíveis ${ }^{291}$.

De caráter mais econômico que disciplinador, a Lei 4.725, de 13 de Julho de 1965, consolidou uma série de decretos promulgados desde junho do ano anterior. Esses decretos visaram diminuir o valor do salário mínimo, que deixou de ser calculado com base na “elevação do custo de vida", e passou a ser estipulado a partir de uma série de cálculos baseados no "salário real médio" dos dois anos anteriores, mais a estimativa futura da inflação para o ano seguinte, e cálculos relativos a produtividade. Os aumentos se tornaram anuais, estipulados pelas classes produtoras em associação com o governo, com margens minímas de negociação por parte dos trabalhadores, agora atados pelas leis cerceadoras do regime ${ }^{292}$.

O ponto alto da ofensiva econômica contra os assalariados foi sem dúvida a Lei 5.107, criada em 13 de setembro de 1966, posta em prática um ano depois, instrumento legal que

290 Idem, ibidem

291 MOREIRA ALVES, Maria Helena. Op. Cit. p. 93

292 Idem, p. 94-95. "O governo também autorizou as empresas que se declararem em situação econômica difícil a reduzirem de $25 \%$ os salários - e aqui se trata de salários nominais - dos trabalhadores". Mauro Brito, Voz Operária. In: FREDERICO, Celso. Op. Cit. p. 25 
institui o FGTS (Fundo de Garantia por Tempo de Serviço). Antes da nova Lei, empregados demitidos sem justa causa tinham direito a uma indenização, que equivalia a um mês de salário para cada ano trabalhado na empresa. Havia também a obrigatoriedade do cumprimento de um mês de aviso prévio antes da dispensa. Empregados com dez anos de casa tinham direito a estabilidade. Esse sistema garantia a segurança dos assalariados no que concerne a rotatividade nos postos de trabalho, e mantinha os salários em patamares relativamente satisfatórios.

Após a lei 5.107, os empregadores foram desobrigados a pagar indenizações aos funcionários dispensados, e foi abolida a estabilidade. As dispensas em massa tornaram-se corriqueiras, e os custos eram debitados dos salários dos empregados. Pelas novas regras, 8\% dos rendimentos mensais dos assalariados passaram a ser depositados no Fundo de Garantia, valor a ser resgatado após dispensa imotivada. Notem que os contratadores não arcavam mais com os custos das demissões, agora financiados pelos próprios dispensados. O FGTS garantiu uma elevada taxa de turn over, e possibilitou uma defasagem crescente nos índices salariais. $\mathrm{O}$ novo sistema atendia sobretudo as exigências das empresas multinacionais, desejosas em ampliar sua taxa de exploração da mais-valia e aumentar sua produção. O novo Fundo também contribuiu "para a acumulação de capital, ao funcionar como fonte de crédito para investimento por parte dos empregadores" ${ }^{293}$. A se somar a esse conjunto de fatores, uma Justiça do Trabalho inclinada a ceder as pressões do patronato, as expensas de uma classe trabalhadora super-explorada.

Em meio a ofensiva militar-patronal ocorreu a segunda eleição para a diretoria do SMO, em substituição a interventoria encabeçada por Luis Camargo ${ }^{294}$. A direção imposta pelos

293 Idem p. 118-121

294 Para o Sindicato dos Metalúrgicos de São Paulo foi imposto como interventor o professor Carlos Ferreira dos Santos, egresso de um grupo conhecido por "oposição democrática", atuante desde o início da década. Essa corrente era contrária a hegemonia trabalhista-pecebista no sindicalismo paulista. Tal grupo contava com a simpatia das classes produtoras, pois defendiam uma linha de atuação moderada, com sindicatos mais voltados a questões assistenciais. Após o golpe, componentes desse movimento foram alçados a interventores nos principais sindicatos de São Paulo. Além de Luis Camargo, direcionado a Osasco, também pertenciam a essa facção Bernardino Testa (indicado para São Caetano), Clemiltre Guedes da Silva (São Bernardo), Isalino Canavezi, (Sorocaba), e Joaquim dos Santos Andrade (em princípio designado para Guarulhos, a partir de 1965 eleito para o sindicato de São Paulo). Após tomar posse em São Paulo, o interventor Carlos Ferreira dos Santos deu a seguinte declaração a imprensa: "envolvido, pela direção de quase um decênio de figuras (sic) altamente conhecidas da subversão da ordem, profissionais do comunismo internacional (...) interessados na destruição de nossas instituições legais, civis e políticas (...). No que tocou a verificação da atitude e conduta dos próprios funcionários, tivemos o cuidado de estabelecermos (...) uma ficha individual, que deveria ser preenchida e anotada pelo respectivo chefe, traduzindo a espécie de funcionário, seus pendores para as atividades extremistas, sua participação nas administrações, mormente no que se refere as atividades ilegais. Baseados nestas informações começamos a limpeza do sindicato com a demissão de advogados, médicos, auxiliares e demais funcionários (...)”. Jornal O Metalúrgico, n 218, janeiro a agosto de 1964. Apud: LOPES, 
militares foi considerada fraca, o que permitiu a rearticulação de antigas lideranças cassadas, como Conrado Del Papa e alguns militantes do proscrito PCB.

O presidente eleito no pleito realizado em julho de 1965, com chapa única e baixo índice de votação, foi Henos Amorina, funcionário da Brown Boveri. A escolha se deveu ao fato do mesmo não possuir antecedentes sindicais, embora fosse uma liderança de base reconhecida, com atuação marcante nas greves pré-1964. Praticamente toda a diretoria eleita em 65 possuía essas características, sendo lideranças não "queimadas" nos órgãos repressores. A escolha da Chapa eleita se efetivou a partir de uma costura política envolvendo a velha militância sindical e os frentistas, em ascensão no período. O objetivo era manter o sindicato sob a batuta de lideranças neutras, enquanto se reconstituía a militância pela base, esta por sua vez assediada por um punhado de grupos políticos de matizes diversos. Destes, o que se mostrava mais organizado taticamente era a FNT. O projeto dos ativistas católicos era solidificar sua influência junto as bases, visando uma futura conquista do sindicato.

Entretanto, Henos Amorina não foi o dirigente anódino que se esperava, aproximou o SMO do Sindicato dos Metalúrgicos de São Paulo, chefiado por Joaquim dos Santos Andrade, e rapidamente se adaptou ao grande jogo político sindical paulista ${ }^{295}$. No início das movimentações para as eleições de 1967, Amorina deu mostras de que não estava disposto a abandonar o cargo que conquistara dois anos entes. O grupo de Conrado Del Papa, reunindo o velho sindicalismo, estreitou laços com o presidente em exercício do SMO, uma vez que os membros deste bloco possuíam divergências programáticas com os frentistas, e não mantinham boas relações com a jovem militância mais a esquerda. Dentro de sua proposta estratégica, socialistas e pecebistas forneceram suporte a formação de uma chapa continuísta, dando prosseguimento a política sindical moderada corrente nos sindicatos da grande São Paulo $^{296}$. Contra essa movimentação, a Frente se aproximou de outro grupo que se dispunha a uma oposição sistemática ao velho sindicalismo de cúpula, o GO.

Vimos acima que José Ibrahim e seus companheiros ganharam notoriedade na Cobrasma depois de sua enérgica reação a despedida de dezenas de empregados da empresa sem justa causa, após medida considerada espúria. Tal atitude ativou o espírito de luta entre os

Carmen Lúcia Evangelho. Op. Cit. p. 130-133

295 Henos Amorina voltou a presidência do SMO em 1972, dirigindo a entidade por três gestões consecutivas. Também se elegeu vereador pelo Partido dos Trabalhadores por duas vezes consecutivas, entre as décadas de oitenta e noventa. Amorina rapidamente se adaptou a vida política. COUTO, Ari Marcelo Macedo. Op. Cit. p. 57.

296 Embora a cúpula pecebista osasquense tenha se alinhado a Henos Amorina, componentes da base do PCB apoiaram a chapa que se formou em torno da FNT e do GO, contrariando as diretrizes da direção comunista local. Entrevista de José Ibrahim aos Cadernos do Presente, Op. Cit. p. 10 
operários da fábrica, e consolidou a posição de vanguarda dos ativistas do GO em âmbito interno. Ao se darem conta de que a comissão tomava um rumo adverso do concebido ao nível da chefia, a administração da Cobrasma iniciou um trabalho de sabotagem ao aparelho de base de seus subordinados. Ficou claro a direção da empresa que o viés de "colaboração" vislumbrado no órgão extra-sindical, articulado por militantes cristãos de jaez moderado, aos poucos adquiria um caráter de luta e mobilização, e nem mesmo a Frente podia fugir a essa realidade. Ciente disso, a direção lançou mão de velhos estratagemas para esvaziar e desqualificar a comissão que ajudara a criar, tais como o atendimento apenas à questões secundárias, postergando problemas que exigiam solução imediata. Outra estratégia foi a tentativa de cooptação de membros do aparelho de base, buscando com isso gerar divisionismo entre seus componentes ${ }^{297}$.

É nesse ambiente que Ibrahim ascende a condição de presidente da Comissão de Fábrica da Cobrasma, tendo Roque Aparecido da Silva como primeiro secretário. Uma das primeiras medidas de impacto da nova diretoria da comissão foi a organização de uma "operação tartaruga", com o objetivo de obter aumento salarial e incorporação de benefícios aos rendimentos da classe. Cientes de que a empresa estava comprometida a atender a encomenda de uma série de vagões ferroviários, feitas pelo Uruguai, os trabalhadores diminuíram a produção a $30 \%$ de seu potencial. A direção se viu obrigada a ceder a pressão de seus empregados, sob a pena de perder futuras concorrências. Embora as reivindicações não tenham sido atendidas em sua completude, o movimento foi considerado um sucesso, fortalecendo o prestígio da nova diretoria da comissão.

A essa altura o GO já era hegemônico no ME da cidade, e possuía influência dentro do aparato político municipal. O controle do principal aparelho de base do MO local representou um salto qualitativo nas pretensões hegemônicas do movimento. A conquista do SMO se apresentava como a oportunidade de dar ao grupo a posição de principal força política regional em oposição a ditadura. De uma articulação formada a partir de estudantesoperários, o GO agora se via na iminência de se consolidar como um contra-poder local, num contexto em que se previa o acirramento das lutas sociais no país. Sobre o debate interno que a nova situação propiciou, comenta Roque Aparecido da Silva:

297 "Durante um certo tempo a comissão ficou "perdida", mas internamente travou-se uma luta entre uma posição passiva, que na prática aceitava ser apenas uma comissão de "leva e trás", jogando quase que um papel de relações públicas da empresa, e outra, que buscava enfrentar o problema, saindo do imobilismo e daquela dinâmica que resumia a atividade da comissão às reuniões preparatórias de pauta e depois com os patrões, sem participação e mobilização da base” IBRAHIM, José. Op. Cit. p. 56 
(...) em 67 teve a eleição no sindicato, e a gente organizou a Chapa Verde, a chapa de oposição, e aí, inclusive, houve uma discussão muito importante que a gente fez dentro do Grupo de Esquerda, porque a gente considerava o sindicato importantíssimo, porém, não era o instrumento mais importante para a luta política, para a luta revolucionária que a gente estava organizando. E aí, nas condições de ditadura, a gente decidiu que o Ibrahim, principal liderança da Cobrasma, a maior fábrica da cidade, integraria a chapa. Os outros não, por que era mais importante continuar o trabalho de base e não se expor tanto, já dentro da perspectiva de consolidação de uma atividade clandestina. Só que a gente não abria mão que o Ibrahim fosse presidente, ele era a única pessoa que a gente indicava, mas tinha que ser para presidente. Conseguimos isso sem muita dificuldade, realizamos alguns seminários para montar o programa da chapa, para organizar a coisa toda, enfim. Nisso participávamos nós também, os outros integrantes do Grupo de Esquerda, mas nós não expúnhamos todo mundo ${ }^{298}$.

Uma vez definida a composição de forças, as chapas em disputa pelo SMO se inscreveram para o pleito. Formaram-se três correntes, as duas supracitadas, e uma terceira, constituída com o propósito de dividir as forças de oposição e beneficiar os situacionistas. Essa chapa tinha a frente Jeremias Miranda, espécie de candidato "laranja", sem pretensão alguma. A chapa da situação foi a Azul, encabeçada por Henos Amorina, congregando as forças do "velho sindicalismo", somado a novos quadros que ascenderam no período pós intervenção. A oposição se reuniu na Chapa Verde, a única a trazer uma proposta efetivamente alternativa para o sindicato, congregando frentistas (majoritários na composição), o GO e independentes. Vejamos suas propostas:

1 - Lutar pela revogação da Lei 4.725 (lei do arrocho salarial), Lei 4.330 (lei antigreve) e de todas as leis que contrariavam o interesse da categoria;

2 - Lutar pelas liberdades sindicais, aumento de suas prerrogativas e sua desvinculação do governo;

3 - Lutar pela reformulação da estrutura sindical brasileira;

4 - Maior participação dos associados na vida do sindicato através da criação das comissões de empresa;

5 - Lutar pela maior participação dos trabalhadores na vida política do País;

298 Embora Ibrahim fosse o único membro do GO na Chapa Verde, outros componentes, sob influência do grupo, saíram candidatos pela chapa. Entrevista de Roque Aparecido da Silva ao autor, 05/11/2008. 
6 - Lutar por uma rigorosa regulamentação da influência do capital estrangeiro no País;

7 - Preparação da categoria para futuras campanhas salariais;

8 - Lutar contra a constante alta do custo de vida ${ }^{299}$.

A contundência das propostas da Chapa Verde, ia de encontro mais a proposições do GO, que da FNT, contemplada em menos itens. Notem que o programa dessa corrente tocava no cerne da política sindical da ditadura, era de um radicalismo surpreendente dentro de um regime autoritário. Registre-se que nessa etapa ainda vigorava o período de "afrouxamento" posto em prática pelo general Costa e Silva, eleito em março desse ano. Essa distensão também se aplicou ao meio sindical, e algumas medidas de cunho liberalizante abriram espaço para o avanço das oposições sindicais ${ }^{300}$.

O jogo de poder entre os componentes da corrente de oposição já se delineava antes mesmo de sua vitória. Para os frentistas, era interessante ter a figura de José Ibrahim como principal candidato, pois se tratava de uma jovem liderança, com popularidade crescente no município. Contudo, as pretensões hegemônicas dos frentistas eram evidentes, sendo os mesmos maioria entre os 24 membros inscritos para o pleito a ser realizado em junho. O GO, por sua vez, deveria contar com a representatividade do posto máximo na diretoria do SMO, assentado sobre uma estrutura que tradicionalmente dilatava as prerrogativas do presidente da entidade, algo, aliás, comum no meio sindical brasileiro. Os membros da Frente contavam com sua posição de maioria, o GO apostava suas fichas na centralidade que o controle da presidência do sindicato poderia proporcionar a seu movimento. As duas tendências alimentavam a pretensão de direcionar o MO da região em direção as suas concepções. Outro ponto a se destacar é a supremacia da comissão de fábrica da Cobrasma na Chapa Verde,

299 IBRAHIM, José. Op. Cit. p. 63

300 O Ministério de Trabalho de Costa e Silva pôs em marcha uma política de "renovação sindical", promovendo a ascensão de novas lideranças alinhadas ao regime. Para tanto, proliferaram cursos de "reeducação" sindical, e distribuição de apostilas com os ditames do governo militar. Outra medida foi o incentivo a formação de novas entidades, entre "1967-1968 854 novos sindicatos urbanos foram criados e 464 sindicatos rurais foram organizados legalmente (...), era do interesse do Estado de Segurança Nacional organizar um grande número de sindicatos, às vezes com apenas 100 membros. Estes "sindicatos fantasmas" assegurariam o controle governamental das confederações". Essa estratégia foi bem sucedida nos principais polos industriais do país, mas em certas regiões não se efetivou, como Osasco e Contagem. A maior abertura a participação de novos grupos no meio sindical acabou cedendo espaço para as oposições. MOREIRA ALVES. Maria Helena. Op. Cit. p. p. 146-154 
estando a mesma representada por quinze membros do colegiado.

As eleições foram realizadas entre os dias 14, 15, e 16 de junho de 1967, obtendo a Chapa Verde mais de $50 \%$ dos votos no primeiro escrutínio, dispensando a necessidade de um segundo turno. O grupo vencedor saiu derrotado em todas as empresas de Osasco, a exceção da Cobrasma, onde obteve cerca de $95 \%$ dos votos. Há que se salientar que $80 \%$ dos sócios do SMO eram empregados da Cobrasma. Na nova diretoria eleita entre os vinte e quatro membros da direção (composta por sete funcionários, com um único diretor não pertencente à Cobrasma e sua comissão de fábrica) a FNT detinha maioria das cadeiras.

Um ponto de intersecção aproximava as tendências vencedoras, internas a Chapa Verde, a formação de comissões de fábrica em todos os espaços laborais em que houvesse condições. Ao menos duas foram legalizadas pelas diretorias de suas respectivas empresas, na esteira do prestígio obtido pelo aparelho de base Cobrasma. Não obstante, tais organismos jamais obtiveram a influência e a representatividade de seu similar mais longevo. As empresas que legalizaram as atividades de suas comissões foram a Brown Boveri, sob influência frentista, e a Lonaflex, a partir de articulações promovidas por Manuel Dias do Nascimento, membro do GO.

Outro mecanismo utilizado pelo GO para popularizar suas propostas foi a formação das vanguardas operárias, sobre a constituição desses grupos, comenta José Ibrahim:

A gente partia do princípio de que em cada fábrica a gente teria que ter um pessoal organizado, normalmente seriam grupos clandestinos, ou seja, não poderiam aparecer pois tinham que fazer um trabalho interno. E era assim, que tipo de trabalho? Sindicalizar, pra gente acumular força no sindicato, fazer o trabalho político pra politizar o pessoal. Na medida em que as pessoas fossem aparecendo como pessoas mais politizadas, interessadas em participar da luta, nós trazíamos para o grupo, era um trabalho natural. Nas assembleias do sindicato a gente já identificava as pessoas, o cara pedia a palavra na assembleia, nas falações, já chamava a atenção da gente. Uma coisa é você ir com a plateia, outra coisa é você se manifestar, dar sua opinião, essas coisas todas. Então a gente ia conhecendo as pessoas, ao mesmo tempo tinha o pessoal que fazia o trabalho de fábrica, então a gente foi ampliando, a Cobrasma era o grupo principal, mas tinha a Braseixos, tinha a Brow Boveri, a Lonaflex (... $)^{301}$.

301 A formação das "vanguardas", para o GO, além de obedecer a motivos estratégicos, também obedecia a um princípio tático, pois era uma forma de contornar a posição minoritária do grupo na diretoria do SMO. José Ibrahim afirma que as vanguardas, sob orientação do GO, chegaram a 250, 300 operários. Já Antônio Roberto Espinosa afirma que sob a batuta do GO, organizaram-se cerca de 400 operários, sendo que na condição de "vanguarda operária" se encontravam cerca de 600 trabalhadores na cidade. Segundo seu relato, a formação de "vanguardas" não foi exclusividade do GO, outros grupos, como os cristãos (FNT, ACO e JOC) também constituíram bases de apoio mais ativas no município, além de grupos menores, como alguns 
Desde o início dos trabalhos da nova Chapa, procurou-se imprimir a entidade representativa dos metalúrgicos da região um modelo democrático de gestão, onde a administração "era exercida de forma coletiva, sem distinção entre efetivos e suplentes". O novo modo de gestão tinha como núcleo decisório um "conselho político", formado pelos diretores do sindicato; diretores das comissões de fábrica da Cobrasma, Brow Boveri e Lonaflex, mais os operários "vanguardistas" de atividade reconhecida. "A burocracia do sindicato foi reorganizada de tal modo a liberar os diretores única e exclusivamente para a atividade sindical" ${ }^{\prime 302}$. Nesse ambiente de democracia ampliada, as decisões não passíveis de acordo ao nível da diretoria passaram a ser discutidas em assembleias sindicais, com direito a ampla participação dos presentes. Tal medida, proposta por Ibrahim, desagradava sobretudo os remanescentes do velho sindicalismo, acostumados ao esquema cupulista. As realização de assembleias se tornou uma praxe em Osasco, medida que claramente beneficiava as posições do GO, em meio a um descontentamento crescente por parte do MO.

O SMO começou consolidar sua diferenciação em relação aos demais sindicatos da grande São Paulo a partir da campanha salarial de 1967, posta em prática em outubro. Os patrões acenaram com um reduzido aumento, pautado pelos índices de reajuste estabelecidos pelo governo, também chamados de tabelinha, dando prosseguimento a politica de arrocho salarial. Os valores estabelecidos pelo patronato não foram aceitos pelos trabalhadores, e a questão foi a dissídio coletivo, a ser decidida pela Justiça do Trabalho. O SMO se recusou a participar do dissídio, alegando se tratar de um "jogo de cartas marcadas", visto que as decisões do TRT sempre "pendiam para o lado" das classes produtoras. Embora não houvesse condições de se organizar uma paralisação, os metalúrgicos de Osasco se declararam "em estado de greve", em protesto contra o "arrocho salarial". O patronato local foi ao dissídio a revelia do sindicato.

A decisão dos trabalhadores osasquenses foi referendada pelas demais oposições operárias de São Paulo, contudo, tais correntes possuíam pouca influência junto a suas respectivas entidades representativas. Destarte, o único sindicato a se abster do dissídio, marcando uma posição protesto, foi o SMO. A direção dos metalúrgicos de São Paulo aventou a possibilidade de se chamar uma greve para o dia 17 de novembro, caso o dissídio não fosse julgado pela Justiça do Trabalho nessa data. Mas o dissídio foi julgado dentro do prazo, e o

partidos de orientação trotskista; ativistas ligados a Polop, e alguns membros da AP, correntes que tinham reduzida atuação em Osasco

302 IBRAHIM, José. Op. Cit. p. 64-65 
aumento concedido foi de $26 \%$. O valor reivindicado pela categoria era de $56,7 \%$.

O descontentamento dos trabalhadores deu ensejo ao fortalecimento das oposições operárias, únicos movimentos a propor um combate efetivo as medidas recessivas do regime. Mesmo as lideranças mais comedidas concluíram que as tensões tendiam a se intensificar, por isso buscaram novas formas de pressão, de modo a resistir ao arrocho salarial crescente imposto pelos patrões, e canalizar a revolta dos trabalhadores. Com essa proposta, foi criado o MIA (Movimento Sindical Anti-Arrocho), formado a partir de lideranças do sindicalismo paulista. $\mathrm{O}$ objetivo da nova sigla era efetuar um combate moderado à política salarial do governo, através de abaixo-assinados e concentrações operárias, sempre obedecendo aos princípios da legalidade. O MIA foi organizado em meio as negociações salariais de novembro de 1967.

Seguindo sua proposta de luta, os articuladores do MIA programaram uma série de concentrações, reunindo os trabalhadores em eventos que tinham por meta discutir a construção de mecanismos legais de combate ao arrocho. O primeiro encontro foi marcado para finais de novembro de 1967, na sede do Sindicato dos Metalúrgicos de São Paulo, o segundo para Santo André, o terceiro para Osasco, o quarto para Campinas, e o seguinte para Guarulhos $^{303}$. Desde a primeira reunião do novo movimento ficaram claras as divergências entre sindicalistas moderados e combativos. De um lado o grupo de Joaquinzão, com sua programática conciliatória, de outro, as oposições sindicais.

Além dos rumos a serem tomados pelo MIA, também se chocavam duas concepções sindicais distintas. De um lado, o sindicalismo tradicional paulista, de outro, uma nova geração em busca de meios mais efetivos de pressão frente ao patronato e ao regime. Estipulou-se entre o colegiado de dirigentes que apenas os diretores falariam nas assembleias, mas já no primeiro encontro Ibrahim quebrou o protocolo. Segundo relato do mesmo, na “primeira assembleia, realizada no Sindicato dos Metalúrgicos de São Paulo, eu não era orador escrito. No entanto, a massa obrigou a mesa a me dar a palavra. Falei cinco minutos, e chamei um companheiro do plenário para falar outros cinco minutos, protestando contra a decisão de só dar a palavra a dirigentes sindicais. Começou aí nosso rompimento com o esquema oficial" 304 .

303 Entrevista de José Ibrahim para a revista Unidade e Luta. Apud: FREDERICO, Celso. Op. Cit. p. 215-216 304 “ (...) Esta reunião teve um caráter eminentemente político, menos por vontade de seus diretores que pela presença dos estudantes (UNE e UEE) e dos operários de Osasco, somados às "oposições" dos metalúrgicos e bancários de São Paulo. A mesa diretora foi obrigada a aceitar sob pressão do plenário o direito de Ibrahim ao uso da palavra (...). Noutra oportunidade teve que aceitar, nas mesmas condições, a palavra do presidente da UNE (Luís) Travassos. E ao final da reunião houve um terceiro incidente quando o presidente dos 
A concentração realizada em Osasco, em dezembro de $1967^{305}$, realizou-se sob comando absoluto das oposições sindicais, com amplo espaço para participação estudantil. Os dirigentes comprometidos com a legalidade se recusaram a se pronunciar, ficando o ato restrito as correntes mais radicais. Foi lida a "Carta de Princípios dos Trabalhadores de Osasco", com ampla aprovação dos presentes, e foi proposta a criação de uma "Central Única dos Trabalhadores". Também foi convocada a construção de uma grande manifestação contra a ditadura, a ser realizada no dia $1^{\circ}$ de Maio do ano seguinte. Após essa reunião, Osasco se firmou como o principal polo de oposição ao regime militar no estado de São Paulo. Nesse meeting também começou a se fortalecer o projeto de construção de uma frente operário/estudantil, tema visto na última seção. Após essa assembleia vieram a tona divergências inconciliáveis entre as tendências que se articulavam dentro do MIA. Não foram convocadas novas concentrações, após esse evento, as duas tendências internas ao movimento passaram a se concentrar na organização do ato a ser realizado no Dia dos Trabalhadores de 1968.

O radicalismo de José Ibrahim nas reuniões do MIA chamou a atenção dos órgãos de repressão, ficou patente que o sindicalismo praticado em Osasco fugia a domesticação imposta pela elite civil/militar aos trabalhadores. A resposta do patronato não tardou, e se efetivou via Delegacia do Trabalho. Foi orientado a diretoria do SMO a destituição do presidente da entidade, sob pena de intervenção caso o ultimato não fosse atendido. O núcleo decisório do sindicato manifestou solidariedade ao dirigente, e se recusou a destituí-lo, contudo, o debate sobre como proceder no caso de uma interferência direta sobre o SMO dividiu o colegiado. Na ótica de Ibrahim, toda a diretoria deveria se demitir em caso de intervenção. Mas tal proposta foi rechaçada pelos militantes da FNT, que defendiam a continuidade da gestão, mesmo que cerceada. Essa querela marcou a primeira divergência

metalúrgicos de São Paulo lia o texto do manifesto proposto pela mesa. Parte do plenário vaiava e gritava: "está fraco", "está frouxo", "a mesa é de pelegos". Sobre a participação de estudantes no evento, Joaquim dos Santos Andrade diz o seguinte, em entrevista ao jornal O Estado de São Paulo: "somos contra a política salarial do governo, contra ela lutaremos enquanto for possível (...). Estamos tão somente refletindo o pensamento do trabalhador médio brasileiro, que é um homem sério, com as responsabilidades, e não um diletante em política, romanticoide, que ainda não sabe o que quer e confunde efeito com causa". Para citação no corpo do texto: Idem, Ibidem; para a citação em nota: matéria da Folha de São Paulo, Apud: WEFFORT. Francisco. Op. Cit. p. 70-71; para a entrevista de Joaquinzão a Folha: LOPES, Carmem Lúcia Evangelho. Op. Cit. p. 151-152

305 Há uma divergência sobre o número de assembleias realizadas pelo MIA, na entrevista a revista Unidade e Luta (p. 216), Ibrahim diz que a reunião de Osasco foi a terceira e última manifestação da entidade parasindical, antes desta se realizara uma em Santo André, que terminou em uma passeata que percorreu a ruas do município. Já MIRANDA (p.155) e WEFFORT (p. 71), e LOPES (p. 153) dizem que houve apenas duas reuniões, sendo a segunda em Osasco. Não há divergência quanto ao fato da última reunião pública do MIA ter sido realizada em Osasco, em dezembro de 1967 
séria entre o grupo de Ibrahim e os frentistas.

A Delegacia do Trabalho acabou não cumprindo a risca suas ameaças, e a questão foi solucionada com uma suspensão de 15 dias para o presidente da entidade. Ao final de 1967, o SMO se encontrava isolado de seus congêneres estaduais, visado pela repressão, e sujeito a perseguições por parte da Justiça do Trabalho. Por outro lado, tal aparelho projetara o município de Osasco como um polo de contestação ao regime, o que não era pouco dentro de um Estado controlado por governo fortemente autoritário.

\subsection{A Greve de Osasco de 1968}

Em fevereiro de 1968, o periódico/panfleto Movimento Operário trouxe em seu segundo número a seguinte conclamação aos trabalhadores do município:

Companheiros, os patrões usam o desemprêgo como um fantasma para assustar, dividir e desmoralizar a classe operária. A gente precisa lutar contra essa divisão, trabalhar para organizar a classe, através dos comitês de empresa. A gente precisa mostrar para todos os companheiros quem é sempre o maior inimigo dos trabalhadores, e que por isso a gente não pode confiar em patrão nenhum. A única garantia que a gente pode ter contra o desemprego é nossa luta organizada.

Todos precisam entender que o desemprego é o companheiro diário do capitalismo. Que o desemprego só vai acabar quando a gente acabar com o capitalismo no Brasil. Quando a gente destruir o governo dos patrões, e puser no poder o governo dos trabalhadores, quer dizer, quando a organização dos trabalhadores armados tomar conta de tudo no Brasil.

O caminho da revolução dos trabalhadores passa pela guerra de guerrilhas, no campo, e na cidade, pela luta organizada, a partir das fábricas, dos trabalhadores contra os patrões. A revolução dos trabalhadores é feita com o fuzil e com o martelo. Por isso é preciso começar já a lutar pelos comitês de empresa que é a organização dos trabalhadores dentro da fábrica.

\section{UNÃO DOS TRABALHADORES CONTRA O DESEMPREGO! $!^{306}$}

O radicalismo presente no texto acima expressa bem o clima de um ano que se tornou célebre. Pelo conteúdo do panfleto, percebe-se que, ao menos no âmbito das vanguardas de esquerda, já se antecipavam meses turbulentos. Especialmente os segmentos engajados nos 
movimentos sociais tinham consciência disso. A política de arrocho salarial prosseguia, e poucas perspectivas de mudanças eram vislumbradas. O MO paulista e nacional se encontravam amordaçados e divididos, com poucos focos de contestação ao regime. A proposta do MIA já dava sinais de esgotamento, embora o Sindicato dos Metalúrgicos de São Paulo ainda insistisse em sua viabilidade, dentro de seu viés conciliatório. A militância radicada em Osasco, apesar de seu voluntarismo e disposição de luta, era apenas um foco de resistência em meio a um panorama de autoritarismo. Sua posição intermediária com relação aos demais centros industriais do estado não the garantia força suficiente para impulsionar a tênue oposição operária paulista, ofuscada pelo colaboracionismo do sindicalismo oficial. Para entender melhor essa fase, vamos a alguns números.

Tabela IV

Evolução do salário mínimo (1959-1970)

\begin{tabular}{|l|c|c|}
\hline \multicolumn{1}{|c|}{ Ano } & Salário mínimo real & Índice de salário real \\
\hline Janeiro de 1959 & $1.735,29$ & 100 \\
\hline Janeiro de 1960 & $1.204,03$ & 69 \\
\hline Janeiro de 1961 & $1.475,00$ & 85 \\
\hline Janeiro de 1962 & $1.406,38$ & 81 \\
\hline Janeiro de 1963 & $1.304,35$ & 75 \\
\hline Janeiro de 1964 & 724,14 & 42 \\
\hline Janeiro de 1965 & 840,00 & 48 \\
\hline Janeiro de 1966 & 849,42 & 49 \\
\hline Janeiro de 1967 & 744,02 & 43 \\
\hline Janeiro de 1968 & 737,88 & 43 \\
\hline Janeiro de 1969 & 732,62 & 42 \\
\hline Janeiro de 1970 & 724,91 & 42 \\
\hline
\end{tabular}

Fonte: DIEESE (Departamento Intersindical de Estatísticas e Estudos Socioeconômicos). Divulgação no 1/76, p. 10, 19 de abril de 1976. Apud: MOREIRA ALVES, Matia Helena. Op. Cit. p. 140. Dados parciais.

A tabela acima descreve em números o que os trabalhadores do período chamaram de arrocho salarial. Notem que em 1967 o valor do salário mínimo equivalia a 43\% de seu valor em 1959; no ano seguinte, a situação não se alterou, mas o rendimento nominal dos vencimentos foi ainda menor. Uma comparação entre o custo de vida e o salário médio da categoria dos metalúrgicos, indica que houve perda de $20 \%$ do poder aquisitivo na 
remuneração desse setor no ano de 1965; 25\% em 1966, 26\% em 1967, e 27\% em 1968. Esta tendência vinha desde a década anterior, mas depois de 1964 se intensificou ${ }^{307}$. Sabe-se que a média de inflação durante toda a década de sessenta esteve na casa dos 40\%, embora o governo tenha maquiado essas cifras. O poder de compra dos salários não acompanhava o ritmo da inflação, pauperizando amplos segmentos da classe trabalhadora, especialmente os setores menos qualificados ${ }^{308}$.

A política recessiva inaugurada com o PAEG tinha como principal sustentáculo a repressão as classes populares e o controle sobre os sindicatos. O saldo dessa política foi o aumento do desemprego, da carestia de vida, da miséria absoluta; acentuação do êxodo rural, trazendo consigo inchaço urbano e crescimento da violência. Estamos nos referindo ao ciclo 1964-1968, sendo que o auge da recessão do período se verificou no biênio 67/68, antecedendo o breve "milagre econômico", tema que discutiremos na próxima seção.

Uma análise sobre os índices sociais do município de Osasco descreve bem o ambiente de crise da fase em discussão. $O$ antigo subúrbio de São Paulo manteve suas características de periferia após sua emancipação, tendo em suas cercanias um núcleo urbano central, margeado por alguns bairros operários, sucedidos por áreas de ocupação recente, habitadas por moradores provenientes de regiões centrais da capital paulista, expulsos pelo aumento do custo de vida, e também por retirantes do interior do estado e de outras regiões do Brasil, especialmente do nordeste. $52 \%$ das famílias da cidade viviam com rendimentos que iam de 1 a 3 salários mínimos, nos valores da época. 50\% da mão de obra local era composta por trabalhadores não qualificados; $15 \%$ da população era analfabeta e 67,6\% tinha apenas instrução primária. 56,5\% das casas não eram servidas por água encanada e 77,1\% carecia de rede de esgoto. A população local girava em torno de 200 mil habitantes, sendo que a maioria trabalhava fora da cidade, característica que definia o município como "cidade dormitório". Esses números caracterizavam a localidade como uma região carente e com sérios problemas de urbanização ${ }^{309}$. Contra tal estado de coisas se batiam os vários movimentos sociais organizados em Osasco.

Vimos acima que as relações entre o SMO e a Justiça do Trabalho do sistema

307 LOPES, Carmem Lúcia Evangelho. Op. Cit. p. 23

308 "Na verdade, o "arrocho" não se fez sentir, igualitária e simultaneamente, sobre todos os níveis salariais, mas seletivamente, atingindo de modo muito mais grave os assalariados menos qualificados cujo nível de ganhos dependia, em maior grau, do poder de barganha da classe em conjunto." SINGER, Paul. A Crise do

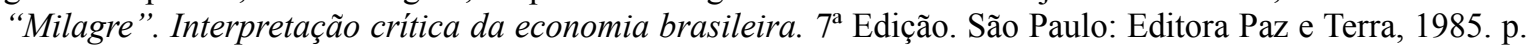
57-58

309 Plano Diretor Básico, Prefeitura do Município de Osasco (PMO) -1968. Apud: MOISÉS, José Alvaro. Op.

Cit. p. 300 
autoritário foram tensas em finais de 1967, e para o ano seguinte as perspectivas não eram animadoras. A partir de março, o levante estudantil ditou o ritmo de luta aos segmentos mais radicais da sociedade nacional. Aguardava-se algo semelhante por parte do MO, e de uma região com pouca tradição de lutas trabalhistas partiu o primeiro grande ato de insubordinação operária no ano de 1968.

Em 16 de abril de 1968 teve início a greve de Contagem, distrito industrial da região de Belo Horizonte, Minas Gerais. A parede furou o bloqueio imposto pela rígida política repressiva dos militares para com a classe trabalhadora. O movimento partiu da empresa siderúrgica Belgo Mineira, espalhando-se para toda a região, paralisando cerca de 16 mil operários. A principal exigência era um aumento de $25 \%$ sobre os salários. A greve foi efetivada a margem do sindicato, cujos dirigentes se disseram "pegos de surpresa". Seus promotores pertenciam as oposições sindicais mineiras. Na localidade já havia algum trabalho de mobilização de base, efetuado por comissões de fábrica clandestinas, e neste movimento também se verificou a participação de ativistas do ME. Para tratar com os grevistas foi designado o próprio Ministro do Trabalho da época, Jarbas Passarinho, que se dirigiu a região para negociar diretamente com os organizadores da parede.

(...) Pedi que representantes do sindicato viessem a Delegacia do Trabalho, para dialogarmos. A cada dia, e até mesmo no próprio dia, os representantes eram diferentes. Nenhum detinha função na Diretoria do Sindicato. Percebi, desde então, que eu ia trabalhar com sujeitos ocultos, isto é, sem contato com os verdadeiros líderes do movimento paredista. Durante oito dias, a greve não só perdurava, como crescia em termos de adesões de todos os metalúrgicos da cidade industrial de Contagem. Então, tomei a decisão de voltar a Brasília e expor ao Presidente Costa e Silva a situação como eu via. ${ }^{310}$

Passarinho considerou a greve justa, embora ilegal, retornou a Brasília e propôs ao presidente Costa e Silva um abono de $10 \%$ para os trabalhadores mineiros, proposta aceita pelo general. De volta a Contagem, o ministro negociou com os grevistas o valor estipulado junto ao mandatário da Nação, aquém do pretendido pelos operários. Em assembleia, decidiuse pela aceitação da proposta e pelo fim da paralisação. Em que pese o aumento abaixo do exigido, a parede foi considerada vitoriosa, e também foi vista como um marco no combate a ditadura. Para as oposições sindicais, o evento de Contagem foi encarado como um renascer 
do MO; para as classes patronais, como um ato de subversão que abria um precedente perigoso $^{311}$.

Em Osasco, a notícia da greve foi recebida com euforia, o exemplo de Minas Gerais demonstrava que era possível resistir ao arrocho salarial imposto pelos militares. Outro fator a motivar o MO local foram as peculiaridades da greve mineira, deflagrada a margem de um sindicato comprometido com o esquema oficial, organizada pela base, e com participação estudantil, ainda que reduzida. Osasco apresentava todas as condições para a construção de um movimento de maior abrangência. Em primeiro lugar por que o SMO se encontrava programaticamente vinculado às oposições sindicais paulistas, coisa que não acontecia em Minas Gerais; segundo, a movimentação de base do município era das mais fortes do país, algo que poderia facilitar na construção de uma greve; terceiro, havia um ME forte a atuante na cidade, com ligações orgânicas com o operariado local, disposto a colaborar em uma eventual paralisação; quarto, Osasco já assumira uma posição de liderança perante as oposições sindicais de seu estado, fator que poderia auxiliar numa possível expansão do movimento.

Essa percepção rapidamente se espalhou entre as vanguardas de fábrica da cidade, contagiando os trabalhadores locais. Some-se a tais fatores o acirramento das lutas estudantis de massa no país, em uma região que abarcava um ME em situação de radicalismo crescente, a essa altura já ocupado com a tarefa de construção de uma união operário-estudantil. De acordo com Roque Aparecido da Silva, a greve de Contagem "teve uma repercussão muito grande em Osasco, era um exemplo concreto de que era possível fazer greve e de que era possível conseguir uma vitória, porque eles ganharam 10\% de aumento. Aí começou haver também uma cobrança do pessoal mais de vanguarda nas fábricas, "pô, como é que é? Vocês falam, falam, e não acontece nada... Vocês são igualzinho aos outros, não fazem nada, cadê a nossa greve? Minas faz e a gente não faz nada..."”312.

Outro evento a acirrar os ânimos da classe operária osasquense foi o célebre protesto de $1^{\circ}$ de Maio na Praça da Sé (ver capítulo anterior), acontecimento que obteve repercussão nacional. Nessa etapa, organizações como a futura a VPR, a futura ALN, AP, grupos trotskistas, além do já consolidado GO, difundiam ideias de caráter insurrecional entre

311 Jarbas Passarinho comenta em suas memórias que leu em um jornal do Rio de Janeiro fortes críticas a respeito de sua atuação junto aos grevistas de Contagem, feitas pelo presidente da Federação das Indústrias desse estado, que o acusou de "ceder demagogicamente à pressão subversiva, comprometendo a política salarial da Revolução”. Idem, p. 181

312 Entrevista de Roque Aparecido da Silva ao autor, 05/11/2008 
estudantes, operários, e estudantes-operários do município. Até mesmo as correntes católicas de esquerda, com presença marcante na cidade, mostravam-se impacientes perante as medidas recessivas do regime militar. A ideia da urgência de uma greve por aumentos reais de salário passou a se fazer presente entre bases, com intensidade crescente.

Mas o clima de tensão social não se apossou apenas dos operários da cidade, entre a classe patronal também se observou tal fenômeno. O temor de um retorno as grandes mobilizações pré 1964 se tornou real entre a os industriais, havia a perspectiva de que se a onda de protestos empreendida pelos estudantes também contagiasse os demais segmentos sociais, especialmente a classe trabalhadora, o regime estaria em perigo. A greve de Contagem pôs a burguesia industrial em estado de alerta, levando a mesma a cobrar dos aparatos da repressão estatal a intensificação da vigilância sobre as regiões de maior movimentação "subversiva".

José Ibrahim comenta que o assédio dos patrões contra os trabalhadores organizados em Osasco se tornou mais agressivo após o $1^{\mathrm{o}}$ de Maio. Embora o ato tenha contado com a participação das oposições sindicais de toda a cidade, os ativistas osasquenses foram considerados, tanto pela elite industrial do estado, quanto por seus representantes na mídia e no meio político, como os responsáveis pelo protesto. Entre maio e julho a diretoria do SMO esteve sob a iminência de uma intervenção. Havia a percepção de que mais cedo ou mais tarde a direção do sindicato seria deposta. Mas os industriais da região sabiam que o núcleo organizacional dos trabalhadores não estava nesse aparelho, e sim nos movimentos de base. Exatamente por isso iniciaram um processo de desmantelamento das comissões de fábrica, especialmente na empresa que desde a década anterior havia se convertido no centro da política operária da região.

Os diretores da Cobrasma, que sempre defenderam a idéia de representação dos operários dentro da fábrica para o diálogo e negociação, começaram a perder influência nas diretrizes da empresa. Nesse momento ganhavam maior espaço aqueles que defendiam o reestabelecimento da disciplina dentro da fábrica, o respeito a hierarquia; diziam que a Cobrasma havia criado um monstro que agora a engolia e que era necessário desativar a Comissão, pois o sindicato preparava uma greve para novembro ${ }^{313}$.

313 "Entre abril e maio, a diretoria da Cobrasma deu um passo mais arrojado no seu objetivo de desestabilizar a Comissão, dispensando dois de seus membros eleitos e que tinham estabilidade (...)". IBRAHIM, José. Op. Cit. p. 68-69. O principal líder do setor "duro" dentro da administração da Cobrasma era Luís Eulálio de Bueno Vidigal, filho do fundador da empresa, Gastão Vidigal. Segundo Ibrahim, Luís Eulálio era chamado por seus pares, "a boca pequena", de "moleque fascista". Outro filho do fundador da Cobrasma, o banqueiro 
Em meio ao desmonte do diálogo interclasses em Osasco eclodiu a greve da Barreto Keller, empresa de materiais elétricos de médio porte, nessa época empregando cerca de 150 funcionários. O movimento ocorreu devido ao não cumprimento por parte da direção da fábrica de um acordo, estipulado entre trabalhadores e patrões, que previa para junho um reajuste, mais equiparação salarial entre os diversos setores da produção. Em resposta a quebra do acordo, os empregados da firma decretaram greve. O não cumprimento do acertado na Barreto Keller se deu por pressão da classe patronal da cidade, havia o temor de que o reajuste conquistado nessa empresa estimulasse os operários das demais fábricas do município a também exigir aumentos salariais. O SMO assumiu a parede, e um movimento de solidariedade a paralisação empolgou os trabalhadores da região. Perante a força da greve, a diretoria concedeu um aumento de $15 \%$ a seus funcionários, e ainda legalizou a comissão de fábrica da empresa, órgão responsável pela organização do movimento paredista.

A vitória dos trabalhadores da Barreto Keller elevou a temperatura do MO osasquense, a pressão por parte das bases tornou inadiável a deflagração de uma greve. As oposições sindicais metalúrgicas estavam se articulando para iniciar um grande movimento a partir de novembro, época da data base da categoria, mas o operariado de Osasco não se mostrava disposto a esperar até o fim do ano. Pichações conclamando a greve se espalharam pela cidade, membros das vanguardas de fábrica passaram a fazer pressão junto a diretoria do SMO, e debates em torno de uma possível paralisação se tornaram comuns entre os empregados das empresas do município. A se somar a esse estado de coisas, a perspectiva de uma dissolução da Chapa Verde, cada vez mais forte entre seus componentes.

Nesse panorama, começou a ser preparada em junho uma paralisação a ser desencadeada no mês seguinte. A organização coube ao GO, na diretoria do sindicato, a articulação ficou por conta de José Ibrahim; nas comissões de fábrica, reconhecidas ou não, aos demais militantes do grupo. A construção da parede também contou com o apoio das vanguardas de fábrica, e ativistas mobilizados no CEO. Na seção anterior vimos que dias antes do deflagrar do movimento já havia sido acertado o dia e a hora de seu início, e o nível da organização foi tal, que o panfleto com o informe sobre a eclosão da greve foi confeccionado de antemão. Essas informações desmentem a tese de Francisco Weffort, acerca do caráter espontâneo do

Gastão Eduardo de Bueno Vidigal, foi um assíduo colaborador da OBAM (Operação Bandeirantes), sendo um dos principais arrecadadores de fundos para a operação. Além do supracitado livro de Ibrahim, para obter mais informações sobre as relações entre os proprietários da Cobrasma e o sistema repressor, consultar: MOTTA, Antônio Carlos Casulari Roxo. Op. Cit.; especialmente os três capítulos iniciais da tese. 
evento $^{314}$.

Sobre a costura da greve na diretoria do SMO, relatos indicam que os componentes da FNT só souberam de seus preparativos as vésperas da deflagração do movimento, fato que suscitou um intenso debate interno entre os frentistas. Uma parte da Frente cristã defendia uma greve de advertência, com duração determinada, outra parcela do grupo refutou por completo qualquer articulação paredista. Porém, perante o assédio a comissão de fábrica da Cobrasma e demais aparelhos de base, mais a ameaça de intervenção no sindicato, a porção maior dos frentistas se viu instigada a aderir a paralisação, uma vez que viam seus trabalhos pastorais ameaçados ante a ofensiva do sistema. Ainda sobre o planejamento da greve, Espinosa afirma que:

(...) o planejamento da greve de Osasco começou a partir do GO, se expandindo para as vanguardas de fábrica, e o pessoal do resto da diretoria, que era da FNT, um pessoal mais devagar, mais cristão, só ficou sabendo ao longo do processo da preparação, ficaram sabendo no final, quando já não tinha mais jeito. Na própria massa foi feita uma campanha genérica da greve, mas não foi marcado um dia, não foi antecipado como seria a greve, ela era um segredo de Estado. ${ }^{315}$

A organização central da greve foi discutida entre o núcleo dirigente do GO, onde foi estipulado que o movimento deveria assumir contornos insurrecionais. A paralisação de julho se somaria a rebelião estudantil em voga desde março, cedo ficou claro ao grupo que essa parede seria um desafio direto a ditadura. $\mathrm{O}$ apoio estudantil foi garantido entre a UNE, UEE, e secundaristas. Também se contava com a adesão de outros centros industriais de São Paulo,

314 O "caráter espontâneo" apontado por Weffort se aplica mais em termos sociológicos, Ricardo Antunes, citando Gramsci, comenta que movimentos espontâneos são aqueles que "não são devidos a uma atividade educadora sistemática por parte de um grupo dirigente já consciente, senão formados através da experiência cotidiana iluminada pelo senso comum, ou seja pela concepção tradicional popular do mundo, coisa que muito vulgarmente se chama "instinto" e que não é senão também uma aquisição histórica, só que primitiva e elementar". Situamos o GO, movimento a liderar a Greve de Osasco, a meio caminho de uma direção efetivamente "consciente", a "atividade educadora sistemática" salientada por Gramsci ainda se encontrava em fase de construção entre os operários osasquenses, embora muitos destes tenham frequentado os cursos de iniciação ao marxismo propostos pelo Grupo de Osasco. A própria consciência dos dirigentes da greve de julho encontrava-se em fase de formação, sempre lembrando a pouca idade e a pouca experiência desses ativistas, especialmente no que respeita a construção de um movimento com tantas pretensões. O nível de politização presente entre os quadros dirigentes do GO ainda era incipiente na massa operária, instintivamente disposta ao combate, mas com pouca clareza sobre suas implicações. Isto posto, o "espontaneísmo" ideal indicado por Weffort deve ser matizado, visto que em termos tático-estratégicos, a greve foi construída e dirigida por um grupo articulado e ideologicamente coeso. Para inferências de Weffort: WEFFORT, Francisco. Op. Cit. p. 51. Para citação de Gramsci, GRAMSCI, Antonio. "Espontaneidad y Dirección Consciente", in: Antonio Gramsci: Antologia. Sacristan, M (org). Apud: ANTUNES, Ricardo. Op. Cit. p. 194-195.

315 Entrevista de Antonio Roberto Espinosa ao autor, 09/06/2008 
impulsionando um movimento que deveria se tornar nacional. Ao menos eram essas as pretensões.

Olha, nós definimos uma estratégia, e aí era papel meu, pois eu era o presidente do sindicato, a pessoa que conhecia a maioria ali dentro, como liderança no movimento. Nós decidimos que iríamos nos articular com outros setores fora de Osasco e fora do estado de São Paulo, nós definimos que essa articulação seria com Minas Gerais e Rio de Janeiro. Em São Paulo nós nos articulamos com a capital, que tinha uma oposição metalúrgica, e uma oposição bancária; com o ABC, onde a $\mathrm{AP}$ era bastante forte, com São Bernardo e Santo André, e com a Baixada Santista. E eu cumpri esse papel, primeiro eu fui para Minas, conversar com os companheiros que tinham feito a greve de Contagem, em abril, eu fui lá em maio de 68, depois do Primeiro de Maio. Fui pro Rio de Janeiro, num encontro intersindical que teve lá, fui pra baixada, conversar com os petroleiros, com os metalúrgicos, com o pessoal da Cosipa. E era isso, nós estávamos nos organizando pro confronto, pra greve que nos íamos desencadear a partir de Osasco, e que, primeiro, eles tinham que ter essa informação, trabalhar com ela; e segundo, que capacidade eles teriam de se solidarizar com o nosso movimento, de participar. ${ }^{316}$.

Sobre o processo de construção da greve, comenta Stanislau Zermeta:

Quando a greve é organizada, poucos sabem dentro da diretoria, mas quando se espalha que a greve aconteceria, aí... O processo de organização da greve foi um processo mais ligado a uma visão necessária naquele momento, por que não dava pra você chegar, como hoje se faz, chegar numa assembleia, marcar a greve, levar a pauta e detonar o processo, lá não foi assim, primeiro se começou a construção da greve, então em todas as empresas em que havia setores organizados se sabia que a greve se realizaria ${ }^{317}$.

Estando tudo acertado, marcou-se o início da greve para as 8:30 do dia 16 de julho de 1968, uma terça-feira. A primeira empresa a parar seria a Cobrasma, coração do MO local, as demais firmas parariam em sequência, de acordo com suas respectivas mobilizações internas. A senha para o início da paralisação seria o soar do apito da fábrica, acionado em horário inusual. O primeiro setor a cruzar os braços, na Cobrasma, seria o de "limpeza e acabamento", uma vez que

316 Entrevista de José Ibrahim ao autor, 27/01/2009

317 Entrevista de Stanislau Zermeta ao autor, 04/11/2008 
se tinha ali um trabalho mais forte, e se tinha também um maior grau de revolta, a gente tinha certeza que ali seriamos mais bem sucedidos, o erro seria pequeno. E dali o pessoal foi seção por seção, foram para as portarias da Cobrasma, onde estavam os guardas, que foram desarmados, e os trabalhadores ocuparam as portarias. Havia ali dentro quatro mil trabalhadores, que precisavam comer, então tomamos conta do restaurante, do refeitório, organizando os banheiros, papel higiênico, era uma operação complicada. A estratégia em grande parte foi montada levando em conta o que havia acontecido em Contagem, em Minas a repressão tinha levado dez dias para intervir. Então, nos nossos cálculos, levaria alguns dias, pelo menos uma semana, para que a repressão interviesse, e esse tempo seria suficiente para que todas as seções transformassem os seus equipamentos naturais em armas. Uma fundição, por exemplo, tem forno de metal de dois mil e quinhentos graus centigrados, pontes rolantes que passam por cima, esteiras que passam por baixo do chão, tudo isso pode ser levantado via ponte rolante, você cria verdadeiros precipícios dentro de uma fundição, e os operários conheciam isso muito bem, a repressão não. Havia mil coisas que poderiam ser transformadas em armas, e isso aconteceria $^{318}$.

O SMO imediatamente reconheceu a legitimidade da greve, e a encampou como sua. Precipitado o movimento, iniciou-se a expectativa de novas adesões, a se efetivarem ao longo do dia. As reivindicações dos grevistas foram expostas no informe apresentado abaixo, distribuído em Osasco.

Companheiros: estamos em greve a partir desse momento, por justas reivindicações. Só obteremos a vitória se permanecemos unidos, tomando as mesmas decisões. Da unidade de nosso pensamento e da nossa ação em conjunto é que depende a nossa vitória.

As nossas reivindicações são: a) $35 \%$ de aumento sobre o salário, b) aumento de salário de $3 \mathrm{em} 3$ meses, de acordo com o custo de vida, c) contrato coletivo de trabalho, legalizado na Justiça do Trabalho, d) problemas específicos das seções, e) segurança absoluta para os grevistas.

Vamos tomar as nossas decisões reunidos em assembléia permanente dentro da fábrica. A vitória tem de ser total. Chega de migalhas insignificantes. Nossa união mostrará que estamos dispostos a exigir nossos direitos. A fome está em nossas casas, nos nossos filhos. Precisamos vencer. Sabemos que lutar isolado é inútil. Juntos venceremos.

A união faz a força, a força faz a vitória ${ }^{319}$.

318 Entrevista de Antonio Roberto Espinosa ao autor, 09/06/2008

319 Panfleto presente no CDHO (Centro de Documentação Histórica de Osasco) da UNIFIEO. Apud: JESUS, Paulo Sérgio de. Op. Cit. p. 46. Não tivemos acesso ao manifesto entregue ao ME, redigido dias antes do deflagrar do movimento 
Embora a greve tenha tido caráter insurrecional, segundo seus próprios organizadores, suas exigências trouxeram apenas exigências corporativas, sem conteúdo político. Não obstante, as exigências tocavam no cerne da política salarial da ditadura, especialmente em seus itens b e c. A guisa do ocorrera em Contagem, o movimento se efetivou com ocupação de fábrica, sobre a inspiração a ensejar esse procedimento, comenta Ibrahim:

(...) claro que (Contagem) influenciou, pois tinha tido uma experiência lá na Belgo Mineira, mas influenciou também o Maio de 68 na França, onde houve ocupações de empresas, principalmente do setor automobilístico francês, tudo isso influenciou. Mas na nossa cabeça também era assim, "pô, os caras vão invadir o sindicato, eles vão tentar prender toda a diretoria, nós temos que nos organizar dentro das fábricas pra segurar a greve, eles podem intervir, fechar o sindicato, prender parte das lideranças, e isso vai acontecer, mas se a gente tiver estrutura dentro das fábricas, a gente segura ${ }^{320}$.

Outra similaridade com o Maio francês foi uma suposta detenção de diretores dentro da empresa, fato controverso. Jarbas Passarinho, Ministro do Trabalho da época, ao tomar conhecimento das características do movimento de Osasco, concluiu que a greve possuía natureza “insurrecional”. Em suas memórias, Passarinho, valendo-se de seu pragmatismo e objetividade militar, conclui que Osasco seria

uma espécie de cabeça de ponte para a generalização da greve em São Paulo, (...) onde se situava a mais aguerrida liderança revolucionária, chefiada por um quase garoto que eu nunca vira. Pela primeira vez, (...) uma greve, além de piquetes, usava o modelo francês de ocupação da fábrica. E mais, muito mais: mantinha em cárcere privado duas dezenas de engenheiros e mestres. Chegara-nos um informe de gente infiltrada da polícia, de que um grevista, José Campos Barreto, que fora seminarista em Olinda, estava ameaçando incendiar o pavilhão em que se encontravam os técnicos confinados, pois estava com a chave de uma bomba de gasolina interna, situada embaixo do pequeno prédio $^{321}$.

320 Entrevista de José Ibrahim ai autor, 27/01/2009

321 Passarinho publicou suas memórias em 1996, não há como precisar se ele realmente se encontrava munido dessas informações no calor dos acontecimentos, e se sua percepção acerca da Greve de Osasco era de fato essa. Em todo caso, a rapidez implacável da dissolução do movimento confirma ao menos sua intuição quanto ao potencial de disseminação da greve. Na edição do jornal Última Hora do dia 17 de julho de 1968, há menção a uma greve em apoio a Osasco, realizada em Santo André, ainda no dia 16; há também informações sobre o início de uma ocupação do Sindicato dos Metalúrgicos do $\mathrm{ABC}$, por membros da oposição sindical local, movimentação rapidamente desbaratada pela repressão. Joaquim dos Santos Andrade, em depoimento a Carmem L. E. Lopes, afirma que reuniu uma comissão de dirigentes de vários sindicatos da grande São Paulo e se dirigiu a Osasco afim de saber que "medidas nós poderíamos tomar no sentido de nos solidarizar com os companheiros". José Ibrahim confirmou esse encontro a autora. A edição do jornal Folha de São Paulo, do dia 17 de julho de 1968, informava que em "São Paulo, o sindicato dos Bancários, dos 
Ainda na manhã do dia 16 de julho, cruzaram os braços os trabalhadores da Barreto Keller e da Fósforos Granada, empresa esta que "tinha uns 400 operários, dos quais cerca de 350 eram mulheres e menores" ${ }^{\prime 322}$. Com o serviço paralisado, os trabalhadores das duas empresas rumaram para o SMO, em passeata pelas ruas do município, portando cartazes previamente preparados pelos organizadores do movimento. Já no sindicato, os grevistas deram início a uma assembleia geral permanente. As catorze horas foi a vez da Lonaflex, empresa que possuía uma comissão fábrica reconhecida pela direção, e um diálogo satisfatório entre trabalhadores e patrões. Como mencionado, o principal representante do GO nessa firma era Manuel Dias do Nascimento, o Neto. Sobre o desenrolar da greve em sua empresa, Neto diz que:

Quando nós vamos parar, tivemos que mudar nosso discurso, de reivindicatório para solidário, porque a empresa já tinha nos proporcionado tudo aquilo que nós tínhamos reivindicado. Na questão interna, ela já (a direção da empresa) tinha se antecipado diante da greve, pois se via a movimentação, "olha, nós vamos dar tudo o que vocês quiserem, mas não parem, não tem que se envolver com isso". Aí, nesse dia, o discurso teve que mudar. Nós não tínhamos parado ainda, só pararíamos depois da Cobrasma. A Cobrasma parou, ao que me parece, as 8:45, 9:00 da manhã, enquanto nós, ninguém sabia; sabíamos nós, do comando de greve e do movimento, mas os trabalhadores não sabiam, nós

Têxteis e dos Metalúrgicos anunciaram sua solidariedade moral aos grevistas". Exemplar disponível em

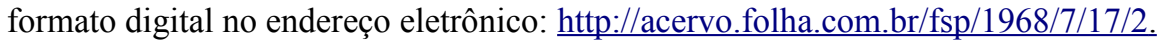

Com relação a detenção de diretores, Orlando Miranda afirma que os mesmos "se trancaram" no escritório da "oficina de modelação", temendo agressões por parte dos grevistas, pois se sabiam "detestados" pelos empregados da Cobrasma. Ainda segundo Miranda, a ameaça de incêndio no recinto onde "engenheiros e mestres" se encontravam acantonados não passou de uma brincadeira promovida pelos operários. Para o relato do ex-ministro: PASSARINHO, Jarbas. Op. Cit. p. 292; para edição do jornal Última Hora, de 17 de julho de 1968: http://www.arquivoestado.sp.gov.br/uhdigital/pesquisa.php; para visita de Joaquinzão a Osasco; LOPES, Carmem Lúcia Evangelho. Op. Cit. p. 156; para informações sobre os diretores "detidos": MIRANDA, Orlando. Op. Cit. p. 180-181. Ainda sobre tentativas de resistência por parte dos grevistas, em entrevista a Marcelo Ridenti, Antonio Roberto Espinosa afirma que "a ALN e, principalmente, a VPR iam fazer algumas ações durante a greve de Osasco, para interromper o funcionamento de energia elétrica nas fábricas. As ações acabaram não sendo fitas porque a greve se esvaziou antes". RIDENTI, Marcelo. Op. Cit. p. 50

322 "Através dos companheiros da Barreto Keller, que conheciam todas as meninas da fábrica, estabelecemos os primeiros contatos. A greve da Barreto Keller em fins de maio tivera grande repercussão na "Granada", onde existiam muitos problemas. A partir de então conseguimos montar um grupo dentro da empresa com as companheiras mais avançadas". A participação feminina na greve foi mais intensa na Fósforos Granada, na Cobrasma, funcionárias do refeitório aderiram ao movimento de modo a alimentar os operários entrincheirados na empresa. Também houve grande participação por parte de esposas de grevistas, organizadas numa "comissão de mulheres de sindicalistas", que teriam por meta divulgar o movimento junto a comunidade, e prestar assistência aos operários em greve. Informações sobre a paralisação na Fósforo Granada, consultar entrevista de José Ibrahim a revista Unidade e Luta, In: FREDERICO, Celso. Op. Cit. p. 226; sobre a participação das mulheres no evento: Revista Visão Trabalhista, editada pelo Sindicato dos Metalúrgicos de Osasco e Região, suplemento especial em comemoração aos 40 anos da Greve de Osasco, julho de 2008. Disponível em formato digital no endereço eletrônico: http://50anos.sindmetal.org.br/pdfs/40AnosGreve.pdf 
paramos as 14:00. Tava programado para as 14:00, paramos dez pras duas, as 13:50, em virtude da troca de turno, pois eram três turnos, então, na troca dos dois turnos, que eram os maiores, o da manhã e o da tarde, onde se concentrava o maior número de trabalhadores, nós paramos. Já com o discurso de ser solidário, (...) nos concentramos mais nas questões diretas, não colocamos o discurso político por que nós não tínhamos estrutura para fazer isso com os trabalhadores $(\ldots)^{323}$.

A essa altura o ministro Passarinho já havia declarado a greve ilegal, decretado uma intervenção no SMO, e designado representantes de seu ministério para irem até Osasco negociar com os paredistas. Houve uma tensa discussão entre José Ibrahim e os "Vidigal", proprietários da Cobrasma. Os representantes do Ministério do Trabalho apresentaram propostas "bastante conciliatórias", segundo Ibrahim, mas já havia sido acertado que os rumos do movimento seriam discutidos dentro da fábrica ocupada, em assembleia, diretamente com os trabalhadores, agora senhores da situação. No pátio da empresa, entre os amotinados, o "representante do Ministério do Trabalho tentou defender as leis do governo, (...) e recebeu uma vaia estrondosa. Os operários começaram a gritar: "não vai sair, não vai sair" e ele acabou criticando alguns aspectos das leis do arrocho"324. Os homens do governo deixaram a empresa com uma aparente disposição para negociar, convencendo as lideranças da greve de que sua tática de ir "ganhando tempo", afim de expandir o movimento, estava ocorrendo conforme o planejado. Mas a postura dos enviados de Passarinho não passou de um blefe. Também em sentido de teste, foi enviado ao SMO um interventor nomeado pela repressão, um ex- militar, funcionário do Ministério do Trabalho. O mesmo foi igualmente hostilizado pelos operários, que sequer o deixaram entrar no recinto. A radicalidade do movimento foi atestada, a partir desse momento, o destino da greve estava traçado ${ }^{325}$.

Com o cair da noite, Osasco foi tomada pela tropa de choque da Força Pública de São Paulo, que trouxe consigo cavalaria, "tatus", "brucutus", além de um contingente de homens do DEOPS. A cidade foi militarmente ocupada. Os policiais passaram a exigir documentos de

323 Entrevista de Manuel Dias do Nascimento ao autor, 16/02/2009

324 Unidade e Luta, In: FREDERICO, Celso. Op. Cit. p. 228

325 Passarinho afirma que logo pela manhã, ao receber a notícia da greve, ligou para o governador paulista Abreu Sodré, para se pôr a par dos fatos. Sodré teria lhe respondido: "Fique certo de que recuperaremos a fábrica em no máximo 24 horas". Passarinho se dirigiu a São Paulo para definir o melhor meio de sufocar o movimento, Sodré reuniu em sua própria casa o Ministro do Trabalho de Costa e Silva, o delegado da seção estadual da Justiça do Trabalho, general reformado Moacyr Gaia, e o comandante da Força Pública paulista, coronel Antonio Ferreira Marques. Esse colegiado decidiu pela ocupação militar da cidade de Osasco, e pela evacuação das fábricas e do sindicato ocupado. A decisão foi ratificada pelo chefe do Gabinete Militar da presidência, general Portela. Passarinho, segundo suas memórias, informou a Portela que se "ampliada a greve, como em Belo Horizonte, e realizada a articulação com os estudantes, haveria risco para o próprio regime". Para conferir essas informações: PASSARINHO, Jarbas. Op. Cit. p. 293-294. 
pessoas que eram vistas circulando pelas ruas, todas as saídas do município passaram a ser controladas por barreiras de soldados, e o SMO, mais as fábricas paralisadas, foram cercados por forte aparato militar. A primeira ação de desocupação se deu na Lonaflex, por volta das 19:30 da noite. O testemunho sobre esta ação é de Manuel Dias do Nascimento:

(...) nós fomos os primeiros a ser desocupados, quando é cerca de oito horas da noite aproximadamente eles nos cercaram, cercaram a empresa, nós estávamos em assembleia nesse momento, não tínhamos nenhuma condição de resistência. Então, nosso pessoal, os companheiros que tavam fazendo a segurança na porta, foram dominados imediatamente pelas tropas, pelas forças do Estado. Lá não foi exército, na Cobrasma sim, teve exército e as forças públicas de São Paulo, enquanto que na Lonaflex não, foi só a parte dos militares, policiais mesmo. (...) fomos cercados por completo, com cavalaria, com tudo, e aí houve um diálogo entre nós e o comandante das tropas, juntamente com o gerente de Recursos Humanos. Nós já tínhamos discutido em assembleia desocupar aquela noite e regressar no dia seguinte, não tivemos outra coisa a falar senão a verdade; "olha, nós tavamos em assembleia antes, vocês chegaram aqui e nós já tínhamos discutido em assembleia e decidido desocupar a empresa e voltar com a intenção de ocupá-la novamente de manhã, engrossando os dois turnos que já tinham aderido com o turno da noite, que não tinha aderido". Aí saímos realmente, depois do diálogo que ele teve comigo, diretamente, saímos, aliás não teve nenhuma provocação nesse momento.

A desocupação da Lonaflex se deu sem maiores incidentes, em bloco os trabalhadores deixaram a empresa e assim prosseguiram boa parte do percurso de volta a seus lares, afim de evitar represálias e provocações por parte da polícia. Uma parte desses operários se dirigiu ao SMO e se juntou a assembleia permanente que ocorria no recinto.

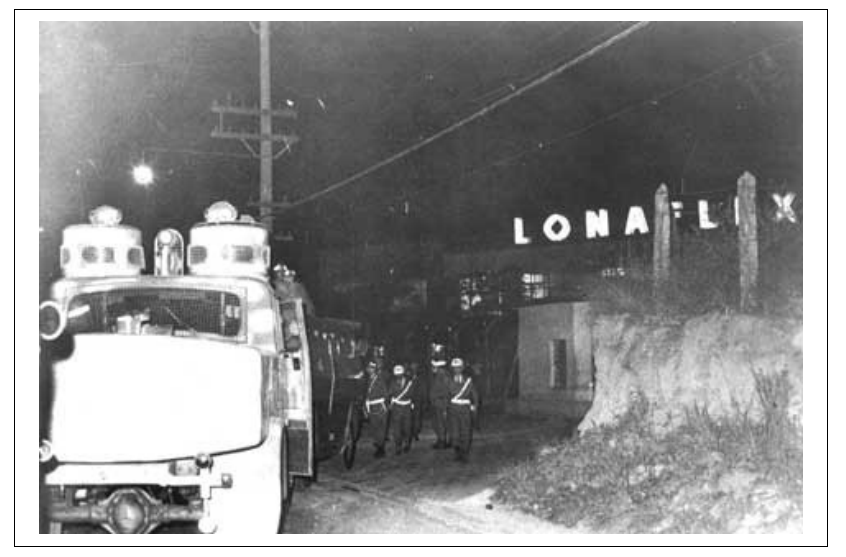


Invasão da empresa Lonaflex, ao contrário do verificado na Cobrasma, a desocupação dessa fábrica se deu sem maiores incidentes. A Lonaflex foi o primeiro espaço controlado pelos grevistas de Osasco a ser retomado pelos militares. Fonte: camaraosasco.sp.gov.br

O mesmo não se verificou na Cobrasma, o grosso do aparato militar a ocupar a cidade se concentrou nas cercanias dessa empresa. Elementos da tropa de choque, agentes do Dops, veículos militares e cavalaria se fixaram no portão principal da fábrica ocupada. Teve início uma ação de "guerra psicológica" por parte dos agentes da repressão, posta em prática através de alto-falantes, com discursos dirigidos a massa, objetivando desqualificar os organizadores do movimento e chamando a atenção para a sua inutilidade. A certa altura, José Campos Barreto se aproximou do portão central da empresa e proferiu um "discurso impressionante" voltado aos soldados da Força Pública, conclamando-os a não atacar os operários, "trabalhadores iguais a eles", "pais de família, não inimigos". Conclamou também as tropas a aderirem ao movimento. "Toda a massa colocou-se atrás dele e os soldados vacilaram". A ação de Zequinha Barreto foi interrompida aos gritos do comandante da tropa, que "teve que usar de firmeza" para dar início a operação de desocupação. Sobre os fatos seguintes, vamos ao depoimento de José Ibrahim:

Entre onze horas e meia noite começou a invasão. Os tatus e brucutus romperam as barricadas. Os companheiros desligaram todas as luzes. A tropa de choque entrou na fábrica às escuras, dando rajadas de metralhadoras para o alto e atirando bombas de gás lacrimogênio e de efeito moral.

Houve muito combate corpo a corpo, os operários estavam dispostos a brigar. Era preciso vários soldados para agarrar um operário. Os companheiros vagavam pelas seções mergulhadas na escuridão. Eles conheciam bem a fábrica, mas os soldados não. Tropeçavam, caiam em buraco de resfriador de peça, enquanto do alto da ponte rolante um grupo operário atirava pedaços de pau, ferro e peças sobre os soldados. Foi uma verdadeira batalha campal na "cidade Cobrasma", pois a fábrica, enorme, ocupava vários quarteirões. Houve companheiros que foram presos desacordados, guardas com a cabeça rachada, braço quebrado. Até de manhãzinha continuavam a prender gente dentro da Cobrasma. Eu cheguei a conversar com um companheiro que passou dois dias dentro de um forno antes de poder sair ${ }^{326}$.

326 Orlando Miranda, em seu romance histórico Obscuros Heróis de Capricórnio, afirma que não houve resistência por parte dos trabalhadores; vejamos a seguinte passagem: “(...) a soldadesca em enxurrada e fúria cega, animais que perseguem e mordem, saltando, correndo, batendo, ignorando os que cobrem a cabeça, tentam correr, caem (...). Batendo, batendo, batendo (...) O massacre diminui de intensidade a medida que os caçadores se dividem, vão ocupando as primeiras oficinas, constando nenhuma resistência". Roque Aparecido da Silva, também testemunha dos eventos de 16 de julho, afirma que "na desocupação da Cobrasma ocorreram muitos confrontos, sem que ninguém tenha 


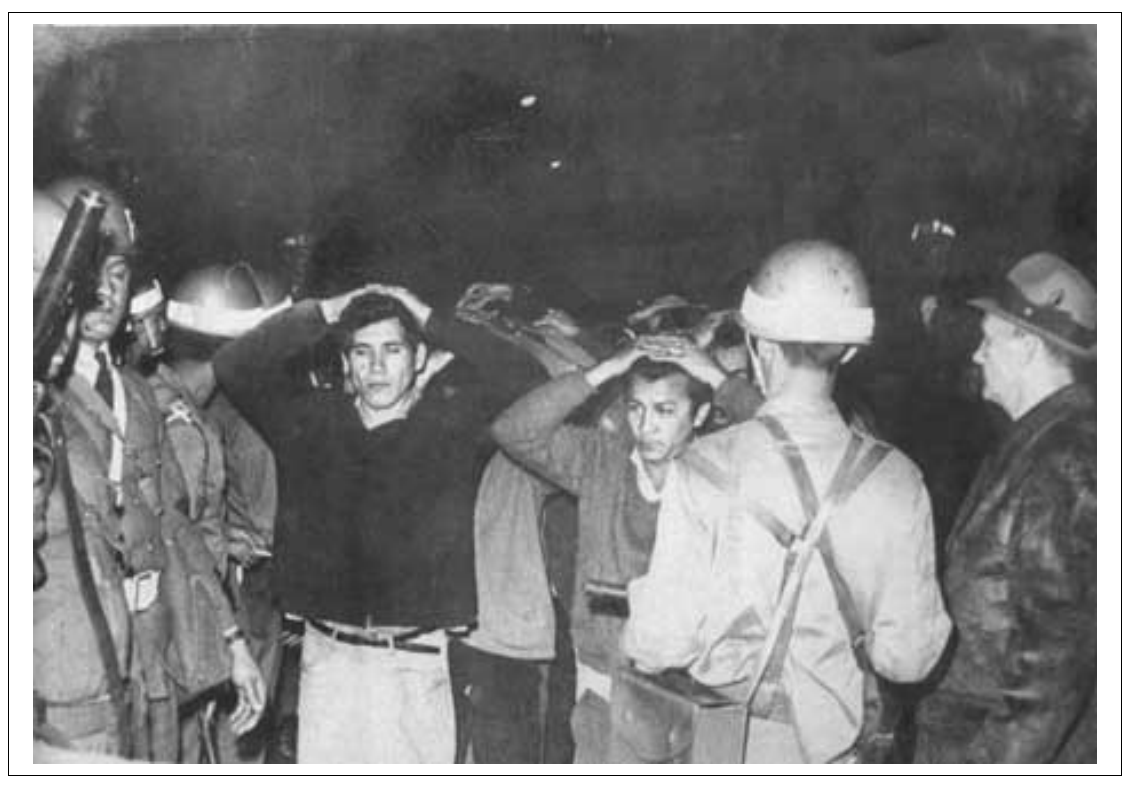

Foto histórica da detenção dos grevistas da Cobrasma, centenas de operários foram espancados e presos pelas forças da repressão.

Fonte: http://www.camaraosasco.sp.gov.br/osasco/fotos/greves.htm

Ao amanhecer do dia 17 de julho de 1968, a Cobrasma se encontrava ocupada pelo Exército e pela Força Pública paulista, centenas de operários foram espancados, cerca de trezentos foram detidos, após triagem, aproximadamente sessenta foram recolhidos a carceragem, dentre estes José Campos Barreto, que permaneceu quase três meses preso. De acordo com relatos, Barreto foi conduzido a viatura policial a socos e pontapés, assoviando de maneira provocativa o hino nacional. Outro preso na invasão, de atividade reconhecida, foi o padre francês Pierre Joseph Wauthier, membro da congregação de São Pedro e São Paulo. ${ }^{327}$ José Groff, liderança da FNT, fundador da comissão de fábrica da Cobrasma e membro da direção do SMO, foi detido após uma sessão de agressões a coronhadas por parte de agentes da repressão.

baixado a cabeça. Mesmo os que foram presos enfrentaram o processo com dignidade." O depoimento de Ibrahim foi obtido em entrevista ao autor, 27/01/2009; para a passagem de Orlando Miranda: MIRANDA, Orlando. Op. Cit. p. 183; para citação de Roque Aparecido da Silva, artigo publicado pela revista Teoria e Debate, edição especial sobre 1968, maio de 2008. Também disponível no endereço eletrônico: http://www.fpabramo.org.br/node/5428 .

327 "Após um mês de prisão, os serviços de inteligência permitiram que Wauthier ficasse na casa do Cardeal de São Paulo, Dom Agnelo Rossi, que se apresentou como mediador entre grevistas e patrões. Em 27 de agosto, dom Rossi ausente por estar em Medelín, a casa foi invadida e, sem processo, Wauthier foi deportado para a França". A deportação provocou protestos internacionais. O pároco francês foi acusado, injustamente, de ser um dos organizadores da greve. MOREIRA ALVES, Márcio. 68 Mudou o Mundo. $2^{\mathrm{a}}$ Ed. Rio de Janeiro: Nova Fronteira, 1993.p. $95-96$ 
A imprensa corporativa, vinculada aos interesses das classes patronais, iniciou uma ofensiva contra a Greve de Osasco um dia após o seu deflagrar. O Jornal da Tarde trouxe expressa em sua edição do dia 17 de julho a opinião do regime sobre o movimento, em matéria que apresentou o seguinte título: "O governo define a ocupação das fábricas: é subversiva".

Nessas condições, ela (a greve) tem implicações criminais, além das penalidades previstas na Lei 4.330, de 1964. Não haverá pagamento dos dias parados. Os implicados no movimento podem ser dispensados do emprego e estão sujeitos a processo-crime. O governo federal reprimirá com energia qualquer atentado maior à ordem instituída. Até agora o governo tem proporcionado aos trabalhadores, através de suas representações legítimas, o direito de dialogar e até mesmo de criticar asperamente. Mas não se pense que isso significa uma condescendência criminosa em relação ao povo em geral, que não pode sofrer a consequência de atos impensados e absolutamente fora de lei. O governo aceita diálogo, mas atentados e violências são monólogos: para eles o governo diz não ${ }^{328}$.

Foi uma prática comum do governo militar utilizar veículos da imprensa para mandar recados a sociedade, especialmente por meio daqueles veículos alinhados ao regime. Nesse sentido, no dia 18 foi a vez do Ministro Jarbas Passarinho ter suas impressões sobre o movimento de Osasco expressas na imprensa corporativa. "Aceitamos todo movimento de reivindicação dos trabalhadores, mesmo quando é expresso em termos grosseiros. Isso faz parte do nosso jogo, o jogo da democracia. O que nunca aceitaremos são as coisas que aconteceram em Osasco, a violência, a desordem, o cárcere privado. Os movimento de rapinagem serão reprimidos $(\ldots)^{329}$.

Mas a greve prosseguiu, e na manhã do dia 17, a Braseixos aderiu a paralisação. $\mathrm{O}$ responsável pela organização da parede na Braseixos foi Joaquim Miranda, membro da diretoria do SMO. Sobre o movimento em sua empresa, comenta Miranda:

A gente parou às 7h:24 e as seções mais mobilizadas eram a que eu trabalhava, fiação de

328 Jornal da Tarde, 17 de julho de 1968. Apud: COUTO, Ari Marcelo Macedo. Op. Cit. p. 111

329 O jornal Folha de São Paulo, em sua edição de 18 de julho de 1968, trouxe uma extensa reportagem sobre a Greve de Osasco, com amplo espaço para as opiniões e impressões de membros do regime sobre o movimento. Não se vê nesse exemplar, nem nos dos dias seguintes, nenhum espaço reservado as opiniões dos grevistas sobre seu movimento. Em linhas gerais, esse foi o comportamento da imprensa corporativa como um todo, apenas o jornal Última Hora fez uma cobertura dos fatos de maneira mais isenta. A ofensiva midiática contra a greve também se verificou via rádio. Para trecho exposto acima, consultar: http://acervo.folha.com.br/fsp/1968/7/18/2 
ferramentas, e a ferramentaria. As duas somavam cerca de 80 trabalhadores. A idéia era sair em passeata (interna) pedindo para o pessoal ir aderindo. Na terceira rodada de passeata, as máquinas estavam todas paradas. Às $9 \mathrm{~h}$ saímos para o pátio e chegamos à conclusão que não dava para manter ocupada a fábrica, pois não tinha clima nem preparação para isso. Às 9h:30 chegou lá o (Luís Eulálio) Vidigal, com seu terno preto, e falou para o rapaz da portaria: "todo mundo para casa, hoje não tem trabalho, abre o portão aí pro pessoal sair". Aí eu disse: "não abre não", e ele não abriu. Nesse dia, aquele homem que parecia um semideus, não tava apitando muito, não (risos) ${ }^{330}$.

Nesse mesmo dia também parou a Brown Boveri, empresa que possuía uma comissão atuante. Após acirrado debate interno, o frentista e vice presidente do SMO Octaviano Pereira dos Santos, mais componentes da vanguarda operária, convenceram os funcionários da calderaria a cruzar os braços, tratava-se do "setor mais importante da empresa, onde trabalhavam 600 operários". Após algum vacilo devido a presença dos patrões na seção, "os próprios funcionários" começaram desligar as máquinas, aos gritos de "viva a greve" e "abaixo o arrocho". Após os acontecimentos da Cobrasma ficou claro que ocupar a fábrica era algo arriscado, além de não haver condições de levar a cabo tal tarefa em uma firma com pouca tradição de mobilizações. Cientes desse fato, os organizadores da greve na Brown Boveri seguiram em passeata junto com a massa até o SMO, ainda em estado de assembleia permanente ${ }^{331}$.

Na última seção vimos que a partir do segundo dia da paralisação, o ME já iniciara sua panfletagem em apoio a greve, e notícias sobre o movimento já se faziam correntes em todo país. Contudo, os militares já haviam tomado medidas para isolar a parede, sitiando a cidade, controlando os acessos a região, e dissolvendo de imediato possíveis focos em outros polos industriais paulistas. Nessa ofensiva, o bairro de Presidente Altino, endereço do SMO, foi completamente tomado pelas forças militares. As 5 horas da manhã, no terceiro dia da greve, o sindicato se encontrava ocupado por centenas de trabalhadores, entre estes, mulheres e crianças. O deputado do MDB David Leher, que se encontrava no recinto em apoio aos grevistas, em vão tentou negociar com a repressão, deixando as dependências pouco antes do

330 Os grevistas da Braseixos deixaram a empresa e a maioria optou por não se dirigir ao SMO, pois já se previa uma invasão militar. Para o dia seguinte foi marcada uma assembleia na Igreja de Santo Antonio, padroeiro da cidade. A essa altura todas do município já se encontravam fortemente vigiadas. Miranda e outros trinta trabalhadores foram detidos na matriz do Santo Antonio, segundo relatos, o pároco local entregou os operários. Joaquim Miranda passou três dias preso. Apesar de ser base de apoio do GO, esse sindicalista não aderiu a VPR após a intervenção militar sobre a cidade de Osasco, optando por se engajar no POC. Para entrevista de Joaquim Miranda: jornal Visão Oeste, 20 a 26 de junho de 2008, edição especial em comemoração aos 40 anos da Greve de Osasco.

331 FREDERICO, Celso. Op. Cit.p. 231-232 
assalto.

Esgotados todos os ultimatos, o edifício O Metalúrgico foi tomado pelos militares, cerca de 120 pessoas foram presas, dentre elas dois padres dominicanos, 20 mulheres e um menor. Octaviano Pereira dos Santos foi preso na ação. No dia seguinte, para a satisfação do Ministro Jarbas Passarinho, que a essa altura já montara seu QG no Sindicato dos Químicos, no bairro do $\mathrm{Km} \mathrm{18}$, tomou posse o interventor Neutar Pithon da Silva, em um edifício ocupado pelos militares ${ }^{332}$.

O cerco não se resumiu aos sindicatos, acima vimos que a igreja de Santo Antonio foi invadida por policiais e os operários que lá se encontravam em assembleia foram presos. $\mathrm{O}$ mesmo se deu na paróquia da Imaculada Conceição, no Km 18. No terceiro dia da parede todos os espaços de concentração dos trabalhadores se encontravam ocupados ou fortemente vigiados. Ainda assim, a vanguarda do movimento tentou prolongá-lo, na esperança de um possível alastramento da greve. Mas a vigilância não se restringiu a Osasco, a repressão estava atenta ao surgimento de possíveis focos nas demais regiões de São Paulo.

No quarto dia veio o refluxo de fato, cerca de $50 \%$ dos operários voltou ao trabalho, e aos poucos a vida foi retornando ao normal. Sobre os limites da organização da greve, em um movimento que fora concebido para atingir largas proporções, comenta Ibrahim que os articuladores da paralisação não "nos esforçamos para montar nos bairros uma infra-estrutura independente do Sindicato. Não criamos uma coordenação inter-comitês independente da máquina sindical. Por isso, quando o Sindicato sofreu intervenção e a liderança de esquerda se viu impossibilitada de circular por Osasco a greve entrou em refluxo" ${ }^{\text {"33. }}$.

Com relação a tentativa de dar continuidade a parede, Espinosa afirma que: "nós tentamos resistir, fizemos um panfleto com pouquíssimas cópias, rodado de noite, na resistência, chamando pra greve de grevilha, que era um dia parar uma seção, um dia uma outra seção, um dia uma fábrica, um dia fazer piquete num bairro para que os trabalhadores desse bairro não fossem trabalhar, com isso ainda a gente resistiu por uns oito ou dez dias, mas a greve acabou sendo derrotada" ${ }^{334}$.

Por parte dos ativistas da FNT também houve tentativas de resistência, mas muitos de

332 Para novo interventor: JESUS, Paulo Sérgio de. Op. Cit. p. 49; para instalação de Passarinho em Osasco: MIRANDA, Orlando. p. 187

333 FREDERICO, Celso. Op. Cit. p. 234

334 Foram paralisadas seis empresas da cidade, sendo estas a Cobrasma, Braseixos, Brow Boveri, Lonaflex, Barreto Keller e Fósforo Granada. José Ibrahim afirma que no segundo dia de greve "apareceram no Sindicato companheiros de uma pequena fábrica de madeira que haviam aderido a greve, sem que nós tivéssemos feito qualquer trabalho, pois nem sabíamos da existência dessa empresa". Para comentário de Espinosa; entrevista ao autor, 09/06/2008; para informações de Ibrahim: Idem. p. 232. 
seus membros foram presos nas operações policiais perpetradas no município. Tanto a Frente, quanto suas congêneres JOC e ACO, passaram a ser visadas pelos órgãos repressores de Osasco após julho de 1968, enquadradas como movimentos subversivos. Em repúdio a violência policial, militantes da ACO lançaram um manifesto voltado as pastorais operárias, eis um trecho do que foi redigido, publicado por Paulo Sérgio de Jesus :

(...) Alguns se perguntam se podem ir inclusive até a defesa por próprias mão dos seus direitos no momento em que ficar provado que a autoridade pública é incapaz de cumprir sua missão de defender os direitos da maioria do Povo ou desonestamente se negar a fazê-lo?

$\mathrm{Na}$ atual situação, só os operários são reprimidos pela polícia de maneira violenta, quando tentam exigir que haja justiça para eles. Os patrões todo dia violam leis trabalhistas, atrasando por meses salários, deixando dolorosamente de registrar trabalhadores, não pagando horas extras, taxas de insalubridade, etc. , e não se vê nenhuma ação repressiva do governo contra tais ilegalidades. Crimes que clamam ao céu e pedem vingança, conforme diz a escritura ${ }^{335}$.

Na sexta-feira alguns panfletos chamavam a continuidade da greve para a semana seguinte, mas a essa altura o movimento já havia sido sufocado. O comparecimento nas empresas já era praticamente normal. O SMO se encontrava sob intervenção, seu presidente desaparecido, o vice preso, assim como outros membros da diretoria. O CEO fora fechado. A FNT permaneceu sob severa vigilância. O núcleo duro do GO já passara para a clandestinidade, a começar por José Ibrahim, escondido em aparelho fornecido pela VPR. Na mesma situação se encontravam Antonio Roberto Espinosa, Roque Aparecido da Silva e Manuel Dias do Nascimento. José Campos Barreto permaneceu atrás das grades até o final de outubro. Na semana seguinte, não houve dúvida, a greve tinha acabado.

$* * * * *$

Qual o legado da Greve de Osasco? Quais foram suas virtudes e limitações? Muito já escreveu sobre esse movimento, para alguns significou o fim de um ciclo, para outros o início de um novo, a ser retomado dez anos depois, no ABC. O fato é que o movimento iniciado no dia 16 de julho de 1968, na Cobrasma, apresentou características peculiares, poucas vezes observadas em movimentações similares longo da história do MO brasileiro. Para 
discorrermos de forma mais objetiva sobre o legado dessa greve, vamos a explanações e autocríticas de personagens envolvidos diretamente no evento.

Stanislau Zermeta, que nessa etapa concentrava suas atividades no CEO, embora também fosse estudante-operário, formula a seguinte análise sobre os acontecimentos de julho em Osasco:

(...) a construção da greve é isso, as pessoas podem dar as suas versões, de como parou, as ações concretas. O grau de organização da greve foi muito grande, por que não é fácil parar uma fábrica com um apito, e aí é que começam as dificuldades, por que ninguém imaginava que depois dez horas Osasco estaria cercado. Quem que podia imaginar que o processo de movimentação seria dificultado, não dava nem pra pensar. Nessas condições, a gente pode pensar que a greve foi desafiadora, uma greve que contava com elementos que ela não tinha construído, a gente não podia dizer assim, tal fábrica, tal lugar, vai fazer a greve pra deslocar a repressão, não tinha isso, São Paulo tava na mão dos pelegos, Guarulhos tava na mão dos pelegos. Mas se podia contar com outras variantes, como o movimento estudantil, que estava em atividade, por que o clima que se construía era uma clima de resistência. Em Osasco, hoje a gente pode dizer, esse clima foi sobrecarregado pelo movimento estudantil, pelo movimento popular, pelo movimento sindical, pelas organizações que acabaram atuando, pela quantidade de vanguarda que existia, devido a elementos que tavam despontado para o processo de luta. A gente pode dizer que Osasco era um seleiro, todas as organizações iam criando suas bases na cidade. Esse processo que aconteceu, a gente não pode desvinculá-lo do golpe, e dizer assim, "nós íamos ter mais tempo", não, isso é papo furado, dizer que isso foi estopim do Ato 5 também é papo furado, o que havia era a necessidade que a burguesia tinha em destruir a oposição para a implantação do seu projeto, não havia conciliação. Qualquer resistência na fábrica e você era mandado embora, podem dizer que foi esquerdismo, que foi uma aventura, que podia ter esperado mais, não tinha que esperar mais, por que as coisas são feitas na hora. O processo de construção da greve pode ter tido influência forte do clima, mas o que a gente pode dizer é o seguinte, uma organização sindical com apenas um ano de existência não pode ser culpada pelos desdobramentos das leis duras da ditadura que foram impostas, o que acontece é que éramos todos muito jovens ${ }^{336}$.

Embora truncado, o raciocínio de Stanislau Zermeta sintetiza bem o ambiente de radicalismo vivido em Osasco - e no país - em meados de 1968. O clima de contestação ao regime foi "sobrecarregado" nesse município, como bem informa o depoente. O subúrbio

336 Entrevista de Stanislau Zermeta ao autor, 04/11/2008 
industrial da Zona Oeste da grande São Paulo acabou atraindo para si as expectativas de diversas corrente em combate a ditadura. Aqui também se verificou a perspectiva de construção de uma frente operário-estudantil, algo não visto em outras regiões do Brasil. Osasco concentrou as esperanças de uma juventude que estabeleceu como meta para si a tarefa de derrubar o regime militar. A hegemonia das oposições sindicais na cidade, um ME forte e atuante, uma militância social cristã de relevante mobilização junto a comunidade; todos esses elementos credenciaram a região como um polo de insubordinação aos governos militares. Todo esse caldo de cultura de contestação foi desembocar no 16 de Julho.

Zermeta faz menção a pouca idade dos implicados na organização da greve, "eramos todos muito jovens"; de fato, a figura central dentre os setores mais radicais da cidade foi o estudante-operário, e o principal agrupamento a congregar essa categoria foi sem dúvida o GO. Coube ao GO a organização da greve de Julho, embora após o deflagrar do movimento, ativistas da FNT tenha aderido ao mesmo de forma ativa, sendo duramente reprimidos após a reação militar. Zermeta imputa os desvios organizacionais da greve a pouca experiência de seus promotores, mas há que se considerar a pressão das bases, compostas por trabalhadores de todas as idades, no chão da fábrica, num contexto de recessão econômica e arrocho salarial. Numa conjuntura de ofensiva patronal contra todos os aparelhos de mobilização laboral da região.

A repressão acusou seu opositores de forçar o recrudescimento do Estado repressor, em contrapartida, as forças em combate ao regime culpavam os representantes da ditadura pela radicalização da luta. Nesse jogo dialético, Osasco foi apenas um elemento na espiral de violência, num período de não conciliação, em um país pouco acostumado a mediações interclasses. O simulacro de legalidade do sistema atingira seus limites, claro estava que a máquina pública se encontrava direcionada as demandas das camadas dominantes de nossa sociedade, e o governo não podia abrir mão de um pacto firmado junto a essas camadas em 1964. A solução para esse impasse viria em dezembro, com a decretação do AI-5, a partir de então, o regime desnudou suas características de ditadura de classe.

Retornando a greve de julho, José Ibrahim vai mais longe na autocrítica ao movimento, vejamos seu depoimento e revista Unidade e Luta:

A ocupação das fábricas e todo o encaminhamento da greve foi fruto de nossa concepção esquerdista. Eu acho que, em princípio teria sido melhor fazer a greve em novembro, na época do dissídio de todos os metalúrgicos. Mas, poderíamos, inclusive, ao chegar aquela data concluir que não 
deveríamos ir a greve, porque não tínhamos organização suficiente ou porque não era o mais conveniente em função da unidade com as demais oposições sindicais e da necessidade de fortalecêlas. O importante não era fazer a greve mas fortalecer a organização independente da classe. Deveríamos escolher melhor forma de combate a partir de uma visão de luta a longo prazo, de acumulação de forças através de vitórias parciais que levassem ao fortalecimento da organização independente da classe.

Hoje eu assumo uma posição de autocrítica com relação a nossa concepção esquerdista tanto de nossa prática no movimento operário quanto de nossas posições dentro da VPR. ${ }^{337}$

As vésperas da paralisação, praticamente todo o núcleo central do GO já havia aderido a organização que futuramente receberia o nome de VPR (a exceção de José Ibrahim, recrutado pouco tempo após greve, já na clandestinidade). A proposta de construção de uma greve insurrecional se deu em sintonia com as diretrizes daqueles agrupamentos que se formaram com o intuito de combater por todos os meios possíveis o regime militar. Ibrahim critica a visão desses grupos, e afirma que "teria sido melhor fazer a greve em novembro", ou sequer executá-la. A visão militarista de uma corrente guerrilheira teria desvirtuado os rumos de um movimento que fugiu em demasia de suas pretensões corporativas. Mas em seu livreto sobre comissões de fábrica, Ibrahim faz menção a uma situação de "se correr o bicho pega, se ficar o bicho come" 338 .

Além da intensa pressão das bases, dentro de um clima de ebulição social poucas vezes visto neste país, havia a percepção de que uma intervenção sobre o SMO era algo inevitável, e para logo. O patronato local já estava se mobilizando para anular as comissões de fábrica, o diálogo entre direção e empregados já se rompera na Cobrasma, após a demissão de dois membros da comissão da empresa, que pelo regulamento interno deveriam ter estabilidade. Haveria condições de se construir uma greve para novembro, data base da categoria? Para essa pergunta não há resposta. Também não se pode responder se um MO mais disposto a negociação conquistaria melhorias para os operários da região, num cenário de arrocho salarial crescente. Como supracitado, as agitações em Osasco se inseriram num contexto de ebulição social em âmbito internacional, os desacertos dos jovens ativistas do GO são os desacertos de toda uma geração, assim como o são as suas virtudes.

Em outubro de 1968 foi distribuído entre os operários da cidade um manifesto redigido por José Ibrahim e José Campos Barreto, intitulado "Manifesto de Balanço da Greve de 
Julho", dentre as conclusões sobre o movimento apresentadas no texto, destacamos três:

Apesar da repressão brutal que impossibilitou a extensão e a continuidade da greve, a demonstração do nível da luta de classe, fez os patrões cederem em várias reivindicações.

A brutalidade da repressão foi prejudicial para o movimento em si, porém benéfica a longo prazo, dado o avanço político da massa, com o desmascaramento da ditadura deixando claro que (a ditadura) reprimirá violentamente qualquer luta justa da classe trabalhadora.

Na luta a classe elevou o seu nível de consciência devido a realização de assembleias, discussão política possibilitando maior aceitação das palavras-de -ordem das lideranças, e o surgimento de novas lideranças o que facilitou a organização dos mais amplos setores da massa, que vem se dando através da formação de núcleos clandestinos para discussão política e realização de ações práticas. ${ }^{339}$

Com relação ao primeiro item do balanço, a direção da empresa, que logo após a retomada da fábrica acenou com demissões em massa, dispensou apenas os trabalhadores que foram detidos, ou estavam envolvidos diretamente na organização da parede. Aqueles que possuíam atividade política reconhecida, mas não se provou participação direta na construção da greve, receberam 45 dias de punição. O direitos salariais foram pagos a todos os demitidos, “inclusive os dias de suspensão", e não houve nenhuma dispensa por justa causa. ${ }^{340}$ Os empregados que continuaram em seus postos receberam $18 \%$ de aumento, algo inusual em tempos de arrocho salarial.

Sobre o segundo item, o nível de politização do biênio 1967-68 não voltou a se repetir entre os operários de Osasco, a intensa repressão desmobilizou a parcela mais consciente e combativa do município, muitos dos que foram demitidos tiveram que se mudar para outras localidades, pois passaram a figurar em uma lista negra distribuída entre as empresas da região. O reduzido espaço de mobilização operária, sobretudo após o AI-5, ficou sob encargo da FNT e demais grupos cristãos, embora seus aparelhos de atuação por excelência, as comissões de fábrica, tenham sido proibidos $^{341}$. O município seguiu fortemente vigiado, e

339 "Manifesto de Balanço da Greve de Julho", Apud: FREDERICO, Celso. Op. Cit. 189-190.

340 MIRANDA, Orlando. Op. Cit. p. 187

341 Em 1970, setores da FNT mais clérigos e ativistas de São Paulo inciaram em Osasco as atividades da Pastoral Operária, movimento que até a fase de abertura política exerceria uma moderada oposição aos interventores sindicais no município. A intervenção sobre o SMO só terminaria por completo em 1978, quando se formaram duas chapas em disputa pela entidade, em eleições livres. O frentistas foram representados pelo militante cristão José Pedro, a chapa da situação teve a frente Henos Amorina, velho cacique político. A onda de greves iniciadas no ABC, em 1978, também chegou a Osasco, dez anos após a greve de julho, os trabalhadores da cidade novamente cruzavam os braços. Para informações sobre a militância cristã operária em Osasco pós AI-5: JESUS, Paulo Sérgio de. Op. Cit. p. 54-80. 
somente após a abertura política grupos mais a esquerda puderam reiniciar seu trabalho político, sem a mesma pujança da década anterior. Por outro lado, a repressão a Osasco de fato desmascarou um regime que abriu mão de qualquer espécie de negociação junto a classe trabalhadora.

Com relação ao terceiro item, a elevação do nível de consciência da classe trabalhadora local, e a "formação de núcleos clandestinos para discussão política e realização de ações práticas", ficou sob o encargo das vanguardas mais combativas e organizadas. Num contexto de cerco quase absoluto, as atividades se reduziram a mais completa clandestinidade. Os segmentos mais radicais do MO osasquense se engajaram no tortuoso caminho da luta armada, sendo que a maioria cerrou fileiras com a VPR. Reduzidas parcelas se engajaram no POC, outros na AP, além dos trotskistas, lotados no POR (Partido Operário Revolucionário), de atividade corrente, porém não radical, mas nem por isso menos visados pela repressão ${ }^{342}$.

Em finais de julho, Osasco era uma das cidades mais vigiadas do Brasil, ocupada militarmente, e com dezenas de presos políticos. Todos movimentos populares de ação reconhecida no município se encontravam desativados ou sob severa vigilância, e vários ativistas locais figuravam na lista dos procurados pela justiça militar. Dentre estes, diversos pertenciam ao GO. A trajetória de lutas desse movimento, dentro de sua cidade natal, encerrase nesse estágio. Suas atividades, a partir de então, passaram a se efetivar em outro nível. Os desafios desse grupo agora seriam maiores, não mais restritos a seu município, categoria profissional, ou conjuntura política. O GO agora assumira para si, junto a outros agrupamentos também radicais, a tarefa de derrubar a ditadura pela força das armas.

342 Em pasta disponível no Arquivo do Estado de São Paulo, referente as atividades operárias em Osasco, há informações sobre a militância do POR, além de um manifesto distribuído nas empresas da cidade, contendo as proposições do grupo. Como é bem sabido, as organizações trotskistas não aderiram a luta armada, prosseguindo com sua tática de construção de uma revolução operária aos moldes soviéticos. Para informações sobre o POR, consultar: Arquivo do Estado de São Paulo, pasta OS - 0704, Osasco. 
4. Guerrilha 
Não cremos na solução pacífica. As condições para a violência nada tem de artificiais e estão criadas no Brasil desde que a ditadura se impôs pela força. Violência contra violência. E a única saída é fazer o que estamos fazendo: utilizar a violência contra os que tiveram a primazia em usá-la para prejudicar os interesses da pátria e das massas populares. A violência que anunciamos, defendemos e organizamos é a da luta armada do povo, concebida como guerrilha.

O Ato Institucional número cinco representou o fim das mobilizações de massa que deram contornos míticos ao ano de 1968. Não obstante, o fechamento do regime, perante os movimentos sociais mais combativos, já se efetivara antes dessa data. A partir da segunda metade desse tumultuado ano, a ofensiva repressora da ditadura desmobilizou tanto o movimento estudantil quanto o operário. Passeatas organizadas pelo ME passaram a ser dissolvidas a bala, o ponto alto da ofensiva contra o estudantado foi a dissolução do Congresso de Ibiúna, em outubro. O último foco de resistência estudantil em São Paulo, o Conjunto Residencial dos Estudantes da USP, o CRUSP, foi invadido quatro dias após a decretação do Ato 5. A greve de julho, em Osasco, foi violentamente reprimida pelo regime empresarial-militar, sendo o último movimento paredista de envergadura verificado no período. A frágil articulação civil consubstanciada na frente ampla fora proscrita em abril. A última centelha de oposição a ditadura, levada a cabo pelo Congresso Nacional, foi suprimida em 13 de dezembro.

O AI-5 representou a ratificação de um processo de fechamento político que se intensificou em princípios de 1968. Contudo, podemos alargar essa escalada, considerando que a radicalização do sistema teve início, de fato, em $1^{\circ}$ de abril de 1964 , data do assalto ao $\operatorname{poder}^{344}$. Destarte, o AI-5 representou o ápice de um processo iniciado quatro anos antes, e

343 MARIGHELLA, Carlos. "Pronunciamento do Agrupamento Comunista de São Paulo". In: Escritos de Marighella. São Paulo: Editora Livramento, 1979. p. 141

344 A coletânea de artigos 1964/1968, a ditadura já era ditadura, organizada pelo professor Marcos Silva, apresenta uma relação de pessoas, entidades e instituições vítimas da repressão estatal nos primeiros quatro anos do período de exceção. Prisões em série, censura, expurgos, torturas e assassinatos foram prática comum durante o regime militar desde seus primórdios. Para mais informações, consultar: SILVA, Marcos. (Org) 1964/1968, a ditadura já era ditadura. São Paulo: LCTE Editora, 2006. 
serviu para desmascarar uma ditadura que se esforçava para apresentar - especialmente no cenário internacional - uma fachada legal. Após 1968, as veleidades institucionais do regime autoritário foram postas de lado, e a sociedade brasileira passou a ser controlada por um verdadeiro Estado policial.

Quais alternativas restaram as forças sociais que se dispunham a combater o governo dos generais? A rigor, poucas, selecionamos três: mobilizar-se desde o exílio, denunciando os crimes da ditadura perante a comunidade internacional; apostar em uma oposição parlamentar legal, engessada pelo bi partidarismo, sob o assédio constante dos militares e seus signatários; partir para a resistência armada. Muitos optaram pelo combate violento ao regime, dentre estes, a esquerda radical de Osasco. No presente capítulo, nosso objetivo é discutir a passagem para a luta armada dos ativistas do GO, sua trajetória dentro das organizações guerrilheiras as quais se engajaram, os debates em torno das estratégias e táticas revolucionárias, e o desbaratamento por parte da repressão dos grupos que enfrentaram a autocracia burguesa pela via das armas.

\subsection{Por que a VPR}

Antes de nos debruçarmos sobre a trajetória do GO durante os Anos de Chumbo, faz-se necessária uma breve contextualização acerca do panorama revolucionário da fase em discussão, panorama este observado em nível internacional.

Ao longo do Século XX, foram verificados ao menos dois grandes ciclos revolucionários, o primeiro abarcou o período imediatamente posterior a $1^{\text {a }}$ Guerra Mundial, iniciado com a tomada do poder pelos bolcheviques na Rússia, seguido por levantes na Alemanha, Itália, Hungria e Áustria. A vaga se estendeu até a China, e em 1927 ocorreu um levante de características soviéticas nesse país, insurreição duramente sufocada pelo governo de Chiang Kai-shek. A fragorosa derrota dos estrategistas de molde russo abriu espaço para a liderança de Mao Zedong, primeiro líder revolucionário a privilegiar a adoção da tática de guerrilha rural no Século $X^{345}$. Embora a luta chinesa tenha chegado a seu termo em 1949, seus

345 Héctor Luis Saint-Pierre comenta que durante a guerra civil russa, o exército branco se valeu de táticas de guerrilha rural para combater o exército vermelho, com motivos contra-revolucionários. Por isso consideramos o movimento liderado por Mao Zedong o primeiro a utilizar essa modalidade de guerrilha como ferramenta de combate revolucionário. A popularização do termo guerrilha se efetivou a partir da resistência levada a cabo pelos espanhóis, durante a invasão de seu país pelas tropas de Napoleão Bonaparte, em princípios do Século XIX. Pequenos grupos armados assediavam constantemente as hostes francesas que se deslocavam pelo interior do reino dominado. O termo "guerrilha" provém dessa fase. Também há referência sobre tal tática de combate na 
primórdios remontam aos anos 1920, ainda sob o impacto da Revolução Russa e dos debates suscitados pelos primeiros congressos da III Internacional Comunista ${ }^{346}$.

A segunda vaga revolucionária internacional, assim como a primeira, iniciou-se após um conflito de proporções globais, dessa vez a Segunda Grande Guerra. De abrangência muito maior que o primeiro, o embate entre as potências centrais do sistema político mundial produziu um desarranjo no tabuleiro geopolítico internacional. Antigos impérios coloniais (ou neocoloniais) iniciaram sua derrocada final, alquebrados devido à devastação provocada por seis anos de guerra total, fato que abriu margem a eclosão de movimentos nacionais de libertação, naqueles territórios que ainda se encontravam sob tutela das economias centrais. Dentro desse contexto, iniciou-se um novo ciclo de revoluções e insurreições nacionais, mais uma vez partir da periferia do sistema político global. Contudo, nessa nova escalada, as precipitações se restringiram as regiões do dito Terceiro Mundo, alguns movimentos e levantes populares de envergadura foram verificados em países desenvolvidos, como França, Itália e Tchecoslováquia, sem, contudo, provocarem abalos efetivos na ordem política da Guerra Fria.

guerra de independência dos EUA, executada por colonos em luta contra o exército colonial inglês. Pesquisadores brasileiros indicam que durante a invasão holandesa ao Brasil, no século XVII, portugueses e nativos lançaram mão de táticas guerrilheiras no combate aos holandeses, tendo como referência as guerras indígenas. Já no Século XX, a Coluna Prestes, que percorreu 25.000 Km pelo interior Brasil, utilizou táticas de guerrilha rural móvel em seu deslocamento. Com relação à guerrilha urbana, tal prática foi utilizada, em princípios do Século XX, pela luta clandestina dos militantes do Partido Social Democrata Russo, o documento base desse princípio de resistência é o livro Que Fazer, de Lenin. Durante a ocupação nazista na Europa, organizaram-se grupos de resistência popular, organizados a guisa de guerrilha urbana. A ocupação nazista fomentou o crescimento de movimentos populares, organizados, na maioria dos casos, por membros dos partidos comunistas dos respectivos países que se encontravam sob jugo alemão. Nestes, verificou-se tanto a utilização de táticas de guerrilha urbana, quanto de rural, com destaque para o processo revolucionário iuguslavo, liderado pelo Marechal Tito, o mais bem sucedido líder comunista em solo europeu desde Lenin. Para referências as guerrilhas chinesas, russo-brancas, espanholas e estadunidenses: SAINT-PIERRE, Héctor Luis. A política armada. Fundamentos da guerra revolucionária. São Paulo: Editora da UNESP, 2000. p. 173-176; para combate guerrilheiros contra os holandeses, consultar: MELLO, Evaldo Cabral de. Olinda Restaurada - Guerra e Açúcar no Nordeste, 1630-1645. Rio de Janeiro: Editora Topbooks, 1998; para Coluna Prestes: CARONE, Edgard. $O$ Tenentismo. São Paulo: Editora Difel, 1975. Para mais informações sobre o cenário russo pré revolucionário, consultar: TROTSKY, Leon. A História da Revolução Russa. Rio de Janeiro: Editora Paz e Terra, 1978. $\left(1^{\circ}\right.$ Volume); para combate ao nazismo por parte das nações ocupadas, nossa referência é a resistência francesa, para informações sobre esse tema consultar: GALLO, Max. Os patriotas: romance histórico da resistência francesa. Rio de Janeiro: Editora Bertrand Brasil, 2004.

346 Ainda na conjuntura dos debates da III Internacional, ocorreram os levantes de El Salvador, em 1932, "única sublevação de massas dirigida por um partido comunista na América Latina”, capitaneada por Farabundo Martí; e o levante comunista de 1935, no Brasil, liderado pelo PCB. Entre 1927 e 1933, o líder guerrilheiro Augusto César Sandino combateu o exército dos EUA lotado na Nicarágua, que ocupava esse país em defesa dos interesses de grandes produtores rurais estadunidenses. Embora sua principal referência de luta tenha sido a Revolução Mexicana, Sandino manteve-se próximo dos movimentos comunistas latino-americanos. Todos os movimentos acima citados foram derrotados, mas suas lideranças se tornaram símbolos de resistência a opressão. Para mais informações, consultar: LÖWY, Michel. O Marxismo na América Latina. Uma antologia de 1909 aos dias atuais. São Paulo: Editora Fundação Perseu Abramo, 1999. p. 120-134. 
A nova onda revolucionária, a partir dos polos coloniais e semicoloniais do cenário geopolítico pós II Guerra Mundial, teve início em 1954, após a comentada batalha de Dien Bien Phu. No mesmo ano, começaram as atividades da Frente de Libertação Nacional, na Argélia, movimento que conquistaria a independência de seu país em 1962. Ainda nessa fase, iniciou-se toda uma série de processos de independência no continente africano. Em 1959 Fidel Castro chegou a Havana, pondo termo a uma luta que começara em 1954, com o assalto ao quartel de Moncada, e retomada em 1956, a partir de um punhado de homens acantonados na Sierra Maestra. A epopeia dos guerrilheiros cubanos se tornaria célebre em todo o mundo, e engendraria um novo modelo de luta insurrecional, tema que veremos com mais vagar adiante.

Já na década de setenta, o último império colonial em solo africano começou cair por terra, em 1973 os seguidores de Amílcar Cabral declaravam unilateralmente a independência de Guiné Bissau frente aos portugueses, impulsionando a luta travada em Cabo Verde, Angola e Moçambique. Em 1975 a própria metrópole lusa foi tomada por um movimento de renovação política radical, evento que ficaria conhecido como a Revolução dos Cravos. Após a mudança de regime em Portugal, a autonomia de suas ex-colônias africanas foi garantida. Em 1973 a Frente Nacional de Libertação finalmente expulsou o exército estadunidense de seu território, dois anos depois a unificação política do Vietnã se tornou uma realidade. Em 1979 ainda seriam verificadas revoluções na Nicarágua e no Irã, a primeira de cunho socialista, a segunda de caráter religioso, embora tenha contado com elementos laicos em sua construção. O ciclo aberto na Indochina, na década de cinquenta, encerrou-se nos anos $1980^{347}$.

A primeira onda revolucionária mundial foi contida pelo advento do nazi-fascismo, a partir da década de vinte; a segunda, pelo novo arranjo geopolítico internacional conhecido por Guerra Fria ${ }^{348}$. Há que se salientar que insurreições populares também foram duramente

347 “Antes do colapso do sistema soviético, estima-se que cerca de 19 - talvez mesmo 20 - milhões de pessoas haviam sido mortas em mais de cem "guerras maiores e ações e conflitos militares" entre 1954 e 1983 , praticamente todas no Terceiro Mundo: mais de 9 milhões no leste da Ásia; 3,5 milhões na África; 2,5 milhões no sul da Ásia; cerca de meio milhão no Oriente Médio, (...); e um pouco menos na América Latina". HOBSBAWM, Eric. Op. Cit. p. 422.

348 Convencionou-se entre a historiografia ocidental a divisão da Guerra Fria em três fases, a primeira compreende o período inicial do conflito, em 1947, até a crise dos misseis de Cuba, em 1962, também chamada de "Guerra Fria Clássica"; a fase seguinte ficou conhecida como período de "Coexistência Pacífica" (19621979), conjuntura em que novos polos socialistas emergem no cenário internacional, com destaque para China e Cuba; e o período conhecido como "Nova Guerra Fria", (1979-1989), ciclo em que se observa uma nova corrida armamentista, e a derrocada final da URSS. Para mais informações sobre as fases, o significado, e a herança da Guerra Fria, consultar: HOBSBAWM, Eric. A Era dos Extremos, Op. Cit. p. 223-253; THOMPSON, Edward. Et. Alii. Extremismo e Guerra Fria. São Paulo: Editora Brasiliense, 1985; VISENTINI, Paulo G. Fagundes. Da 
reprimidas pelo bloco liderado pela URRS, com destaque para a Revolução Húngara de 1956, e a Primavera de Praga, sufocada pelos blindados russos em agosto de 1968. Mas a grande contenção aos movimentos e levantes populares observados na segunda vaga revolucionária do Século XX esteve sob encargo dos Estados Unidos, a grande potência econômico-militar do período. Já nos primórdios da Guerra Fria, os EUA tomaram para si a tarefa de defesa do "mundo livre", em oposição ao bloco comunista ${ }^{349}$.

$\mathrm{Na}$ ativa desde 1947, a CIA (Agência Central de Inteligência) passou a ofensiva justamente em 1954, ano da simbólica batalha de Dien Bien Phu. Nesse mesmo ano, foi derrubado do poder o presidente da Guatemala Jacobo Arbenz Gúzman, por meio de uma minuciosa operação montada pela CIA, agência que contou com a conivência da elite local, vinculada aos negócios da United Fruit, multinacional cujos interesses estavam sendo prejudicados pelas reformas nacionalistas do governo Arbenz. A deposição do Primeiro Ministro nacionalista iraniano Mohammad Mossadegh, também em 1954, valeu-se igualmente dos serviços da CIA. Nas décadas seguintes, as agências internacionais de espionagem relacionadas (diretamente ou não) ao Pentágono aperfeiçoariam seu know hall na construção de cenários desestabilizadores, naqueles países em que os interesses econômicos do grande capital estadunidense se encontrassem sob ameaça.

Tal situação se verificou na Argentina em 1966 e 1976; no Brasil em 1964; na República Dominicana em 1965, com participação ativa dos EUA, via marines, ação legitimada pela OEA (Ordem dos Estados Americanos). Com envolvimento direto e indireto, os Estados Unidos estiveram presentes na contensão a governos não aliados, e a movimentos rebeldes, em pontos diversos do planeta. Patrocinando Golpes de Estado na Indonésia e na República Democrática do Congo, em 1965; na Grécia em 1967; na Bolívia em 1971, no Uruguai em 1973; nesse mesmo ano foi derrubado Salvador Allende, no Chile. A contenção não se limitaria ao fomento a derrubada de governos insubmissos, também se efetivaria através do

guerra fria à crise (1945-1990): as relações internacionais contemporâneas. Porto Alegre-RS: Editora da URGS, 1990; PAINTER, David. The Cold War: an international history. London: Routledge, 1999.

349 "Apesar das formas histéricas e maniqueistas da Guerra Fria (...), esta possuía uma racionalidade cristalina, pois permitia a este país (EUA) manter o controle político e a primazia econômica tanto sobre seus aliados industriais europeus como sobre a periferia subdesenvolvida (sobretudo latino-americana). Ao manipular a idéia de uma ameaça externa, Washington obtinha a unidade do mundo capitalista e orientava-a contra a URSS e os movimentos de esquerda e nacionalistas, tanto metropolitanos quanto coloniais, emergidos da Segunda Guerra Mundial. A manutenção de um clima de tensão militar conferia aos EUA uma posição privilegiada para consolidar sua expansão econômica mundial e administrar convenientemente o processo de emancipação das colônias que desejava subtrair ao controle de seus próprios aliados europeus. Esta permanente tensão também permitia a hegemonia inconteste da formidável máquina militar americana em pleno tempo de paz. A Guerra Fria constitui-se, assim, numa verdadeira Pax Americana”. VISENTINI, Paulo G. Fagundes. Op. Cit. p. 27-28 
fornecimento de tecnologia antissubversão.

Em se tratando especificamente da América Latina, os efeitos da Guerra Fria se fizeram sentir, em escala crescente, após a Revolução Cubana. Em 16 de abril de 1961, por meio de um discurso célebre, Fidel Castro afirmou pela primeira vez o "caráter socialista e democrático" do processo revolucionário cubano. O movimento que se iniciara com viés de libertação nacional, democrático-burguês, a partir dessa data passou a se pronunciar como socialista, gravitando na órbita do bloco soviético. Historicamente a América Latina foi vista como uma área de influência dos EUA, e o arranjo bipolar pós Segunda Guerra Mundial reforçava os laços de Washington sobre o continente. A insubmissão cubana rompia as convenções geopolíticas internacionais, num território que desde os primórdios de sua independência possuía status de protetorado estadunidense. A aproximação ao bloco soviético apenas galvanizou os ímpetos revanchistas do Pentágono. O primeiro passo em defesa de sua área de interesse, por parte dos EUA, foi isolar política e economicamente a ilha caribenha, o seguinte, foi impedir que o exemplo da Sierra Maestra se espalhasse pelo continente. Com esse desiderato, foram redefinidas as diretrizes da Escola das Américas, em atuação desde 1946, no Panamá, instituição agora voltada ao combate a um inimigo efetivo, o castroguevarismo ${ }^{350}$.

Em que pese todas as medidas de contensão tomadas por Washington, o exemplo vitorioso da Revolução Cubana se tornou um tema candente nos debates da esquerda latinoamericana, e mesmo mundial. Destarte, era demasiado temerário, para os articuladores da grande política estadunidense, vislumbrar em sua principal área de influência o advento de governos que de alguma forma delineassem contornos que se assemelhassem ao regime cubano.

Tomando como exemplo o caso brasileiro, as propostas políticas do bloco organizado em torno da liderança trabalhista-populista de João Goulart sequer se aproximavam do radicalismo revolucionário da ilha caribenha. Porém, na conjuntura em que vieram a luz, as margens de negociação se encontravam reduzidas a mínima movimentação. Os preceitos anticomunistas a emanar do Pentágono não abriam brechas para apostas mais avançadas em sentido democrático e nacionalista, o espaço de articulação independente era reduzido, e

350 A Escola das Américas funcionou no Panamá de 1946 até 1984, quando expirou o acordo de intervenção estadunidense sobre o Canal do Panamá. Posteriormente foi transferida para a Georgia, nos EUA. Por esse centro de ensino passaram cerca de 60 mil militares de 23 países latino-americanos. Tal escola se notabilizou por ministrar cursos de contra-insurreição e combate a guerrilhas, por ela passaram membros das comunidades de informação e repressão de todo o continente. Para mais informações: COMBLIN, Joseph. A Ideologia da Segurança Nacional. O Poder Militar na América Latina. Rio de Janeiro: Editora Civilização Brasileira, 1978. 
qualquer encaminhamento que fugisse as diretrizes estreitas impostas pela Casa Branca era rapidamente taxado de "comunizante".

Tais preceitos se mesclaram perfeitamente aos projetos antidemocráticos de elites nacionais desejosas em estreitar seus vínculos junto ao grande capital internacional especialmente o estadunidense - e por em prática projetos modernizadores de viés autoritário e excludente. A imposição de regimes de força facilitava a execução desses projetos, e o espectro do "comunismo", seja de jaez soviético ou cubano, era um tema caro a governos que precisavam disseminar o pânico entre as classes médias e altas de seus respectivos países, legitimando políticas repressivas e antipopulares. O corpus doutrinário das elites latinoamericanas, temerosas perante o avanço das camadas populares, foi a ideologia de segurança nacional, conjunto de conceitos básicos adaptáveis a distintas realidades.

Se o Pentágono forneceu a visão geral de contenção estratégica ao bloco soviético e "defesa do mundo livre", os serviços de informação franceses deram o suporte inicial a elaboração de táticas de combate e repressão a guerrilha.

Com o advento da guerra fria, elementos da teoria da guerra total e do confronto inevitável das duas superpotências incorporaram-se a ideologia da segurança nacional na América Latina. A forma específica por ela assumida na região enfatizava a "segurança interna", face à ameaça de "ação indireta" do comunismo. Desse modo, enquanto os teóricos americanos da segurança nacional privilegiavam o conceito de guerra total e a estratégia nuclear, e os franceses (envolvidos na Guerra da Argélia) concentravam suas atenções na guerra limitada como resposta à ameaça comunista, os latinoamericanos, preocupados com o crescimento de movimentos sociais da classe trabalhadora, enfatizavam a ameaça da subversão interna e da guerra revolucionária ${ }^{351}$.

O conceito central da nova "ideologia de segurança nacional" em solo latino-americano foi o de inimigo interno. Estando descartada a ameaça de invasões por parte do bloco que se opunha as "democracias ocidentais", os promotores do comunismo internacional se valeriam

351 MOREIRA ALVES, Maria Helena. Op. Cit. p. 39-40. João Roberto Martins Filho, em seu artigo "A influência doutrinária francesa sobre os militares brasileiros...", indica que, ao contrário do que afirma Joseph Comblim, os preceitos de "segurança interna" e "combate a subversão" antecedem as diretrizes do programa anti-insurreição formulados a partir do governo Kennedy e disseminados via Escola das Américas. Ainda em finais dos anos 1950, especificamente em 1957, instrutores franceses com experiência nos conflitos da Indochina e da Argélia ministraram palestras na ESG de Buenos Aires, baseados no conceito da guerre révolutionnaire francesa, voltada ao combate a guerrilhas. Tal conceito foi introduzido no Brasil pelo coronel Augusto Fragoso, em 1959, os novos conceitos de guerra insurrecional e revolucionária foram expostos através de um ciclo palestras proferidas pelo oficial na ESG brasileira. MARTINS FILHO, João Roberto. "A Influência doutrinária francesa sobre os militares brasileiros nos anos de 1960". IN: Revista Brasileira de Ciências Sociais. Vol. 23, n 67. Retornaremos a esse tema quando analisarmos o sistema repressivo da ditadura brasileira. 
de agentes incrustados nos países aos quais desejavam dominar. A larga tradição dos partidos comunistas no continente dava vasão a nova mentalidade. $\mathrm{O}$ inimigo estaria infiltrado entre os nacionais, preparando a tomada do poder desde dentro dos territórios a se conquistar. A vitoriosa Revolução Cubana legitimava essa assertiva. Pautados por essa convicção, regimes autoritários (ou semi- autoritários) de todo o continente reforçaram seus aparatos de repressão e segurança.

$* * * * *$

Em meio a crescente comoção anticomunista continental, realizou-se em Havana, em agosto de 1967, o primeiro e único congresso da Organização Latino-Americana de Solidariedade, conhecida por OLAS. Ao término dos trabalhos, uma declaração dividida em 19 pontos revelava a nova postura do regime cubano em relação ao panorama revolucionário regional, num momento decisivo para os povos das Américas. O documento falava em nome dos "povos de nossa América”, endereçava-se aos grupos formados - ou por se formar voltados ao combate violento as ditaduras e sistemas autoritários de toda região, e buscava direcionar a luta tendo como referencial básico a Revolução Cubana. Articulou-se uma espécie de Internacional latino-americana, cuja sede se encontrava em Havana. Enquanto centro de resistência e capital alternativa das esquerdas do continente, Cuba não se propunha a apenas servir como referência ideológica as organizações revolucionárias da região, dispunhase também a fornecer apoio logístico aos grupos sintonizados a sua proposta. Vejamos alguns dos 19 pontos expressos na declaração da OLAS, precedidos pelo subtítulo Proclamamos:

1. Que constitui um direito e um dever dos povos da América Latina fazer a revolução

3. Que o conteúdo essencial da revolução na América Latina está dado por seu enfrentamento ao imperialismo e às oligarquias de burgueses e latifundiários. Consequentemente, o caráter da revolução é o da luta pela independência nacional, a emancipação das oligarquias e o caminho socialista para seu pleno desenvolvimento econômico e social.

4. Que os princípios do marxismo-leninismo orientam o movimento revolucionário da América Latina. 
5. Que a luta revolucionária armada constitui a linha fundamental da revolução na América Latina.

7. Que para a maioria dos países do continente, o problema de organizar, iniciar, desenvolver e fazer culminar a luta armada constitui hoje a tarefa imediata e fundamental do movimento revolucionário.

10. Que a guerrilha - como embrião dos exércitos de libertação - constitui o método mais eficaz para iniciar e desenvolver a luta revolucionária na maioria dos nossos países.

14. Que a Revolução Cubana, como símbolo do triunfo do movimento revolucionário armado, constitui a vanguarda do movimento antiimperialista latino-americano. Os povos que realizam a luta armada, à medida que avançam por esse caminho, situam-se também na vanguarda ${ }^{352}$.

15.

Com a organização da OLAS, Cuba se definia como um contraponto a hegemonia estadunidense sobre o continente. A proclamação endereçada aos movimentos de resistência americanos, já em seu primeiro item, define como um "direito e um dever" dos povos da região pôr em marcha processos revolucionários em seus respectivos territórios. O viés antiimperialista, anti-oligárquico e anticapitalista é patente no documento, que vai até as raízes históricas do continente para legitimar a tomada do poder por meio das armas. O caráter socialista da revolução é uma realidade, e seu substrato teórico é de matriz marxista-leninista. A necessidade da conquista do poder é imediata, e o método guerrilheiro - a guisa do que ocorrera na Sierra Maestra - é o caminho indicado, mas tal tática de combate significa apenas o "embrião" de futuros "exércitos de libertação", formados durante a luta. Cuba é identificada como a "vanguarda" do movimento revolucionário latino-americano, e chama para si a liderança de tal processo. O documento termina com a célebre frase: "O dever de todo revolucionário é fazer a revolução".

$\mathrm{Na}$ segunda fase da Guerra Fria, a proeminência soviética entrou em declínio, outros protagonistas despontaram dentro do chamado bloco socialista, Cuba e China surgiram como opções alternativas, frente ao desgastado modelo da cortina de ferro. Após o ano de 1968, o modelo de sociedade a emanar de Moscou deixou de ser uma opção entre a maioria dos militantes mais jovens. Na seção passada vimos a postura conservadora dos partidos pró- 
soviéticos diante das rebeliões estudantis mundo afora. A repressão a Primavera de Praga apenas corroborou um processo já em andamento. Em contrapartida, Cuba apresentava um socialismo de resistência, capaz de recuperar o vigor anticapitalista dos descontentes perante os rumos da Revolução de Outubro. Por sua vez, a República Popular da China passava por um pujante processo de reformulação interna, conhecido por Revolução Cultural, fenômeno que atraia a atenção de intelectuais e estudantes do Ocidente. Não esquecendo a luta travada pelo povo do Vietnã contra o poderoso exército estadunidense, luta que também galvanizava os ímpetos revolucionários da juventude mundo afora.

Enquanto se realizavam os trabalhos do encontro de Havana, em agosto de 1967, diversos grupos já haviam dado início as suas atividades guerrilheiras no continente. A Declaração da OLAS menciona quatro territórios em que já se observavam grupos armados de resistência.

$\mathrm{Na}$ Guatemala, primeiro país atingido pelos modernos Golpes de Estado assessorados pela CIA, desde princípios da década organizações como a FAR (Forças Armadas Revolucionárias) e o MR-13 (Movimento Revolucionário 13 de julho) se batiam contra o regime autoritário imposto aos guatemaltecos. Na Venezuela, Douglas Bravo dirigia a luta guerrilheira contra a oligarquia de seu país, representando o braço armado do Partido Comunista Venezuelano. Em 1965 esse dirigente rompeu com o PCV, e poucos anos depois fundou sua própria organização, o Partido da Revolução Venezuelana (PRV). Douglas Bravo, a altura da conferência de Havana, já era um líder conhecido e respeitado no mundo todo. Nas selvas da Colômbia, o exemplo de Camilo Torres, guerrilheiro de origem cristã, assassinado pelo exército colombiano em 1966, impulsionava a ação de movimentos como o ELN (Exército de Libertação Nacional da Colômbia) e as FARC (Forças Armadas Revolucionárias da Colômbia), siglas com forte penetração junto às camadas populares de seu país. Na Bolívia, o ELN (Exército de Libertação Nacional da Bolívia), sob comando de Ernesto Che Guevara, entrava em sua fase final, sem o apoio do Partido Comunista Boliviano de Mário Monje, sem contar com o auxílio e a colaboração dos camponeses locais, num cenário de tragédia anunciada ${ }^{353}$.

Não citadas pelos conferencistas da OLAS, experiências guerrilheiras já haviam sido realizadas no Peru, por meio de organizações como o MIR (Movimento Esquerda

353 Para mais informações sobre as organizações guerrilheiras em combate a altura da Conferência da OLAS, consultar documentos redigidos pelos grupos acima citados em LÖWY, Michael. Op. Cit. p. 293-384. Para informações sobre a guerrilha boliviana de Che Guevara: PERICÁS, Luiz Bernardo. Che Guevara e a luta revolucionária na Bolívia. (2 ${ }^{\mathrm{a}}$ Ed.) São Paulo: Xamã, 2008. 
Revolucionária) e o ELN peruano, grupos desbaratados em 1965; e na Argentina, pelo EGP (Exército Guerrilheiro do Povo), organização liderada por Jorge Massetti, comandante militar que agia sob ordens diretas de Che Guevara. Sua experiência ficou conhecida como "a guerrilha de Salta", região localizada no noroeste argentino. O projeto revolucionário de Guevara para sua pátria foi desmobilizado em finais de $1964^{354}$. Igualmente não mencionado em Havana, destacamos o Movimento de Libertação Nacional, do Uruguai, cujos membros eram conhecidos como tupamaros, agrupamento que já executava ações armadas em seu território. Experiências de fundo guerrilheiro vinham sendo realizadas em diversos pontos da América Latina e Caribe. Mesmo nos EUA, centro da contra-revolução, organizaram-se grupos de resistência armada, como os Black Panters, na ativa desde 1966. No Brasil, verificou-se a breve guerrilha de Três Passos, desmantelada em 1965, e a experiência de Caparaó, desbaratada em abril de 1967.

O encontro de Havana se somou aos trabalhos da Conferência de Solidariedade entre os Povos da Ásia, África e América Latina, também conhecida como “Tricontinental", inaugurada em janeiro de 1966, e presidida pelo chileno Salvador Allende, iniciativa que buscava um esforço conjunto de combate ao imperialismo e ao jugo das potências centrais do capitalismo. No evento se formou a OSPAAAL (Organização de Solidariedade entre os Povos da Asia, África e América Latina). Em princípios de 1967, foi realizada a segunda Conferência "Tricontinental", data deste encontro a divulgação da célebre "Mensagem a Tricontinental", redigida por Che Guevara, ausente do encontro, texto que conclamava a “criação do um, dois, muitos Vietnãs". O testamento político do líder argentino se conclui com o seguinte parágrafo: "Em qualquer lugar que a morte nos surpreenda, bem vinda seja, sempre que nosso grito de guerra tenha chegado a um ouvido receptivo, e outra mão se estenda para empunhar as nossas armas, e outros homens se disponham a entoar os cantos de luto com o matraquear de metralhadoras e novos gritos de guerra e vitória” ${ }^{\circledR 35}$.

Em linhas gerais, esse era o panorama revolucionário contemplado nas Américas as vésperas de 1968. Salientamos a Conferência da OLAS pois compreendemos esse evento como um divisor de águas no processo revolucionário latino-americano, e por conseguinte, brasileiro. Destacamos às experiências guerrilheiras em curso, no período em discussão, a fim de contextualizar a fase que antecede o deflagrar dos Anos de Chumbo no Brasil. A luta

354 Para informações sobre a guerrilha de Salta, PERICÁS, Luiz Bernardo. Idem, p. 40-44. 355 GUEVARA, Ernesto Che. "Mensagem a Tricontinental”, In: Che Guevara. Textos politicos. 4ª Ed. São Paulo: Global Editora, 2009. p. 84 
armada nacional não significou um fenômeno isolado, somou-se a uma série de movimentos em operação no continente, numa época em que a democracia figurava apenas na esfera da retórica. A importância de Cuba, por nós salientada, não se resumiu ao exemplo heroico dos guerrilheiros da Sierra Maestra, efetivou-se também por meio de apoio direto a organizações armadas espalhadas por diversos pontos da América Latina, dentre estes, o Brasil. Seu modelo de revolução suscitou intensos debates entre os grupos em armas, gerando aproximações e divisionismos. Abaixo veremos como se organizou a luta armada em solo brasileiro.

Segundo Eric Hobsbawm, um Golpe de Estado é sempre

um jogo com três jogadores (omitimos a potência ou empresa estrangeira dominante que pode ter os trunfos ou um efetivo poder de veto): as forças armadas, que podem levá-lo a cabo; os políticos e os burocratas, cuja disposição em aceitá-lo o faz viável; e as forças políticas, oficiais ou não, que podem detê-lo ou derrotá-lo totalmente. Porquê êxito de um golpe depende essencialmente da passividade do aparato existente e do povo. Se um dos dois ou ambos resistem, ele ainda pode ser vitorioso, mas já não é um golpe ${ }^{356}$.

Em 1961, dois dos "atores" mencionados por Hobsbawm entraram em cena para barrar a iniciativa golpista da direita nacional. Representando as "forças políticas", mas não atuando em nome destas, o líder trabalhista Leonel Brizola, desde o Rio Grande do Sul, liderou a resistência a movimentação que visava impedir a posse do vice presidente João Goulart, após a renúncia do titular Jânio Quadros. O outro “ator", mencionado no excerto supracitado, a se engajar na luta pela garantia da legalidade, foi o povo riograndense, o mesmo que cerrou fileiras junto a Brizola para bloquear a virada de mesa intentada pelas cúpulas militares. Enquadramos como "povo" também os quadros subalternos das Forças Armadas, fundamentais para a posse de Jango em Brasília.

Não obstante, em 1964, a "passividade" salientada pelo historiador britânico permitiu o êxito do assalto ao poder que vinha sendo articulado por certos segmentos das elites nacionais desde os anos 1950. Em 1964, as forças políticas, “oficiais ou não”, que poderiam 
ter liderado uma reação ao levante militar, omitiram-se. Os setores populares, organizados na Frente de Mobilização Popular, estavam dispostos a reagir ${ }^{357}$, no aguardo de uma voz que pusesse amalgamar as forças de resistência ao pronunciamento. As correntes políticas legais, incluindo o PCB (legalizado dias antes do golpe) nada fizeram para tentar impedir o avanço da reação. O presidente João Goulart falou em evitar derramamento de sangue, Brizola, a voz mais radical em atuação no cenário político brasileiro, exilou-se em silêncio.

Em meados de 1968 parecia que a reação não empreendida pelas forças populares nacionais, em 1964, finalmente estava se tornando uma realidade. Passeatas estudantis tomaram as ruas do Brasil, depois de muito tempo se liam nos jornais notícias sobre greves de envergadura; amplos setores das classes medias se mostravam descontentes com os rumos tomados pelo regime militar (sendo que destes, muitos haviam apoiado o golpe quatro anos antes); vozes opositoras no Congresso Nacional começavam se insubordinar perante a ditadura. Tudo isso veio abaixo em 13 de dezembro de 68. O fechamento do sistema político nacional, para muitos encarado como um retrocesso sem precedentes, para amplos setores da esquerda foi visto como uma senha para se intensificar um projeto de resistência que vinha se delineando muito antes do AI-5.

Daniel Aarão dos Reis Filho, em seu estudo pioneiro intitulado “A Revolução Faltou ao Encontro", apresenta um organograma no qual identifica quatro troncos principais nas origens das organizações armadas atuantes em território brasileiro a partir de 1968, sendo estes o tradicional PCB, a Polop, formada em 1961; o PC do B, fruto do primeiro grande racha do Partidão; e a AP, grupo oriundo da esquerda católica em voga no período ${ }^{358}$. A partir de uma série de cisões internas a esses movimentos, dezenas de siglas guerrilheiras estiveram em atividade entre 1968 e 1975. Não há como compreender esse processo de rachas sem se

357 Jacob Gorender comenta que "Teria sido possível paralisar o golpe se, ao menos, alguma ação viável de contra-ofensiva imediata fosse empreendida". Também existem relatos que os militares de baixa patente, engajados nas associações de classe de suas respectivas armas, estavam dispostos a reagir ao golpe iniciado em 31 de março, contudo, a ausência de diretrizes partidas de canais superiores desmobilizou os miliares. Orlando Miranda indica que uma célula dos grupos de 11 de Leonel Brizola, organizada em Osasco, tentou articular uma resistência em nível local, a espera de ordens que nunca chegaram. Para citação de Gorender; GORENDER, Jacob. Op. Cit. p. 66-67; para tentativa de resistência por parte dos militares de esquerda, MACIEL, Wilma Antunes. "Militares de Esquerda: formação, participação política e engajamento na luta armada (1961-1974)". Tese de Doutorado. São Paulo: FFLCH-USP, 2009. p. 103-110; para grupo dos 11 em Osasco; MIRANDA, Orlando. Op. Cit. p. 112-116

358 REIS FILHO, Daniel Aarão. A Revolução faltou ao encontro. Os comunistas no Brasil. São Paulo: Editora Brasiliense, 1989. p. 13. Antes de 1968 foram verificadas algumas ações armadas no Brasil, como o atentado ao aeroporto dos Guararapes, perpetrado em uma ação isolada de um militante da AP, ação esta condenada pelo movimento. Consideramos o ano de 1968 como o período inicial das ações sistemáticas de guerrilha urbana no Brasil, pois a partir dessa data tornou-se patente entre os grupos mais radicais que o caminho das armas era o único possível para se combater uma ditadura que dava sinais de que não deixaria o poder tão cedo. O AI-5 intensificou esse processo. 
debruçar sobre os debates inter-esquerdas travados ao longo dessa conjuntura. Os principais pontos de divergência entre os agrupamentos se situavam em questões táticas e estratégicas ${ }^{359}$, referentes ao combate a ditadura e a tomada do poder pela via armada, seguida de uma mudança qualitativa no sistema político-econômico nacional.

Com relação ao PCB, seus rachas antecederam a 1964, sendo que sua primeira cisão ocorreu em 1962, motivada por questões políticas, relacionadas a debates que se efetuavam em nível internacional, e questões programáticas relativas aos rumos que o partido vinha tomando desde 1958. Tanto o velho PC quanto o iniciante PC do B mantiveram, em linhas gerais, a antiga estratégia revolucionária consubstanciada a partir do VI Congresso da III Internacional Comunista, realizado em 1928, evento que marcou a ascensão da liderança de Stalin sobre o Comintern. Esse Congresso marcou o enquadramento dos PC's latinoamericanos aos novos moldes soviéticos, agora dominados pela corrente stalinista ${ }^{360}$. Dentro do quadro geo-estratégico internacional, estipulado pelos teóricos do Comintern, o processo revolucionário nos países periféricos deveria se consolidar em duas etapas, uma democráticoburguesa e uma socialista, tendo como principal ator aquilo que se convencionou chamar de bloco das quatro classes, sendo estas: o proletariado urbano, os camponeses, as classes médias e as burguesias nacionais. O sentimento anti-imperialista seria o elo de ligação entre as classes na primeira fase do processo de transição revolucionária. Tal teoria teve como molde a China. Fugiria ao escopo desse trabalho pormenorizar as origens e os desdobramentos dessa estratégia, o que vale salientar é que esse modelo foi direcionado - ou imposto - aos PC's do dito Terceiro Mundo, independentemente de suas condições históricoconcretas.

Mas nem todos se convenceram do viés revisionista tomado pelo PCB em princípios da década de sessenta, e o racha capitaneado por João Amazonas, Pedro Pomar e Maurício Grabois não provocou sérios abalos na tradicional legenda, agora reformulada. Após a razia praticada pela repressão nos primeiros meses posteriores ao golpe, a militância pecebista

359 Compreendemos estratégia como uma medida de caráter global, a longo prazo, destinada a conquista efetiva dos objetivos almejados; tática seriam medidas mais pontuais, de caráter imediato, visando a conquista de posições, até que as condições permitam a consolidação dos objetivos estratégicos. A estratégia se subordina a um planejamento racional, permite prognósticos, enquanto a tática está presa a contingências. Para mais informações sobre o tema, consultar: SAINT-PIERRE, Héctor Luis. Op. Cit.

$360 \mathrm{O}$ enquadramento definitivo dos PC's latino-americanos ocorreu na I Conferência Comunista LatinoAmericana, realizada em Buenos Aires em 1929, nesse encontro aconteceu o famoso debate entre os enviados de Mariátegui, e os emissários da III Internacional, liderados por Victório Codovilla, dirigente do PC argentino. As teses do teórico peruano foram rejeitadas pela Conferência, e o modelo desenvolvido pelo Comintern foi incorporado pelos PC's de todo o continente. Para mais informações sobre esse debate: SCORSIM, Leila. Mariátegui: Vida e Obra. São Paulo: Editora Expressão Popular. 2006. 
começou a se rearticular, tendo como meta a reorganização do partido, e a realização de um balanço crítico acerca do que vinha se passando desde 1964. Em julho de 1966, o periódico comunista Voz Operária, em situação de clandestinidade, publicou suas Teses para Discussão, a serem debatidas no VI Congresso, a ser realizado no ano seguinte. No item 64, presente na seção VI das Teses, chamado "Sobre o Partido", a cúpula pecebista expressou uma autocrítica, condenando os "desvios de esquerda" de sua agremiação. Vejamos alguns pontos desse documento:

O revés sofrido em 1964 pôs a nu muitas de nossas debilidades e revelou com maior clareza a nefasta influência que ainda tem em nossas fileiras, a começar do próprio CC, uma falsa concepção da revolução brasileira, de fundo pequeno burguês e golpista. É uma concepção que, independentemente da linha política, acertada ou não, se tem manifestado de maneira predominante nos momentos decisivos de nossa atividade revolucionária e que consiste em admitir a revolução não como um fenômeno de massas, mas como resultado da ação das cúpulas ou, no melhor dos casos, do Partido. Ela imprime a nossa atividade um sentido imediatista, de pressa pequeno burguesa, desviando-nos da perspectiva de uma luta persistente e continuada pelos nossos objetivos táticos e estratégicos, através do processo de acumulação de forças e da conquista da hegemonia pelo proletariado ${ }^{361}$.

Na seção V das Teses, chamada "Nossa Tática Atual”, a partir do item 43, o PCB define a composição de forças capazes de se opor ao novo regime.

O bloco das forças que se opõem a ditadura pode alcançar grande amplitude do ponto de vista social e deve abranger desde os operários e os camponeses, os intelectuais, os estudantes, os funcionários e demais setores da pequena burguesia até a burguesia nacional e outros setores das classes dominantes cujos interêsses sejam afetados pela política da ditadura. Do ponto de vista político, esta ampla frente deve incluir os comunistas, trabalhistas, socialistas, brizolistas, janguistas, janistas, juscelinistas, além de outros setores dos antigos partidos e de correntes religiosas que tomam posição contra a ditadura, bem como personalidades de prestígio político e líderes religiosos, $(\ldots)^{362}$.

361 Em contraposição ao afirmado "desvio de esquerda" expresso no documento, afirma Gorender que as "Teses apresentam o partido como força temerária, quando todas as análises de protagonistas dos, acontecimentos, jornalistas e historiadores atestam a atuação prudente do PCB”. Voz Operária, No 19, 1966. p.12. Disponível em formato digital no CEDEM da UNESP. Para citação de Gorender: GORENDER, Jacob. Op. Cit. p. 90.

362 Idem, p. 8. É digno de nota que a proposta de alianças do PCB tem grandes semelhanças com a Frente Ampla articulada por Juscelino Kubitschek, Carlos Lacerda e João Goulart, criada no mesmo ano da divulgação das Teses, embora o documento pecebista não reclame a participação de lacerdistas em seu periódico. Em todo caso, Prestes apoiou a Frente Ampla convocada por Lacerda. 
A autocrítica apresentada pela cúpula pecebista se direcionou as correntes minoritárias do partido, embora seja citado o CC (Comitê Central), os "desvios de esquerda" de certos segmentos da legenda desvirtuaram os rumos estratégicos preconizados, na visão dos dirigentes. A recomposição do movimento, agora num contexto ditatorial, deveria obedecer a mesma tática pré-64, com mesmo rol de alianças, incluindo a burguesia nacional. Os princípios permaneceram inalterados, as relações junto ao poder deveriam se balizar nos mesmos moldes daqueles estabelecidos em ambiente democrático. A autocrítica enviesada, e a insistência em uma tática que se mostrou desacertada, em termos práticos, suscitou uma nova escalada de cisões dentro do PCB, de proporções muito maiores do que as verificadas no início do decênio, redundando em "sangrias substanciais em todas as frentes: entre os operários, os camponeses, os intelectuais e variados setores da classe média. No setor estudantil, a situação já era de desmoronamento"363. Tal ambiente de "desmoronamento" prosseguiria nos anos seguintes.

Na cidade de Campinas, em abril de 1967, foi realizada a Conferência Estadual do PCB paulista, sob um clima crescente de insatisfação das bases junto a direção partidária. Nesse encontro, foi eleito primeiro-secretário estadual o veterano militante Carlos Marighella, compondo um agrupamento que cada vez mais se distanciava do programa do CC. Prestes e seu grupo sofreram derrotas semelhantes no Rio Grande do Sul e no Rio de Janeiro, evidenciando o descontentamento da militância frente os rumos delineados pela direção da legenda. Dos 37 delegados eleitos pelas bases para participar do pleito interno de Campinas, 33 votaram a favor de Marighella, a maioria dos votantes era proveniente dos meios estudantil e operário. De acordo com Gorender, a cúpula pecebista não aceitou com "espírito democrático" o revez sofrido e decretou uma intervenção em São Paulo, impondo Hércules Corrêa dos Reis como primeiro-secretário da seção estadual ${ }^{364}$.

Marcando posição de distanciamento, Marighella participou da Conferência da OLAS, na capital de Cuba, em agosto de 1967, contrariando as recomendações da direção pecebista, que recusara o covite enviado por Havana e decidira pela não participação no encontro, por motivos de divergência programática. Em dezembro do mesmo foi realizado o VI Congresso do PCB, consolidando as Teses de julho de 1966,. No encontro foi negando veementemente o caminho da luta armada. Nesse sentido, membros da agremiação que possuíam posições

363 GORENDER, Jacob. Op. Cit. p. 89

364 Informações sobre o Congresso de Campinas, Escritos de Carlos Marighella. São Paulo: Editora Livramento, 1979. p.7 (Introdução); para informações de Gorender: GORENDER, Jacob. Op. Cit. p. 91. 
diferentes sobre tal temática foram sumariamente expulsos do partido, a começar por Carlos Marighella. Além do dirigente baiano, também foram excluídos Mario Alves, Manuel Jover Telles, Jacob Gorender, Joaquim Câmara Ferreira, Miguel Batista dos Santos e Apolônio de Carvalho $^{365}$. A resolução acerca do desligamento dos militantes supracitados foi publicada no número 35 do periódico Voz Operária, em janeiro de 1968. Os motivos alegados foram resumidos em duas palavras: "atividade fracionária". Junto a esses nomes, acrescentou-se a identificação de mais alguns componentes desligados do partido, expulsos por delação ${ }^{366}$.

A resposta de Marighella (e Joaquim Câmara Ferreira, dirigente que compartilhava das mesmas proposições revolucionárias do líder baiano) veio por meio do "Pronunciamento do Agrupamento Comunista de São Paulo". Neste documento ficou expressa a nova linha a ser adotada pela oposição às diretrizes políticas do CC de Prestes e Giocondo Dias. Antes de pormenorizar o caminho a ser seguido, o grupo fez questão de deixar claro que considerava as medidas adotadas pelo VI Congresso do PCB uma fraude, visto que foram ratificadas "sem a presença dos discordantes". Logo em suas primeiras linhas, definiu-se a posição de discordância frente a "linha pacífica" sustentada pelo Comitê Central. Afirmou-se que o programa político do agrupamento é o adotado pela Declaração Geral da OLAS, e que o caminho revolucionário brasileiro deveria se efetivar por meio da guerra de guerrilhas. $\mathrm{O}$ texto também deixa claro que não se pretendia adotar de maneira mecânica o foco guerrilheiro no Brasil, afirmando que tal modalidade de luta armada, em solo nacional, "não terá condições de vitória senão como parte de um plano estratégico e tático global”.

Ao longo do documento fica clara a aversão do novo grupo ao burocratismo ala Partidão. O Comitê Estadual foi desativado, definindo-se a necessidade de uma "organização clandestina, pequena, bem estruturada, flexível, móvel. Uma organização de vanguarda para agir, para praticar a ação revolucionária constante e diária, e não permanecer em discussões e reuniões intermináveis". A organização que se delineava era em tudo oposta ao PCB, antiburocrática, norteada pela práxis revolucionária, isto é, voltada a ação; dinâmica e vanguardista, dispensando a construção de um partido aos moldes bolcheviques, ficando postergada a construção de um organismo partidário a estágios superiores da luta pela tomada do poder. Nos últimos parágrafos do pronunciamento se lê que a "mesa das discussões hoje em dia já não une os revolucionários. O que une os revolucionários brasileiros é desencadear

365 Idem, p. 91-92

366 Jornal Voz Operária, № 35, janeiro de 1968. p. 1 
a ação, e a ação é a guerrilha" ${ }^{\text {367 }}$. O documento é mais um compêndio de princípios táticos, faz poucas referências ao caráter da revolução a ser desencadeada no país, ficando patente apenas sua vinculação ao programa da OLAS. Adiante discutiremos essa temática ao expormos os projetos de transição pós capitalista em voga nos Anos de Chumbo.

Dois dos dirigentes expulsos na VI Conferência pecebista, Jacob Gorender e Mário Alves, lideraram a formação do PCBR (Partido Comunista Brasileiro Revolucionário), no começo de 1968. Ao contrário do Agrupamento Comunista de São Paulo, a nova organização não defendia o início imediato da luta armada, considerando ser necessário um período de preparação. Outro diferencial em relação ao grupo de Marighella, foi a adoção de uma estrutura partidária, não burocrática, norteada por preceitos de democracia interna e mais flexível no que concerne seu campo teórico. O PCBR se situava a meio termo entre o tradicionalismo organizacional de matriz bolchevique, e o modelo insurrecional cubano. Tinha por meta articular ações de massa, legais e ilegais, e a formação de futuras guerrilhas rurais, estando todas as forças em luta subordinadas as diretrizes do partido revolucionário. $\mathrm{O}$ PCBR foi constituído em abril de 1968, em uma conferência realizada na Serra da Mantiqueira, no Rio de Janeiro ${ }^{368}$.

$* * * * *$

Outro tronco-matriz das esquerdas brasileiras surgidas nos anos 1960 foi a Organização Revolucionária Marxista-Política Operária (ORM-Polop), mais conhecida como Polop, sigla que identificava o periódico redigido por esse movimento. A nova agremiação foi fundada em um congresso efetuado entre os dias 16 e 19 de janeiro de 1961, na cidade Jundiaí, interior de São Paulo. Tal sigla foi o resultado de uma coalizão que reuniu diversos grupos de esquerda, contrários as teses do PCB. O congresso reuniu a "Juventude Socialista, da Guanabara, parte da Juventude Trabalhista de Minas Gerais, membros da Liga Socialista e do Partido Socialista Brasileiro (PSB)" ${ }^{\text {369 }}$, e dissidentes do Partidão descontes com os rumos tomados por sua legenda. Em seu primeiro exemplar, lançado cerca de um ano após a criação do grupo (vendido a 15 cruzeiros), o periódico Política Operária trazia expresso, em primeira página, sua proposta de travar um debate alternativo, qualitativamente novo, e que rompesse com os 367 Idem, p. 134-137

368 Para informações sobre o PCBR, consultar; GORENDER, Jacob. Op. Cit. p. 101-106

369 MATTOS, Marcelo Badaró. “Em busca da revolução socialista: a trajetória da Polop (1961-1967). Op. Cit. p. 197 
velhos esquemas da esquerda tradicional.

Que significa essa política operária? Em que consiste esse programa? Poderíamos responder simplesmente que se trata da renovação da Esquerda no País. A velha esquerda, que já teve um papel significativo nas lutas do passado, gastou-se e mostrou-se incapaz de acompanhar o desenvolvimento que tanto se fala. Hoje não consegue mais galvanizar a nova geração destinada a continuar a obra.

Essa nova geração revolucionária demonstra a sua existência em tôda crise política, nas Universidades, nas fábricas, nas ruas. É ela que toma as iniciativas da luta anti-imperialista; que propaga as idéias da revolução cubana e que defende os precários direitos democráticos quando ameaçados por golpes da direita. Esses novos, todavia, ainda não conseguiram definir-se como fator político capaz de oferecer objetivos de luta que representem de todo uma alternativa à política burguesa tradicional. Depois do desgaste dos velhos surgiu um vácuo. Contribuir para preenchê-lo, eis a nossa razão de $\operatorname{ser}^{370}$.

Em que consistia o "desgaste dos velhos" expresso no primeiro número do informativo polopista? E qual o vácuo a ser preenchido? A nova organização foi formada por militantes refratários as teses pecebistas, atuantes desde os anos cinquenta, reunia ativistas oriundos de agremiações socialistas, trotskistas, luxemburguistas. Em seu rol de leituras figuravam teóricos desconhecidos no Brasil, ou menos requisitados, como Buckárin, Brandler, Talheimer, etc. Os "novos" intelectuais ativistas a compor o núcleo original Polop rapidamente ganharam destaque no meio acadêmico nacional, dentre estes estavam Theotônio dos Santos, Moniz Bandeira, Vânia Bambirra, Ruy Mauro Marini, Juarez Guimarães de Brito, Emir Sader, Eder Sader, Michael Löwy, dentre outros.

Mas o grande agregador do movimento foi um militante não tão jovem, o judeu austríaco emigrado Eric Czaczkes Sachs, conhecido pelo pseudônimo de Ernesto Martins. Sachs era remanescente das lutas anti-fascistas da Europa, estudara em Moscou, e convivera com um grupo de exilados em Paris alguns anos antes da II Guerra Mundial. Na capital francesa, aproximou-se da Oposição Comunista Alemã ${ }^{371}$, cisão do KPD (Partido Comunista

370 Jornal Política Operária; № 1, Rio de Janeiro, janeiro de 1962. p. 1. Disponível em formato digital no CEDEM da UNESP

371 A Oposição Comunista Alemã, organizada no KPO (Partido Comunista de Oposição), formou-se a partir de divergências entre alguns dirigentes locais, dentre estes Talheimer e Brandler, contra a novas diretrizes impostas por Stalin ao Comintern. O afastamento de Bukharin da direção do Partido Comunista da União Soviética acelerou o processo de cisão na Alemanha, uma vez que o dirigente soviético possuía posições políticas próximas as dos dois dirigente supracitados, os mesmos que foram expulsos do KPD (Partido Comunista da Alemanha), formando posteriormente o KPO. O KPO foi filiado a OIC (Oposição Comunista Internacional), organização formada por Nicolai Bukharin e Alexei Rykov, movimento que obteve representação em diversos 
Alemão), convivendo com August Talheimer e Heinrich Brandler, veteranos das revoluções alemãs do início dos anos 1920. No mesmo ambiente, conviveu com Nicolai Bukharin, pouco antes da prisão e condenação do mesmo pelo regime stalinista, em 1938. Com o eclodir do conflito mundial, Sachs migrou para o Brasil em 1939, onde passou a atuar inicialmente como operário gráfico, e posteriormente como jornalista. Sua militância política junto a correntes anti-stalinistas definiu sua posição de distanciamento em relação ao PCB. Seu pensamento possuía matizes leninistas, trotskistas - sem o ranço dogmático comum aos ativistas dessa tendência na América Latina; luxemburguistas, além da influência direta que recebera das correntes heterodoxas do marxismo alemão, através de Talheimer e Brandler. Coube a Sachs a introdução do pensamento desses dois teóricos no Brasil ${ }^{372}$.

O "vácuo" deixado pelo superado - segundo os polopistas - programa comunista seria preenchido por uma nova estratégia revolucionária, concebida a partir das matrizes teóricas supracitadas, mas nem por isso desatenta ao panorama político contemporâneo ao contexto em discussão. Destarte, o segundo número do Política Operária trouxe em sua primeira página uma declaração de Fidel Castro, dizendo que "A Revolução Antiimperialista e Socialista tem que ser uma só". Contudo, o corpo do texto trás a advertência de que "dificilmente a experiência cubana se repetirá", visto que "o imperialismo e as burguesias" do continente estariam alertas para o surgimento de novos focos insurgentes análogos aos cubanos, fato este que implicava numa mudança "estratégica" dentro do campo revolucionário latino-americano. Também é evocado o início "pequeno-burguês" do processo caribenho, louvando-se sua viragem socialista em princípios da década de sessenta ${ }^{373}$. Desde sua concepção, a Polop se definiu como defensora da passagem imediata ao socialismo, após a supressão do regime burguês, a ser derrubado por uma frente popular, a mesma que deveria unir os trabalhadores "da cidade e do campo", sob a liderança do proletariado urbano.

Num país como o Brasil, com três milhões de operários industrias, nenhum movimento de esquerda poderá viver e crescer à margem da classe operária. É esta que fornece o caminho da ação e

\footnotetext{
países, chegando a ter ramificações na Índia, na Argentina e no México. Com o encrudescimento do regime nazista, Brandler e Talheimer se refugiaram na França, período em que conheceram Eric Sachs, com o deflagrar da II Guerra Mundial, ambos se refugiaram em Cuba. Talheimer veio a falecer em Havana, em 1948, Brandler retornou a sua pátria após o fim do conflito mundial, e retomou as atividades do KPO, vindo a falecer em 1967. Para mais informações, consultar: CLIFF, Tony. "Trotsky: The darker the night the brigher the star (19271940)". Artigo disponível em formato digital no site: www.marxists.org

372 MEYER, Victor. Texto de apresentação do livro: SACHS. Eric. "Qual a Herança da revolução russa e outros textos". Belo Horizonte-MG: Editora Segrac, 1988.

373 Jornal Política Operária, № 2, Rio de Janeiro, abril de 1962. p. 6-11
} 
os objetivos da luta a milhares de jovens do movimento estudantil que hoje procuram imprimir novos rumos a política nacional. É ela capaz de agrupar em torno de si os milhões de camponeses que despertam para a vida, e dar consciência a sua luta. E igualmente, o movimento operário é o único capaz de mobilizar as camadas mais radicais da pequena pequena-burguesia $(\ldots)^{374}$.

Nessa passagem fica expresso o caráter obreirista da organização em análise, fruto de uma formulação eclética que tinha como referências o processo soviético, passando pela revolução alemã, sem desprezar as recentes experiências revolucionárias a emanar da periferia do sistema capitalista. Se estrategicamente a meta a se atingir era a edificação do socialismo, taticamente o objetivo a ser perseguido deveria ser o da construção de uma frente revolucionária, sob a hegemonia do proletariado, algo a ser preparado ao longo dos anos. Para a Polop, a revolução no Brasil não poderia se efetivar por meio de uma guerra de guerrilhas, e sim através de uma insurreição operária. Tendo isso em vista, uma das iniciativas dessa organização foi o incentivo a formação de organismos de base entre os trabalhadores. Os comitês funcionariam como células do movimento, de modo a agregar os trabalhadores e orientá-los dentro do projeto revolucionário da Polop. Na seção passada vimos que militantes polopistas estiveram presentes na condução das comissões de fábrica de Osasco.

A Polop também logrou uma importante participação no movimento estudantil, esteve presente nas jornadas de luta pré-64, e no turbulento ano de 1968. Embora se anunciasse como uma organização operária, o grosso de sua militância sempre se situou entre os estudantes. Segundo Marcelo Badaró Mattos, “em seus textos mais doutrinários, a Polop tratava o movimento estudantil em termos de uma análise da dinâmica das classes sociais, ao discutir o papel da pequena-burguesia no processo revolucionário" 375 . Apesar do estudantado possuir status de força auxilar no processo insurrecional brasileiro dentro do programa polopista, em termos práticos, a hegemonia dentro dessa organização sempre pertenceu a quadros provenientes dos meios acadêmicos, especialmente do ME. Do meio universitário partirão os ativistas a organizar o racha da organização, em 1967.

Entre os militares também se verificou relevante penetração polopista. Atentos a crescente politização nos quartéis, militantes da organização acompanharam de perto a movimentação dos quadros militares subalternos. Em sua edição de janeiro de 1964, o periódico Política Operária trouxe uma lúcida análise sobre o fenômeno que a essa altura 
provocava abalos no seio das Forças Armadas do país, vejamos um trecho.

Entre os acontecimentos que marcaram o ano de 1963, poucos terão sido tão importantes quanto a irrupção do movimento dos sargentos na política nacional. A análise em profundidade desse movimento ainda está por ser feita. É inegável, entretanto, que ele surge a partir de uma consciência política empiricamente adquirida, em função do trato diário de problemas imediatos. $\mathrm{Na}$ raiz da politização verificada nas camadas inferiores das Fôrças Armadas, encontramos o mesmo elemento que determinou a politização geral das massas, que se vem operando no país: os sacrifícios decorrentes da política inflacionária e o desencanto gerado pelas soluções reformistas. Que as Fôrças Armadas não escapam às leis gerais que regem a luta de classes no país, demonstra-o as atitudes assumidas pelos oficiais e graduados, em relação ao aumento do funcionalismo civil e militar. (...)

É, pois, encarando o movimento dos sargentos como um setor do movimento de massas que podemos compreendê-lo. É, também, a partir de tal perspectiva que sua manifestação mais espetacular - o levante de Brasília, de 12 de setembro último - deixa de apresentar-se como dado isolado e acidental, no quadro nacional das lutas de classe, para surgir como resultado necessário de uma evolução e prenúncio de uma nova etapa ${ }^{376}$.

Em que pese sua densidade teórica e o seu corpo de quadros intelectuais de renome, a Polop jamais conseguiu grande penetração junto aos movimentos sociais aos quais se dispôs a conquistar, seu grande mérito foi sofisticar o debate intelectual inter-esquerdas, enriquecendo a teoria marxista brasileira. $\mathrm{O}$ grande debate incitado pelos polopistas foi o travado ante as teses do PCB, sobretudo no que concerne ao caráter da revolução nacional. Enquanto os comunistas seguiam com seu modelo etapista, dividido em duas fases, sendo a primeira democrático-burguesa, o programa polopista definia a necessidade de uma passagem imediata ao socialismo, visto que o Brasil era considerado - por essa corrente - uma nação plenamente capitalista. "Segundo os teóricos da Polop, as diferenças nacionais entre os países integrados no sistema capitalista mundial se tornavam secundárias diante do amadurecimento geral do

376 Jornal Política Operária, São Paulo, 15 a 21 de janeiro, 1964. p.3. Com relação ao recrutamento militar por parte da organização em análise, Marcelo Badaró Mattos chama a atenção para o fato da "concepção de revolução da Polop ser diretamente derivada do modelo insurrecional soviético, sendo, portanto, natural que a bandeira da unidade entre operários, camponeses e soldados fosse referência importante para as análises produzidas pelo agrupamento". Contudo, em seu programa inicial, expresso no primeiro exemplar do jornal Política Operária, não há menção ao elemento militar no chamamento para a formação da "frente única" reclamada pela organização. Marcelo Ridenti atesta que a porcentagem de militares de baixa patente engajados na Polop representou $20 \%$ do total dos membros lotados na organização, ficando atrás apenas dos estudantes. A porcentagem de oficiais foi bem menor, $1,3 \%$. Os dados se referem apenas aos processados na Polop, não faz menção aos detidos após os rachas pós 1967. Para citação de Mattos: MATTOS, Marcelo Badaró. Op. Cit. p. 206. Para dados de Ridenti: RIDENTI, Marcelo. Op. Cit. p. 275-276. 
sistema para a transição direta para o socialismo"377.

Tal pensamento teve como principal referência a teoria do desenvolvimento desigual e combinado de Leon Trotsky, teórico que como vimos acima foi uma das fontes formadoras do campo teórico do Polop. Segundo Michael Löwy, a conceituada teoria proposta pelo líder soviético é derivada de uma análise que inferia que da "combinação de traços pré-capitalistas (notadamente no campo) e capitalistas modernos (na grande indústria das cidades) Trotsky concluía a possibilidade de uma revolução russa combinando as "tarefas democráticas" (derrubada do czarismo, partilha das terras, democratização do Estado) e as medidas socialistas (expropriação do grande capital), num processo de revolução permanente". Mais adiante, Löwy comenta que segundo "Ernest Mandel, a idéia do desenvolvimento desigual e combinado do capitalismo mundial é - com a exceção da concepção de Marx sobre a determinação econômica da luta de classes - a tese marxista mais amplamente assimilada desde há meio século, mesmo que raramente seja feita referência ao seu autor"378.

Tal teoria adaptava-se a realidade brasileira - e latino-americana - , pois se tratava de uma região que vinha experimentando um importante ciclo de desenvolvimento ao longo do Século XX, sem, contudo, efetivar reformas que dessem contornos plenamente capitalistas a região. O Brasil era um caso típico no continente, país cujo crescimento expressivo se encontrava territorialmente localizado, possuidor de um parque industrial em crescimento, e por conseguinte, de uma camada operária relativamente numerosa. País que possuía uma grande concentração fundiária; de flagrantes desigualdades sociais, tendo amplas parcelas de sua população excluídas do processo produtivo. Pelo programa da Polop, em consonância com a teoria trotskista, caberiam duas revoluções simultâneas no processo de transição brasileiro, uma burguesa e uma socialista.

Ao longo de sua trajetória, a Polop realizou quatro congressos, o de fundação, em 1962, um seguinte, um ano depois; um em 1964, e finalmente o encontro de 1967, que marcou o grande racha da organização. Adiante discutiremos os desdobramentos dessa cisão. Para completar esta exposição, é necessário um comentário sobre a situação da organização em análise após o golpe de 1964. Diferentemente do PCB, vitimado por uma bateria de críticas após o assalto ao poder, a Polop se fortaleceu moralmente, em que pese a inevitável

377 GORENDER, Jacob. Op, Cit. p. 36.

378 LÖWY, Michael. "A teoria do desenvolvimento desigual e combinado". Artigo publicado na revista Actuel Marx, No 18, 1995. Tradução de Henrique Carneiro. 
repressão sofrida. Na edição número 7 do informativo Política Operária (em formato de revista), publicado em outubro de 1963, Eric Sachs, sob o pseudônimo de Eurico Mendes, chamou a atenção para "a nova ameaça da ditadura".

Quem representam essas forças que ameaçam novamente o país com uma ditadura aberta?

As classes dominantes estão divididas. De um lado, temos a burguesia industrial, que tanto deve a Getúlio, que cresceu com Juscelino e que depois se entregou a fracassada experiência de Jânio. Hoje ela exige reformas políticas e sociais para sair da situação econômica e financeira desesperada, para afastar os obstáculos internos à sua futura expansão e para afastar o espectro da revolução que paira latentemente sôbre a nossa sociedade subdesenvolvida. (...)

Do lado oposto, na coligação das classes dominantes, encontramos o latifúndio, ligado ao capital comercial e bancário e a tôda uma escala de intermediários, que exploram o campo e estão interessados na conservação do status quo. Seu ideal - na medida que essa facção raciocina nesses termos - seria um regime conservador, sustentado pela força, como se realiza atualmente nas Península Ibérica.

Os dois expoentes das duas facções, em virtude da posição real que tomam na política nacional, são Goulart e Lacerda. (...) ambas as facções colaboram com o imperialismo, procurando a benção oficial do Departamento de Estado (dos EUA) para seus fins políticos. (...)

Uma coisa as duas facções tem em comum: ambas visam soluções de força, visam a golpes, visam a restringir os precários direitos democráticos populares. Isso só reflete a situação objetiva da classe dominante, que, em vista da latente crise econômica e financeira, não vê outra saída senão baixar mais ainda o nível de vida das massas trabalhadoras e abafar o seu grito de revolta. Essa situação econômica objetiva determina, independentemente dos métodos recomendados, pelas facções antagônicas, o caráter final do golpe. Mesmo iniciado sob um um rótulo de esquerda, uma vez consolidado, ele terá de lançar-se contra o movimento operário e camponês e acabará desfraldando a gasta bandeira do anticomunismo ${ }^{379}$.

Discorrer sobre uma possível ditadura de João Goulart pertenceria ao terreno da especulação, muito já se discutiu sobre os ímpetos autoritários de Jango, e não caberia aqui tal tarefa. Vale apenas destacar que a época da distribuição do texto, o Congresso Federal recusara um pedido de Estado de Sítio proposto pelo presidente, dando ensejo a desconfianças, tanto a esquerda, quanto a direita. Não obstante, o artigo de Eric Sachs é de uma lucidez notável, a "gasta bandeira do anticomunismo" serviu de justificativa não apenas 
para o golpe de 1964, mas para o período ditatorial como um todo. As medidas de arrocho foram largamente utilizadas para contornar a crise econômica que assolou o país durante a década de sessenta, e a repressão foi usada em larga escala para "abafar o grito de revolta" das classes populares.

Com relação a identificação das "duas facções antagônicas" da burguesia, presentes no jogo político nacional, o artigo não antecipa (algo que não retira em nada os méritos do prognóstico de Eric Sachs) a coalizão verificada entre os dois grupos na reta final da conspiração golpista, formando a frente que daria suporte aos militares. Em todo caso, o conflito de interesses identificados nas duas facções supracitadas se fariam presentes logo nos primeiros anos do ciclo autoritário, evidenciando a pouca viabilidade de uma coalizão que rapidamente deixou de lado suas veleidades no que respeita a divisão equitativa de poder e representatividade. Os interesses da "burguesia nacional" rapidamente foram ultrapassados pelos do bloco vinculado ao grande capital multinacional, como é bem sabido. O fato é que o único compromisso a unir as elites brasileiras foi a contenção as classes populares. No rol de quebras de compromissos estabelecidos pelos conspiradores, Carlos Lacerda, citado no artigo, foi um dos penalizados mais notórios.

Embora extensa, fez-se necessária a apreciação dos anos iniciais da Polop, devido a importância dessa organização no debate entre as esquerdas nacionais, tanto no pré, quanto no pós golpe. A lucidez teórica dos quadros da Polop deixou de empolgar largas parcelas de sua militância a partir de 1967, fase em que a radicalização política do país se anunciava como iminente. O movimento em questão deu origem a uma série de agrupamentos, os mesmos que após 1968 se direcionariam a resistência violenta ao regime. Dentre estas organizações, ao menos duas formaram bases em Osasco, e receberam ativistas do GO em suas fileiras, adiante discorreremos sobre esses grupos.

Não enquadrados ao espectro das esquerdas de matriz comunista, mas bastante atuantes, destacaram-se os movimentos de origem militar formados por quadros das Forças Armadas cassados após o golpe de 1964. Os militares de baixa patente, através de suas associações de classe, chamaram a atenção do país para as demandas políticas de sua categoria, e por isso atraíram a atenção de distintos setores da sociedade, tanto a esquerda, 
quando a direita. O sonho soviético de uma articulação civil-militar, capaz de desafiar as elites, empolgou tanto os que almejavam uma mudança radical nas estruturas de poder do país, quanto aqueles que trabalhavam apenas pela efetivação das Reformas de Base propostas por Jango. Por outro lado, o mesmo contexto soviético foi evocado pela direita com o objetivo de estimular o pânico, sobretudo entre as classes médias.

O estudo de Maria Helena Moreira Alves aponta que somente no ano de 1964, por meio do expurgo inicial pós AI-1, foram exonerados 505 membros do Exército, 335 da Marinha, e 360 da Aeronáutica. Os expulsos adquiriram o status de "mortos", e suas esposas passaram a receber pensões como "viúvas", em valores muito abaixo do soldo de seus companheiros afastados de sua profissão. Além disso, cassado e afastado de suas funções, o militar encontrava muitas dificuldades para obter trabalho como civil" ${ }^{380}$. Afastados de sua profissão e com reduzidas perspectivas de futuro profissional, muitos desses militares passaram a trabalhar pela construção de uma resistência armada a ditadura. Dos grupos que se formaram a partir dos militares cassados, o MNR foi o que obteve maior destaque.

Essa organização era composta por sargentos, marinheiros (muitos vindos da extinta Associação dos Marinheiros e Fuzileiros Navais do Brasil, conhecida pela sigla AMFNB); e mesmo alguns civis. O grande líder político desse grupo foi Leonel Brizola, que desde o exterior comandava o movimento. A coordenação militar esteve sob encargo do sargento Amadeu Felipe e do subtenente Jelcy Correa. O MNR também recebeu em suas fileiras ativistas com treinamento em $\mathrm{Cuba}^{381}$. Em São Paulo, o grande articulador dessa organização foi o sargento Onofre Pinto, no Rio de Janeiro, os marinheiros Edson Neves Quaresma, Cláudio Ribeiro de Souza, e Antonio Geraldo da Costa, remanescentes da AMFNB ${ }^{382}$. Ao menos duas tentativas de levantes foram coordenados pelo MNR, a primeira em 1965, sob a liderança do coronel Cardim, conhecida como "guerrilha de Três Passos", rapidamente

380 MOREIRA ALVES, Maria Helena. Op. Cit. p. 78-79

381 Segundo Denise Rollemberg, houve três levas de brasileiros que se deslocaram a Cuba a fim de receber treinamento guerrilheiro. A primeira geração dos que receberam treinamento em Cuba antecede o golpe de 64, nesse momento a ponte entre o Brasil e o governo de Fidel Castro era Francisco Julião, líder das Ligas Camponesas em sua fase mais radical. Após o golpe, as articulações passaram a se dar entre Brizola e o governo cubano, e militares ligados ao MNR passaram a se descolar para a ilha. Com o desfecho de Caparaó, Carlos Marighella, após sua participação na Conferência da OLAS, tornou-se o principal interlocutor brasileiro junto aos cubanos. Segundo a autora, o abandono do programa de "exportação" do modelo revolucionário cubano terminou em 1970, quando Fidel estreitou os laços de sua pátria com a URRS. Ao longo dos anos 1960, cerca de três mil pessoas receberam treinamento em Cuba. Para mais informações: ROLLEMBERG, Denise. $O$ apoio de Cuba à luta armada no Brasil: o treinamento guerrilheiro. p. 2-6. Obra disponível em forma de artigo, no endereço eletrônico:

http://www.historia.uff.br/nec/sites/default/files/O_apoio_de_Cuba_a luta armada.pdf 382 MACIEL, Wilma Antunes. Op. Cit. p. 115-116 
desbaratada pela repressão. A segunda foi a conhecida tentativa de instalação do foco de Caparaó, sob influência direta da Revolução Cubana, iniciativa igualmente desmobilizada pelas forças armadas do regime, guerrilha que caiu sem disparar um tiro.

Após a mal sucedida experiência de Caparaó, Leonel Brizola se afastou do MNR, e o movimento passou por um período de recomposição interna. Militantes radicados no Rio de Janeiro, especialmente os marinheiros, dirigiram-se para São Paulo, e passaram a se organizar em torno da liderança de Onofre Pinto. Outra porção do grupo permaneceu no Rio de Janeiro, e a partir de 1968 aproximou-se de um grupo de militantes vindos do racha da Polop. Tal composição ajudou a consolidar as coalizões que ocorreram entre egressos dos rachas do Política Operária e do MNR, tanto em São Paulo, quanto no Rio de Janeiro e Minas Gerais.

\section{$* * * * *$}

Na última seção vimos que em finais de 1967, após os eventos relacionados ao MIA e sua dissolução, o município de Osasco se tornou uma espécie de polo de contestação ao regime militar. Os fatos verificados ao longo de 1968 credenciaram ainda mais a região como um foco de resistência e oposição ao sistema autoritário. No primeiro capítulo vimos que os órgãos de repressão também estavam informados sobre as atividades subversivas praticadas na cidade, o que levou o Dops a qualificar a Greve de Osasco como uma etapa na escalada da "guerra revolucionária", travada pelas forças que estariam se congregando para tomar o poder no país ${ }^{383}$.

Cientes do clima de insubordinação que incidia sobre a cidade, diversos grupos de esquerda enviaram representantes seus - ou reforçaram as atividades daqueles que já se encontravam mobilizados na localidade - com fins de arregimentar aquele grupo de jovens militantes que vinham de destacando como força de oposição a ditadura. Pelo município passaram ativistas da Polop, Ação Popular; Agrupamento Comunista de São Paulo, futura ALN; correntes trotskistas, além do já tradicional PCB. Em Osasco também estavam articulados membros de um grupo que em meados de 1968 se identificava apenas pela letra “O.” (O de Organização, pronunciava-se “ó pontinho”).

A “O.” possuía entre seus quadros remanescentes do MNR, egressos do racha da Polop, e intelectuais de esquerda independentes. Seus trabalhos remontam a princípios de 1968, por 
volta do mês de agosto do mesmo ano, a organização já se subdividia em três setores: o Logístico, o Urbano, e o setor de Campo. No Logístico, responsável pela aquisição de fundos para a manutenção do movimento, figuravam militares oriundos do MNR, liderados por Onofre Pinto, o coordenador do setor. Neste departamento se concentraram os militantes adeptos do militarismo agressivo que marcaria a futura VPR.

O setor Urbano era coordenado por João Quartim de Moraes, e o setor Campo estava sob direção de Ladislas Dowbor, cabia a este departamento a preparação do foco guerrilheiro. Esses dirigentes representavam a porção intelectual da organização, eram teóricos marxistas de algum renome, especialmente entre a esquerda universitária, e chegaram a "O.” por um itinerário semelhante. Ambos estudaram na Europa entre 1964 e 1968, em Paris tomaram contato com um grupo de exilados brasileiros, reunidos em torno do deputado cassado José Maria Crispim, que rompera com o PCB e se aproximara do trotskismo. Crispim manteve contato com o MNR, depositando esperanças na resistência articulada pelo brizolismo, após o fim da sigla militar, em finais de 1967, manteve-se próximo de Onofre Pinto e seus companheiros. Ainda na França, Quartim e Dowbor tomaram conhecimento das movimentações dos ex-militares em solo brasileiro, e de retorno ao Brasil, aproximaram-se da "O."384. Embora ambos viessem de militância intelectual, Ladislas, desde o princípio de suas atividades na organização, sempre se norteou por princípios militaristas, aproximando-se da ala mais radical do grupo. Em contrapartida, Quartim de Morais, em seu curto período como teórico do movimento, sempre se chocou com as opções vanguardistas da corrente militarista.

Em meados de 1968, dois grupos que em menos de seis meses formariam as maiores organizações guerrilheiras do país, o Agrupamento Comunista de São Paulo e a "O.”, já se encontravam num acelerado processo de arregimentação de quadros, e dentro dessa conjuntura, o GO era um ajuntamento de ativistas deveras cobiçado. Paralelamente, grupos menores também focavam novas adesões em Osasco, tais como a AP, em processo de adesão ao maoísmo e a luta armada, e o POC, que herdara parte dos quadros da Polop no município. Faz-se necessário um parêntese para apreciação das atividades do POC na região, visto que esta sigla também recebeu membros do GO em suas fileiras.

O Partido Operário Comunista foi formado em abril de 1968 a partir da união entre

384 Informações obtidas através de entrevista com João Quartim de Morais a mim concedida; e no texto de memórias redigido por Ladislas Dowbor: "O mosaico partido (a economia além das equações)", 2007. Disponível em formato digital no site do autor: http://dowbor.org/artigos.asp. Fernando Kolleritz, francês que se radicou no Brasil a partir de 1968, seguiu o mesmo itinerário dos militantes supracitados, também engajando-se na VPR. Para mais informações: Arquivo do Estado de São Paulo, acervo DEOPS, pasta OS-0239. Inquérito VPR/VAR-PALMARES/REDE/MRM 
militantes da Polop pós racha (que permaneceram na legenda) e a dissidência leninista do PCB do Rio Grande do Sul. Suas atividades estiveram concentradas em São Paulo, Minas Gerais, Rio Grande do Sul, e "com menor expressão, no Paraná, Rio de Janeiro, Bahia e Pernambuco". ${ }^{385}$ O grupo teve como principais articuladores Marco Aurélio Garcia e Flávio Koutzi, vindos da dissidência comunista gaúcha, Eder Sader, dirigente polopista de renome em São Paulo, Nilmário Miranda, atuante em Minas Gerais, além da liderança histórica de Eric Sachs. Tal partido jamais logrou grande penetração no MO, seu território por excelência, ao menos em tese. Em contrapartida, conseguiu boa penetração no movimento estudantil ${ }^{386}$. Em termos programáticos e organizacionais, o GO, movimento de matriz operário-estudantil, possuía mais afinidades com o POC do que com a "O.". Contudo, a evolução dos fatos não se deu maneira mecânica, outras variantes incidiram sob o panorama político da cidade, e o clima explosivo que se verificou no ano em análise não deixava margens satisfatórias para cálculos frios. O fato é que o POC herdou da Polop o criticado "Programa Socialista Para o Brasil”, documento que ensejou o racha da organização após seu VI Congresso, no ano anterior.

O novo Partido seguia com a proposta leninista de construção de um grande movimento de massas a partir das cidades, centrado no operariado, elemento este que coordenaria a futura insurreição de moldes soviéticos, a ser construída sob a hegemonia do proletariado urbano, em coalizão com os trabalhadores do campo e elementos das classes médias mais radicais, com destaque para o estudantado. Contudo, abria-se a possibilidade para o trabalho conjunto com organizações voltadas a guerrilha urbana e rural, na perspectiva de luta combinada, seguindo o conceito do foco catalizador, com o objetivo de "dar exemplo de atividade revolucionária que represente uma alternativa prática aos diversos matizes da política pequeno-burguesa existente e que nos permita liderar setores, organizações e alianças dentro da esquerda para influir em seu reagrupamento" ${ }^{\text {"387 }}$. O diferencial entre o novo grupo e a Polop

385 REIS FILHO, Daniel Aarão \& SÁ, Jair Ferreira de. Op. Cit. p. 321-322

386 O POC não conseguiu penetração junto ao proletariado rural. Sua composição foi majoritariamente estudantil, dentre os quadros processados, tal categoria representou 40,6\% (50 militantes) de seu efetivo, enquanto que a porcentagem de trabalhadores manuais urbanos detidos, representando a sigla, foi de $3,3 \%$ (4 militantes). Números do "Projeto Brasil: Nunca Mais", disponíveis em: RIDENTI, Marcelo. Op. Cit. p. 276.

387 Dentre os "diversos matizes da política pequeno-burguesa" figuravam as organizações guerrilheiras. O POC almejada se tornar o partido a liderar o processo revolucionário brasileiro, dentro de uma composição de frente que congregasse todos os movimentos de resistência a ditadura, inclusive os armados. O projeto frentista do POC veio expresso no primeiro número da revista Marxismo Militante, lançada em 1968, como veículo de divulgação do novo Partido que se insinuava no cenário político nacional. $\mathrm{O}$ periódico, em seu primeiro editorial, anunciava-se "como órgão do Núcleo Marxista Leninista, que tomou a iniciativa para a formação de uma FRENTE DE ESQUERDA REVOLUCIONÁRIA, como instrumento de luta de classe proletária em escala nacional". Em manifesto presente em sua edição inicial, a revista Marxismo Militante inferia que "na estratégia 
foi a sua vinculação efetiva a um processo revolucionário, já em marcha, com prazos menos dilatados. A mudança de nome (sigla) foi uma forma de atualizar uma organização que para muitos se pautava por teses superadas num contexto de radicalização política.

O POC trouxe expresso no documento "Por uma Prática Partidária" o papel a ser desenvolvido pelo operariado no processo revolucionário brasileiro, coisa que nenhum outro grupo apresentou em contornos tão definidos.

1 - O que nos confere posição única nas esquerdas é o papel que atribuímos à classe operária no processo revolucionário do país. É verdade que todas as correntes que assumem profissões de fé marxistas-leninistas pagam também um tributo teórico ao proletariado. Além disso, a insistência com que divulgamos nossas teses e posições fizeram com que diversos setores da esquerda que antes se limitavam a raciocinar em termos de "povo e massa" se dediquem ou procurem dedicar-se praticamente a algum tipo de "trabalho operário". Entretanto, o que essas tentativas em diversos níveis, de setores do PCB, da Corrente, dissidências, AP e dissidências da AP tem em comum é que não pretendem, ou não conseguem enquadrar essas atividades numa estratégia e tática revolucionárias numa linha política proletária. (...)

No item 8 , o documento define os objetivos imediatos a serem logrados pelo grupo.

(...) Nossa situação, tanto quanto a do próprio proletariado, exige a concentração de esforços, a tentativa de utilização concentrada dos recursos, de maneira econômica. Isso requer que concentremos nossas forças em setores do proletariado que sejam decisivos para o comportamento do conjunto da classe, localmente, regionalmente, nacionalmente. Esses setores podem ser certas indústrias - metalúrgicas, de transportes, têxteis - mas, também podem ser determinados bairros onde o proletariado tradicionalmente atua em conjunto. A escolha desses pontos-chave dependerá, naturalmente, das condições locais, mas um critério deve ser aplicado: é sempre preferível escolher

militar da Revolução a guerrilha terá um papel de destaque, por garantir a continuidade da ação numa guerra que assumirá inevitavelmente um caráter prolongado de dimensões continentais contra o potencial bélico do imperialismo. Mas desde o início a guerrilha terá quer se dirigir as massas trabalhadoras e em especial a classe operária, dando-lhe a direção e o estímulo para sua luta de classe. Ao colocar a questão do poder revolucionário o foco guerrilheiro já colocará sua principal função, de elevar o nível da luta política do proletariado". Notem que a guerrilha está subordinada as lutas insurrecionais de jaez proletário, sob enfoque leninista, matriz teórica do Partido. Segundo Daniel Aarão Reis Filho, o conceito do foco catalizador significou "uma original, sofisticada e estranha síntese entre a ortodoxia marxista e a heterodoxia da revolução cubana (...)". Para citação no corpo do texto: REIS FILHO, Daniel Aarão \& SÁ, Jair Ferreira de. Op. Cit. p. 234-235; para "foco catalizador"; REIS FILHO, Daniel Aarão. "Classe Operária, partido de quadros e revolução socialista. O itinerário da Política Operária - Polop (1961-1986)”. In: FERREIRA, Jorge. \& REIS FILHO, Daniel Aarão (Org). As Esquerdas no Brasil (Vol. 3) -“Revolução e Democracia - 1964 ...". Rio de Janeiro: Editora Civilização Brasileira, 2007. p. 62. Para revista do POC: Marxismo Militante, 1968 - Ano 1, № 1. p. 50. Disponível em formato digital no CEDEM da UNESP. 
um lugar de atuação onde já tenhamos, pelo menos, contatos internos. (...) $)^{388}$

No município de Osasco, a Polop, desde antes do golpe, já possuía seus "contatos internos", embora tais contatos se resumissem a poucos militantes, sendo sua penetração junto a classe operária local pouco expressiva. Na conjuntura da criação do POC, um dos principais representantes da nova sigla na cidade era Laurindo Martins Junqueira, estudante-operário remanescente do CEO, também ligado aos trabalhos de fábrica, membro ativo do GO. Outro quadro atuante em Osasco foi Joaquim Miranda Sobrinho, eleito diretor do SMO em 1967, coube a esse militante a organização da paralisação dos funcionários da Braseixos em julho de 1968. Joaquim Miranda foi preso no segundo dia da greve, ao ser libertado, três dias depois, soube que havia sido sumariamente demitido de seu emprego. Deslocou-se então para o $\mathrm{ABCD}$, trabalhando na Ford, Volkswagem e Mercedes Bens, já como militante profissional de sua organização. Esteve sob seu encargo a articulação do POC na região ${ }^{389}$.

Outro ativista, estudante a altura da greve de julho, a optar pelo Partido Comunista Operário, foi Stanislau Zermeta. De acordo com o mesmo, a escolha pela sigla se deu pois ele havia sido "ganho pelo POC, era uma proposta que eu achava mais viável, eu não tive nenhuma experiência de atividade armada, mas isso não quer dizer que eu não olhasse com bons olhos. Mas era um processo que para mim não cabia, optar por esse caminho era uma mudança de vida muito radical, não tinha mais volta". As atividades do grupo, após o início do fechamento do regime, são descritas abaixo por Zermeta:

Após o processo da greve houve uma desarticulação completa, não havia mais clima para trabalhar em Osasco, não se podia mais circular, as principais lideranças não poderiam nem pensar em passar por aqui, quando vinham era de madrugada, com muita cautela. Saindo desse processo da greve, o POC institui a ideia de se formar células, que seriam grupos que se incrustariam em vilas operárias, os militantes seguiriam se empregando na indústria para prosseguir com a ideia de formação de comissões de fábrica, comitês de fábrica. A repressão tinha atingido Osasco, mas não tinham atingido o $\mathrm{ABC}$, não tinha atingido São Paulo, que não tinha entrado na história, então havia ainda um clima de resistência no processo de avançar a luta, (...).

388 Idem, p. 232 e 236.

389 Ainda não conseguimos agendar uma entrevista com Laurindo Martins Junqueira, portanto, as informações a respeito de sua pessoa são baseadas na entrevista concedida a mim por Stanislau Zermeta. Partimos do pressuposto que Junqueira não se engajou na VPR devido a sua não adesão ao racha da Polop, organização a qual fazia parte. As informações sobre Joaquim Miranda Sobrinho foram obtidas através de uma entrevista concedida pelo mesmo ao jornal Visão Oeste, n 244, 20 a 26 de julho de 2008. p. 12 
Segundo o depoente, seu grupo possuía dois aparelhos em Osasco, um na Bela Vista, de acordo com o mesmo ocupado por "quatro pessoas", e um em Presidente Altino, antigo bairro operário da cidade, sendo que "esse era bem maior, por que nele transitavam pessoas de outros estados, umas seis ou oitos pessoas”. Tal sigla formou células, além das atuantes em Osasco, na região do $\mathrm{ABCD}$, e em outras localidades da cidade de São Paulo com atividade industrial, como Santo Amaro. Acerca da colaboração do POC com outras siglas revolucionárias, voltadas a luta guerrilheira, comenta Zermeta.

(...) o POC não era imune a relação com o militarismo, nós tínhamos relações com grupos mais militarizados, e uma das atividades que nós tínhamos era fazer o levantamento das fábricas, e fazer panfletagem armada, pregando o enfrentamento a ditadura, mostrando aos trabalhadores que era possível tocar uma resistência ao regime, e que essa questão não avançava por que os sindicatos pelegos não atuavam, e que não podíamos continuar nos submetendo aquela situação porque nós íamos acabar perecendo sem lutar. Então a ideia era levantar os problemas específicos da fábrica, fazer boletins mosquitinhos, ou em alguns lugares, em que era possível, fazer boletins maiores, que eram distribuídos ou deixados nas bancadas; ou alguma panfletagem exemplar, que era assim: via-se um horário de maior concentração dos trabalhadores, geralmente na entrada do serviço, jogava o que tinha que jogar, e "perna pra que te quero", carro com motor ligado. Esse era o clima, entende ${ }^{390}$.

Em março de 1970, membros do POC realizaram uma conferência em São Paulo para discutir os rumos da agremiação, direções que provinham da antiga Polop divergiam sobre o apoio dado pela sigla a ações e grupos armados. A corrente divergente acabou por rachar com o Partido, essa tendência era encabeçada, desde o exterior, por Eric Sachs, liderança contrária aos rumos tomados pelo POC, crítico ácido a luta armada, a qual chamava de "aventura pequeno-burguesa”. Liderada por Sachs, seria formada a Organização de Combate MarxistaLeninista/Política Operária (OCML-PO), organização que reativou o periódico Política Operária, em circulação até princípios dos anos 1980.

Stanislau Zermeta não aderiu ao racha e manteve suas atividades no grupo, até ser preso em 1971, no Rio Grande do Sul, onde se encontrava clandestino. No mesmo ano foram

390 “(...) o POC realizou algumas ações armadas, principalmente em 1970, atuando em frente com outras organizações, como a VAR, o Partido Revolucionário dos Trabalhadores (PRT) e o M3G - sigla do grupo Marx, Mao, Marighella e Guevara, atuante de abril de 1969 a abril de 1970, chefiada por Edmur Péricles Camargo (...)". Citações do texto: entrevista de Stanislau Zermeta ao autor, 04/11/2008; citação em nota: RIDENTI, Marcelo. "Esquerdas Armadas Urbanas". In: RIDENTI, Marcelo. \& REIS, Daniel Aarão. (Org) História do Marxismo no Brasil. Partidos e movimentos após os anos 1960. (Vol. 6) Campinas-SP: Editora da Unicamp, 2007. (Vol. 6) p119 
detidos Laurindo Martins Junqueira e Joaquim Miranda Sobrinho. Devido a sua não participação em ações armadas, Zermeta passou 16 meses preso, retornando posteriormente a Osasco, onde retomou sua vida, trabalhando como operário nas fábricas da região, voltando as suas atividades sindicais após 1978. As células do partido em Osasco não resistiram as prisões em cascata que praticamente desbarataram a sigla no decorrer de 1971. Um punhado de militantes no exílio retomariam as atividades do grupo, agora sob a legenda POC-Combate, corrente que se filiou Internacional Trotskista/ Secretariado Unificado, tendência liderada por Ernest Mandel, partidária do pensamento revolucionário castro-guevarista, com ramificações na América Latina. O POC-Combate jamais logrou participação efetiva na luta guerrilheira no Brasil, mantendo-se como um movimento de exílio ${ }^{391}$.

$* * * * *$

Acimas traçamos um breve relato sobre os militantes oriundos de Osasco que ingressaram no POC, organização que recebeu em suas fileiras uma pequena parcela de ativistas dessa cidade, alguns egressos do GO. Vimos também que em meados de 1968 uma série de agrupamentos que se dispunham ao combate pela via das armas a ditadura passaram a cortejar a jovem militância articulada em Osasco. Através dos relatos daqueles que estiveram envolvidos diretamente na conjuntura, procuraremos delinear como se deu o recrutamento da ala mais radical envolvida com as atividades do GO por parte da (ainda em formação) VPR.

Pouco antes de greve de julho, a "O.” já congregava em seu efetivo boa parte dos partidários da Polop (atuantes em São Paulo) que haviam aderido ao racha do ano anterior, e todo um grupo de ex-militares sob a orientação de Onofre Pinto. Intelectuais de peso também já haviam aderido as propostas iniciais do grupo, e a essa altura, o programa revolucionário do ajuntamento estava em fase de construção. A estruturação interna do grupo apresentava uma

391 A pesquisa do movimento Brasil Nunca Mais identificou oito processos relacionados as atividades do POC, "sendo que apenas um deles eram abordados conjuntamente ações com outros grupos". Nos sete processos contra o grupo, "somam-se 145 réus e mais 74 indiciados na etapa de inquérito'”. "Sete militantes ligados ao POC foram mortos pela repressão política no Brasil e no exterior. Um foi assassinado em São Paulo, em 1971, seu nome era Luiz Eduardo da Rocha Merlino; dois no Rio Grande do Sul (Helio Zanir Sanchotene Trindade e Ary Abreu Lima e Rosa) e quatro outros foram mortos no exílio: Luiz Carlos Almeida e Nelson Kohl, no Chile, durante o golpe militar que derrubou o governo do presidente Salvador Allende, em 13 de setembro de 1973; e Jorge Alberto Basso e Maria Regina Marcondes Pinto (ligada na época ao MIR do Chile), na Argentina, em 1976". Para informações sobre os processos contra o POC: Projeto BRASIL NUNCA MAIS. Perfil dos Atingidos. Petrópolis-RJ: Editora Vozes, 1988. p. 73; para militantes mortos: MIRANDA, Nilmário. \& TIBÚRCIO, Carlos. Dos filhos deste solo - Mortos e desaparecidos políticos durante a ditadura militar: a responsabilidade do Estado. São Paulo: Editora Boitempo, 1999. p. 509-511 
estrutura primeva. Faltava a definição clara de uma estratégia para a tomada do poder, a tática a ser aplicada não propiciava grandes surpresas, o caminho a se seguir era o traçado nos manuais de Ernesto Che Guevara e Regis Debray. Isto posto, qual o papel vislumbrado para o GO dentro dessa organização? Além do contingente de quadros, tal grupo possuía em suas fileiras ativistas com reconhecida experiência organizativa junto a diversos movimentos sociais. Mas como aproveitar esse potencial dentro de um grupo que preconizava a luta armada imediata? Nesse ponto se verificou o diferencial da "O.”, organização que se afastava do gradualismo do POC, e do militarismo estremado - ao menos em seus primórdios - do Agrupamento Comunista de São Paulo, corrente voltada quase que exclusivamente a ação.

O fato da "O." ter entre seus componentes uma maioria de ex polopistas facilitou o diálogo obreirista com GO, cujos militantes tinham por meta seguir com suas atividades junto ao operariado, agora num outro nível. Onofre Pinto, embora pertencente a ala militar do movimento, mantinha contatos com correntes obreiristas desde sua época de Quitaúna ${ }^{392}$. A convocação dos estudantes-operáros osasquenses era do agrado de todas as tendências internas ao grupo, pelo que se pôde comprovar. A “O.” foi o agrupamento que ofereceu as melhores oportunidades de participação em seu efetivo aos quadros egressos do GO, que poderiam atuar sem fugir em demasia às suas características. O relato de Antonio Roberto Espinosa vai nesse sentido.

Na verdade a VPR foi a única que tentou ganhar de fato o grupo, e também foi a única, ou talvez a que mais respeitou a identidade do grupo. Talvez até pelo fato da VPR ser uma organização guerrilheira, que naquele tempo estava lendo o Regis Debray, o Guevara; ser uma organização que estava em transição para o campo, para o foco guerrilheiro, e portanto não ter uma política pro movimento operário, ela respeitava o que era feito pelo G.O., ao contrário de outras organizações. A antiga POLOP, da qual a VPR era um racha, tinha uma proposta para o movimento operário, que enfatizava os sindicatos, a AP (Ação Popular) também tinha uma política definida, o Partidão sempre teve. As outras organizações procuravam nos ganhar pra fazer aquilo que eles achavam ser a política a ser feita para o movimento operário, tinham uma proposta, nas quais nós não nos encaixávamos. A VPR não, ela se integrou (...), enfim, essa foi a primeira razão. A segunda razão é que nós víamos a VPR como uma organização coerente, que defendia a ideia da luta armada e já estava começando fazêla, tinha lançado algumas bombas contra empreendimentos americanos, no $1^{\circ}$ de Maio se prontificou a

392 No IPM sobre as atividades subversivas dos militares de Quitaúna cassados após o golpe, há menção sobre o envolvimento de Onofre Pinto e outros militares com militantes (operários e estudantes) da organização trotskista POR-T (Partido Operário Revolucionário - Trotskista). Para mais informações: MACIEL, W. A. Op. Cit. p. 50 
fazer uma defesa da manifestação montando ninhos de metralhadoras lá na Praça da Sé, participou da organização da Greve de Osasco, inclusive colocando a nossa disponibilidade quadros militares para dar algum apoio que nós precisássemos, e nós acreditávamos que ela de fato estivesse montando o foco guerrilheiro ${ }^{393}$.

Os depoimentos de José Ibrahim e Manuel Dias do Nascimento vão no mesmo sentido do de Espinosa, no entanto, apresentam mais detalhes acerca do assédio de outras organizações sobre o GO . Vejamos o que diz sobre o tema José Ibrahim.

(...) nós tínhamos um histórico com o os ex-sargentos, ex-militares que foram cassados em 64, que eram da região, tínhamos uma relação antiga com eles. Ao mesmo tempo a gente tinha uma relação com o pessoal que havia rompido com o PC, e se juntado com o Marighella, ainda não havia a ALN, mas era o grupo do Marighella, que tava rompendo com o Partidão. Na verdade foi uma coisa muito simplória o fato da gente decidir pela VPR, por que eu tive um encontro com o Marighella, eu era o negociador do grupo, a proposta do Marighella era de que a maioria do GO fosse treinar em Cuba, inclusive eu, e ele disse claramente pra mim "olha, você é uma pessoa muito visada, já, já os caras te pegam, é melhor você recuar, então você passa um tempo em Cuba com o seu pessoal, depois vão voltando e ingressando na luta guerrilheira”. Eu disse claramente ao Marighella, “olha, eu vou levar essa proposta pro pessoal mas não ta na nossa ideia sair, nós queremos continuar organizando, não sair do país, mas eu vou levar”. Com a VPR a gente já tinha até mais intimidade, eles colocaram "nós sabemos que a coisa vai se resolver com a luta armada e tal, guerrilha, mas é necessário um movimento operário organizado, é necessário a população organizada; então nós queremos fortalecer o trabalho de vocês, vocês podem deixar que assalto a banco, roubo de arma, grupo de fogo; é com a gente, vocês não fazem isso". E era mais ou menos isso que nós tavamos querendo ${ }^{394}$.

O depoimento de Manuel Dias do Nascimento vai na mesma direção, salientando os contatos com a futura Aliança Libertadora Nacional.

(...) companheiros que eram nossos interlocutores, como o Roque, o Barreto e o Espinosa, e outros companheiros, trouxeram para discussão, em nosso movimento, as propostas de vários grupos, e entre as organizações que mais se aproximavam de nossas posições, que era exatamente de como passar a atuar numa organização de esquerda, foi a VPR, a que teve maior convergência nesse sentido. Eu por exemplo militei no PCB, nessa época eu não tava no Partido, mas tinha todo um vínculo

393 Entrevista de Antonio Roberto Espinosa ao autor, 30/09/2008.

394 Entrevista de José Ibrahim ao autor, 27/01/2009. 
estreito, por que muitos companheiros continuaram, muitos deles davam assistência em Osasco, continuaram militando na cidade, e nos deram toda a assistência no movimento sindical durante a greve, (...) alguns companheiros da ALN também. Eu to te dando um exemplo aqui por que a ALN e o Partidão tinham duas posições diferentes, ideologicamente a VPR tava muito mais próxima de nós, tava próxima pra atuar em conjunto, numa frente, mas não pra gente militar só na guerrilha. A ALN tinha uma reivindicação diferente, nossa posição era de explorar o trabalhador que tava num processo de formação o máximo possível, até ele se queimar, pra passar ele pra uma frente armada, a ALN, teoricamente, também tinha essa posição, mas na prática não fazia isso. A VPR não, eles falavam que nós tínhamos que passar por todo um processo de formação, eles concordavam com a nossa visão política de aproveitar o máximo possível os trabalhadores dentro de sua organização sindical ou estudantil $(\ldots)^{395}$.

Pelo depoimento de Manuel Dias do Nascimento temos uma distinção clara de alguns dos preceitos organizacionais das futuras ALN e VPR. Acima mencionamos o "Pronunciamento do Agrupamento Comunista de São Paulo", neste documentou ficou expressa a posição do grupo de Marighella em partir imediatamente para ação ${ }^{396}$, concentrando as atividades de seus quadros dentro dentro dessa linha. Os militantes incorporados a essa corrente deveriam de imediato acolher a condição de "revolucionários profissionais", dedicados a luta em tempo integral. Os que já possuíssem algum know hall em ações táticas, seriam empregados nos Grupos Táticos Armados (GTA's), em caso contrário, o caminho era se dirigir a Cuba para se integrar aos cursos de guerrilha em voga no período.

A (futura) VPR possuía diferenças substanciais em relação ao grupo de Marighella, embora também professasse o modelo insurrecional cubano, era uma organização ainda em fase de formação, com um modo de estruturação interna distinta da ALN. A ALN foi uma sigla que possuía uma direção centralizada nas lideranças históricas de Carlos Marighella e Joaquim Câmara Ferreira, veteranos comunistas, remanescentes das contendas anti Estado Novo. A VPR era um grupo novo, composto por diferentes correntes, e exatamente por isso adotou a estrutura de colegiado ao nível de sua direção. Apesar de também defender o início imediato da luta armada, esse agrupamento abria espaço em seu programa para atuação política junto as classes trabalhadoras, visando a efetivação de lutas combinadas, que abarcassem tanto a guerrilha, quanto as lutas de massa, com ênfase nos movimentos operário

395 Entrevista de Manuel Dias do nascimento ao autor, 16/02/2009.

396 "Nossa estratégia é partir diretamente para a ação, para a luta armada. O conceito teórico pelo qual nos guiamos é o de que a ação faz a vanguarda”. MARIGHELLA, Carlos. Op. Cit. p. 137. 
e estudantil. No mais, como vimos pelo relato de Neto, o prosseguimento dos trabalhos de base, de aparência legal, poderiam propiciar uma fonte constante de novos quadros para a organização.

O processo de cooptação de quadros em Osasco se deu de forma gradativa, segundo Espinosa, "nós fomos sendo ganhos um a um". O mesmo depoente afirma que os articuladores da "O." se dirigiram primeiramente àqueles que "eram mais sensíveis ao ingresso na organização, então recrutaram primeiro o Roque Aparecido da Silva e o José Campos Barreto, que foram contatados pelos contatos da VPR em Osasco”. Espinosa comenta que quando os demais membros do núcleo do GO passaram a desconfiar das novas ligações dos dois ativistas, "nós até ficamos meio bravos com eles, "pô, como é que vocês vão quebrando a unidade do nosso grupo!"”. O mesmo afirma que foi recrutado logo após o $1^{\circ}$ de Maio. João Quartim de Morais, em meados de 1968 dirigente do setor Urbano da “O.”, acerca de suas relações com a militância osasquense, diz que passou

a ir pra Osasco já na condição de militante da futura VPR, e pra cumprir tarefa mesmo, conheci o grupo lá, tinha três militantes já integrados, alguns acho que já tinham contato com a Polop, e os três eu posso dizer a você com muita precisão, um eu não sei o nome, o nome de guerra dele era Paiva (Neto), outro era o Roque Aparecido, e o outro era o José Campos Barreto. O Ibrahim era presidente do sindicato, o Ibrahim aderiu a futura VPR somente depois da repressão a Greve de Osasco $(\ldots)^{397}$

Logo após a greve de Julho e toda a repressão que se abateu sobre o município de Osasco, as lideranças de esquerda mais visíveis da cidade partiram de imediato para a clandestinidade. Espinosa, Neto e Roque Aparecido se refugiaram em um aparelho fornecido pela VPR, no bairro da Vila Yara, divisa com a capital paulista. José Ibrahim ficou escondido em uma república que pertencia a um grupo de universitários que futuramente formaria o Movimento Comunista $1^{\circ}$ de Maio. Ibrahim mantinha contatos com grupos trotskistas desde o início de suas atividades políticas. Posteriormente, após reatar contato com seus companheiros de Osasco, o jovem presidente do SMO foi incorporado a futura VPR, assim como Espinosa, com um certo ressentimento devido a quebra de unidade do grupo. Uma vez arregimentado o núcleo do $\mathrm{GO}$, os demais militantes do movimento foram sendo introduzidos a nova organização, relatos dão conta de que cerca de 60 ativistas de Osasco e região se engajaram na 
“O." ${ }^{398}$.

O GO, agora uma corrente interna da "O.”, foi incorporado ao setor Urbano, os estudantes-operários osasquenses militariam no departamento voltado ao trabalho de massas, e José Ibrahim foi alçado a coordenação do mesmo, com atividades voltadas ao MO. Em que pese sua origem obreirista, vários ativistas oriundos de Osasco passaram a se dedicar as ações armadas, colaborando com o setor de Logística, braço militar do agrupamento, dirigido por Onofre Pinto.

Em meados de 1968 a futura VPR já se destacava como um dos grupos de guerrilha urbana mais ativos no país. Desde o começo do ano a organização vinha realizando ações de expropriação ${ }^{399}$ em bancos da capital paulista, além de ações de propaganda armada, como atentados a bomba, com destaque para a ação contra o Consulado dos EUA de São Paulo, em março. Em 22 de junho a ainda "O." realizou uma ação de maior envergadura, o assalto ao Hospital Geral do Exército, localizado no bairro paulistano do Cambuci. Na operação estiveram presentes Eduardo Collen Leite, o Bacuri, que servira na unidade, Wilson Fava, Renata Andrade, Pedro Lobo, José Araújo da Nóbrega, Antonio Raymundo de Lucena, João Quartim de Morais, dentre outros. A ação rendeu doze fuzis FAL ao grupo e alguma notoriedade na imprensa nacional.

No dia seguinte, o comandante da $2^{\mathrm{a}}$ Região Militar, general Manoel Rodrigues Carvalho Lisboa, lançou pela imprensa um desafio a organização, incitando os guerrilheiros a "atacar um quartel de verdade". A resposta veio no dia 26 do mesmo mês, através de um

398 A VPR recebeu também a adesão de estudantes secundaristas vinculados a UPES, um grupo organizado na Zona Leste de São Paulo, encabeçado por Celso Lungaretti; mais componentes da entidade articulados na Zona Sul. De acordo com Lungaretti, sua célula foi recrutada por Antonio Roberto Espinosa. Na regiões central e oeste, os secundaristas se aproximaram da dissidência estudantil paulista do PCB, ligados a liderança de José Dirceu. Parte da dissidência universitária não seguiu o caminho tomado pela liderança do movimento, preferindo o engajamento na VPR ao invés da ALN, o mesmo caminho seguido por alguns militantes comunistas veteranos, como Pedro Lobo. Segundo os dados reunidos pelo projeto BNM, foram processados 145 militantes da VPR, destes, 24 eram estudantes, 25 profissionais liberais com formação superior, 14 professores, 13 foram identificados como trabalhadores manuais urbanos, 9 como militares de baixa patente, 4 como oficiais, dentre outras ocupações. Os ativistas do GO se diluíram nessas classificações. Os números do projeto BNM levam em conta aqueles que foram processados nas organizações após sua prisão, não considerando os rachas, por isso alguns foram processados por atividades em mais de uma sigla. No período de formação da VPR, seu número de militantes era bem maior do que o indicado pelos processos. Além das cisões posteriores, houve quadros que migraram para outros grupos, alguns se exilaram, outros seguiram clandestinos ao longo da luta e nunca foram presos. É impossível identificar os ativistas oriundos do GO que atuaram na VPR, por isso focamos as trajetórias dos militantes mais visíveis do grupo, certamente há muitos outros que deram sua contribuição para a luta revolucionária do período. Para adesão da UPES a VPR; LUNGARETTI, Celso. Op. Cit. p. 73-74; os dados do projeto BNM estão presentes em: RIDENTI, Marcelo. Op. Cit. p. 276.

399 Pedro Lobo, em sua memórias, afirma que a primeira ação de expropriação em bancos, praticada por membros da futura VPR, ocorreu em 7 de março de 1968, em uma agência do Banco do Comércio e da Indústria, localizada na Rua Guaicurus, bairro da Lapa, São Paulo. LAQUE. João Roberto. Op. Cit. p.155 
atentado a bomba ao Quartel General do II Exército. A biografia de Pedro Lobo indica que a equipe a participar do ato foi basicamente mesma do roubo ao Quartel do Cambuci. Contudo, desta feita, a ação não saiu como planejado, pois "a rota da caminhonete deveria ser em linha reta até a colisão com a parede que serve de arrimo ao alojamento dos Oficiais. Por um erro de cálculo, entretanto, ela sofre um desvio, sobe no passeio, abalroa um poste, e atinge o quartel, 30 metros distante do local imaginado". O estrondo chamou a atenção da sentinela Mario Kosel Filho, que se aproximou do caminhão, com o detonar do artefato explosivo o jovem de 18 anos teve morte instantânea, outros cinco militares se feriram devido a $\operatorname{explosão~}^{400}$.

Outra ação de renome foi o justiçamento do militar estadunidense Charles Chandler, acusado pela organização de ser um agente da CIA em atuação no Brasil. Chandler, veterano da Guerra da Vietnã, estudava sociologia na Fundação Armando Alvares Penteado, na manhã em que foi executado, dirigia-se a Universidade Mackenzie para ministrar uma palestra sobre o conflito ao qual participara na Indochina. Do fuzilamento participaram Diógenes José de Carvalho, Marco Antonio Braz de Carvalho (o Marquito, pertencente ao grupo de Marighella) - executores dos disparos - e Pedro Lobo, o motorista do grupo. No dia 14 de outubro, o Jornal Última Hora trouxe estampado em sua manchete de capa "Capitão morto é terror antiEUA” ${ }^{401}$. Às vésperas de seu primeiro congresso, a futura VPR era uma das organizações revolucionárias em atuação mais respeitadas e temidas do país.

$* * * * *$

Por volta do dia 10 de dezembro de 1968, realizou-se na praia do Perequê Mirim, litoral norte de São Paulo, o primeiro congresso da organização que após esse evento passou a se chamar Vanguarda Popular Revolucionária, nome sugerido por João Quartim de Morais. A estrutura da antiga "O." foi mantida, as teses guevaristas-debraystas seguiram norteando as orientações táticas do grupo, e o projeto de revolução socialista imediata, herdado da Polop,

400Idem, p. 185-186

401 Em depoimento a Chain Litewski, no documentário Cidadão Boilesen, o delegado do Dops paulista Paulo Bonchristiano, membro da equipe de Sérgio Paranhos Fleury, afirma que após a morte do capitão Chandler, os serviços de inteligência dos EUA passaram a encarar a questão da resistência armada a ditadura brasileira com preocupação, passando a "dar um outro enquadramento para a situação no Brasil". O mesmo depoente aponta esse evento como um dos elementos a impulsionar a criação da futura Operação Bandeirantes. Cidadão Boilensen. Direção: Chain Litevski, ano de produção, 1999. Para mais informações sobre o justiçamento: LAQUE, João Roberto. Op. Cit. p. 209-211. Para manchete: Ultima Hora, Rio de Janeiro, 15 de outubro de 1968. 
foi sustentado. Após o evento, a delimitação de áreas se tornou mais nítida na sigla, expressa pela rivalidade que se formou entre o setor Urbano de Quartim de Morais, a frente do segmento mais intelectualizado da VPR, egresso dos meios acadêmicos, e o setor Logístico, capitaneado por Onofre Pinto, líder da corrente militarista. A sequência de ações audaciosas ao longo do ano pôs em relevo a porção militarista da organização, algo que pendia a balança para o lado dos ex-graduados.

A primeira grande divergência interna da VPR se deu em torno de uma ação espetacular a ser perpetrada sob comando do setor Logístico. O plano era realizar um grande saque ao arsenal de armas e artefatos do $4^{\circ} \mathrm{RI}$, em Quitaúna, e a partir desse feito por em marcha uma grande operação de propaganda armada, realizando ataques simultâneos ao QG do II Exército, no Ibirapuera, ao Palácio dos Bandeirantes, sede do governo de São Paulo, e a Academia de Polícia, situada na Cidade Universitária. O trunfo da sigla para tal empreitada era uma célula de militares que serviam no regimento a ser tomado, célula esta formada pelo capitão Carlos Lamarca, sargento Darci Rodrigues, cabo José Mariane, e soldado Carlos Alberto Zanirato. Lamarca flertava com a esquerda desde seus tempos de academia, frequentava um grupo de estudos junto a militantes da Polop desde 1967. Após o racha, a corrente polopista pró luta armada estreitou seus vínculos com Quitaúna, militantes como Renata Andrade e Iara Yavelberg se dirigiam com frequência a região para orientar os debates travados em torno do grupo de estudos do capitão Lamarca ${ }^{402}$. Os contatos com o grupo de Onofre Pinto também eram frequentes, de modo que a célula do $4^{\circ}$ RI estava a par dos rumos tomados pelo agrupamento que desde princípios de 1968 se dedicava a guerrilha urbana.

Os ataques em série foram marcados para princípios de 1969, deveriam ser uma resposta ao AI-5, um desafio a ditadura, e um chamamento a resistência. O objetivo era desnudar a fragilidade do regime. Após o feito, Lamarca e seu grupo estariam oficialmente integrados a VPR. Contudo, a ala anti-militarista da organização não concordou com a ação, fato que deu ensejo a um debate que se concluiria com a primeira cisão da sigla. Em contraposição ao militarismo extremo do Logístico, o grupo de Quartim defendia uma volta ao trabalho de massas, e um recuo nas ações armadas, e isso pressupunha o cancelamento do ataque ao $4^{\circ}$ RI. Quartim argumenta que sua defesa de um recuo tático se baseava na certeza de que uma vez posto em marcha o desafio frontal a ditadura, proposto pela corrente militarista, "os caras iam vir como animais, iam ter carta branca pra fazer qualquer coisa, 
terror de Estado, contra o nosso terrorismo artesanal, viria o terrorismo de Estado, a máquina toda, então eu dizia que deveríamos ficar quietos, abaixar agora. Quando eu falava isso me diziam: "mas companheiro está propondo um recuo"; e eu respondia: "é, recuo!"”. O depoente também afirma que Onofre Pinto exagerava ao expor o quadro das condições objetivas e subjetivas para a intensificação da luta, superdimensionando o potencial da guerrilha urbana perante seus simpatizantes ${ }^{403}$. Dentre os ativistas a fechar com as posições de Quartim, estiveram Wilson Fava, Renata Andrade e Maryse Fari.

No começo de 1969, o antagonismo entre as posições internas a VPR colocou a organização em um impasse, duas correntes definidas divergiam sobre os rumos futuros da sigla, e a disputa política chegou a afetar a própria estrutura grupo. Segundo Espinosa, a animosidade frente ao setor militar levou Quartim a buscar estruturar um departamento armado subordinado diretamente a sua liderança. Tal medida foi denunciada pelos militantes lotados no Logístico, que acusaram Quartim de estar "querendo criar um setor militar no urbano", preparando um racha futuro. Em meio as disputas de cúpula, surgia uma solidariedade forjada na ação, entre aqueles que participavam das operações de expropriação, a margem da disputa setorial. Quadros vindos de Osasco, dentre estes Espinosa, passaram a participar frequentemente de ações armadas. O convívio junto ao pessoal do Logístico estreitou os laços entre quadros desse setor e membros dos demais departamentos da VPR que participavam das operações táticas. Nesse cenário, o grupo de Quartim foi sendo isolado dentro da organização.

Os ataques estavam sendo preparados para finais de janeiro, em meio ao impasse entre as correntes, o segmento militarista, numa solução de força, decidiu unilateralmente pela ação. "Eu entrei em desespero quando vi que eles iriam fazer a ação do quartel, então resolvi jogar todas as fichas, fui falar com as pessoas e explicar que aquela não seria a única ocasião coisa nenhuma, poderia ser feito em outro momento, desde que o Lamarca continuasse no Exército, o Darcy e os outros continuassem lá" ${ }^{404}$. Porém, a atitude de Renata Andrade não

403 Darcy Rodrigues, em entrevista a Judith Patarra, afirma que informações provenientes do setor Rural davam conta de que a VPR contava com dois mil camponeses aliados no Pará, um estímulo para a corrente militarista acirrar a luta contra a ditadura, e partir de imediato para a guerrilha rural. "As informações erradas vinham principalmente do Onofre, que elevou as promessas a enésima potência, pois abusava do direito de sonhar. Não incorria em desonestidade proporcional. Os dados chegavam parciais, às vezes superpostos. Impossível checálos". Idem, ibidem.

404Depoimento de Renata Andrade a Fábio A. Gonçalves Chagas. CHAGAS, Fábio A. Gonçalves. "Ação e Revolução: os zigue-zagues estratégicos da VPR em 1968”. In: Cadernos de Pesquisa do CDHIS, No 35, 2006. p. 99. Disponível também em formato digital, no endereço eletrônico: http://www.seer.ufu.br/index.php/cdhis/article/viewFile/487/456. Jacob Gorender comenta que Carlos Marighella foi consultado sobre a ação e discordou "por considerar que a VPR não estava em condições de 
surtiu efeito, poucos dias antes da invasão do $4^{\circ}$ RI, a jovem egressa do racha do Polop, juntamente com Quartim, cuja liderança se encontrava desgastada, Wilson Fava e sua companheira Maryse Fari, foram expulsos da VPR ${ }^{405}$.

As divergências verificadas ao nível da direção da VPR também se deram entre os militantes vindos do GO, mas as discordâncias não chegaram ao mesmo desgaste entre esses ativistas. Vejamos o que José Ibrahim diz sobre o assunto.

Quando teve a discussão sobre a ação grande, lá de Quitaúna, (...) eu fiz todo um trabalho de consulta no meu setor, colocando minha posição, eu era contra. Era contra esse tipo de ação naquele momento, a minha tese era de que a gente não ia suportar a repressão, nós íamos montar uma força que a gente não tinha, e ia ser desencadeada uma repressão forte em São Paulo, a gente não tinha tanta estrutura assim pra segurar, e portanto, taticamente, não era viável. Era melhor acumular mais forças, era melhor continuar com as pequenas ações, e não dar esse susto tão grande na ditadura, por que a reação viria. A minha posição foi perdida, por exemplo, o Espinosa, o próprio Roque, e o Barreto, fecharam com a posição militarista ${ }^{406}$.

Afastados os que se opunham mais sistematicamente, a grande ação passou a ser preparada para breve, não obstante, uma série de fatos inviabilizaram a operação da forma como ela havia sido concebida. No dia 23 de janeiro de 1969, numa chácara de nome Ibiti, localizada no município de Itapecerica da Serra, um grupo de quatro indivíduos foi detido enquanto pintavam um caminhão com as cores do Exército Brasileiro. Os surpreendidos tentaram uma reação, mas foram logo detidos pelos policiais que os renderam e os conduziram a delegacia da cidade. Um quinto elemento conseguiu escapar, seu nome era José Araújo da Nóbrega. O caminhão seria peça chave na invasão do $4^{\circ} \mathrm{RI}$, a nova situação demandou uma mudança imediata nos planos da operação que recebera o nome de "Noite de São Bartolomeu".

No dia seguinte, devido aos recentes acontecimentos, Lamarca e seu grupo fugiram do Quartel de Quitaúna, levando consigo 63 fuzis FAL. Os presos em Itapecerica da Serra foram Pedro Lobo, Ismael Antonio de Souza, Oswaldo Antonio dos Santos e Hermes Camargo Batista. Este último, desertor da Brigada de Paraquedistas do Exército, homem de confiança de Onofre Pinto e um dos responsáveis pelo setor Logístico, o mesmo que "sabia de muita iniciar a guerrilha rural, nem resistir a contra-ofensiva da ditadura militar. GORENDER, Jacob. Op. Cit. p. 134 405 Os quatro militantes saíram clandestinos do país pelo Uruguai, posteriormente João Quartim de Morais se exilou na França, retomando suas atividades acadêmicas.

406 Entrevista de José Ibrahim ao autor, 27/01/2009 
coisa e não só transmitiu aos órgãos de investigação os dados de sua memória, como ajudou a orientar interrogatórios de prisioneiros. Converteu-se em ativo colaborador da repressão policial’407. Hermes Camargo auxiliou agentes do Dops no sequestro do pai de Antonio Roberto Espinosa, a essa altura o jovem de pouco mais de vinte anos já era um elemento visado pela repressão. Tal medida foi largamente utilizada como meio de pressão a militantes engajados na luta armada.

Após a expulsão de João Quartim de Morais e seu grupo, José Ibrahim foi alçado a condição de dirigente do setor Urbano. Esse fato representou uma mudança qualitativa para os remanescentes do GO dentro da VPR, visto que a ascensão de Ibrahim implicava no crescimento da influência de seu grupo, embora no mesmo também se observasse o início da dicotomia militaristas versus massistas. Não obstante, a coordenação de Ibrahim foi breve.

As delações do ex paraquedista provocaram uma onda de quedas entre os membros da VPR, em meio ao assédio da repressão, estipulou-se que não haviam condições de segurança para a guarda dos fuzis retirados de Quitaúna nos aparelhos pertencentes a organização. Componentes da direção decidiram pedir auxílio a ALN de modo a garantir a posse do arsenal recém-adquirido. Marighella aceitou de pronto esconder os armamentos. Nessa etapa se cogitava a formação de uma frente entre os movimentos de guerrilha, proposta partida da VPR, mas o diálogo entre as siglas revolucionárias foi bloqueado pela desestruturação provocada pelas prisões em cascata após as quedas de Itapecerica da Serra.

Dois dias depois das detenções da chácara Ibiti, Dulce Maia, promotora cultural e antiga colaboradora do MNR, caiu nas mãos dos agentes do Dops paulista. Sob intensa tortura, Dulce revelou o endereço de um aparelho que pertencia a ALN, supondo que o mesmo se encontrasse vazio. Em um apartamento localizado na Rua Fortunato, no bairro paulistano de Santa Cecília, foi preso João Leonardo da Silva de Carvalho ${ }^{408}$. No dia seguinte, no mesmo endereço, foi surpreendido pela equipe do delegado Raul Careca o comandante do GTA da ALN, Marco Antonio Braz de Carvalho, o Marquito, que reagiu a voz de prisão e acabou morto a tiros. Marighella responsabilizou a VPR pelas quedas em sua organização, após esse fato as relações entre os dois maiores grupo de guerrilha do país começaram a se deteriorar.

No dia 2 de abril de 1969, num encontro combinado entre Espinosa, Ibrahim, e Roque Aparecido, às onze horas da manhã, numa padaria de São Paulo, o último não 407 GORENDER, Jacob. Op. Cit. p. 135 
compareceu. Roque fora preso em um ponto na manhã do mesmo dia, entregue por um militante (não identificado pelos depoentes) que caíra devido as delações de Hermes Camargo. Era parte da metodologia dos órgãos de repressão iniciar suas seções de martírio imediatamente após o sequestro dos militantes, com o objetivo de obter informações o mais rápido possível. Em situação de tortura, o tempo era vital para garantir a segurança dos companheiros de guerrilha e salvaguardar a estrutura das organizações. Os torcionários estavam cientes desse fato, por isso tinham por prática intensificar as torturas desde os momentos iniciais de captura. Ciente disso - segundo Ibrahim - Roque Aparecido resistiu durante toda a manhã as violências impostas pelos agentes do Dops, revelando informações cruciais a seus verdugos apenas após o horário do ponto junto a seus homólogos.

As regras de segurança previam que após o não comparecimento de um companheiro a um ponto, devia-se de imediato abandonar o aparelho e buscar outro refúgio. “(...) passou batido o fato do Roque não ter aparecido, e a noite eu volto pra casa, o Roque segurou de manhã, segurou o ponto na hora do almoço, mas a noite ele abriu a casa" ${ }^{409}$. Ibrahim não observou as condições de segurança de seu agrupamento e retornou a residência que dividia com Roque Aparecido, cerca de nove horas da noite. Segundo o mesmo, ao adentrar o recinto, deparou-se com o "Roque lá fudido, todo inchado, algemado, todo arrebentado". As torturas sobre o depoente tiveram início no local em que morava clandestino, na frente de seu colega dos tempos de Ceneart, através de choques aplicados por meio de equipamentos portáteis trazidos pelos policiais, nas palavras de Ibrahim, “eles traziam a UTI completa (risos)".

Ambos foram transportados para a delegacia da Rua Tutóia, nesse estágio ainda não incorporada pela Oban, operação que seria desencadeada alguns meses depois. O itinerário seguido pelos dois ativistas foi o mesmo de muitos que passaram pelos órgãos de repressão paulistas do período, Tutóia, Dops, Presídio Tiradentes. Ibrahim seria trocado pelo embaixador dos EUA, em setembro de 1969, Roque permaneceria preso por mais tempo, sendo trocado pelo embaixador da Suíça em janeiro de $1971^{410}$. Após a queda desses dois militantes, do núcleo do GO permaneceriam em atividade revolucionária, atuando pela VPR, José Campos Barreto, Manuel Dias do Nascimento e Antonio Roberto Espinosa.

Em 2 de março a VPR foi duramente atingida com a prisão de Onofre Pinto, empreendida na Praça Benedito Calixto, bairro de Pinheiros. No mesmo dia caiu Diógenes

409 Entrevista de José Ibrahim ao autor, 27/01/2009.

410 Idem. As informações sobre as atividades guerrilheiras de Roque Aparecido da Silva foram obtidas através de relatos de seus companheiros de GO, visto que o mesmo evita dar declarações sobre essa etapa de sua trajetória. 
José de Carvalho, um dos responsáveis pelo setor Logístico, deixando o mesmo acéfalo. No Urbano restou apenas Valdir Sarapu na direção, vendo-se isolado no posto, Sarapu convocou Espinosa para integrar a coordenação de seu setor, e o mesmo que levou consigo Zequinha Barreto para compor a direção. Mas as quedas prosseguiam, ameaçando implodir a sigla. Em seu depoimento Espinosa faz menção a prática do liberalismo, que seria o descuido com as normas de segurança que uma situação de cerco exige. $\mathrm{O}$ acúmulo de tarefas, o isolamento, somados a perspectiva de uma prisão iminente, seguida de torturas brutais, ensejavam comportamentos liberais por parte de alguns militantes, sobretudo os mais jovens.

(...) era tudo muito intenso, as pessoas se encontravam no extremo de sua vida, trabalhar, fazer material, formação, ter relações no bairro; era militância 24 horas, era preciso ter muito cuidado, suas relações pessoais ficavam prejudicadas, não tínhamos fim de semana. Havia atividades domingo a noite, nós vivíamos no contra fluxo, quando o povo ia dormir, nós íamos trabalhar. Mas era necessário uma atividade social, tínhamos quer ir no bar, ver uma televisão, ter uma participação social, se não fizesse isso, você "estourava", mas o tempo era curto. Muita gente "estourou" por causa do acúmulo de tarefas. Há muitos elementos de segurança, mas chega uma hora em que você baixa a guarda, há muita tensão em jogo, tinha horas que você tinha tomar uma cachacinha, mesmo que você rompesse as normas de segurança $a^{411}$.

A metodologia empregada pelas organizações guerrilheiras que se espalharam pelo mundo, entre as décadas de sessenta e setenta, foi em larga medida baseada nos preceitos da obra Que Fazer? ${ }^{412}$, de Lenin, manual que delineou a figura do "revolucionário profissional". No Brasil, apenas os veteranos do PCB possuíam alguma experiência no que diz respeito a clandestinidade. A nova situação ditatorial, intensificada após o AI-5, era algo desconhecido para a maioria dos que se engajaram no combate violento a ditadura. O comportamento temerário de Zequinha Barreto dava mostras das dificuldades de adaptação a dura rotina da clandestinidade.

(...) o próprio Barreto quase foi preso na ponte da Euzébio Matoso, clandestino, procurado, tinham saído da prisão em dezembro, pouco antes do Ato 5, o Barreto ia pra Osasco fazer serenata (para sua namorada). Um dia pegou uma batida (policial) na ponte Euzébio Matoso, ele conseguiu

411 Entrevista de Stanislau Zermeta ao autor, 04/11/2008

412 Para Lenin somente o revolucionário profissional poderia combater a "repressão profissional", ou seja, a polícia política, só estes poderiam "romper seu cerco tático e estratégico"; só estes poderiam "organizar e informar os operários". LENIN, Vladimir. Que Fazer?. São Paulo: Editora Hucitec, 1978. p. 81-86 
fugir de cima da ponte correndo pelo meio dos carros, a polícia atrás, entrou numa rua (...), então ele bateu numa porta, atendeu uma senhora, ele explicou que estava sendo procurado pela polícia, disse que era estudante, e a mulher o recebeu dentro de casa, lhe deu guarida até o dia seguinte, quando ele saiu. Havia uma pressão dentro da organização contra flacidez, contra o liberalismo (... $)^{413}$

Valdir Sarapu, temeroso frente a razia da repressão contra seu movimento, pediu desligamento da VPR, exilando-se pouco tempo depois. Barreto foi mantido fora de circulação. Lamarca se encontrava sob a mais severa clandestinidade, juntamente a seu grupo. Em meio a derrocada da organização, uma solução de força foi articulada entre a corrente militar e Espinosa, um dos poucos militantes com trânsito entre as distintas tendências da sigla. Vejamos o depoimento abaixo.

(...) o Cláudio Marinheiro (Cláudio de Souza Ribeiro), o Nóbrega e os sargentos me pressionaram, dizendo "nós estamos sendo todos presos, não vai sobrar ninguém desse jeito, tem que ter um comando forte, você tem que dar um golpe nesse negócio e acabar com a brincadeira desses estudantes". E eu dei, peguei o Rui (Valdir Sarapu) e o Barreto, para o Rui eu falei "você está com medo, você está vacilante", e estava mesmo, tava querendo ir embora para o exterior, e foi, nem participou do congresso de abril, e assumiu que estava vacilando. Nós arrumamos os meios para ele ir embora do país. Pro Barreto eu falei, nem Barreto era, ele estava sendo chamado de Daniel, e eu falei “ assim não dá, ponto a partir de agora não é chegar dez minutos depois, é na hora! É um daqui e outro de lá, cinco minutos de espera, se não aparecer ninguém, tchau, nunca mais”. Era um momento em que todas as discussões estavam suspensas, e só havia um comandante geral, que era eu (...). Mas isso durou dois meses, a VPR era um colegiado, sempre foi, e após esse período voltou a ser, assim que as quedas fossem estancadas isso acabaria. Fizemos uma ação bem sucedida na Vila Prudente, deu dinheiro suficiente para nos mantermos durante um certo período, nós passamos a ter fundos de novo para comprar novos carros, alugar casas, aparelhos visados foram abandonados ${ }^{414}$.

Até meados de 1969 a VPR conseguiu estancar as prisões que quase a destruíram, a

413 Entrevista de Antonio Roberto Espinosa ao autor, 30/09/2008

414 Espinosa aponta que o rendimentos dos componentes da VPR correspondiam a "um salário mínimo, e todos os militantes recebiam igual, inclusive os dirigentes, você recebia um salário mínimo para viver, e a organização pagava o aluguel, por que os aparelhos pertenciam a organização". Sobre a obtenção dos aparelhos, estes eram alugados "de gente legal, eu cheguei a alugar com documentos falsos, você pagava três meses de fiança, nesse período ainda nós tínhamos muitos aliados, então se conseguia fiador com mais facilidade, depois isso foi acabando, aí nós passamos a alugar pagando seguro fiança, então a polícia passou a fiscalizar nas imobiliárias gente que alugava imóvel pagando seguro fiança, começou a utilizar os porteiros de prédio perguntando quem que morava ali pagou seguro fiança, porteiro de prédio para investigar moradores, sobretudo os mais jovens, quer dizer, a repressão foi acossando”. Idem, ibidem. 
organização foi reconstituída, e iniciaram-se os trabalhos para um novo congresso para estabelecer os rumos da sigla. Estando a situação sobre controle, ao menos provisoriamente, as armas retiradas do $4^{\circ}$ RI foram requisitadas junto a ALN, que criou dificuldades para a devolução do material que lhe fora confiado. Marighella ainda se ressentia das quedas que atingiram também a sua organização após as prisões de Itapecerica da Serra, e especialmente da morte de Marquito, o comandante de GTA em São Paulo. Segundo Antonio Roberto Espinosa, "houve uma quase guerra entre VPR e ALN, chegou ao ponto do Matos (o Cláudio Marinheiro), e do Lamarca botarem uma arma na cabeça do Toledo, e dizerem "ou você devolve essas armas, ou vai ser guerra, nós entramos no quartel pra buscar e vamos localizar esse aparelho da ALN onde essas armas estão e vamos buscar da mesma maneira"415. O problema se resolveu com a devolução de parte dos fuzis de Quitaúna, outro tanto permaneceu sob posse da ALN. A questão dos armamentos azedou qualquer possibilidade de formação de uma frente entre as duas maiores organizações em atuação no período.

Resolvida a querela dos armamentos, foi marcado para abril o congresso que teve por pauta a escolha da nova coordenação da VPR, e o encaminhamento de uma proposta que vinha sendo delineada desde o ano anterior, ainda sob a orientação de João Quartim de Morais, a fusão com os Colina. Os detalhes da união foram acertados no congresso de Mongaguá, o mesmo que elegeu uma nova direção, composta por cinco membros, sendo estes Espinosa (que permaneceu na direção), Mario Japa (Shizuo Osawa), Cláudio Ribeiro, Fernando Mesquita e Carlos Lamarca. Outro ponto retirado do encontro foi o acerto da união com os Colina, fusão a ser ratificada através de um novo congresso, marcado para o segundo semestre. Para um melhor entendimento acerca dessa fusão, traçaremos um breve histórico sobre a trajetória dos Comandos de Libertação Nacional, até a altura do congresso de Mongaguá.

A origem dos Colina (Comandos se refere a composição interna do grupo, organizado por meio de "comandos", grupos com relativa autonomia) é semelhante a da VPR, a partir da união entre remanescentes do racha da Polop e setores militares vindos do MNR, ambos os grupos em atuação em Minas Gerais e no Rio de Janeiro. Em princípios de 1969, correntes menores foram se integrando ao movimento, como a "fração da dissidência do Rio Grande do Sul que não aceitara a fusão como POC; a Dissidência da Dissidência (DDD), que agrupava militantes descontentes com a orientação tomada pela DI-GB; o Núcleo Marxista-Leninista da 
AP, do Rio de Janeiro, além de militantes na Bahia, Pernambuco e Goiás" ${ }^{416}$. A sigla incorporou as teses da OLAS, e desde sua formação esteve aberta a fusão com outras organizações. Embora o grupo se anunciasse como de "libertação nacional", setores internos da sigla defendiam a passagem imediata ao socialismo. Essa questão ficou em aberto, visto que os Colina sempre apresentaram um certo caráter provisório, postergando definições estratégicas e se concentrando em ações táticas.

No núcleo de formadores do grupo figuraram Carlos Alberto Soares de Freitas, Juarez Guimarães de Brito e sua esposa Maria do Carmo Brito, veteranos vindos da cisão da Polop; um grupo de estudantes de medicina; dentre estes Ângelo Pezzuti, Herbert Eustáquio de Carvalho, Apolo Heringer Lisboa, Maria José Nahas e Jorge Nahas; universitários vindos do curso de economia, com destaque para Dilma Rousseff; e militares cassados como João Lucas Alves e Severino Viana Colon. O comando da sigla pertenceu "majoritariamente a estudantes pertencentes ao curso de Medicina da UFMG, vindos da militância no CEM - Centro de Estudos de Medicina, lugar de debates e discussões sobre diversos temas - desde questões referentes à Indústria Farmacêutica, passando pelo Poder Negro dos Estados Unidos até a guerra do Vietnã' ${ }^{\prime 17}$. Os principais dirigentes em atuação em Minas Gerais foram Carlos Alberto Soares de Freitas e o estudante de medicina Ângelo Pezzuti, no Rio de Janeiro, a coordenação ficou sob encargo do casal Maria do Carmo e Juarez de Brito, mineiros deslocados para a região.

Os Colina (que assim como seus homólogos de São Paulo, em princípio se identificavam apenas como “O.”), iniciaram suas ações de expropriação na mesma época em que a "O." paulista, assaltando bancos na região de Belo Horizonte. Os Colina tiveram participação ativa na Greve de Contagem, em abril de 1968, editaram o jornal O Piquete, distribuído entre os operários, e uma revista de fundo mais teórico, chamada América Latina. O programa do grupo passou a ser divulgado em abril de 68 , e recebeu o nome de "Concepção da luta revolucionária", no subitem intitulado "a guerrilha como embrião do exército revolucionário", vemos um resumo do ecletismo estratégico dessa organização. De acordo com o programa, a guerrilha

é o embrião de um novo poder, assim como o primeiro soviete de operários e soldados, na

416 REIS FILHO, Daniel Aarão. \& SÁ, Jair Ferreira de. Op. Cit. p. 172

417 LEITE, Isabel Cristina. "Radicalização Política Frente ao Regime Militar em Belo Horizonte - Grupo Colina, (1967-1969)". In: REVISTA HISTÓRIA HOJE. Volume 3 - No 8, dezembro de 2005. p.6. Disponível em formato digital no site da Anpuh; www.anpuh.org 
Rússia, foi o embrião do poder político. É isto que não compreenderam certos setores da esquerda brasileira. Em cada país, em cada circunstância histórica definida, o exercício do poder das classes dominantes apresenta uma falha, uma brecha, um ponto mais fraco que permite aos revolucionários introduzir uma cunha e - acumulando forças, organizando as massas - forçar a ruptura nesse poder ao mesmo tempo em que essa acumulação de forças, essa organização se constitua numa alternativa política, numa alternativa de poder. É na análise dialética da realidade que descobrimos esse ponto débil, esse botão certo. (...)

O ponto fraco do poder burguês-latifundiário no Brasil não são as cidades. Na Rússia, o proletariado organizado nas cidades, a revolta dos soldados e marinheiros, o Exército fatigado nas frentes de guerra contra a Alemanha permitiram uma corrente de forças francamente favorável a revolução a partir das cidades. No Brasil o elo mais fraco é o campo. Nas cidades concentra-se o poder policial-militar inimigo sem nenhuma solução de continuidade que permita a introdução de uma cunha, o movimento das massas organizado etc. O poder revolucionário no Brasil deverá ser construído a partir do campo e o foco guerrilheiro é o seu embrião $0^{418}$.

Por este excerto vemos o leque de influências que definiram a linha política da então “O.”, o leninismo de fundo polopista é uma constante no texto, com referências a Revolução Russa e a teoria do "elo mais fraco do poder", discutida por Lenin em O Imperialismo... O elo mais fraco, ou "ponto débil"; o "botão certo" a ser acionado pela luta guerrilheira seria o campo, local a ser construído o "poder revolucionário no Brasil". Aqui encontramos o matiz guevarista da sigla, o ponto chave de seu projeto, a edificação da guerrilha rural, a guisa de Cuba. Do processo cubano também apreendemos tintas debraystas, nas "cidades concentra-se o poder policial-militar inimigo sem nenhuma solução de continuidade", as cidades vistas como "túmulo dos revolucionários", a ensejar o deslocamento da luta para o campo. Em linhas gerais, no programa dos Colina estão presentes pressupostos caros a maioria dos grupos que se dedicaram ao combate a ditadura pela via das armas. Assim como dezenas de outros movimentos espalhados pelo Brasil, e pela América Latina, tal programa trabalhava com a ideia da formação do foco, o passo inicial para a construção da grande frente a se desenvolver ao longo do processo, a semelhança do que se passara em Cuba.

Se o caminho era o campo, fazia-se necessária uma etapa inicial nas cidades, a fim de se obter fundos para a iminente instalação do foco, nalgum ponto do imenso território brasileiro. Pelo relato abaixo notamos a confluência de projetos entre organizações de guerrilha.

418 REIS FILHO, Daniel Aarão. \& SÁ, Jair Ferreira de. Op. Cit. p. 191-192 
(...) tinha um cara, que se chamava Carlos Brasil, médico, gaúcho de Porto Alegre, eu estive com ele mais ou menos em 69, até comemos um churrasco juntos, esse mesmo cara, que a VPR achava que fosse quadro seu, os Colina também achavam. Esse militante foi lá pra região do chamado Bico do Papagaio, entre Maranhão e Pará, se instalou nessa região como médico, montou ali uma pequena clínica, identificou as possibilidades, de vez em quando ele passava por São Paulo e conversava com o pessoal. O Bacuri não era do Logístico, ele era do setor Campo da VPR, quem também era do setor Campo era o Ladilas Dowbor, assim como o Fernando Kolleritz, filósofo. O que que eles faziam, o Jamil, o Bacuri e o Kolleritz? Eles se metiam num carro, iam pro meio do mato, cheios de mapas e tal, pra tentar definir a região, a área estratégica, encontrar a área do foco, ver quais eram as possibilidades, se fosse o caso comprariam alguma fazenda, terras na região, e preparariam a aterrissagem da organização nessa área, esse era o trabalho do setor Campo. Voltando ao Carlinhos Brasil, nas viagens entre Porto Alegre e Maranhão, ele passava por São Paulo e tinha contato com o pessoal do campo, então eles imaginavam que o Carlinhos Brasil fizesse no Maranhão um trabalho para a VPR, mas eles pesquisavam outras regiões também, como Mato Grosso. Agora, o próprio Carlinhos Brasil se sentia mais próximo dos Colina que da VPR ${ }^{419}$.

A construção do foco foi o grande objetivo da guerrilha brasileira, mesmo grupos de viés mais leninista, como o POC, apostavam nesse modelo tático, contudo, a única sigla a efetivamente se dedicar ao desenvolvimento da luta no campo foi o PC do B. Desde 1967 a organização oriunda do primeiro racha do PCB enviava quadros para desenvolver um trabalho político, e lançar as bases para a eclosão da guerrilha rural, na mesma região onde se movimentava Carlos Brasil, ativista que alimentava as pretensões foquistas de duas frentes armadas. Mas como se sabe, a orientação do PC do B não obedecia a princípios guevaristasdebraystas, e sim as teses de Mao Zedong, que preconizavam a "guerra popular prolongada" ${ }^{420}$.

Num congresso realizado em julho de 1968, a então “O.” passou a se chamar Colina, estruturada em Minas Gerais e no Rio de Janeiro, com ramificações em outros estados, e com um histórico recente de ações, como roubos a banco, atentados a bomba, e expropriações de armamentos. Ao menos um justiçamento foi creditado ao grupo, produto de um engano fatal, o assassinato do major do Exército alemão Edward Ernest Tito Otto Maximilian von Westernhagen, que fazia um curso militar na Praia Vermelha, Rio de Janeiro, morto por 
engano ao ser confundido com Gary Prado, chefe da operação que capturou e executou o comandante Ernesto Che Guevara. Prado também também frequentava o curso. Descoberto o engano, a ação foi mantida sob sigilo e desvendada anos após o fim da ditadura.

A sorte dos Colina começou mudar em novembro de 1968, com a prisão do exsargento da aeronáutica João Lucas Alves, graduado remanescente das lutas militares pré-64, e um dos lideres da Rebelião dos Sargentos de 1963. Cassado após golpe, passou a atuar no MNR, fazendo parte da coalizão que deu origem aos Colina, atuando no braço militaroperacional da organização, sendo o responsável pelo comando de diversas ações de expropriação. João Lucas foi preso no Rio de Janeiro, em sua moradia-aparelho foram encontradas "munições, armamentos, documentos da organização, uniformes das Forças Armadas, mimeógrafos $(\ldots)^{421}$. O ex-graduado pernambucano foi detido em novembro, cerca de um mês antes da decretação do AI-5, após a imposição do Ato, suas possibilidades de libertação se tornaram nulas. Mantido preso na Polícia do Exército (PE) carioca, após dezembro passou a ser barbaramente torturado, dentre seus colegas de presídio esteve Onofre Pinto, que do exílio denunciou o martírio sofrido por seu colega de armas. Em 28 de fevereiro de 1969 o veterano de lutas do MNR foi transferido para Belo Horizonte, em 6 de março foi anunciada oficialmente sua morte por "suicídio". O assassinato sob torturas de João Lucas se deu em meio a derrocada de sua organização.

Em 13 de janeiro caiu preso o dirigente e fundador dos Colina Ângelo Pezzuti da Silva, em Belo Horizonte. No dia 28 foi a vez de Pedro Paulo Bretas, que sob intensa tortura deu o endereço de um aparelho onde se concentrava o arsenal da organização, além dos fundos obtidos em ações de expropriação. Murilo Pinto da Silva, irmão de Ângelo Pezzuti, vendo o aparelho cercado, recebeu os policiais com tiros de metralhadora. Sua reação levou a morte dois agentes da repressão, o subinspetor Cecildes Moreira Fria, e o guarda civil José Antunes Ferreira, um investigador ficou gravemente ferido. Contudo, Murilo Pinto foi logo rendido pelas forças policiais, e a queda do aparelho redundou nas prisões do casal Jorge e Maria José Nahas, e também de Afonso Celso Lana Leite, Maurício Vieira de Paiva, Nilo Sérgio Menezes Macedo e Júlio Bittencourt de Almeida ${ }^{422}$. Após esse evento, os Colina foram desmobilizados em Minas Gerais, para estancar as quedas, os quadros da organização que escaparam ao cerco se deslocaram para outras cidades, regiões onde eram menos visados pela repressão, especialmente São Paulo e Rio de Janeiro. A degringola dos Colina acabou por 
apressar seus planos de fusão com a VPR, outra sigla que no mesmo período também passava por uma vaga de prisões.

\subsection{Por que a VAR-Palmares}

Acima vimos que o acerto para a fusão entre os Colina e a VPR se efetivou no Congresso de Mongaguá, realizado em abril de 1969. A costura final entre os dois grupos seria definida em agosto, no encontro de Teresópolis. Entre os dois congressos, um comando representando a VPR realizou mais uma ação expropriatória num quartel, este localizado em São Caetano, cidade da grande São Paulo, invasão que rendeu 94 fuzis FAL ao grupo, mais de uma dezena de metralhadoras INA, cerca de cinquenta revólveres, centenas de granadas e mais de cinco mil cartuchos de diversos calibres ${ }^{423}$, sendo o roubo de armamentos mais bem sucedido da sigla. Ao todo, a VPR assaltou três quarteis, adquirindo mais de 150 fuzis FAL, incontáveis armamentos de menor calibre, como metralhadoras e pistolas, além de farta munição, o que credenciou a sigla como uma das mais bem armadas do período.

Atuando já como VAR-Palmares ${ }^{424}$, um comando reunindo militantes oriundos dos dois grupos que deram origem a nova organização, executou a maior operação para obtenção de fundos perpetrada por um movimento guerrilheiro no Brasil durante os Anos de Chumbo, num roubo que ficou conhecido como "a ação do cofre do Adhemar". O dinheiro retirado estava guardado em um cofre de uma das amantes do governador cassado de São Paulo, identificada pelo codinome "doutor Rui". O comando da operação ficou sob encargo de Juarez Guimarães de Brito, que já se notabilizara no planejamento de ações em Minas Gerais. Juarez "tinha a seu comando" um grupo de secundaristas cariocas, alguns vindos do Colégio de Aplicação, dentre estes Gustavo Buarque Benchimol, sobrinho de Ana Benchimol Capriglione, amante de Adhemar de Barros.

423 Idem, p. 268. Esses números são confirmados por Antonio Roberto Espinosa, que participou da ação. 424 De acordo com Espinosa, "Quanto ao nome da organização, uma parte da Colina não tinha um nome a propor, surgiram algumas ideias, uma que eu me lembro bem, partiu do pessoal do Rio de Janeiro, o Juvenal (Juarez de Brito), e a Maria do Carmo, que propuseram que a nova organização se chamasse VPR-Palmares, e aí acabou surgindo no meio uma proposta intermediária, pra não parecer que os Colina estivessem sendo incorporados pela VPR, então se decidiu mudar o nome de VPR para VAR, Vanguarda Armada Revolucionária - Palmares, inclusive porque seria mais sonoro, seria mais fácil de falar". O nome da nova organização fazia uma alusão ao Quilombo dos Palmares, símbolo da resistência popular, e ao mesmo tempo aos Tupamaros, grupo que ganhou notoriedade no período. A organização uruguaia se chamava Movimento de Libertação Nacional (MLN) - Tupamaros, e assim como a VAR, possuía caráter de frente. Entrevista de Antonio Roberto Espinosa ao autor, 08/10/2008. 
Informações indicavam a existência de 25 milhões de dólares espalhados por dez cofres em pontos distintos do país, destes, ao menos dois estavam na cidade do Rio de Janeiro, e Gustavo Benchimol afirmava saber onde os mesmos se encontravam. De acordo com suas informações, um dos cofres estava guardado num apartamento de Copacabana, e outro no bairro de Santa Teresa, na casa de sua tia Ana Benchimol. Após averiguar a veracidade das informações, a direção da VAR decidiu se apoderar dos dois cofres conhecidos. Devido a uma série de dificuldades, a ação de Copacabana foi abortada, direcionando todos os esforços para Santa Teresa. No dia 18 de julho, um grupo de 13 guerrilheiros, liderados por Juarez de Brito e José Araújo da Nóbrega, disfarçados de policiais, invadiram a casa de Ana Benchimol sob o pretexto de uma inspeção. O grupo deixou o casarão carregando um cofre de 350 quilos, que foi transportado numa caminhonete C-14. A ação rendeu 2,5 milhões de dólares (10,3 milhões de cruzeiros), sendo o maior roubo já executado por uma guerrilha até então ${ }^{425}$. De posse de generosos fundos, a VAR-Palmares agora tinha condições de por um freio as ações de expropriação, e se dedicar a constituição do tão aguardado foco rural, a ser definido em seu próximo encontro.

Em contraste com o êxito momentâneo da sigla, a repressão seguia provocando baixas entre seus componentes, em 23 de junho foi detido ao sair de seu aparelho Carlos Roberto Zanirato, que pertencera a célula do capitão Lamarca, em Quitaúna. Após seis dias de intensa tortura, Zanirato levou seus algozes para um cruzamento entre a Rua Bresser e a Avenida Celso Garcia, bairro do Brás, Zona Leste de São Paulo, sob o pretexto de ter um ponto com um companheiro de guerrilha. Aproveitando um descuido dos agentes que o conduziam, o jovem de vinte anos se atirou debaixo de ônibus em movimento, tendo morte instantânea. Lamarca ficou profundamente abalado com a morte de seu amigo dos tempos de $4^{\circ}$ RI.

Na noite de 29 de julho, João Domingues da Silva, codinome Elias (irmão de Roque Aparecido da Silva) e Fernando Borges de Paula, o Fernando Ruivo, (estudante de Ciências Sociais, ex-dirigente da Dissidência Estudantil do PCB, pertencente a corrente que não se integrara a ALN) foram interceptados por policiais civis na Avenida Pacaembu, proximidades do Largo da Banana, Zona Oeste de São Paulo. A dupla reagiu a interpelação policial e houve troca de tiros, Fernando Ruivo morreu na ação, João Domingues, ferido a bala, conseguiu escapar e buscou refugio na casa de sua irmã, em Osasco. Foi preso na mesma noite e levado

425 "No dia 12 de dezembro (do mesmo ano) os Tupamaros uruguaios saquearam o Banco da República e levaram o equivalente a 6 milhões de dólares, quase tudo em jóias". Helio Gaspari também afirma que a família não procurou a polícia para denunciar o assalto. Para mais informações, Idem, p. 272-275; Para citação em nota: GASPARI, Hélio. A Ditadura Escancarada. São Paulo: Companhia das Letras, 2002. p. 52-57 
ao Hospital das Clínicas, onde passou por delicada cirurgia. Mesmo "correndo risco de vida", foi trasportado por policiais para o Hospital Geral do Exército, onde foi torturado, apesar de seu estado de saúde. Após mais de trinta dias torturas e maus tratos, João Domingues veio a falecer, em 23 agosto $^{426}$.

Elias fora nomeado comandante do Grupo Tático de São Paulo, voltado a ações armadas, por Antonio Roberto Espinosa (que ficou profundamente abalado com a morte de seu companheiro de Osasco), o dirigente do setor Urbano. Segundo Celso Lungaretti, o responsável pelo GT fornecia poucas informações sobre o andamento de seus trabalhos e planos futuros, "Elias organizou tudo em torno de si mesmo". Havia "aparelhos cuja localização só ele conhecia", e muitos endereços tiveram que ser abandonados a pressas devido a incerteza sobre o leque de informações concentradas no dirigente preso ${ }^{427}$. Espinosa comenta que entre os ex-militares também houve um mal estar devido a nomeação de Domingues para a direção do setor voltado as ações táticas da organização, visto que o jovem de vinte anos não possuía a mesma experiência dos quadros aos quais deveria comandar. Não obstante, o mesmo possuía uma considerável experiência em ações expropriação, tendo inclusive participado do roubo ao cofre de Adhemar de Barros. O mesmo depoente o definiu como um quadro de sua inteira confiança, e também um militante "politicamente bom", dentro de sua ótica. A indisposição gerada pela questão João Domingues, somada aos transtornos propiciados pela sua queda prematura, deterioraram as relações entre o dirigente do setor Urbano e a corrente militarista da VAR, fato este que traria sérias consequências para o futuro da sigla revolucionária.

\section{$* * * * *$}

O ano de 1969 pode ser considerado como de ofensiva para os grupos guerrilheiros em atuação no país, entretanto, a balança começou pender para o lado da repressão a partir de julho desse mesmo ano, quando da criação da Operação Bandeirantes, conhecida como Oban. Para se entender a mentalidade a nortear os articuladores da Oban, é necessário um retorno ao início da década de sessenta, fase em que o tradicional anti-comunismo das classes conservadoras nacionais passou por um processo de atualização. Salientamos neste trabalho

426 "Direito à verdade e à memória: Comissão Especial sobre Mortos e Desaparecidos Políticos / Comissão Especial sobre Mortos e Desaparecidos Políticos". Brasília-DF: Secretaria Especial dos Direitos Humanos, 2007. p. $100-101$

427 LUNGARETTI, Celso. Op. Cit. p. 102 
que os preceitos de combate a subversão interna, travada por meio da guerra irregular e insurrecional, foram introduzido na América Latina via teóricos franceses. No Brasil, tais concepções passaram a ser divulgadas a partir das palestras ministradas pelo coronel Augusto Fragoso, no curso de "Estado-Maior e Comando" da Escola Superior de Guerra, em 1959. A conceito chave da escola francesa de contra-insurreição é o da guerre révolutionnaire.

Expondo de uma forma sintética, tal doutrina preconizava um modelo de guerra não convencional, adaptado a nova realidade imposta pelo conflito bipolar internacional, marcado pela tensão nuclear. Estando descartado o enfrentamento direto entre as duas potencias mundiais, a disputa político-ideólogica pelo domínio do globo seria então travada em outras frentes. A invasão não se daria mais por meio de uma agressão externa, e sim por meio da arregimentação de quadros dentro de cada país a ser conquistado, dando relevo a figura do inimigo interno ${ }^{428}$. O novo paradigma teria como tática, em sua fase de construção, uma ofensiva psicológica ${ }^{429}$ (psicossocial), atuante nos meios culturais e acadêmicos, de modo a conquistar "corações e mentes". Dentro da ótica militar, as novas regras de combate demandavam uma mudança qualitativa na luta contra a subversão, pois

um dos problemas mais difíceis no combate à GR (Guerra Revolucionária) seria o papel a ser desempenhado diretamente pelas Forças Armadas. Algumas conclusões, no entanto, servem de ponto de partida: de um lado, é preciso criar serviços de informação capazes de antecipar os movimentos do inimigo interno; de outro, cabe às Forças Armadas construir uma organização de defesa interna do território, ao mesmo tempo em que cria unidades especialmente adestradas na luta anti-revolucionária. Porém, antes de tudo, é necessário reconhecer que a preparação para a guerra anti-subversiva supera as atribuições tradicionais das Forças Armadas. A ação contra-revolucionária exigiria uma iniciativa conjunta decidida por todos os poderes do Estado ${ }^{430}$.

428 “Como a guerra revolucionária não é declarada e é promovida secretamente por forças externas do comunismo internacional, ela recruta seus combatentes entre a população do "país-alvo". Por definição, portanto, torna-se suspeita toda a população, constituída de "inimigos internos" potencias que devem ser cuidadosamente controlados, perseguidos e eliminados”. MOREIRA ALVES, Maria Helena. Op. Cit. p. 45

429 "Os elementos psicossociais deveriam, (...), para os militares e civis que articularam o golpe de 1964, se constituir em um dos fundamentos do poder nacional e, por conseguinte, do Estado que se objetiva criar, a partir de um amplo conhecimento das tradições, aspirações, sonhos, desejos, enfim, todos os elementos constituintes da cultura do povo brasileiro. (...) A segurança nacional dependia, assim, para os civis e militares que compunham a ESG antes e durante o regime militar, de uma ampla sondagem que deveria ser feita por diversos pesquisadores sobre as condições naturais, culturais e sociais em todo território nacional. O objetivo deste processo era detectar os sentimentos, a mentalidade, as atitudes, as aspirações, os sonhos, os desejos, os ideais, enfim, todos os valores que moviam e organizavam a vida social brasileira. REZENDE, Maria José de. $A$ ditadura no Brasil: repressão e pretensão de legitimidade 1964-1984. Londrina-PR: Editora da UEL, 2001. p. 43

430 Os conceitos supracitados estão presentes em: MARTINS FILHO, João Roberto. Op. Cit. p. 44 
A nova doutrina anticomunista foi divulgada, em princípio, entre os círculos de oficiais mais conservadores, com o acirramento dos conflitos de classe no país, no pré-1964, tais ideias foram se popularizando no meio militar por meio de publicações internas às Forças Armadas. Sua divulgação para o "público externo" se verificou a partir dos discursos proferidos pelo deputado udenista Bilac Pinto, que citou diretamente fontes francesas em suas explanações no Congresso Nacional. A popularização dos conceitos da GR foi empreendida num momento chave, em princípios de 1964, e foram amplamente divulgados pela imprensa mancomunada com a conspiração golpista, a essa altura em estágio avançado.

Bilac Pinto seguiu a risca os manuais divulgados pela ESG, e didaticamente fez menção as distintas etapas da GR, que estaria subdivida em cinco fases. A primeira seria de fundo "organizacional", de formação de quadros e infiltração, a segunda compreendia a "ampliação da infraestrutura", coroada pela "promoção de greves, desordens e sabotagem"; a terceira, (fase em que o Brasil se encontrava, segundo os estudiosos), seria a de formação de grupos guerrilheiros e aplicação de "terrorismo seletivo e sistemático"; a quarta daria origem ao exército revolucionário e a formação de "zonas liberadas"; a quinta e última, engendraria a consolidação de uma "Superestrutura Nacional" e a "instalação do governo comunista ostensivo" "431. O livro de Bilac Pinto cumpriu seu objeto de "assustar" as classes médias nacionais no imediato pré golpe. Contudo, o debate entre as cúpulas militares acerca desse tema era mais sério, e uma vez no controle do país, o conceito da GR foram sendo incorporados pelos aparatos de repressão.

O grande polo divulgador da nova mentalidade foi sem dúvida a ESG, que serviu de referência para todas as escolas militares nacionais ${ }^{432}$. Seus manuais foram reproduzidos entre os meios militares e acadêmicos, e sua filosofia empolgou amplos segmentos da sociedade. Contudo, nos anos iniciais do ciclo autoritário, a GR parecia ter se resumido a um prognóstico, a desorientação da esquerda nos primeiros anos da ditadura parecia comprovar isso.

O combate inicial a subversão foi perpetrado pelas Forças Armadas em conjunto com as policias militares estaduais, mais agentes do velho Dops. A razia pós golpe obedeceu a

431 Bilac Pinto citou como fonte para sua exposição, no dia 23 de janeiro de 1964, o "trabalho" do Coronel J. Hogart, oficial do Exército francês. PINTO, Bilac. Guerra Revolucionária. São Paulo: Editora Forense, 1964. p. 63-64

432 "Em 1968 o currículo da ECEME (Escola de Comando do Estado-Maior do Exército) contava um total de 222 horas de aulas dedicadas exclusivamente a discussão da Doutrina de Segurança Interna, e outras 129 à análise de formas não clássicas de guerra. Apenas 21 horas eram dedicadas a tópicos militares tradicionais como defesa territorial contra agressão externa do país”. MOREIRA ALVES, Maria Helena. Op. Cit. p. 41 
métodos tradicionais de busca e apreensão, reativando antigas práticas executadas em períodos autoritários pregressos. Os serviços de inteligência seguiram sendo empreendidos pelo Dops, veterano no combate a subversão e adversário histórico do PCB e seus militantes. Até 1968 o contingente repressor a disposição foi bem sucedido na contenção aos adversários do regime.

Contudo, junto ao ressurgimento das lutas de massa no país, veio à tona uma militância de novo tipo, não se tratava mais do velho modelo organizacional pecebista, a muito conhecido pela repressão. Organizações com um nível de desempenho tático jamais visto passaram a se movimentar nos grandes centros urbanos do país, surpreendendo os órgãos de segurança do regime militar. A conjugação das lutas de massas e as ações iniciais de guerrilha no Brasil deram novo alento aos prognósticos de GR em voga nos círculos acadêmicos das Forças Armadas. Seguíamos na terceira fase do programa do coronel Hogart, com o deflagrar de greves insurrecionais, atos de terrorismo, infiltrações nos movimentos estudantis e operários, etc. A luta revolucionária de novo tipo demandava uma reação de novo tipo, integrada as doutrinas anticomunistas em relevo na ESG desde finais dos anos 1950.

A ação de Quitaúna, o roubo do "cofre do Adhemar", as ações de expropriação que diariamente desconcertavam os órgãos de repressão país afora, passaram a alimentar o temor dos militares frente ao crescimento das organizações guerrilheiras. Advertências de fundo alarmista clamavam por medidas urgentes, segundo o general Jayme Portella, secretário-geral do Conselho de Segurança Nacional, em comunicado ao presidente Costa e Silva, "a persistir tal situação é de prever-se: a eclosão de guerrilhas urbanas e rurais; a atuação mais violenta em atos de terrorismo; a criação de 'bases' e 'zonas liberadas'" ${ }^{433}$. O informe do general Portella remete ao já usual esquema dos cinco estágios. Reforçando seu catastrofismo, a advertência sobrepõe estágios da GR e sobrevaloriza o nível operacional de organizações que sequer haviam estruturado seus focos rurais. Em todo caso, esse grau de alarmismo esteve presente entre os signatários da ditadura desde seus primórdios, antes mesmo do assalto poder; e no mais, era uma excelente fórmula para angariar o apoio daqueles setores sempre temerosos ante o "espectro" do comunismo.

Desde maio de 1968 o II Exército se encontrava sob o comando do general José Canavarro Pereira, um linha dura. Coube a esse comandante o esforço inicial a dar origem a Operação Bandeirantes, destinada a por um fim as atividades "terroristas" praticadas pelas 
organizações revolucionárias em atuação no estado. São Paulo foi visto como o grande polo de atividade guerrilheira no país, neste estado estavam concentradas as ações dos maiores grupos armados em combate ao regime militar, aqui estavam mobilizadas a ALN e a VARPalmares, siglas que tinham em suas fileiras centenas de militantes armados e prontos para a ação; além de uma dezena de agrupamentos menores, mas nem por isso menos atuantes. A nova operação policial foi lançada numa solenidade que contou com a participação do governador Abreu Sodré, o prefeito paulistano Paulo Maluf, e o Ministro da Fazenda Delfim Neto, sendo realizada em julho de 1969. Para servir de sede ao empreendimento, o governador paulista cedeu uma velha delegacia localizada na Rua Tutóia, a cinco minutos do QG do Ibirapuera. A Oban foi delineada por

meio de uma Diretriz para a Política de Segurança Interna, expedida pela Presidência da República em julho de 1969, que resultou no surgimento de estruturas semelhantes em outros estados. Estabelecia as normas que centralizavam o sistema de segurança, colocando-os sob as ordens de um oficial do Exército classificado na seção de informações do comando militar. Ele requisitaria efetivos à PM, delegados e escreventes a polícia. Manteria algo parecido com o cartório para tomada de depoimentos e teria sua própria carceragem. Buscava-se a centralização das atividades repressivas nas grandes cidades. As delegacias policiais, inclusive o Dops, estavam obrigadas a mandar à Oban todos os suspeitos de atividades terroristas ${ }^{434}$.

Ainda segundo Hélio Gaspari, o general Canavarro fora orientado pela "burocracia de Brasília" a edificar seu projeto sem o apoio financeiro federal, algo que demandou a procura por financiadores de origem civil. O patrocínio a Oban foi negociado junto a um grupo de empresários paulistas, num encontro realizado no "clube São Paulo", aos olhos do Ministro da Fazenda Delfim Neto. A reunião foi organizada pelo banqueiro Gastão Vidigal (filho do fundador da Cobrasma e irmão do presidente em exercício da empresa), dono do Banco Mercantil. O expositor do projeto foi o próprio Delfim Neto, que apresentou um quadro alarmante, convencendo seus interlocutores acerca da escalada revolucionária no país, valorizando o potencial da guerrilha, visando amedrontar os detentores do capital. Junto às classes produtoras, o grande propagandista da Oban foi o empresário dinamarquês Henning Albert Boilesen, presidente do Grupo Ultra, grande entusiasta da repressão e anticomunista convicto, chegando mesmo a participar pessoalmente de sessões de tortura, e desenvolver 
artefatos de martírio ${ }^{435}$.

A Operação Bandeirantes significou o ponto alto daqueles militares que desde inícios da década se orientavam pelos conceitos da GR, o fortalecimento da guerrilha urbana deu a esses técnicos a certeza de que seus prognósticos estavam certos. As estruturas repressoras tradicionais vinham se mostrando antiquadas frente a operacionalidade de novo tipo posta em prática por grupos como a ALN e a VPR, algo que serviu como justificativa para a formulação de todo um aparato voltado ao combate a subversão. As tradicionais medidas de "contenção e vigilância", levadas a cabo pela polícia política em atuação desde os anos 1920, foram substituída pela prática de "eliminação física" das organizações armadas de esquerda. Dentro desse desiderato, foi mobilizada uma equipe de policiais que atuava na Delegacia de Roubos de São Paulo, conhecida pela crueldade de seus agentes na repressão ao crime. A equipe era chefiada pelo delegado Sérgio Paranhos Fleury, incorporado ao Dops junto com seus subordinados, passando a colaborar com os esforços da Oban ${ }^{436}$. Mas a ofensiva dos militares contra a esquerda não se resumiu a repressão violenta, também foi empreendida por meios econômicos e publicitários, abaixo veremos como se efetivaram os outros dois pilares da ofensiva dos militares contra a guerrilha.

$435 \mathrm{O}$ artefato desenvolvido por Henning Boilesen foi chamado de pianola Boilesen, um teclado que emitia choques em voltagem crescente. Segundo Fernando Henrique Cardoso, em depoimento a Chain Litevsky, a parceria entre a OBAN e burguesia paulista obedecia mais a princípios políticos do que econômicos, visto que, segundo sua visão, havia condições do Estado brasileiro financiar a empreitada do general Canavarro. A busca de apoio junto ao empresariado selou a cumplicidade entre civis e militares na fase mais aguda da repressão, e engendrou um apoio político que seria fundamental para futuros acobertamentos dos crimes cometidos pelos agendes da Oban. Para informações sobre o encontro entre os formuladores da Oban e a plutocracia paulista: GASPARI, Hélio. Op. Cit. p. 62-64; para depoimento de Fernando Henrique Cardoso: Cidadão Boilesen. Direção: Chain Litevski, ano de produção, 1999.

436 Segundo Percival de Souza, na Delegacia de Roubos predominava a "cultura do pau", coube aos agentes lotados nessa unidade a criação do famigerado "esquadrão da morte", que durante toda a década de sessenta e parte da seguinte executou de forma sumária centenas de pessoas na região da Grande São Paulo. Ainda segundo esse autor, quando se iniciaram as atividades da guerrilha urbana, os agentes do Dops foram "pegos de surpresa", visto que nessa instituição, "nunca, apesar de sua longa existência, se vira nada igual. Os militares começaram a cobrar respostas". A solução partiu da própria Secretaria de Segurança, que designou para o combate a subversão policiais da Delegacia de Roubos, investigadores com larga experiência em ação. Para os homens dessa unidade, "acostumados a arrancar serviço de ladrões, mudaria somente o alvo a ser atingido: em vez de caçar autores de crimes contra o patrimônio, agora correriam atrás de subversivos". Em contraposição a tecnicismo preconizado pela ESG no combate a esquerda, a metodologia da equipe do delegado Fleury era mais pragmática, resumida em prisões, torturas afim de se obter informações, que por sua vez gerariam novas prisões, e assim sucessivamente. Os agentes da Delegacia de Roubos chegaram ao Dops, em setembro de 1969, por intermédio de Benedito Nunes Dias, diretor da entidade, tido como intelectual. Professor de Direito Constitucional, professava um anticomunismo militante. O delegado Fleury e seu grupo foram os principais responsáveis pelo desbaratamento da guerrilha urbana em São Paulo. De acordo com Hélio Gapari, Fleury vendia proteção para traficantes de drogas que atuavam na região central de São Paulo, mantendo ligações estreitas com o crime organizado. Para nomeação de Fleury e sua equipe para o Dops, SOUZA, Percival. Op. Cit. p. 29-37; para "esquadrão da morte", BICUDO, Hélio. Meu depoimento sobre o Esquadrão da Morte. São Paulo: Editora Martins Fontes, 2002; para ligações de Sérgio Fleury com o crime organizado, GASPARI, Hélio. Op. Cit. 316 
A contenção aos adversários da autocracia militar não se resumiu a repressão policial, outros fatores deram suporte ao isolamento ${ }^{437}$ da guerrilha no Brasil, dentre estes, o mais poderoso foi sem dúvida o comentado "Milagre Econômico", ciclo de crescimento econômico que perdurou de 1968 a 1973. Segundo Paul Singer, os "milagres econômicos têm sobretudo caráter político. Eles são promovidos através dos meios de comunicação de massa para popularizar determinados aspectos da política econômica, aos quais se atribui grande eficácia na promoção do crescimento"438. Embora o crescimento do país tenha atingido notáveis $11,1 \%$ em média durante o período, tal pujança não logrou proporcionar ao Brasil um salto qualitativo em termos de desenvolvimento, visto que o caráter deste "milagre" seguiu as diretrizes excludentes e concentradoras de renda das ditadura civil-militar.

O salto verificado entre finais de 1968 e 1973 seguiu a trilha aberta pelas medidas de austeridade imprimidas pelo PAEG da dupla Campos-Bulhões. A contenção ao crédito abriu espaço para o avanço dos monopólios no meio industrial brasileiro, e as melhorias levadas a cabo no aparelho arrecadador permitiram aumentos reais na receita da união, reduzindo os déficits orçamentários. Entretanto, nenhuma medida foi mais eficaz para o saneamento em moldes ortodoxos da economia brasileira do que o arrocho salarial imposto a classe trabalhadora. A contensão dos salários possibilitou as empresas nacionais e estrangeiras um

437 Os diversos grupos de guerrilha brasileiros trabalharam com a hipótese de uma grave recessão que atingiria o país já em finais dos anos 1960. O período recessivo dos quadriênio inicial do regime militar ajudaram a cristalizar essa certeza. Um série de teóricos deram vasão a essa perspectiva, diagnosticando o "esgotamento do modelo de substituição de importações". Dentre os teóricos que anteciparam uma inevitável "estagnação" do sistema econômico brasileiro, destacaram-se Celso Furtado, Caio Prado Junior, e o economista estadunidense André Gunder Frank. Guido Mantega, em apreciação as concepções estagnacionistas presentes em Celso Furtado, tece o seguinte raciocínio: "A falha principal reside, no meu entender, na própria concepção que o Modelo de Substituição de Importações possuía das leis da acumulação capitalista e da lógica de funcionamento desse modo de produção. Pelo menos é o que se depreende da análise de Furtado, que raciocina em termos de um sistema capitalista onde a concentração de renda ou a compressão do poder aquisitivo dos assalariados leva à estagnação e inviabiliza a própria acumulação. É por isso que o autor de Formação Econômica do Brasil vê uma certa comunhão de interesses entre lucros e salários, uma vez que aqueles dependeriam, em grande medida, do poder de compra destes. Porém, isso ocorreria caso o sistema capitalista estivesse orientado para o consumo e, mais especificamente, para o consumo dos trabalhadores, ou seja, para a satisfação de suas necessidades materiais, quando, na verdade, está voltado para a acumulação de capital, para a produção pela produção; e o consumo dos trabalhadores, sem deixar de ser importante e necessário para a realização de parte da mais-valia, está atrelado ao objetivo central desse modo de produção". Para Celso Furtado; FURTADO, Celso. Subdesenvolvimento e Estagnação na América Latina. Rio de Janeiro: Editora Civilização Brasileira, 1966; para Caio Prado Junior; PRADO JUNIOR, Caio. A Revolução Brasileira. São Paulo: Editora Brasiliense, 1966; para André Gunder Frank; FRANK, André Gunder. Capitalismo y Subdesarollo em América Latina. México: Siglo Veintiuno Editores, 1978. Para citação de Mantega; MANTEGA, Guido. Op. Cit. p. 101.

438 SINGER, Paul. Op. Cit. p. 15 
incremento na extração de mais-valia sobre a massa trabalhadora, proporcionando elevados lucros ao empresariado. O sistema repressor permitia esse tipo logro, visto que o MO se encontrava sobre o mais férreo controle.

O ciclo recessivo dos anos iniciais do regime militar começou ser superado após a chegada de Delfim Neto ao Ministério da Fazenda, em 1967, nomeado pelo marechal Costa e Silva. A nova equipe econômica empossada era de viés desenvolvimentista, dentro dos parâmetros da elite civil-militar. A rigor, o modelo de acumulação em voga nessa fase foi o mesmo implementado nos anos $\mathrm{JK}$, centrado no setor de produção de bens de consumo duráveis, direcionados as classes media e alta, em detrimento dos bens salário, voltados as camadas mais baixas.

(...) a expansão do Departamento III, já em si mesma um sinal de concentração de renda, levou essa concentração a um ponto em que a expansão do Departamento II da economia - o da produção de bens de consumo não duráveis - passa a depender, de novo, da exportação de produtos agropecuários. Isto quer dizer que essa expansão do Departamento III penalizou fortemente o crescimento dos salários reais dos trabalhadores; mesmo os salários dos trabalhadores desse setor, que concentra certamente a mão-de-obra mais qualificada do País, na faixa de operários, não fez senão acompanhar o ritmo de crescimento dos preços e não houve nenhum ganho real ${ }^{439}$.

O setor produtivo do país foi voltado a atender as demandas de cerca de $20 \%$ da população, a parcela com acesso a renda e ao consumo, o restante permaneceu a margem. Vimos acima que o "milagre" foi mais uma peça de propaganda do que um programa efetivo de desenvolvimento econômico, com crescimento e distribuição de renda. Destarte, restou aos articuladores do governo formular campanhas de convencimento, segundo as táticas de ofensiva psicológica presentes nos manuais da ESG. Estando o operariado desmobiliado a forceps pela repressão, em um país que possuía $40 \%$ de sua população analfabeta, excluída do processo político, restava ao governo se ancorar nos setores médios, o único segmento que a essa altura poderia esboçar alguma reação a seu projeto de país. A conquista de "corações e mentes" ficou sob encargo da AERP (Assessoria Especial de Relações Públicas da Presidência da República), a grande formuladora das campanhas publicitárias da ditadura, focadas na classe média, mas de efeitos que ecoavam para toda sociedade.

A AERP fora criada em princípios de 1968, pelo governo Costa e Silva, em seus

439 OLIVEIRA, Francisco de. Op. Cit. p. 100-101 
primeiros meses de existência, tal aparelho não logrou grandes resultados em sua tarefa propagandear os feitos do regime. A situação começou mudar em novembro de 1969, quando foi nomeado diretor da entidade, pelo próprio presidente da república, marechal Emílio Garrastazu Médici, o coronel Octávio Costa, tido como intelectual entre seus pares. A designação "relações públicas" não passou de um eufemismo para um departamento que tinha por missão vender os feitos da ditadura, a guisa do velho DIP, porém com roupagem atual. Dentro do "jargão militar", as metas da AERP iam no sentido de motivar a vontade coletiva em direção a um "esforço nacional de desenvolvimento", buscando também "mobilizar a juventude", "fortalecer o caráter nacional", estimular o "amor a pátria”, a "coesão familiar", a "dedicação ao trabalho", a "confiança no governo" 440 , etc. A mentalidade dos técnicos da AERP coadunava como o jaez modernista-conservador do regime militar, cujo projeto buscava atualizar as estruturas produtivas e o campo tecnológico do país, sem tocar nas estruturas sociais, mantendo, e mesmo atualizando, tradições e arcaímos calcados em preceitos como família, autoridade, hierarquia, nacionalismo de tipo instrumental, etc.

A ditadura civil-militar inaugurada em 1964 se caracterizou como um regime desmobilizador, entre seus signatários a política era vista como uma relação de poder, e não de consenso, apanágio do governantes, especialmente militares. A ideia da crítica foi abolida das tribunas sociais, a censura forjava um discurso único, uma representação uniforme das estruturas de poder, sob viés acrítico. Foi esse tipo de mentalidade que a AERP buscou incutir na consciência nacional, por meio de slogans como "ninguém segura esse país", "esse é um país que vai pra frente", "Brasil: ame-o, ou deixe-o". De modo a plasmar o descontentamento da classe trabalhadora aviltada pelo arrocho salarial, pela superexploração, e pela precarização das condições de trabalho ${ }^{441}$, vendia-se ufanismo, otimismo e esperança, além de breves momentos de felicidade proporcionados pelo futebol e pelo carnaval.

Enquanto o regime vendia satisfação ao povo, nas trevas um combate de morte era

440 FICO, Carlos. "Espionagem, polícia política, censura e propaganda: os pilares básicos da repressão". In: FERREIRA, Jorge. \& DELGADO, Lucília de Almeida Neves(Org). O Brasil Republicano (Vol. 4). "O tempo da ditadura: ditadura militar e movimentos sociais em fins do século XX”. $2^{\mathrm{a}}$ Ed. Rio de Janeiro: Editora Civilização Brasileira, 2007. p. 196

441 “(...) a notável disciplina imperante permitiu a muitas empresas elevar ao máximo a intensidade do trabalho. Face a um rápido aumento da procura, o trabalho em horas extraordinárias generalizou-se de tal modo que já se considera que a jornada de oito horas, consagrada em lei, foi na prática abolida na maioria das indústrias. (...) Em 1971, para uma população ativa de 7,6 milhões de pessoas, foram registrados 1,4 milhão de acidentes; em 1972, para 8 milhões de trabalhadores, 1,5 milhão de acidentes; em 1973, para uma população ativa um pouco superior a do ano anterior, foi registrado 1,6 milhão. Em números relativos, algo próximo da assombrosa taxa de 20\% de ocorrências, um dos mais altos índices do mundo". Revista Opinião, No 83, junho de 1974. Apud: SINGER, Paul. Op. Cit. p. 80-82. 
travado entre os órgãos de repressão e as organizações revolucionárias. A censura a imprensa, o "milagre econômico", e as campanhas de manipulação em massa, executadas pelo regime, ajudaram a isolar a guerrilha. Cada vez mais o recrutamento de novos quadros foi se tornando escasso, a ponto de organizações começarem a desaparecer por falta de efetivo, não obstante, até meados da década de setenta ainda se veriam brasileiros em armas contra a ditadura.

$* * * * *$

Vimos que a ratificação da fusão entre VPR e Colina ficou para o Congresso de Teresópolis, a ser realizado em setembro de 1969. Os acertos finais do encontro se deram em julho, entre as lideranças das duas siglas, nas cidades litorâneas de Praia Grande e Mongaguá, em São Paulo. Nessas reuniões ficou acertado o nome da nova organização, e também se definiu o colegiado a dirigir a VAR-Palmares, composto por seis membros, três da VPR e três dos Colina. Representando os primeiros foram alçados a direção Carlos Lamarca, Antonio Roberto Espinosa e Cláudio de Souza Ribeiro, o Cláudio Marinheiro, todos componentes da antiga direção da VPR, que era composta por cinco membros. Ficaram de fora do comando da VAR Chizuo Osawa (Mário Japa), e Fernando Mesquita. Dos Colina, foram indicados para o comando Carlos Franklin Paixão Araújo, o Max, e o casal Juarez Guimarães de Brito e Maria do Carmo Brito. Dos sete que formavam a direção dos Colina, ficaram de fora Dilma Rousseff, Herbert Daniel, Carlos Alberto Soares de Freitas, o Breno, e Carlos Brasil. A eleição foi realizada apenas entre os dirigentes dos dois grupos, algo que foi visto por alguns como uma manobra. A justificativa dos que se reuniram em Mongaguá, com relação a não sondagem das bases para a ratificação da fusão, foi ausência de segurança devido ao cerco da repressão.

A exigência de um novo congresso para consolidar a união foi uma exigência dos mineiros, especialmente de Dilma Rousseff e Breno, algo que desagradou sobretudo a corrente militarista da antiga VPR, cujos componentes diziam estar "de saco cheio de fazer congresso" ${ }^{442}$. Desconfianças mutuas anteciparam divergências entre quadros de origem militar e de origem estudantil, embora todos exercessem o ofício de guerrilheiros. "Os militantes do Colina concordavam sobre o caráter da revolução brasileira. Mas vários repeliam os métodos da VPR, ações sem fim. Desconfiavam também de seus nomes famosos,

442 Entrevista de Antonio Roberto Espinosa ao autor, 08/10/2008. 
a começar por Lamarca. Facilmente imporiam à futura organização o militarismo imediatista" ${ }^{443}$.

Embora a fusão estivesse sendo trabalhada desde meados de 1968, as vésperas do Congresso de Teresópolis, as duas organizações haviam passado por processos de mudanças nada desprezíveis, com diversos componentes presos e/ou mortos. As antigas direções haviam sido substituídas por quadros sem a experiência organizacional de Onofre Pinto e João Lucas Alves, e a VPR passava por um processo de luta interna desde inícios de 1969. A união antecipava não uma comunhão de projetos, mas a explicitação da dicotomia militaristas $\mathrm{x}$ massistas, flagrante entre os paulistas, virtual entre os Colina. Em que pese as diferenças latentes, o congresso foi marcado para finais de agosto.

O aparelho escolhido foi uma chácara em Teresópolis, local para onde a maioria dos participantes foi conduzido de os olhos vedados, poucos sabiam o endereço com clareza. Para executar os trabalhos foram designados delegados eleitos a partir de congressos regionais, para a escolha dos representantes eram levadas em conta teses apresentadas pelos mesmos, desenvolvidas em seus respectivos plenos setoriais. Uma vez discutidas entre os congressistas, as teses aprovadas pela maioria eram levadas ao encontro nacional pelos seus formuladores, ou pelos representantes destes. Além dos delegados, estiveram presentes os dirigentes eleitos da nova sigla, sem direito a voto, e um contingente requisitado para dar apoio logístico ao evento.

(...) tinha que convocar um grupo razoavelmente grande, pessoas para cuidarem da cozinha, da alimentação, da infraestrutura, e sobretudo, da segurança, pois era uma casa numa pequena chácara em Teresópolis. A proteção disso tinha que começar na estrada, e tinha sentinelas permanentes, com metralhadoras, fuzis FAL, em toda região, cercando, isso dia e noite, foi um congresso defendido... Não foi preciso por que a repressão não localizou, mas era um congresso defendido a bala, porque estava ali a nata da nata da organização, não só a direção nacional, como as antigas direções nacionais das duas organizações formadoras, e todos os delegados que vinham num processo de decantação, eleitos pelas bases, tavam todas as lideranças da organização ali, e os principais quadros militares, que tavam participando da defesa, e durou vinte e sete dias ${ }^{444}$.

A VAR-Palmares foi estruturada em torno de dois grande setores, o Comando de

443 Judith Patarra comenta que Dilma Rousseff, dirigente e quadro intelectual dos Colina, dedicava-se a "boicotar a fusão". PATARRA, Judith Lieblich. Op. Cit. p. 294-295

$444 \mathrm{O}$ congresso havia sido programado para durar algo em torno de uma semana, ou pouco mais. Entrevista de Antonio Roberto Espinosa ao autor, 08/10/2008 
Lutas Fundamentas (CLF) e o Comando de Lutas Secundárias (CLS), o primeiro seria o carro chefe da organização, encarregado de implantar a guerrilha rural, dirigido por Carlos Lamarca, Cláudio de Souza Ribeiro, e o casal Brito, assessorados por Mario Japa e Carlinhos Brasil. O CLS ficou sob encargo de Antonio Roberto Espinosa e Carlos Araújo, assessorados por Dilma Rousseff, Carlos Alberto Soares de Freitas e Fernando Mesquita. A esse departamento caberia a articulação das lutas de massa nas cidades, a organização dos trabalhadores urbanos e rurais, dos estudantes, e demais segmentos com potencial de luta. Abaixo dos Comandos havia a GRUMA (Grupo de Manutenção), “era um pessoal que dava apoio, alugava aparelhos, proporcionava segurança"; em seguida haviam os comandos regionais, espalhados por São Paulo, Rio de Janeiro, Minas Gerais, Rio Grande do Sul, Bahia e Pernambuco. Outro setor era o dos "deslocados", que possuíam um comando próprio, organizados também em células, lotados especialmente no Rio de Janeiro, pois nessa cidade era mais fácil se obter imóveis "fora do período de temporada". ${ }^{445}$

Todos os detalhes acertados, os trabalhos do congresso tiveram início nos últimos dias de agosto de 1969. O encontro que ficou estipulado para poucos dias, estendeu-se além do planejado, Espinosa indica alguns dos motivos que levaram ao alargamento dos prazos.

(...) ia durar pouco, era para durar quatro ou cinco dias no máximo, e as discussões acabaram se estendendo, por que logo que se instalou o congresso se decidiu formar comissões, para que essas comissões formulassem pré projetos, minutas, que seriam debatidas pelo congresso, então uma minuta sobre estratégia, sobre análise internacional, uma outra sobre análise da conjuntura nacional; estratégia, tática. Na tática, foram dividas comissões, uma comissão para discutir o foco guerrilheiro, as colunas, outra pra discutir guerrilhas irregulares, uma terceira pra discutir movimento operário, uma quarta pra discutir movimento estudantil, cada uma delas produziu um documento. Pra comissão do movimento operário, por exemplo, (...), ficamos eu e o Max, o gaúcho, pra levar em conta a experiência de Osasco, e a experiência do Rio Grande do Sul com uniões operárias, esse documento eu não sei se existe ainda hoje, se ele é acessível, mas era um documento que propunha o seguinte, qual era a tática para o movimento operário? A organização de uniões operarias ${ }^{446}$.

445 Idem

446 “A união operária não é um organismo da VAR, é um organismo representativo de massas, ela também não é contra o sindicato, não é sindicalismo paralelo, é uma organização alternativa, mas que participa do sindicato, das lutas sindicais, mas já vai com posições fechadas. É um organismo de massas, então pra entrar nela não precisa ser marxista, nem ser materialista, como era necessário para entrar na organização. Na união operária você poderia fazer frente com outras organizações, em São Paulo nós tínhamos uma frente entre a VAR e o POC, e podiam entrar outras organizações, pra implantarmos uniões operárias, que era a política da VAR, nacional. Então, o que era a união operária? Era um organismo de massas, que os militantes promoviam, tinha um estatuto próprio, parecido com a maçonaria, parecido com entidades católicas, tinha uma espécie de constituição de dez 
Além dos intensos debates, outra questão acabou atrasando o andamento do congresso, os militantes Celso Lungaretti e José Raimundo da Costa, ambos signatários da corrente militarista, auto escolheram-se delegados para o encontro de Teresópolis, não consultando as bases. Em seu livro de memórias, Lungaretti afirma que não havia condições de segurança em São Paulo para reunir uma conferência, por isso, na condição de dirigente regional, em companhia de José Raimundo, decidiu partir para o Rio de Janeiro a revelia das bases ${ }^{447}$. O comando nacional da VAR foi informado sobre a atitude desses militantes, e por unanimidade se decidiu que deveria ser realizada uma conferência em caráter de urgência em São Paulo, de modo a eleger novos delegados. A dupla foi atribuída a pecha de "golpistas", e medidas referentes a expulsão de ambos foram encaminhadas para o depois do congresso. A conferência extraordinária foi realizada em dois dias, no litoral paulista. Lungaretti e José Raimundo, que permaneceram no Rio de Janeiros, foram incorporados a segurança do encontro.

Em meio as atividades de Teresópolis, em 4 de setembro foi sequestrado o embaixador estadunidense Charles Elbrick, por um comando reunindo MR-8 e ALN, fato que instigou os ânimos da corrente militarista, "olha, enquanto vocês estão aqui com bla-blá-blá, com conversa fiada, imaginado como vai ser a revolução no futuro, com união operária, se o operário pode ou não pode usar crucifixo, o companheiro Marighella tá la fora fazendo a revolução, eles acabaram de sequestrar o embaixador americano"448. Em meados de setembro a situação do novo agrupamento revolucionário se tornou insustentável, a questão a detonar o racha foi a das "uniões operárias". Vejamos abaixo o relato de Espinosa, envolvido diretamente nos fatos, embora longo, o depoimento narra em detalhes os acontecimentos que ensejaram o racha da VAR-Palmares. Segundo o depoente, a divergência partiu de Chizuo

pontos, uma espécie de juramento que o cara fazia, "jamais entregar um companheiro, jamais falar os segredos da união operária, não entregar ninguém caso seja preso, ser fiel”, que colocava tanto os princípios da democracia, "colocar todos os meus pontos de vista, defendê-los com ardor, subordinar-me as decisões da maioria", era uma espécie de organização de massas, secreta, criada pela organização, mas independente em relação a ela, podia atuar no sindicato, no comitê de fábrica. Tem uma coisa que deu muito certo, tanto em São Paulo, quanto em Minas, as uniões operárias se multiplicaram, por que você não exigia nenhum... Agora, claro que os quadros das uniões operárias que se destacassem, que fizessem mais cursos, não tinha cursos de marxismo dentro da união operária, mas se podia dar esses cursos para indivíduos que você selecionasse, esses até poderiam ser recrutados para a VAR, mas era uma coisa pra implementar o movimento, que priorizava a participação nos sindicatos e a criação de comitês de fábrica. Da mesma maneira, baseado na união operária, se definiu uniões camponesas, que também eram tanto para participar de sindicatos rurais, quanto para a formação de ligas, quanto para fazer guerrilhas irregulares, para montar cooperativas nos movimentos camponeses; união operária e união camponesa no movimento de massas. Não definimos com esse nome, mas poderíamos ter também uniões estudantis, que não é união estadual de estudantes, mas grupos de massa de estudantes". Ibidem. 447 LUNGARETTI, Celso. Op. Cit. p. 112

448 Frase atribuída a Chizuo Ozawa. Entrevista de Antonio Roberto Espinosa ao autor, 08/10/2008 
Osawa, o Mário Japa, que a certa altura interpelou os presentes com o seguinte questionamento:

eu só queria saber uma coisa, onde é que vocês vão arranjar tanto militante para formar tanta união operária no Brasil inteiro". Bom, a resposta de que o movimento produz para ele não bastou, aí ele coçou a cabeça e disse "ué, eu acho que vocês tão querendo colocar todos os nossos quadros pra fazer movimento operário, to vendo que daqui não vai sobrar ninguém pra "ir pro mato pegar no pau furado", to achando que não vai sair coluna não". Criou um tremendo dum mal estar, porque o cara tinha acabado de chegar, não tava acompanhando as discussões, havia um incômodo no congresso por que tava demorando demais, (...) aí o Mario Japa criou esse clima, em seguida chamou sete para uma reunião, esses sete quem eram? Nenhum delegado com direito a voto, os quadros da VPR, da direção, que estavam lá, ele (Mario Japa), o Cláudio Marinheiro, o Lamarca, o Lungaretti (...). Também participou desse negócio o (José Araújo) Nóbrega, que era ex sargento, que tava lá como segurança, e o Darcy (Rodrigues), que também tava lá como segurança. E ali entre os sete, durante a madrugada, decidiram promover o racha, e pra poder consolidar o racha - eles achavam que deveriam reconstituir a VPR - eles dependiam de mim, que era do GO, maioria da VPR, e aí foram me acordar de madrugada, chamando pra reunião. Eu me sentei com sete pistolas apontadas para mim, sobre a mesa, em direção a minha cadeira, um deles se dirigiu a mim, não lembro quem foi, e disse "nós decidimos rachar com essa estudantada do Colina, por que com esse pessoal não vai dar samba, esse negócio de união operária é besteira, é conversa fiada, e você inclusive andou meio equivocado com isso, e decidimos reconstituir, e você vai junto por que você é da VPR". "Como eu vou junto? Se vocês quiserem rachar vocês rachem, adotem o nome que vocês quiserem, se quiserem adotar o nome VPR adotem, só que eu vou chamar de VPR 2, por que vai ser um simulacro da primeira organização, e eu tenho minha liberdade, eu não vou nessa, e eu acho inclusive que vocês estão equivocados, vocês vão acabar caindo no foquismo, numa coisa estreita, porraloca, e eu não vou nessa, eu quero pensar a revolução brasileira como um todo, (...)". Poucos dias antes, havia morrido num hospital, debaixo de tortura, o João Domingues, irmão do Roque, que vinha de Osasco, (...) foi preso com um tiro, e depois apareceu morto com quatro (tiros), foi morto dentro do hospital, foi uma coisa que me deixou muito chocado. Aí o Nóbrega levanta e fala "a nossa cabeça você não faz não, você fica colocando no comando aqueles acólitos seus, aquele João Domingues, aquele viadinho"; falou alguma coisa desse tipo, aí eu disse "lava a boca pra falar o nome de um companheiro que morreu semana passada"; ele tava com um copo de café na mão, eram seis da manhã, e jogou o copo de café em mim, eu estava com outro copo e joguei nele também, e já levantei, aí entrou o pessoal do deixa disso, nisso, com a gritaria, com a xingação, desceu o pessoal todo que tava no congresso, que eram uns cinquenta, 
desceram, foi um racha tumultuoso, $(\ldots)^{449}$.

Comprometido com a corrente militarista, Celso Lungaretti dá a seguinte versão sobre as divergências entre as duas tendências em choque.

No Congresso, as posições massistas vencem em toda linha. Há algumas discussões acaloradas, Matos (Cláudio de Souza Ribeiro) se descontrola, mas não consegue deter o avanço da direita. A VARPalmares sairá desse congresso empenhada em recriar os laços orgânicos com as massas, sem conferir à montagem da coluna móvel estratégica a prioridade que ela precisa ter para sair do papel.

Quando já se discute a constituição do novo comando, em que Lamarca ficará claramente isolado no campo e sem poder para contrabalançar a ascensão dos massistas nas cidades, ele dá sua cartada definitiva: resolve romper com a VAR e recriar a $\mathrm{VPR}^{450}$.

Dois conceitos devem ser destacadas do excerto acima, "coluna móvel estratégica" e "prioridade". O primeiro conceito foi comum as duas correntes em choque na VAR, segundo Espinosa, a "coluna era um foco melhorado". O termo surge a partir das reflexões de Carlos Marighella, consubstanciadas na ideia de "ofensiva estratégica".O fundador da ALN, através de seus escritos, inferiu que um processo a guisa do ocorrera em Cuba seria inviável no Brasil, devido as dimensões continentais deste país, isto posto, o esquema da Sierra Maestra, iniciado através de um punhado de homens, deveria ser substituído por algo melhor adaptável ao território nacional. Vejamos abaixo sua definição de "ofensiva estratégica".

(...) Para livrar-se da ditadura e do imperialismo e de suas forças armadas de repressão, as forças populares e revolucionárias têm que sair da defensiva e passar à luta de guerrilhas, enfrentando o inimigo. Nesse caso, o principal método de condução da luta armada é a ofensiva estratégica.

O Brasil é um país de área continental e, por conseguinte, apropriado para a ofensiva estratégica da guerrilha, que precisa de espaço para mover-se.

A guerrilha brasileira tem que estar educada para operações móveis, desde as mais elementares até as mais complexas, pois uma guerra revolucionária prolongada no Brasil será uma guerra de movimento.

A ofensiva estratégica, como método principal de conduzir a luta armada, proporciona o máximo de iniciativa à guerrilha e uma liberdade de movimentos que não é permitida ao inimigo, 
lançado aos azares de uma perseguição interminável, em áreas rurais tremendamente hostis e desconhecidas. $(\ldots)^{451}$

Marighella colocou a guerrilha em posição central no processo revolucionário brasileiro, como principal pressuposto estratégico, e não como linha auxiliar de luta. No esquema de Marighella, as células guerrilheiras não deviam se limitar a um único terreno (Sierra Maestra) e sim se encontrar dispersas, em diversos grupos, cada um empregado em objetivos táticos distintos. Tais concepções deram suporte a formulação da "coluna estratégica móvel", tema caro aos debates de Teresópolis. Se não havia divergências de fundo com relação a tática/estratégia guerrilheira, a posição desse método no programa global das correntes em disputa no congresso gerou discussões acaloradas. Tal tema nos remete ao outro conceito citado por Lungaretti acima, o de "prioridade". O debate mais intenso se deu em torno de duas duplas de palavras, fundamental/complementar, e principal/secundária.

Os documentos da VAR definiam que a coluna guerrilheira era a forma principal de luta, e que as demais, ou seja, guerrilhas irregulares, movimento camponês, movimento urbano, inclusive ações armadas na cidade, tudo isso eram formas secundárias, e, enfim, numa leitura meio tosca do Hegel, nós dizíamos que a classificação como principal e secundário não era uma coisa definitiva, não era uma coisa essencialista, ou seja, o principal e o secundário dependem da conjuntura, e o que era secundário, poderia no curso do processo se transformar em principal. Por exemplo, nós vivíamos uma fase que nós definíamos como defensiva-estratégica, ou seja, em que o equilíbrio de forças era francamente favorável a reação. Então você acumularia forças nos movimentos de massa, nos vários

451 "Com relação a guerrilha rural, elevada a condição primordial de tarefa estratégica, Marighella também introduziu uma modificação na teoria cubana em voga. Após o fracasso do foco de Caparaó e da derrota de Guevara, na Bolívia, o foquismo puro e simples foi questionado pelos partidários da luta armada. Marighella se declarou contrário aos focos e, inspirado na experiência histórica brasileira (da luta contra os holandeses ao cangaço de Lampião), apresentou a tarefa das colunas guerrilheiras móveis, que se deslocariam contando com pontos de apoio de antemão assentados. Todavia, a modificação introduzida é secundária no contexto geral. $\mathrm{O}$ foquismo se mantém, na medida em que a guerrilha começa do zero, dissociada de qualquer movimento de massas, incorporada a função de vanguarda política". Segundo Carlos Eugênio da Paz, Marighella pretendia lançar em grande estilo a coluna móvel estratégica em finais de 1969, através de uma série de ações de impacto nas cidades, que serviriam de senha para o início dos trabalhos da guerrilha rural. Os planos do comandante da ALN foram bloqueados após seu assassinato, em 4 de novembro de 1969. Cerca de um ano depois, Joaquim Câmara Ferreira preparava mais uma grande ofensiva nos centros urbanos, de modo a mais uma vez tentar desencadear a coluna móvel guerrilheira. As operações de impacto nas capitais receberiam o nome de "semana Marighella", e o início da ofensiva rural foi marcado para o dia em que se completaria um ano da morte do dirigente baiano. Assim como em 1969, os planos da ALN foram interrompidos após a captura do principal líder da organização, Câmara Ferreira, preso e torturado até a morte pela mesma equipe que executara Marighella. Citação no corpo do texto: MARIGHELLA, Carlos. Op. Cit. p. 120; para citação em nota, GORENDER, Jacob. Op. Cit. p. 97-98; informações sobre o lançamento da coluna móvel estratégica, PAZ, Carlos Eugênio. Viagem a Luta Armada. Memórias romanceadas. Rio de Janeiro: Editora Civilização Brasileira, 1996. p. 49-56 
movimentos pelo campo, mas acumularia, sobretudo, colocando uma direção estratégica, apontando um caminho para a tomada do poder, e o que apontava esse caminho era coluna guerrilheira. (...) Por isso não teria sentido você chamar a coluna de forma fundamental, quando você diz fundamental é fundamental sempre, quando você diz principal e secundaria há uma dialética hegeliana nisso, porque o secundário pode se transformar em principal. Então na fase do equilibro estratégico (posterior a fase defensiva-estratégica), a forma principal de luta seria outra, nesse momento, pra gente, ou poderiam ser as ações militares desenvolvidas pelo exército revolucionário na guerra de movimento, ou a forma principal poderia ser as lutas de massa na cidade, dependendo do amadurecimento do movimento operário, do movimento estudantil $(\ldots)^{452}$

A rigor, o elemento central no racha da VAR foi a dicotomia militarismo x massismo, a concentração da luta em seus aspectos militares, ou a valorização de seus princípios políticos; a subordinação da luta à política, ou seu inverso ${ }^{453}$. Do ponto de vista teórico, os quadros alinhados ao esquema da VAR eram mais preparados intelectualmente, sendo boa parte egressos dos meios universitários, veteranos dos debates da Polop. A corrente militarista era mais voltada a práxis, seus membros possuíam pouca densidade teórica. Esta lacuna foi preenchida pelas teses do militante Jamil Rodrigues (Ladislas Dowbor), que aderiu ao racha e se engajou na nova VPR.

Jamil teceu seu programa revolucionário a partir de insumos teóricos provenientes, sobretudo, dos escritos de Frantz Fanon, Regis Debray e André Gunder Frank. Suas concepções tático-estratégicas se ajustavam a coluna móvel, e em seu esquema a guerrilha era forma fundamental de luta, para o agrado da corrente militarista. De Frantz Fanon, Jamil resgatou a tática da propaganda armada, comum no processo argelino, um meio de chamar a

452 Entrevista de Antonio Roberto Espinosa ao autor, 30/03/2009. Enquanto a VAR se balizava pela dupla de palavras principal/secundária, a nova VPR adotou a dupla fundamental/complementar. Para os segundos, a luta revolucionária deveria ter na guerrilha seu carro chefe durante todo o processo de luta, sendo todas as outras formas de combate complementares, subordinadas a coluna móvel estratégica.

453 Hector Luis Saint-Pierre recorre a Che Guevara para comentar o debate militarismo x massismo, presente em toda América Latina, galvanizado pelo foquismo de matriz guevarista-debraysta. Segundo Guevara, "Criticase aqueles que querem fazer a guerra de guerrilhas, aduzindo que se esquecem da luta de massas, quase como se fossem métodos contrapostos. Rejeitamos o conceito que encerra essa posição; a guerra de guerrilhas é uma guerra do povo, é uma luta de massas. Pretender fazer esse tipo de guerra sem o apoio da população é o prelúdio de um desastre inevitável". Mais adiante, sobre o mesmo tema, Saint-Pierre afirma que "A iminência de um conflito generalizado levou a cometer um pecado capital para a guerra revolucionária: subordinar a formação política do militante à formação militar do quadro guerrilheiro. Dessa maneira, acabaram simplificando a tarefa da repressão, pois, ao aniquilar militarmente a guerrilha, eliminavam também a resistência política que poderia manter viva a luta de classes e a esperança da revolução até que houvesse condições objetivas mais propícias para o confronto bélico. Para citação de Che, "CHE” GUEVARA, Ernesto. Obras Completas, vol. 1, p. 204. Apud: SAINT-PIERRE, Hector. Op. Cit. p. 199; para citação de Saint-Pierre; Idem, p. 200. 
atenção das massas para o processo revolucionário em voga, preparando o terreno para o estágio seguinte, o insurrecional. O recrutamento de novos quadros armados deveria privilegiar a população excluída, visto que o operariado, em países como o Brasil, e demais nações da América Latina, não representava parcelas significativas da população, encontrando-se muitas vezes em situação privilegiada. De Debray, Ladislas retirou a primazia da luta no campo, por meio de guerrilhas rurais, dentro das concepções de mobilidade salientadas acima. Sua análise econômica do Brasil partia das premissas de Gunder Frank, este país já seria plenamente capitalista, embora subdesenvolvido, o grande inimigo a ser combatido era o imperialismo estadunidense, uma vez que o Brasil seria um satélite dessa potência hegemônica, e portanto, a luta deveria ser de caráter socialista e de libertação nacional ao mesmo tempo. Sobre a divergência entre militaristas e massitas na VAR, e a cisão consequente, motivada por esse debate, vejamos o que diz Ladislas Dowbor.

Eu fui favorável a aproximação, mas eu fui desfavorável a uma coisa que pra mim era de confusão, eu nunca gostei de um extremismo de palavras, vamos fazer a ditadura do proletariado quando a gente ta lutando contra a ditadura, não tem muito é a cabeça, tem que se pôr na pele do povo, tínhamos que provocar uma aliança de classes muito mais ampla, para favorecer o movimento e tentar isolar a ditadura, e não a gente se isolar no extremismo. Em particular isso implicava em não confundir movimento de massas e movimento armado, se você pega um movimento desses antigos, com uma massa de trabalhadores, e põe armas no meio, você tira a legitimidade do movimento, e você provoca massacre... Então havia um papel para a luta armada, digamos que era de chamar a atenção muito mais pelo impacto político dela existir, gente que punha a vida em desafio e não aceitava determinadas coisas, mas ela (a luta) não podia, em termos organizacionais, se misturar com o movimento massas, pois tira sua legitimidade, põe ela em perigo e da argumentos para os militares reprimirem o povo. Essa tentativa, digamos, de não confundir os processos, de trabalhar com o movimento de massas de maneira ampla, e por outro lado, a parte militar, for feita de maneira extremamente densa, fechada, treinada e profissional, para reduzir os riscos, digamos assim . Bem ou mal você estava colocando em risco a vida de muitas pessoas, pra mim era uma visão essencial. Os Colina, devido a sua origem na Polop e coisas do gênero, de movimentos operários, estava muito fixado na visão de que se deveria atuar na base operaria, a base do Brasil não era operária, o operário industrial representava menos que $15 \%$ da mão de obra, o grosso dos que tavam prejudicados pela ditadura era gente do campo, que tavam sendo expulsos para a cidade. Nessa época, São Paulo era a cidade que mais crescia no mundo, o que nos deu todas as cidades dormitórios que temos hoje. (...) Então naquela época a gente ignorava qual era a parte do população que mais estava sofrendo com o 
processo da ditadura, eu achava uma bobagem entende, ter uma fidelidade a textos políticos do Século XIX, que na época eram até elegantes, mas no Século XIX né, Marx nunca foi idiota de sugerir que se aplique as visões dele em situações diferentes, por isso que se chama materialismo histórico, processo.

\section{Sobre os debates com a corrente massista, Ladislas afirma que}

as vezes o pessoal se referia a luta pelo poder, o que era ridículo, por que esse poder era minúsculo, a nossa perspectiva maior, ou maior probabilidade pela frente, era perder a vida no processo... Quando não simplesmente cair preso, mas sim, havia a visão de que se você se mete no processo militar, e a sua proteção é armada, e você tem um nome que é conhecido, portanto tem que ser clandestino, esta sendo procurado por um gigantesco aparato policial e militar, e tem que se organizar para se proteger em função disso, a tua proteção não deve ser se diluir no movimento de massas, por que o movimento de massas tem que ser protegido do tipo de repressão que sua presença atrai. Então você tem que trabalhar de um lado com um movimento de massas muito amplo, e de outro lado, com uma estrutura de luta armada bastante enxuta, e aí não há muito mistério, é a forma como se organizou a FLN nas Argélia, a forma como se organizaram os vietnamitas, nos mais variados movimentos que haviam no mundo. Havia a simplificação de que um grupo relativamente pequeno, com armas, consegue derrubar um poder desse tamanho, acho que todos nós amadurecemos e entendemos quem um grupo assim não derruba, derruba em condições muito particulares, como foi em Cuba, mas pra nós as limitações eram muito grandes.

\section{Acerca do militarismo,}

militarista foi como o pessoal da VAR-Palmares chamou, a gente era, digamos, muito mais abertos para estimular o movimento de massas, e muito contrários a você organizar um grupo armado e dizer que é um movimento de massas, quando eles diziam, "nossas bases em Guarulhos", ali tinha três pessoas, entende... Não vamos confundir as coisas, movimento de massas é uma coisa muito mais séria, a gente não tinha a mínima ilusão sobre a eficiência militar de um pequeno grupo, a gente via isso basicamente como um fator de contestação política, que é forte, em termos de repercussão junto a população, agora, você não pode imaginar que você resolve pela via militar, isso seria simplesmente ridículo, eu acho que fomos chamados de militaristas simplesmente porque a gente quis carregar um pouco nas costas a causa da sobrevivência material ${ }^{454}$.

454 Entrevista de Ladislas Dowbor ao autor, 19/03/2009. Os objetivos da luta guerrilheira em sua primeira fase, expressos no programa da nova VPR, redigido por Jamil, na linha de seu depoimento acima exposto, definiram a fase conjuntural (período em questão) da luta revolucionária como "defensiva estratégica", em visão próxima a 
O esquema de Jamil dividia o processo revolucionário em duas fases, a primeira impulsionada pela propaganda armada, já em marcha. Tratava-se de preparar o terreno para a intensificação da luta por meio das colunas móveis guerrilheiras, no campo. Na cidade, uma série de ações de impacto, como sequestros, justiçamentos, atentados contra símbolos do imperialismo e seus defensores em território nacional, chamariam a atenção da população para o caráter autoritário do regime, e ao mesmo tempo exporiam suas fragilidades. Ladislas põe enfase na "proteção das massas", na manutenção de sua "legitimidade", que poderia ser quebrada em caso de penetração de organizações armadas junto as mesmas. Tal esquema tinha como referência principal o processo argelino, propaganda armada em sua primeira fase, recrutamento do lúmpem proletariado ${ }^{455}$, sensibilização do povo e galvanização de sua revolta. O sacrifício dos que pegaram em armas, no estágio inicial da revolução, lançaria as bases para o futuro levante de massas, pondo em marcha a segunda fase da revolução, a insurrecional.

Espinosa afirma que Jamil foi um quadro proscrito na fase inicial da VPR, e suas teses foram pouco levadas a sério, a adoção de seu programa pela corrente militarista teria se dado "por falta de algo melhor". Não obstante, Maria do Carmo Brito, em suas memórias, indica que os escritos de Jamil foram lidos com atenção por parte dos Colina, logo após sua distribuição, em princípios de 1969. Celso Lungaretti comenta que os documentos assinados por Dowbor vinham sendo discutidos por sua célula, em São Paulo, e que as vésperas do Congresso de Teresópolis, a corrente militarista lotada na capital paulista já considerava a

da VAR-Palmares. A forma de atuação, nesse estágio, foi subdividida em três fases: 1 - propaganda armada; 2 guerrilha tática; 3 - coluna estratégica. $\mathrm{O}$ último item era a meta a ser atingida a curto prazo.

455 Os chamados excluídos (bandidos, traficantes, prostitutas) foram incorporados pela FLN argelina, Ali la Point, ex-presidiário, personagem principal de Batalha de Argel, filme épico de Gillo Pontecorvo, expressa bem o tipo salientado por Frantz Fanon em Os Deserdados da Terra. "O grande erro, o vício congênito da maioria dos partidos políticos nas regiões subdesenvolvidas foi ter seguido o esquema clássico, dirigindo-se prioritariamente aos elementos mais conscientes: o proletariado das cidades, os artesãos e os funcionários, isto é, uma ínfima parte da população que não representa muito mais de um por cento". A luta de guerrilhas na Argélia perdurou durante a segunda metade dos anos 1950, a partir da década seguinte, tornou-se de massa. Os militantes voltados a propaganda armada foram massacrados pela repressão francesa, e suas organizações quase aniquiladas, mas seu exemplo de resistência calou fundo na consciência do povo argelino, ocupado por uma potência estrangeira a mais de cem anos. Através de um levante popular, a população da Argélia conseguiu conquistar sua independência em 1962. Tal processo Jamil achou ser possível instalar no Brasil. FANON, Frantz. Op. Cit. p. 90. 
adoção de tais teses ${ }^{456}$. O fato é que a ênfase na ação, preconizada na tática da "propaganda armada", foi facilmente assimilada por aqueles que fomentaram a cisão da VAR-Palmares.

Tecendo uma comparação com o programa jamilista, no que respeita a relação com "as massas" (e as lutas de massa), o programa da VAR defendia a combinação das "lutas das massas em todas as frentes e travando a guerra em todos os níveis", o elemento central nessa escalada seria o proletariado, relegado por Jamil, mas enquadrado como peça chave pelos massistas, “o núcleo proletário legitima-se como vanguarda no processo de transformação qualitativa $^{\natural 57}$. A VAR, ao contrário do sublinhado por seus adversários militaristas, não defendia o fim das ações armadas, mas buscava combiná-la a outras formas de atuação política. Nesse sentido, como vimos no depoimento de Espinosa, buscava-se conjugar lutas operárias, estudantis e populares, a ações mais incisivas, deixando que a conjuntura política definisse qual tipo de luta deveria a "principal".

Jamil buscou romper com os esquemas tradicionais de revolução, introduzindo novos atores ao processo, diminuindo a importância do proletariado, e alargando o papel da vanguarda. Em seu esquema, a participação das massas no processo deveria se dar após a legitimação da guerrilha através da propaganda armada, somente nessa etapa começaria se constituir o "partido revolucionário", brotado do seio do povo. O esquema da VAR preconizava a construção do processo de transição pós capitalista junto as camadas sociais, em todas as etapas da luta, seu projeto delineava o crescimento global da oposição a ditadura, em amplos setores populares. Nesse processo, seria forjado o verdadeiro partido revolucionário, definido como "uma organização político-militar, aliando o domínio da ciência e da ideologia ao lado da linha estratégica e tática do proletariado, numa conjunção dialética entre a função - função de vanguarda histórica - e uma forma de organização dada organização do partido marxista-leninista" ${ }^{458}$.

Em finais de setembro de 1969, a situação da organização VAR-Palmares se tornou insustentável, tendências inconciliáveis se antagonizaram no interior da sigla, e o caminho comum aos grupos armados do período foi o adotado, o racha. O novo grupo formado a partir

456 Todos os documentos produzidos pelos quadros da VPR eram mimeografados e distribuídos entre as células da organização, de acordo com sua aceitação, tais documentos eram encaminhados para serem apreciados em plenos setoriais, conferências e congressos. Segundo Espinosa, Jamil não conseguiu se eleger, nem eleger delegados para o congresso de Teresópolis, devido o pouco interesse por suas teses. Para informações sobre a recepção das teses de Jamil entre os Colina: VIANNA, Martha. Uma tempestade como sua memória - a história de Lia, Maria do Carmo Brito. Rio de Janeiro: Editora Record, 2003. p. 51; e LUNGARETTI, Celso. Op. Cit. p.107-109. Informações fornecidas por Espinosa, entrevista ao autor, 08/10/2008

457 "Programa da VAR-Palmares", In: REIS FILHO, Daniel Aarão, \& SÁ, Jair Ferreira de. Op. Cit. p. 349

458 Idem, p. 348 
dos Colina e da VPR não durou mais que três meses. O agrupamento cindido em Teresópolis possuía a altura de seu racha cerca de 300 membros, Espinosa afirma que entre aliados e colaboradores, a VAR chegava a 600 componentes. E mais, era a organização de maior capital, enriquecida após a ação do cofre de Adhemar de Barros. Também era das siglas mais bem armadas, com uma reserva mais de uma centena de fuzis FAL, metralhadoras, revólveres, farta munição, explosivos, etc. Os melhores quadros voltados a ação se encontravam nesse grupo, homens com larga experiência em operações de táticas. Tinha em suas fileiras quadros de embasamento teórico significativo, veteranos dos debates políticos que desde meados da década eram travados nos meios acadêmicos. Também havia o obreirismo dos ativistas egressos de Osasco e outros centros industriais, fundamental para o alargamento da luta em outros movimentos. Uma organização que tinha tudo para se tornar o agrupamento mais poderoso em combate a ditadura, sucumbiu perante suas contradições internas.

Os grupos que se formaram após o racha de Teresópolis eram substancialmente diferentes em relação a suas formações pregressas. A nova VPR era uma organização distinta daquela formada a partir da O., defasada de seus melhores quadros teóricos, balizada por um programa adotado sem maiores reflexões, voltada quase que exclusivamente a ação, numa época em que a violência organizada do sistema intensificava seus métodos de repressão, somados a ofensiva propagandística do regime, insuflada pelo "milagre econômico". Em contrapartida, a VAR perdeu seus melhores homens de ação, tendo seu projeto de "luta combinada" prejudicado no que tange a construção da coluna móvel estratégica, num panorama em que as "lutas de massa" se encontravam extremamente dificultadas devido a presença incisiva da repressão nos meios populares, especialmente o estudantil e o operário.

Se o elemento central da cisão foi a dicotomia militaristas x massistas, a adesão às respectivas siglas saídas do racha não obedeceu sempre a critérios político-estratégicos. Exemplo emblemático dessa assertiva foi o comportamento de Iara Iavelberg, militante histórica da Polop. Sua opção pela nova VPR se deu mais por causa de seu envolvimento amoroso com Carlos Lamarca, prócere da corrente militarista, do que por divergências programáticas. Seu irmão, Samuel Iavelberg, também veterano da Polop, prosseguiu na VAR. Sobre esse ponto, comenta Ladislas Dowbor que "a constituição é extremamente progressiva, em geral por afinidade de pessoas que lutaram juntas nessa área. Nem sempre a visão de um militar que quer mudar as coisas é parecida com a do profissional liberal, ou com a do estudante, de um professor universitário, um sindicalista; havia culturas que aprendiam a 
conviver. A origem também de posicionamentos políticos era muito diferenciada, então o único denominador comum era que a gente queria derrubar a ditadura $(\ldots)^{459}$.

A divisão dos quadros também não se subordinou as origens dos componentes, visto que por motivos diversos, dentre estes o alinhamento programático, militantes de origem militar se engajaram na VAR, e vice e versa. O exemplo do cabo Mariane sublinha bem essa realidade, ex-militar, membro da célula do capitão Lamarca em Quitaúna, participante da operação de fuga e da expropriação de armamentos desta unidade militar, Mariane optou por seguir na VAR. Outro exemplo digno de nota foi o casal Juarez Guimarães de Brito e Maria do Carmo, ambos membros fundadores da Polop, considerados quadros intelectuais dos Colina. Juarez se engajou na nova VPR comprometido com seu novo metier, adquirido em sua fase revolucionária, o de grande planejador de ações táticas, foi de sua autoria o plano do roubo ao cofre do Doutor Rui. Há outros exemplos como os supracitados. As duas organizações surgidas em Teresópolis se formaram a partir de uma mescla entre quadros da antiga VPR e dos Colina.

A divisão do espólio da VAR também se efetivou em meio a acusações e agressões vindas de ambas as partes em separação. O patrimônio financeiro do grupo girava em torno de dois milhões e meio de dólares, estipulou-se que a nova VPR receberia $250 \mathrm{mil}$, em contrapartida, ficaria com a maioria das armas. Maria do Carmo, em posse da maior parte do dinheiro da organização, decidiu não cumprir o acordo e reter uma quantia maior dos dólares que se encontravam sob sua guarda. A quebra do acordo ensejou uma séria crise entre as duas novas siglas.

no congresso ainda nós ficamos sabendo que, por exemplo, a Maria do Carmo, a Lia, e o Juvenal, Juarez de Brito, que não tinham participado do racha dos sete, decidiram aderir, e a Lia e o Juvenal eram responsáveis pela guarda de uma boa parte do dinheiro que vinha do cofre do Adhemar, e aí decidiram não entregar o dinheiro para a VAR, decidiram desfazer o acordo. Em contrapartida, a VPR nova ficaria com a maior parte das armas, só que em São Paulo quem guardava as armas era um cara chamado JB, um baixinho, e o contato com o JB era feito pelo Mariane. O cabo Mariane não acompanhou o Lamarca, ficou conosco, não rachou, e aí, sabendo que a Lia havia dado o golpe do dinheiro, decidiu dar um contragolpe com as armas, já que ela não repassou o dinheiro que era da VAR, nós também não repassamos as armas. Bom, a gente também saía pra fazer alguns pontos, e num desses pontos, o Lamarca disse que ia submeter o Mariane a um tribunal revolucionário, tribunal

459 Entrevista de Ladislas Dowbor ao autor, 19/03/2009 
revolucionário quer dizer execução, Mariane seria executado, e então nós dissemos a ele, "tá bom, olho por olho, dente por dente, nós também submeteremos a Lia, a Maria do Carmo, a um tribunal" ${ }^{460}$.

A questão permaneceu em aberto, uma série de fatos posteriores desviaria a foco de ambas as organizações para outras questões, mais urgentes.

Qual a posição dos remanescentes do GO na contenda de Teresópolis? A principal liderança osasquense em atuação, a altura dos acontecimentos supracitados, era Antonio Roberto Espinosa, dirigente tanto da VPR, quanto da VAR-Palmares. Segundo informações fornecidas pelo mesmo, a maioria dos quadros oriundos de Osasco optou por seguir na VAR. Não temos informações sobre o conjunto dos militantes vindos do GO, nossos dados foram obtidos com quadros articulados ao nível da direção das organizações, mas o depoimento de Manuel Dias do Nascimento nos da conta de que ao menos uma parcela dos ativistas de Osasco se decidiram pela nova VPR. Vejamos o que diz Neto sobre esse ponto.

$\mathrm{Na}$ época estava havendo um processo de formação, que uniu, houve um encontro em que eu não participei, minha esposa participou por que ela tava dentro da logística com meus filhos, então minha posição foi de primeiro reunir com a VAR-Palmares, para poder ter uma frente mais ampla, e nossa estrutura ser mais dinâmica em nível interestadual e nacional, com o Lamarca a frente, pois ele tinha uma capacidade muito grande de arregimentação. Passando o tempo, houve o racha, e nesse racha eu não tive dúvida, fiquei na VPR. Eu não vou ter condições de entrar numa discussão política e teórica num todo agora, mas todas as pessoas da VPR que eu tinha mais contado, no conjunto, saiu (da VAR-Palmares), e eu saí junto com todos eles, continuei na VPR sem mudar a nossa postura de trabalho e os contatos que nós tínhamos ${ }^{461}$.

No esquema dialético de lutas de VAR, a classe operária (a frente de diversos outros movimentos sociais), de acordo com a conjuntura, poderia assumir a posição de vanguarda no processo revolucionário brasileiro. Para tanto, todo um trabalho organizatório deveria ser executado pela militância var-palmarina, de modo a preparar o MO para futuras lutas de

460 Celso Lungaretti confirma que o casal Brito "vacilou" nos momentos iniciais do racha, optando posteriormente, ainda durante o congresso, pela nova VPR, pois este agrupamento, segundo os mesmos, era a "Organização mais apta a fazer a revolução". Citação no corpo do texto; entrevista de Antonio Roberto Espinosa ao autor, 30/03/2009; informações em nota, LUNGARETTI, Celso. Op. Cit. p. 122.

461 Segundo Espinosa, José Ibrahim, do exterior, demonstrou mais afinidades com a VAR, Roque aparecido, então preso, decidiu-se pela mesma organização. José Campos Barreto seguiu pelo mesmo caminho. Do núcleo central do GO, apenas Manuel Dias do Nascimento optou pela nova VPR. Depoimento no corpo do texto; entrevista de Manuel Dias do Nascimento ao autor, 16/02/2009; para informações de Espinosa; entrevista ao autor, 08/10/2008 
caráter insurrecional. A grande contribuição do GO, a nosso ver, no debate travado entre as forças que se opunham a ditadura, seja de modo violento, ou não, foi a definição do papel a ser desempenhado pela classe operária durante o processo revolucionário. Em Osasco, a estratégia de lutas combinadas, vislumbrada pela VAR, foi posta em prática, mesmo que de forma não sistematizada, durante o ciclo de atuação política do GO.

\subsection{Derrocada e recomeço}

Mitigada a tensão entre os dois agrupamentos saídos de Teresópolis, ambas as siglas deram prosseguimento a seus respectivos projetos revolucionários, cada uma dentro de suas concepções. A nova VPR realizou seu congresso em novembro de 1969, onde foram ratificadas as teses de Jamil. Mas seu projeto começou degringolar a partir da desativação, por parte de forças do Exército, de sua área de treinamento instalada no Vale Ribeira, interior de São Paulo. Embora a ação tenha adquirido contornos espetaculares, com a fuga de Lamarca e parte de seus homens de um cerco montado pelos militares, cerco este que mobilizou em torno de 20 mil soldados, o justiçamento do tenente Alberto Mendes Junior atraiu a ira da repressão para o grupo, e seu principal líder foi declarado inimigo público número 1.

A derrocada teve início após a prisão de Maria do Carmo Brito, seu companheiro, Juarez Guimarães, cometera suicídio em meio ao cerco policial, na mesma operação que capturou sua esposa. As informações fornecidas por Maria do Carmo, sob intensa tortura, levaram ao desbaratamento de toda direção da nova VPR, a exceção de Lamarca, sitiado no Vale do Ribeira. Nessa vaga também foi preso Ladislas Dowbor.

$\mathrm{Na}$ onda de prisões aberta após informações de Maria do Carmo, acabou detida Tercina Dias de Oliveira, mãe de Manuel Dias do Nascimento, em Peruíbe, litoral paulista. Junto a Tercina, foram aprisionados três sobrinhos/netos seus. Pouco tempo depois foi a vez de Neto, capturado num ponto em Santo Amaro, bairro paulistano, sua esposa Jovelina Tonello e seu filho Ernesto Carlos, de apenas dois anos, tiveram a mesma sorte. Neto e sua companheira foram torturados na presença de seu filho. Tercina e as crianças acabaram libertadas e banidas do Brasil após o sequestro do embaixador alemão Ehrenfried Anton Theodor Ludwig Von Holleben, em junho de 1970. O destino dos 40 presos trocados por Von Holleben foi a Argélia. Em dezembro, após o sequestro do embaixador suíço Giovanni Enrico Burcher, foi a 
vez de Neto deixar o Brasil, juntamente a sua esposa.

Entre 1970 e 1971, a nova VPR realizou três sequestros, libertando 115 militantes presos, sempre em associação com outros grupos, como a REDE, o MRT e a ALN. A frente de siglas se tornou uma necessidade devido ao cerco da repressão e as quedas em série. Os quadros da organização tiveram prioridade nas negociações, mas diversos militantes de outros grupos foram contemplados nas listas de permuta. Apesar do sucesso de suas operações, a nova VPR não pôde suportar a ofensiva dos militares, agora lotados em departamentos com um grau de especialização não visto em épocas pregressas. ${ }^{462}$ Esse foi o agrupamento que mais baixas sofreu durante a ofensiva das forças repressivas, intensificada após a ascensão do general Emílio Garrastazu Médici a presidência da República. Apenas em 1970, foram assassinados pelo regime - boa parte sob tortura - Antonio Raymundo de Lucena, Juarez Guimarães de Brito, Joelson Crispim, Roberto Macarini, Alceni Maria Gomes da Silva, José Maria Ferreira de Araújo, Edson Neves Quaresma, Yoshitane Fugimori e Celso Gilberto de Oliveira. As quedas prosseguiram no ano seguinte, inviabilizando as ações da organização. $\mathrm{O}$ que deu sobrevida a nova VPR foi o fato de seu corpo de dirigentes se encontrar em grande parte no exílio. Especialmente no Chile, em Santiago, viviam na condição de banidos Onofre Pinto (que do exterior referendou a cisão com a VAR), Ladislas Dowbor, Maria do Carmo Brito, Mario Japa, dentre outras lideranças ${ }^{463}$.

O sequestro do embaixador suíço abriu uma crise na nova VPR, diversos nomes propostos em listas enviadas aos militares foram vetados, a ditadura mudara sua sua tática, militantes envolvidos em "crimes de sangue" não eram aceitos. O fato de Giovanni Enrico Burcher pertencer a um país sem o mesmo peso no cenário internacional que possuíam Estados Unidos e a Alemanha deu poder de barganha aos representantes do regime. Lista após lista foi rejeitada, numa clara manobra para ganhar tempo e desgastar a guerrilha. Por votação, decidiu-se pelo justiçamento do suíço, hipótese de pronto rechaçada por Lamarca. A postura do dirigente máximo da nova VPR desgastou sua liderança junto a seus comandados, rancores

462 O mais alto grau de operacionalidade da repressão durante os Anos de Chumbo foi executado através dos DOI-CODI (Destacamento de Operações de Informação e Centro de Operações de Defesa Interna), em atuação a partir de 1970. Tais unidades agiam em parceria com demais órgãos de informação e vigilância, como o Serviço Nacional de Informações. Era responsabilidade dos CODI reunir dados que permitissem a concentração de informações a serem passados aos DOI, voltados a busca e vigilância. O primeiro funcionava como centro de inteligência, as informações (obtidas sob tortura e delação) eram passadas ao segundo, o braço operacional desses aparelhos de repressão. Para mais informações sobre os DOI-CODI, consultar: D'ARAUJO, Maria Cecília; SOARES, Gláucio Ary Dillon; CASTRO, Celso (org). Os Anos de Chumbo. A memória militar sobre a repressão. Rio de Janeiro: Editora Relume-Dumará, 1994.

463 SECRETARIA ESPECIAL DOS DIREITOS HUMANOS. Direito a Memória e a Verdade. Comissão Especial Sobre Mortos e Desaparecidos Políticos, 2007. p. 112-140 
vieram à tona, e o próprio Lamarca passou a fazer uma autocrítica sobre os rumos de sua organização. O programa ultra militarista de Jamil Rodrigues passou a ser questionado pelo ex capitão do Exército. Após intensos debates internos, em março de 1971 Carlos Lamarca deixou a organização que ajudara a criar, e se engajou no MR-8, disposto a concentrar esforços na montagem da guerrilha rural ${ }^{464}$.

Além do cerco da repressão, e de uma série de divergências internas, a infiltração de informantes (cachorros) foi fatal para a nova VPR. Dentre os infiltrados, ganhou notoriedade José Anselmo dos Santos, o cabo Anselmo, remanescente e liderança mais notória da extinta AMFNB, marinheiro que ganhou destaque nos estertores do governo João Goulart. Em finais de 1972 e princípios do ano seguinte, o comando da nova VPR, em exílio no Chile, trabalhava por uma rearticulação de sua organização no Brasil, tendo como base o nordeste. Uma célula localizada em Recife estava incumbida de tal tarefa. Um engano das forças de repressão levou para a delegacia da Rua do Tutóia, antiga sede da Oban, o cabo Anselmo, que foi solto pouco tempo depois, não sem antes ser visto por vários militantes. Suspeitas chegaram ao comando da organização no Chile, mas Onofre Pinto, companheiro do acusado desde os tempos das lutas pré-64, não acreditou nas acusações. No começo de 1973 não havia mais dúvida sobre a verdadeira ocupação do ex-marinheiro, as informações sobre o infiltrado chegaram a sua esposa, Soledad Barret Viedma, paraguaia radicada no Brasil, que avisou seu companheiro sobre o que se passava em Santiago. No dia seguinte, 7 de janeiro de 1973, seis militantes da nova VPR foram assassinados no Recife, graças a delação de Anselmo, dentre estes estava sua esposa, grávida de quatro meses, jovem que completaria 28 anos no dia seguinte ${ }^{465}$. A matança do Recife significou o fim das ações da sigla em discussão no Brasil.

Em meados de 1974, o que restou do comando da nova VPR no exterior decidiu retomar as atividades do agrupamento em solo brasileiro. Organizado na Argentina - visto que no ano anterior o golpe contra Salvador Allende provocara uma debandada dos exilados no Chile - um grupo reunido em torno de Onofre Pinto preparou seu retorno ao Brasil, via Foz do Iguaçu. O que ocorreu em julho de 1974 “constitui um dos episódios mais recobertos de incertezas e mistério, até hoje, entre todos os casos de mortes e desaparecimentos registrados 464 Para mais informações sobre o desligamento de Lamarca da nova VPR, JOSÉ, Emiliano; MIRANDA, Oldack. Op. Cit. p. 108-112

465 Os militantes assassinados, além de Soledad Barret Viedma, foram Pauline Reichstul, Eudaldo Gomes da Silva, Evaldo Luís Siqueira, Jarbas Pereira Marques e José Manuel da Silva. Informações sobre a denúncia contra Anselmo no Chile, VIANNA, Martha. Op. Cit. p. 119-123; acerca da ação policial no Recife; Secretaria Especial dos Direitos Humanos. Comissão Especial Sobre Mortos e Desaparecidos Políticos. Op. Cit. p. 326331. Há também a recente publicação Soledad no Recife, que narra a trajetória da militante paraguaia; MOTA, Uraniano. Soledad no Recife. São Paulo: Editora Boitempo, 2009. 
no período ditatorial". Junto com Onofre, atravessaram a fronteira os irmãos Daniel José e Joel José de Carvalho, o argentino Enrique Ernesto Ruggia, o veterano militante José Lavecchia, e Vitor Carlos Ramos. Ao entrar no Paraná, os guerrilheiros foram "atraídos para uma cilada e executados no município de Medianeira”, no mesmo estado ${ }^{466}$. A organização fundada no Congresso de Mongaguá não resistiu a mais essa chacina, foi fisicamente eliminada pela repressão estatal brasileira. Seus dirigentes no exterior optaram por não retomar a atividades da sigla e a declararam extinta.

A trajetória da VAR-Palmares foi semelhante a da nova VPR, duramente atingida pela repressão, cindida por divergências internas, isolada das massas, cujo programa visava conquistar. O isolamento dessa sigla também se verificou perante as demais organizações armadas, o tumultuoso racha de Teresópolis gerou rancores profundos e alargou as diferenças entre as correntes massistas e militaristas, sendo que os segundos foram mais bem sucedidos no diálogo com os demais agrupamentos armados em combate a ditadura. O programa comedido em termos operacionais da VAR lhe permitiu executar tarefas em associação ao POC, cujas diretrizes lhe eram próximas.

Logo após o congresso de Teresópolis, um racha afastou uma pequena parcela de componentes da VAR, que se mantiveram a parte do debate militarismo $\mathrm{x}$ massismo, discordando de ambas as tendências. Essa corrente formou a DVP (Dissidência da VARPalmares), ajuntamento de dimensões reduzidas, reunindo algumas dezenas de quadros ${ }^{467}$. A

466 "Militantes que conviveram com Onofre Pinto após o Massacre da Chácara São Bento, em janeiro de 1973, quando foram mortos seis militantes da VPR em Pernambuco, relataram que esse exilado expressava desespero e inconformismo pela confiança que tinha depositado no agente infiltrado cabo Anselmo. Onofre era o dirigente principal da VPR, fora alertado sobre a infiltração de Anselmo, mas não aceitara as evidências. A partir daquele episódio, passou a viver obcecado pela ideia de retornar à luta clandestina no Brasil. No entanto, é provável que tenha incorrido uma segunda vez no mesmo erro fatal, confiando em um ex-sargento da Brigada Militar gaúcha, ligado a Leonel Brizola, Alberi Vieira dos Santos, que parece ter sido um outro agente infiltrado, que atraiu esse grupo para a morte, conforme informações divulgadas quase 20 anos depois. A data da viagem para o Brasil somente foi estabelecida através de informação fornecida por Idalina, mulher de Onofre. As informações acerca do ocorrido com o grupo tiveram novos elementos a partir de 1992, quando foi revelada a atuação do casal Maria Madalena Lacerda de Azevedo e Gilberto Giovanetti, que confessaram terem sido cooptados pelos órgãos de repressão, passando a realizar missões policiais, inclusive no exterior. Giovanetti tinha sido companheiro de Daniel e Joel na Ala Vermelha de São Paulo, tendo participado, segundo documentos dos órgãos de segurança, de assalto a um carro forte, em 14/04/1969, em que dois guardas foram mortos". SECRETARIA ESPECIAL DOS DIREITOS HUMANOS. Op. Cit. p. 386-387.

467 A DVP acusava tanto a VAR quanto a nova VPR de "desvios debraystas", seus militantes, reunidos no Rio de Janeiro e Minas Gerais, através de seus documentos, defendiam a "necessidade de desenvolver estudos científicos sobre os rumos do processo político brasileiro; a luta pela unidade dos revolucionários; a constituição 
ausência de um corpo militar mais experimentado em medidas de segurança trouxe dificuldades ao grupo em conter o fluxo de quedas em suas fileiras. A sigla em discussão foi duramente atingida em 21 de novembro de 1969, com a prisão do dirigente Antonio Roberto Espinosa, sua esposa Maria Auxiliadora Lara Barcelos, e Chael Charles Shreier, militante egresso da dissidência estudantil paulista, ex-estudante de medicina da Santa Casa de São Paulo. O grupo foi detido em um aparelho localizado no bairro carioca de Lins de Vasconcelos ${ }^{468}$. Espinosa narra os fatos que desencadearam sua prisão nos seguintes termos:

(...) cheguei em Lins (de Vasconcelos) as sete e meia, o Chael e a Maria Auxiliadora queriam falar comigo, saber detalhes recentes sobre a organização, visto que eles estavam tendo pouco contato com o restante da organização, quando cheguei eles exigiram que eu desse um informe, se queixaram de não saber nada do que se passava, resolvi dar o informe (...), sentei para conversar com eles, foi aí que a repressão chegou. Chamaram na porta, cercaram a casa, o dono da casa tinha nos entregado, seu nome era Antonio Sobrinho, nós tínhamos alugado a casa e pagado três meses antecipados, sem fiador. A casa do lado, que também era dele, estava para ser alugada, ele morava no Meyer, era economista, todo dia ele ia lá por conta de alugar a casa vizinha. Nós, gatos escaldados, trocávamos de carro com uma grande velocidade, por que na rua, quando eu achava que alguém estava olhando demais, achava que era tira, não tinha dúvida, trocava de carro, num mês eu troquei de carro umas cinco vezes. E o cara (dono da casa) que tava alugando a casa vizinha desconfiou, achou que nós lidávamos com carro roubado, então ele procurou o Dops do Rio, a fim de evitar problemas com a polícia. O Dops ficou uns quinze dias seguindo a Maria Auxiliadora, a mim eles não conseguiram seguir, só no último dia, e aí eles decidiram atacar nessa noite, devem ter imaginado que eu tinha percebido que eles estavam na campana, mas eu não tinha sacado. A Maria Auxiliadora disse ter visto uns tipos estranhos na rua, falando em aparelho, ficamos meio grilados, mas uma preocupação que nós também tínhamos era não cair no securantismo, no excesso de preocupação com a segurança, senão você fica louco, por que tudo pode ser polícia, então descartamos essa possibilidade, mas era polícia mesmo. Bateram no portão, nós achamos que era alguém querendo saber da casa ao lado, saímos juntos para atender o sujeito, o cara começou me olhar de cima a baixo para saber se eu estava armado, percebi que era um

de uma alternativa imediata de organização; o trabalho de construção do partido do proletariado". Sua atuação se concentrou na Baixada Fluminense, Rio de Janeiro, e o grupo editou o periódico mensal Unidade. A maior parte dos militantes da DVP foi preso numa operação que desmantelou a sigla em 1973. p. BNM, Tomo III. Op. Cit. p. $89-90$

468 Gabriel Figueiredo afirma que articulou o contato entre Chael e Espinosa ainda na Santa Casa, o primeiro fazia parte de uma corrente da dissidência que optou por não se engajar na ALN, caminho seguido pela maioria dos membros da dissidência estudantil de São Paulo. "O Chael estudava medicina comigo na Santa Casa. Era de esquerda. Sabia que eu era do PCB e já tinha história em Osasco e na região. Pediu-me um contato com o Espinosa, que também era de Osasco (...)". Entrevista de Gabriel Figueiredo ao autor, 31/05/2010. 
policial $(\ldots)^{469}$.

Maria Auxiliadora foi brutalmente torturada, inserida na lista de prisioneiros a serem trocados pelo embaixador suíço, viveu até 1973 no Chile. Após passar por México, Bélgica e França, fixou residência na Alemanha, onde retomou seus estudos em Medicina. Não conseguiu se recuperar das sequelas advindas das intensas torturas que sofreu, vindo a cometer suicídio em 1976, em Berlim. Não voltou a ver seu marido Antonio Roberto Espinosa. Chael Charles Shreier também foi torturado de maneira selvagem, mas ao contrário de seus dois companheiros, não pode resistir aos torcionários, morreu horas depois de sua prisão ${ }^{470}$. As quedas de Lins de Vasconcelos provocaram um profundo abalo na estrutura da organização, Espinosa, enquanto principal dirigente do setor Urbano, tinha sob sua responsabilidade uma série de projetos a serem efetuados a curto prazo, sua detenção desorganizou o cronograma de ações da sigla ${ }^{471}$.

Ainda em janeiro de 1970, foi presa a dirigente Dilma Roussef, num ponto a ser efetuado na Rua Augusta, em São Paulo. Até o final desse ano, a VAR veria fora de ação boa parte de seus quadros. Destes, foram assassinados pela repressão Cassimiro Luís de Freitas, veterano do movimento agrário de Trombas e Formoso, interior de Goiás, militante empregado na construção do foco rural; Avelmar Moreira de Barros, Marco Antonio Dias Batista, e Lucimar Brandão Guimarães. Em fevereiro do ano seguinte morreram sob tortura Mariano Joaquim da Silva e Carlos Alberto Soares de Freitas, o Breno, dirigente na Polop, Colina e VAR- Palmares, ativista histórico em sua organização. Ambos foram mortos na "casa da morte", localizada em Petrópolis ${ }^{472}$.

Desfalcados de suas principais lideranças, o que sobrou de militantes da VAR passou a se dedicar a pequenas ações de expropriação, mais em caráter de sobrevivência do que como projeto revolucionário, retornando a sigla ao militarismo ala VPR. Debilitada, distante de seu

469 Entrevista de Antonio Roberto Espinosa ao autor, 30/03/2009

470 O martírio de Chael foi noticiado pela Revista Veja, e também foi publicado em veículos internacionais como New York Times, Le Mond e The Times, causando constrangimento a um regime que insistia e se pronunciar como democrático. Após esse evento, os órgãos repressores passaram a redobrar suas técnicas de ocultamento de cadáveres e confecção de laudos necroscópicos falsos. SECRETARIA ESPECIAL DOS DIREITOS HUMANOS. Op. Cit. p. 109-110

471 Uma das ações a serem efetuadas pela VAR seria o sequestro do Ministro da Fazenda Antonio Delfim Neto, a operação estava sob encargo de Espinosa, após sua prisão, o projeto foi desativado. Entrevista de Antonio Roberto Espinosa ao autor, 30/03/2009.

472 A "casa da morte" foi um dos principais centros clandestinos de tortura localizados no estado do Rio de Janeiro. Daqueles que foram seviciados nesse endereço, apenas Inês Ettiene Romeu conseguiu sair com vida, por que fora dada como morta e atirada numa estrada deserta, em um subúrbio carioca. Para mais informações sobre os mortos da VAR e sobre a "casa da morte": Idem, p. 112-141. 
projeto inicial, a VAR-Palmares encerrou suas atividades em 1973.

$* * * * *$

No arrefecer da luta armada brasileira, a maior parte dos guerrilheiros se encontravam presos, no exílio, ou mortos. O último foco de resistência a ditadura pela via das armas se efetivou na região do Araguaia, e como é bem sabido, terminou em tragédia. Em meados da década de setenta, os sobreviventes da caçada implacável do regime contra suas organizações deram início a sua fase de autocrítica. Em termos operacionais, todas as siglas que se dedicaram ao combate violento ao sistema imposto pela elite civil-militar brasileira foram desmobilizadas. Na segunda metade dos anos 1970, apenas grupos esparsos se dedicavam a uma luta que perdera seu caráter revolucionário, estando estes militantes ocupados apenas com sua sobrevivência.

Os dados do projeto BNM indicam que 7367 pessoas foram denunciadas pela Justiça Militar, sendo 4460 só no período Médici, auge dos Anos de Chumbo. Dos processados, 2868 $(38,9 \%)$ tinham idade inferior ou igual a 25 anos. 374 pessoas foram assassinadas pelo regime, 136 constam até hoje como desaparecidos, pelos números levantados até agora ${ }^{473}$. A repressão esteve concentrada nos grandes centros urbanos, sobretudo o eixo Rio-São Paulo, centro das atividades revolucionárias, contudo, a mão pesada do sistema se fez sentir em todos os recantos do país, imiscuiu-se na sociedade, penetrou consciências e deixou profundas marcas no caráter nacional.

Dentre os municípios brasileiros mais atingidos pela repressão figura a cidade de Osasco, especialmente após a greve de julho de 1968, com dezenas de prisões, intervenção sindical, e fechamento de todas as entidades não oficiais vinculadas aos movimentos sociais do município. Relacionados diretamente a cidade, três militantes foram mortos pelo regime. Dorival Ferreira, 38 anos, osasquense de nascimento, membro da ALN. Exercia o ofício de trabalhador da construção civil, egresso da oposição sindical de sua categoria, foi ferido a bala e detido em sua residência, no bairro de Presidente Altino. De acordo com testemunhas, quando foi levado pela polícia ainda se encontrava com vida. Dorival forneceu as barras de ferro que foram usadas no ataque ao palanque em que discursava o governador Abreu Sodré, no célebre $1^{\circ}$ de Maio de 1968 . Também tombaram João Domingues da Silva, irmão de Roque

473 BNM, Tomo III. Op. Cit. p. p. 9-14 
Aparecido, morto sob tortura em setembro de 1969, e José Campos Barreto. Um memorial em homenagem aos três militantes mortos pela ditadura foi edificado em Osasco, em 2008.

Dezenas de ativistas da região foram processados e presos por envolvimento com grupos armados, como supramencionado, tivemos acesso a uma minoria desses ativistas. Abaixo traçaremos um breve relato das trajetórias de alguns dos quadros do GO, aqueles tivemos acesso.

Dos componentes do GO, o que obteve maior notoriedade foi sem dúvida José Ibrahim, considerado pela opinião pública - e pela repressão - o principal líder da Greve de Osasco. $\mathrm{Na}$ segunda seção deste trabalho vimos que o manifesto da greve foi distribuído entre as principais agremiações estudantis paulistas e cariocas, especialmente no Rio de Janeiro a experiência osasquense foi recebida com entusiasmo. A essa altura ainda se buscava a construção de uma frente operário-estudantil, aos moldes franceses. O manifesto redigido alguns dias antes por Espinosa e Roque Aparecido chegou as mãos de operários dos subúrbios cariocas, na perspectiva de ampliação de um movimento de pretensões insurrecionais. A imagem de Ibrahim também foi moldada pela imprensa, um líder político de apenas 21 anos, a frente de uma parede desafiadora, numa fase de recrudescimento político. A silhueta do jovem insubmisso não deixou de adquirir certo contorno romântico, em sintonia com a vaga imagética do "poder jovem", em voga no contexto internacional. Tal imagem contribuiu para a introdução do nome do estudante-operário na lista das quinze pessoas a serem trocadas pelo embaixador estadunidense Charles Elbrick, em setembro de 1969.

Após breve temporada no México, local para onde foram transportados os banidos, Ibrahim se instalou em Cuba, e retornou a sua profissão de metalúrgico. Em seguida fixou residência no Chile de Salvador Allende, de onde teve que fugir após o golpe de 11 de setembro de 1973. Na Europa, instalou-se na Bélgica, onde exerceu sua profissão, nessa fase já casado e pai de um filho. Retornou ao Brasil na conjuntura da anistia, em 1979, voltou as suas atividades sindicais em Osasco, ajudou na criação da Central Única dos Trabalhadores, e foi membro fundador do PT, já nos anos 1980. Posteriormente rompeu com o PT e se filou ao PDT de Brizola. Sua atuação nos meios sindicais sempre se pautou pela organização dos trabalhadores pela base, por meio da construção de comissões de fábrica, aos moldes do bem sucedido processo osasquense em vigor até o ano de 1968.

Roque Aparecido da Silva foi preso junto com José Ibrahim, mas diferentemente de seu companheiro de lutas estudantis e operárias, permaneceu mais de um ano preso, saindo do 
Brasil em janeiro de 1971, após ser incluído na lista de presos a serem trocados pelo embaixador da Suíça Giovanni Enrico Burcher. Os setenta militantes banidos após último sequestro realizado pela guerrilha brasileira se fixaram no Chile, o caminho pós exílio dos mesmos obedeceu a um itinerário semelhante, fuga a partir de setembro de 1973, e asilo na Europa. Ainda no Chile, Roque Aparecido completou seus estudos em Sociologia. Em Paris, para onde se dirigiu, fez mestrado na mesma disciplina, pela Universidade de Paris I. Retornou ao Brasil após a anistia, filou-se ao PT, e se tornou pesquisador na área de sociologia do trabalho.

Manuel Dias do Nascimento foi vítima de um dos episódios mais cruéis da ditadura, torturado juntamente a toda sua família, seviciado com sua esposa na presença de seu filho de apenas dois anos. Foi banido do Brasil após o sequestro do embaixador suíço, acompanhado de sua esposa e seu companheiro de lutas dos tempos de Osasco, Roque Aparecido. Alguns meses antes tinham sido banidos sua mãe, filho e sobrinhos, como visto acima. No Chile sua família pôde finalmente se reunir novamente, quase dois anos depois partiriam para Cuba, onde Neto fixou residência. Em princípios da década de oitenta Manuel Dias do Nascimento retornou ao Brasil com a família, a exceção de seu filho mais velho, que permaneceu em Cuba estudando, e retomou suas atividades sindicais.

Dos quadros dirigentes vindos do GO, Antonio Roberto Espinosa foi o único a não figurar nas listas de troca dos sequestros de embaixadores. Segundo seus depoimentos, a contenda de Teresópolis abriu feridas não cicatrizadas, "não fui incluído nas listas, primeiro, por que as duas tentativas de sequestro que a VAR fez foram mal sucedidas, uma em Recife e outra em Porto Alegre, com dois consuls dos EUA, meu nome era o primeiro da lista, mas as ações não deram certo, os sequestros não aconteceram e a lista dos pedidos caiu, e eu me ferrei. Segundo, houve o desdobramento da luta interna, eles estavam putos por que eu não rachei”, ${ }^{\prime 74}$. Em que pese as divergências entre a nova VPR e a VAR, membros desta organização foram incluídos nas listas de resgate, como Roque Aparecido, que não aderira a cisão, permanecendo na VAR, e Maria Auxiliadora, esposa de Espinosa. Segundo impressões do depoente, a inclusão de sua companheira e a exclusão de seu nome, na lista do embaixador suíço, deu-se por represália.

Não obtivemos informações por parte de pessoas que estiveram envolvidas diretamente no processo de montagem das listas de permuta, mas o espaço destinado a outras 
organizações, que não as dos envolvidos diretamente nas ações, foi reduzido. Dos quadros da VAR contemplados nas listas, nenhum fazia parte do corpo de dirigentes desse grupo armado, lideranças como Dilma Roussef e Carlos Franklin Paixão de Araújo também não foram incluídos. Ao que tudo indica, os rancores estiveram concentrados nos quadros que definiram os rumos da fusão Colina-VPR, dando contornos massistas ao novo agrupamento, ensejando o racha da corrente militarista.

Após temporada de sevícias em quartéis do Rio de Janeiro, na Oban, e no Dops paulista, Espinosa foi encarcerado no Presídio Tiradentes, sem acusação formalizada. Permaneceu quatro anos preso, conseguiu sua liberdade em 1973 graças a uma estratégia bem sucedida adotada por seu advogado.

(...) o que que meu advogado foi fazendo? Ele foi pedindo litis pendencia, que é a junção de processos, do mais novo para o mais antigo. Eu tinha três processos, um na Marinha do Rio, pela VAR, ele pediu para unificar com o processo da VAR daqui de São Paulo, o que acabou acontecendo. $\mathrm{Na}$ segunda auditoria, o processo da VAR foi julgado, no meu caso, eles deram litis pendencia, por que o mais antigo era da VPR, a ser julgado na primeira auditoria, então unificaram todos os meu projetos num só, eu não fui julgado pela VAR, só pela VPR. Da VPR tinham sido presas várias pessoa que tinham vínculos menores, várias pessoas, os que tinham maior envolvimento, todos, saíram nos sequestros (...). Tinha no processo da VPR aquele pessoal que traiu e foi para a televisão, o Hermes Camargo Batista, Celso Lungaretti, Rômulo Fontes, um bando, todos esses caras haviam sido postos em liberdade, vários fizeram curso no SNI, viraram agentes do Estado. De repente fiquei só eu no processo, o pessoal no exílio não tinha como ser julgado, tinha o pessoal que havia sido preso por pouca participação, a maioria acabou solto, além dos traidores. Só havia eu para condenar, fazer um processo só para me condenar não era viável, eles não tinham nenhuma prova contra mim, só o testemunho dos traidores. Meu advogado entrou com uma ação no STM, seu nome é Francisco Antonio Marques da Cunha, um bom advogado, ele entrou com um processo chamado ação de correição parcial, quando um tribunal superior é instado pelo advogado a intervir no tribunal inferior onde estaria ocorrendo parcialidade, ele argumentou que eu estava preso há quase quatro anos, que a prisão preventiva já havia vencido várias vezes, e o processo não havia sido julgado. Então ele dizia, “ou julga o processo, ou solta meu cliente, ou o STM fará uma intervenção e afastará o juiz". O processo foi para o STM, me levaram para a auditoria, deram um sabão. Então o juiz perguntou o que eu estudava e em que eu trabalhava, eu disse que tinha feito filosofia e era professor, depois ele perguntou se acaso eu fosse solto, o que que eu faria, disse que procuraria terminar meu curso, e dar aulas para sobreviver. Então ele me perguntou se eu voltaria a militar na VPR, e eu disse não senhor, 
na VPR não (risos). A resposta agradou a todo mundo, a prisão foi relaxada, com a condição deu voltar toda semana para a auditoria, depois me levaram para o Dops, e eu fiquei mais um dia lá, os agentes me fizeram sentar na cadeira do dragão, fizeram uma porção de ameaças, intimidações, xingaram o juiz. Até que no dia seguinte, 17 de setembro de 1973, eu saí caminhando pelo corredor, sozinho, não me conduziram pois estavam putos, saí sozinho, com uniforme de preso, sem nenhum centavo no bolso. Peguei um táxi até Osasco, minha mãe acabou pagando ${ }^{475}$.

Em liberdade, Espinosa retornou a cidade de Osasco, tornou-se editor chefe do jornal Primeira Hora, em circulação na região oeste da Grande São Paulo, completou seus estudos em Filosofia e voltou a lecionar. Constituiu família e se tornou uma personalidade influente no meio político de seu município.

No ano de 1971, José Campos Barreto era o único quadro remanescente do núcleo do GO ainda em atividade. Zequinha foi um misto de revolucionário e poeta, acusado por seus pares de incidir no liberalismo, teve dificuldades em se adaptar a aridez da vida clandestina. Dentre suas atitudes temerárias esteve o hábito, severamente criticado, de ir até Osasco fazer serenata para sua namorada, ou tocar violão entre amigos nos bares da cidade, enquanto seu nome figurava na lista de guerrilheiros procurados pela polícia. Seu romantismo se mesclava a uma coragem notável, no decorrer da greve da Cobrasma, em julho de 1968, Barreto tomou a frente do movimento, diversos relatos afirmam que os soldados destinados a repressão a greve vacilaram após ouvir seu discurso, pouco antes da invasão da fábrica pela repressão. Detido pela polícia não se entregou ao desespero, respondendo em inglês as perguntas que lhe faziam os agentes repressores. No dia seguinte após a retomada da empresa, seu nome estava estampando nos principais jornais de São Paulo como o principal agitador do movimento.

Em meio a razia policial e a onda de cisões, Zequinha optou por retornar a sua terra natal, Brotas de Macaúbas, no interior da Bahia. Após breve período de reclusão voluntária, o

475 O modelo de justiça imposto após o golpe de 1964 trouxe mudanças drásticas ao sistema jurídico brasileiro, adaptado ao Estado autoritário em vigor. A partir do AI-5 e do recrudescimento do sistema repressor, a formação dos inquéritos policiais de presos políticos passou a ser efetivada em duas fases, a primeira a partir dos DOICODIS, marcada pela "incomunicabilidade e os maus tratos físicos e mentais", estando os presos a disposição de equipes de torturadores, "nem mesmo a Justiça Militar era comunicada sobre as detenções efetuadas pelos órgãos de segurança”. Muitos não sobreviveram a essa etapa. Foi "vedada a impetração de Habeas-corpus, pois o AI-5 proibia a apreciação judicial desta garantia "nos casos de crimes políticos contra a Segurança Nacional, a ordem econômica e social e a economia popular" (art. 10). Sem direito a Habeas-corpus, sem comunicação de prisão, sem prazo para conclusão de inquérito, o preso ficava absolutamente indefeso nos órgãos de segurança, desde o dia em que fora sequestrado até quando passasse a Justiça Militar". A fase seguinte era "a do "cartório", quando os presos passavam a disposição dos Dops ou da Polícia Federal, encarregados de "formalizar" os inquéritos. Para citação no corpo do texto: Idem; para informações em nota, consultar: BRASIL NUNCA MAIS.10 Ed. Petrópolis-RJ: Editora Vozes, 1985. 173-176. 
jovem militante decidiu retornar às suas atividades políticas. Passou uma temporada no Rio de Janeiro, e em seguida se deslocou para Salvador. Estando a VAR quase desmobilizada, e a VPR vitimada infiltrações, Barreto optou pelo MR-8, aproximando-se de uma célula dessa organização situada na capital baiana. $\mathrm{O}$ agrupamento de origem carioca passava por um processo de redefinição de rumos após a adesão de um valioso quadro, Carlos Lamarca. Em princípios de 1971, a direção do MR-8 recebeu de forma positiva um projeto de José Campos Barreto que propunha iniciar um trabalho político junto aos moradores de sua região. Especialmente Lamarca recebeu a ideia com entusiasmo, nessa fase o ex-capitão estava empenhado em apressar os trabalhos de construção da tão aguardada guerrilha rural, e o sertão da Bahia parecia ser uma área promissora, segundo seus prognósticos.

Por volta de junho de 1971 Lamarca chegou a Brotas de Macaúbas, e se reuniu a uma célula formada por José Campos Barreto, seus irmãos Otoniel e Olderico, e Luís Antonio Santa Bárbara, membro do MR-8 que já realizava um trabalho político na região. Preso e rapidamente solto após o AI-5, esse jovem professor remanescente da dissidência estudantil baiana também era um quadro visado pela repressão ${ }^{476}$. Reunido o grupo, os trabalhos de formação da tão aguardada guerrilha rural mais uma vez tiveram início, agora no sertão baiano. Novamente a repressão se antecipou aos movimentos de Lamarca, delações levaram a prisão de militantes em Salvador, e informações sobre foco a ser montado no interior do estado chegaram a polícia.

Por meio dos trabalhos da "Operação Pajuçara", Fleury e seus homens chegaram a Brotas de Macaúbas, o cerco inicial causou a morte do professor Santa Bárbara e de Otoniel Campos Barreto, Olderico, gravemente ferido foi detido, passaria dois anos na cadeia. Lamarca e Zequinha se encontravam refugiados em área próxima, alertados, iniciaram um marcha que percorreu cerca de 300 quilômetros sertão a dentro. Sérgio Paranhos Fleury foi substituído pelo oficial Nilton de Albuquerque Cerqueira, que a frente da equipe cão comandou o cerco final a Carlos Lamarca. Em 17 de setembro de 1971, o ex- capitão do

476 Nascido de uma família pobre de Inhambupe (BA), Luiz Antonio estudara no Colégio Municipal Joselito Amorim, em Feira de Santana, onde presidiu o Grêmio Estudantil. Trabalhou como tipógrafo na Gazeta do Povo, onde começou sua prática política. Em 1967 passou a militar na dissidência baiana do PCB, núcleo de ativistas que aderiu ao MR-8. Já atuava na clandestinidade desde 1969, depois de enfrentar uma primeira prisão, na onda repressiva que se seguiu ao AI-5. Foi o primeiro militante do MR-8 a ser deslocado para a região. Chegou no Buriti Cristalino como Roberto, o professor. Hospedou-se na casa de José Barreto, pai de Zequinha. Sua tarefa era formar uma escola de alfabetização no povoado carente, onde poucos sabiam ler. Todas as tardes a casa dos Barreto se enchia de crianças e adultos para ouvir o professor Roberto. Chegou a montar uma encenação teatral sobre as dificuldades sentidas pela população local, como a pobreza e cobrança de impostos. SECRETARIA ESPECIAL DOS DIREITOS HUMANOS. Op. Cit. p. 176-177. 
exército, alquebrado, vítima de enfermidades, foi sumariamente fuzilado na região de Pintada, interior baiano. Juntamente ao comandante foi assassinado José Campos Barreto, testemunhos indicaram que antes de tombar, o jovem de 21 anos teria gritado "abaixo a ditadura".

Gabriel Figueiredo, fundador da UEO e grande agitador do ME na região de Osasco, afirma ter participado da cooptação de Barreto, ainda em tempos ginasiais. Sobre o militante morto em 1971 afirma que:

O Zequinha, Barreto como eu o chamava, tinha vocação poética, literária e de grande sensibilidade social. Nordestino de origem, estava em Osasco há pouco tempo, como emigrante, em busca de estudo e trabalho. Estudou no GEPA e frequentemente saíamos juntos da escola, a pé, durante uns 40 minutos até alcançarmos nossas moradias. Nossos temas prediletos de conversas eram sobre literatura. A exemplo de Sérgio Zanardi comigo, eu já era um pouco mais velho e experiente do que ele. Assim introduzi ideologia a conversa nas nossas peripatéticas caminhadas. Sensível e inteligente, logo em seguida ele percebeu o humanismo contido no socialismo, e aderiu, mas ainda sem filiação partidária. Era um quadro político que estava bem próximo de ingressar no PCB. Após a minha prisão e uma tentativa de resistência depois da extinção da UEO, Zequinha foi um dos mais importantes ativistas do Círculo Estudantil de Osasco (...) Era um idealista, acreditava no socialismo e na capacidade de humanização do homem ${ }^{477}$.

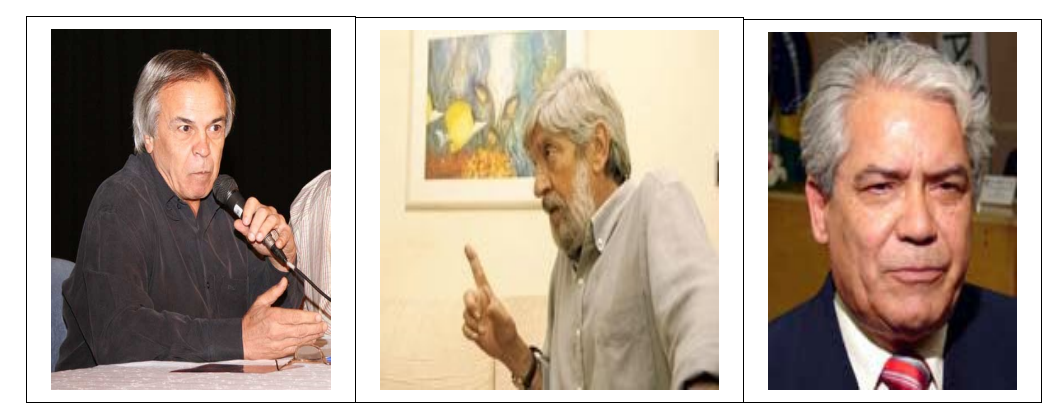

Antonio Roberto Espinosa, Roque Aparecido da Silva e José Ibrahim. Atualmente, o primeiro trabalha como professor universitário, Roque é assessor da prefeitura de Salvador, e Ibrahim presta assessoria a área sindical. Fonte: http://www.camaraosasco.sp.gov.br

477 Entrevista de Gabriel Figueiredo ao autor, 31/05/2010. Em setembro de 2009 foi inaugurado um monumento em homenagem a José Campos Barreto, Otoniel e Carlos Lamarca em Brotas de Macaúbas, e o dia da morte desses militantes foi transformado em feriado municipal. 


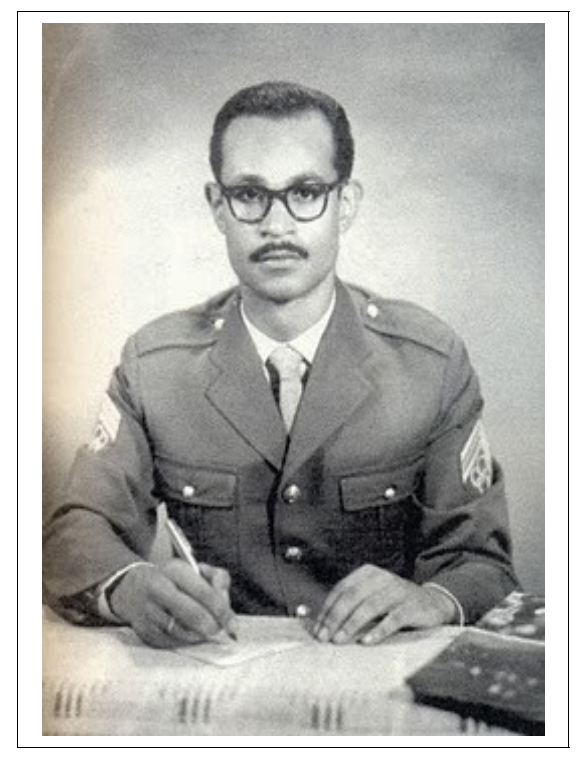

Sargento Onofre Pinto, presidente da Associação dos Sargentos e Subtenentes do estado de São Paulo, principal expoente do MNR, e fundador da VPR. Banido do Brasil em setembro de 1969, após ser incluído na lista de troca do sequestro do embaixador dos EUA Charles Elbrick. Assassinado ao tentar retornar clandestino para o Brasil em 1974. Onofre foi um dos principais organizadores da luta armada em São Paulo. Fonte: http://blogdolaque.blogspot.com/2010/10/um-enigma-chamado-onofrepinto.html

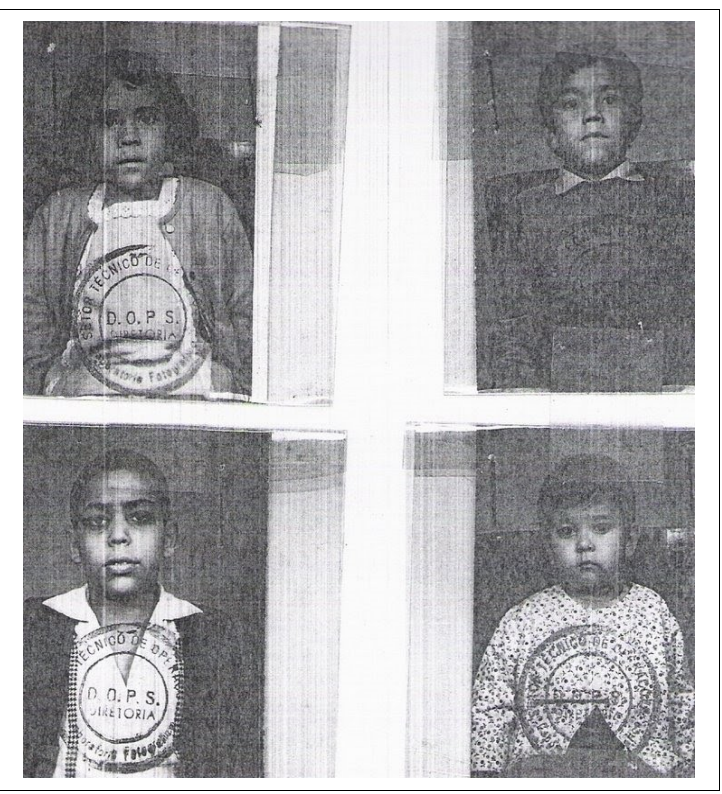


Filho e sobrinhos de Manuel Dias do Nascimento, banidos do Brasil juntamente a Tercina Dias de Oliveira, com destino a Argélia. O menor testemunhou os pais serem torturados nos órgãos de repressão paulistas. Fonte: http://ernesto.blog.br/index.php/sobre/

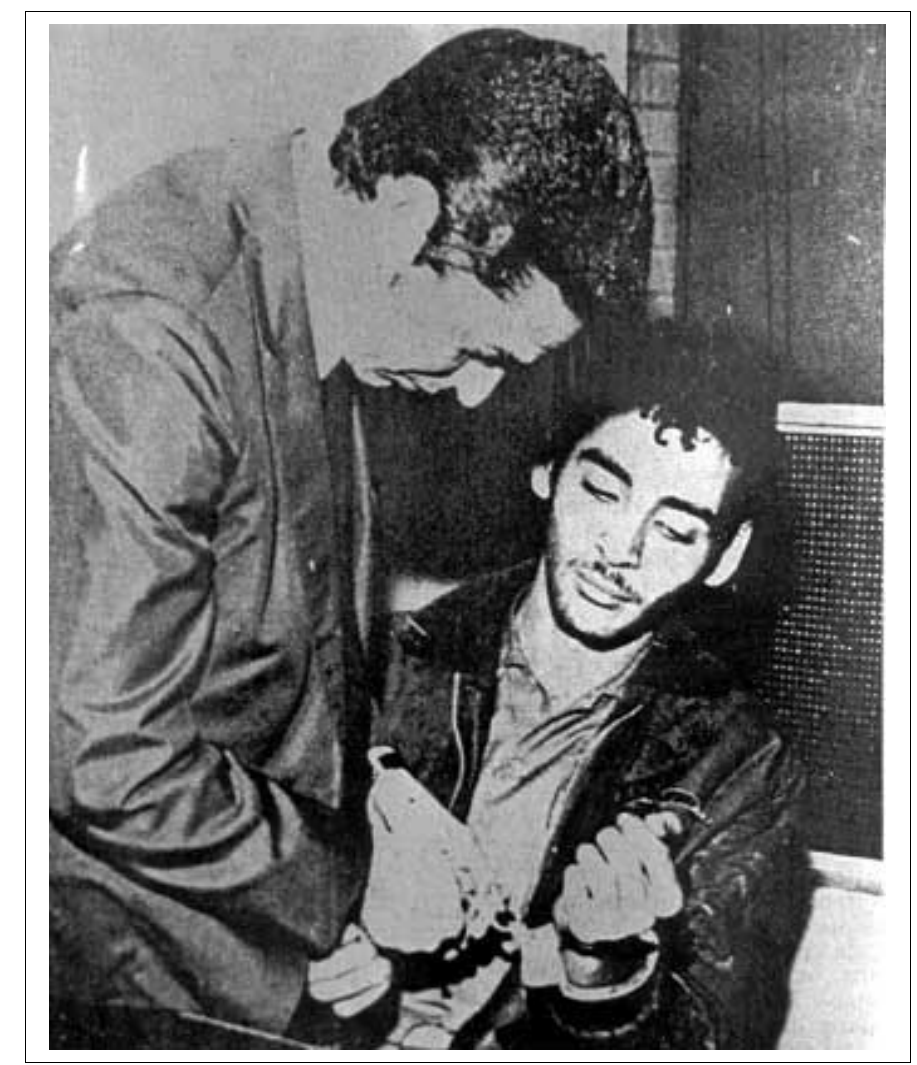

José Campos Barreto em 1968, após ser detido durante a invasão da Cobrasma pela polícia. Misto de guerrilheiro e poeta, Zequinha tombou no sertão da Bahia ao lado do capitão Carlos Lamarca, em 1971. A data da morte de Zequinha se transformou em feriado municipal em sua cidade, Brotas de Macaúbas. Fonte:http://www.zequinhabarreto.org.br/ 


\section{Considerações Finais}


Dez anos após os eventos de abril, em Contagem, e os de julho, em Osasco, a revista acadêmica Cadernos do Presente ${ }^{478}$ publicou uma edição especial, tecendo comparações entre o promissor movimento surgido em São Bernardo do Campo, em maio de 1978, e as greves deflagradas em 1968, nos dois municípios supracitados. A publicação buscou discutir qual o legado das greves de 68, quais as semelhanças/diferenças entre o que se passava no ABC em finais da década de setenta e início dos anos 1980, e teceu prognósticos, através de entrevistas e artigos, acerca dos rumos do MO brasileiro pós 1978. Das questões colocadas na publicação referida, as duas primeiras vão de encontro as nossas considerações finais. Sobre o primeiro ponto levantado, fazendo referência especificamente a experiencia de Osasco, propomos outro questionamento: a greve de julho significou o fim de um ciclo, ou início de um próximo? Iniciaremos nossas considerações a partir dessa interrogação. Não pretendemos avançar muito nessas questões, visto que as mesmas, por si só, ensejariam um novo trabalho, o que não nos cabe, por hora. Nossos apontamentos são mais de fundo expositivo, buscando intersecções entre duas experiencias distanciadas pelo tempo de uma década, em conjunturas políticas bastantes distintas.

Discorreremos sobre as questões acima indicadas de modo retrospectivo, começando pelo ponto por nós destacado. É de nossa conclusão que o movimento paredista de julho de 1968, ocorrido em Osasco, está mais próximo das agitações operárias pré 1964 do que das verificadas no $\mathrm{ABCD}$ paulista na fase final da ditadura. Ao longo desse trabalho especificamos a singularidade dos movimentos sociais osasquenses, e definimos a excepcionalidade do GO. Vimos que a UEO/CEO, o SMO e mesmo a católica FNT se formaram dentro da recente tradição de lutas levadas a cabo no processo autonômico do então subdistrito da capital paulista. O nível do ativismo estudantil do município em discussão acompanhou o clima de contestação geral que se apossou do ME brasileiro e internacional, na fase em apreciação, mas poucas cidades, considerando o cenário nacional, possuíram um elemento de coesão como o GO. Os operários-estudantes articulados no GO deram uma direção consistente a mobilização política em sua região, ocuparam os espaços deixados pelas velhas lideranças pré golpe, e imprimiram novos rumos as demandas populares de sua cidade. Em se tratando do MO, a ruptura com o discurso das tradicionais lideranças locais, egressas

478 “1968 -1978: após dez longos anos de hibernação ressurge a mobilização operária, inaugurando uma nova fase na vida política do país. As greves atuais apontam para rumos diferentes das de 1968. Porém, estas últimas são um referencial obrigatório para a compreensão das formas de organização, a amplitude e os rumos do movimento operário, deflagrado com as greves do ABC". Revista Cadernos do Presente - Greves Operárias (1968-1978), Op. Cit. p. 5. 
do modelo populista, deu legitimidade a um grupo de jovens que tinha por meta combater as políticas autoritárias e recessivas impostas a classe trabalhadora pela ditadura empresarialmilitar. O discurso radical desses jovens lhes permitiu suplantar até mesmo a moderação das organizações cristãs atuantes no meio operário local, trazendo as mesmas para suas propostas luta.

Se o panorama osasquense esteve sob a hegemonia de um grupo diferenciado como GO, como é possível associá-lo as lutas do período anterior ao regime militar? Consideramos que a vaga de contestação, que teve como ponto de ebulição o ano de 1968, é fruto de uma decantação observada em todos os movimentos sociais durante essa década, e mesmo na anterior. Os debates em torno da estrutura sindical brasileira, do sistema educacional, do modelo agrário, dentre outros, antecedem 1964. As bandeiras radicais de 68 retomaram as demandas conclamadas em princípios do decênio. O debate inter-esquerdas ainda gravitava em torno das teses do PCB, debate este travado em todo período em análise, tanto entre organizações refratárias aos comunistas, como entre os próprios quadros do Partidão. O emprego da luta armada, pauta anterior ao assalto ao poder, tornou-se um empreendimento inadiável para os setores mais radicais da esquerda, após a imposição do AI-5.

Em 1978 o debate era outro, a dicotomia PCB versus rachas e correntes divergentes em torno de um projeto revolucionário para o Brasil não mais se colocava. Aliás, tal contenda fora excluída a fórceps do processo político brasileiro. Discussões mais avançadas, nesse sentido, eram realizadas no exterior, e mesmo entre os exilados, a questão da tomada violenta do poder se encontrava fora de pauta. A profusão de siglas em atuação no meio operário, a desmobilização da classe por meio de interventorias comprometidas com o patronato, somados a repressão e a vigilância constantes, deram novos contornos ao $\mathrm{MO}$, num tempo em que a ditadura entrava em sua etapa final. Este fenômeno esteve presente no ME, também em estado de refundação ${ }^{479}$.

As lutas impulsionadas a partir de São Bernardo se juntaram as pressões que a essa altura se faziam presentes em diversos setores da sociedade brasileira. Desde 1974, após a votação expressiva recebida pelo partido da oposição consentida, o MDB, ficou claro o distanciamento entre a sociedade civil e o governo militar. O fim do "milagre econômico"

479 Após um período de inatividade devido ao feroz cerco da repressão, em outubro de 1979 a UNE realizou seu $31^{\circ}$ Congresso, onde foi eleito como presidente da entidade o baiano Rui César Costa e Silva. A radicalidade dos debates de finais dos anos 1960 foi suplantada por posições mais moderadas, voltadas a reconstrução do ME brasileiro, agora sob a liderança de quadros articulados no recente Partido dos Trabalhadores e ao PC do B. Para mais informações sobre retomada da UNE: HISTÓRIA DA UNE. (Vol. 1) Depoimentos de ex-dirigentes. São Paulo: Editorial Livramento, 1980. 
retirou o álibi da ditadura, desnudando seu modelo excludente. Os anos de chumbo já haviam revelado seu caráter autoritário. Nessa fase afloram iniciativas como o Movimento Feminino pela Anistia, atuante a partir de 1973, organizado por Therezinha de Godoy Zerbine, esposa do general legalista Euryales de Jesus Zerbini, oficial cassado em 1964. Outra iniciativa de oposição ao regime foi a formação do Movimento do Custo de Vida, articulado por donas de casa, responsáveis pela organização de abaixo-assinados que denunciavam a "carestia de vida" imposta pelas políticas de arrocho salarial da ditadura. É nesta conjuntura que se forma o novo sindicalismo brasileiro, de contornos distintos, sem, contudo, romper por completo com as tradições de luta da classe trabalhadora ${ }^{480}$.

Em meio aos cruentos "anos de chumbo", foi travada uma luta comedida por parte do MO brasileiro contra o regime autoritário, através de ativistas articulados em células clandestinas, sob o constante assédio da polícia, a margem dos sindicatos cerceados. As formas elementares de atuação eram "operações tartaruga", atrasos propositais, danificação de peças, recusa a fazer horas extras, etc. A organização subterrânea dos trabalhadores era realizada em grande parte pelas Oposições Sindicais. Na última seção vimos que as siglas revolucionárias, que atuavam junto ao operariado, formaram pequenos grupos em zonas industriais brasileiras, boa parte no estado de São Paulo. Em Osasco, cidade muito vigiada após julho de 1968, o que restou de mobilização dentro das fábricas esteve sob encargo dos movimentos católicos, menos visados pela repressão. Grupos cristãos também se destacaram nos outros polos industriais paulistas, mas tiveram que disputar espaço com remanescentes da Polop, em seus diversos agrupamentos; egressos da AP, trotskistas, sobreviventes do PC do B, dentre outros. As vésperas de 1978 o que se testemunhava era uma discreta reorganização do MO, com lutas localizadas e de pequena monta, articulações de cúpula entre comunistas e

480 Segundo Celso Frederico, duas grandes tendências se formaram no MO durante os anos 1970. A primeira articulada em torno do PCB, voltada ao sindicalismo de cúpula, alinhada ao MDB e sua luta por uma nova constituinte, contando também com o apoio do PC do B e do MR-8, organizações que passavam por um processo de autocrítica em relação a luta armada. A segunda tendência foi definida como um "conjunto heterogêneo de agrupamentos", dentre os quais a APML, a OCML-PO, o MEP e diversos grupos de matriz trotskista. A estes se somaram movimentos oriundos da esquerda católica, como a PO, CEB's, ACO, JOC, FNT, etc. Esta corrente defendia "o trabalho de base, a formação de círculos operários fora da estrutura sindical". Propunham "uma organização horizontal e descentralizada, apoiados principalmente nos núcleos ou grupos de fábrica, e nas comissões". Segundo o mesmo autor, esses grupos se congregaram nas oposições sindicais, vimos que as OP's já se articulavam desde meados dos anos 1960, e tinham suas origens na luta ideológica travada contra o PCB em finais da década de cinquenta. As oposições também passaram por um processo de decantação durante a fase mais dura do regime militar, dando ensejo a discursos mais moderados a altura das greves de 1978. A perseguição as correntes mais radicais abriu espaço para a atuação dos movimentos cristãos, os mesmos que suplantaram a influência das tendências de jaez marxista-leninista na conjuntura da anistia. FREDERICO, Celso. A Esquerda e o Movimento Operário, 1964-1984. (Vol. II) A crise do "milagre brasileiro". Belo Horizonte: Oficina de Livros, 1990. p. 145-153. 
políticos do MDB, e cuidadosos projetos de reconstrução por parte das OS.

Enquanto se desenvolviam os trabalhos da transição "lenta, gradual e segura", empreendida pelo general Geisel, um fato inesperado, ocorrido em São Bernardo do Campo, serviu para acelerar o processo de transição democrática nacional: a greve de Scania, em maio de 1978. Da Scania, as paralisações se estenderam a Mercedes, a Ford, a Volkswagem; rapidamente se espalharam para cidades vizinhas do Grande ABCD; chegando a São Paulo e Osasco. O movimento de São Bernardo se desenvolveu por vias paralelas as observadas nas demais regiões da Grande São Paulo, não foi fruto do trabalho das OS's, surgiu de forma espontânea, e o mais surpreendente, foi encampado pelo sindicato dos Metalúrgicos local. O presidente desta entidade era Luís Inácio Lula da Silva, eleito em 1975, e reeleito dois anos depois. Durante sua gestão, "Lula e um pequeno grupo de dirigentes realizaram um penoso e paciente trabalho de ocupação do aparelho sindical e de lenta renovação da diretoria. Alheio à luta contra o regime militar à ação intermitente das oposições sindicais para organizar a categoria, o grupo de Lula travou uma prolongada "guerra de posições" no interior da burocracia sindical que só se completou em 1978"481.

Nos dois anos seguintes eclodiriam novas greves, sempre tendo como foco detonador o ABCD. O grupo a encabeçar tais mobilizações se apresentava como "sem ideologia", distante dos tradicionais matizes da esquerda brasileira, essa posição de equidistância em relação as oposições ao regime conferiu um livre trânsito a Lula, personalidade de maior destaque na conjuntura. Também foi fundamental para o arranjo interclasses que se consubstanciaria na formação do Partido dos Trabalhadores, legenda que reuniu correntes diversas da esquerda nacional, de grupos oriundos das CEB's a trotskistas; de trabalhadores rurais a intelectuais de renome, como Florestam Fernandes. O discurso independente de Lula também serviu para desconcertar os aparelhos repressivos, que não podiam enquadrá-lo, junto a seu grupo, aos quadros comunistas correntes, dentro de um panorama não favorável a discursos e atitudes radicais. $\mathrm{O}$ movimento do $\mathrm{ABCD}$ reintroduziu a classe trabalhadora no jogo político nacional, retomou as mobilizações de massa, congeladas por dez anos, e abriu novas perspectivas a esquerda nacional. Nesse ponto começamos a responder a segunda questão proposta, acerca das semelhanças e diferenças entre os movimentos de Osasco e do ABCD.

De certo que o cenário político nacional e internacional passou por profundas 481 FREDERICO, Celso. A Esquerda e o Movimento Operário, 1964-1984. (Vol. III) A reconstrução”. Belo Horizonte: Oficina de Livros, 1991. p. 12 
transformações em dez anos, embora o Brasil ainda fosse governado por uma ditadura civilmilitar, e a maioria dos países da América Latina se encontrassem geridos por governos autoritários. Não obstante, cerca de um ano antes da greve da Scania, fora eleito como presidente dos EUA o democrata Jimmy Carter, cujo programa de governo tinha por meta mitigar os anos de belicosidade do ciclo Richard Nixom. As novas diretrizes da Casa Branca privilegiavam medidas de caráter não beligerante e em defesa dos Direitos Humanos. No mesmo ano de sua posse em Washington, Carter visitou o Brasil e se reuniu com o general Ernesto Geisel, em Brasília, uma das pautas do encontro era o processo de transição democrática brasileiro. Dez anos antes o panorama era outro, com o governo dos EUA intensificando seus bombardeios na região do Vietnã, enquanto protestos pacifistas levados a cabo pela sociedade civil estadunidense eram severamente reprimidos pelas forças armadas desse país.

Em 1978 a esquerda armada não mais existia, a oposição ao regime estava concentrada em grupos de viés moderado, como vimos acima, e este fator foi fundamental para a postura menos violenta da repressão, embora excessos tenham sido observados por parte do polícia, nos três anos em que se organizaram movimento paredistas na região da Grande São Paulo, sempre capitaneadas pelo ABCD. Na década anterior, o Ministro do Trabalho Jarbas Passarinho enquadrava a greve de Osasco como "insurrecional" e dava ordens a polícia e ao exército (juntamente ao governador paulista da época, Abreu Sodré) para invadirem as fábricas ocupadas no município, assim como SMO, e decretava uma intervenção na entidade representativa dos metalúrgicos de toda a região ${ }^{482}$. Vimos que o caráter greve de Osasco foi radical, seus articuladores já confabulavam com representantes da guerrilha urbana paulista, e a proposta última do movimento era a derrubada da ditadura. As lideranças de São Bernardo sempre salientaram o viés econômico-corporativo de suas reivindicações, a partir de dirigentes sindicais que se pronunciavam "sem ideologia", como já mencionado. Autores como Ricardo Antunes buscaram problematizar o discurso não-ideológico de Lula e seu grupo, buscando desnudar o conteúdo político implícito a suas propostas de luta e mobilização.

Tendo como causalidade fundamental a precariedade das condições de salário e trabalho, (a

482 Em entrevista a revista Cadernos do Presente, Abreu Sodré afirmou que a posição do governo paulista "era a defesa da propriedade". Cadernos do Presente, Revista Cadernos do Presente - Greves Operárias (19681978), No 2.2 de julho de 1978. Op. Cit. p. 28. Para impressões do ministro Jarbas Passarinho sobre a greve de Osasco, PASSARINHO, Jarbas. Op. Cit. p. 297-309 
greve de São Bernardo) assumiu desde logo nítida dimensão política, ao confrontar a base material do próprio poder político. Desnudou o processo excludente e autocrático da auto-reforma (anistia) do regime e mostrou os imensos limites do liberalismo oposicionista parlamentar, incapaz de incorporar as reivindicações oriundas do mundo fabril. Apontou o atraso político dos partidos e aflorou a importância política do movimento sindical. Se ainda muito havia que avançar no plano político e ideológico - visto que se tratava de um movimento espontâneo, desprovido de independência teórica e ideológica, e portanto carente de uma direção consciente - o agente capaz de fazê-lo já estava em cena, de maneira irreversível. Esta a dialeticidade presente nas Greves metalúrgicas do $\mathrm{ABC}^{483}$.

O texto faz menção ao espontaneísmo presente nas paredes do $\mathrm{ABCD}$, na terceira seção deste trabalho vimos que em Osasco a greve foi detalhadamente planejada. Embora sua direção, em termos sociológicos, não tivesse a necessária consciência sobre o processo que punha em movimento, em termos táticos e estratégicos, sua ação foi consciente, em que pese seus desacertos. Nesse ponto ponto, acerca da condução da greve, houve diferenças substanciais entre as duas experiências, as mobilizações iniciadas em 1978 não se valeram da tática de ocupação de fábrica, interagindo junto aos operários por meio dos tradicionais piquetes, fora das empresas. A comunicação entre base e direção, nos dois casos, foi permeada pela atuação das comissões da fábrica. Vimos que José Ibrahim, ocupando o posto de presidente do SMO, adotou a prática de consulta direta as bases reunidas nas assembleias de sua entidade, tal postura ganhou destaque nos encontros do MIA. Dez anos depois, outra liderança carismática praticava o mesmo tipo de interlocução junto as massas, por meio das “assembleias plebiscitárias", especialmente as realizadas no estádio da Vila Euclides, em São Bernardo, contando com a participação de milhares de operários.

De maneira mais avançada do que foi observado em Osasco, no ABCD foi amplamente requerido o auxílio das associações de bairro, trazendo para o movimento esposas e filhos de operários em greve. O papel da igreja católica apresentou contornos semelhantes nos dois eventos, com clérigos dando guarida aos trabalhadores dentro de seus templos, usados como espaço de reunião e refúgio ante a repressão policial. Contudo, vimos que em julho de 1968 a repressão não poupou igrejas e espaços sacros em sua caçada aos trabalhadores osasquenses, chegando mesmo a prender padres, como o francês Joseph Wauthier.

De certa forma, as pretensões do GO foram em boa parte efetivadas dez anos depois a partir do ABCD, o movimento iniciado pelos operários da Scania, em maio de 1978, 
rapidamente se espalhou por toda grande São Paulo. O sucesso da primeira parede, vitoriosa em suas exigências, ensejou a continuidade das paralisações em anos posteriores, reconquistando via mobilização o direito de greve, cerceado após o golpe de 1964. Apesar de Lula e seus companheiros não contemplarem em seus projetos a derrubada da ditadura, como os ativistas de Osasco o fizeram na década anterior, as greves do ABCD foram capazes de abalar as estruturas do poder empresarial-militar, deram novo vigor as lutas pela democracia no Brasil, e na sua esteira, foi possível a formação de uma grande frente de massas mobilizadas em torno do movimento Diretas Já! Três anos depois a esse movimento o militares retornaram aos quartéis, o comando da Nação retornou as mãos de civis, apesar de todo esse processo ter se efetivado perante os auspícios das forças armadas.

Por fim, o potencial de pressão verificado em ambas as greves, levando-se em conta a importância das duas regiões, em termos econômicos, foi bastante distinto. O parque fabril de Osasco era diversificado, com empresas voltadas setor da base, e bens de consumo não duráveis. Tomemos como exemplo a Cobrasma, maior empresa da localidade no período em questão, cuja produção estava voltada ao segmento ferroviário - aqui encontramos uma diferença crucial com relação ao que se veria dez anos depois, no ABCD. Sabemos que o carro chefe da indústria brasileira, desde finais dos anos 1950, foi a indústria automobilística. A Cobrasma foi edificada na conjuntura do nacional-desenvolvimentismo varguista, num impulso de integração em termos de trasporte barato e eficaz, por meio da ampliação da malha ferroviária nacional. A partir do ciclo $\mathrm{JK}$, a orientação da industria brasileira deixou de privilegiar seu setor de base, e se voltou a produção de bens de consumo duráveis, voltados as classes médias e altas, como já discutido nesse trabalho. Em 1968, a maior empresa de Osasco concentrava seu faturamento em encomendas estatais e internacionais. Vimos que essa indústria fechou suas portas em princípios dos anos 1990.

Por outro lado, no ABCD se concentrava o eixo dinâmico da indústria nacional, voltado a produção de veículos automotivos. Nesta região se constituiu "um operariado inserido na grande indústria moderna, com níveis de qualificação do trabalho superiores aos da indústria tradicional, (...) com um contingente significativo de trabalhadores concentrados nas unidades industriais. Esse proletariado novo, vinculado a indústria automobilística viveu, (...) a intensidade das contradições imanentes ao desenvolvimento do industrial no Brasil (...) ${ }^{\natural 484}$ A posição central ocupada pelos trabalhadores de São Bernardo e região conferia 
destaque as suas mobilizações, a paralisação de suas máquinas interferia diretamente nos lucros de um dos mais poderosos setores da burguesia brasileira. Tal posição conferiu maior destaque na imprensa paulista, ciosa na defesa dos interesses das classes produtoras, chamou a atenção de toda sociedade, angariou a simpatia de artistas e intelectuais, e inquietou os núcleos do poder civil-militar.

Se o movimento de julho de 1968 chamou a atenção pelo seu caráter desafiador, insurgente e radical, o de 1978 se notabilizou por suas dimensões econômicas e políticas. A importância do ABCD para a economia nacional deu aos trabalhadores da região o posto de vanguarda do MO brasileiro, a força de seu movimento trouxe de volta a palavra greve ao léxico do proletariado. As dimensões modestas do parque industrial osasquense não permitiam aos paredistas de julho proporcionar sérias perturbações no setor produtivo nacional. Se em última instância a economia determina tudo, os ativistas do GO estavam atentos a essa realidade, mesmo que de forma não declarada, exatamente por isso apostaram suas fichas na expansão de sua greve, única forma de provocar abalos significativos no regime. Restrita a Osasco, a parede era facilmente neutralizável, como se verificou. A dura repressão ao movimento poucas horas após o seu deflagrar corroborou essa assertiva. Como dissemos acima, a greve da Scania pegou a todos de surpresa, os patrões, as OS, o PCB, o MDB, e, sobretudo, a polícia. Dez anos antes a repressão estava vigilante.

Para concluir nossa exposição final, resta discorrer sobre qual o legado da greve de Osasco. A importância histórica desse evento já foi salientada ao longo desse trabalho, e de diversas teses, artigos, textos memorialistas, documentários, etc. Antonio Roberto Espinosa chama as as grandes greves de de 1968 de "dois relâmpagos" na noite escura que representou a ditadura. Diogo Marques, em artigo publicado na revista Cadernos do Presente, comenta que a "existência pioneira de4 um movimento de massas capaz de realizar formas diversificadas de participação política, através de uma prática de rompimento com o populismo, constitui a experiência básica de Osasco para o movimento operário popular atual, desde que não se deixe de levar em conta os limites provocados pelo isolamento e difusão de sua vanguarda" ${ }^{\prime 45}$. Ainda sobre este ponto, João Quartim de Moraes tece os seguintes comentários:

julho de 1968, possuía algo em torno de 3 mil operários (em 1964 o contingente de trabalhadores chegou a 6 mil), somente a Volkswagem, em 1977, possuía 39.057 operários. Uma empresa de porte médio, em ternos de ABCD, possuía 3.777 empregados. ANTUNES, Ricardo. Op. Cit. p. 128; para números citados em nota, Idem, p. 144.

485 MARQUES, Diogo. "Osasco: referência viva para o movimento atual". In: Cadernos do Presente - Greves Operárias (1968-1978), № 2. 2 de julho de 1978. Op. Cit. p. 60 
Um novo sindicalismo está pois emergindo das catacumbas da sociedade civil. Face à maturidade que tem demonstrado, Osasco aparece como um brado na noite sombria cujo termo parece estar se anunciando. Enquanto forma de condução de uma luta reivindicativa, a greve de julho de 1968 nada tem a ensinar à de maio-junho de 1978. Mas vimos justamente que o símbolo Osasco não se reduz à dimensão sindical. Se uma das questões colocadas pelos grevistas da Cobrasma, da Braseixos, da Lonaflex, da Brown Boveri (que fazer para pôr fim aos salários de miséria, à insalubridade e aos riscos do trabalho?) encontrou uma resposta mais construtiva, mais eficaz, mais realista do novo movimento sindical, a outra (que fazer para que os operários afirmem seus interesses não somente enquanto produtores das riquezas materiais da sociedade capitalista, mas também como cidadãos, para que façam pesar seu ponto de vista sobre os grandes assuntos da vida nacional e internacional, para que surja uma nova sociedade que lhes abra horizontes mais amplos que os da fábrica onde se consomem suas energias e do bairro pobre onde vivem a privação daquilo mesmo que produziram?) permanece colocada: definitivamente, o que se há de reter da experiência de Osasco é a vontade (que os pedantes chamarão "voluntarista") de construir seu próprio destino. E esse símbolo é imorredouro $^{486}$.

Não é possível estabelecer uma relação teleológica entre as experiencias de Osasco e do ABCD, os continuadores das proposições suscitadas no biênio 1967-68 seguiram articulados nas Oposições Sindicais, espalhadas por toda Grande São Paulo. No caso de Osasco, tal tarefa foi encampada pelos setores cristãos das OS. Vimos que o novo sindicalismo surgido em São Bernardo guardava uma posição de equidistância em relação as tendências atuantes no MO paulista. O que ficou do movimento de Osasco foi sua proposta de um modelo alternativo de organização e postura diante do Estado. Questões propostas pela classe operária mais avançada, em suas mais distintas tendencias, foram postas em pauta durante a gestão de José Ibrahim a frente do SMO. Comissões e fábrica, interlocução direta entre direção e bases, iniciativas culturais, cursos de iniciação política, aproximação junto as associações de bairro, todos esses elementos foram resgatados nas greves do $\mathrm{ABCD}$, em finais da década de setenta. Questionamentos a estrutura sindical brasileira também estiveram presentes entre os operários osasquenses, em propostas de mudanças que até hoje continuam pendentes, como o atrelamento das entidades representativas laborais ao Estado.

Especificamente sobre o GO, tal movimento significou algo único na história das lutas sociais brasileiras, procuramos especificar essa proposição ao longo deste trabalho. A

486 QUARTIM , João. “O símbolo de Osasco". In: Cadernos do Presente - Greves Operárias (1968-1978), № 2. 2 de julho de 1978. Op. Cit. 69 
notoriedade das mobilizações políticas verificadas na cidade em discussão, na segunda metade dos anos 1960, teve como setor de ponta os estudantes-operários articulados em torno de lideranças como José Ibrahim, Roque Aparecido da Silva, Antonio Roberto Espinosa, Manuel Dias do Nascimento, José Campos Barreto, e muitos outros não citados nesse estudo. A ação impetuosa desse grupo colocou município de Osasco no centro das agitações políticas em combate ao regime militar em 1968. O comprometimento desses jovens, todos na faixa dos vinte anos, lhes permitiu estar na vanguarda do movimento estudantil, operário, e na guerrilha urbana. O destino desses ativistas foi o mesmo de todos aqueles que pegaram em armas contra a autocracia política que governou o Brasil por 21 anos, prisão, tortura, exílio e morte.

Após a redemocratização do país, o sacrifício daqueles que ousaram desafiar a ditadura foi resgatado, chegando até as gerações mais jovens por meio de publicações, teses, filmes, séries de TV, novelas, etc. Em tempos de revisionismo, quando intelectuais e publicistas conservadores buscam mitigar o autoritarismo do ciclo militar, a trajetória de vida - de morte - de militantes como aqueles reunidos no GO serve como indicativo da natureza classista, excludente e violenta da ditadura brasileira. 


\section{Referências Bibliográficas}

ALI, T. O poder das barricadas: uma autobiografia dos anos 60. São Paulo: Editora Boitempo, 2008.

ANTUNES, R. C. \& NOGUEIRA, A. 2a Ed. O que são Comissões de Fábrica. São Paulo: Editora Brasiliense, 1982.

ANTUNES, R. O que é sindicalismo”. São Paulo: Editora Brasiliense, 1985.

A Rebeldia do Trabalho (O Confronto Operário no ABC Paulista: As greves de 1978/80).

$2^{\text {a }}$ Edição. Campinas-SP: Editora da Unicamp, 1992.

ARNS, P. E. Brasil: Nunca Mais. $2^{\text {a }}$ Ed. Petrópolis-RJ: Vozes, 1985.

BANDEIRA, M. O Governo João Goulart: as lutas sociais no Brasil: 1961-1964. 6 a Edição. Rio de Janeiro: Civilização Brasileira, 1983.

BASSANEZI PINSKY, C. (org). Fontes históricas. São Paulo, Contexto, 2005.

BARCELOS, J. CPC da UNE: Uma História de Paixão e Consciência. Rio de Janeiro: Editora Nova Fronteira, 1994

BENEVIDES, M. V. O PTB e o trabalhismo: partido e sindicato em São Paulo (1945-1954). São Paulo: Editora Brasiliense, 1989.

BICUDO, H. Meu depoimento sobre o Esquadrão da Morte. São Paulo: Editora Martins Fontes, 2002.

BLOCH, M. Apologia da História: ou o ofício de historiador. Rio de Janeiro, Jorge Zahar, 2002. 
BOBBIO, N. Et alii (org). Dicionário de Política. $7^{\text {a }}$ Ed. Brasília-DF: Editora da Universidade de Brasília, 1995.

BOITO Jr. A. Sindicalismo de Estado no Brasil. Campinas-SP: Editora da Unicamp \& Editora Hucitec, 1991.

BRASIL NUNCA MAIS. Perfil dos Atingidos. Petrópolis-RJ: Editora Vozes, 1988.

BRESSER PEREIRA, L. C. Desenvolvimento e crise no Brasil: 1930-1983. $3^{\text {a }}$ Edição. São Paulo: Editora Brasiliense, 1985.

CANO, W. Raízes da Concentração Industrial em São Paulo. $4^{\mathrm{a}}$ Ed. Campinas-SP: Editora da Unicamp, 1998

CAllado, A. Tempo de Arraes: Padres e Comunistas na Revolução sem Violência. Rio de Janeiro: José Álvaro Editor S.A, 1964.

CARDOSO, F. H. Empresário Industrial e Desenvolvimento Econômico no Brasil. São Paulo: Editora Difel, 1972

CARONE, E. Movimento operário no Brasil (1964-1984). São Paulo: Difel, 1984.

A República Velha. $3^{\mathrm{a}}$ Ed. São Paulo: Editora Difel, 1975.

__ A Segunda República (1930-1937). São Paulo: Editora Difel, 1973.

O Estado Novo (1937-1945). São Paulo: Editora Difel, 1977.

Movimento Operário no Brasil (1877-1944).2ª Ed. São Paulo: Editora Difel, 1984.

_Movimento operário no Brasil (1945-1964). 2a Ed. São Paulo: Editora Difel, 1981.

CASTRO, S. “Apogeu e Crise do Populismo - (1945-1964)”. In: Movimento Operário 
Brasileiro. Belo Horizonte-MG: Editora Vega, 1980.

CAUTE, D. 1968 Dans le Monde. Paris-França: Editions Robert Laffont. 1988.

CAVALCANTE, P. O caso eu conto, como o caso foi. $3^{\text {a }}$ Ed. Recife-PE: Editora Guararapes, 1980.

CHAGAS, V. F. A. G. “A Vanguarda Popular Revolucionária: dilemas e perspectivas da luta armada no Brasil (1968-1972)”. Franca-SP: Dissertação de Mestrado, UNESP, 2000.

CHE GUEVARA, E. Textos políticos. $4^{\text {a }}$ Ed. São Paulo: Global Editora, 2009. p. 84

CHILCOTE, R. O Partido Comunista Brasileiro. Rio de Janeiro: Editora Graal, 1982.

COHN-BENDIT, D. Et. alii. A Revolta Estudantil. Rio de Janeiro: Editora Laudes S.A., 1968.

COELHO, M. Z. Et. Alii. Osasco, História e Identidade. Osasco-SP: Editora da Fundação Instituto Tecnológico de Osasco - FITO, 2004.

COMBLIN, J. A Ideologia da Segurança Nacional. O Poder Militar na América Latina. Rio de Janeiro: Editora Civilização Brasileira, 1978.

COSTA, S. A. CGT: e as lutas sindicais brasileiras (1960-1964). São Paulo: Editora do Grêmio Politécnico, 1981

COUTO, A. M. M. Greve na Cobrasma: uma história de resistência. São Paulo: Editora Annablume, 2003.

CUNHA, L. A. C. R. A Universidade Reformada: o golpe de 1964 e a modernização do ensino superior. São Paulo: Editora da UNESP, 2007.

D’ARAÚJO, M. C. Et. alii. (Org) Os anos de chumbo: a memória militar sobre a repressão. Rio de Janeiro: Editora Relume-Dumará, 1994. 
DEBRAY, R. Revolução na Revolução. São Paulo: Centro Editor Latino-Americano, sd

DREIFUSS, R. 1964: a conquista do Estado. 2a Ed. Petrópolis-RJ: Editora Vozes, 1981.

DULLES, J.W.F. Anarquistas e Comunistas no Brasil, 1900-1935. Rio de Janeiro: Nova Fronteira, 1977

ESPINOSA, A. R. Abraços que sufocam. São Paulo: Editora Viramundo, 2000.

FANON, F. Os Condenados da Terra. 2a Ed. Rio de Janeiro: Editora Civilização Brasileira, 1979.

FERREIRA, J. ; REIS FILHO, D. A. (Org). As Esquerdas no Brasil (Vol. 3) "Revolução e Democracia - 1964 ...”. Rio de Janeiro: Editora Civilização Brasileira, 2007.

FICO, C. "Espionagem, polícia política, censura e propaganda: os pilares básicos da repressão”. In: FERREIRA, J. ; DELGADO, L. A. N. (Org.). O Brasil Republicano (Vol. 4). "O tempo da ditadura: ditadura militar e movimentos sociais em fins do século XX". 2 Ed. Rio de Janeiro: Editora Civilização Brasileira, 2007.

FONTES, P. Trabalhadores e cidadãos: Nitro Química, a fábrica e as lutas operárias nos anos 50. São Paulo: Editora Annablume, 1997.

FORACCHI, M. M. A Juventude na Sociedade Moderna. São Paulo: Livraria Pioneira Editora, 1972.

FRANK, A. G. Capitalismo y Subdesarollo em América Latina. México: Siglo Veintiuno Editores, 1978

FREDERICO, C. (org). A esquerda e o movimento operário, 1964-1984. (Vol.1) São Paulo: Editora Novos Rumos, 1987. 
Esquerda e o Movimento Operário, 1964-1984. A crise do “milagre brasileiro”. (Vol. II) Belo Horizonte-MG: Editora Oficina de Livros, 1990.

_ A Esquerda e o Movimento Operário, 1964-1984. A reconstrução. (Vol. III) Belo Horizonte-MG: Editora Oficina de Livros, 1991.

FURTADO, C. Formação Econômica do Brasil. $6^{\text {a }}$ Ed. Rio de Janeiro: Fundo de Cultura, 1964.

_ Subdesenvolvimento e Estagnação na América Latina. Rio de Janeiro: Editora Civilização Brasileira, 1966.

GARCIA, M. A. ; VIEIRA, M. A. Rebeldes e Contestadores: 1968, Brasil, França e Alemanha. São Paulo: Editora Perseu Abramo, 2009.

GASPARI, H. A ditadura envergonhada. (Vol. 1) São Paulo: Companhia das Letras, 2002

_ A ditadura escancarada. (Vol. 2) São Paulo: Editora Companhia das Letras, 2002

GORENDER, J. Combate nas Trevas. 4ª Ed. São Paulo: Editora Ática, 2000.

GRAMSCI, A. Cadernos do Cárcere. (Vol. 3) Edição e tradução Carlos Nelson Coutinho Et alii. Rio de Janeiro: Civilização Brasileira, 2000.

GRAMSCI, A. ; BORDIGA, A. Conselhos de Fábrica. São Paulo: Editora Brasiliense, 1981

GURGEL, A. P. A rebelião dos estudantes, (Brasília, 1968). Brasília-DF: Editora da UNB, 2002.

HISTÓRIA DA UNE. Depoimentos de ex-dirigentes. (Vol.1) São Paulo: Editorial Livramento, 1980. 
HISTÓRIA DO MARXISMO NO BRASIL: O impacto das revoluções. (Vol.1). QUARTIM DE MORAES, J. \& REIS FILHO, D. A. (Org). $2^{\text {a }}$ Ed. Campinas-SP: Editora da UNICAMP, 2007.

Os influxos teóricos. (Vol.2). QUARTIM DE MORAES, J. \& REIS FILHO, D. A. (org). $2^{\text {a }}$ Ed. Campinas-SP: Editora da UNICAMP, 2007.

Teorias e interpretações. (Vol.3). QUARTIM DE MORAES, J. (Org). $2^{\mathrm{a}}$ Ed. CampinasSP: Editora da UNICAMP, 2007.

Visões do Brasil. (Vol. 4). QUARTIM DE MORAES, J. \& DEL ROIO, M. (Org). 2a Ed. Campinas-SP: Editora da UNICAMP, 2007.

Partidos e organizações dos anos 1920 aos 1960. (vol. 5). RIDENTI, M. \& REIS FILHO, D. A. (Org). 2a Ed. Campinas-SP: Editora da UNICAMP, 2007.

Partidos e movimentos após os anos 1960. (vol. 6). RIDENTI, M. \& REIS FILHO, D. A. (Org). 2a Ed. Campinas-SP: Editora da UNICAMP, 2007.

HOBSBAWM, E. História do Marxismo. O marxismo na época da terceira internacional: a revolução de outubro: (Vol. 5). Rio de Janeiro: Editora Paz e Terra, 1984.

História do Marxismo: O marxismo na época da terceira internacional: da internacional comunista de 1919 às frentes populares (vol. 6). Rio de Janeiro: Editora Paz e Terra, 1985.

História do Marxismo: O marxismo na época da terceira internacional: a URSS da construção do socialismo ao stalinismo (vol. 7). Rio de Janeiro: Editora Paz e Terra, 1986.

História do Marxismo: O marxismo na época da terceira internacional: o novo capitalismo, o imperialismo, o terceiro mundo (vol. 8). Rio de Janeiro: Editora Paz e Terra, 1988. 
Era dos Extremos. O breve século XX (1914-1991). São Paulo: Editora Companhia das Letras, 2009.

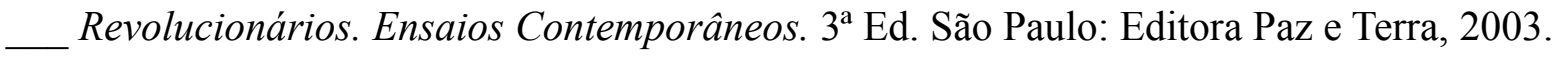

IANNI, O. O colapso do populismo no Brasil. Rio de Janeiro: Editora Civilização Brasileira, 1971.

IBRAHIM. J. O que todo cidadão deve saber sobre comissões de fábrica. São Paulo: Editora Global, 1986.

JESUS, P. S. Osasco: JOC, ACO e PO no Movimento Operário (1960-1970). Dissertação de Mestrado. São Paulo: PUC-SP, 2007.

JOSÉ, E. \& MIRANDA, O. Lamarca, o capitão da guerrilha. $8^{\mathrm{a}}$ Ed. São Paulo: Editora Global, 1984.

LAQUE, J. R. Pedro e os Lobos. Os anos de Chumbo na trajetória de um guerrilheiro urbano. São Paulo: Ava Editorial, 2010

LE GOFF, J. A História nova. $4^{\text {a }}$ Ed. São Paulo: Editora Martins Fontes, 1998.

LENIN, V. Que fazer? São Paulo: Editora Hucitec, 1978.

LOPES, C.L.E. “A Organização Sindical dos Metalúrgicos de São Paulo”. Tese de Doutorado. São Paulo: FFLCH-USP, 1992.

LÖWY, M. O Marxismo na América Latina. Uma antologia de 1909 aos dias atuais. São Paulo: Editora Fundação Perseu Abramo, 1999.

LUNGARETTI, C. Náufrago da Utopia. São Paulo: Geração Editorial, 2005. 
MACIEL, W. A. "Militares de Esquerda: formação, participação política e engajamento na luta armada (1961-1974)”. Tese de Doutorado. São Paulo: FFLCH-USP, 2009.

MANDEL, E. Controle Operário, Conselhos Operários e Autogestão. São Paulo: Centro Pastoral Vergueiro, 1987

MANTEGA, G. A economia política brasileira. 8a Ed. Rio de Janeiro: Editora Vozes, 1995.

MARANHÃO, R. Sindicatos e Democratização (Brasil, 1945/1950). São Paulo: Editora Brasiliense, 1979.

MARIGHELLA, C. Escritos de Marighella. São Paulo: Editora Livramento, 1979.

MARTIM, S. A Escola Secundária e Cidade: Osasco, anos 1950/1960. Tese de Doutorado. São Paulo: PUC-SP, 2006.

MARTINS, L. A Geração do AI-5 e Maio de 68: Duas manifestações intransitivas. Rio de Janeiro: Editora Argumento, 2004.

MARTINS FILHO, J. R. Movimento Estudantil e Ditadura Militar - 1964 -1968. CampinasSP: Editora Papirus, 1987.

"MEMOREX: elementos para uma história da UNE". São Paulo: Edições Guaraná. Único exemplar, s/d

MINISTÉRIO DO EXÉRCITO - II Exército (Quartel General). Inquérito Policial Militar (IPM) - CRUSP. Relatório, anos 1968-1969. Encarregado: coronel Sebastião Alvim. Disponível no endereço eletrônico: http://movebr.wikidot.com/crusp:ipm-68

MIRANDA, N. ; TIBÚRCIO, C. Dos filhos deste solo - Mortos e desaparecidos politicos durante a ditadura militar: a responsabilidade do Estado. São Paulo: Editora Boitempo, 1999.

MIRANDA, O. Obscuros heróis de Capricórnio. São Paulo: Editora Global, 1987. 
__ “Sindicato e Classe Operária”. São Paulo. Tese de Livre Docência: FFLCH-USP, 1987.

MOISÉS, J. A. “Classes Populares e Protesto Urbano. São Paulo”. Tese de Doutorado. São Paulo: FFLCH-USP, 1978. p. 127

MOISÉS, J. A. Greve de Massa e Greve Política (estudo da Greve dos 300 Mil em São Paulo). São Paulo: Editora Polis, 1978.

MONIZ BANDEIRA, L. A. Presença dos Estados Unidos no Brasil - dois séculos de História. 8a Ed. São Paulo: Editora Civilização Brasileira, 1978.

__ O Governo João Goulart: as lutas sociais no Brasil ( 1961-1964). Rio de Janeiro: Editora Civilização Brasileira, 1983.

MOREIRA ALVES, M. Beabá dos MEC-Usaid. Rio de Janeiro: Edições Gervasa, 1968. 68 Mudou o Mundo. 2a Ed. Rio de Janeiro: Nova Fronteira, 1993

MOREIRA ALVES, M. H. Estado e Oposição no Brasil (1964-1984). Bauru-SP: Edusc, 2005.

MOTTA, A. C. C. R. "Cobrasma: trajetória de uma empresa brasileira”. Tese de Doutorado. São Paulo: FFLCH-USP, 2006.

MOTTA, R. P. S. Em guarda contra o "perigo vermelho": o anticomunismo no Brasil (19171964). São Paulo: Editora Perspectiva, 2002.

MURARO, V. F. Juventude Operária Católica. São Paulo: Editora Brasiliense, 1985.

NASCIMENTO, B.H. A Ordem Nacionalista Brasileira. São Paulo: Humanitas/FFLCH-USP, 2002. 
OLIVEIRA, F. "Padrões de acumulação, oligopólios e Estado no Brasil (1950-1976)". In: A Economia da Dependência Imperfeita. 2 ${ }^{\text {a }}$ Edição. Rio de Janeiro: Edições Graal, 1977.

OLIVEIRA, N. C.; NEGRELli, A. L. M. R. Osasco e Sua História. São Paulo: CG Editora e Distribuidora, 1992.

PAINTER, D. The Cold War: an international history. London: Routledge, 1999.

PASSARINHO, J. Um híbrido fértil. Rio de Janeiro: Editora Expressão e Cultura, 1997.

PATARRA, J. Iara: reportagem biográfica. $2^{\text {a }}$ Ed. Rio de Janeiro: Rosa dos Tempos, 1992.

PAZ, C. E. Viagem a Luta Armada. Memórias romanceadas. Rio de Janeiro: Editora Civilização Brasileira, 1996.

PEDREIRA FILHO, V. S. Comissões de Fábrica: um claro enigma. São Paulo: Entrelinhas/Cooperativa Cultural da UFRN, 1997.

PERICÁS, L. B. Che Guevara e a luta revolucionária na Bolívia. $2^{\mathrm{a}}$ Ed. São Paulo: Xamã, 2008.

PETRONE, P. “A influência da imigração italiana nas origens da industrialização brasileira”. IN: DE BONI, L. A. A Presença Italiana no Brasil. Porto Alegre-RS: Fondazione Giovanni Agnelli, 1987.

PINTO, B. Guerra Revolucionária. São Paulo: Editora Forense, 1964.

PITERI, G. Sonhar é Preciso: comunidade e politica nos anos da ditadura. Osasco-SP: Editora da FIEO, 2008.

POERNER, A. J. O poder jovem. $2^{\text {a }}$ Ed. Rio de Janeiro: Editora Civilização Brasileira, 1979. 
PORTO, A. R. História Urbanística de São Paulo (1554-1988). São Paulo: Carthago \& Fortes Editoras Associadas Ltda, 1992.

PRADO JR, C. P. A revolução brasileira. 2a Ed. São Paulo: Editora Brasiliense, 1966.

REIS FILHO, D. A. A revolução faltou ao encontro. São Paulo: Editora Brasiliense, 1990 1968, a paixão de uma utopia. Rio de Janeiro: Editora Espaço e Tempo, 1988. p. 203

REIS FILHO, D. A; SÁ, J. F. Imagens da revolução. $2^{\mathrm{a}}$ Ed. São Paulo: Editora Expressão Popular, 2006.

RESUMO DOS FATOS HISTÓRICOS DE OSASCO (1639-1991). Editora de Prefeitura de Osasco. sd

REZENDE, M. J. A ditadura no Brasil: repressão e pretensão de legitimidade 1964-1984. Londrina-PR: Editora da UEL, 2001.

RIDENTI, M. S. O fantasma da revolução brasileira. São Paulo: Editora da UNESP, 1993.

RIZEK, C. S. Osasco: 1968. A Experiência de um Movimento. Dissertação de Mestrado. São Paulo: PUC-SP, 1988.

RODRIGUES, L. M. Conflito Industrial e Sindicalismo no Brasil. São Paulo: Editora Difel, 1966.

SACHS. E. "Qual a Herança da revolução russa e outros textos". Belo Horizonte-MG: Editora Segrac, 1988.

SAES, D. Classe média e sistema político no Brasil. São Paulo: Editora T. A. Queiroz, 1985.

SAINT-PIERRE, H. L. A política armada. Fundamentos da guerra revolucionária. São Paulo: Editora da UNESP, 2000. 
SANTOS, M. C. L. Dos. (org). Maria Antonia: uma rua na contramão. São Paulo: Editora Nobel, 1988.

SANAZAR, H. Osasco, Sua História, Sua Gente. Osasco-SP: Edição do Autor, 2003.

SCORSIM, L. Mariátegui: Vida e Obra. São Paulo: Editora Expressão Popular. 2006.

SEBE BOM MEIHY, J. C. Manual de História Oral. 4a Ed. São Paulo: Edições Loyola, 2002.

SECCO, L. Gramsci e a revolução. São Paulo: Editora Alameda, 2006.

SECRETARIA ESPECIAL DOS DIREITOS HUMANOS. Direito a Memória e a Verdade. Comissão Especial Sobre Mortos e Desaparecidos Políticos, 2007.

SKIDMORE, T. E. Brasil: de Getúlio a Castelo (1930-1964). 9ª ed. Rio de Janeiro, Paz e Terra, 1982.

__ Brasil: de Castelo a Tancredo (1964-1985). Rio de Janeiro, Paz e Terra,1988.

SILVA, M. (Org) 1964/1968, a ditadura já era ditadura. São Paulo: LCTE Editora, 2006.

SILVA, M. A. M. Os escritores da guerrilha urbana: literatura de testemunho, ambivalência e transição política (1977-1984). São Paulo: Editora Annablume; Fapesp, 2008.

SINGER, P. Desenvolvimento Econômico e evolução Urbana. São Paulo: Companhia Editora Nacional, 1968.

A Crise do "Milagre". Interpretação crítica da economia brasileira. $7^{\mathrm{a}}$ Edição. São Paulo: Editora Paz e Terra, 1985.

SINGER P.; CALDEIRA BRANT, V. (Org.). São Paulo: O Povo em Movimento. São Paulo: Vozes, 1980.

SIMÕES, S. Deus, pátria e família. Petrópolis, Vozes, 1985. 
SIRKIS, A. Os carbonários. $8^{a}$ ed. São Paulo, Global, 1983.

SOUZA, P. Autópsia do Medo: vida e morte do delegado Sérgio Paranhos Fleury. São Paulo: Globo, 2000.

SOUZA MARTINS, H. H. O Estado e a Burocratização no Brasil. São Paulo: Editora Hucitec. 1979

STACCHINI, J. Março de 64: a mobilização da audácia. São Paulo, Companhia Editora Nacional, 1965.

TAVARES, R.R. A "moscouzinha" brasileira : cenários e personagens do cotidiano operário de Santos (1930-1954). Dissertação de Mestrado. São Paulo: FFLCH-USP, 2004.

THOMPSON, E. Et. alii. Extremismo e Guerra Fria. São Paulo: Editora Brasiliense, 1985.

TROTSKY, L. A História da Revolução Russa. Rio de Janeiro: Editora Paz e Terra, 1978. (Vol. 1)

VALLE. M. R. 1968: O diálogo é a violência: movimento estudantil e ditadura militar no Brasil. São Paulo, Editora da UNICAMP, 1999.

VIANNA, M. Uma tempestade como sua memória - a história de Lia, Maria do Carmo Brito. Rio de Janeiro: Editora Record, 2003.

VISENTINI, P. F. A revolução vietnamita: da libertação nacional ao socialismo. São Paulo: Editora da UNESP, 2008.

Da guerra fria à crise (1945-1990): as relações internacionais contemporâneas. Porto Alegre-RS: Editora da URGS, 1990.

WERNER, H. P. Raizes do movimento operário em Osasco. São Paulo, Cortez Editora, 1981. 
WEFFORT, F. Participação e conflito industrial: Contagem e Osasco, 1968. Cadernos CEBRAP 5. São Paulo, 1972.

__ Movimiento Obrero y Política em Brasil: Las Huelgas da 1968 em Contagem e Osasco. $\mathrm{s} / \mathrm{d}$.

O populismo na política brasileira. Rio de Janeiro, Paz e Terra, 1978.

\section{Artigos Consultados}

ANTUNES, R. ; RIDENTI, M. “1968 no Brasil”. In: Revista Margem Esquerda. Ensaios Marxistas. No 11. São Paulo: Editora Boitempo, 2008.

CHAGAS, Fábio A. Gonçalves. “Ação e Revolução: os zigue-zagues estratégicos da VPR em 1968”. In: Cadernos de Pesquisa do CDHIS, No 35, 2006. Disponível também em formato digital, no endereço eletrônico:

http://www.seer.ufu.br/index.php/cdhis/article/viewFile/487/456.

CLIFF, T. "Trotsky: The darker the night the brigher the star (1927-1940)". Artigo disponível em formato digital no site: www.marxists.org

CUNHA, L. F. “A Universidade Reformada” Apud: REIS, Ana Maria. Formas de Acesso a Educação Superior: Méritos e Privilégios. Artigo disponível no site: www.histedbr.fae.unicamp.br

DANUSA, M. “A Luta pela emancipação”. Artigo disponível no Site da Prefeitura de Osasco: www.camaraosasco.sp.gov.br

DOWBOR, L. "O mosaico partido (a economia além das equações)", 2007. Disponível no site do autor: http://dowbor.org/artigos.asp. 
FIORI, J. L. "Estado de Bem-Estar Social: padrões e crises". Artigo disponível em: http://www.iea.usp.br/iea/artigos/fioribemestarsocial.pdf

LEITE, I. C. "Radicalização Política Frente ao Regime Militar em Belo Horizonte - Grupo Colina, (1967-1969)". In: REVISTA HISTÓRIA HOJE. Volume 3 - № 8, dezembro de 2005. Disponível em formato digital no site da Anpuh: www.anpuh.org

LOLLO, A. "Itália-1968: movimento estudantil e conflito social". In: Revista História: Debates e Tendências / Universidade de Passo Fundo, Instituto de Filosofia e Ciências Humanas, Programa de Pós- Graduação em História. - Vol. 1, n. 1, (junho, 1999). Passo Fundo-RS : UPF, 1999. Disponível em:

http://www.upf.br/ppgh/download/rev_hist_v8_n1.pdf

MARTINS FILHO, J. R. “A Influência doutrinária francesa sobre os militares brasileiros nos anos de 1960". IN: Revista Brasileira de Ciências Sociais. Vol. 23, nº 67.

Disponível em:http://www.scielo.br/pdf/rbcsoc/v23n67/04.pdf

MATOS, O. C. “Tardes de Maio". In: Revista Margem Esquerda. Ensaios Marxistas. № 11. São Paulo: Editora Boitempo, 2008.

PORTELLI, A. "Tentando aprender um pouquinho. Algumas reflexões sobre a ética na história oral”. In: Projeto História. Revista do Programa de Estudos Pós-graduados em História e do Departamento de História da Pontifícia Universidade Católica de São Paulo. Número 15. Ética e História Oral. São Paulo, 1981.Disponível em formato digital no endereço eletrônico:

http://www.pucsp.br/projetohistoria/downloads/revista/PHistoria15.pdf

ROLLEMBERG, D. O apoio de Cuba à luta armada no Brasil: o treinamento guerrilheiro. Obra disponível em forma de artigo, no endereço eletrônico:

http://www.historia.uff.br/nec/sites/default/files/O_apoio_de_Cuba_a_luta_armada.pdf

SECCO, L. "Cooperativas e Conselhos Operários". Artigo publicado pelo site da PUC, 
disponível em formato digital:

http://www.pucsp.br/neils/downloads/v9 artigo_lincoln_secco.pdf

SILVA, R. A. "Osasco 1968: a história de um movimento". Artigo publicado pela revista Teoria e Debate, edição especial sobre 1968; maio de 2008. Também disponível no endereço eletrônico:

http://www.joaopaulo.org.br/20080527633/artigos/osasco 1968 historia de um movimento. $\underline{\mathrm{html}}$

\section{Periódicos consultados}

Cadernos do Presente - Greves Operárias (1968-1978), № 2; julho de 1978. São Paulo: Editora Aparte, 1978.

Revista Cult, $\quad \mathrm{N}^{\mathrm{o}}$ 126, março de 2010. Disponível no site: http://revistacult.uol.com.br/home/2010/03/1968-a-rebeliao-estudantil-nos-estados-unidos

Jornal Folha de São Paulo, acervo da particular da empresa disponível em formato digital no endereço eletrônico: http://acervo.folha.com.br.

Jornal Política Operária, órgão de comunicação da Organização Revolucionária Marxista Política Operária, disponível em formato digital no CEDEM da UNESP

Jornal Última Hora, acervo digital disponível no arquivo do Estado de São Paulo, no endereço eletrônico: http://www.arquivoestado.sp.gov.br/uhdigital/pesquisa.php

Jornal Visão Oeste, no 244, 20 a 26 de julho de 2008.

Revista Visão Trabalhista, editada pelo Sindicato dos Metalúrgicos de Osasco e Região, suplemento especial em comemoração aos 40 anos da Greve de Osasco, julho de 2008. Disponível em formato digital no endereço eletrônico: http://50anos.sindmetal.org.br/pdfs/40AnosGreve.pdf 
Jornal Voz Operária, órgão de comunicação do Partido Comunista Brasileiro, acervo disponível em formato digital no CEDEM da UNESP.

\section{Sites Consultados}

Arquivo Marxista na Internet: www.marxists.org

Blog de Ernesto Carlos do Nascimento, filho de Manuel Dias do Nascimento, militante do GO: http://ernesto.blog.br/

Câmara Municipal de Osasco: www.camaraosasco.sp.gov.br

Centro Victor Meyer: www.centrovictormeyer.org

Instituto Brasileiro de Geografia e Estatística (IBGE): www.ibge.gov.br

Instituto Zequinha Barreto: http://www.zequinhabarreto.org.br

Site de Márcio Moreira Alves: www.marciomoreiraalves.com

Nações Unidas: www.nu.org

Ordem dos Emancipadores de Osasco: emancipadoresosasco.org.br

\section{Filmes e documentários}

A Batalha de Argel, Dir. Gillo Pontecorvo, ano de produção, 1966

Cidadão Boilesen, Dir. Chain Litevsky; ano de produção, 1999

Le Fond de l'air est rouge, Dir. Chris Marker, ano de produção, 1977

\section{Arquivos e centros de documentação consultados}

Arquivo do Estado de São Paulo

Arquivo do Sindicato dos Metalúrgicos de Osasco e Região

Centro de Documentação Histórica de Osasco da UNIFIEO (CDHO)

Centro de Documentação e Informação Científica da PUC (CEDIC)

Centro de Documentação e Memória da UNESP (CEDEM) 
Instituto Zequinha Barreto

Museu Municipal de Osasco

\section{Entrevistas}

Antonio Roberto Espinosa

Antonio Salgueiro

Gabriel Figueiredo

João Quartim de Moraes

José Ibrahim

Ladislas Dowbor

Manuel Dias do Nascimento

Maria Lygia Quartim de Moraes

Roque Aparecido da Silva

Stanislau Zermeta 